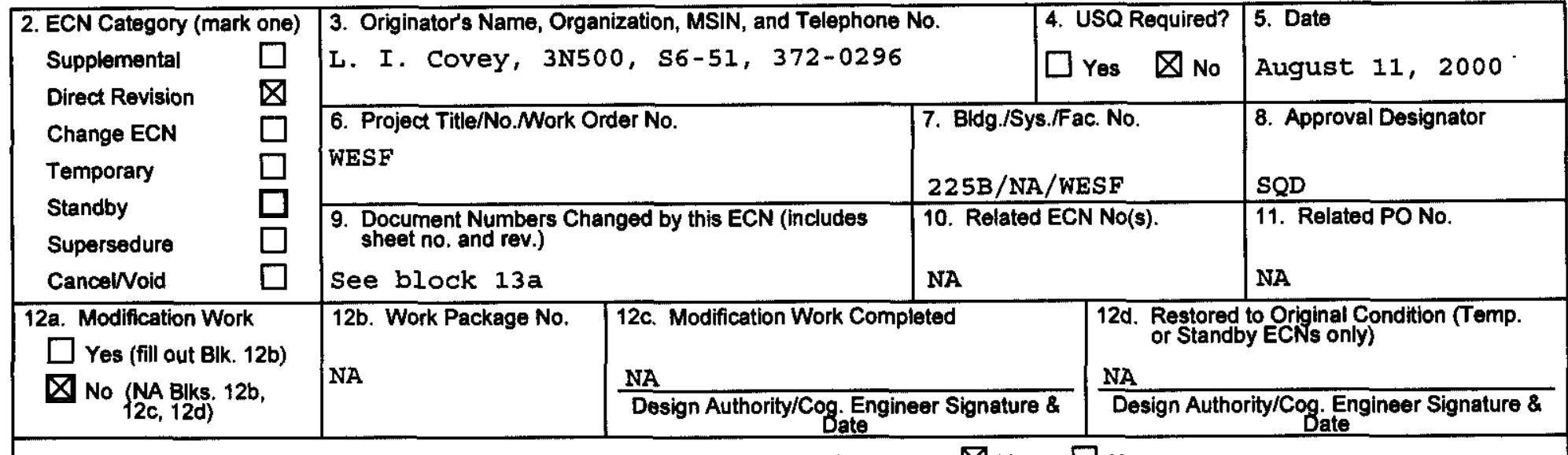

13a. Description of Change

13b. Design Baseline Document? $\square$ Yes $\square$ No

Block 9 .

HNE-SD-WM-BIO-002, Rev. 0

HNF-SD-WM-IOSR-001, Rev. 0

This update to the WESF Basis for Interim Operation (BIO) and Interim Operational Safety Requirements (IOSRs) satisfies the annual update requirement in HNF-PRO-700. This update includes incorporation of the analyzes and controls in the WIXM Safety Analysis Document (HNF-2316), deletion of two Administrative Controls (AC 5.11 and 5.13), and development of LCO 3.2 .

\begin{tabular}{ll|}
\hline 14a. Justification (mark one) \\
Criteria Change & $\square$ \\
Design Improvement & $\square$ \\
Environmental & $\square$ \\
Facility Deactivation & $\square$ \\
As-Found & $\square$ \\
Facilitate Const. & $\square$ \\
Const. Error/Omission & $\square$ \\
Design Error/Omission & $\square$
\end{tabular}

15. Distribution (include name, MSIN, and no. of copies)

L. I. Covey S6-51 (2) HNF-PRO-700 and DOE Order 5480.23. Approval designator SQD was selected per HNF-PRO-233. Design verification by review per FSP-WESF-001 EN-1 and HNF-PRO-1819. A USQ screening is not required since this document will be approved by RI. 


\section{ENGINEERING CHANGE NOTICE}

1. ECN (use no. from pg. 1)

16. Design Verification

Required

X Yes

$\square$ No
17. Cost Impact

ENGINEERING

Additional $\square \leqslant \underline{N A}$

Savings

$\$ \underline{N A}$

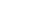

-

口 NA

19. Change Impact Review: Indicate the related documents (other than the engineering documents identified on Side 1) that will be affected by

Additional $\square \leqslant$ NA
Savings $\square \leqslant$ NA

\section{CONSTRUCTION}

Page 2 of 2 - 661030

18. Schedule Impact (days)

Improvement

NA

Delay

NA the change described in Block 13. Enter the affected document number in Block 20.

$\begin{array}{llll}\text { SDD/DD } & \square & \text { Seismic/Stress Analysis } & \square \\ \text { Functional Design Criteria } & \square & \text { Stress/Design Report } & \square \\ \text { Operating Specification } & \square & \text { Interface Control Drawing } \\ \text { Criticality Specification } & \square & \text { Calibration Procedure } & \square \\ \text { Conceptual Design Report } & \square & \text { Installation Procedure } \\ \text { Equipment Spec. } & \square & \text { Maintenance Procedure } & \square \\ \text { Const. Spec. } & \square & \text { Engineering Procedure } & \square \\ \text { Procurement Spec. } & \square & \text { Operating Instruction } & \square \\ \text { Vendor Information } & \square & \text { Operating Procedure } & \square \\ \text { OM Manual } & \square & \text { Operational Safety Requirement } \\ \text { FSAR/SAR } & \square & \text { IEFD Drawing } & \square \\ \text { Safety Equipment List } & \square & \text { Cell Arrangement Drawing } & \square \\ \text { Radiation Work Permit } & \square & \text { Essential Material Specification } \\ \text { Environmental Impact Statement } & \square & \text { Fac. Proc. Samp. Schedule } & \square \\ \text { Environmental Report } & \square & \text { Inspection Plan } \\ \text { Environmental Permit } & \square & \text { Inventory Adjustment Request } & \square\end{array}$

\begin{tabular}{lll}
$\square$ & Tank Calibration Manual & $\square$ \\
$\square$ & Health Physics Procedure & $\square$ \\
$\square$ & Spares Multiple Unit Listing & $\square$ \\
$\square$ & Test Procedures/Specification & $\square$ \\
$\square$ & Component Index & $\square$ \\
$\square$ & ASME Coded Item & $\square$ \\
$\square$ & Human Factor Consideration \\
$\square$ & Computer Software & $\square$ \\
$\square$ & Electric Circuit Schedule & $\square$ \\
$\square$ & Process Control ManualPlan & $\square$ \\
$\square$ & Process Flow Chart & $\square$ \\
$\square$ & Purchase Requisition & $\square$ \\
\hline & Tickler File & $\square$ \\
\hline & Training & $\square$
\end{tabular}

20. Other Affected Documents: (NOTE: Documents listed below will not be revised by this ECN.) Signatures below indicate that the signing organization has been notified of other affected documents listed below.

\section{Document Number/Revision}

WESF EPAPC

WESF IOSR Training

FSP-WESF-001, sections NSand NS-2

\section{Document Number/Revision}

WESF Operating and

maintenance procedures which implement IOSRs

21. Approvals

Sesign Authority J. L. Pennock
Cog. Eng. NA
Cog. Mgr. NA
QA M. A. Hill
Safety D. R. Ellingson

Environ. NA

Other

Design Verification L. I. Covey

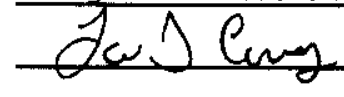

Facility Manager B. Oldfield

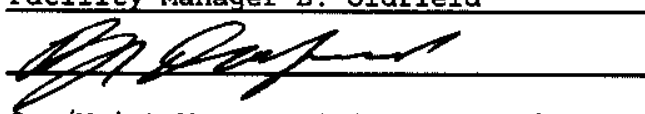

ops/Maint Manager P.T. Saueressig Bonk Someresteg

Training S.R. Stark

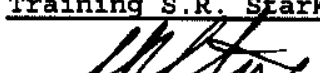

Date $8-2 y-\infty$

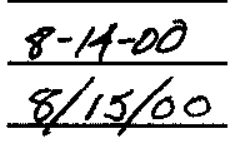

\section{$8 / 14 / \omega$}

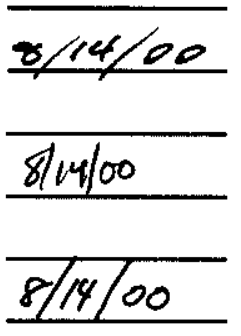

Signature

Date

Design Agent

PE

QA

Safety

Design

Environ.

Other

Document Number/Revision 


\section{Waste Encapsulation and Storage Facility Basis for Interim Operation}

Prepared for the U.S. Department of Energy

Assistant Secretary for Environmental Management

Project Hanford Management Contractor for the

U.S. Department of Energy under Contract DE-AC06-96RL13200

Fluor Hanford

P.O. Box 1000

Richland, Washington 


\title{
Waste Encapsulation and Storage Facility Basis for Interim Operation
}

Document Type: BIO

\author{
Division: WM
}

L. I. Covey

Fluor Hanford

Date Published

November 2000

Prepared for the U.S. Department of Energy

Assistant Secretary for Environmental Management

Project Hanford Management Contractor for the

U.S. Department of Energy under Contract DE-AC06-96RL13200

Fluor Hanford

P.O. Box 1000

Richland, Washington
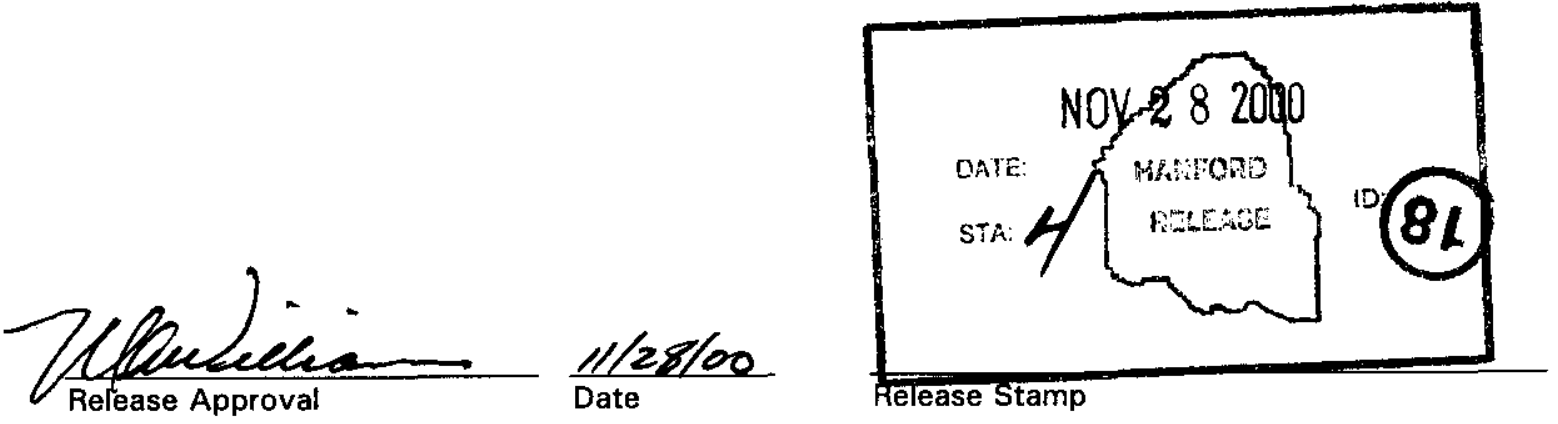


\begin{abstract}
LEGAL DISCLAIMER
This report was prepared as an account of work sponsored by an agency of the United States Government. Neither the United States Government nor any agency thereof, nor any of their employees, nor any of their contractors, subcontractors or their employees, makes any warranty, express or implied, or assumes any legal liability or responsibility for the accuracy, completeness, or any third party's use or the results of such use of any information, apparatus, product, or process

disclosed, or represents that its use would not infringe privately owned rights. Reference herein to any specific commercial product, process, or service by trade name, trademark, manufacturer, or otherwise, does not necessarily constitute or imply its endorsement, recommendation, or favoring by the United States Government or any agency thereof or its contractors or subcontractors. The views and opinions of authors expressed herein do not necessarily state or reflect those of the United States Government or any agency thereof.
\end{abstract}

This report has been reproduced from the best available copy.

Printed in the United States of America

Total Pages:

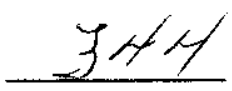




\section{RECORD OF REVISION}

(1) Document Number
HNF-SD-WM-IOSR-001

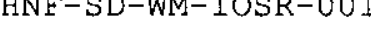

Page 1

(2) Title

Waste Encapsulation and Storage Facility Basis for Interim Operation

Change Control Record

\begin{tabular}{l|l} 
(3) Revision & (4) Description of Change - Replace, Add, and Delete Pages
\end{tabular}

(7)

Originally released May 4, 1998 (EDT 620310)

R8 1 BIO revised to reflect facility modifications and incorporate HNE-2316 (ECN 661030)

Authorized for Release

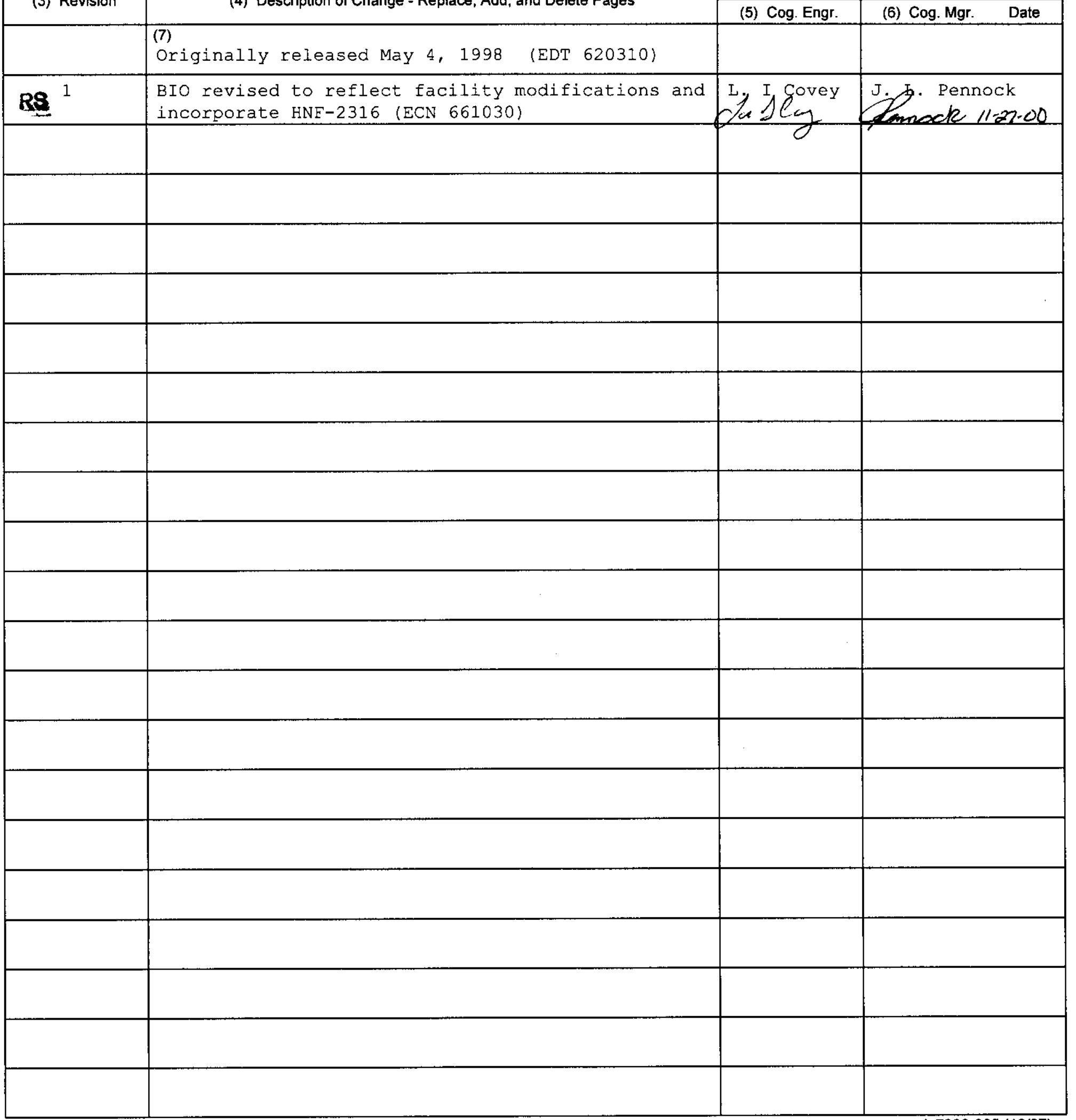




\section{TABLE OF CONTENTS}

1.0 INTRODUCTION

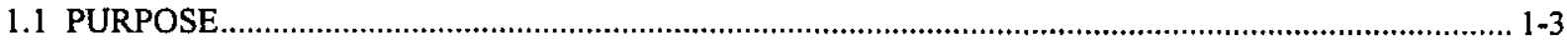

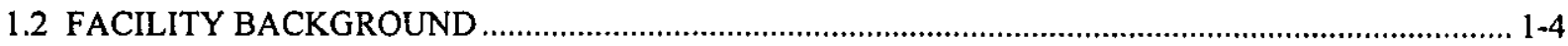

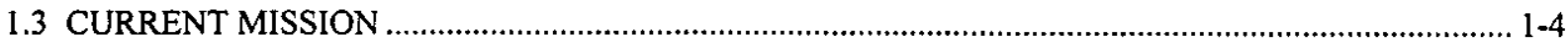

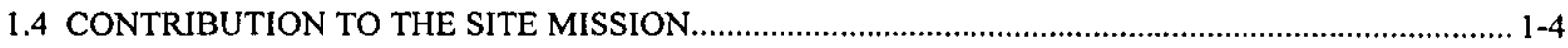

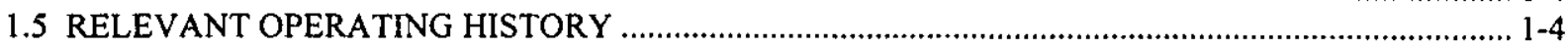

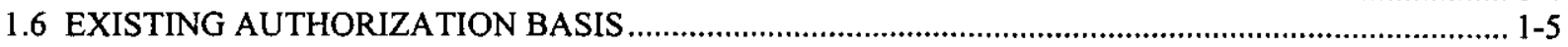

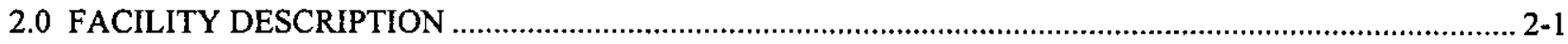

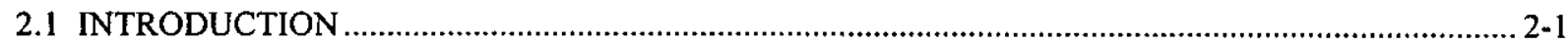

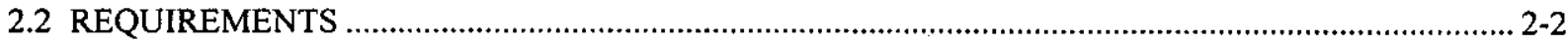

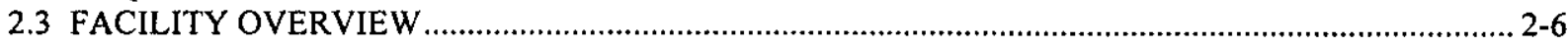

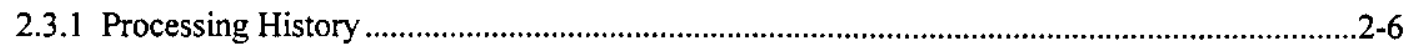

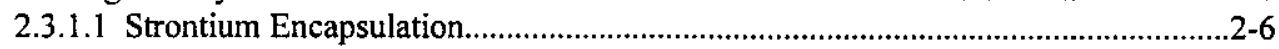

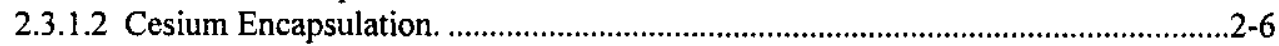

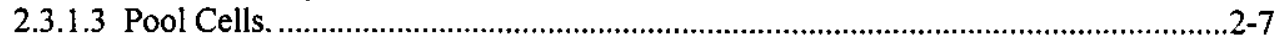

2.3.1.4 Beneficial Capsule Use........................................................................................2-7

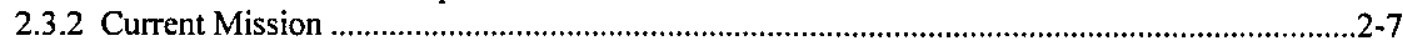

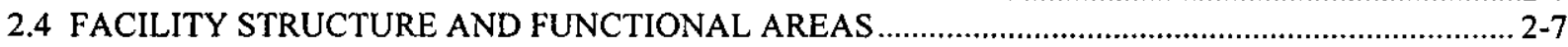

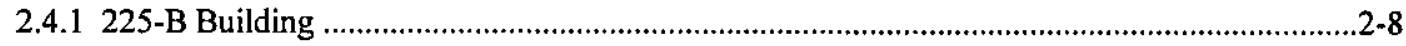

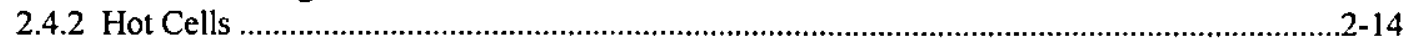

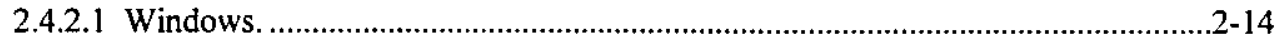

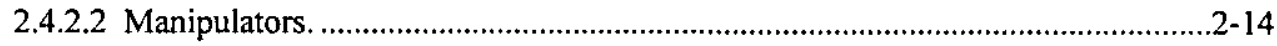

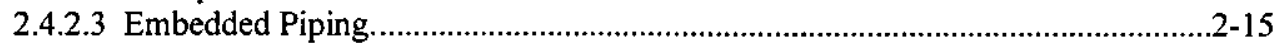

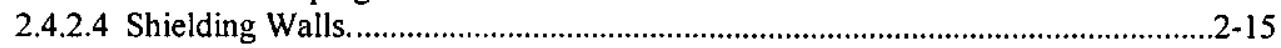

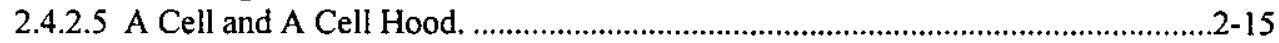

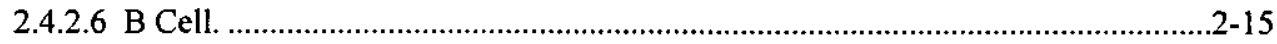

2.4.2.7 C Cell.

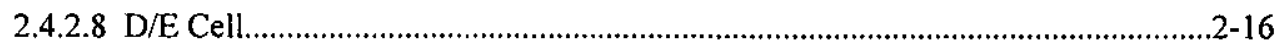

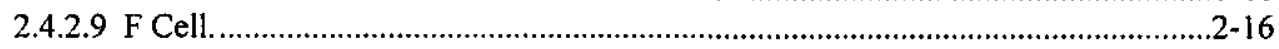

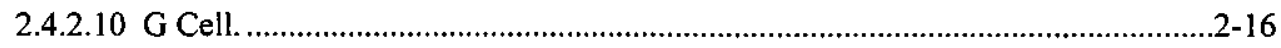

2.4.2.11 Hot Pipe Trench..............................................................................................

2.4.2.12 Hot Cell Ventilation............................................................................................ $2-16$

2.4.2.13 Hot Cell Water Detection and Removal...........................................................2-17

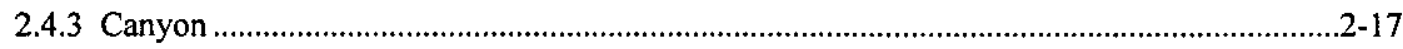

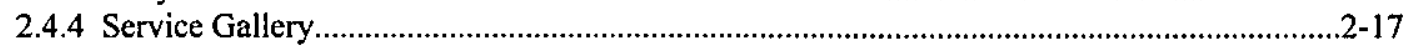

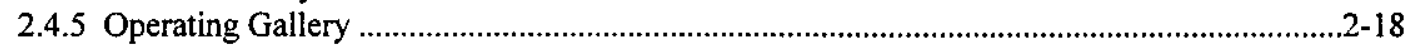

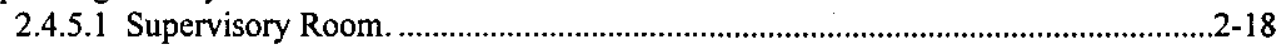

2.4.5.2 Pool Cell Monitoring Area............................................................................... $2-18$

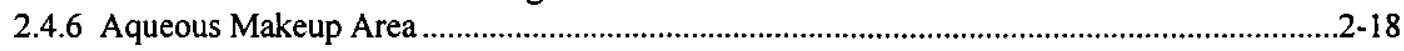

2.4.6.1 Transmitter Rooms ................................................................................... 18

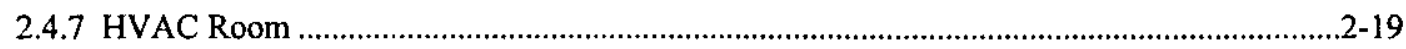

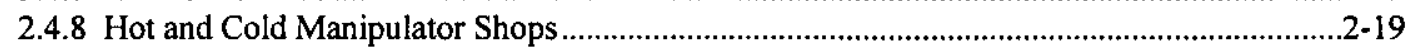

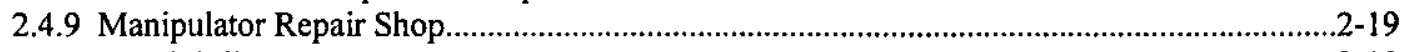

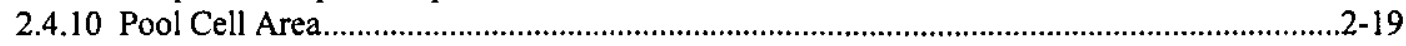

2.4.10.1 Pool Cell Leak Detection System..................................................................2-20

2.4.10.2 Pool Cell Water Removal and Circulation Lines................................................2-20

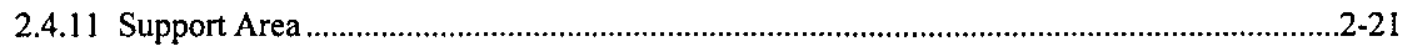

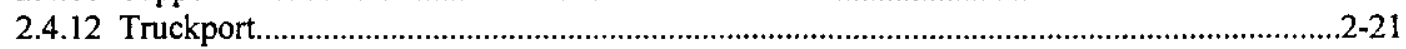

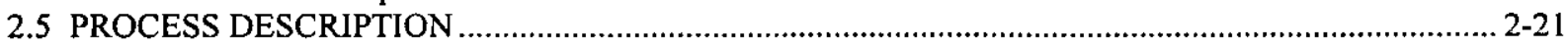

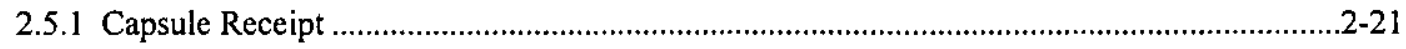

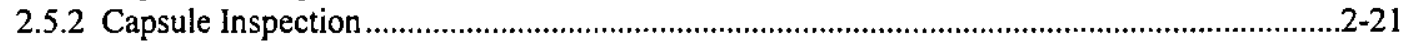

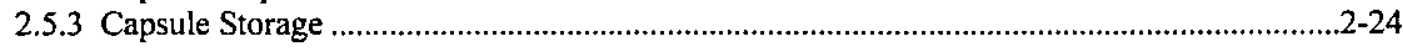

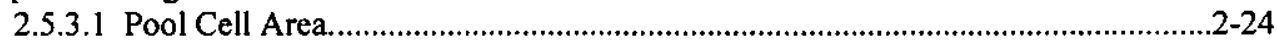




\section{HNF-SD-WM-BIO-002 REV 1}

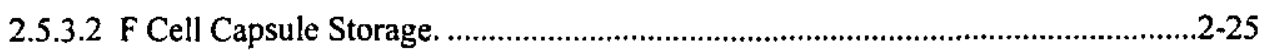

2.5.4 Solid Radioactive Waste ..................................................................................................2-26

2.5.4.1 Routine Low-Level Radioactive Waste................................................................2-26

2.5.4.2 Non-Routine Low-Level Radioactive Waste......................................................2-26

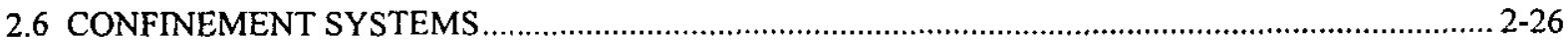

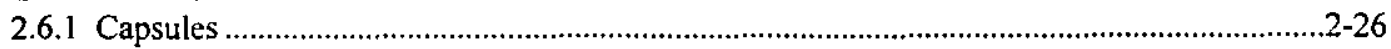

2.6.1.1 WESF Encapsulated Capsules........................................................................2-27

2.6.1.2 Type-W Overpack Capsules...........................................................................2-27

2.6.2 Airbome Radioactive Contamination Confinement …….........................................................2-27

2.6.2.1 K-1 HVAC Supply and Exhaust System. .........................................................2-28

2.6.2.2 K-2 HVAC Supply and Exhaust System. ..........................................................2-28

2.6.2.3 K-3 HVAC Supply and Exhaust System. …….................................................2-29

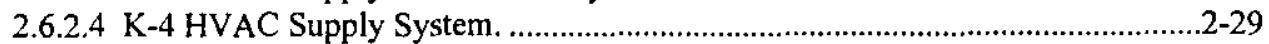

2.6.2.5 Miscellaneous HVAC Systems. ..............................................................................2-33

2.6.3 Liquid Radioactive Waste Confinement ....................................................................................2-33

2.6.3.1 Low-Level Waste Headers. .......................................................................................2-33

2.6.3.2 Low-Level Liquid Waste Collection Tank .........................................................2-33

2.6.3.3 Pool Cell Backup Cooling Water Discharge Line..............................................2-34

2.6.4 Radiation Confinement Provided by the Facility Structure......................................................2-34

2.6.4.1 Hot Cells. ..............................................................................................................

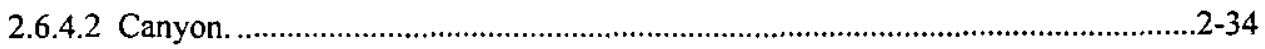

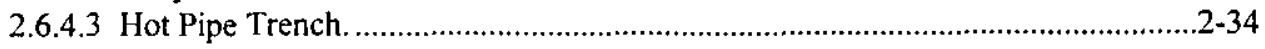

2.6.4.4 Pool Cell Area...................................................................................................2-34

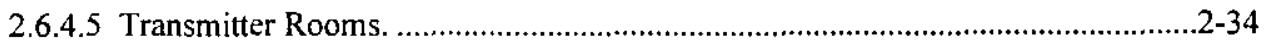

2.6.4.6 Viewing Windows. ……................................................................................2-34

2.7 SAFETY SUPPORT SYSTEMS

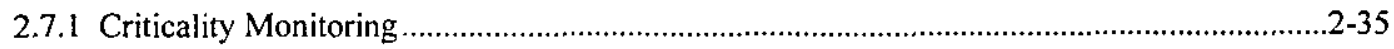

2.7.2 Fire Protection System .....................................................................................................2-35

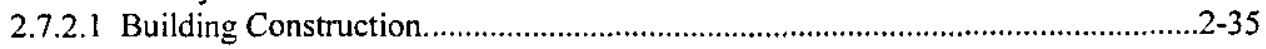

2.7.2.2 Fire Detection Systems.................................................................................... $2-35$

2.7.2.3 Fire Sprinkler Systems …….........................................................................2-35

2.7.2.4 Hot Cell Fire Protection Systems. …………...................................................2-35

2.7.2.5 Truckport Fire Protection Systems..................................................................2-36

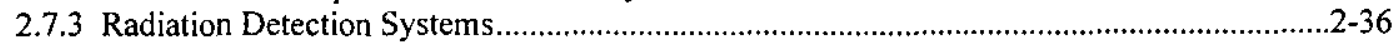

2.7.3.1 Airborne Contamination Sampling and Monitoring............................................2-36

2.7.3.2 Area Radiation Monitors (ARMs) ..................................................................2-37

2.7.3.3 Ion Exchange Radiation Monitors......................................................................2-37

2.7.3.4 K-3 Filter Radiation Monitors..........................................................................2-37

2.7.3.5 Pool Cell Beta Monitors. ...................................................................................2-37

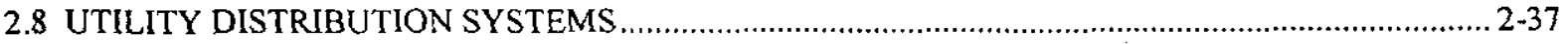

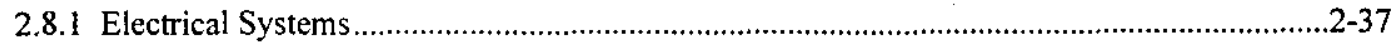

2.8.1.1 Primary Power Source.........................................................................................2-37

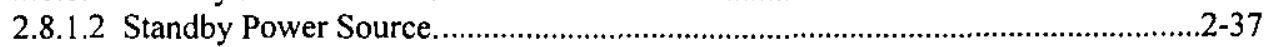

2.8.1.3 Load Transfers. ................................................................................................

2.8.1.4 225-BG Closed Loop Cooling System Electric Power............................................2-39

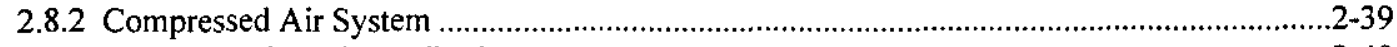

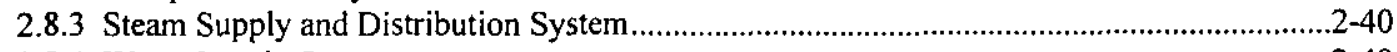

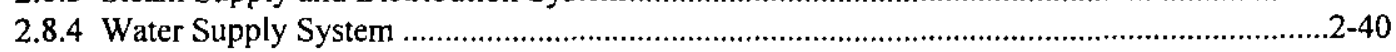

2.8.4.1 Export Water Systems ......................................................................................2-40

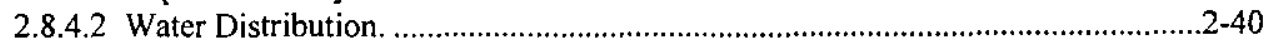

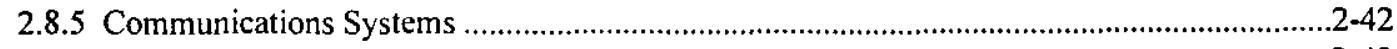

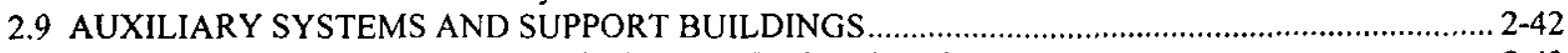

2.9.1 TK-100, Low Level Liquid Waste Tank and Vault.............................................................2-43

2.9.2 225-BG Pool Cell Closed Loop Cooling System ................................................................... 2-43

2.9.3 WESF Pool Cell Emergency Ion Exchange System................................................................2-43

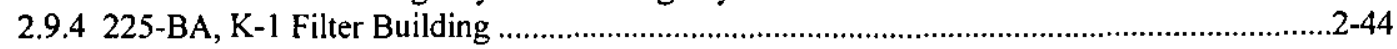




\section{HNF-SD-WM-BIO-002 REV 1}

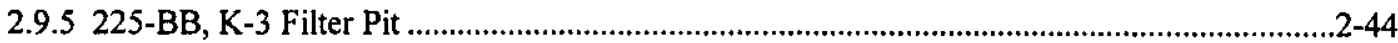

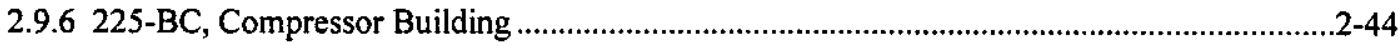

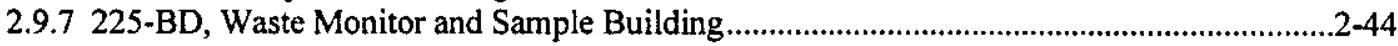

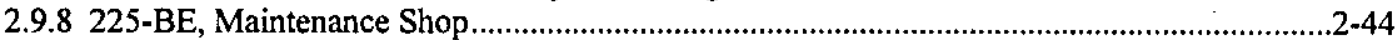

2.9.9 296-B-10, K-1 and K-3 Exhaust Stack and Duct.............................................................2-24

2.9.10 282-B and 282-BA Backup Well Pump Houses..............................................................2-45

2.9.11 294-B Raw Water Backflow Preventer Building ................................................................2-45

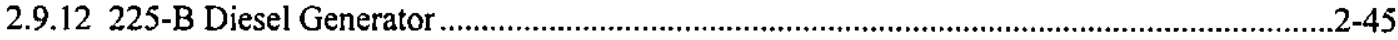

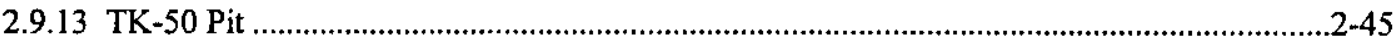

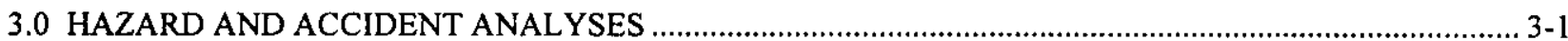

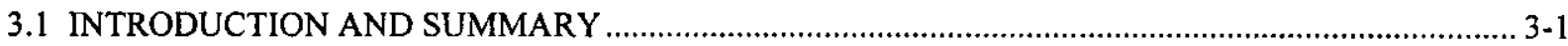

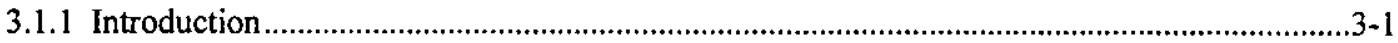

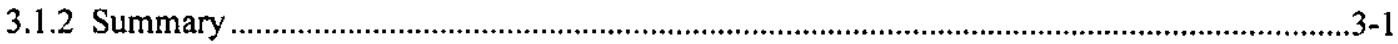

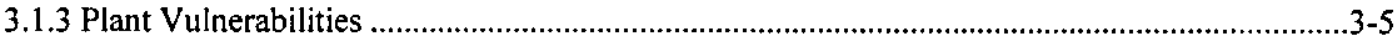

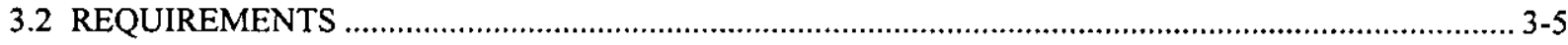

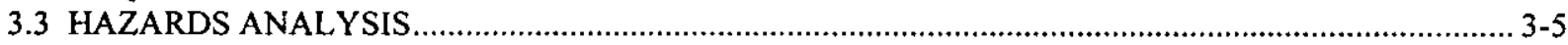

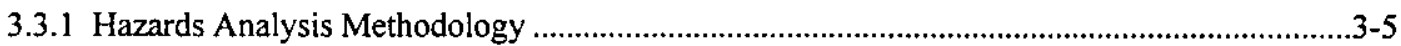

3.3.1.1 Hazard Identification Methodology. .....................................................................

3.3.1.2 Hazard Evaluation Methodology. .......................................................................

3.3.2 Hazard Analysis Results .................................................................................................. 3-8

3.3.2.1 Hazard Identification Results. ............................................................................ 3-8

3.3.2.2 Hazard Categorization. ................................................................................

3.3.2.3 Hazard Evaluation Results................................................................................17

3.3.2.3.1 Planned Design and Operational Safety Improvements. ........................................... 3-18

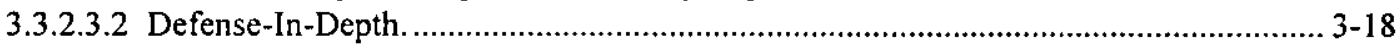

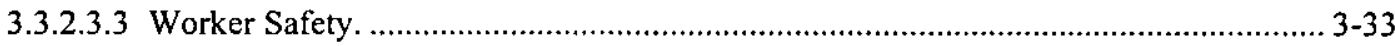

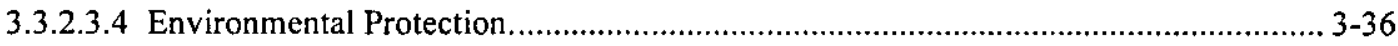

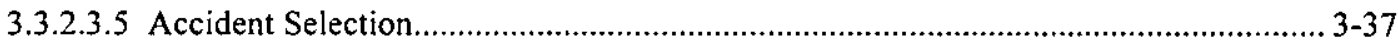

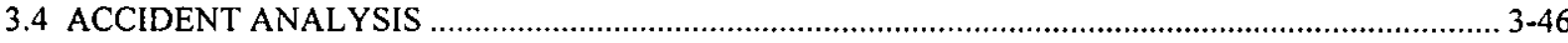

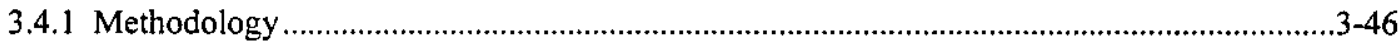

3.4.1.1 Accident Scenario Development Methodology ..................................................3-46

3.4.1.2 Source Term Modeling Methodology ...............................................................

3.4.1.3 Consequence Analysis Methodology...................................................................

3.4.1.4 Application of Risk Evaluation Guidelines.......................................................3-52

3.4.1.5 Safety Class and IOSR Designation Methodology ............................................

3.4.2 Design Basis Accidents .................................................................................................... $3-53$

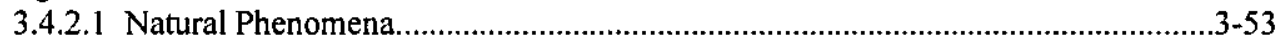

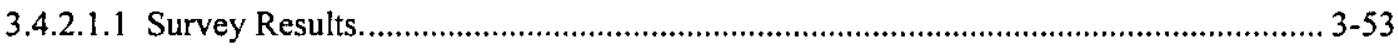

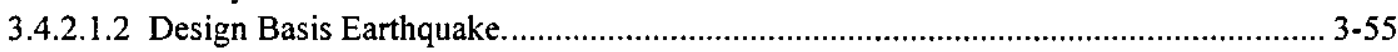

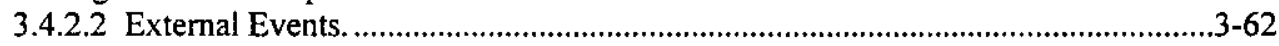

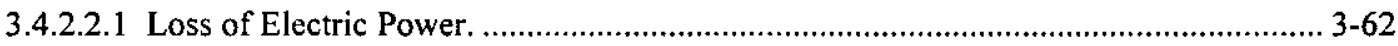

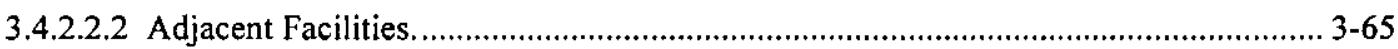

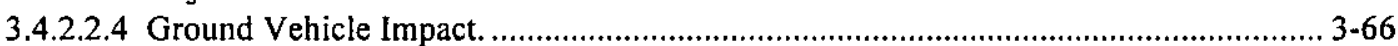

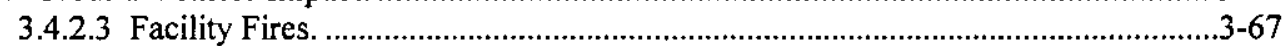

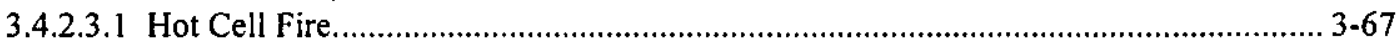

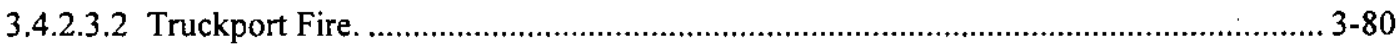

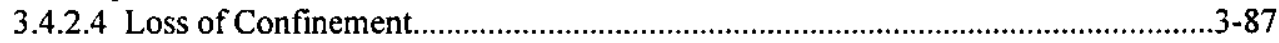

3.4.2.4.1 High Flow in K-3 Ventilation System............................................................. 3-87

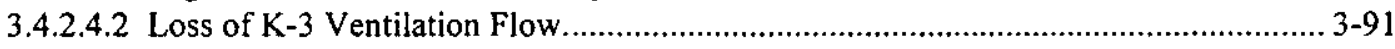

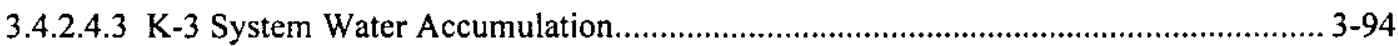

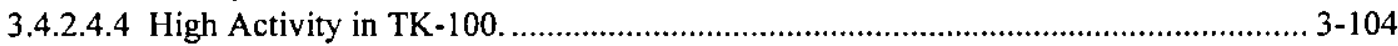

3.4.2.4.5 Hydrogen Accumulation in Hot Cells................................................................ 3-109

3.4.2.5 Facility Explosions. ......................................................................................... 3.113 
3.4.2.5.1 Hydrogen Explosion in the Pool Cell Area. ....................................................... 3-113

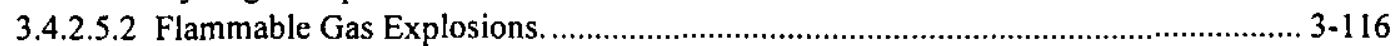

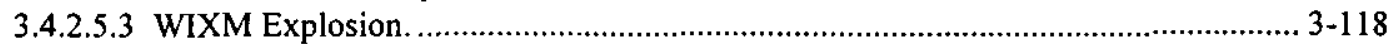

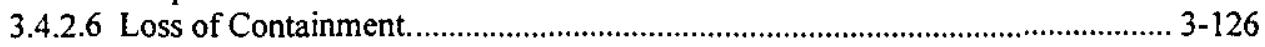

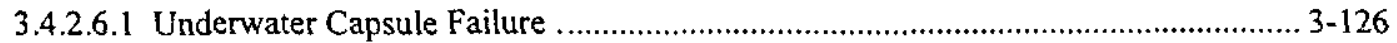

3.4.2.6.2 Underwater Capsule Failures Due to Drop Impacts................................................. 3-132

3.4.2.6.3 WIXM Loss of Containment .......................................................................... 3-137

3.4.2.7 Loss of Pool Cell Water.................................................................................. 3-138

3.4.3 Beyond Design Basis Accidents.............................................................................. 3-144

3.4.3.1 Introduction............................................................................................... 3-144

3.4.3.2 Beyond Design Basis Earthquake. ……........................................................ 3-145

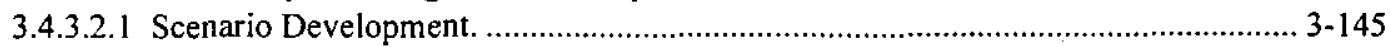

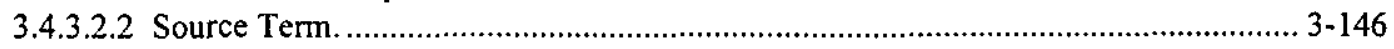

3.4.3.2.3 Consequence Analysis.................................................................................. 3-147

3.4.3.3.2 Loss of Water from All Pool Cells...................................................................... 3-155

3.4.3.4 Post Loss of Pool Cell Water Accident Concerns. ............................................. 3-160

4.0 SAFETY STRUCTURES, SYSTEMS, AND COMPONENTS ................................................................ $4-1$

4.1 INTRODUCTION

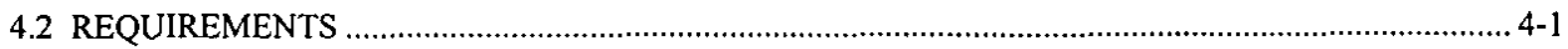

4.3 SAFETY SYSTEMS, STRUCTURES, AND COMPONENTS …......................................................... 4-1

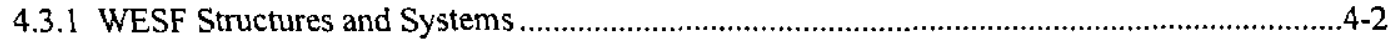

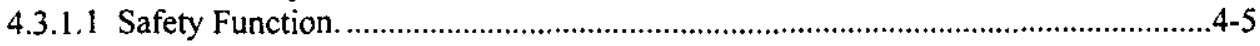

4.3.1.2 Safety Description..................................................................................................4-5

4.3.1.3 Functional Requirements ...................................................................................4-7

4.3.1.4 System Evaluation. ........................................................................................

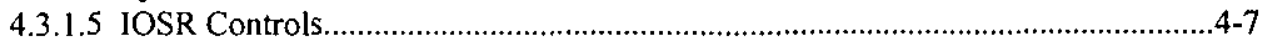

4.3.2 K-3 HEPA Filter .....................................................................................................

4.3.2.1 Safety Function................................................................................................4-8

4.3.2.2 Safety Description..........................................................................................

4.3.2.3 Functional Requirements...............................................................................

4.3.2.4 System Evaluation. ......................................................................................... 4-8

4.3.2.5 IOSR Controls................................................................................................

4.3.3 Pool Cell Area Radiation Monitors (ARMs) ……................................................................4-9

4.3.3.1 Safety Function................................................................................................

4.3.3.2 Safety Description............................................................................................... $4-9$

4.3.3.3 Functional Requirements. ...............................................................................4-9

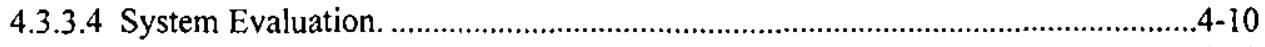

4.3.3.5 IOSR Controls.............................................................................................

4.3.4 Pool Cell Water Loss Detection System ....................................................................

4.3.4.1 Safety Function............................................................................................. $4-10$

4.3.4.2 Safety Description.................................................................................................

4.3.4.3 Functional Requirements.............................................................................4-10

4.3.4.4 System Evaluation. .............................................................................................

4.3.4.5 IOSR Controls........................................................................................... $4-12$

4.3.5 Pool Cell Emergency Makeup Water Fill Pipe ...................................................................4-12

4.3.5.1 Safety Function............................................................................................. $4-12$

4.3.5.2 Safety Description.............................................................................................4-12

4.3.5.3 Functional Requirements.......................................................................... $4-12$

4.3.5.4 System Evaluation. ...................................................................................

4.3.5.5 IOSR Controls.......................................................................................

5.0 DERIVATION OF INTERIM OPERATIONAL SAFETY REQUIREMENTS ........................................ 1-1

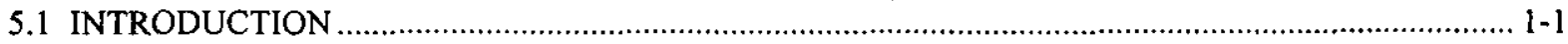

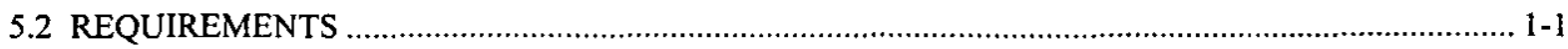


5.3 INTERIM OPERATIONAL SAFETY REQUIREMENTS COVERAGE............................................. $1-2$

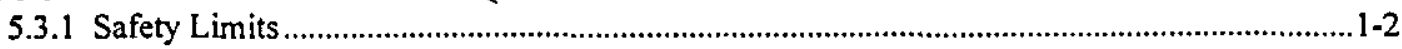

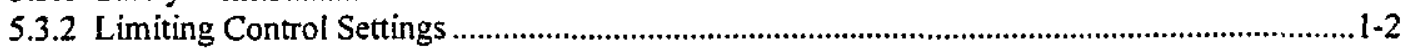

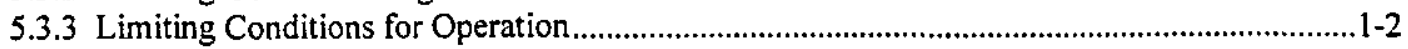

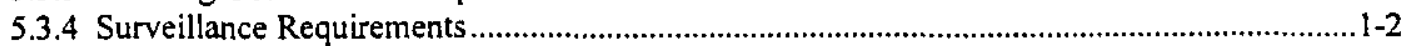

5.3.5 Administrative Controls................................................................................................... $1-3$

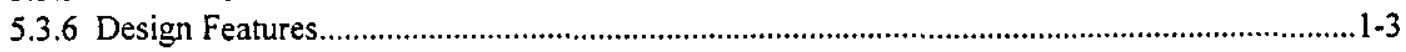

5.3.7 Significant Defense-in-Depth ..............................................................................................

5.3.8 Significant Worker Safety ................................................................................................

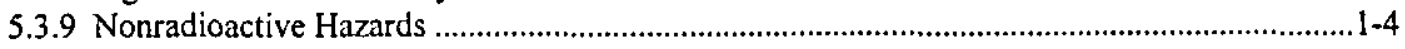

5.3.10 Maintain Consequences Below Evaluation Guidelines ............................................................1.4

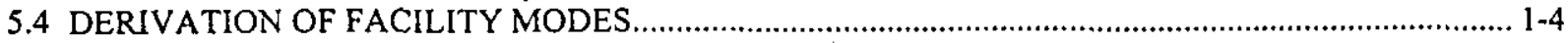

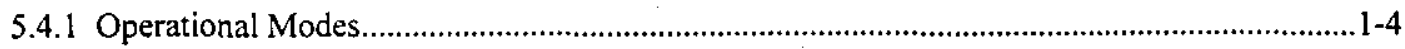

5.4.2 Minimum Staffing Levels...................................................................................................

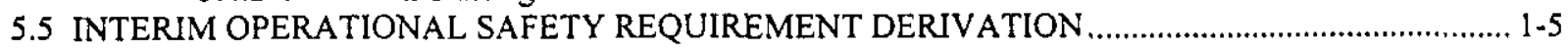

5.5.1 Applicable Hazards.....................................................................................................

5.5.1.1 Limiting Conditions for Operation.......................................................................1-5

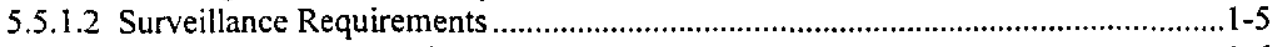

5.5.1.3 Administrative Controls................................................................................. 1-6

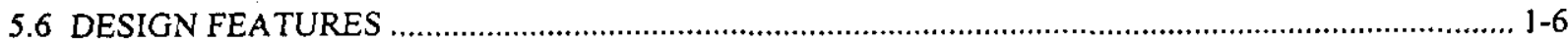

5.7 INTERFACES WITH IOSRS FROM OTHER FACILITIES ........................................................... 1-7

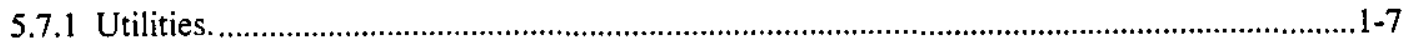

6.0 SAFETY RELATED PROGRAMS AND CONTROLS ........................................................................ $1-1$

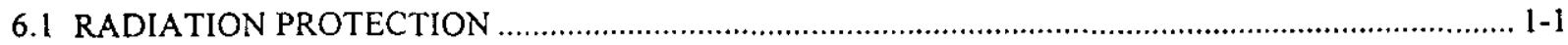

6.1.1 Radiation Protection Program and Organization .................................................................. $1-1$

6.1.2 As Low As Reasonably Achievable Policy and Program .....................................................1-1

6.1.3 Radiological Protection Training .......................................................................................

6.1.4 Radiation Exposure Control ..............................................................................................

6.1.5 Radiological Monitoring, Instrumentation, and Record Keeping …........................................ 1-2

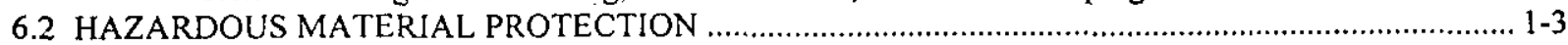

6.2.1 Hazardous Material Protection and Organization ................................................................... 1-3

6.2.2 Hazardous Material Training .............................................................................................

6.2.3 Hazardous Material Monitoring ……...............................................................................

6.2.4 Hazardous Material Instrumentation ................................................................................... $1-4$

6.2.5 Hazardous Material Exposure Control, Record Keeping, and Communication .......................... 1-4

6.2.6 Occupational Chemical Exposure ....................................................................................

6.3 RADIOACTIVE AND HAZARDOUS WASTE MANAGEMENT ....................................................... 1-4

6.3.1 Radioactive and Hazardous Waste Management Program and Organization .......................... 1-4

6.3.2 Radioactive and Hazardous Waste Streams and Sources .....................................................1-5

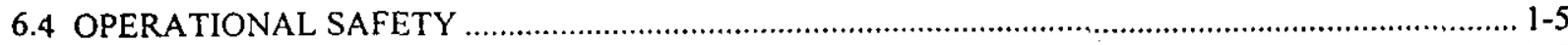

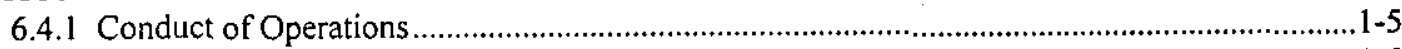

6.4.2 Configuration Management ...............................................................................................

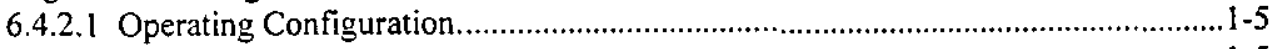

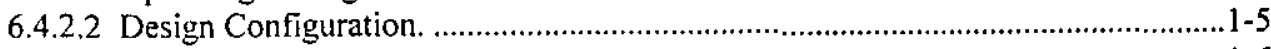

6.4.2.3 Critical Interfaces....................................................................................

6.4.2.4 Engineering Design Interface.......................................................................1-6

6.4.2.5 Maintenance History ........................................................................................1-6

6.4.2.6 Performance Indicators..................................................................................1-6

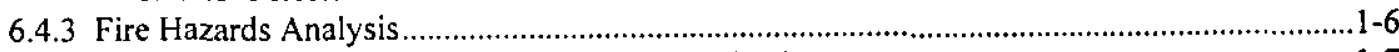

6.4.3.2 Fire Protection Program and Organization. .........................................................1-7

6.4.3.3 Combustible Loading Control............................................................................1-7

6.4.3.4 Fire Fighting Capabilities. .............................................................................. $1-7$

6.4.3.5 Fire Fighting Readiness Assurance..................................................................1-8

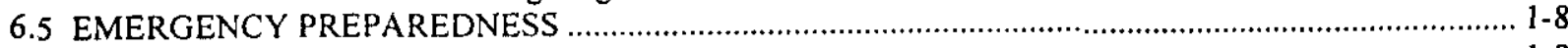

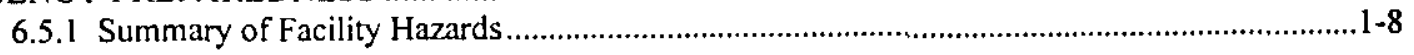


6.5.2 Summary of Emergency Preparedness Planning Program ..................................................... 1-9

6.5.2.1 Emergency Response Organization. .................................................................1-9

6.5.2.2 Assessment Actions....................................................................................1-9

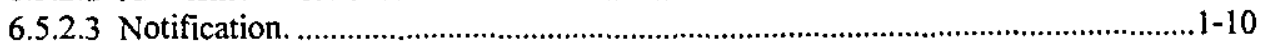

6.5.2.4 Emergency Facilities and Equipment..............................................................1-10

6.5.2.5 Protective Actions..........................................................................................1-11

6.5.2.6 Training and Exercises. ............................................................................. 11

6.5.2.7 Recovery and Reentry. ...............................................................................1-12

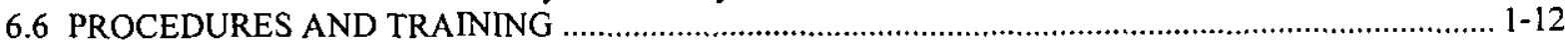

6.6.1 Procedure Program .................................................................................................1-12

6.6.2 Training Program .......................................................................................................1-13

6.7 INITIAL TESTING, IN-SERVICE SURVEILLANCE, AND MAINTENANCE ............................... 1-13

6.7.1 Initial Testing .............................................................................................................. 1.13

6.7.2 In-Service Surveillance and Maintenance Program.........................................................1-14

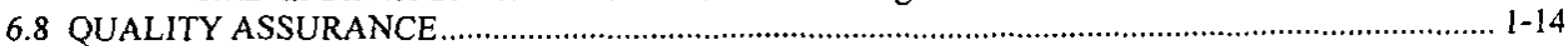

6.9 MANAGEMENT ORGANIZATION AND INSTITUTIONAL SAFETY PROVISIONS ….................. $1-14$

6.9.1 Organizational Structure, Responsibilities, and Interfaces .................................................1-15

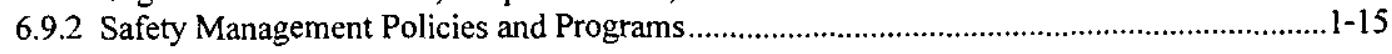

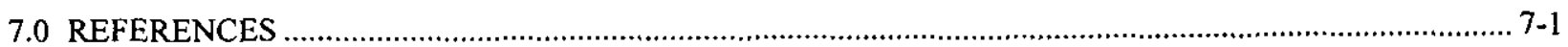

APPENDIX A DEPARTMENT OF ENERGY SAFETY EVALUATION REPORT ........................................A-1

APPENDIX B DEPARTMENT OF ENERGY REVIEW COMMENT RECORDS ….......................................B-1 


\section{LIST OF TABLES}

Table 1-1. DOE-STD-3011-94 and WESF BIO Cross-Reference Error! Bookmark not defined.

Table 3-1. Accident Analysis Results Summary.

3-3

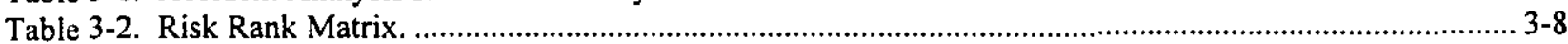

Table 3-3. Hazard Identification Results for WESF. . ................................................................................ 3-8

Table 3-4. ORPS Abnormal Occurrences and Consequences............................................................................ 3-13

Table 3-5. Nodes Analyzed in WESF HAZOP ................................................................................................. 3-19

Table 3-6. Summary of HAZOP S1 Deviations. ......................................................................................... 3-20

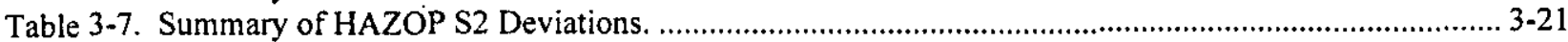

Table 3-8. Summary of HAZOP S3 Deviations.

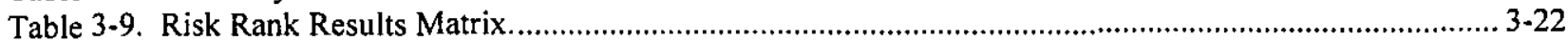

Table 3-10. Summary of SSCs Having a Safety Function................................................................................ 3-23

Table 3-11. Summary of Accident Selection Results. ......................................................................................... 3-38

Table 3-12. ARF, ARR, RF, and LPF Values Used in the Accident Analysis. ............................................... 3-47

Table 3-13. Site Boundary Distances Used in Offsite Dispersion Calculations (Hey 1999) .................................. 3-50

Table 3-14. Atmospheric Dispersion Coefficients $(\chi / \mathrm{Qs})$ Used in the Accident Analysis.................................. 3-51

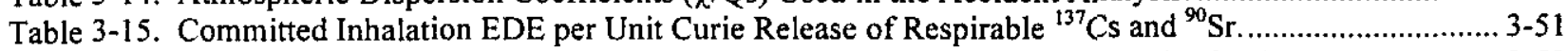

Table 3-16. Committed Inhalation EDE per Unit Kilogram Release of Respirable WESF CsCl.......................... 3-52

Table 3-17. Risk Evaluation Guidelines Based on Initiating Event Frequency.................................................. 3-52

Table 3-18. Mitigated and Immediate Design-Basis Earthquake Dose Consequences........................................ 3-60

Table 3-19. Unmitigated A Cell Fire Event Dose Consequences. ............................................................... 3-77

Table 3-20. Mitigated A Cell Fire Event Dose Consequences. ........................................................................ 3-77

Table 3-21. Unmitigated B/C Cell Fire Event Dose Consequences (Bounding Over D/E Cell)........................ 3-78

Table 3-22. Mitigated with Coverblocks B/C Cell Fire Event Dose Consequences (Bounding Over D/E Cell).... 3-78

Table 3-23. Unmitigated Truckport Fire Event Dose Consequences (Chem-Nuc Cask) ....................................... 3-86

Table 3-24 Unmitigated Truckport Fire Event Dose Consequences (WIXM) ....................................................... 3-86

Table 3-25. Unmitigated K-3 High Flow Event Dose Consequences................................................................. 3-89

Table 3-26. Mitigated K-3 High Flow Event Dose Consequences.................................................................... 3-90

Table 3-27. Unmitigated Dose Consequences from Hydrogen Explosion in the K-3 HEPA filter Housing........ 3-103

Table 3-28. Unmitigated Dose Consequences from Hydrogen Explosion in TK-100....................................... 3-108

Table 3-28a. Unmitigated Dose Consequences from WIXM Explosion........................................................... 3-125

Table 3-28b. Mitigated Dose Consequences from WIXM Explosion. ............................................................. 3-125

Table 3-29. Example WESF Cesium Capsule Leak Scenarios. ${ }^{\text {(a) }}$.................................................................... 3-128

Table 3-36. Beyond Design Basis Earthquake Onsite 100-m Worker Dose Consequences............................... 3-148

Table 3-37. Beyond Design Basis Earthquake Alternate Site Boundary Dose Consequences........................... 3-148

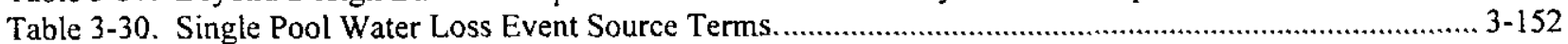

Table 3-31. Unmitigated Single Pool Water Loss Event Consequence............................................................ 3-153

Table 3-32. Dose Fields Within and Near WESF (Pool Cell 7 with 715 Cesium Capsules or $31 \mathrm{MCi}{ }^{137} \mathrm{Cs}$ ) ..... 3.154

Table 3-33. All Pool Water Loss Event Source Terms. " ................................................................................ 3-158

Table 3-34. Unmitigated All Pool Water Loss Event Consequence................................................................ 3-159

Table 3-35. Dose Fields Within and Near WESF (All Pools Drained $55 \mathrm{MCi}{ }^{137} \mathrm{Cs}$ ) .................................... 3-160

Table 4-1. Safety Class and Safety Significant Systems, Structures, and Components Summary List .................... 4-3

Table 5-1. Hazard and Accident Analyses; Safety Structures, Systems and Components; and Interim Operational Safety Requirement Cross-Reference. ................................................................................... 5-8

Table 5-2. BIO Chapter and Administrative Control IOSR Cross-Reference. .................................................. 5-13 


\section{HNF-SD-WM-BIO-002 REV 1}

\section{LIST OF FIGURES}

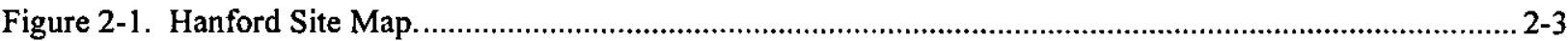

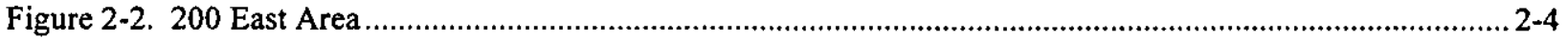

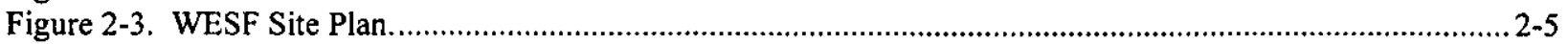

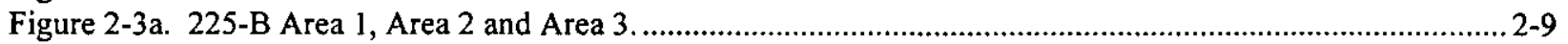

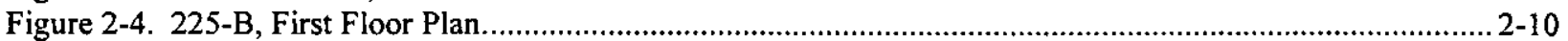

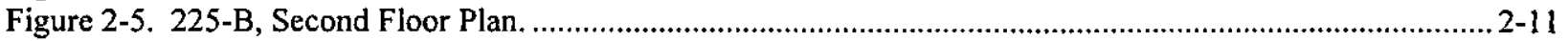

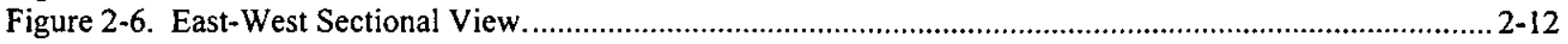

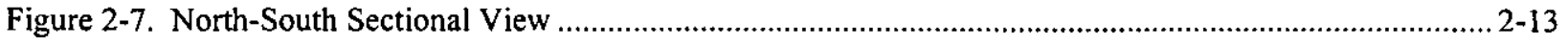

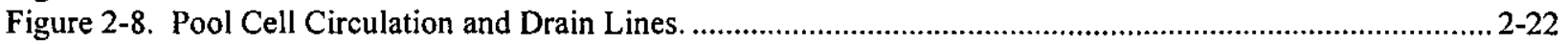

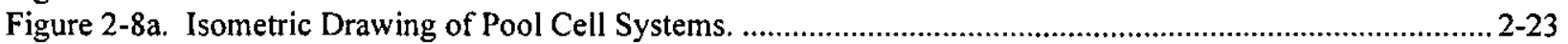

Figure 2-9. K-1, K-2, \& K-4 Ventilation.

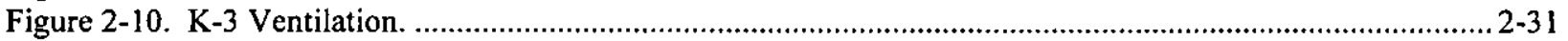

Figure 2-11. K-3 Filter Housing Elevation view. .................................................................................... 2-32

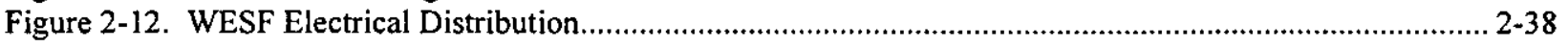

Figure 3-1. Flow Diagram of WESF Accident Analyses................................................................................ 3-41

Figure 3-2. Isometric View of K-3 Exhaust Ducting, K-3 Filter Pit, and TK-100 ........................................... 3-96

Figure 3-3. Eye Level Dose Map of Pool Cell Area with $53.2 \mathrm{kCi}{ }^{137} \mathrm{Cs}$ Dissolved in Pool Cell 5 .................... 3-131

Figure 3-4. Capsule Storage Pool Water Level Versus Evaporation Time........................................................... 3-141 


\section{LIST OF TERMS}

\begin{tabular}{|c|c|}
\hline $\mathrm{AC}$ & Administrative Controls \\
\hline ACES & Access Control Entry System \\
\hline ACGIH & American Conference of Governmental Industrial Hygienists \\
\hline ACI & American Concrete Institute \\
\hline AED & aerodynamic equivalent diameter \\
\hline AISC & American Institute of Steel Construction \\
\hline ALARA & as low as reasonably achievable \\
\hline AMU & aqueous make-up \\
\hline ARF & airborne release fraction \\
\hline ARM & area radiation monitor \\
\hline ARR & airborne release rate \\
\hline ATS & automatic transfer switches \\
\hline BDBA & beyond design basis accident \\
\hline BDBE & beyond design basis earthquake \\
\hline BED & Building Emergency Director \\
\hline $\mathrm{BIO}$ & Basis for Interim Operation \\
\hline BUSS & Beneficial Uses Shipping System \\
\hline $\mathrm{C}$ & dose per unit curie release $(\mathrm{rem} / \mathrm{Ci})$ \\
\hline CAM & continuous air monitor \\
\hline CERCLA & Comprehensive Environmental Response, Compensation, and Liability Act of 1980 \\
\hline $\mathrm{Ci}$ & curie \\
\hline CLCS & closed loop cooling system \\
\hline $\mathrm{CSO}$ & Cognizant Secretarial Officer \\
\hline DBA & design basis accident \\
\hline DBE & design basis earthquake \\
\hline DCF & dose conversion factor \\
\hline DD & defense-in-depth \\
\hline DOE & U.S. Department of Energy \\
\hline DOE-RL & U.S. Department of Energy - Richland Operations Office \\
\hline DOT & Department of Transportation \\
\hline DOV & diaphragm-operated valve \\
\hline $\mathrm{dpm}$ & disintegrations per minute \\
\hline $\mathrm{ECN}$ & Engineering Change Notice \\
\hline EDE & effective dose equivalent \\
\hline EDS & Encapsulation Database System \\
\hline EG & evaluation guidelines \\
\hline EMIX & emergency ion exchange \\
\hline $\mathrm{EP}$ & environmental protection \\
\hline ERF & entrainment rate fraction \\
\hline ES\&H & Environmental, Safety and Health \\
\hline ETF & Effluent Treatment Facility \\
\hline FACP & fire alarm control panel \\
\hline $\mathrm{FH}$ & Fluor Hanford, Inc. \\
\hline FHA & Fire Hazards Analysis \\
\hline FPE & Fire Protection Engineers \\
\hline FSAR & Final Safety Analysis Report \\
\hline HASP & health and safety plan \\
\hline HAZCOM & Hazard Communication Program \\
\hline HAZOP & hazard and operability study \\
\hline HEPA & high-efficiency particulate air \\
\hline HFD & Hanford Fire Department \\
\hline $\mathrm{HIC}$ & high integrity container \\
\hline HSRCM & Hanford Site Radiological Control Manual \\
\hline
\end{tabular}




\begin{tabular}{|c|c|}
\hline HVAC & heating, ventilation, and air conditioning \\
\hline $\mathrm{ICM}$ & inner capsule movement \\
\hline ICRP & International Commission on Radiological Protection \\
\hline IOSR & Interim Operational Safety Requirement \\
\hline IS\&FP & Industrial Safety and Fire Protection \\
\hline ISMS & Integrated Environment, Safety and Health Management System \\
\hline JCS & job control system \\
\hline $\mathrm{LCO}$ & Limiting Conditions of Operation \\
\hline LCS & Limiting Control Settings \\
\hline LFL & lower flammability level \\
\hline LLLW & low level liquid waste \\
\hline LLW & low level waste \\
\hline LOEP & loss of electric power \\
\hline LPF & leak path factor \\
\hline MCC & motor control centers \\
\hline MSDS & Material Safety Data Sheet \\
\hline MWTF & Multi-Function Waste Tank Facility \\
\hline NBS & National Bureau of Standards \\
\hline NFPA & National Fire Protection Association \\
\hline NPH & Natural Phenomenon Hazard \\
\hline NPHS & Natural Phenomenon Hazards Survey \\
\hline NRC & U.S. Nuclear Regulatory Commission \\
\hline OBE & operational basis earthquake \\
\hline OBED & On-Call Building Emergency Director \\
\hline ORPs & Occurrence Reporting and Processing System \\
\hline OSHA & Occupational Safety and Health Administration \\
\hline OSR & Operational Safety Requirements \\
\hline PLC & programmable logic controller \\
\hline PNL & Pacific Northwest Laboratory (pre 1996) \\
\hline PNNL & Pacific Northwest National Laboratories (current) \\
\hline Q & source term $(\mathrm{Ci})$ \\
\hline RadCon & Radiological Control \\
\hline RF & respirable fraction \\
\hline RL & Richland Operations Office \\
\hline RSI & Radiation Sterilizers, Inc. \\
\hline SAR & Safety Analysis Report \\
\hline SARA & Superfund Amendment and Reauthorization Act of 1986 \\
\hline SARP & Safety Analysis Report for Packaging \\
\hline $\mathrm{SC}$ & safety class \\
\hline SDC & standard design criteria \\
\hline SL & safety limits \\
\hline SNL & Sandia National Laboratory \\
\hline SR & surveillance requirements \\
\hline S/RID & Standards/Requirements Identification Document \\
\hline SS & safety significant \\
\hline SSCs & systems, structures, and components \\
\hline STEL & short-term exposure limit \\
\hline SWP & special work permit (protective clothing) \\
\hline TEDF & Treated Effluent Disposal Facility \\
\hline TLD & thermoluminescent dosimeters \\
\hline TLV & threshold limit value \\
\hline TSP & trisodium phosphate (solution) \\
\hline TSR & Technical Safety Requirements \\
\hline TWA & time-weighted average \\
\hline UBC & Uniform Building Code \\
\hline USQ & Unreviewed Safety Question \\
\hline
\end{tabular}


WESF

WIXM

WMP

WPMCS

WS

WSFC

$\mathrm{X} / \mathrm{Q}$
Waste Encapsulation and Storage Facility

WESF Ion Exchange Module

Waste Management Project

WESF Process Monitor and Control System

worker safety

wet surface fluid coolers

atmospheric dose coefficient 


\section{HNF-SD-WM-BIO-002 REV 1}

This page intentionally left blank. 


\section{EXECUTIVE SUMMARY}

The Waste Encapsulation and Storage Facility (WESF) is located in the 200 East Area adjacent to B Plant on the Hanford Site north of Richland, Washington. The current WESF mission is to receive and store the cesium and strontium capsules that were manufactured at WESF in a safe manner and in compliance with all applicable rules and regulations. The scope of WESF operations is currently limited to receipt, inspection, decontamination, storage, and surveillance of capsules in addition to facility maintenance activities. The capsules are expected to be stored at WESF until the year 2017, at which time they will have been transferred for ultimate disposition.

The WESF facility was designed and constructed to process, encapsulate, and store the extracted long-lived radionuclides, ${ }^{90} \mathrm{Sr}$ and ${ }^{137} \mathrm{Cs}$, from wastes generated during the chemical processing of defense fuel on the Hanford Site thus ensuring isolation of hazardous radioisotopes from the environment. The construction of WESF started in 1971 and was completed in 1973 . Some of the ${ }^{137} \mathrm{Cs}$ capsules were leased by private irradiators or transferred to other programs. All leased capsules have been returned to WESF. Capsules transferred to other programs will not be returned except for the seven powder and pellet 'lype Woverpacks already stored at WESF.

The former WESF Safety Analysis Report (SAR) was not based on current WESF operations and was not in compliance with current mandated U.S. Department of Energy (DOE) Orders. An implementation plan (Knoll 1992. Wagoner 1994, Holten 1994, I lanson 1999) was prepared for the facility in response to DOE Orders 5480.21 , Unreviewed Safety Questions, 5480.22, Technical Safety Requirements, and 5480.23, Nuclear Safety Analysis Reports. The implementation plan identified the need to prepare a Basis for Interim Operation (BIO) document, and interim controls and restrictions until the SAR and Technical Safety Requirements (TSR) could be upgraded in accordance with the new DOE orders. The BIO and interim controls will serve as the safety basis for the Unreviewed Safety Question (USQ) process as defined in DOE Order 5480.21 until a new SAR is developed, approved, and implemented.

The WESF BIO is a hybrid of DOE-STD-3009-94, Preparation Guide for U.S. Department of Energy Nonreactor Nuclear Facility Safety Analysis Reports (DOE 1994a) and DOE-STD-3011-94, Guidance for Preparation of DOE 5480.22 (TSR) and DOE 5480.23 (SAR) Implementation Plans (DOE 1994b). Although WESF prepared a BIO, specific key chapters were developed to DOE-STD-3009 (DOE 1994a) to replace the existing WESF accident analyses and facilitate development of the new WESF SAR. These key chapters include Chapter 2 "Facility Description," Chapter 3 "Hazard and Accident Analyses," and Chapter 4 "Safety Structures, Systems, and Components." Chapter 5 of the WESF BIO and the WESF Interim Operational Safety Requirements were developed to DOE 5480.22 .

Chapter 3 of the WESF BIO contains the hazards and accident analyses. In order to determine the level of analysis necessary for the WESF BIO, a final hazard categorization was performed as required by DOE Order 5480.23 and in accordance with the guidance provided in DOE-STD-1027-92, Hazard Categorization and Accident Analysis Techniques for Compliance with DOE Order 5480.23, Nuclear Safety Analysis Reports (DOE 1992). Chapter 3.0, Section 3.3.2.2, defines WESF as a Hazard Category 2 facility.

Table 3-1 identifies the potential accidents associated with the operation of WESF. All identified accidents are prevented or mitigated below evaluation guidelines. The guidelines used in the BIO from WHC-CM-4- 46 Safey Analysis Munual are consistent with current HNF-PRO-7()4 guidelines. The analyzed accident with the worst potential consequences is the loss of pool cell water.

The WESF Interim Operational Safety Requirements, HNF-SD-WM-IOSR-001 (HNF 1998c), were developed to implement those controls identified to prevent or mitigate accidents with unmitigated consequences above the onsite and offsite evaluation guidelines. The WESF IOSRs include two Limiting Conditions for Operation (LCOS) and nine Administrative Controls (ACs). The two LCOs are for pool cell water level and K-3 HIFA filter efficiency testing. The nine ACs are source inventory controls, pool cell water makeup, hydrogen prevention controls, heavy loads over pool cells, fire protection program, flammable gas controls. Pool Cell Area Radiation Monitors. WIXM Radiation Monitoring and Venting, and WIXM Post-Use Filling of Void Space. 
Institutional safety programs also provide defense-in-depth barriers to accident conditions at WESF. A summary of the site institutional safety related controls and programs, which ensure the facility is maintained in a configuration that supports the defined safety envelope, is included in Chapter 6.0 of the WESF BIO.

In conclusion, with the analyses contained in this WESF BIO and the controls established in the IOSRs, WESF can continue to operate in a safe manner. A fully compliant WESF SAR will be prepared in accordance with DOE Order 5480.23 and the guidelines in DOE-STD-3009-94 (DOE 1994a) in fiscal year 2002 to replace the WESF BIO. 


\subsection{INTRODUCTION}

The Waste Encapsulation and Storage Facility (WESF) is located in the 200 East Area adjacent to B Plant on the Hanford Site north of Richland, Washington. The facility is currently used for interim underwater storage of cesium and strontium capsules produced during the separation of these elements at B Plant, a fission products separation facility. Interim controlled storage of the encapsulated cesium and strontium at WESF will be necessary until 2017.

Since WESF will be in use for several years, a Basis for Interim Operation (BIO) and Interim Operational Safety Requirements (lOSRs) were prepared to effectively describe the safety basis for the near term. A Safety Analysis Report (SAR) and Technical Safety Requirements (TSR) will then be prepared in accordance with the DOE Orders 5480.23, Nuclear Safety Analysis Reports, and 5480.22, Technical Safety Requirements, unless the current mission for WESF is shortened substantially.

The DOE Order 5480.23 allows for a safety analysis to be prepared using a graded approach. The level of analyses and documentation for the facility must be commensurate with the magnitude of the hazards, the complexity of the facility and/or systems, and the stage of the facility life cycle. Since the ultimate goal is to prepare a SAR in accordance with DOE Order 5480.23, the BIO approach has been expanded to include several sections using the guidelines of DOE-STD-3009-94, Preparation Guide for U.S. Department of Energy Nonreactor Nuclear Facility Safety Analysis Reports (DOE 1994a). The content and format of DOE-STD-3009-94, Chapter 2, "Facility Description," Chapter 3, "Hazard and Accident Analyses," Chapter 4, "Safety Structures, Systems, and Components, and Chapter 5, "Derivation of Technical Safety Requirements," were used for the BIO to replace comparable chapters in WHC-CM-4-46, Section 8.0, "Interim Safety Basis" [Note: the WHC-CM-4-46 mantual has been replaced with Hanford Site Procedures (IINF-PRO's) and there is no longer a procedure on preparing Interim Salety Bases]. In addition, the generic institutional safety related controls and programs section discussed in Section 8, has been reformatted to include the guidelines of DOE-STD-3009-94 (DOE 1994a) for each program and combined into a single chapter, Chapter 6.0, "Safety Related Programs and Controls," of this BIO. The remaining sections of the BIO observe the content and format guidelines of WHC-CM-4-46, Section 8.0, "Interim Safety Basis." The IOSRs observe the old format and content guidelines of WHC-CM-4-46, Section 6.0, "Technical Safety Requirements" which are consistent with the existing llanford Site Procedure. IINF-PRO-700, Safiofy" Analysis and Technical Saftety Re'yircments. The guidelines of DOE-STD-3011-94, Guidance for Preparation of DOE 5480.22 (TSR) and DOE 5480.23 (SAR) Implementation Plans (DOE 1994b), identify a format and content for the preparation of a BIO. The WESF BIO is a hybrid of WHC-CM-4-46, Section 8.0, DOE-STD-3011-94 (DOE 1994b), and DOE-STD-3009-94 (DOE 1994a) requirements. Table 1-1, identifies where DOE-STD-301 1-94 (DOE 1994a) required information is located in the WESF BIO.

Table 1-1. DOE-STD-3011-94 and WESF BIO Cross-Reference.

\begin{tabular}{|l|c|c|l|}
\hline \multicolumn{2}{|c|}{ DOE-STD-3011-94 } & \multicolumn{2}{c|}{ WESF BIO } \\
\cline { 2 - 4 } & CHAPT & SECT & \\
\hline Executive Summary & ES & & Executive Summary \\
\hline Introduction & 1.0 & 1.1 & "Purpose" \\
\hline Reasons for the BIO & 1.0 & 1.2 & "Facility Background" \\
Brief Facility Background & 1.0 & 1.3 & "Current Mission" \\
\cline { 2 - 4 } $\begin{array}{l}\text { Current Mission } \\
\text { Contribution to the Site Mission } \\
\text { Past Relevant Operating History } \\
\text { Status of the Existing Authorization Basis }\end{array}$ & 1.0 & 1.4 & "Contribution to the Site Mission" \\
\cline { 2 - 5 } & 1.0 & 1.5 & "Relevant Operating History" \\
\cline { 2 - 5 } & 1.0 & 1.6 & "Existing Authorization Basis" \\
\hline
\end{tabular}


HNF-SD-WM-BIO-002 REV 1

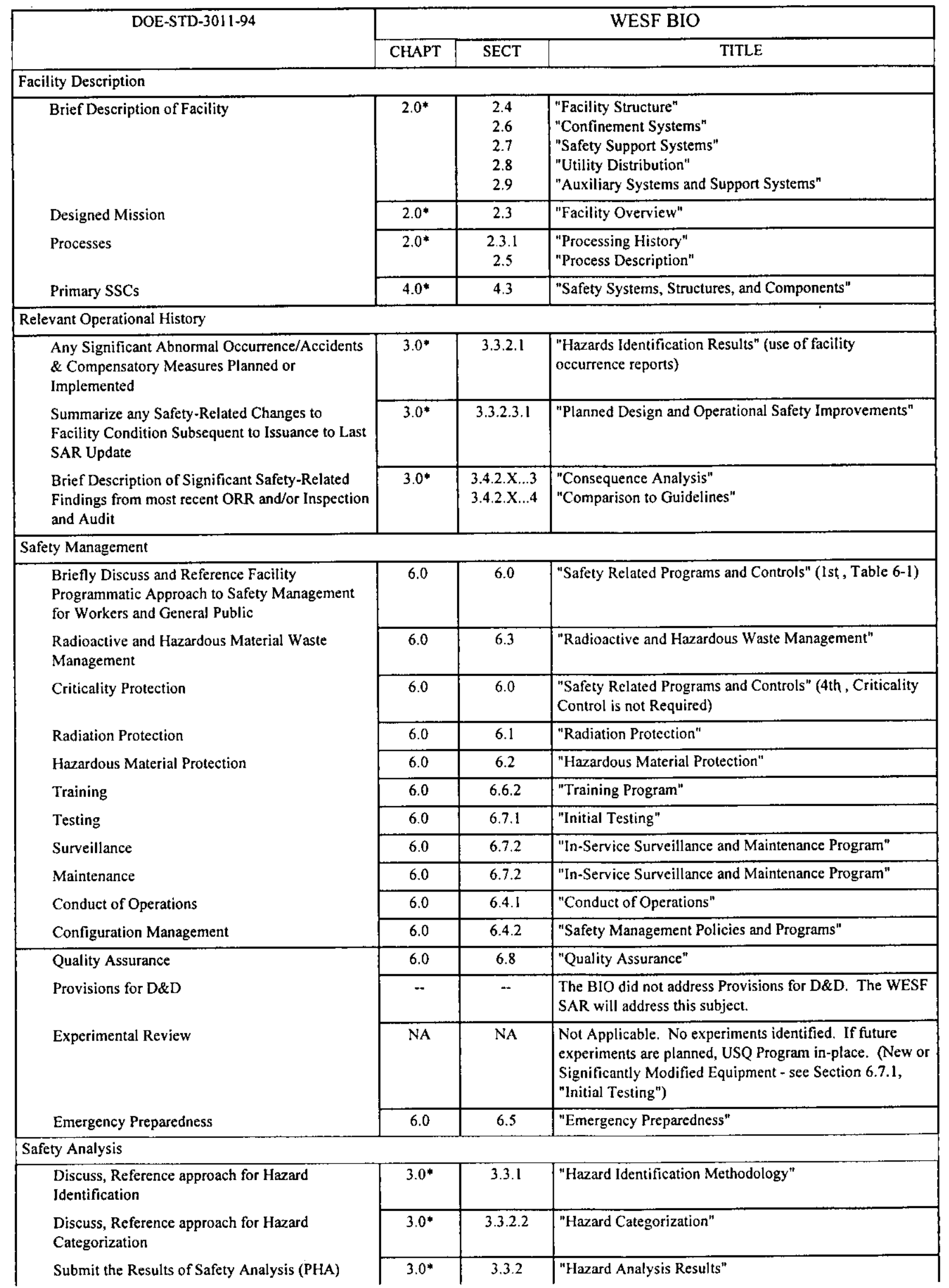


HNF-SD-WM-BIO-002 REV 1

\begin{tabular}{|c|c|c|c|}
\hline \multirow[t]{2}{*}{ DOE-STD-3011-94 } & \multicolumn{3}{|r|}{ WESF BIO } \\
\hline & CHAPT & SECT & TITLE \\
\hline $\begin{array}{l}\text { Provide a description of the Analytical Methods } \\
\text { and Results }\end{array}$ & $3.0^{*}$ & $\begin{array}{l}3.4 .1 \\
3.4 .2\end{array}$ & $\begin{array}{l}\text { "Methodology" } \\
\text { "Design Basis Accidents" }\end{array}$ \\
\hline $\begin{array}{l}\text { Discuss impact of postulated accidents on workers } \\
\text { and general public }\end{array}$ & $3.0^{*}$ & $\begin{array}{l}3.4 .2 . X \ldots 3 \\
3.4 .2 . X \ldots 4\end{array}$ & $\begin{array}{l}\text { "Consequence Analysis" } \\
\text { "Comparison to Guidelines" }\end{array}$ \\
\hline $\begin{array}{l}\text { Evaluate the potential (from postulated accidents) } \\
\text { for contamination of the environment, } \\
\text { particularly, those with significant insult and } \\
\text { easily implemented changes to mitigate }\end{array}$ & $3.0^{*}$ & 3.3 .2 .3 .4 & "Environmental Protection" \\
\hline $\begin{array}{l}\text { Identify and evaluate the dominant accident } \\
\text { scenarios, including vulnerabilities, and describe } \\
\text { controls, restrictions }\end{array}$ & $3.0^{*}$ & $\begin{array}{c}3.4 .2 . \mathrm{X} \\
3.4 .2 . \mathrm{X}\end{array}$ & $\begin{array}{l}\text { Design Basis Accident } \\
\text { "Summary of Safety SSCs and IOSR Controls" }\end{array}$ \\
\hline $\begin{array}{l}\text { Identify systems functions and operator actions } \\
\text { that have been accredited in the accident } \\
\text { scenarios. }\end{array}$ & $3.0^{*}$ & $3.4 .2 . X \ldots 5$ & "Summary of Safety SSCs and IOSR Controls" \\
\hline $\begin{array}{l}\text { Describe the approach to derive estimates for } \\
\text { credited system unavailabilities and operator error } \\
\text { probabilities. }\end{array}$ & - & -- & $\begin{array}{l}\text { The BIO analyses did not take credit for frequency, except } \\
\text { in the DBE evaluation section of the B Plant endwall } \\
\text { impacting A Cell. See Section 3.4.1, "Methodology." }\end{array}$ \\
\hline $\begin{array}{l}\text { Discuss the potential for administrative controls, } \\
\text { compensatory or corrective measures, or } \\
\text { restrictions to reduce the consequences or } \\
\text { frequencies of the highest risk scenarios }\end{array}$ & $3.0^{*}$ & $3.4 .2 . X \ldots 5$ & "Summary of Safety SSCs and IOSR Controls" \\
\hline $\begin{array}{l}\text { For lower risk scenarios, identify cost-effective or } \\
\text { simple fixes for risk reduction and assess } \\
\text { adequacy of existing safeguards, etc. }\end{array}$ & $3.0^{*}$ & 3.3 .2 .3 .2 & "Defense-In-Depth" \\
\hline \multicolumn{4}{|l|}{ Operational Controls } \\
\hline $\begin{array}{l}\text { Discuss the controls in place that maintain the } \\
\text { safety envelope of the facility; OSRs, restrictions } \\
\text { on operations, and administrative controls }\end{array}$ & $\begin{array}{l}5.0^{*} \\
\text { IOSRs }\end{array}$ & 5.3 & $\begin{array}{l}\text { "Interim Operational Safety Requirements Coverage" } \\
\text { Table 5-1 } \\
\text { WESF Interim Operational Safety Requirements }\end{array}$ \\
\hline $\begin{array}{l}\text { Identify the safety function, gradation of safety } \\
\text { systems, operability requirements procedures, } \\
\text { surveillances, and OSRs }\end{array}$ & $\begin{array}{l}3.0^{*} \\
4.0^{*} \\
5.0^{*} \\
\text { IOSRs }\end{array}$ & $\begin{array}{c}3.4 .2 . X \ldots 5 \\
4.3 . X \\
5.3\end{array}$ & $\begin{array}{l}\text { "Summary of Safety SSCs and IOSR Controls" } \\
\text { System Titles } \\
\text { "Interim Operational Safety Requirements Coverage" } \\
\text { Table 5-1 } \\
\text { WESF Interim Operational Safety Requirements }\end{array}$ \\
\hline \multirow[t]{2}{*}{$\begin{array}{l}\text { Identify any safeguards that are considered } \\
\text { significant contributors from a defense-in-depth } \\
\text { perspective }\end{array}$} & $3.0^{*}$ & 3.3 .2 .3 .2 & "Defense-In-Depth" \\
\hline & 7.0 & & References \\
\hline
\end{tabular}

* Complies with DOE-STD-3009-94, "Preparation Guide for U.S. Department of Energy Nonreactor Nuclear Facility Safety Analysis Reports"

The new safety documentation identifies hazards associated with the current capsule storage mission and quantitatively analyzes those hazards with the potential for exceeding predetermined dose consequences for the nonWESF facility worker and the public. In addition, accident consequences to the environment and the WESF facility worker are identified. Administrative and engineered controls are used to prevent or mitigate the risk associated with the hazards to the WESF and non-WESF facility worker, the public, and the environment.

\subsection{PURPOSE}

This document establishes a basis for interim operation for WESF in accordance with the requirements of WHC-CM-4-46, Safety Analysis Manual, Sections 8.0, and 6.0 (equivalent to existing procedures HNF-PRO-700 and IINF-PRO-704, Hotard and Accident Analysis Process).

The BIO and IOSRs provide the authorization basis to be used with the USQ process as defined in DOE 
Order 5480.21, Unreviewed Safety Questions, and IINF-PRO-062, Identifying and Resolving Unreviewed Safety Questions. The BIO and IOSRs are in compliance with the implementation plan (Wagoner 1994, Holten 1994, WHC-SP-1164. Ilanson 1999) for DOE Orders 5480.21, 5480.22, and 5480.23.

\subsection{FACILITY BACKGROUND}

The WESF facility was designed and constructed for radioactive cesium and strontium processing, encapsulation, and capsule storage. The original role of the WESF waste management program was to process, encapsulate, and store the extracted long-lived radionuclides, ${ }^{90} \mathrm{Sr}$ and ${ }^{137} \mathrm{Cs}$, from wastes generated during the processing of defense fuel on the Hanford Site. The cesium and strontium feed materials used in WESF were separated from tank wastes and concentrated in B Plant before final processing in WESF. The products cesium chloride and strontium fluoride were doubly encapsulated and stored underwater in the WESF pool cells, where they remain today. Some of the encapsulated products were shipped offsite and either leased by private irradiators or transferred to other programs for removal of the product from the capsules. All leased capsules have been returned to WESF. Processing of the cesium and strontium feed materials was completed in 1983 and 1985, respectively.

Shutdown of the cesium, strontium, and capsule handling processes involved equipment cleanout, equipment isolation or removal, jumper removal, nozzle blanking, and instrumentation deactivation for the hot cells. Only equipment and instruments that were required for cell maintenance and surveiliance remained operational in the hot cells. Cleanup efforts included refurbishment of most of the hot cells' cerium windows.

\subsection{CURRENT MISSION}

The current WESF mission is to store the Hanford Site's inventory of cesium and strontium capsules in a safe manner and in compliance with all applicable rules and regulations. See section 2.3 .2 for additional detail regarding the WFSF nission.

\subsection{CONTRIBUTION TO THE SITE MISSION}

WESF is one component of the Hanford Site waste management program. The original role of WESF was to process, encapsulate, and store the extracted long-lived radionuclides, ${ }^{90} \mathrm{Sr}$ and ${ }^{137} \mathrm{Cs}$, from wastes generated during the chemical processing of defense fuel produced on the Site. Today, safe storage of the encapsulated ${ }^{90} \mathrm{Sr}$ and ${ }^{137} \mathrm{Cs}$ until final disposition is the only mission for the facility.

\subsection{RELEVANT OPERATING HISTORY}

The relevant operating history of WESF includes: past significant occurrences or accidents and compensatory measures; safety-related changes to the facility condition since the last safety analysis update; and any safety-related findings from recent inspections, audits, or analyses.

WESF has not experienced an accidental release of hazardous material outside of the facility, since the start of operations. However, several operational events and unusual occurrences have occurred and are summarized in the following categories; capsule upsets, facility near-accident events, and unusual occurrences.

A capsule upset was detected at WESF in the past. A leak in an outer capsule was discovered by operating personnel when the inner capsule failed to pass the inner capsule movement test and upon visual examination, was observed to be leaking steam from a series of microfissures in the area of the end cap weld. This capsule has been re-encapsulated in a Type W overpack and returned to the WESF facility with twenty-two ot ther Type W overpack capsules for storage in the pool cells.

Facility near-accident events are those events which might resemble an accident condition, such as a fire, but which resulted in only operational consequences. These include:

- A partial flood of a K-3 filter housing through the filter washdown system, which resulted in an operational upset to the K-3 system. 
- During the processing period when encapsulation of cesium and strontium was occurring in the hot cells, fires inside the hot cells were reported. Such fires were small and adequately controlled by movement of other combustibles away from the location of the fire.

- A hot cell was flooded when the processing water feed valve inside the hot cell was inadvertently left open. The water level in the hot cell reached approximately half way up the cerium window.

Several unusual occurrences at WESF, including; spread of contamination, facility worker hazards (electrical, falls, etc.), equipment failures, operator and management errors, etc. are documented in the Occurrence Reporting and Processing System database.

Several WESF modifications and upgrades were completed since the last update to the $\mathrm{BIO}$, including; decoupling from B Plant, installation of the pool cell closed-loop cooling system (CLCS), installation of the pool cell emergency ion exchange system (EMIX), and installation of the new low level liquid waste (LLLLW) system. The CLCS replaced the once through cooling system and reduced liquid effluent discharge. The pool cell EMIX system and LLLW systems replaced systems that were dependent on B Plant.

During the preparation of this safety basis document, analyses disclosed several areas of safety-related concerns. All concerns have been addressed with compensatory measures as necessary. No new areas of concern were identified during the annual update.

\subsection{EXISTING AUTHORIZATION BASIS}

An implementation plan (Knoll 1992) was prepared for the facility in response to DOE Orders 5480.21 , 5480.22 , and 5480.23. The implementation plan identified the need to prepare a BIO and interim controls and restrictions until the SAR and TSRs could be upgraded in accordance with the new DOE orders. The implementation plan was transmitted to DOE, along with the other Hanford Site facility implementation plans, on October 28, 1992 and has since been approved (Wagoner 1994, Holten 1994. Wanson 1999). The WFSF BIO and IOSRs were approved and implemented in FY 1998 and will continue to serve as the safety basis for the unreviewed safety question (USQ) process as defined in DOE Order 5480.21 until a SAR is developed, approved, and implemented. 
HNF-SD-WM-BIO-002 REV 1

This page intentionally left blank. 


\subsection{FACILITY DESCRIPTION}

This chapter provides a description of the Waste Encapsulation and Storage Facility (WESF) in accordance with DOE Order 5480.23 as amplified by DOE-STD-3009-94 (DOE 1994a). In addition to supplying an overall understanding of the facility, the facility description provides the basis for the assumptions made in the hazards and accident analysis (Chapter 3.0 ).

In accordance with the precepts of the graded approach described in DOE 5480.23, the following topics are discussed in this chapter:

- Overview of the facility including history and mission (Section 2.3),

- Facility structure and design basis (Sections 2.2 and 2.4),

- Facility process (Section 2.5 ),

- Confinement systems (Section 2.6),

- Facility safety support systems (Section 2.7),

- Facility utilities (Section 2.8),

- Facility auxiliary systems and support buildings (Section 2.9).

I The systems, structures, and components (SSCs) and operational parameters identified in Chapter 3.0 as important to safety are discussed in a level of detail that is commensurate with their impact on safety. The SSCs and operational parameters not identified as important to safety in Chapter 3.0 are discussed only in sufficient detail to provide an overall understanding of the facility and its mission.

\subsection{INTRODUCTION}

The 225-B Building, is adjacent to the west end of B Plant, 221-B Building, both of which are situated in the Hanford 200 East Area (see Figures 2-1 and 2-2). The WESF facility consists of the 225-B Building and the following support buildings and systems:

- TK-100, Low Level Waste Tank and Pit

- 211-BA, Auxiliary Building

- 218-B, Emergency Equipment Storage

- 225-BA, K-1 Filter Building

- 225-BB, K-3 Filter Pit

- 225-BC, WESF Compressor Building

- 225-BD, WESF Waste Monitor and Sample Building

- 225-BE, Maintenance Shop

- 225-BF, Utility Building

- 225-BG, WESF Closed Loop Cooling Equipment Building 
- 272-B, WESF Support Building

- 272-BA, Auxiliary Building

- 272-BB, Auxiliary Building

- 282-B, Pump House

- 282-BA, Pump House

- 296-B-10, K-1 and K-3 Exhaust Stack

- 294-B, Raw Water Backflow Preventer Building

- Diesel Generator

- $\quad$ TK-50 Pit

- MO-312, Laundry Storage Trailer

The WESF facility and support buildings are shown in Figure 2-3.

\subsection{REQUIREMENTS}

Several codes and standards were used for the design of WESF and are listed in this section. Current codes and standards applicable to WESF are identified in the WESF standards/requirements identification document (S/RID). The design codes, standards, regulations, and U.S. Department of Energy (DOE) orders that are pertinent to the structure, confinement systems, utility systems, and safety support systems with respect to the safety analysis are described in Chapter 4.0.

The WESF facility was designed in the late 1960s. The facility structures were designed in accordance with the following codes and standards in effect at the time of design:

- Building Code for Reinforced Concrete (American Concrete Institute [ACI] 318-63)

- Specifications for the Design of Structural Steel (American Institute of Steel Construction [AISC] Manual)

- Hanford Standards Design Criteria (HWS-10,000 and HES 10,008)

- The Uniform Building Code (UBC), 1970

- American Standards Building Code for Masonry (Standards)

- Underwriters Laboratories, Inc. (Standards)

- National Fire Protection Association (Standards). 
Figure 2-1. Han ford Site Map.

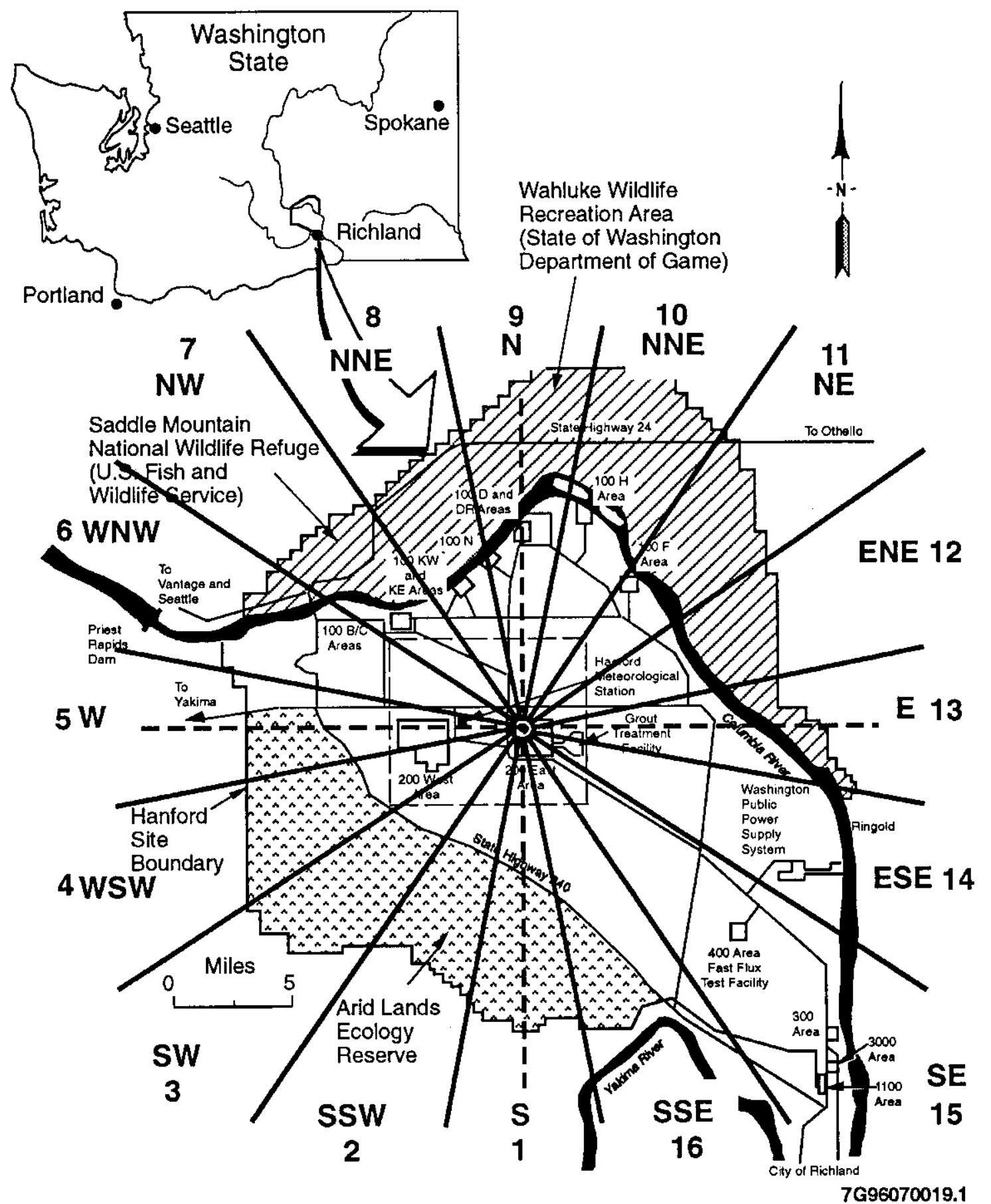




\section{HNF-SD-WM-BIO-002 REV 1}

Figure 2-2. 200 East Area

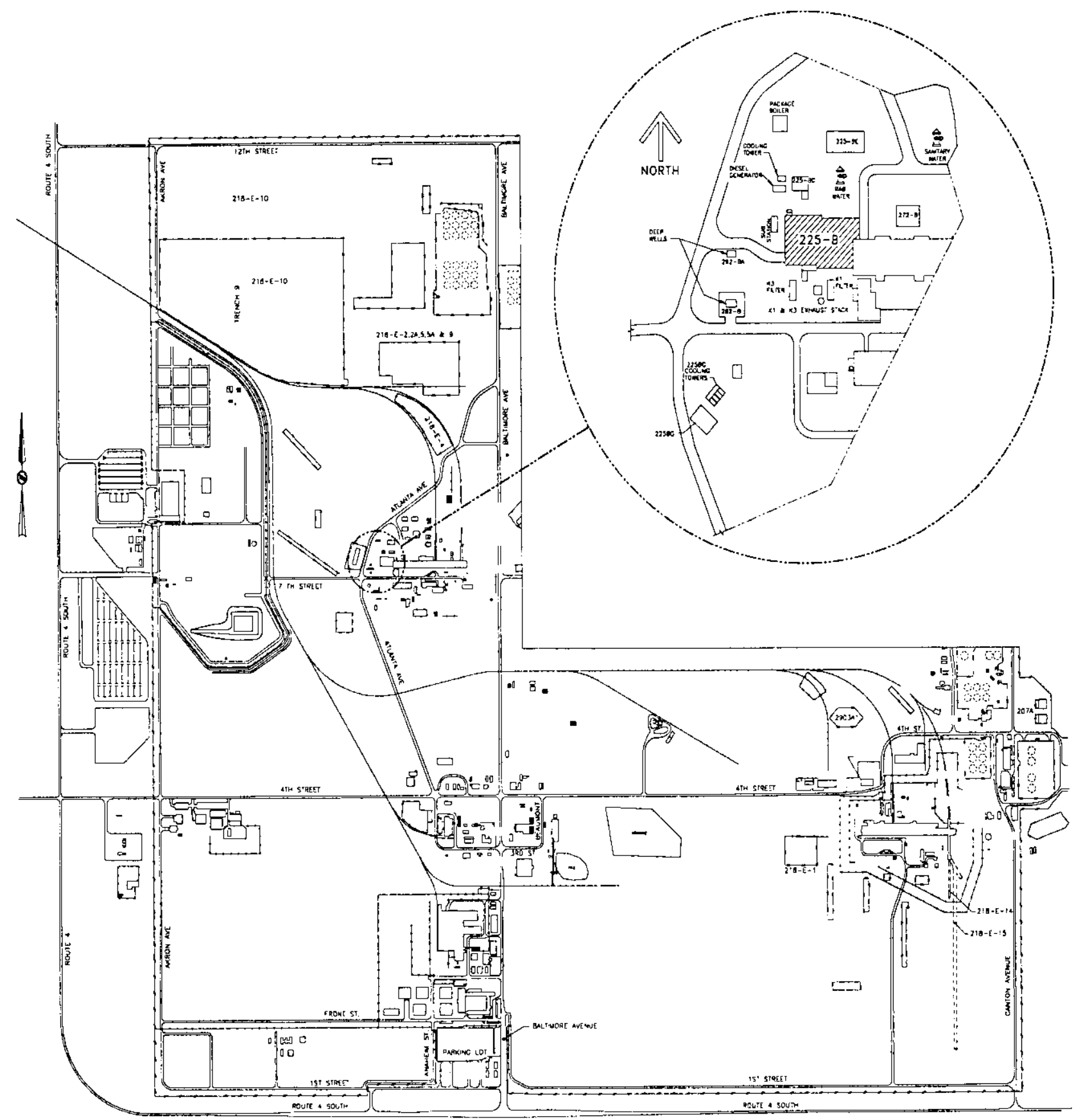


Figure 2-3. WESF Site Plan.

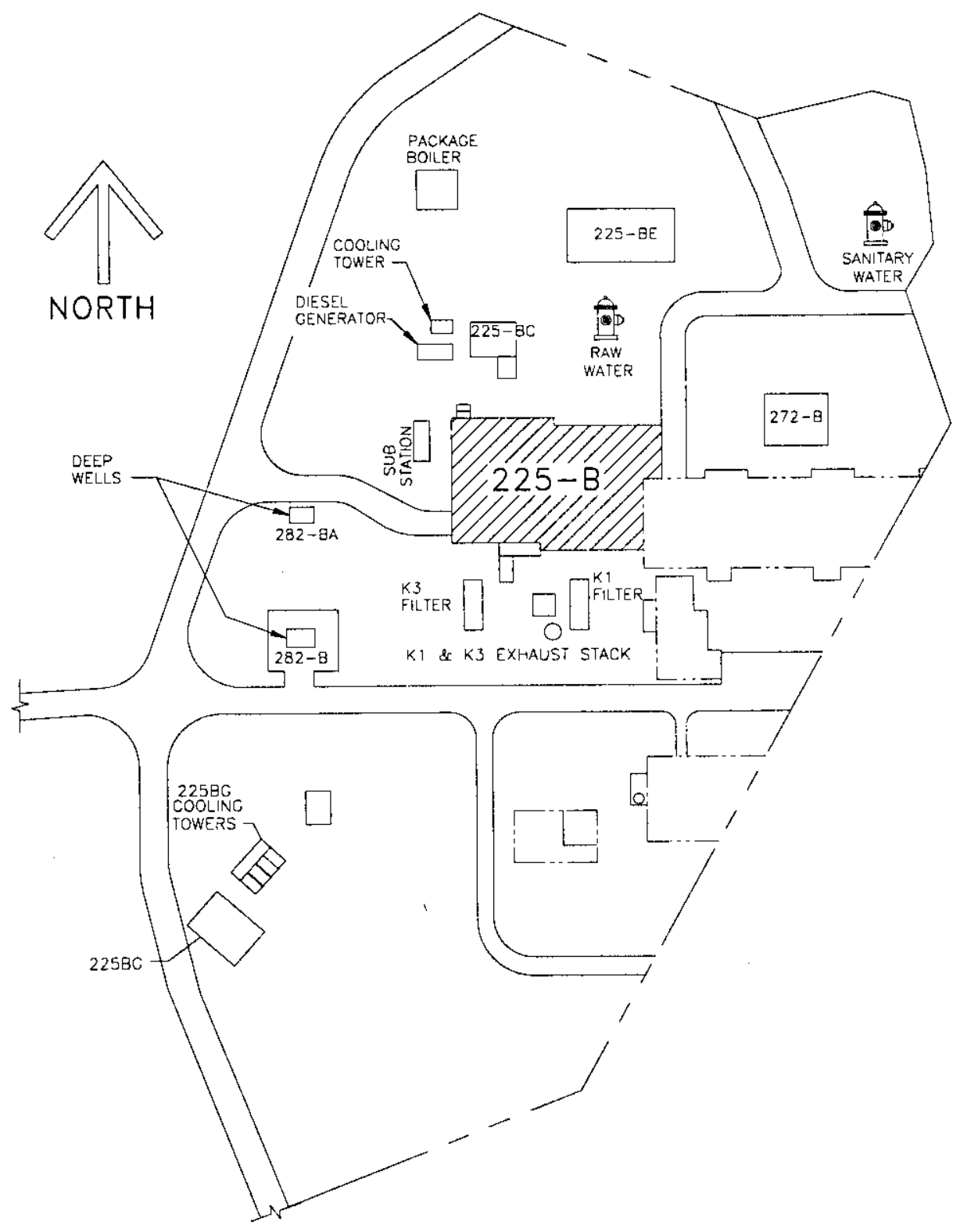




\section{HNF-SD-WM-BIO-002 REV 1}

The WESF facility was designed prior to the implementation of Standard Architectural-Civil Design Criteria, Design Loads for Facilities (SDC), SDC 4.1, Rev. 12, (DOE-RL 1993) [now HNF-PRO-097 Engineering Design and Evaluation!, however this standard was used for comparison purposes in a review of natural phenomena (Wagenblast, et al. 1999).

\subsection{FACILITY OVERVIEW}

The WESF facility was designed and constructed to process. cncapsulate. and store the extracted long-lived radionuclides, ${ }^{\text {" }} \mathrm{Sr}$ and ${ }^{1 / 7} \mathrm{Cs}$. from wastes generated during the chemical processing of defense fuel on the Hanford Site. The construction of WESF, 225-B Building, started in 1971 and was completed in 1973. Cesium processing was shut down in October 1983 and strontium processing was shut down in January 1985. Final overall process shutdown was accomplished in September 1985. Shut down for the essium and strontium processes involved equipment cleanout. equipment isolation or removal. jumper removal. nozzle blanking. ceriun window refurbishment. and instrumentation deactivation for the hot cells. Only eqtipment and instruments that were recpuired for cell maintenance and surveillance remained operational in the hot cells. WESF continues to store the Hanford Site's inventory of cesium and strontium capsules in the pool cells.

\subsubsection{Processing History}

Using process technology developed by Pacific Northwest Laboratory (PNL), cesium and strontium encapsulation started in the fall of 1974 . The cesium and strontium feed materials used in WESF were separated from tank wastes and concentrated in B Plant before final processing in WESF. The products cesium chloride and strontium fluoride were doubly encapsulated and stored underwater in the WESF pool cells. Some of the encapsulated products were shipped offsite. These capsules were either leased by private irradiators or transferred to other programs for removal of the product from the capsules. Processing and encapsulation of the cesium and strontium feed materials was completed in 1985.

\subsubsection{Strontium Encapsulation.}

1 The strontium encapsulation process used concentrated strontium nitrate solution generated by B Plant. The solution $\mathrm{pH}$ was adjusted with sodium hydroxide and was then converted to a strontium fluoride precipitate by adding sodium fluoride. The precipitate was then filtered and washed to remove excess sodium and fluoride. The filtrate was fired at $1073 \mathrm{~K}\left(800^{\circ} \mathrm{C}\right)$ for 8 hours in a sintering furnace to eliminate moisture and volatile components. The dried $\mathrm{SrF}_{2}$ was then added into a stainless steel hastelloy inner capsule in increments and compacted after each addition. A sintered metal disk to aid in helium leak checking was added to each inner capsule and the capsule was purged with helium. The capsule was then capped, welded, helium leak checked to verify integrity of the inner capsule weld, and decontaminated before insertion into a stainless steel outer capsule. The outer capsule cap was welded in place, and the weld was examined ultrasonically. The curie content of the ${ }^{90} \mathrm{Sr}$ capsule was then determined using a calorimeter. After the curie content was determined, the capsule was placed in a pool cell storage rack. Approximately $37 \mathrm{MCi}$ of ${ }^{90} \mathrm{Sr}$ were encapsulated between September 1974 and January 1985 , when the strontium encapsulation process was completed. The half-life of ${ }^{90} \mathrm{Sr}$ is 29 years.

\subsubsection{Cesium Encapsulation.}

The cesium encapsulation process was started in 1974. The purified cesium carbonate solution generated by B Plant was converted to a cesium chloride solution by adding hydrochloric acid. The solution was then transferred to the evaporator-melter where the cesium chloride solution was evaporated to a dry salt. The salt was melted and transferred into stainless steel inner capsules. A sintered metal disk was added to each inner capsule, and the capsule was purged with helium. The capsule was then capped, welded, helium leak checked to verify the integrity of the inner capsule weld, and decontaminated before insertion into a stainless steel outer capsule. The outer capsule cap was welded in place, and the weld was examined ultrasonically. The curie content of the ${ }^{137} \mathrm{Cs}$ capsule was then determined using a calorimeter. After the curie content was determined, the capsule was placed in 
a pool cell storage rack. Approximately $86 \mathrm{MCi}$ of ${ }^{137} \mathrm{Cs}$ were encapsulated before the cesium encapsulation process was completed in October 1983 . The half-life of ${ }^{137} \mathrm{Cs}$ is 30 years.

\subsubsection{Pool Cells.}

During production, Pool Cell 1 served as a surveillance pool. One capsule from every fifth batch of cesium processed and one capsule from every tenth batch of strontium processed were stored in this pool for observation. The remaining capsules were stored in Pool Cells 3 through 6, which normally had cover blocks in place except when the pool received capsules.

\subsubsection{Beneficial Capsule Use.}

A number of cesium capsules produced at WESF were leased to private enterprises for use as radiation sources. All leased capsules have been returned to WESF.

\subsubsection{Current Mission}

The current WESF mission is to receive and store the cesium and strontium capsules that were manufactured at WESF in a safe manner and in compliance with all applicable rules and regulations. The scope of the WESF mission is currently limited to the following activities: (1) facility maintenance activities; (2) receipt, inspection, and decontamination (if necessary) of capsules; and (3) storage and surveillance of capsules.

| The WESF operations include maintenance activities. decontamination of equipment and capsules, and surveillance of stored capsules. The capsules are expected to be stored at WESF until the year 2017, at which time they will be transferred for ultimate disposition.

The following activities are specifically excluded from the scope of this safety basis document:

- Cesium chloride or strontium fluoride salt retrieval, processing, or repackaging,

- Capsule experimentation or destructive testing,

- Facility transition to decontamination and decommissioning activities,

- Alternative modes of capsule disposal and storage, such as those evaluated in the WESF Hazards and Operability Study (HAZOP) (Siemer 1995),

- Capsule electropolishing,

- Wet storage of capsules in hot cells,

- Receipt of any capsule not meeting WESF capsule storage criteria (Section 2.5.3.1.1),

- K-3 filter changeout.

\subsection{FACILITY STRUCTURE AND FUNCTIONAL AREAS}

The 225-B Building, WESF, consists of the following functional areas:

- Hot Cells

- Canyon

- Service Gallery 


\section{HNF-SD-WM-BIO-002 REV 1}

- Operating Gallery

- Aqueous Makeup (AMU)

- Transmitter Rooms

- HVAC Room

- Hot and Cold Manipulator Shops

- Manipulator Repair Shop

- Pool Cell Area

- Pool Cell Monitoring Area

- Supervisory Room

- Support Area (offices and change rooms)

- Truckport.

The original project design of the 225-B Building included a seismic design analysis and review (evaluation of original analyses is contained in Wagenblast, et al. 1999). The previous onsite Architect/Engineer, VITRO Engineering, conducted the necessary seismic analysis, wind load analysis, soil pressure analyses for retaining walls in the Pool Cells and K-3 Filter Pit, and hydrodynamic (seismic sloshing) analysis for the pool cells. Additional seismic discussion can be found in Chapters 3.0 and 4.0 .

\subsubsection{5-B Building}

The 225-B Building is adjacent to and structurally independent of the existing B Plant (221-B Canyon Building) to the east (Wagenblast, et al. 1999). A 0.6-cm (1/4-in.) expansion joint exists between the 225-B Building and the 221-B Building from the foundation to the first floor slab. The building is divided into Area 1. Area 2. and Area 3, sec Figure 2-3a. The 225-B Building is a two-story structure $48 \mathrm{~m}$ ( $157 \mathrm{ft}$ ) long by $30 \mathrm{~m}$ ( $97 \mathrm{ft}$ )

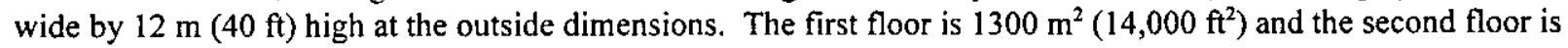
$600 \mathrm{~m}^{2}\left(6,000 \mathrm{ft}^{2}\right)$. The ground elevation at this facility is about $213 \mathrm{~m}(700 \mathrm{ft})$ above sea level and is

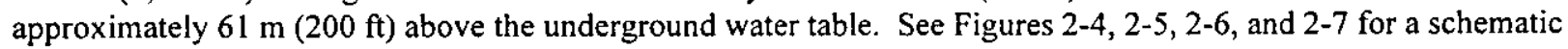
plan of the building.

Area 1 is a one-story above grade reinforced masonry wall structure with a metal deck diaphragm roof supported on open-web steel joists and steel beams and includes the WESF Support Area, heating ventilating and air conditioning (HVAC) room, pool cell entry airlock, and Pool Cell Monitoring Area. The foundation spread footings, grade slab, and masonry walls of the Support Area are separated from the rest of the structure and the 221-B Building by a $0.6-\mathrm{cm}(1 / 4-i n$.) expansion joint. The roof deck joists and beams bear on masonry shear walls at the north and east, on the reinforced concrete wall enclosing the Operating Gallery (south), and on the 221-B Building at the south. Slotted holes in both the north/south and the east/west directions are provided in the bearing brackets on the Operating Gallery, Pool Cell Area, and the 221-B walls to allow for a 5-cm (2-in.) seismic joint between the Support Area and HVAC Room roof and adjacent structures. The roof is structurally dependent on the adjacent structures for resisting both dead and live gravity loads (such as snow and ashfall). 
Figure 2-3a. 225-B Area 1, Area 2 and Area 3.

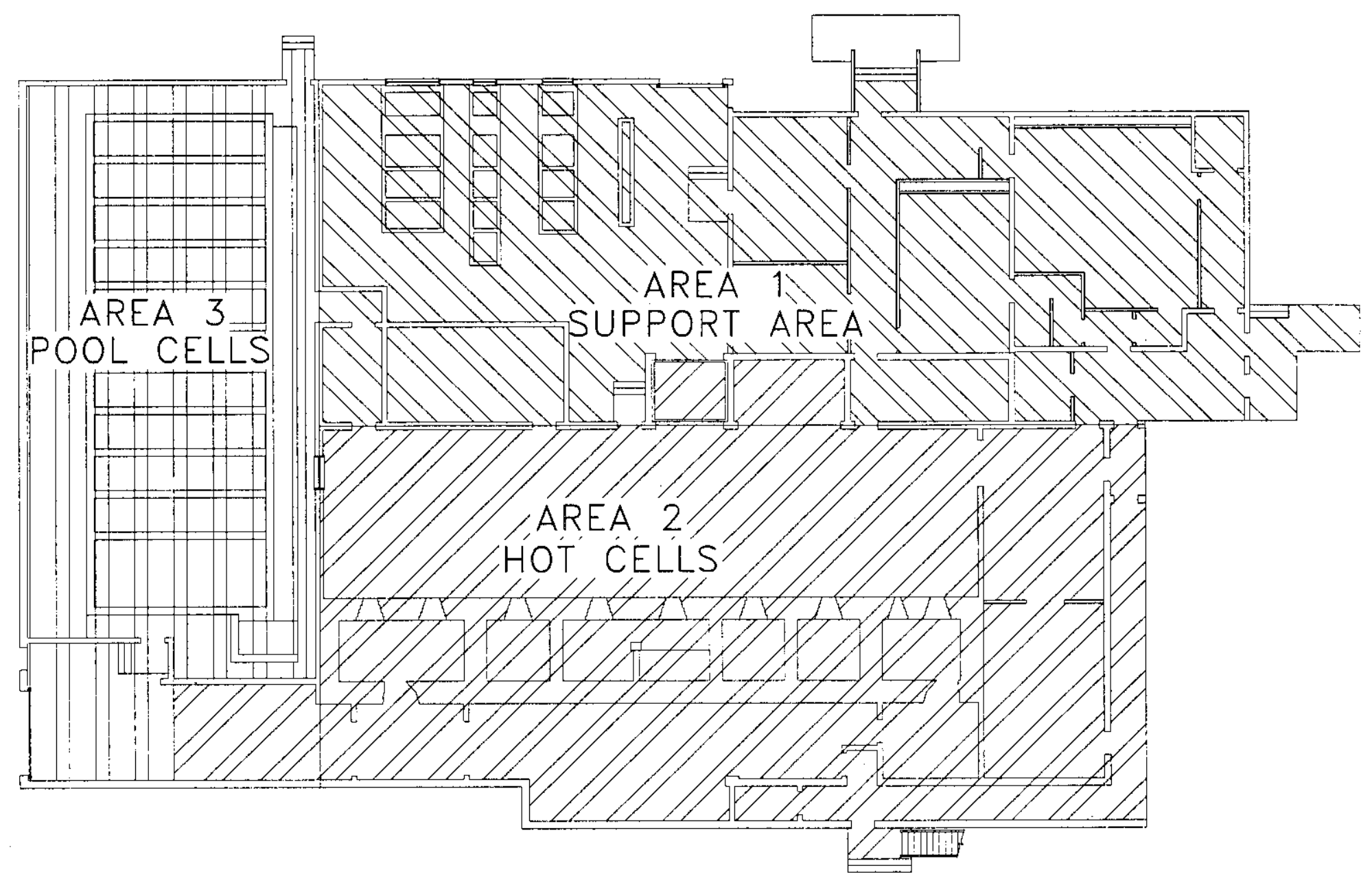


Figure 2-4. 225-B, First Floor Plan.

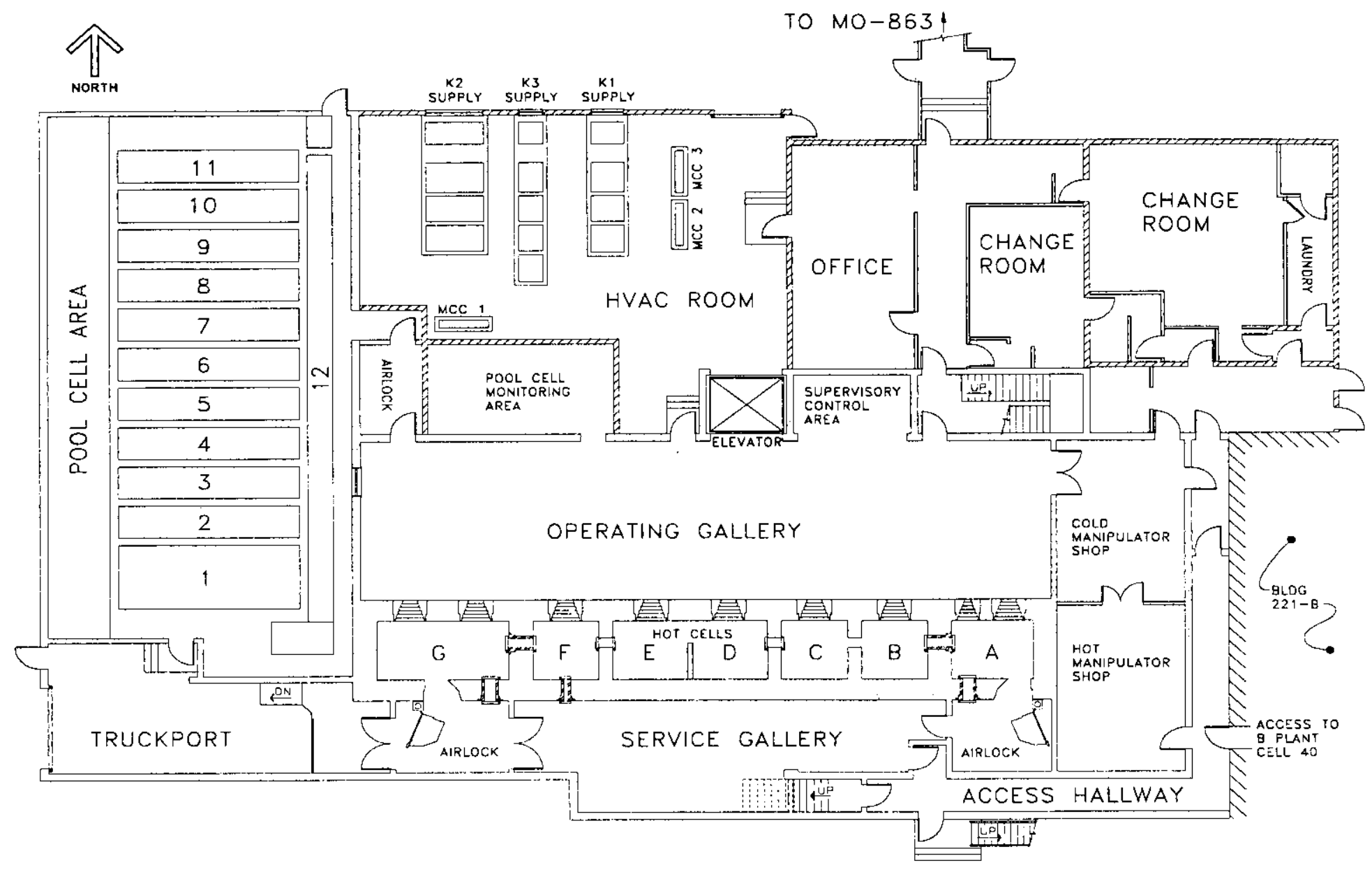


HNF-SD-WM-BIO-002 REV 1

Figure 2-5. 225-B, Second Floor Plan.

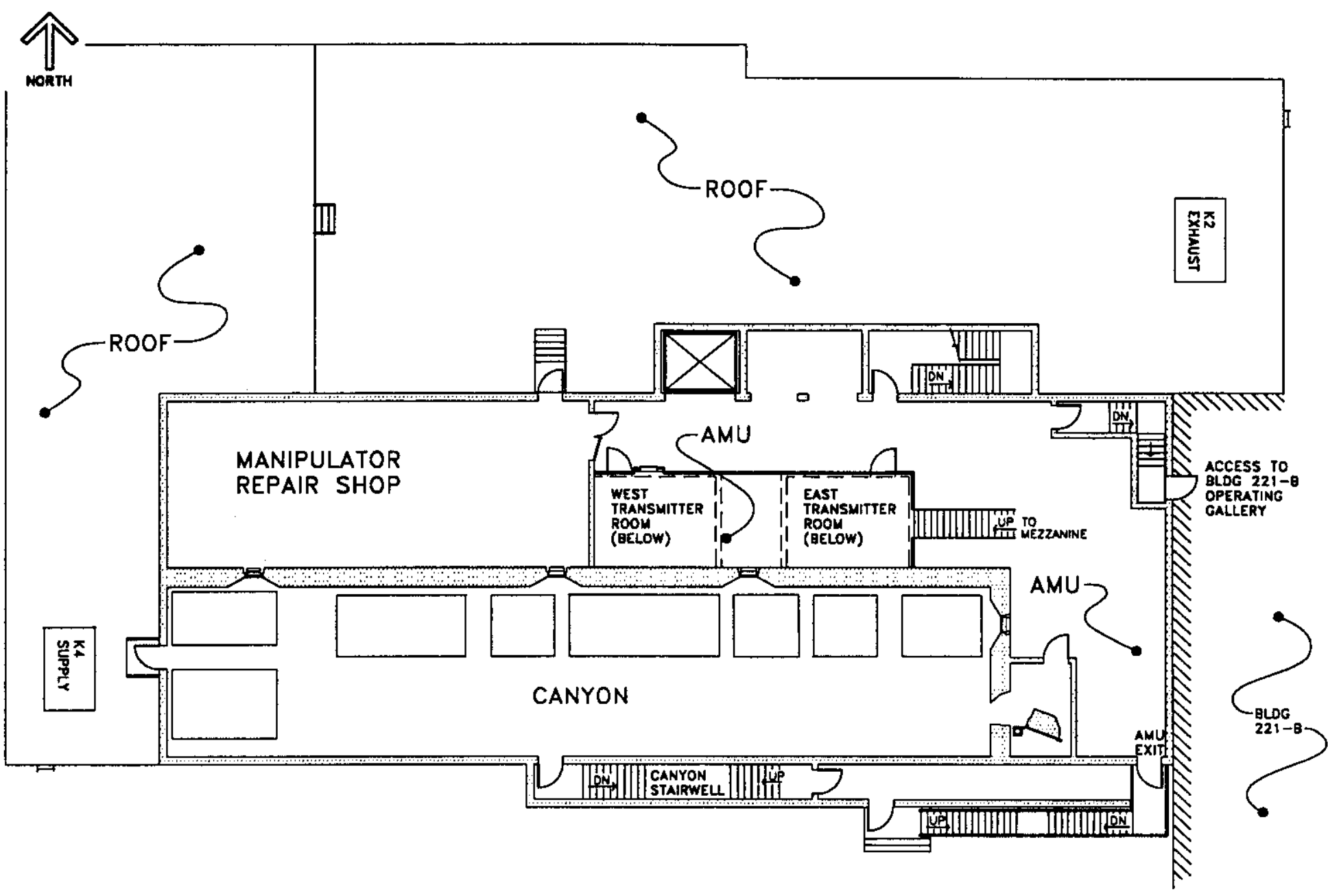




\section{HNF-SD-WM-BIO-002 REV 1}

Figure 2-6. East-West Sectional View.

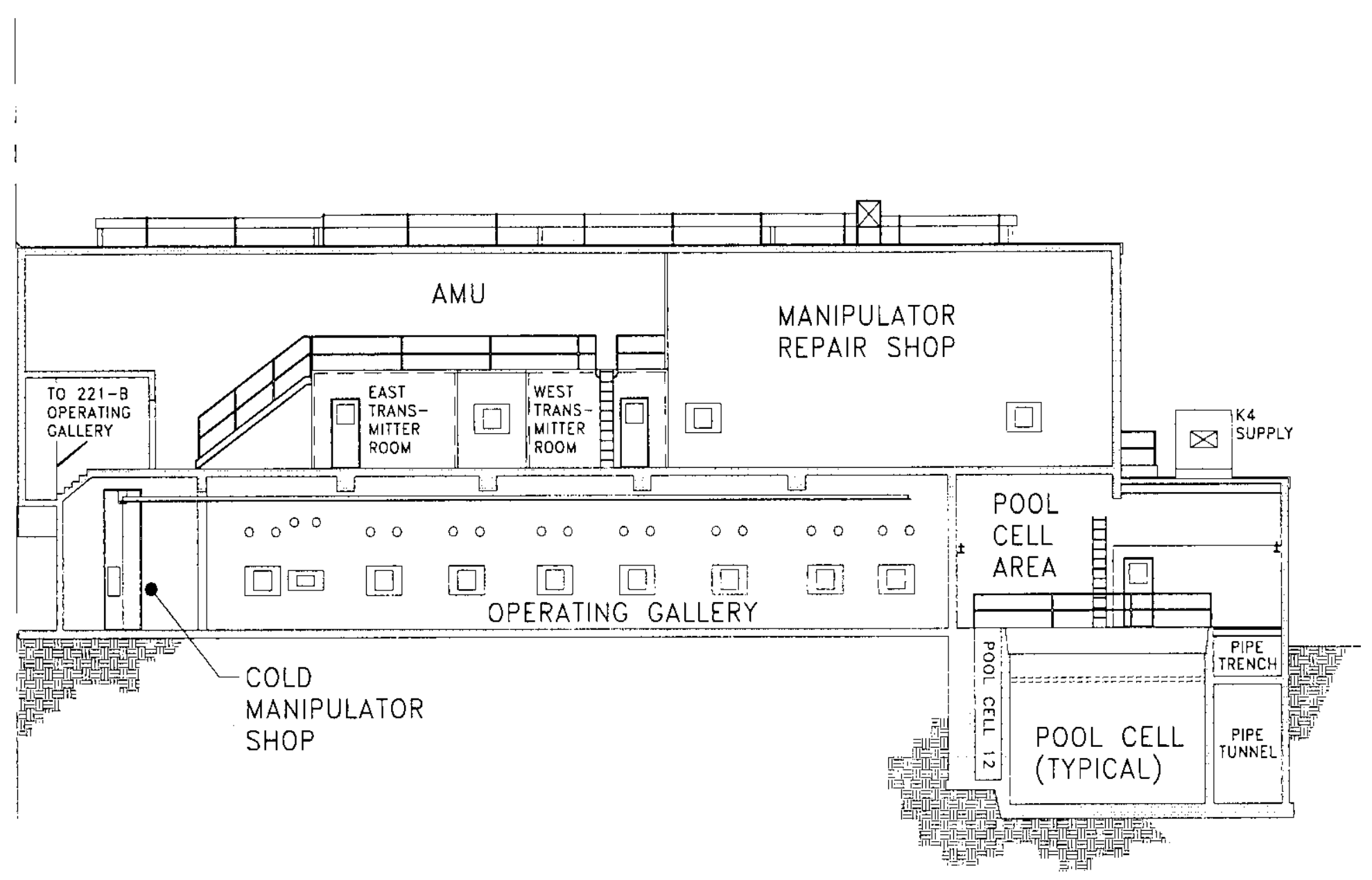


Figure 2-7. North-South Sectional View

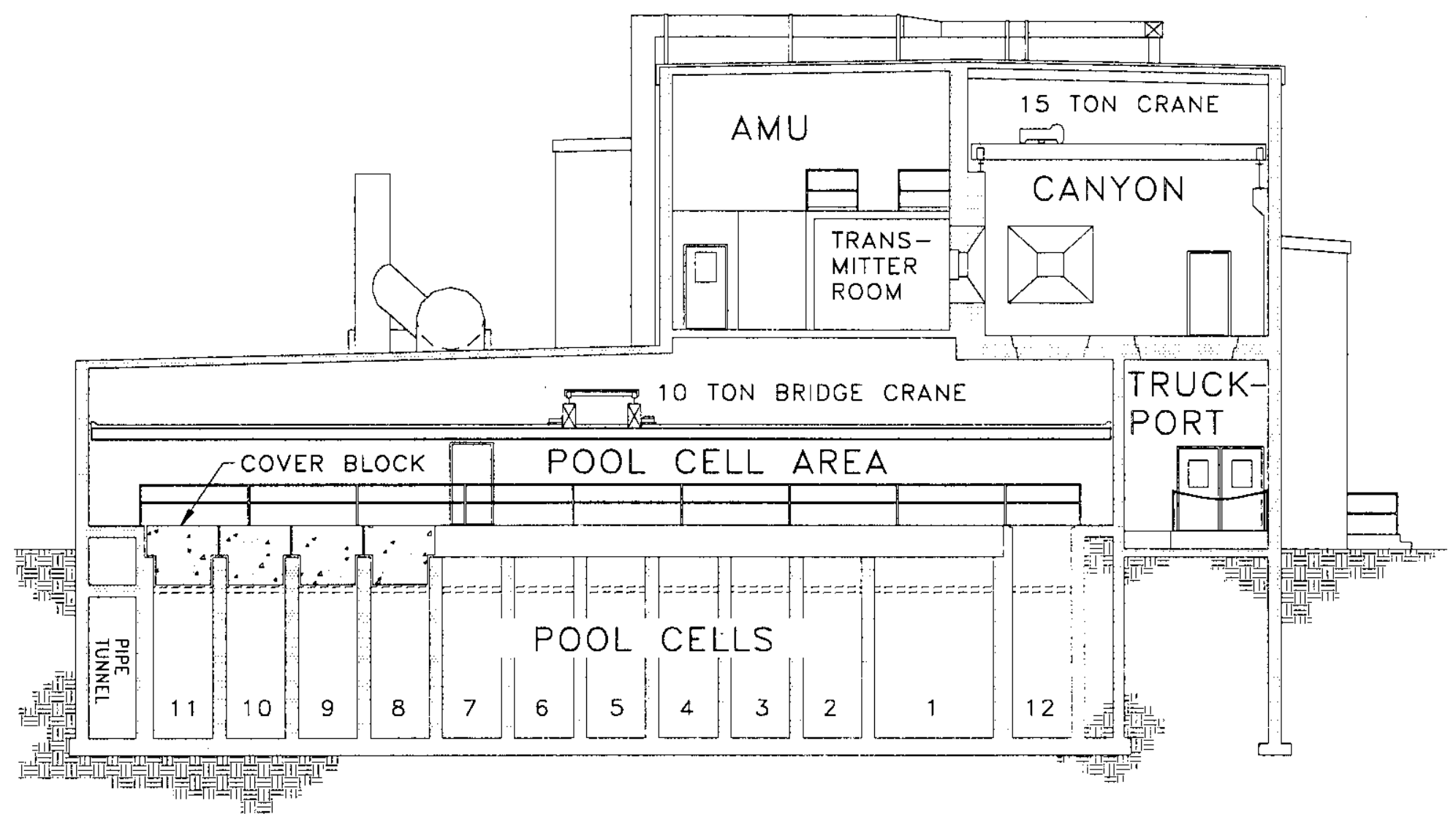




\section{HNF-SD-WM-BIO-002 REV 1}

Area 2 is a two-story above grade structure with reinforced concrete roof and floor slabs supported by reinforced concrete shear walls in the section of the 225-B Building enclosing the Hot Cells, Canyon, Hot and Cold Manipulator Shops, Manipulator Repair Shop, Operating Gallery, Service Gallery, and AMU. High-density concrete shielding for the hot cells provides additional shear walls for resisting lateral loads on both the first and second floors. The building foundation consists of continuous and spread footings at a depth of $1.8-\mathrm{m}$ ( $6 \mathrm{ft}$ ) below the grade slab. The high-density concrete shielding for the hot cells walls has a separate foundation. The east end of the Hot Cell Area foundation spread footings, grade slab, and floor slab are separated from the 221-B Building by a $0.6-\mathrm{cm}(1 / 4-i n$.$) expansion joint. A 5-\mathrm{cm}(2-i n$.) gap, which serves as a seismic joint, extends along the wall from the floor slab to the roof which includes both first and second floors. A portion of the second floor cantilevers out over the Pool Cells. The above grade reinforced concrete shear walls and floor slabs including the portion cantilevered out, are separated from the section of the building that contains the Truckport and Pool Cells by a $5 \mathrm{~cm}$ ( 2 in.) gap. Thus, this section is structurally independent of the adjacent sections of the 225-B Building for resisting lateral seismic loads, wind loads, and vertical gravity loads, including dead and live roof loads (such as snow and ashfall).

Area 3 is a two-story structure in the section of the 225-B Building that contains the Truckport and Pool Cells. The first-story pool cells are below grade. The reinforced concrete roof and pool cell floor slab at grade are supported by reinforced concrete shear walls. The above grade structure is independent of the adjacent structures for resisting lateral seismic and wind loads and vertical gravity loads including dead and live loads (such as snow and ashfall). To enhance the lateral load capacity during an earthquake, the below grade structure (i.e., the pool cells) is structurally connected to the foundation supporting Area 2.

\subsubsection{Hot Cells}

The past chemical processing and encapsulation of the radioactive isotopes ${ }^{90} \mathrm{Sr}$ and ${ }^{137} \mathrm{Cs}$ was accomplished in hot cells equipped with remote manipulators. Removable high-density concrete cover blocks located on the floor of the canyon provide access to the hot cells.

The Hot Cell Area is designed to a 0.25 gravity design basis earthquake (DBE) and exceeds the SDC 4.1, Rev. 12, (DOE-RL 1993), seismic design criteria of 0.20 gravity DBE for safety class seismic loads (Wagenblast, et al. 1999).

\subsubsection{Windows.}

Lead-glass windows are provided for shielding and direct viewing into the cells from the Operating Gallery. The viewing windows are composed of $25 \mathrm{~cm}$ ( $10 \mathrm{in}$.) of 3.3-density glass (cell side) and $40 \mathrm{~cm}$ (15.6 in.) of 6.2-density glass. An oil barrier separates the glass sections. As a result of the radiation exposure through the lead glass windows, the window units become electrically charged. This is not important to daily activities but needs to be addressed during window change-out. These windows provide radiation shielding equivalent to $89 \mathrm{~cm}$ (35 in.) of high-density concrete. The soft lead-glass is protected by cerium-stabilized non-browning cover glass on the cell side and by plate glass on the Operating Gallery side.

Horizontal seismic forces on the shielding windows are resisted by the friction developed by the lead shims and compacted lead wool surrounding them. The windows and frame are resistant to a $2.5 \mathrm{~m} / \mathrm{s}^{2}(0.25$ gravity) earthquake (Wagenblast, et al. 1999).

\subsubsection{Manipulators.}

The mechanical manipulators used in the hot cells are master-slave manipulators. The manipulator boot is a flexible sleeve protecting the slave end from contamination and providing an air barrier between the cell and the Operating Gallery.

The A and G Cells each have wall ports for four manipulators and B through $F$ Cells each have wall ports for two manipulators. The manipulators are installed or removed from the cells through the $25-\mathrm{cm}$ (10-in.) diameter 
ports in the wall. An overhead monorail system with a trolley is mounted in the Operating Gallery for removing the manipulators from the hot cells and transporting them to the Hot and Cold Manipulator Shops for decontamination.

\subsubsection{Embedded Piping.}

Extensive process and service piping is embedded in the concrete walls of each hot cell. The pipes could connect the cells to each other as well as to the pipe trench, Transmitter Rooms, AMU Area, Service Gallery, Operating Gallery. Manipulator Repair Shop, and Truckport. Spare piping is provided between all areas and the hot cells.

\subsubsection{Shielding Walls.}

The north and south walls of all the hot cells and both east and west walls of $A$ and G Cell are 89-cm (35-in.) thick, high-density $\left(3,770 \mathrm{~kg} / \mathrm{m}^{3}\left[235 \mathrm{lb} / \mathrm{ft}^{3}\right]\right.$ ) (Wagenblast, et al. 1999) reinforced concrete for personnel shielding. The A and G Cells also have an $89-\mathrm{cm}(35$-in.) high-density concrete shielding door for personnel entry from the Service Gallery.

\subsubsection{A Cell and A Cell Hood.}

A Cell contains the equipment required for handling high-level radioactive solid waste from the other hot

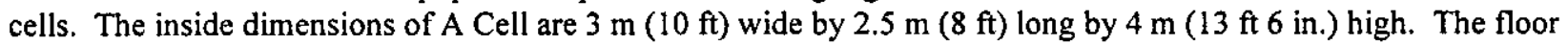
and walls are lined with $2-\mathrm{mm}$ (14-gauge) type $304 \mathrm{~L}$ stainless steel. The portion of A Cell adjacent to B Cell contains a $1.2-\mathrm{m}(4-\mathrm{ft})$ by $2.5-\mathrm{m}(8-\mathrm{ft})$ by $1.2 \mathrm{-m}(4-\mathrm{ft})$ stainless steel hood for receiving the contaminated solid waste. A pass-through with doors is located between the A Cell hood and B Cell for passage of solid waste from other hot cells. This cell is equipped with a shielded personnel entry door accessible from the Service Gallery. A transfer drawer in the A Cell hood is accessible from the Service Gallery.

A Cell is used for storage of 208-L (55-gal) drums containing hot cell solid waste (i.e., solid waste combustibles such as plastic manipulator boots and cleanup swabs). A covered port that has an outer diameter of $56-\mathrm{cm}(22$-in.) is located in the bottom of the hood for loading of solid waste into 208 -L (55-gal) drums. The hood is equipped with ventilation and filtration equipment for maintaining a slight negative pressure within the hood relative to A Cell to control the spread of contamination.

\subsubsection{B Cell.}

B Cell contains some of the equipment that was used for the strontium wet-chemistry processing. The

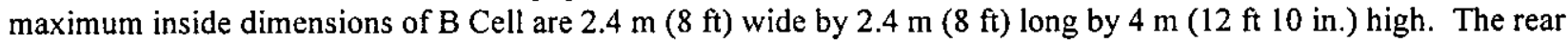

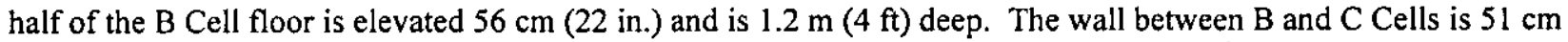
(20 in.) thick and is constructed from reinforced structural concrete $\left(2,400 \mathrm{~kg} / \mathrm{m}^{3}\left[150 \mathrm{lb} / \mathrm{ft}^{3}\right]\right)$. The floor and lower portion of the walls are lined with 14 -gauge $304 \mathrm{~L}$ stainless steel. The unlined portions were originally coated with white radiation-resistant and corrosion-resistant paint. Two recesses in the rear elevated section of the cell floor are provided for placement of the strontium precipitation tank and the supernate holding tank. A 86-cm (34-in.) wide by $137-\mathrm{cm}(54-\mathrm{in}$.) high penetration through the interior wall between B Cell and C Cell is provided for placement of the strontium fluoride sintering furnace and the filtrate holding tank. A pass-through without doors is located between $\mathrm{B}$ and $\mathrm{C}$ Cells for passage of equipment and solid waste.

\subsubsection{C Cell.}

$\mathrm{C}$ Cell contains some of the equipment that was used for the strontium fluoride encapsulation process. The

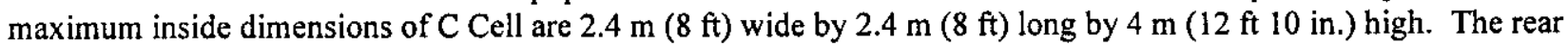

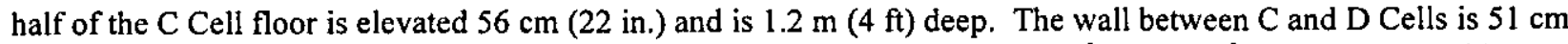
(20 in.) thick and is constructed from reinforced structural concrete $\left(2,400 \mathrm{~kg} / \mathrm{m}^{3}\left[150 \mathrm{lb} / \mathrm{ft}^{3}\right]\right)$. The floor and lower portion of the walls are lined with 14 gauge $304 \mathrm{~L}$ stainless steel. The unlined portions were originally coated with white radiation-resistant and corrosion-resistant paint. A recess in the rear elevated section of the cell floor is provided for placement of the strontium fluoride compactor foundation and two shielded storage containers. A pass-through with doors is located between $C$ and D Cells for passage of equipment and solid waste. 


\subsubsection{D/E Cell.}

D/E Cell contains some of the equipment that was used for the conversion and encapsulation of the cesium chloride. This double cell is $5.5 \mathrm{~m}(18 \mathrm{ft})$ wide by $2.4 \mathrm{~m}(8 \mathrm{ft})$ long by $4 \mathrm{~m}(12 \mathrm{ft} 10 \mathrm{in}$.) high and is partitioned by a

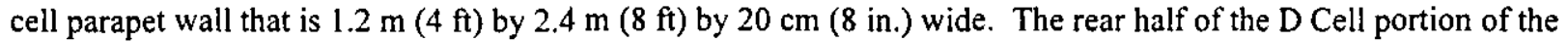

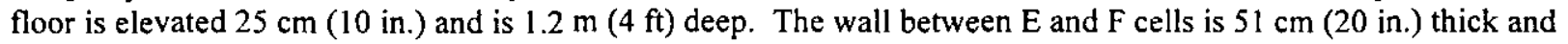
is constructed from reinforced structural concrete $\left(2,400 \mathrm{~kg} / \mathrm{m}^{3}\left[150 \mathrm{lb} / \mathrm{ft}^{3}\right]\right)$. The floor and lower portion of the walls are lined with 14 gauge Inconel ${ }^{\top M}{ }^{1}-600$ alloy. The unlined portions were originally coated with white radiation-resistant and corrosion-resistant paint. A recess in the elevated section is provided for placement of the cesium converter tank. A pass-through with doors is located between $\mathrm{E}$ and $\mathrm{F}$ Cells for passage of equipment and solid waste.

\subsubsection{F Cell.}

F Cell contains some of the equipment that was used for the decontamination of the inner capsules. In addition, $\mathrm{F}$ Cell is also used for interim dry storage of non-conforming capsules which cannot be stored in the pool

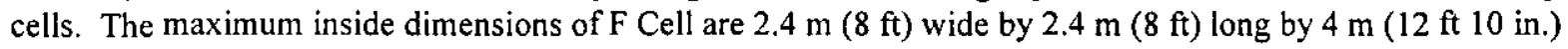
high. The rear portion of the cell floor is elevated $56 \mathrm{~cm} \mathrm{(22} \mathrm{in.)} \mathrm{and} \mathrm{is} 50 \mathrm{~cm}(2 \mathrm{ft})$ deep. The wall between $F$ and G Cells is $89 \mathrm{~cm}$ ( 35 in.) thick and is constructed from high-density reinforced structural concrete $\left(3,770 \mathrm{~kg} / \mathrm{m}^{3}\right.$ $\left[235 \mathrm{lb} / \mathrm{ft}^{3}\right]$ ). The floor and lower portion of the walls are lined with 14-gauge $304 \mathrm{~L}$ stainless steel. The unlined portions were originally coated with white radiation-resistant and corrosion-resistant paint. A recess in the elevated portion of the cell floor is provided for the placement of a shielded capsule storage tank. The F Cell is equipped with a special transfer drawer that is accessible from the Service Gallery. A pass-through with doors is located between $F$ and $G$ Cells for passage of equipment and solid waste.

\subsubsection{G Cell.}

G Cell was originally the final encapsulation cell. The maximum inside dimensions are $4.8 \mathrm{~m} \mathrm{(16ft)} \mathrm{wide}$

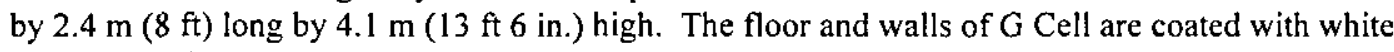
radiation-resistant and corrosion-resistant paint. This cell is equipped with a shielded personnel entry door and a transfer drawer, both of which are accessible from the Service Gallery (G Cell airlock). Normally G Cell contains very little contamination. The $\mathrm{G}$ Cell has a significant radiation source only when capsules are present. A penetration through the G Cell floor into Pool Cell 12 is provided for transferring the capsules between G Cell and the pool cells. A transfer cart is used to move capsules into or out of Pool Cell 12.

\subsubsection{Hot Pipe Trench.}

The hot pipe trench, is a concrete channel $1.5 \mathrm{~m}(5 \mathrm{ft})$ wide by $0.6 \mathrm{~m}(2 \mathrm{ft})$ in depth that contains the hot process feed piping and waste lines. It is located beneath the floor of the hot cells and extends from $G$ Cell to the outside wall of the 221-B Building. At this location, the hot pipe trench is reduced to a 36-cm (14-in.) stainless steel pipe encasement that terminates in Cell 39 at B Plant. The hot pipe trench and encasement have a slope of $10 \mathrm{~mm}$ per $\mathrm{m}(1 / 8$ in. per $\mathrm{ft})$ so that any leakage from process piping would flow to the Cell 39 sump for detection. To provide the necessary radiation shielding, the walls of the hot pipe trench and encasement are constructed of high-density concrete and are lined with lead where required. B Plan has been isolated from WESF and the piping in the hot pipe trench is no longer used.

\subsubsection{Hot Cell Ventilation.}

The K-3 ventilation system provides airflow through the hot cells. The airflow is a consequence of the primary radioactive confinement function of the K-3 system. The K-3 ventilation system is described in Section 2.6.2.3.

Air is supplied to each hot cell through one of two flow-controllable and high efficiency particulate air HEPA-filtered inlet ducts. The airflow is from the WESF Canyon through HEPA filters and flow control dampers located on the south side of the Canyon. The air enters close to the top of the cell and exits each cell through one of 
two HEPA-filtered and flow-controllable exhaust ducts that are set vertically in the cell floor and extend approximately a meter $(3.28 \mathrm{ft}$.) above the floor. The exhaust ducts lead to a common duct under the hot cells, which in turn leads to the final system HEPA filtration located in the K-3 filter housing located in the K-3 Filter Pit.

The negative pressure in each hot cell is controlled by adjusting the flow control dampers in each hot cell inlet and outlet duct. The inlet dampers are adjusted by air-operated damper control motors. These inlet dampers may be operated in either the automatic or manual control mode. The outlet dampers are manually operated only.

\subsubsection{Hot Cell Water Detection and Removal.}

All liquid sources to A Cell through $\mathrm{E}$ Cell have been removed. Air driven pumps have been installed in $\mathrm{F}$ Cell and $\mathrm{C}$ Cell to transier any accumulated water to $\mathrm{TK}-100$. The air pump controls are located next to the F Cell and $\mathrm{G}$ Cell windows.

\subsubsection{Canyon}

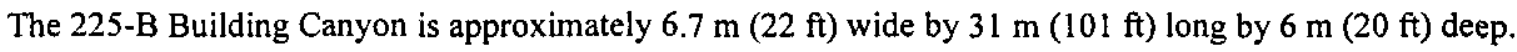
The walls of the Canyon are constructed from 46-cm (18-in.) thick reinforced structural concrete, except for the lower $4 \mathrm{~m}$ (13 ft) of the north and east interior walls, which are $76 \mathrm{~cm}$ (30 in.) thick to provide radiation shielding for the adjacent AMU Area and Manipulator Repair Shop.

The canyon is accessible from the AMU Area through a shielded personnel entry door and from the Service Gallery to a stairwell leading to the access hallway. Both access doors are contained in an air lock. An outside access door is also provided at the west end of the Canyon for an emergency exit only.

Canyon operations can be viewed from the AMU Area and Manipulator Repair Shop through four windows in the interior walls of the Canyon. The windows are dry-type (no oil), lead-glass and provide the equivalent shielding of $76 \mathrm{~cm}$ (30 in.) structural concrete.

The canyon provides access to the Hot Cells, Truckport and Pool Cell Area by means of removable high-density, stepped cover blocks. A 13,600-kg (15-ton) capacity, remotely operated crane, capable of traveling the full length of the Canyon, removes the cover blocks and handles equipment. A decontamination and maintenance area for the crane is located at the east end of the Canyon.

A remote-control television system mounted to the crane allows the crane operator to observe the movement of the crane hooks and the load using a television monitor located in the AMU Area.

The Canyon is designed to a 0.25 gravity DBE and exceeds the SDC 4.1, Rev. 12, (DOE-RL 1993), seismic design criteria of 0.20 gravity DBE for safety class seismic loads (Wagenblast, et al. 1999).

\subsubsection{Service Gallery}

The Service Gallery is approximately $3 \mathrm{~m}(10 \mathrm{ft})$ wide by $25 \mathrm{~m}(83 \mathrm{ft})$ long. It is used to service the hot cells from the rear side and contains some of the auxiliary cold (non-radioactive) process piping. Access to the hot cells from the Service Gallery is provided by transfer drawers (in A, F, and G Cells) and by personnel entry doors (in $A$ and $G$ Cells). Both personnel entry doors are located in air locks ( $A$ and $G$ ) at each end of the Service Gallery. The Service Gallery may be accessed from the Truckport and the access hallway by remote electrically operated switches.

Loads of filled laundry bags (some laundry bags contain contaminated clothing) and plastic sheets used to cover the floor during cleaning or maintenance work are temporarily stored in the Service Gallery.

The Service Gallery is designed to a 0.25 gravity DBE and exceeds the SDC 4.1, Rev. 12, (DOE-RL 1993), | seismic design criteria of 0.20 gravity DBE for safety class seismic loads (Wagenblast, et al. 1999). 


\subsubsection{Operating Gallery}

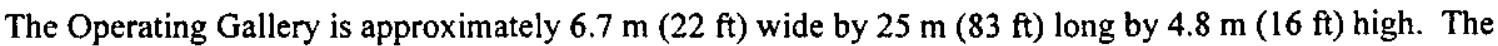
Operating Gallery is accessible from the Support Area, elevator, Cold Manipulator Shop, Pool Cell Area, and HVAC Room. Remote work in the cells is accomplished with master-slave manipulators operated from the Operating Gallery. The hot cell instrumentation control panels are located adjacent to the manipulator operating areas. In the event of a manipulator failure, the manipulator is pulled from the hot cell wall by an overhead trolley and moved to the Hot Manipulator Shop, which is located adjacent to and east of the Operating Gallery. Replacement manipulators are inserted into the cell using an overhead trolley. Lead-glass windows are provided for direct viewing of the interior of each hot cell at the Operating Gallery level. A non-shielding window for viewing the Pool Cell Area is located on the west wall.

All areas of the Operating Gallery, except the Pool Cell Monitoring Area are designed to a 0.25 gravity DBE and exceed the SDC 4.1, Rev. 12, (DOE-RL 1993), seismic design criteria of 0.20 gravity DBE for safety class seismic loads (Wagenblast, et al. 1999). The Pool Cell Monitoring Area structure is designed to UBC Seismic Zone 2 and meets the SDC 4.1, Rev. 12, (DOE-RL 1993), seismic design criteria of UBC Seismic Zone 2 for safety significant seismic loads (Wagenblast, et al. 1999).

\subsubsection{Supervisory Room.}

The supervisory control area occupies a $2 \mathrm{~m}(8 \mathrm{ft})$ wide by $4.3 \mathrm{~m}(14 \mathrm{ft})$ long by $4.8 \mathrm{~m}(16 \mathrm{ft})$ high recess on the north wall of the Operating Gallery. This area contains the critical instrumentation for surveillance of the building. The Supervisory Control Area structure is designed to a 0.25 gravity DBE and exceeds the SDC 4.1, Rev. 12, (DOE-RL 1993), seismic design criteria of 0.20 gravity DBE for safety class seismic loads (Wagenblast, et al. 1999).

\subsubsection{Pool Cell Monitoring Area.}

The instrumentation for control and surveillance of the Pool Cell Area is located in a $3.6 \mathrm{~m}(12 \mathrm{ft})$ wide by $7 \mathrm{~m}$ ( $23 \mathrm{ft}$ ) long by $4.8 \mathrm{~m}$ ( $16 \mathrm{ft}$ ) high room that is accessible from the Operating Gallery. Specific monitoring equipment is addressed in Sections 2.4.10.1 through 2.4.10.3. The Pool Cell Monitoring Area structure is designed to UBC Seismic Zone 2 and meets the SDC 4.1, Rev. 12, (DOE-RL 1993), seismic design criteria of UBC Seismic

| Zone 2 for safety significant seismic loads (Wagenblast, et al. 1999).

\subsubsection{Aqueous Makeup Area}

The AMU is on the second floor of the 225-B Building and contains several tanks that are no longer used, a manipulator storage area and a 3,785-L (1,000-gal) storage tank for deionized water. The AMU is an $\mathrm{L}$-shaped area

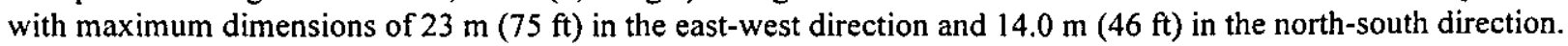
This area is accessible from the first floor stairway, elevator, Manipulator Repair Shop, B Plant Operating Gallery, and outside access door. The AMU also contains a $3.7-\mathrm{m}(12-\mathrm{ft})$ by $12.0-\mathrm{m}(40-\mathrm{ft})$ mezzanine that is located above the Transmitter Rooms and accessed by a staircase or ladder. The mezzanine contains several tanks that are no longer used and a 2,271-L (600-gal) tank for decontamination solution makeup.

The canyon can be viewed from the AMU Area through two lead-glass windows. The canyon can be entered from the AMU Area by a shielded personnel entry door and air lock.

The AMU Area is designed to a 0.25 gravity DBE and exceeds the SDC 4.1, Rev. 12, (DOE-RL 1993), seismic design criteria of 0.20 gravity DBE for safety class seismic loads (Wagenblast, et al. 1999).

\subsubsection{Transmitter Rooms}

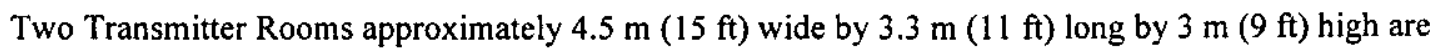
located beneath the AMU mezzanine on the second floor of the 225-B Building. They house inactive piping and instrumentation connected directly to the hot cells. When WFSF was processing. these Transmitter Rooms provided shielding and confinement in the event of a contaminated process solution drawback. These rooms 
currently provide no function.

\subsubsection{HVAC Room}

The HVAC Room is approximately $9 \mathrm{~m}(30 \mathrm{ft})$ wide by $11 \mathrm{~m}(35 \mathrm{ft})$ long by $3.6 \mathrm{~m}(12 \mathrm{ft})$ high and located on the first floor of the 225-B Building. The HVAC Room contains the ventilation supply equipment and the backup air dryer for the building except for the Pool Cell Area. An equipment door for maintenance and for access to the elevator is located on the north side of the building. The HVAC Room is also accessible from the elevator, | Operating Gallery, and Support Area.

The HVAC Room is designed to UBC Seismic Zone 2 and meets the SDC 4.1, Rev. 12, (DOE-RL 1993), seismic design criteria of UBC Seismic Zone 2 for safety significant seismic loads (Wagenblast, et al. 1999).

\subsubsection{Hot and Cold Manipulator Shops}

The manipulator decontamination area is located on the east end of the first floor of the 225-B Building and is accessible from the Operating Gallery and the access hallway. The area is partitioned into two sections with a large access door contained in the partition, the Cold Manipulator Shop and Hot Manipulator Shop. These rooms are $4.5 \mathrm{~m}(15 \mathrm{ft})$ by $7.6 \mathrm{~m}(25 \mathrm{ft})$ by $4.8 \mathrm{~m}(16 \mathrm{ft})$ and $4.5 \mathrm{~m}(15 \mathrm{ft})$ by $6.1 \mathrm{~m}(20 \mathrm{ft})$ by $4.8 \mathrm{~m}(16 \mathrm{ft})$, respectively. Manipulators are moved into and out of these areas by an overhead trolley system.

Loads of filled laundry bags (some containing contaminated clothing) and plastic sheets, used to cover equipment to prevent contamination during maintenance work, are temporarily stored in the Manipulator Shops.

The Hot and Cold Manipulator Shops are designed to a 0.25 gravity DBE and exceed the SDC 4.1, Rev. 12, (DOE-RL 1993), seismic design criteria of 0.20 gravity DBE for safety class seismic loads (Wagenblast, et al. 1999).

\subsubsection{Manipulator Repair Shop}

The Manipulator Repair Shop is $7.3 \mathrm{~m}(24 \mathrm{ft})$ wide by $15.8 \mathrm{~m}(52 \mathrm{ft})$ long by $6.1 \mathrm{~m}(20 \mathrm{ft})$ high and is located on the second floor west of the AMU and north of the Canyon. It is accessible from the AMU and from a door to the roof. Decontaminated manipulators are placed on a transfer cart and taken by the elevator to the Manipulator Repair Shop. Spare manipulators may be stored in the Manipulator Shop or in the manipulator storage enclosure at the east end of the AMU.

The Manipulator Repair Shop is designed to a 0.25 gravity DBE and exceeds the SDC 4.1, Rev. 12, (DOERL 1993), seismic design criteria of 0.20 gravity DBE for safety class seismic loads (Wagenblast, et al. 1999).

\subsubsection{Pool Cell Area}

The Pool Cell Area has 12 pool cells, which provide underwater storage for the strontium and cesium capsules. It is located on the west side of the 225-B Building.

Pool Cell 1 is $2.7 \mathrm{~m} \mathrm{(} 8 \mathrm{ft} 9 \mathrm{in}$.) wide, $6.6 \mathrm{~m}$ ( $21 \mathrm{ft} 9 \mathrm{in}$.) long, and $5.5 \mathrm{~m}(18 \mathrm{ft})$ deep. Pool Cells 2 through

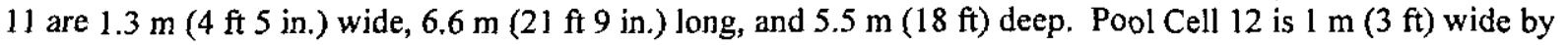
$19.8 \mathrm{~m}$ (64 ft $11 \mathrm{in}$.) long by $4.7 \mathrm{~m}$ ( $15 \mathrm{ft} 6 \mathrm{in}$.) deep. The south end of Pool Cell 12 contains a cask pit $1.3 \mathrm{~m}(4 \mathrm{ft} 5$ in.) wide by $2.3 \mathrm{~m} \mathrm{(} 7 \mathrm{ft} 5 \mathrm{in}$.) long by $5.5 \mathrm{~m}$ ( $18 \mathrm{ft}$ ) deep. All pool cells have liners constructed of 16 gauge type 304 stainless steet at the sides and 14 gatge type 304 stainless steel flooring. Transfer ports connect Pool Cells 1 through 11 to Pool Cell 12. A transfer port is a ball valve (identified as PC12-PCX-1 where X is the pool cell transfer poit) that can be opened and closed to transfer capsules or water between each of the pool cells and Pool Cell 12. The transfer port is located approximately $1 \mathrm{~m}$ (3 it) above the pool cell thoor. Although all pool cells, except pool Cell 12, are designed for cover block installation, cover blocks are not normally installed on pool cells that store capsules to prevent polential damage to the capsules due to a cover block drop. Pool Cells 8 through 11 do not store capsules and each lrave three $76-\mathrm{cm}$ ( $30 \mathrm{in}$.) thick concrete cover blocks installed. Pool Cell I has one 76-cm (30 in.) cover block installed. Cover blocks may be installed on a pool cell containing capsules in response 
to an emergency (e.g., loss of capsule integrity). The pool cells also have a maintenance platform for performing maintenance on the pool cell heat exchanger(s) and other pool cell systems. The design of the plation is such that it cannot fit into a pool cell regardless of orientation.

There are three personnel access doors (approximately $1 \mathrm{~m}$ by $2 \mathrm{~m}$ [ $3 \mathrm{ft}$ by $7 \mathrm{ft}]$ ) in the Pool Cell Area. An access door to the Truckport is located on the south wall, an access door to the outside is located in the northeast corner, and an access door to the Operating Gallery through an airlock is located on the east wall.

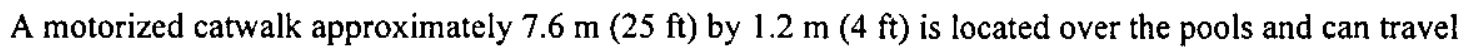
the full length of the Pool Cell Area. This catwalk provides access to each of the pool cells for capsule inspection, movement, and maintenance activities. necessary.

A bridge crane with a 9,100-kg (10-ton) capacity is used in the Pool Cell Area to move equipment as

The Pool Cell Area structure, pool cell water removal lines (no longer active). pool cell circulation lines, and load bearing components on the crane are designed to a 0.25 gravity DBE and exceed the SDC 4.1, Rev. 12, (DOE-RL 1993), seismic design criteria of 0.20 gravity DBE for safety class seismic loads (Wagenblast, et al. 1999).

\subsubsection{Pool Cell Leak Detection System}

Each pool cell has a sloped leak collection system under the liner. Each system (for Pool Cells 1-11) drains to a collection sump located in the pipe tunnel, to the west of each pool cell. The liner for Pool Cell 5 is known to have a very minor leak that dratins to the P'ool Cell 5 collection sump. Pool Cell 12 has two sumps, one located to the east and the other located to the southwest of Pool Cell 12. The pipe tunnel consists of three sections, $2.3 \mathrm{~m}(7$

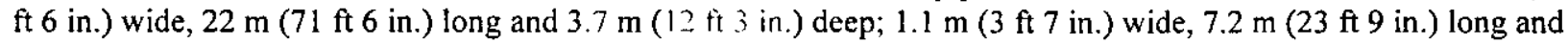

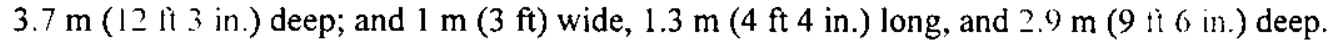

The collection system in Pool Cell 1 consists of a central trough running the length of the pool cell with 10 troughs feeding the central trough from each side. A $2.5-\mathrm{cm}$ (1-in.) drain line at the west end leads to the collection

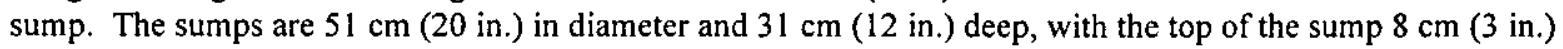
below the cell liner. A $2.5-\mathrm{cm}$ ( 1 -in.) line extending from $1 \mathrm{~cm}(1 / 2 \mathrm{in}$.) above the sump bottom to below the grating on the west side of the pool cell is used to remove any leak water from the sump. A 15-cm (6-in.) line extending from $28 \mathrm{~cm}(11 \mathrm{in}$.) above the sump bottom to above the Pool Cell Area trench floor houses a conductivity probe used to detect water collected in the sump. The sump and lines are $304 \mathrm{~L}$ stainless steel.

| Pool Cells 2 through 11 each have a main collection trough near the north side with 10 feeder troughs. Each sump is the same as the one described in Pool Cell 1.

One of the two sumps in Pool Cell 12 is located on the east side of the pool, approximately on the center line between Pool Cells 6 and 7. The pool cell has a single trough running $31 \mathrm{~cm}(12 \mathrm{in}$.) from the west wall. The north third and the middle third of the pool cell drain toward each other where the drain line to the sump is located. The $2.5-\mathrm{cm}(1-\mathrm{in}$.) line for transferring water from the sump is in the wall between Pool Cells 6 and 7 and ends below the grating on the west side of the pool cells. The second sump is located south of Pool Cell 1 and west of the cask pit portion of Pool Cell 12. This sump collects water from the south third of the transfer aisle part of Pool Cell 12 and from a single trough in the cask pit part of Pool Cell 12. The transfer line also ends below the grating on the west side of Pool Cell 1. Each of these sumps has a conductivity probe used to detect water collected in the sumps. The water is removed from the sump using a portable pump.

\subsubsection{Pool Cell Water Removal and Circulation Lines.}

Each pool cell has an abandoned 5 - $\mathrm{cm}$ (2-in.) diameter stainless steel water removal pipe extending from an open end at $1-\mathrm{cm}(0.5$-in.) above the pool cell floor. A simplified diagram of the water removal, or drain, line is 
shown in Figure 2-8. Each pipe penetrates the pool cell liner and wall into the pipe tunnel $90-\mathrm{cm}(3-\mathrm{ft})$ above the pool cell floor, extends horizontally $2.3-\mathrm{m}(7.5-\mathrm{ft})$, then vertically up $2.7-\mathrm{m}$ (9-ft) where it penetrates (embedded) the pipe tunnel ceiling. Fach pool cell also has a $7.6-\mathrm{cm}(3-$ in) diameter stainless steel circulation line extending from a distribution header approximately $10-\mathrm{cm}(4-\mathrm{in})$ from the pool cell floor. A simplitied diagram of the circulation line is shown in Figure 2-8. Each pipe penetrates the pool cell liner and wall into the pipe tunnel $90-\mathrm{cm}$ (3-fi) above the pool cell floor, extends horizontally 90 - $\mathrm{cm}$ (3-fi). then vertically up $2.7-\mathrm{m}$ (9-ft) where it penetrates (sleeved) the pipe tunnel ceiling and connects to the pool cell heat exchanger.

\subsubsection{Support Area} building.

The Support Area consists primarily of the Office Areas and two change rooms located in the 225-B

\subsubsection{Truckport}

The Truckport, located at the southwest comer on the first floor of the 225-B Building, is approximately $3.6 \mathrm{~m}(12 \mathrm{ft})$ by $11 \mathrm{~m}(37 \mathrm{ft})$ by $4.5 \mathrm{~m}(15 \mathrm{ft})$. A personnel door and two truck doors (bifold and rollup) provide access from the outside. Interior access is available from doors in the Service Gallery and Pool Cell Area. An opening in the Canyon deck above the Truckport provides for movement of transport casks and solid waste burial containers. Cover blocks normally close this opening.

The Truckport is designed to a 0.25 gravity DBE and exceeds the SDC 4.1, Rev. 12, (DOE-RL 1993), seismic design criteria of 0.20 gravity DBE for safety class seismic loads (Wagenblast, et al. 1999).

\subsection{PROCESS DESCRIPTION}

The current WESF mission is the receipt, inspection, and continued safe storage of the WESF manufactured cesium and strontium capsules. Although not a process, the receipt, inspection, and storage activities are described in this section because it represents the normal operation of the facility.

\subsubsection{Capsule Receipt}

Capsules are returned from outside facilities to WESF in casks approved by DOE and/or the Nuclear Regulatory Commission (NRC). Either the 23,000-kg (25-ton) capacity installed crane or an approved mobile crane offloads the cask onto the crane pad (between the 282-B and 282-BA Buildings). The cask is then placed in the Truckport with the transport vehicle or forklift. The cask is moved from the Truckport to G Cell by the Canyon crane. The Truckport and Hot Cells are accessed from the Canyon by means of removable cover blocks. In G Cell, the capsules are removed from the cask using the manipulators and in-cell hoist. After the capsules are removed from the cask, they are decontaminated, if necessary, and inspected. Capsule decontamination consists of a mechanical scrub tank supplied with decontamination solution (tri-sodium phosphate) and a rinse with deionized water.

At this time, all leased capsules have been returned to the facility, and WESF is not expected to receive any additional capsules.

\subsubsection{Capsule Inspection}

I Returned capsules that have not been overpacked are visually examined and then gauged using an outside diameter go/no-go gauge to verify the outer capsule has not bulged. An inner capsule movement test is also performed to ensure the inner capsule has not bulged against the inside of the outer capsule. A smear test is performed to verify there is no radiological contamination present prior to transfer from $G$ Cell to the pool cells. If the capsules pass the examination criteria, they are transferred through Pool Cell 12 to one of the pool cells for storage. If a capsule does not pass the inspection criteria, the capsule is either placed in G Cell capsule storage for further evaluation or stored in F Cell. 
Figure 2-8. Pool Cell Circulation and Drain Lines.

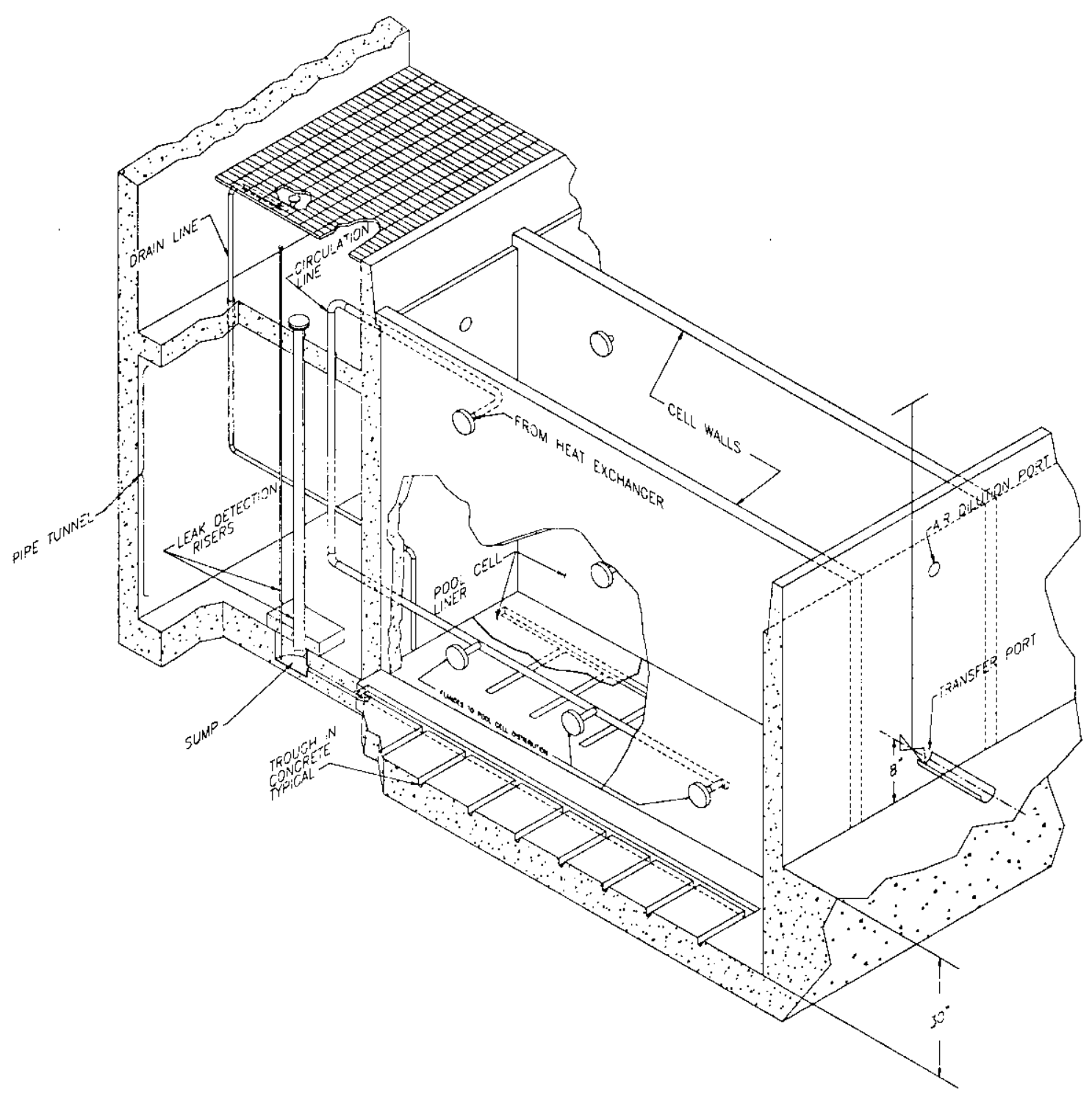


HNF-SD-WM-BIO-002 REV 1

Figure 2-8a. Isometric Drawing of Pool Cell Systems.

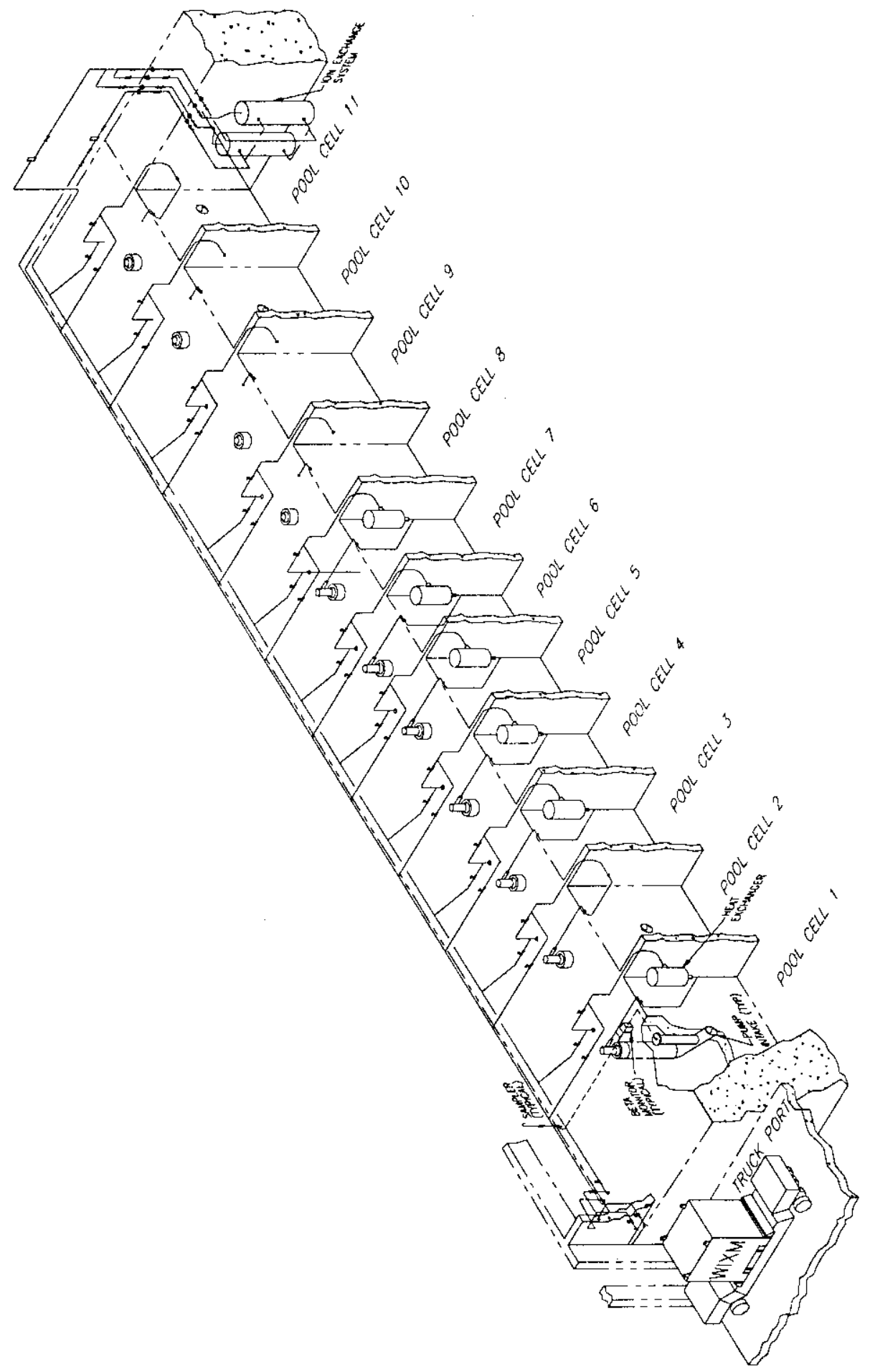




\subsubsection{Capsule Storage}

\subsubsection{Pool Cell Area.}

Capsules are transferred individually to the Pool Cell Area through a capsule chute between G Cell and Pool Cell 12. The capsule transfer chute is equipped with a trolley device for lowering the capsules into Pool Cell 12. The capsule is moved down Pool Cell 12 with a tong, through the transfer port (see Figure 2-8), to the assigned pool cell.

The normal configuration of the transfer ports between Pool Cells 1 through 11 and Pool Cell 12 is closed. However, there are several operations in which one or more of the transfer ports are opened. Upon completion of the operation, the transfer ports are returned to the closed position. These operations include the following,

- Capsule transfer into, out of, and between pool cells,

1 - Pool cell cooling upon loss of heat exchanger(s),

- Equalization of pool cell water levels,

- LCO actions.

Pool Cells $1,3,4,5,6$, and 7 are currently used for capsule storage. Each of these pools is filled with water and contains three capsule storage racks. Capsules are placed in designated positions in the capsule rack with the end containing the alpha designation and serial number in the up position. Pool Cells 2 and 8 are also normally filled with water and used as shielding pools. Pool Cells 9 and 10 store collected waste water (e.g., steam condensate) from the Pool Cell Areal for sampling prior to batch discharge to the Treated ffftuent Disposal Facility (TEDF). Pool Cell 11 (normally dry) contains the pool cell water quality ion exchange system. Pool Cell 12, also known as the transfer aisle. is used to transfer capsules between pool cells and $\mathrm{G} \mathrm{Cell}$ and can temporarily store capsules il necessary.

\subsection{Capsule Design Criteria for Pool Cell Storage.}

Listed below are criteria that a capsule must meet before being placed in a WESF pool cell.

- The capsule must be designed for long term storage in water (expected lifetime of facility).

- A helium leak was performed on the inner capsule or Type $W$ overpack during production to verify containment integrity.

- Cesium capsules with an inner and outer capsule (excluding Type W overpack capsules) must pass an inner capsule movement test.

- The outer capsule of capsules which were thermally cycled (excluding Type W overpacks) can pass a ring gauge test to ensure there is no capsule swelling.

- The capsule is welded and has no mechanical joints.

- All welds have manufacturing records which document the weld conforms to applicable acceptance criteria.

- The capsule fits through the transfer chute on the transfer cart from G Cell to Pool Cell 12.

- The capsule fits through the transfer ports between Pool Cell 12 and any other pool cell.

- The capsule fits in the pool cell storage racks. 
HNF-SD-WM-BIO-002 REV 1

- The capsule must be decontaminated to current Hanford site radiological release limits.

- The capsule must be marked with a unique and permanent identification number.

- Capsule handling must be possible with existing equipment.

\subsection{Water Level Monitoring.}

The pool cells are equipped with purge system, differential pressure type water ievel indicators and alarms. The pool cell water level is displayed in the Pool Cell Monitoring Area adjacent to the Operating Gallery.

\subsection{Temperature Monitoring.}

The pool cells are equipped with water temperature indicators and alarms. The pool cell temperature is displayed in the Pool Cell Moniloring Area adjacent to the Operating Gallery.

\subsection{Radiation Monitoring.}

See Section 2.7.3.2 (Area Radiation Monitors), 2.7.3.3 (Ion Exchange Radiation Monitors), and 2.7.3.5 (Pool Cell Beta Monitors) for details on the pool cell radiation monitoring systems.

\subsection{Pool Cell Heat Exchanger.}

To remove the heat generated by the capsules. Pool Cells 1 and 3 through 7 are each equipped with a circulation punp that circulates the pool cell water continuously (see Figure 2-8a). A simplified diagram of the circulation line is shown in Figure 2-8. The circulated water passes through a spiral heat exchanger for Pool Cells 1 and 3 through 7 and is returned to the pool cell by three distributors on the bottom of the pool cell. Heat is removed using the pool cell closed loop cooling system or backup once-through raw water. The water in Pool Cell 12 circulates continuously between the opposite ends bul does not pass through a heat exchanger. Deionized water is added to the pool cells periodically to maintain water level due to evaporation.

Radiation detection instrumentation is provided in each pump circulation stream. Although not required, water samples could also be taken and monitored for total Beta, conductivity and $\mathrm{pH}$.

\subsection{Pool Cell Water Quality Ion Exchange System.}

The water from Pool Cells 1 and 3 through 7 is periodically diverted to a deionizing system. The water is filtered prior to entering the ion-exchange column(s) containing technical grade (strong acid-hydrogen form, strong base-hydroxide form. low-chloride) mixed-bed ion-exchange resin. The deionizing system removes impurities such as corrosion products, dissolved salts. chloride ions. and solid debris. After purification, the stream is returned directly to the same pool cell. The conductivity of the purilied water stream is monitored to determine when the ion-exchange resin in the column(s) needs to be replaced. Replacing the ion-exchange resin requires personnel to access the columns. For personnel protection and ALARA, an automatic shut-off valve is located in the ion-exchange discharge line to prevent radioactive water from flowing through and depositing radioactive isotopes. The feed and return lines of the ion-exchange system also provide a method for comecting the pool cells to each other. The circulation pump on one or more of the pool cells supplying water must be operational to transfer the water to another pool cell by this method. Due to the design of the system, a pool cell with water below approximately $356 \mathrm{~cm}$ (140 in.) cannot supply another pool cell with water using this method. A simplified diagram of the ion exchange syslem is shown in Figure 2-8a.

\subsubsection{F Cell Capsule Storage.}

The F Cell is used to store capsules that do not meet storage pool criteria (2.5.3.1.1). In order to avoid the possibility of long-term corrosion associated with the higher temperatures of dry storage, analyses (WHC 1996c) have been performed to indicate the number of capsules that could be stored while maintaining acceptable 


\section{HNF-SD-WM-BIO-002 REV 1}

salt-capsule interface temperatures. The thermal analysis concluded that the number of capsules which equate to a total heat release of $4.5 \mathrm{~kW}$, spaced a minimum of $20 \mathrm{~cm}(8 \mathrm{in}$.) apart and $20 \mathrm{~cm}(8 \mathrm{in}$.) from the floor, can be stored dry in $\mathrm{F}$ Cell with a ventilation flow of $570 \mathrm{~L} / \mathrm{min}\left(250 \mathrm{ft}^{3} / \mathrm{min}\right)$. If there is no ventilation flow or less than $570 \mathrm{~L} / \mathrm{min}\left(250 \mathrm{ft}^{3} / \mathrm{min}\right), 1.8 \mathrm{~kW}$ can be stored dry in F Cell.

\subsubsection{Solid Radioactive Waste}

Solid waste generated at WESF is segregated into radioactive or nonradioactive categories. Radioactive waste is handled and disposed of as described in the following sections.

Low-level radioactive waste is collected from areas throughout the facility and either placed into a burial box or moved to the compaclible conex box and stored until shipped. Most of the material consists of gloves, paper, swipes, plastic, broken tools, etc. To avoid any potential for cross contamination, dirty laundry from the change room is bagged and stored separately from the radioactive wastes generated elsewhere in the facility.

\subsubsection{Routine Low-Level Radioactive Waste.}

Routine low-level radioactive waste originating from the hot cell consists of manipulator sleeves, swipes, metal pails, failed equipment, etc. The hot cell manipulators are used to place these small waste items into a pail that is then passed through adjacent, more contaminated cells leading to A Cell for final disposal. The waste in ACell is packaged into 208-1. (55-gal) drums. Two methods are available to remove the waste drum(s) from WESF. One method is the Chem-Nuclear Systems (Chem-Nuc) cast and the other is the Department of Transportation (DOT) $7 \wedge$ Type $\Lambda$ container.

Chem-Nuc Cask. Up to two drums are removed from $\Lambda$-Celt by the canyon crante to one of three disposable high integrity container (HIC) overpacks staged in the WESF canyon. The sealed HIC is placed into the Chem-Nuc reusable lead-lined steel cast staged on a rolting plattorm in the WiSt Truckport. Up to three HICs can be loaded in the Chem-Nue cask.

Type A Container. Up to tive drums are removed from A Cell by the canyon crane and staged in a 4 fit $x 4 \mathrm{ft} \times 8 \mathrm{ft}$ plywood box located on the canyon deck. The plyworod box is then placed inside the steel $5 \mathrm{ft} x 5 \mathrm{ft} x 9 \mathrm{ft}$ Type $\mathrm{A}$ container and shipped.

\subsubsection{Non-Routine Low-Level Radioactive Waste.}

Removal of large items from WESF, such as hot cell equipment that cannot fit in a 208-L (55-gal) drum, is infrequent and requires special waste management procedures that are prepared in accordance with the requirements at the time of the waste removal activity.

\subsection{CONFINEMENT SYSTEMS}

The systems and controls that provide confinement of radioactive contamination within WESF are discussed in this section. The majority of the cesium and strontium radioactive material at WESF is confined in doubly encapsulated stainless steel capsules or Type $W$ overpacks. The contamination within the facility is the result of spills, residual material, and processing vessel heels produced during cesium chloride and strontium fluoride production and encapsulation. The majority of contamination is deposited within the hot cells and the K-3 ventilation system ductwork. The material is confined by the structural shielding walls of the hot cells, the ventilation system ductwork, and the HEPA filters.

\subsubsection{Capsules}

This section will describe both the WESF doubly encapsulated capsuks and the Type-W overpack capsules. 


\section{HNF-SD-WM-BIO-002 REV 1}

\subsubsection{WESF Encapsulated Capsules.}

The strontium inner capsule and end caps are made of Hastelloy C-276 and the outer capsule and end caps are made of $316 \mathrm{~L}$ stainless steel. Strontium fluoride was added to the inner capsule in increments and compacted after each addition. The dimensions of the inner capsule are $5.72 \mathrm{~cm}(2.25$ inches $)$ outside diameter by $48.39 \mathrm{~cm}$ (19.05 inches) long, including end caps, with a wall thickness of $0.305 \mathrm{~cm}(0.12$ inches). Following the welding of the end cap and a helium leak test on the inner capsule, each capsule was welded into an outer capsule. The dimensions of the outer capsule are $6.67 \mathrm{~cm}$ ( 2.625 inches) outside diameter by $51.05 \mathrm{~cm}$ (20.1 inches) long, including end caps, with a wall thickness of $0.305 \mathrm{~cm}(0.12$ inches). For a summary of the strontium encapsulation process refer to Section 2.3.1.1.

The cesium inner and outer capsules and end caps are made of $316 \mathrm{~L}$ stainless steel. Molten cesium chloride was cast into the inner capsule. Following the welding of the end cap and a helium leak test on the inner capsule, each capsule was welded into an outer capsule. The dimensions of the inner and outer capsules changed during WESF encapsulation. The outer diameter of the inner capsule was $5.72 \mathrm{~cm}(2.25$ inches $)$ and later increased to $6.48 \mathrm{~cm}$ (2.55 inches). The wall thickness of the inner capsule increased from $0.24 \mathrm{~cm}(0.095$ inches) to $0.26 \mathrm{~cm}$ ( 0.103 inches) to $0.34 \mathrm{~cm}$ ( 0.136 inches). The length of the inner capsule always remained $50.16 \mathrm{~cm}$ (19.75 inches). The inner diameter of the outer capsule decreased from $6.11 \mathrm{~cm}$ ( 2.407 inches) to $6.06 \mathrm{~cm}$ (2.385 inches); the outer diameter is $6.67 \mathrm{~cm}$ ( 2.625 inches). The wall thickness of the outer capsule increased from $0.28 \mathrm{~cm}$ ( 0.109 inches) to $0.30 \mathrm{~cm}(0.119$ inches) to $0.34 \mathrm{~cm}(0.136$ inches). The length of the outer capsule always remained $52.77 \mathrm{~cm}$ (20.775 inches). For a summary of the cesium encapsulation process, refer to Section 2.3.1.2.

\subsubsection{Type-W Overpack Capsules.}

Although the original capsules were designed specifically for containnent of the cesium chloride in the WESF storage pool environment, several commereial tirms petitioned DOE to oblain this material for radiation sterilization of commercial products. Cesium chloride capsules totaling approximately $38.000,000 \mathrm{Ci}{ }^{\mathrm{C}} \mathrm{Cs}$ were leased to three tims.

All but 13 ol the cesium chloride capsules were returned direcly to WESF following service at the commercial irradiators. The 13 capsules not returned directly to WF:SF were stored in the 327 Building on the Hanlord site. Eventually these 13 eapsules, in addition to thee capsules fom WLSF, were overpacked with an additional outer containment designated Type-W. In addition to the 16 WFSF capsules being placed in Type W overpacks. there were seven additional Type $W$ overpack cesium caljsules produced which contain remnants from destructive WFSF capsule testing. loose powder and peltets. two Oak Ridge Type 4 containers. and 10 Nordion capsules.

The Type-W overpack is a single capsule made from $316 \mathrm{~L}$ stainless steel endcaps and tubing with a maximum outside diameter of $8.35 \mathrm{-cm}(3.25-\mathrm{in}$.). minimum inside diameter of $7.48-\mathrm{cm}(2.945$-in.), and a minimum length of $53.91-\mathrm{cm}(21.225-\mathrm{in}$.).

\subsubsection{Airborne Radioactive Contamination Confinement}

The WESF ventilation system is designed to produce airflow patterns that move air throughout the building from areas of lesser contamination to areas of greater contamination. Contaminated areas are maintained at a negative pressure with respect to the atmosphere.

The HVAC system has four separate supply systems and three separate exhaust systems that service the major confinement areas in the 225-B Building. In accordance with DOE Order 6430.1A and Heating, Ventilating, and Air-Conditioning Design Guide for Department of Energy Nuclear Facilities (ASHRAE 1993), WESF is divided into three confinement areas: primary, secondary, and tertiary confinement. The definition of the three confinement areas is provided by the Nonrectur Nuclete Safety Design Criteria and Explosives Sufity Criteria Giticle (DOt ( $120.1-1$ ). Primary confinement is defined as follows: "Provides confinement of hazardous material 
to the vicinity of its processing. This confinement is typically provided by piping, tanks, glove boxes, encapsulating material, and the like, along with any offgas systems that control effluent from within the primary confinement." The capsules are considered to be primary confinement barriers. Secondary confinement is defined as follows: "Consists of a cell or enclosure surrounding the process material or equipment along with any associated ventilation exhaust systems from the enclosed area. Except in the case of areas housing glove-box operations, the area inside this barrier is usually unoccupied (e.g., Canyons, Hot Cells); it provides protection for operating personnel." Tertiary confinement is defined as follows: "Typically provided by walls, floor, roof, and associated ventilation exhaust systems of the facility. It provides a final barrier against the release of hazardous material to the environment."

\subsubsection{K-1 HVAC Supply and Exhaust System.}

The K-1 HVAC system provides ventilation for secondary confinement areas such as the Operating and Service galleries and the Truckport. A simplified schematic flow diagram is shown in Figure 2-9. The system supplies $100 \%$ outside air. The supply air is filtered by $8 \%$ and $80 \%$ efficiency National Bureau of Standards (NBS) filters, heated or cooled appropriately, and distributed through a duct network to the areas shown on the airflow diagram.

The K-1 exhaust system provides ventilation exhaust for the Pool Cell Area, Transmitter Rooms, and Manipulator Repair Shop as well as for the areas supplied by the K-1 supply system. The ventilation flow to the exhaust system removes hydrogen from the Pool Cell Area that is produced by radiolysis of the pool cell water. This flow-through of fresh air prevents the accumulation of hydrogen gas.

Air balance control and isolation of the rooms is accomplished by dampers in all supply and exhaust ducts. The exhaust of the K-1 system sequentially passes through a stage of $8 \%$ efficiency NBS filters, a stage of $35 \%$ NBS filters, and two stages of HEPA filters. One of two redundant fans exhausts the air from the filter banks. The exhaust air then flows to the discharge stack. Stindby power is available to the K-1 exhaust system as well as to the $\mathrm{K}-1$ supply fan units. Failure of the online $\mathrm{K}-1$ exhaust fan (or an overload in the system) automatically initiates action of the stindby fan.

The areas that are ventilated with the K-1 system vary in contamination from very low to moderate. Of these areas, the Hot Manipulator Shop contains the highest contamination, with levels ranging up to several thousand disintegrations per minute $(\mathrm{dpm}) / \mathrm{cm}^{2}$.

\subsubsection{K-2 HVAC Supply and Exhaust System.}

The K-2 HVAC system provides ventilation for tertiary confinement areas such as the offices and the AMU, which are uncontaminated areas. The system supplies $100 \%$ outside air. The supply air is filtered by $8 \%$ and $80 \%$ efficiency NBS filters, heated or cooled appropriately, and distributed through a duct network to the areas shown on the air flow diagram in Figure 2-9.

Part of the K-2 ventilation supply is directed to the HVAC Room. Because the HVAC Room is considered to have no potential for contamination, the exhaust air from this source is released directly to the atmosphere through a centrifugal fan located on the roof of the 225-B Building.

The K-2 system also provides supply air to the two Transmitter Rooms. The supply air passes through HEPA filtration at the inlet to each room. Because the Transmitter Rooms are potentially contaminated, the exhaust from these two areas is passed through an additional single-stage HEPA filter before flowing into the K-1 exhaust system upstream of the existing K-1 HEPA filters. The remainder of the K-2 system, exhausts air from the Change Rooms, AMU, and assorted office spaces to the atmosphere. With the exception of the two Transmitter Rooms, the remainder of the $\mathrm{K}-2$ system is not considered to provide source terms for the transfer of radioactivity to the environment. 


\subsubsection{K-3 HVAC Supply and Exhaust System.}

The WESF Hot Cells and the Canyon are primary confinement areas and are supplied and exhausted by the K-3 ventilation system. The supply air is filtered by $8 \%$ and $80 \%$ efficiency NBS filters, heated or cooled appropriately, and distributed through a duct network to the areas shown on the air flow diagram in Figure 2-10.

The K-3 HVAC system supplies $100 \%$ outside air. All of the K-3 air supply flows into the Canyon. The air going to the Hot Cells from the Canyon is drawn through one stage of HEPA filters before it enters the hot cells. These HEPA filters are located in the Canyon. Each hot cell has two parallel inlet HEPA filters.

Each hot cell has two exhaust paths to a common duct. Each exhaust path has one stage of HEPA filtration. After passing through the exhaust filters, the effluent from the cells is combined with the Canyon exhaust stream and ducted to the final K-3 HH.PA filters. Even though HIPA filters are used in several locations throughout the $K-3$ system, only the final stage $k-3$ fillers are required to be maintained and tested as HEPA filters.

The final K-3 HEPA filters consist of two parallel filter housings as shown in Figure 2-10. Each filtration housing unit is located in a separate K-3 Filter Pit. Normally, one unit is operating and the other is on standby. Only one unit is required to be available to support the BIO hazards and accident analysis. Each filter housing contains a system of impingement vanes, moisture separators, heaters, a built-in sump, and two banks of six HEPA filters. This system is capable of handling large particulate loading if some contamination from the duct migrates toward the filter housings.

Each filter housing consists of three functional sections; the inlet plenum, the section containing the moisture separators and air heaters, and the filtration section as shown in Figure 2-11. The separator/heater section is partitioned from the bottom to near the top to direct airflow upward through the separators and heaters and prevent water from flowing into the HEPA section. The inlet plenum section of the housing contains a plenum spray system and water collection sump. Quick-disconnects are used to connect the filter spray system to the water source. The K-3 filter housing sump is the low point of the K-3 HVAC system. The moisture separator, sump, and heaters would be used to accommodate the washdown of the K-3 duct. Thus, the sump would collect any water de-entrained during a duct washdown, and the subsequent rinsing of the inlet plenum, moisture separators, and the heaters. The sump is equipped with a water level monitor (air bubbler) and steam jets for water removal. The water level monitor consists of two rotometers supplied by $172 \mathrm{kPa}(25 \mathrm{psi})$ instrument air and a high level alarm. The filtration section contains two, six-filter sections in series. Differential pressure monitors are in place to check the pressure drop across each bank of HEPA filters.

The K-3 system contains two exhaust fans. Standby power is available to the K-3 exhaust system as well as to the K-3 supply fan units. Failure of the online K-3 exhaust fan (or loss of K-3 negative duct pressure in the system) automatically initiates action of the standby fan. The exhaust from the K-3 filter is discharged to a stack common to the $\mathrm{K}-1$ and $\mathrm{K}-3$ exhaust systems at WESF.

The K-3 underground exhaust duct and filter pit are designed to withstand a 0.25 gravity DBE which exceeds the SDC 4.1, Rev. 12, (DOE-RL 1993), design criteria of 0.20 gravity for safety class (Wagenblast, et al. 1999). The K-3 filter housing is not seismically anchored within the pit (see Section 3.4.2.1.2 for results of Design Basis Earthquake analysis).

\subsubsection{K-4 HVAC Supply System.}

The K-4 HVAC system supplies $100 \%$ outside air to the Pool Cell Area. The K-4 incoming air passes through one stage of $8 \%$ efficient and one stage of $35 \%$ efficient NBS filters. The air is also treated with appropriate heating and cooling by evaporative media cooling before it enters the centrifugal fan for dispersion to the K-4 system. The Pool Cell Area is exhausted through the K-1 exhaust system, (see Figure 2-9). 


\section{HNF-SD-WM-BIO-002 REV 1}

Figure 2-9. K-1, K-2, \& K-4 Ventilation.
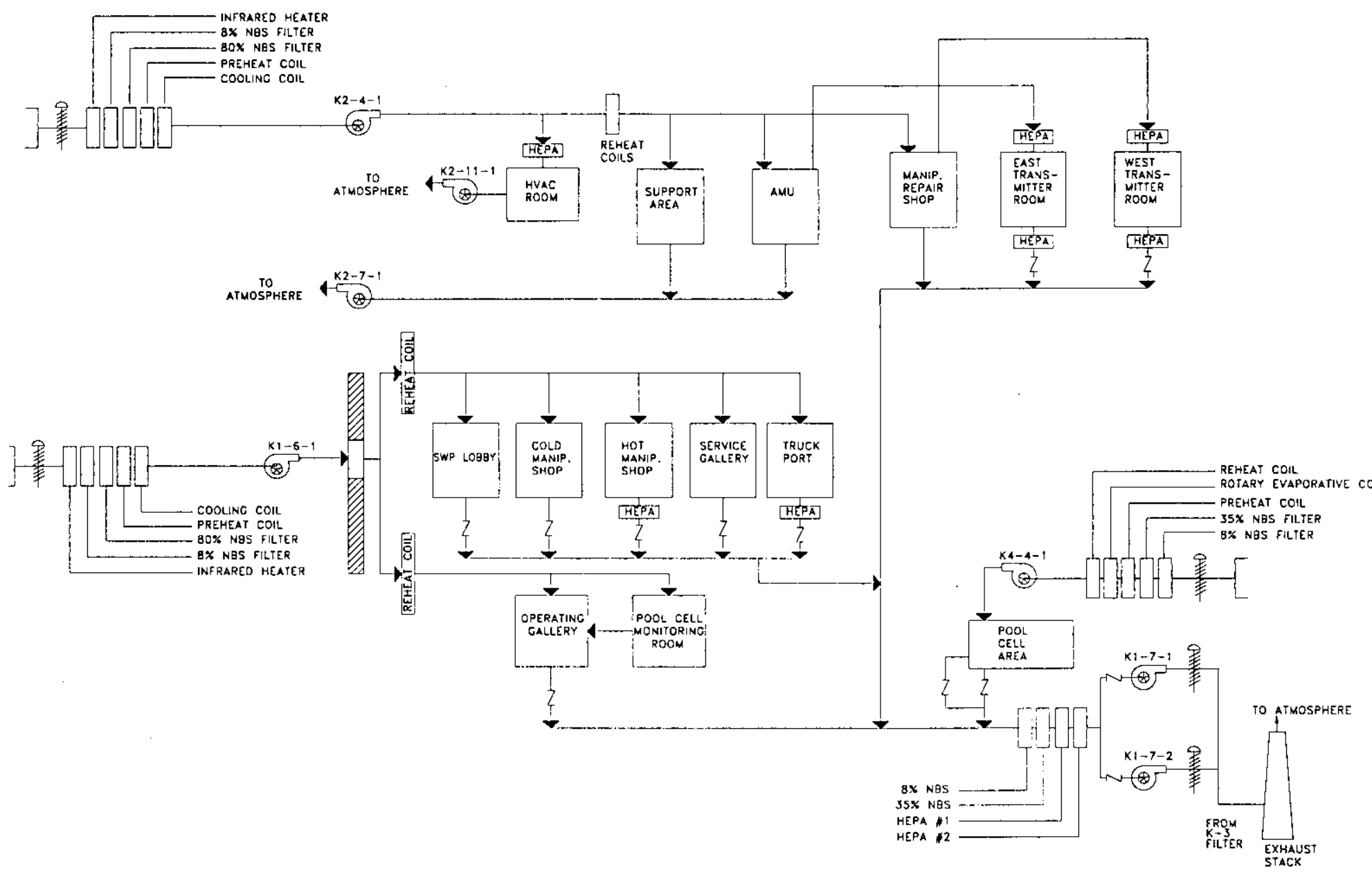
Figure 2-10. K-3 Ventilation.

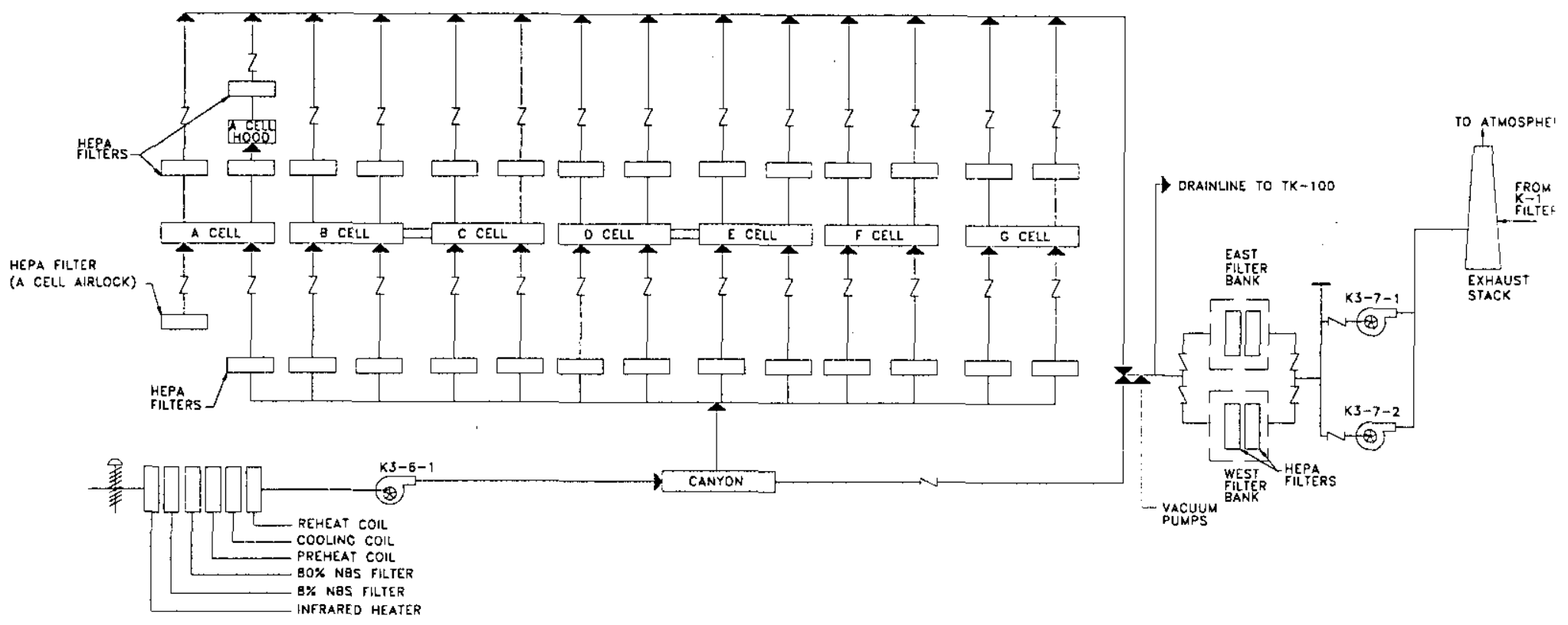




\section{HNF-SD-WM-BIO-002 REV 1}

Figure 2-11. K-3 Filter Housing Elevation view.

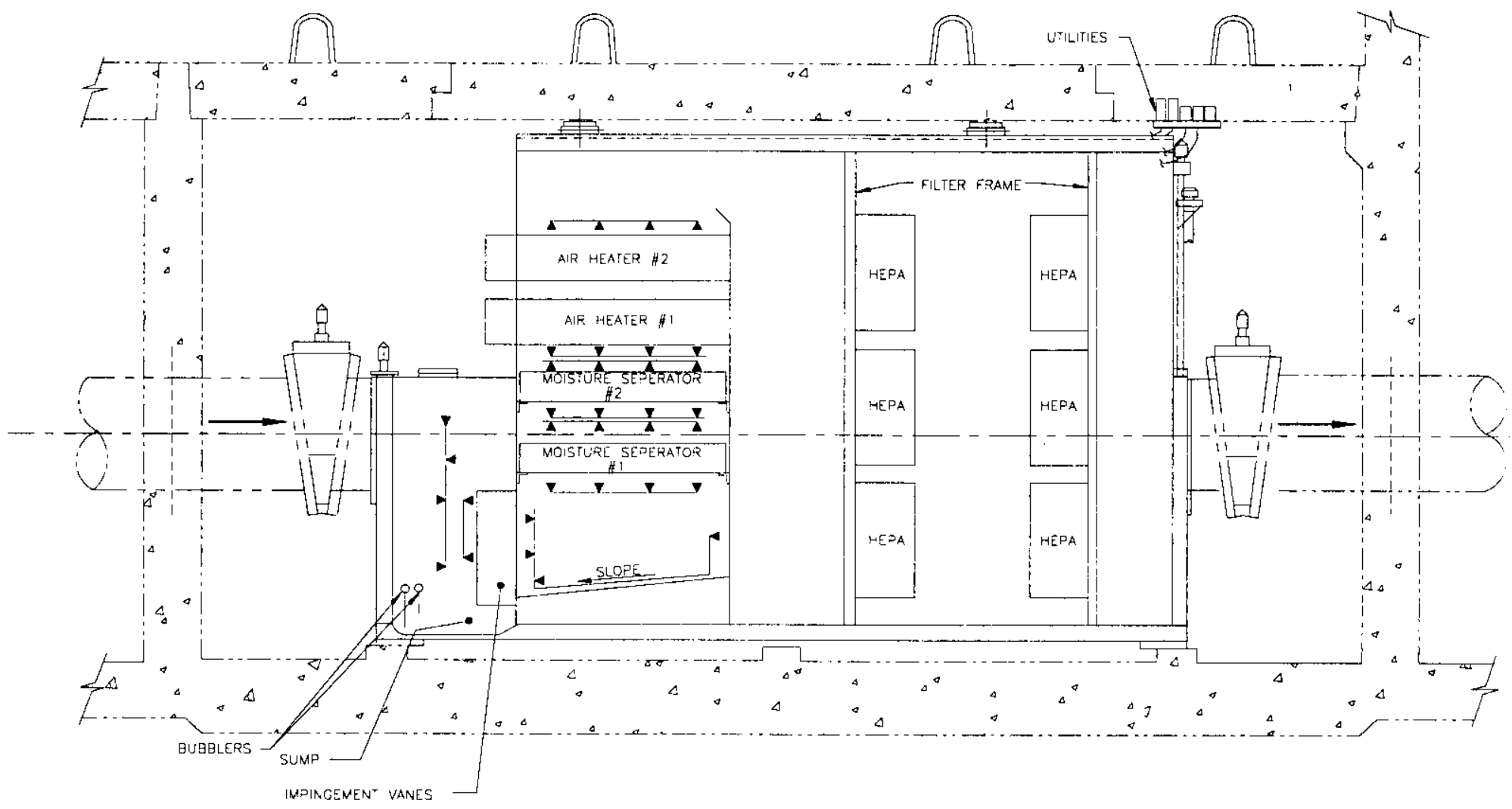




\subsubsection{Miscellaneous HVAC Systems.}

\subsection{K-5 HVAC System.}

The K-5 HVAC system is a closed loop system that supplies cooling water for the 225 -B Building K-1. K2 and $K-3$ ventilation supply units in the HVAC room and has no potential for contaminated effluent release. The cooled air is then distributed 10 all areas of $225 \mathrm{~B}$ except for the Pool Cell Area.

\subsection{K-6 HVAC System.}

The K-6 HVAC system ventilates the 225-B Compressor Building, which is separate from the 225-B Building and has no potential for a contaminated release. No source terms are identified, and no radiological treatment of this air is necessary

\subsubsection{Liquid Radioactive Waste Confinement}

Liquid radioactive waste streams generated at WESF are handled and disposed of as described in the following sections.

\subsubsection{Low-Level Waste Headers.}

The two low-level waste headers provided a collection system for liquid waste from the pool cells, the hot cells, and TK-100. This system is now out of service.

\subsubsection{Low-Level Liquid Waste Collection Tank.}

TK-100 is a 15,000-1 ( 4.000 -gal) stainless steel low level waste collection tank contained in a reinforced concrete pit with cover blocks. Water collected in TK-I(0) is translerred to a tanker truck for disposal. The majority of liquid waste effluents that flow into the tank by gravity drain are from the following sources:

- AMU tanks and floor drains

- Personnel decontamination room sink and shower

- Transmitter Rooms

- Exhaust Stack drain

- $\mathrm{K}-1$ exhaust filter building floor drains

- K-3 Filter Pits

- K-3 Filter unit sumps

- Hot Manipulator Shop floor drains

- Canyon decontamination sink

- TK-50 pit floor drain

- Crane maintenance platform floor drain

- Operating Gallery floor drains

- Service Gallery floor drains

- Truckport drain

- Cold Manipulator Shop floor drain

- Canyon floor drains

- Manipulator Repair Shop floor drains.

Additional sources include water from $F$ and $\mathrm{G}$ Cells, water collected in Pool Cells 9 and 10 (if contanination levels are too high for normal disposal), and llush water from operation of the WIXM. 


\subsubsection{Pool Cell Backup Cooling Water Discharge Line.}

Normal pool cell cooling is provided through a closed loop system (see section 2.9.2). If the closed loop. cooting system is unavailable. an altemate once-through cooling system is available using raw water and the existing pool cell heat exchangers. The once-through raw water system discharges to the Treated Effluent Disposal Facility (TEDF) via Line E.

\subsubsection{Radiation Confinement Provided by the Facility Structure}

\subsubsection{Hot Cells.}

To provide radiation shielding, the north and south walls of all the hot cells and both east and west walls of A and G Cells are $89 \mathrm{~cm}$ (35 in.) thick, high-density $3,770 \mathrm{~kg} / \mathrm{m}^{3}\left(235 \mathrm{lb} / \mathrm{ft}^{3}\right)$ reinforced concrete for personnel shielding. The walls between $B$ and $C, C$ and $D$, and $E$ and $F$ Cells are $51 \mathrm{~cm}(20 \mathrm{in}$.) thick and are constructed from reinforced structural $2,400 \mathrm{~kg} / \mathrm{m}^{3}\left(150 \mathrm{lb} / \mathrm{ft}^{3}\right)$ concrete. Shielded viewing windows are provided for observation of work being done remotely in the cells.

\subsubsection{Canyon.}

The walls of the Canyon are constructed from 46-cm (18-in.) thick reinforced structural concrete, except

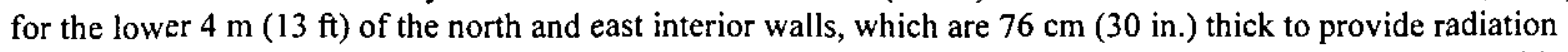
shielding for the adjacent AMU and Manipulator Repair Shop Areas. High-density, concrete-stepped cover blocks for the Hot Cells, Truckport, and pool cells are also located on the floor of the canyon.

\subsubsection{Hot Pipe Trench.}

The WLSF hot pipe trencl was used to transfer solutions between B Plant and WESF. These lines have not been used since WESF completed encapsulation processes in 1985. The lines have been capped in B Plant

\subsubsection{Pool Cell Area.}

Water is maintained in active (containing capsules) pool cells as the primary radiation shield. During an emergency, concrete cover blocks $76 \mathrm{~cm}$ (30 in.) thick are available for installation on pool cells if needed.

\subsubsection{Transmitter Rooms.}

Two Transmitter Rooms are located in the AMU Area below the mezzanine. These rooms contain instrumentation connected to the hot cell process vessels. These rooms provided area isolation in the event of a contaminated solution drawback through the instrumentation piping during processing. This piping and instrumentation has now been abandoned in place.

\subsubsection{Viewing Windows.}

Shielded windows in the Operating Gallery are designed to provide maximum in-cell viewing of work being conducted in the hot cells. The windows provide radiation shielding equivalent to $89 \mathrm{~cm}$ (35 in.) of high-density concrete, $25 \mathrm{~cm}$ ( $10 \mathrm{in}$.) of 3.3 -density glass on the cell side and $40 \mathrm{~cm}$ (15.6 in.) of 6.2 -density glass on the Operating Gallery side providing a total of 3.3 density meters (130 density in.) of glass. An oil barrier separates the glass sections.

Canyon crane operations can be observed through four viewing windows in the Canyon wall at the AMU level. The viewing windows provide the equivalent shielding of the adjacent $76-\mathrm{cm}(30$-in.) structural concrete wall. These windows are dry (non-oil) type lead-glass shielding windows.

\subsection{SAFETY SUPPORT SYSTEMS}

The WESF safety support systems are the Fire Protection System and the Radiation Protection System. A 


\section{HNF-SD-WM-BIO-002 REV 1}

criticality control system is not required.

\subsubsection{Criticality Monitoring}

According to the Compliance Assessment and Implementation Plan for DOE Order 5480.24, Nuclear Criticality Safety, Statement of Non-Applicability, WESF is exempt from criticality control, since the facility I contains no fissile material. As identified HNF-PRO-334. Crinculity Safety General Requirments, WESF is also exempt from implementing a criticality management program, therefore, no further discussion of criticality is required.

\subsubsection{Fire Protection System}

The WESF fire protection provisions are designed for the particular building construction, occupational usage, and potential hazards of each area.

\subsubsection{Building Construction.}

The building exterior and interior solid concrete walls and roof have an estimated fire resistance rating of at least 4 hours (UBC 1991, Section 43). Concrete construction of this type is classified as Type I (443) Fire-Resistive construction in accordance with NFPA 220 [1992 ed., paragraph 3-1]. However, because portions of the structure consist of unprotected steel (e.g., truck port) the overall construction classification of the structure is Type II (000), unprotected, noncombustible.

The interior walls of WESF are constructed of concrete (except for the partition between the Hot Manipulator Shop and Cold Manipulator Shop, the partition between the AMU and the Manipulator Repair Shop. and the Area 1 partilions). The floors are reinforced concrete slabs covered with vinyl tile in some locations. The walls are classified as Class A in accordance with NFPA Standard 255, Standard Method of Test of Surface Burning Characteristics of Building Materials (NFPA 1996). The floor is classified as a Class I interior floor finish in accordance with NFPA Standard 253, Standard Method of Test for Critical Radiant Flux of Floor Covering Systems Using a Radiant Heat Energy Source (NFPA 1990). The interior finish complies with the criteria in the NFPA Standard 101, Life Safety Code (NFPA 1994).

\subsubsection{Fire Detection Systems.}

Two kinds of fire detectors are used either alone or in combination in the 225-B Building: (1) ionization-type elements responsive to products of combustion and, (2) fixed-temperature, rate-compensated elements. Electrical signals from the fire detectors are transmitted to a central fire alarm panel located in the main entrance corridor. The central panel will initiate an audible alarm system throughout the buildings. The alarm system can also be activated by flow alarm switches installed in the sprinkler system piping. The fire alarm signals are transmitted to the 200 Area central fire station.

The fire detection and alarm system is capable of electronically supervising its own operation and providing trouble signals for loss of electrical power, open circuits, or other problems that could affect the operation of the system. The system also provides battery power for approximately 60 hours of operation upon loss of electrical power.

\subsubsection{Fire Sprinkler Systems.}

The Support Area, HVAC Room, Operating Gallery, Service Gallery, Manipulator Shops. and AMU Area are protected with a wet pipe automatic sprinkler system that alarms, when activated, directly to the Hanford Fire Department (HFD). Portable fire extinguishers are located in the building in accordance with code practice.

\subsubsection{Hot Cell Fire Protection Systems.}

$F$ and $G$ cells are equipped with a manually activated water spray system actuated from the Operating Gallery. The manual system consists of fixed and manipulator-directed spray nozzles. The spray ring for $G$ Cell is 


\section{HNF-SD-WM-BIO-002 REV 1}

supplied by a $1-\mathrm{cm}(1 / 2$-in.) raw water line from the WESF Service Gallery. F Cell is supplied from deionized water. A heat detection system is provided in each hot cell which alarms within the building and directly to the HFD.

The fuel loads are such that the structural integrity of the hot cells is not threatened by the fire scenarios without sprinkler activation. The severity of the potential fire is not of sufficient duration or intensity to cause damage to structural concrete around the Hot Cell or Canyon or to cause thermal damage to ventilation exhaust filters not located in the hot cell. The hot cells comply with NFPA 101 (1994) criteria for a building without sprinkler protection. (Mertz 1998.)

\subsubsection{Truckport Fire Protection Systems.}

The Truckport area is equipped with an automatic wet-pipe sprinkler served from the sanitary water supply. When activated, the system provides an alarm within the building and directly to the HFD.

The Truckport is constructed from $2(0-\mathrm{cm}$ to $30-\mathrm{cm}(8$-in 10 12-in) thick concrete and the entire Canyon above the Truckport is constructed from $46-\mathrm{cm}$ (18-in.) thick reinforced high density concrete. The impact of an uncontrolled combustible liquid oil fire would be to damage the structure and equipment. It is certain that extensive damage would occur if the sprinkler system did not operate. Even though sprinkler protection would not be expected to extinguish the fire, the cooling effect of the sprinkler discharge is expected to reduce the intensity of the fire, limiting the damage to the structure and control the spread of the fire to other combustible items. It is expected that the overall integrity of the concrete structure would be maintained with minimal damage. A fire in the Truckport would not structurally damage the Canyon. (Mertz 1998.)

\subsubsection{Radiation Detection Systems}

Radiation detection instrumentation is installed throughout the WESF facility for personnel protection and effluent monitoring.

\subsubsection{Airborne Contamination Sampling and Monitoring.}

Several different types of sampling and monitoring devices are used at WESF to ensure confinement of airborne radioactive contamination.

\subsection{Air Samplers.}

Air samplers sample the airstream or working area by drawing a metered flow of air through a filter. The filter is retrieved periodically and the radioactive content is measured after an appropriate delay time to permit the decay of naturally occurring isotopes.

\subsection{Air Sampler with Count-Rate Meter and Alarm.}

The K-1 filter air samplers are provided with a radiation detection instrument that monitors the filter media and indicates the amount of beta-gamma radioactivity using a count-rate meter. The $\mathrm{K}-1$ filter air samplers have been provided with an audible and visual alarm.

\subsection{Continuous Air Monitor.}

The CAMs have either local or remote sampling capabilities. Both the local and remote alarms are initiated if the beta/gamma radioactivity of the air sample exceeds a predetermined value. All CAMs in WESF also have recorders which continuously record activity.

\subsection{Airborne Discharge Monitoring.}

A multi-nozzle sampler in the WESF stack performs constant flow sampling and monitoring with a CAM. A record sample is achieved with a fixed-head sampler coupled to a conventional gas flow meter which records the 


\section{HNF-SD-WM-BIO-002 REV 1}

total gas flow sampled so that concentration values can be determined. There is continuous monitoring of the air stream with both local and remote alarms as required for a major stack.

\subsubsection{Area Radiation Monitors (ARMs).}

The ARMs are geiger-muller detectors which monitor for gamma radiation throughout the facility including the Pool Cell Area.

\subsubsection{Ion Exchange Radiation Monitors.}

The ion exchange radiation detector is located between the ion exchange resin beds in Pool Cell 11. This geiger-muller detector monitors for gamma radiation accumulated in the resin columns. Upon alarm, the ion exchange system is shut down to minimize radioactive material from accumulating on the resin columns.

\subsubsection{K-3 Filter Radiation Monitors.}

There are four independent detectors in the K-3 filter pits. The geiger-muller detectors are located adjacent to the east and west filter housing inlet sections and HEPA filter sections to detect and measure gamma radiation.

\subsubsection{Pool Cell Beta Monitors.}

Beta monitors are located in pool cells that store or could potentially store capsules (Pool Cell 12 currently hals a gamma monitor instead). Each detector monitors a sample line from the circulation pump and passes it into a sample chamber composed of a cerium crystal and photomultiplier tube. The monitor is designed and calibrated to detect gross beta radiation in the pool cell water providing early indication of a capsule leak. A simplified diagram of the pool cell beta monitor system is shown in Figute 2-8a.

\subsection{UTILITY DISTRIBUTION SYSTEMS}

\subsubsection{Electrical Systems}

The Bonneville Power Administration grid supplies the Hanford electrical distribution loop that in turn supplies WESF. Three independent $230-\mathrm{kV}$ sources are available to the loop, which is designed to allow for multiple component failure without irrecoverable power loss. From the 251-W substation, power is routed to WESF by overhead line C8-L7. See Figure 2-12 for a simplified diagram of the electrical system. The primary and | standby power sources and the load transfers that occur between these two sources are discussed in the following sections.

\subsubsection{Primary Power Source.}

A $13.8-\mathrm{kV}$, three-phase, $60-\mathrm{Hz}$ power line supplied from the existing $251-\mathrm{W}$ substation provides normal power. Power at WESF is reduced to $480-\mathrm{V}$, which is distributed throughout the facility by unit substation C8-S26.

Three motor control centers (MCC) are located in the HVAC Room of the 225-B Building, and two MCCs are located in the 225-BC Compressor Building.

\subsubsection{Standby Power Source.}

The WESF standby electrical system consists of a 625-kVA diesel-driven generator and two 480-V automatic transfer switches (ATS). The generator provides a $480-\mathrm{V} / 277-\mathrm{V}$ power source and is located in an outdoor skid-mounted enclosure located adjacent to the 225-BC Compressor Building. The engine is a 1,725-hp, 12-cylinder, diesel. Fuel is provided to the engine from a nearby aboveground 4,000-L (1,000-gal) fuel tank. 
Figure 2-12. WESF Electrical Distribution

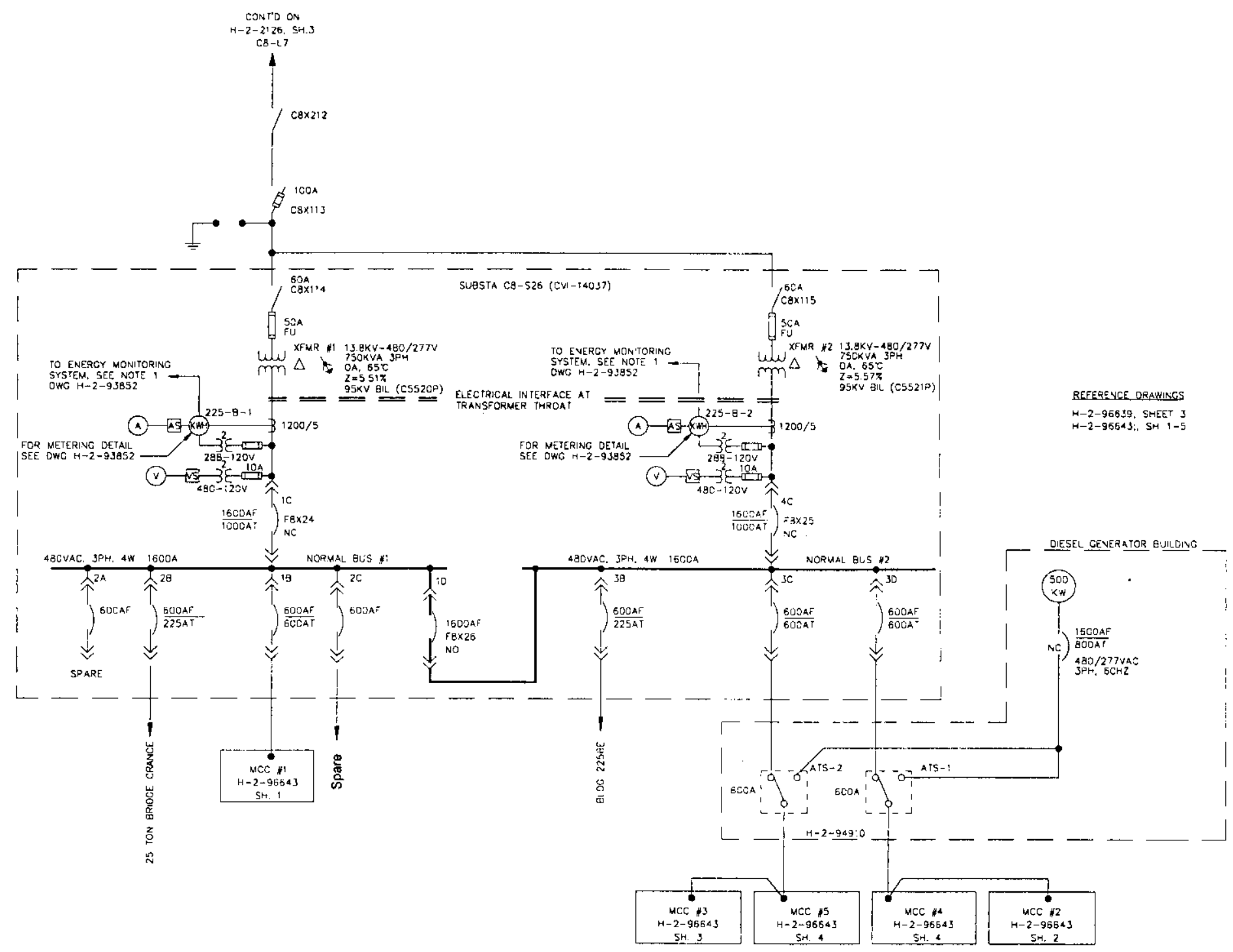


Upon loss of normal power to WESF, the generator will start after a time delay of approximately 6 seconds. This delay prevents the generator from starting due to power transients on the grid. When the ATS senses the appropriate generator voltage and frequency, the ATS will transfer the load to generator power. This takes approximately 20 seconds after the loss of normal power. When normal power is restored, the ATS will retransfer the load to normal power after a short time delay of no more than $30 \mathrm{~min}$. This time delay ensures the normal power source is stable prior to the retransfer. The generator will then automatically shut down after a cool-down period of approximately five minutes.

\subsubsection{Load Transfers.}

One of the three MCCs in the 225-B Building provides normal service to loads not requiring standby power. The other two MCCs in the 225-B Building serve critical loads and are supplied by the ATS from either the normal supply or the standby supply. Both MCCs in the 225-BC Compressor Building are connected to normal and standby power. Equipment served by the MCCs is restarted in a timed sequence after transfer to the diesel generator to prevent high starting currents from overloading the generator. Sequencing times range from approximately 15 to 60 seconds, depending on the components being energized, and are based on the time necessary for the starting surges to level off.

When the generator reaches operating voltage and frequency, the ATS transfers to stanciby power. As soon as the ATS has switched, $\mathrm{K}-1$ and $\mathrm{K}-3$ exhaust fans, the vacuum pump, and the fixed loads (instrumentation power, stand-by lighting, etc.) are energized. Following an additional delay, an air compressor and the refrigeration equipment are started. Following a second delay, the refrigeration unit is started, and following a third delay, the pool cell circulation pumps are started

\subsubsection{225-BC, Closed Loop Cooling System Electric Power}

Normal power is provided by a $13.8-\mathrm{kV}$ three phase, $60-\mathrm{H} z$ power line supplied trom the existing $251-\mathrm{W}$ substation. Power at the closed loop cooling system (CLCS) is distributed throughout the facility by motor control center 225 -BG-MCC-t.

The CLCS standby power system consists of a 375 kVA diesel driven generalor and one 480 volt ATS. The generator provides a 480 volt power source and is located in a building adjacent to Building 225-BG. Upon loss of normal power to the lacility. the generator will start alter a delay of approximately live seconds. When the ATS senses the appropriate generator voltage and frecuency, the ATS will transfer the motor control center to generator power. When nomal power is restored, the ATS will retranslier the load to the normal power source following a short delay. This detay assures that normal power is stable before transferring the foad. The generator will shut down following a short cool-down period.

\subsubsection{Compressed Air System}

Compressed air is primarily used for instrumentation and ventilation control. Compressed air for 225-B Building is supplied by two leased compressors located outside the northeast corner of the 225-BC Compressor Building. This compressed air system consists of two oil-free rotary compressors capable of providing $309 \mathrm{cfm}$ of air at a gauge pressure of $690 \mathrm{kPa}(100 \mathrm{psi})$. The compressors are normally operated with one unit in the lead position supplying all the facility air, and the second unit operates in the lag position and will activate if the lead unit fails or cannot maintain adequate air pressure. The compressors are connected to substation power and provided backup power by the standby diesel driven generator.

Compressed air from the main header is passed through an air dryer and is distributed throughout the facility at a gauge pressure of $690 \mathrm{kPa}(100 \mathrm{psi})$ and $172 \mathrm{kPa}(25 \mathrm{psi})$. 


\subsubsection{Steam Supply and Distribution System}

Steam is primarily used for heating the 225-B facility. Steam is also used to remove water from the K-3 Filter pit and stmps and heat the tri-sodium phosplate solution used lor manipulator decontamination. Steam is supplied to the facility by a diesel fired pachage boiler that is located on the WESF site and operated by Johnson Controls Inc.

\subsubsection{Water Supply System}

The Columbia River provides water for the Hanford Site. River water is pumped from the 100 Area through underground export water piping to the 200 East Area for use at WESF.

\subsubsection{Export Water Systems}

Two alternate pumping sources. located in the 100-B and 100-1) areas. feed the Export Water System pipelines and provide a redundant system as long as the pipelines remain intact.

Three electric pumps located at the 181 -B Pump House in the 100-B Area deliver Columbia River water to the 94,600,000 L. (25,000,000 gal) 182-B Export Water System Reservoir. These pumps have a rated capacity of $39,747 \mathrm{~L} / \mathrm{min}(10,500 \mathrm{gal} / \mathrm{min})$ per pump and a total pumping capacity of $283,000 \mathrm{~L} / \mathrm{min}(75,000 \mathrm{gal} / \mathrm{min})$. The 182-B Punp House contains four pumps each with 22.712-1/min (6.000-gal min) capacity and one pump with $11,352 \mathrm{~L} / \mathrm{min}(3,000-\mathrm{gal} / \mathrm{min})$ capacity. These pump water from the reservoir into the Export Water System distribution pipeline. 182-B also has four diesel engine driven pumps. each rated at $11.352 \mathrm{l} / \mathrm{min}(3,000 \mathrm{gal} / \mathrm{min})$. which serve as backup pumping units.

Three electric pumps located at the 181-D Pemp House in the 100-D Area deliver Columbia River water to the $56.781 .1781 .(15.000 .000$ gal) 182-1) F.xpent Water Sistem Rescrvoir. These pumps have a rated capacity of $49.210 \mathrm{~L} / \mathrm{min}$ (13,000 gal'min) per pump and a tolal pumping calpacity of 39.000 gal min. The 182-D Pump House contains five pumps rated at $7.571 \mathrm{l} / \mathrm{min}(6.000$ gal $: \mathrm{min})$ per pump. These pump water from the reservoir into the Export Water System distribution pipeline.

The electric pumps in the 100-D Area are the nomal backup system to the 100-B Area pumps with the auxiliary diesel pumps as the second level backup system.

Fxport water from 100-B or 100-D) Area sites is pumped through 107-cm (42-in.) lines to the 1901-Y Area. At 1901-Y, the lines meet and divide into two $80-\mathrm{cm}(30-$ in. $)$ lines that are then routed to the $2901-\mathrm{Y}$ Area. At 2901-Y. the lines meet and then divide one final time. From 2901-Y, there are two $61-\mathrm{cm}$ (24-in.) lines running to $200 \mathrm{E}$ and one $61-\mathrm{cm}(24-\mathrm{in}$.) line $10200 \mathrm{~W}$. All water lines are provided with valves that can be used to isolate reservoirs and/or pipelines to ensure al source of water to the various locations.

The Export Water System storage and pumping systems are monitored and controlled from each pumphouse. Pressure and flow delivered to 200-E and 200-W are centrally monitored from the $283-\mathrm{W}$ Control Room.

\subsubsection{Water Distribution.}

The WESF water system consists of sanitary, deionized, raw, and the deep well systems as described in the following sections.

\subsection{Sanitary Wher System.}

Sanitary (Potable) Water for $200 \mathrm{E}$ and $200 \mathrm{~W}$ is produced in the $283-\mathrm{W}$ Water Filtration Plant. The 283-E Water Filtation Plant is currently shut down and being maintained as a maintenance emergency backup for the 283-W Waler Filuation Plant. 200E and 200W Sanitary Water Systems are tied logether through a 12-inch 
distribution pipeline.

Sanitary Water for normal use in $200 \mathrm{~W}$ is stored in a 1.514,1651. ( 400,000 gal) underground clearwell system consisting of two 757,082 L. (200,000 gal) concrete tanks adjacent to the 283-W building. 200E Sanitary Water is stored in a similar system adjacent to the $283-\mathrm{E}$ building.

There are 4 Sanitary Water System distribution pumps in 283-E and in 283-W, each with a capacity of $1,000 \mathrm{gal} / \mathrm{min}$, for total of $8,000 \mathrm{gal} / \mathrm{min}$ capacity.

The Sanitary Water System in each area supplies a 4.162.400 L (1,100,000 gal) Emergency Sanitary Water reservoir (283-EA in 200t and 283-WA in 200W). In the 282-FC pumphouse there is an Fimergency Sanitary Water System Pump (Fire Pump), with a 17.028 (4.500 gal) per minute capacity. In the 283-WC pumphouse there is an Emergency Sanitary Water System Pump (Fire Pump) with a 15,1361, (4,000 gal) per minute capacity. There

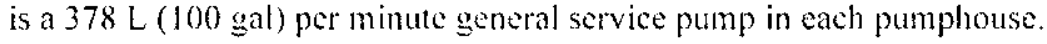

The $200 \mathrm{E}$ and $200 \mathrm{~W}$ Sanitary Water treatment, storage and pumping systems are centrally monitored and controlled from the 283-W Control Room.

The 200E Sanitary Water System distribution piping is configured to provide dual delivery to the Southeast corner of B-Plant complex. All the lines are provided with valves that can be used to isolate sections of the distribution system to ensure a source of water in the event of line problems.

Sanitary water is used at WESF for drinking, toilet facilities, deionized water production, and a supply for the automatic fire suppression system. The sanitary water enters WESF from the north side of the facility through -a $5-\mathrm{cm}(2-\mathrm{in}$.) supply header which supplies water for drinking and toilet services in the office wing of the 225-B Building and leed to the deionized water system. This system also serves as a backup water source to the pool cells in the event of a loss of pool cell water accident.

\subsection{Deionized Water System.}

Deionized water is generated for use at WESF with a deionized water system installed on the second floor of the AMU. There is also a 3,800-L (1,000-gal) storage tank (TK-210) in the AMU Area .

Deionized water is used at WESF for several activities including make-up of decontamination solutions and $\mathrm{F}$ Cell fire suppression, but is primarily used to maintain the pool cell water level. The usage varies but averages approximately $3,800 \mathrm{~L} / \mathrm{wk}(1,000 \mathrm{gal} / \mathrm{wk})$.

\subsection{Raw Water System.}

The Export Water System is piped direcly into the Raw Water System distribution systems in 200E and $200 \mathrm{~W}$. There are two booster pumps in $282-\mathrm{EC}$, each with a capacity of $18,920 \mathrm{~L} / \mathrm{min}(5,000 \mathrm{gal} / \mathrm{min})$, and two in 283-WC. each with capacity of $11,352 \mathrm{~L} / \mathrm{min}(3,000 \mathrm{gal} / \mathrm{min})$. These are started and run as system pressure and flow demands dictate.

The Export Water System also supplies the $11,352,000$ L (3,000,000 gal) Emergency Raw Water reservoir in 200E (282-E) and one of the same size and type in $200 \mathrm{~W}(282-\mathrm{W})$. In the 282-E pumphouse there are 3 Emergency Raw Water System Pumps (Fire Pumps). each with a 14.0001. (3.500 gal) per minute capacity. In the 282-W pumphouse there are 2 Emergency Raw Water System Pumps (Fire Pumps), each with a $11,352 \mathrm{~L}$ (3,000 gal) per minute capacity. There is a $1.200 \mathrm{l}$ ( $300 \mathrm{gal}$ ) per minute general service pump in each pumphouse.

The 200F and 200W Raw Water storage and pumping systems are centrally monitored and controlled from the 283-W Control Room.

The 200E Raw Water System distribution piping is configured to provide dual delivery to the Southeast corner of B-Plant complex. All the lines are provided with valves that can be used to isolate sections of the 


\section{HNF-SD-WM-BIO-002 REV 1}

distribution system to ensure a source of water in the event of line problems.

The 200E and 200W Raw Water Systems supply makeup water to the 200F and 200W Water Filtration Plants.

Raw water is used at WESF as backup cooling for pool cell heat exchangers, air compressor after-coolers, and the hot cell fire fog suppression system. This system also serves a backup water source to the pool cells in the even of a loss of pool cell waler accident.

There are three sources of raw water to the 225-B Building-. One source enters at the northwest corner of the 225-B Building through a $25-\mathrm{cm}$ (10-in.) header and is used for backup pool cell cooling. The second line enters on the west wall through a 10-cm (4-in.) header and is used primarily for tire stupression of the cast and west Transmitter Rooms and $\mathrm{G}$ Cell. The thitd source enters on the north side through a $15-\mathrm{cm}(6$-in.) header and supplies the facility automatic fire suppression system.

\subsection{Deep Well Supply.}

Two diesel-driven backup well pumps identified as No. 1 (282-B) and No. 2 (282-BA) are located west of the 225-B Building at wells 299-E28-11 and 299-E28-15, respectively. In the event of loss of the raw water pressure to WESF, these pumps will be used to supply the minimum volume of raw water required for WESF pool cell cooling. This system also serves a backup water source to the pool cells in the event of a loss of pool cell water accident.

\subsubsection{Communications Systems}

A commercially maintained telephone system provides phone service for the entire Hanford Site, including WESF. This commercially maintained telephone system provides a line for reporting emergency conditions to proper authorities. The number is 911 . This system can also be used to make amnouncements during normal and emergency conditions.

\subsection{AUXILIARY SYSTEMS AND SUPPORT BUILDINGS}

The support buildings and systems for WESF are as follows:

- TK-100, Low Level Liquid Waste Tank and Pit

- 225-BG. Closed Loop Cooling System

- WESP Pool Cell Emergency lon Fxchange System

- 225-BA, K-1 Filter Building

- $\quad 225-B B, K-3$ Filter Pit

- $\quad 225-\mathrm{BC}$, Compressor Building

- 225-BD, Waste Monitor and Sample Building

- 225-BE, Maintenance Shop

- $\quad 296-B-10$, K-1 and K-3 Exhaust Stack

- 282-B, Pump House

- 282-BA, Pump House

- $\quad$ 294-B, Raw Water Backflow Preventer Building

- 225-B Diesel Generator

- TK-50 Pit

These support buildings and systems are described in the following sections (there are additional miscellaneous buildings associated with WESF which are not described here). The plan location of each building with respect to the 225-B Building is shown in Figure 2-3. 


\section{HNF-SD-WM-BIO-002 REV 1}

\subsubsection{TK-100, Low Level Liquid Waste Tank and Vault}

TK-100 is a collection tank located underground to the south of the 225-B Building and collects miscellaneous contaminated or potentially contaminated wastes from sources identified in section 2.6.3.2. Tank-100 is $2.7 \mathrm{~m} \mathrm{(9} \mathrm{ft)} \mathrm{in} \mathrm{diameter} \mathrm{by} 3 \mathrm{~m}(10 \mathrm{ft})$ deep and has an approximate capacity of $15.000 \mathrm{~L}(4.000 \mathrm{gal})$. The outside vault dimensions are $4.0 \mathrm{~m}(13 \mathrm{ft})$ by $4.0 \mathrm{~m}(13 \mathrm{ft})$ by $5.2 \mathrm{~m}(17 \mathrm{ft})$ deep and is constructed of $30.0-\mathrm{cm}$ (12-in.) thick reinforced concrete. The top of the vault is at grade level and removable cover blocks provide access to the tank. The TK-100 vault contains a sump with level and alarm capabilities. The sump can be pumped to the tank to remove accumulated liquid.

The contents of TK-100 are transferred through lines located in the lruckport to a tanker truck or temporary storage tank for final transfer to Effuem Treatment Facility or Tank Farms. If necessary, the low level licuid waste can be routed througl a WESF Ion Fxchange Module (see section 2.9.3) to reduce to amount of "' $\mathrm{Sr}$ and $/$ or $^{1: 7} \mathrm{Cs}$ prior to disposal. TK-100 has the capability to be circulated and sampled prior to transfer and the lines can be flushed with deionized water following transfer.

\subsubsection{5-BGi Pool Cell Closed Loop Cooling System}

The C1.CS circulates water from the outlet of the wet surface fluid coolers (WSFCs), through the Pool Cell Heat Exchangers, back to the inlet of the WSFCs using two 480 V, $100 \mathrm{HP}$, circulation pumps connected in parallel and located in building 225-BG. Only one pump is required to be in operation to supply the recpuired flow. Three IVSFCs are provided to transfer heat removed trom the pool cell heat exchangers to the atmosphere. Each WSFC consists of cooling coils, an enclosed spray system. cooling fans and air danpers, and makeup and chemical addition system. During normal operation one WSFC is selected for "Primary," one for "Sccondary," and one for "Standby."

An expansion cank focated in 225-BG maintains system water inventory. The nomat source of makeup water is the site sanilary water which also supplies the building emergency shower and eyewash. Raw water is provided to 225-BG as a backup supply to Sanitary Water. Chemicals are added to the system via the chemical addition system to reduce corrosion, climinate biological growth within the system, and control water $\mathrm{pH}$.

All discharges from the CLCS are routed to the sump tank located in 225-BG. The sump is equipped with two disclarge pumps, sampler, and alssociated instrumentation. The discharge flow to THDF is monitored for $\mathrm{pH}$, conductivity, temperature and llow.

\subsubsection{WESF Pool Cell Emergency Ion Exchange System}

The WESF emergency ion exchange (EMIX) system provides a method to decontam inate the water in the pool cells in the event of a capsule leak. Water from the atfected pool cell is circulated through a WESF Ion Exchange Module (WIXM) located in the truck port, and the purified water is returned to the pool cell (see Figure 2-8a for simplified diagram). Remotely operated valves and controls are installed to perform this activity. The WESF Process Monitor and Control System (WPMCS) will control the EMIX system and, in doing so. controls the routine circulation of pool cell water through the existing pool cell heat exchanger's and water purifying ion exchange system, as well.

The WIXMs, which are used as part of the EMIX system, are portable, shielded, disposable ion exchange resin units designed to remove " $\mathrm{Sr}$ and ${ }^{17} \mathrm{Cs}$ from a pool cell in the event of a leaking capsule or the low level liquid waste system. The WIXM consists of a stainless steel ion exchange column and support piping encased in a reinforced concrete shielding block measuring 86 inches by 86 inches by 106 inches tall. When in use. the WIXM is loaded with an organic ion exchange resin at a ratio to prevent excess loading. It is noted here that the WIXM can also be used to remove "Sr and or ${ }^{1: 7} \mathrm{Cs}$ from the low level liquid waste contained in $\mathrm{TK}-100$ prior to disposal. 


\subsubsection{5-BA, K-1 Filter Building}

The K-1 Filter Building is located outside and directly south of the 225-B Building. A one-story above

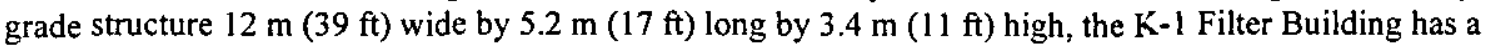
reinforced concrete roof slab supported by reinforced concrete shear walls. The foundation is a continuous footing at $0.76 \mathrm{~m}(2.5 \mathrm{ft})$ below the grade slab.

The 225-BA Building is structurally independent of the adjacent structures. The building was evaluated, and found adequate for a $1.23-\mathrm{m} / \mathrm{s}^{2}(0.125-\mathrm{g}) \mathrm{OBE}$ and a $2.5-\mathrm{m} / \mathrm{s}^{2}(0.25-\mathrm{g}) \mathrm{DBE}$. The roof was designed for dead loads plus a live load of $960 \mathrm{kPa}\left(20 \mathrm{lb} / \mathrm{ft}^{2}\right)$ (Wagenblast, et al. 1949$)$ ).

\subsubsection{5-BB, K-3 Filter Pit}

The K-3 Filter Pit is approximately $4.9 \mathrm{~m}(16 \mathrm{ft})$ wide by $11 \mathrm{~m}(37 \mathrm{ft})$ long by $3.3 \mathrm{~m}(11 \mathrm{ft})$ deep and is constructed from $30-\mathrm{cm}$ (12-in.) reinforced concrete and located south of the 225-B Building. The top of the building is at grade elevation. The building is partitioned into 5 sections by reinforced concrete dividers. Each section is equipped with cover blocks for remotely replacing the filters. The foundation is a continuous reinforced concrete slab $3 \mathrm{~m}$ (10 ft) below grade. The K-3 Filter Pit is structurally independent of the adjacent structures.

The structure has been designed to survive a $2.5-\mathrm{m} / \mathrm{s}^{2}(0.25-\mathrm{g}) \mathrm{DBE}$ and extreme wind loads (Wagenblast, et al. 1999). The last section of the K-3 Filter Building is above ground.

\subsubsection{5-BC, Compressor Building}

The 225-BC Compressor Building is located north of the 225-B Building. It contains the K-5 refrigeration

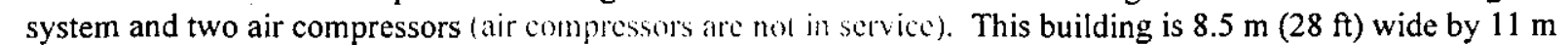

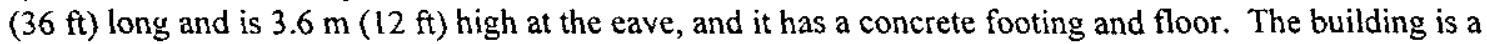
prefabricated steel, insulated, self-framing structure with a gable roof. An annex, $225-\mathrm{BF}$, is located directly south of the 225-BC Building, which houses the compressed air system receiver tank and the primary dryer. A cooling tower is located outside of the 225-BC Building on an adjacent concrete foundation.

\subsubsection{5-BD, Waste Monitor and Sample Building}

The 225-BD Waste Monitor and Sample Building is located south of the 225-B Building. The building supplies power, pneumatic air, and instrumentation for the operation of the K-1, K-3, and TK-100 systems and 296-B-10 stack sampling system.

\subsubsection{5-BE, Maintenance Shop}

The 225-BE Maintenance Shop is located just north of MO-863. It houses the millwright and the pipefitter shops.

\subsubsection{6-B-10, K-1 and K-3 Exhaust Stack and Duct}

The colluent stach for building 225-B is a freestanding stack, $23 \mathrm{~m}$ ( $75 \mathrm{fl}$ ) high with a $1.1 \mathrm{~m}$ (42 in.) inside dianeter. made from glass-fiber- reinforced polyester resin: the base of the stack is fastened to a steel base ring assembly. The steel base ring assembly consist of a $1.3 \mathrm{~cm}(1 / 2 \mathrm{in}$.) thick plate rolled into a cylinder having a $1.1 \mathrm{~m}$ (44 in.) inside diameter (II)) and . $5 \mathrm{~m}$ (20 in.) high; the cylinder is welded to a $2 \mathrm{~cm}(3 / 4 \mathrm{in}$.) thich ring plate having an inside dianeter of $1.1 \mathrm{~m}$ ( $4.4 \mathrm{in}$.) and an outside diameter of $1.4 \mathrm{~m}$ (53 in.), the cylinder and ring are reinforced with sixteen $1 \mathrm{~cm}(3 / 8 \mathrm{in}$.) gusset plates. The base ring assembly is anchored with sixteen $3.2 \mathrm{~cm}(1 / 4 \mathrm{in}$.) diameter by $0.4 \mathrm{~m}$ ( $16 \mathrm{in}$.) long anchor holts embedded in a reinforced concrete foundation $2 \mathrm{~m}(6 \mathrm{ti})$ in diameter and $4.3 \mathrm{~m}$ ( $14 \mathrm{ft}$ ) deep. The stack has two main penetrations: a $0.8 \mathrm{~m}$ (30 in.) penetration for the $\mathrm{K}-1$ and a $0.5 \mathrm{~m}$ (20 in.) penetration for the $K-3$ exhaust duct connections, as well as several other penetrations ranging between $2.5 \mathrm{~cm}$ ( 1 in.) and $0.4 \mathrm{~m}$ ( $1.5 \mathrm{in}$. .) in diameter for stack sampling. Nll penetrations are equipped with stainless steel flanges molded into the stack. The stack is equipped with a spray ring, drain, and lightening arrestor. 


\section{HNF-SD-WM-BIO-002 REV 1}

The $\mathrm{K}-3$ fiberglass duct, having a $0.5 \mathrm{~m}(20 \mathrm{in}$.) ID and $0.6 \mathrm{~cm}(1 / 4 \mathrm{in}$.) wall thickness, connects the $0.5 \mathrm{~m}$ (20 in.) flanged stack opening and the $\mathrm{K}-3$ exhaust fan assembly to the west. The $\mathrm{K}-3$ duct is $18 \mathrm{~m}(60 \mathrm{ft})$ long. with 6 supports spaced at $3 \mathrm{~m}(10 \mathrm{ft})$ centers. The $\mathrm{K}-1$ liberglass duct, having a $0.8 \mathrm{~m}(30 \mathrm{in}$.) ID and $0.6 \mathrm{~cm}(1 / 4$ in.) wall thickness. connects the $0.8 \mathrm{~m}$ (30 in.) flanged stack opening and the $\mathrm{K}-1$ exhaust fan assembly to the east. The $\mathrm{K}-\mathrm{l}$ duct is $3 \mathrm{~m}(10 \mathrm{ft})$ long and has one support at the center. The fiberglass ducts are connected to the $K-1$ and $K-3$ stainless steel fan outlet ducts that are connected to the fans with flex connection.

A seismic evaluation qualifies the stack and duct for WESF DBE loads of 2.5 mis' $(0.25$ gravity). (Wagenblast, et al., Appendis (G. 1999).

\subsubsection{2-B and 282-BA Backup Well Pump Houses}

The diesel-driven backup well pumps are located in the 282-B and 282-BA Buildings to the southwest of the $225-\mathrm{B}$ Building. These pumps have capacities of $757 \mathrm{~L} / \mathrm{min}(200 \mathrm{gal} / \mathrm{min})$ and $3,028 \mathrm{~L} / \mathrm{min}(800 \mathrm{gal} / \mathrm{min})$ respectively. The fuel tanks are located inside concrete structures $3 \mathrm{~m}$ (10 ft) west of the pump houses and are connected to the diesel engines by underground pipelines.

\subsubsection{4-B Raw Water Backflow Preventer Building}

The 294-B raw water backflow preventer building is located in the southeast corner of the B Plant/WESF complex. The building houses two $25-\mathrm{cm}(10$-in.) backflow preventer assemblies that operate in parallel to prevent the possibility of radioactively contaminated water from migrating into the $200 \mathrm{E}$ main raw water supply header.

\subsubsection{5-B Diesel Generator}

The 225-B diesel generator is located in an outdoor skid-mounted enclosure adjacent to the 225-BC Compressor Building. The engine is a $1,725-\mathrm{hp}, 12$-cylinder diesel. Fuel is provided to the engine from a nearby, aboveground 4,000-L (1,000-gal) fuel tank.

\subsubsection{TK-50 Pit}

The tank and piping located in the TK-50 pit were removed during installation of the new WESF LLLW project. The low level licjuid waste discharge lines from the hot cells and the Pool Cell Area were routed to TK-100 through the TK-50 pit. 
HNF-SD-WM-BIO-002 REV 1

This page intentionally left blank. 
HNF-SD-WM-BIO-002 REV 1

\subsection{HAZARD AND ACCIDENT ANALYSES}

\subsection{INTRODUCTION AND SUMMARY}

\subsubsection{Introduction}

This chapter documents the hazard and accident analyses performed for operation of the Waste Encapsulation and Storage Facility (WESF). The principal guidance documents used in the performance and preparation of the hazard and accident analyses were DOE-STD-3009-94 (DOE 1994a), DOE-STD-1027-92 (DOE 1992), and WHC-CM-4-46. The rigor of this chapter meets Hazard Category 2, which is the hazard category of WESF (Section 3.3.2.2).

Located adjacent to B Plant in the 200 East Area of the Hanford Site, WESF is designed to receive, inspect, decontaminate, and store strontium and cesium capsules that were produced in past campaigns at WESF. The capsules were produced in WESF from 1974 to 1985 to reduce the quantity of ${ }^{90} \mathrm{Sr}$ and ${ }^{137} \mathrm{Cs}$ in liquid waste in underground tanks. The ${ }^{90} \mathrm{Sr}$, in the form of strontium fluoride, and the ${ }^{137} \mathrm{Cs}$, in the form of cesium chloride, were doubly encapsulated in WESF hot cells and then stored underwater in WESF pool cells. Some of the cesium capsules were leased to private enterprises for use as radiation sources; all these capsules have been returned to WESF. Sixteen of the cesium capsules have been placed into Type $W$ overpacks due to the original capsule being damaged or swollen. There are also seven additional Type W overpacks stored at WESF containing powder and pellets from former cesium capsules.

The primary product of this chapter is the identification of the systems, structures, and components (SSCs) and controls required for the safe operation of WESF. To this end, the hazard and accident analyses consist of performance of hazards identification, facility hazard categorization, hazards evaluation, and quantitative accident analysis. The hazards identification results incorporate bounding estimates of hazardous material and energy quantities, forms, and locations. The facility hazard categorization establishes the hazard category of WESF in accordance with DOE-STD-1027-92 (DOE 1992). The hazards evaluation places the identified hazards within the context of the facility processes, evaluates deviations from design intentions that might impact those hazards, and specifies controls based on the principles of defense-in-depth, worker safety, and environmental protection. The quantitative accident analysis takes representative and unique deviations from the hazards evaluation, systematically analyzes potential accident sequences and consequences, and identifies any controls required to prevent or mitigate the accidents (Table 3-1).

The facility SSCs are identified and described in Chapter 2.0, "Facility Description." Likewise, the operations identified in Chapter 2.0, Section 2.5, define the operational configuration used as the basis for the hazard and accident analyses. These operations include maintenance of the facility, capsule receipt, decontamination, inspection, storage, and surveillance. Excluded activities are destructive testing, electropolishing, K-3 filter changeout, decontamination and decommissioning activities, and wet storage of capsules in TK-F5 in F Cell. Because these activities are not anticipated within the short timeframe of this basis for interim operation (BIO) applicability, and because they may introduce additional risks to those evaluated here, they are not included as allowable activities.

Throughout the hazard and accident analyses, the term "active pool cell" is used to refer to a pool cell in which capsules are stored. The term "inactive pool cell" is used to refer to pool cells that are not used for capsule storage. Although it does not store capsules, an inactive pool cell may be used for other purposes, such as emergency water supply, shielding, monitoring, and support equipment storage.

\subsubsection{Summary}

The results documented in this hazards and accident analysis can be summarized by discussing each phase of the analysis: hazards identification, hazards evaluation, hazard category, and accident analysis.

Hazards Identification. The hazards identification performed for WESF is documented in Sections 3.3.1.1 and 3.3.2.1 for methodology and results, respectively. By far the most significant hazard identified at WESF is the approximately $52 \mathrm{MCi}$ of ${ }^{137} \mathrm{Cs}$ and $23 \mathrm{MCi}$ of ${ }^{90} \mathrm{Sr}$ (not including daughter products) stored in the pool cells. This radioactive material is doubly encapsulated and stored under water, and has numerous controls and SSCs designed to ensure that it is properly controlled. Also a significant hazard, but to a lesser degree than the radioactive material in the pool cells, is radioactive 


\section{HNF-SD-WM-BIO-002 REV 1}

material in the hot cells and the K-3 exhaust duct. The radioactive material hazard in the hot cells is compounded by the presence of combustible materials. As with the pool cells, the radioactive material in the hot cells and exhaust duct have associated controls and SSCs designed to ensure that it is properly controlled.

Hazards Evaluation. The hazards evaluation performed for WESF is documented in Sections 3.3.1.2 and 3.3.2.2 for methodology and results, respectively. The hazards evaluation tables themselves are documented in a supporting document

(Hey 1999). For those hazards which could have significant consequences, the hazards evaluation provides the event risk rank for input into the accident selection process. The specific accidents selected for analysis are listed in Section 3.3.2.3.5.

Hazard Category. WESF is a Hazard Category 2 facility based upon the quantity, form, and location of the radioactive material. The detailed discussion of hazard category is provided in Section 3.3.2.2.

Accident Analysis. Several potential accidents were analyzed in this chapter and are summarized, along with appropriate protective measures, in Table 3-1. Table 3-1 presents each accident type, the particular accidents selected for analysis, the mitigated and unmitigated consequences of each accident, and the credited controls and SSCs. The table is organized to present the results for each accident type roughly in the order of worst consequences to least consequences, with the beyond design basis events listed last.

The most significant event which could happen at WESF is a loss of pool cell water. An event sequence which results in a loss of pool cell water has associated direct radiation concerns as well as a release of radioactive material. Several such sequences were identified including:

- heavy object drop (e.g., a cover block),

- inadvertent pool drain,

- drain or circulation line failure,

- failure to provide water makeup,

- aircraft impact,

- beyond design basis earthquake, and

- hydrogen or flammable gas explosion impacting the Pool Cell Area structure.

In addition to posing long-term water makeup problems, a seismic event could also have significant immediate consequences. The radioactive material from the hot cells and $\mathrm{K}-3$ exhaust duct could be suspended and released through an unfiltered pathway because of lack of seismic anchors for the K-3 HEPA filters. Possible failure of the B Plant endwall could damage A Cell and result in a release of radioactive material through openings to the environment. The long-term hazard associated with a seismic event is the lack of seismically qualified water makeup systems. If all makeup systems failed, a water delivery system using tanker trucks would have to be initiated.

The remaining potential events found to be significant, roughly in the order of lessening consequences, include loss of confinement events, facility fires, loss of containment events, and external events. As shown in Table 3-1, adequate measures are specified in the analysis to ensure that protective measures are taken against the identified vulnerabilities.

Beyond design basis events are also analyzed. For natural phenomena, the beyond design basis event is bounded by the analysis for the seismic event. External events are specifically excluded from beyond design basis analysis per DOE-STD3009-94 (DOE 1994a). For internal events (i.e., all remaining events) the beyond design basis analysis requirements are satisfied by estimating the unmitigated dose consequences, which also serves the purpose of identifying safety class and safety significant functions.

The safety analysis documented in this chapter is a comprehensive analysis of the potential upsets which could occur at WESF. Safety class and safety significant SSCs and IOSRs have been identified to ensure that the capsules in the pool cells are maintained in a safe and controlled environment. Likewise, for the hot cells. K-3 exhaust duct, and WESF lon Exchange Module (WIXM), controls have been established to ensure that there are no adverse impacts to the radioactive material present there. Overall, this set of SSCs and controls, defined by the analysis, ensures all identified hazards associated with WESF are adequately controlled. 
Table 3-1. Accident Analysis Results Summary.

\begin{tabular}{|c|c|c|c|c|}
\hline $\begin{array}{l}\text { Accident } \\
\text { type/section } \\
\text { location }\end{array}$ & Accidents selected & $\begin{array}{l}\text { Unmitigated doses } \\
\text { onsite/alternate site } \\
\text { boundary }{ }^{2} \text { (rem) }\end{array}$ & $\begin{array}{l}\text { Mitigated doses } \\
\text { onsite/alternate site } \\
\text { boundary (rem) }\end{array}$ & $\begin{array}{l}\text { Credited controls and commitments } \\
\text { (See Chapter } 4 \text { for SSCs and } \\
\text { Chapter } 5 \text { for IOSRs) }\end{array}$ \\
\hline \multirow[t]{2}{*}{$\begin{array}{l}\text { Loss of Pool } \\
\text { Cell Water/ } \\
3.4 .2 .7 / 3.4 .3 .3 \\
\text { Note: Rapid loss } \\
\text { af pool cell } \\
\text { water is al } \\
\text { Beyond Design } \\
\text { Basis Event }\end{array}$} & $\begin{array}{l}\text { Loss of water from a } \\
\text { single pool cell }\end{array}$ & $\begin{array}{l}\text { Direct consequences could } \\
\text { lead to a loss of facility } \\
\text { control and eventual loss } \\
\text { of all pool cell water. } \\
\text { Direct dose rate is } 120 \\
\text { rem } / \text { hr just outside } \\
\text { facility }\end{array}$ & Prevented & \multirow[t]{2}{*}{$\begin{array}{l}\text { 1. Safety class rapid loss of water detection system } \\
\text { (IOSR on operability) } \\
\text { 2. Safety class emergency makeup water pipe } \\
\text { 3. Safety class Area } 3 \text { structure } \\
\text { 4. IOSR on single pool capsule heat output } \\
\text { 5. IOSR to maintain water level } \\
\text { 6. IOSR restricting lifts of heavy object, that could } \\
\text { damage capsules, over active pool cells except in } \\
\text { emergencies } \\
\text { 7. IOSR on cmirgunly water makeup sources }\end{array}$} \\
\hline & $\begin{array}{l}\text { Loss of water from all } \\
\text { Pool Cells }\end{array}$ & $\begin{array}{c}1,700 / 9.2^{(\mathrm{d})} \\
\text { Direct dose rate is } 1,700 \\
\text { rem } / \mathrm{hr} \text { just outside } \\
\text { facility }\end{array}$ & Prevented & \\
\hline \multirow{3}{*}{$\begin{array}{l}\text { Facility } \\
\text { Explosions/ } \\
3.4 .2 .5\end{array}$} & $\begin{array}{l}\text { Hydrogen explosion in } \\
\text { Pool Cell Area }\end{array}$ & $\begin{array}{l}\text { See loss of water in all } \\
\text { pool cells }\end{array}$ & Prevented & 1. IOSR to provide alternate ventilation within 9 days. \\
\hline & Flammable gas explosion & $\begin{array}{c}\text { Initiator to loss of pool cell } \\
\text { water }\end{array}$ & Prevented & $\begin{array}{l}\text { 1. OSR to prohibit flammable gas and highly volatile } \\
\text { fuel use within the facility. }\end{array}$ \\
\hline & WIXN exphosion & $72 / 0.12$ & 0.440 .0007 & $\begin{array}{l}\text { 1. IOSR w post-lill soid space in used WTKM with } \\
\text { inerr material }\end{array}$ \\
\hline $\begin{array}{l}\text { Natural } \\
\text { Phenomena/ } \\
\text { 3.4.2.1 }\end{array}$ & $0.25 \mathrm{~g}$ earthquake & See BDBA below & $\begin{array}{c}4.8 / 0.45 \\
\text { (stack) } \\
\\
19 / 0.47^{(e)} \\
\text { (stack+A Cell) }\end{array}$ & $\begin{array}{l}\text { 1. Safety Class Area } 2 \text { structures } \\
\text { 2. Safety Class bridge crane, catwalk, and associated } \\
\text { supports } \\
\text { 3. Safety Class drain line and circulation piping } \\
\text { 4. Safety Class K-3 Filter Pit structure } \\
\text { 5. Safety Class Area } 3 \text { structures } \\
\text { 6. Safety Class Stack and K-3 exhaust duct }\end{array}$ \\
\hline \multirow{5}{*}{$\begin{array}{l}\text { Loss of } \\
\text { Confinement/ } \\
3.4 .2 .4\end{array}$} & $\begin{array}{l}\text { High flow in } \mathrm{K}-3 \\
\text { ventilation system }\end{array}$ & $390 / 0.66$ & $0.39 / 6.6 \mathrm{E}-04$ & $\begin{array}{l}\text { 1. Safety Class K-3 HEPA filters } \\
\text { 2. IOSR on K-3 HEPA filter inventory }\end{array}$ \\
\hline & Loss of $K-3$ flow & \multicolumn{2}{|c|}{$\begin{array}{l}\text { Negligible outside facility, worker safety issue in } \\
\text { facility. }\end{array}$} & $\begin{array}{l}\text { 1. IOSR on thermal inventory } \\
\text { 2. IOSR on structural surface to capsule distance }\end{array}$ \\
\hline & $\begin{array}{l}\text { K-3 system water } \\
\text { accumulation }\end{array}$ & $170 / 0.29$ & Prevented & $\begin{array}{l}\text { 1. IOSR on K-3 HEPA filter inventory } \\
\text { 2. IOSR on A Cell inventory } \\
\text { 3. IOSR on packaged waste in A Cell } \\
\text { 4. IOSR to prevent, detect and act on hot cell flood }\end{array}$ \\
\hline & High activity in TK-100 & $0.30 / 5.0 \mathrm{E}-04$ & $\begin{array}{l}\text { Mitigation not } \\
\text { required }\end{array}$ & None \\
\hline & $\begin{array}{l}\text { Hydrogen Accumulation } \\
\text { in Hot Cells }\end{array}$ & $\begin{array}{l}\text { Undetermined. } \\
\text { Consequence model not } \\
\text { developed; a hydrogen } \\
\text { explosion in a hot cell is } \\
\text { assumed to be } \\
\text { unacceptable. }\end{array}$ & Prevented & $\begin{array}{l}\text { 1. IOSR on A Cell inventory } \\
\text { 2. IOSR to prevent, detect and act on hot cell flood }\end{array}$ \\
\hline $\begin{array}{l}\text { Facility Fire/ } \\
3.4 .2 .3\end{array}$ & A hot cell fire & $7.1 / 0.012$ & $2.8 / 4.8 \mathrm{E}-03$ & $\begin{array}{l}\text { 1. Safety Class K-3 filter } \\
\text { 2. IOSR on A Cell inventory } \\
\text { 3. IOSR on } 200 \mathrm{~kg} \text { packaged solid waste in A Cell }\end{array}$ \\
\hline
\end{tabular}




\section{HNF-SD-WM-BIO-002 REV 1}

Table 3-1. Accident Analysis Results Summary.

\begin{tabular}{|c|c|c|c|c|}
\hline $\begin{array}{l}\text { Accident } \\
\text { type/section } \\
\text { location }\end{array}$ & Accidents selected & $\begin{array}{l}\text { Unmitigated doses } \\
\text { onsite/alternate site } \\
\text { boundary (rem) }\end{array}$ & $\begin{array}{l}\text { Mitigated doses } \\
\text { onsite/alternate site } \\
\text { boundary }(\mathrm{rem})\end{array}$ & $\begin{array}{l}\text { Credited controls and commitments } \\
\text { (See Chapter } 4 \text { for SSCs and } \\
\text { Chapter } 5 \text { for IOSRs) }\end{array}$ \\
\hline & B-E hot cell fire & $\begin{array}{c}760 / 1.3 \\
33 / 0.056 \\
\text { (with cover blocks) }\end{array}$ & Prevented & $\begin{array}{l}\text { 1. Safety Class K-3 filter } \\
\text { 2. IOSR to control hot cell combustible material } \\
\text { 3. IOSR to have hot cell pass-throughs closed } \\
\text { 4. IOSR on plug/cover block installation }\end{array}$ \\
\hline & F or G hot cell fire & Not analyzed ${ }^{(b)}$ & Prevented & $\begin{array}{l}\text { 1. IOSR to prevent concurrent conditions of } \\
\text { combustibles, exposed capsules, and open cells }\end{array}$ \\
\hline & Truckport fire & $\begin{array}{l}2.40 .004 \text { (wasti drums) } \\
1.60 .0027(\text { WIX.11) }\end{array}$ & $\begin{array}{l}\text { Mitigntion mot } \\
\text { reyuired }\end{array}$ & $\begin{array}{l}\text { 1. IOSR limit of } 25.200 \mathrm{Ci}^{\% /} \mathrm{Sr} \text { or } 31.500 \mathrm{Ci}^{1.77} \mathrm{Cs} \mathrm{in} \\
\text { WIXM } \\
\text { 2. IOSR Truckport inventory controls } \\
\text { 3. IOSR limit of } 5 \mathrm{kCi}{ }^{90} \mathrm{Sr} \text { or }{ }^{337} \mathrm{Cs} \text { in waste drums }\end{array}$ \\
\hline \multirow[t]{3}{*}{$\begin{array}{l}\text { Loss of } \\
\text { Containment/ } \\
3.4 .2 .6\end{array}$} & $\begin{array}{l}\text { Underwater capsule } \\
\text { failure due to corrosion }\end{array}$ & \multicolumn{2}{|c|}{$\begin{array}{l}\text { Direct consequences limited to worker safety only. } \\
\text { However, rapid leaks could lead to loss of capsule } \\
\text { access for several years. }\end{array}$} & $\begin{array}{l}\text { 1. Safety Significant ARMs } \\
\text { 2. Commitment to evaluate enhanced response } \\
\text { altematives. }\end{array}$ \\
\hline & $\begin{array}{l}\text { Underwater capsule } \\
\text { failures due to load drop } \\
\text { on capsules }\end{array}$ & $\begin{array}{l}\text { Direct consequences could } \\
\text { lead to a loss of facility } \\
\text { control and eventual loss } \\
\text { of pool cell water. }\end{array}$ & Prevented & $\begin{array}{l}\text { 1. Safety Class bridge crane, catwalk, and associated } \\
\text { supports } \\
\text { 2. IOSR restricting lifts of heavy object, that could } \\
\text { damage capsules, over active pool cells except in } \\
\text { emergencies }\end{array}$ \\
\hline & $\begin{array}{l}\text { WIxith less of } \\
\text { containment }\end{array}$ & \multicolumn{2}{|c|}{$\begin{array}{l}\text { Direct comsectemets would be limiled to worker } \\
\text { sately anly. }\end{array}$} & 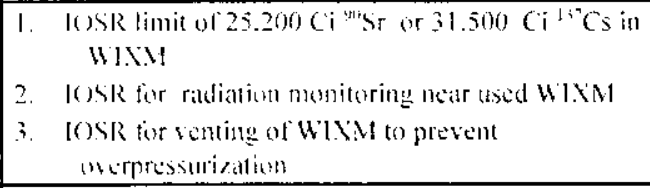 \\
\hline \multirow[t]{3}{*}{$\begin{array}{l}\text { External Events/ } \\
3.4 .2 .2\end{array}$} & Loss of electric power & \multicolumn{2}{|c|}{$\begin{array}{l}\text { See loss of K-3 flow (loss of confinement), } \mathrm{H}_{2} \\
\text { accumulation in Pool Cell Area, and loss of water in } \\
\text { all pool cells. Loss of electric power is an initiator } \\
\text { to these events. }\end{array}$} & $\begin{array}{l}\text { See loss of } \mathrm{K}-3 \text { flow (loss of confinement), } \mathrm{H}_{2} \\
\text { explosion in the Pool Cell Area, and loss of water from } \\
\text { all pool cells. Loss of electric power is an initiator to } \\
\text { these events. }\end{array}$ \\
\hline & Adjacent facility accident & \multicolumn{3}{|c|}{$\begin{array}{l}\text { Not applicable for selection of WESF controls. Possible impact resulting from failure of B Plant endwall is } \\
\text { taken into consideration. }\end{array}$} \\
\hline & Ground vehicle impact & \multicolumn{2}{|c|}{$\begin{array}{l}\text { Initiator to loss of } \mathrm{K}-3 \text { ventilation, and } \mathrm{H}_{2} \text { explosion } \\
\text { in the Pool Cell Area. }\end{array}$} & $\begin{array}{l}\text { See loss of K-3 ventilation and hydrogen explosion in } \\
\text { the Pool Cell Area. }\end{array}$ \\
\hline $\begin{array}{l}\text { External Events/ } \\
3.4 .2 .2 \text { (cont.) }\end{array}$ & Aircraft impact & \multicolumn{2}{|c|}{$\begin{array}{l}\text { Initiator to several events including loss of Pool } \\
\text { Cell water. }\end{array}$} & DOE low-altitude overflight restriction. \\
\hline \multirow[t]{2}{*}{$\begin{array}{l}\text { Beyond Design } \\
\text { Basis Accidents/ } \\
3.4 .3\end{array}$} & $\begin{array}{l}\text { Beyond design basis } \\
\text { earthquake }\end{array}$ & $\begin{array}{c}2,200 / 9.8 \\
\text { Direct dose rates would be } \\
\text { similar to loss of pool cell } \\
\text { water accidents }\end{array}$ & N/A & $\begin{array}{l}\text { Site area emergency response plan. No qualified } \\
\text { barriers by definition. }\end{array}$ \\
\hline & $\begin{array}{l}\text { Unmitigated operational } \\
\text { accidents }\end{array}$ & \multicolumn{3}{|c|}{ See above unmitigated doses onsite/altemating site boundary column. } \\
\hline
\end{tabular}

(a) Alternate Site Boundary is defined in Section 3.4.1.3.

(b) WESF capsules are designed to survive the conditions of a fire, however, the status of the capsules stored in $F$ or $G$ Cells is unknown. Conditions conducive to a fire involving the capsules are avoided regardless of the consequences.

${ }^{(c)}$ Direct dose rates are shown for various locations in Tables 3-33 and 3-35 for loss of water in one pool cell and all pool cells, respectively.

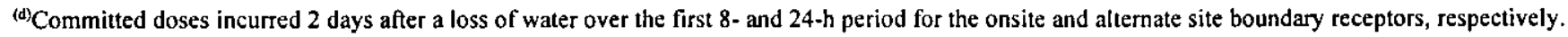

${ }^{\left({ }^{(c)}\right.}$ Onsite evaluation guideline for this accident only is $25 \mathrm{rem}$. 


\subsubsection{Plant Vulnerabilities}

One of the purposes of a BIO, which is not shared by a SAR, is the identification of any plant vulnerabilities and corresponding interim controls and commitments. At WESF only one such vulnerability existed: the possible inadvertent draining of a pool cell during recovery from a leaking capsule event. The facility las since removed this vulnerability by replacing the former "bleed and feed" system with the new WF.SF Emergency lon Exchange Systen (EMIX).

\subsection{REQUIREMENTS}

The hazard and accident analyses in this chapter are prepared to comply with Nuclear Safety Analysis Reports, DOE Order 5480.23. Guidance in meeting the requirements in DOE Order 5480.23 is derived from Chapter 3.0, "Hazard and Accident Analysis", Preparation Guide for U.S. Department of Energy Nonreactor Nuclear Facility Safety Analysis Reports, DOE-STD-3009-94 (DOE 1994a). The Order also requires a facility hazard categorization with guidance drawn from Hazard Categorization and Accident Analysis Techniques for Compliance with DOE Order 5480.23, Nuclear Safety Analysis Reports, DOE-STD-1027-92 (DOE 1992). In addition, general guidance is provided by Guidelines for Hazard Evaluation Procedures (AIChE 1992), issued by the Center for Chemical Process Safety of the American Institute of Chemical Engineers.

\subsection{HAZARDS ANALYSIS}

\subsubsection{Hazards Analysis Methodology}

\subsubsection{Hazard Identification Methodology.}

The hazards identification methodology used for the hazards analysis consisted of determining the presence of hazardous materials and energy sources. Information from several sources was used.

The hazardous materials, which include radioactive and non-radioactive toxic materials, were identified for WESF from several sources: a radioactive material inventory report, a WESF hazards and operability study (HAZOP), the WIXM specific HAZOP, existing and past facility safety documentation, a fire hazards analysis (FHA) for the facility, reviews of the safety documentation for nearby facilities, facility occurrence reports, a facility walkdown, and a review of a hazardous material database maintained for the facility. The WESF HAZOP (Siemer 1995) serves to identify the existence of hazardous materials and their forms and locations. The separate IIA\%OP for the W'IXM was performed as part of the installation of the emergency ion exchange system at WESF and identifies hazards specilically associated with operation of the WIXM. Existing and past facility safety documentation also provides an indication of areas of concern and ensures that hazards remaining from past operations are identified. An FHA for WESF (Mertz 1998) was reviewed to ensure that all fire and explosion hazards had been identified and taken into account. The B Plant accident analysis in existence at the time, WHC-SD-WM-SARR-030, Rev. 0, (WHC 1996a) was reviewed to determine potential impacts accident conditions at B Plant might have on WESF. The new B Plant accident analysis (HNF 1999) has since been reviewed for any additional impacts on WESF. Facility occurrence reports for WESF were reviewed not only for the purposes of hazards evaluation but also to bring to light any hazardous material information, such as migration of contamination. The results obtained from the hazards identification effort are included in Section 3.3.2.1. The hazardous material database maintains records of non-radiological hazardous materials at the facility for the purpose of compliance with environmental protection requirements.

Another source of information used in the hazards identification, and to a lesser degree the hazards evaluation, was the operating history of WESF. An extensive review of former operating practices, process parameters, and operating procedures was performed in an attempt to identify hazards which might still exist. The information used in this review is predominantly contained in four documents:

- Waste Encapsulation and Storage facility - Cesium Line Standby/Surveillance, SD-WM-ER-014, Rev. 0 (Adams, 1984)

- Safety Analysis Report Waste Encapsulation and Storage Facilities (Project HAP-631), ARH-1986 (Braden, 1971)

- Waste Encapsulation and Storage Facility Overall Hot Cell Standby/Surveillance, SD-WM-ER-024, Rev. 0 (Carlstrom, 1985a)

- Waste Encapsulation and Storage Facility Strontium Line Standby/Surveillance, SD-WM-ER-022, Rev. 0 (Carlstrom, 1985b) 
To augment the information contained in these documents, direct operational experience was available from at least one operator, who had been present when the facility was in a processing mode. This direct experience facilitated a better understanding of the operation history of WESF, especially during facility walk-throughs.

In addition to identifying facility hazards, the HAZOP also serves to differentiate and provide an interface between worker safety issues and facility safety issues. Worker safety issues unique to WESF were documented in the HAZOP as they were identified and analyzed as necessary, however the majority of such issues are covered by other plant and WESF industrial health and safety measures and are not considered for quantitative analysis. Based on the results of the hazards evaluation, Section 3.3.2.3.3 contains a discussion pertaining to the SSCs and administrative controls necessary for the protection of the facility worker. Chapter 6.0 contains details pertaining to industrial health and safety programs (also called institutional safety programs) associated with WESF.

\subsubsection{Hazard Evaluation Methodology.}

Qualitative details of potential accident sequences were evaluated using the HAZOP methodology discussed in detail in AIChE (1992). Later, frequencies and challenged safety barriers were also determined and are included in Hey (1999). The HAZOP method in general, which uses plant personnel to postulate deviations from normal operations and processes, is appropriate for WESF hazards evaluation because of its thoroughness and analytical rigor. The HAZOP technique focuses on the current state of equipment and processes that contain, or may contain, hazardous materials with the potential for adverse consequences to facility workers, onsite workers, and offsite individuals. For each deviation, the HAZOP provides a summary description of the scenario, the cause(s) of the deviation, the detection and mitigation feature(s), and the estimated consequences.

The WESF facility and WIXM HAZOPs were performed with a team of individuals with relevant system and operational experience to conduct the study. The team identified hazards and potential accidents by examining the process flow paths and identifying important points in the process (called nodes). For each node, the important operating parameters (e.g., temperature and pressure) were enumerated, and potential deviations from the normal values of these parameters were studied, including deviations from "structural integrity." Once the deviation was postulated, the team identified possible causes, methods of detection and mitigation, and qualitative consequences. The HAZOP process nodes, parameter deviations, possible causes, and qualitative consequences comprise the documentation of accident scenarios used for the hazards evaluation (1)ey 1999).

In the HAZOPs, the potential unmitigated consequences of each deviation are addressed by focusing on airborne releases of radioactive or chemically toxic materials, or exposure to radiation fields. The consequence of each deviation was ranked by group consensus according to the following scheme.

- $\underline{\mathrm{S}}$ No effect outside the facility confinement systems. This rank considers events that might interrupt operations but have no safety significance.

- $\quad$ 1 Potential industrial injury, radiological dose consequences or chemical exposure to the facility worker, or limited environmental discharge of hazardous material outside the facility. This rank considers deviations that have safety implications for the facility worker but not for the onsite or offsite receptors.

- $\quad$ S2 Potential significant radiological dose consequences or chemical exposure to the maximally exposed onsite individual outside the facility, or environmental discharge of hazardous material within the Hanford Site boundary.

- $\quad$ S3 Potential significant radiological dose consequences or chemical exposure to the maximally exposed offsite individual, or environmental discharges of hazardous material outside the Hanford Site boundary or to the groundwater.

Worker safety issues (S1 deviations) are identified and qualitatively evaluated in the HAZOPs and addressed in Section 3.3.2.3.3 and Chapter 6.0 of this document. 
Accidents with potential onsite and offsite dose consequences (S2 and S3 deviations) underwent further evaluation outside of the W'ESF HAZOP (Hey 1999) by another plant team in order to assign deviation frequencies and identify challenged safety barriers. The challenged safety barriers and qualitative frequencies, along with the qualitative consequences from the WESF HAZOP, were required for input into the accident selection process detailed in Section 3.3.2.3.5.

The methodology used to identify the facility barriers consisted of a team discussion of the accident scenario postulated in both the WESF and WIXM HAZOPs to determine what engineered systems and administrative controls are in place to prevent or mitigate the accident. The following definitions were used in the identification of barriers.

- Scenario. The sequence of events that achieves the consequences of interest for the deviation from the design/operational intent of the process activity.

- Systems. The engineered features that act to prevent and/or mitigate the consequences of the scenario.

- $\quad$ Controls. The administrative features that act to prevent and/or mitigate the consequences of the scenario.

The methodology used to assign the frequency estimates is identical to the methodology used to assign the qualitative consequence estimates. The frequencies were obtained by team consensus, taking into account information gleaned from appropriate mitigating factors (safety barriers or systems), operating procedures and controls, and historical process upsets. Frequencies were categorized using the following ranking scheme.

- F0 Events that are not expected to occur and are categorized as beyond extremely unlikely. The frequency range is less than $1.0 \times 10^{-6} / \mathrm{yr}$.

- E1 Events that are not expected to occur within the lifetime of a typical facility and are categorized as extremely unlikely. The frequency range is $1.0 \times 10^{-6} / \mathrm{yr}$ to $1.0 \times 10^{-4} / \mathrm{yr}$.

- $\quad$ 2 Events that may occur during the lifetime of the facility and are categorized as unlikely. The frequency range is $1.0 \times 10^{-4} / \mathrm{yr}$ to $1.0 \times 10^{-2} / \mathrm{yr}$.

- $\quad$ F3 Events that are expected to occur one or more times during the lifetime of the facility and are categorized as anticipated. The frequency range is $1.0 \times 10^{-2} / \mathrm{yr}$ to $1 / \mathrm{yr}$.

Typically, events with a frequency of $>1 / \mathrm{yr}$ are considered off-normal or operational events and are considered in the safety analysis only to the extent that they play a role in an accident sequence.

The combination of the consequence and frequency assigned to each evaluated deviation results in a qualitative risk rank for that deviation. The risk rank allows the identified accident scenarios to be compared for the purpose of selecting bounding and unique accidents for quantitative analysis. The risk ranks are assigned using the matrix shown in Table 3-2 with the following definitions:

- $\quad$ R1 Combinations of consequence and frequency that are of minor concern

- $\quad$ R2 Combinations of consequence and frequency that are of moderate concern

- $\quad$ R3 Combinations of consequence and frequency that are of major concern. 
Table 3-2. Risk Rank Matrix.

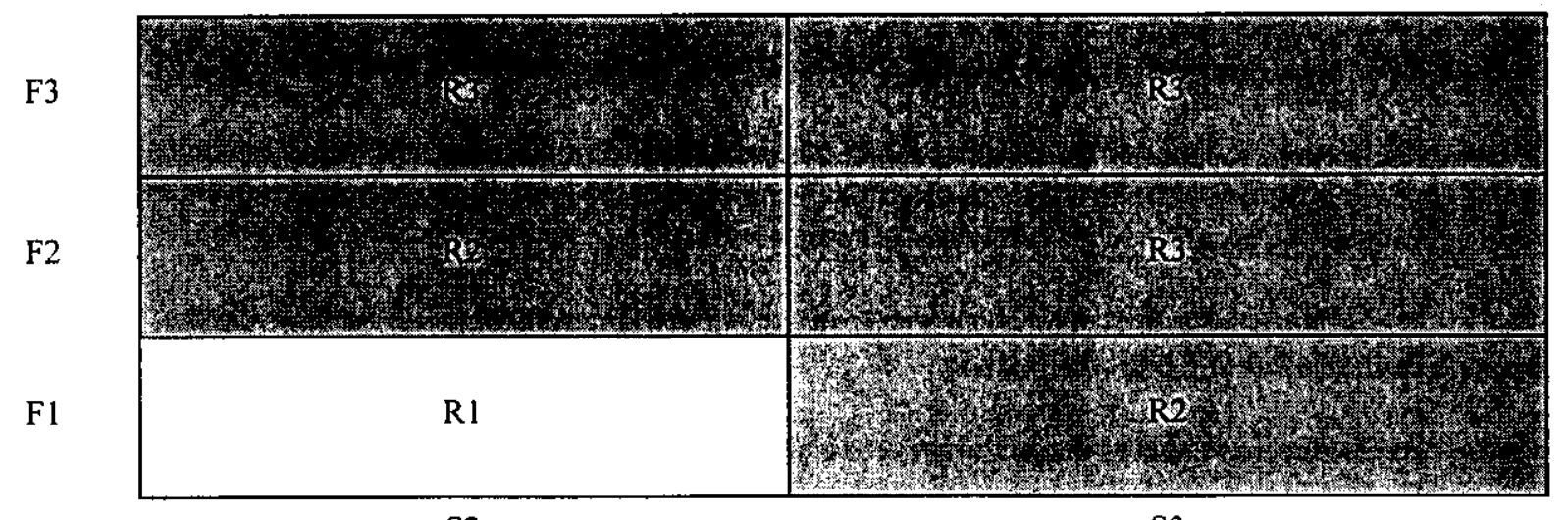

S2

\subsubsection{Hazard Analysis Results}

The results of the hazards analysis performed for WESF is contained in the following sub-sections. The results consist of the hazards identification, hazard classification, and hazards evaluation. The hazards evaluation in turn consists of planned design and operational safety improvements, defense in depth, worker safety, environmental protection, and accident selection.

\subsubsection{Hazard Identification Results.}

This section shows the results of the process used to identify the hazardous materials and energies at WESF as described in Section 3.3.1.1. The hazards identification effort found radioactive material hazards, direct radiation hazards, explosion hazards (hydrogen generation and flammable gas use), fire hazards, and kinetic energy hazards. The locations, quantities, and forms of the hazards identified for WESF are summarized in Table 3-3.

Table 3-3. Hazard Identification Results for WESF.

\begin{tabular}{|c|c|c|c|c|c|}
\hline Hazard & Location & Quantity & Form & Remarks & Ref. \\
\hline \multirow[t]{5}{*}{$\begin{array}{l}\text { Radioactive } \\
\text { material }\end{array}$} & Pool cells & $52.05 \mathrm{MCi}^{137} \mathrm{Cs}$ & $\begin{array}{l}\text { Cesium chloride, } \\
\text { doubly encapsulated }\end{array}$ & \multirow[t]{2}{*}{$\begin{array}{l}\text { This is the total WESF cesium } \\
\text { and strontium capsule } \\
\text { inventory. including all uncul } \\
\text { ciflsules and all lype II } \\
\text { (O)erpack capsules. decined to } \\
1 / 1 / 96 \text {. }\end{array}$} & \multirow[t]{2}{*}{ lles f(9)9 } \\
\hline & & $22.58 \mathrm{MCi}{ }^{91} \mathrm{Sr}$ & $\begin{array}{l}\text { Strontium fluoride, } \\
\text { doubly encapsulated }\end{array}$ & & \\
\hline & A Cell & $\begin{array}{l}15 \mathrm{kCi}{ }^{90} \mathrm{Sr} \\
\text { or }{ }^{137} \mathrm{Cs}\end{array}$ & $\begin{array}{l}\text { 208-L (55-gal) steel } \\
\text { drums of contaminated } \\
\text { solid waste }\end{array}$ & -- & Smith 1995 \\
\hline & B Cell & $\begin{array}{l}2 \mathrm{kCi}{ }^{137} \mathrm{Cs} \text { and } 20 \\
\mathrm{kCi}{ }^{90} \mathrm{Sr}\end{array}$ & $\begin{array}{l}\text { Strontium fluoride and } \\
\text { cesium chloride, } \\
\text { contamination on } \\
\text { equipment, waste, and } \\
\text { surfaces }\end{array}$ & - & fhey 1959) \\
\hline & C Cell & $\begin{array}{l}2 \mathrm{kCi}{ }^{137} \mathrm{Cs} \text { and } 20 \\
\mathrm{KCi}^{90} \mathrm{Sr}\end{array}$ & $\begin{array}{l}\text { Strontium fluoride and } \\
\text { cesium chloride, } \\
\text { contamination on } \\
\text { equipment, waste, and } \\
\text { surfaces }\end{array}$ & $\because$ & Ifey 1969 \\
\hline
\end{tabular}




\section{HNF-SD-WM-BIO-002 REV 1}

Table 3-3. Hazard Identification Results for WESF.

\begin{tabular}{|c|c|c|c|c|c|}
\hline Hazard & Location & Quantity & Form & Remarks & Ref. \\
\hline & B/C Cell Furnace & $40 \mathrm{kCi}^{90} \mathrm{Sr}$ & $\begin{array}{l}\text { Strontium fluoride floor } \\
\text { sweepings contained in } \\
4 \text { boats and } 2 \text { waste } \\
\text { pipes }\end{array}$ & $\cdots$ & Hey 1999 \\
\hline & D/E Cells & $20 \mathrm{kCi}{ }^{137} \mathrm{Cs}$ & $\begin{array}{l}\text { Cesium chloride, } \\
\text { contamination on } \\
\text { equipment, waste and } \\
\text { surfaces }\end{array}$ & - & Hey 1999 \\
\hline & F Cell & $\begin{array}{l}4.5 \mathrm{~kW} \text { (i.e. } 940 \\
\left.\mathrm{kCi}{ }^{137} \mathrm{Cs}\right)\end{array}$ & $\begin{array}{l}\text { Encapsulated cesium } \\
\text { chloride in suspect or } \\
\text { single capsules }\end{array}$ & $\begin{array}{l}\text { Since capsules stored in F Cell } \\
\text { would be suspect, the first } \\
\text { confinement boundary is } \\
\text { considered to be F Cell. } \\
\text { Minimum } 20 \mathrm{~cm} \text { ( } 7.9 \text { in.) } \\
\text { capsule to surface distance. }\end{array}$ & WHC $1996 \mathrm{c}$ \\
\hline & $\mathrm{K}-3$ exhaust duct & $\begin{array}{l}5.1 \mathrm{kCi}^{137} \mathrm{Cs} \text { or } 200 \\
\mathrm{kCi}{ }^{90} \mathrm{Sr}\end{array}$ & $\begin{array}{l}\text { Cesium chloride and } \\
\text { strontium fluoride } \\
\text { surface contamination }\end{array}$ & $\begin{array}{l}\text { The makeup of the } \\
\text { contamination in the duct is } \\
\text { unknown so two possible } \\
\text { isotopic distributions are } \\
\text { given. }\end{array}$ & Hey 1990 \\
\hline & K-3 filter & $\begin{array}{c}240 \mathrm{Ci}^{137} \mathrm{Cs} \text { and } \\
18 \mathrm{kCi}{ }^{90} \mathrm{Sr} \text { on each } \\
\text { train }\end{array}$ & $\begin{array}{l}\text { Cesium chloride and } \\
\text { strontium fluoride } \\
\text { contamination }\end{array}$ & $\begin{array}{l}\text { Based on accident analysis } \\
\text { assumption }\end{array}$ & WESF BIO \\
\hline & Truckport & $\begin{array}{l}5 \mathrm{kCi} \text { of }{ }^{137} \mathrm{Cs} \text { or } \\
{ }^{90} \mathrm{Sr} \text { contained in } \\
\text { hot cell waste } \\
\text { Jfums(s) }\end{array}$ & $\begin{array}{l}\text { One } 208-\mathrm{L} \text { (55-gal) } \\
\text { drum of contaminated } \\
\text { solid waste from hot } \\
\text { cell. }\end{array}$ & - & Smith 1995 \\
\hline & & $\begin{array}{l}1 \mathrm{Ci}^{137} \mathrm{Cs} \text { and } 1 \mathrm{Ci} \\
{ }^{90} \mathrm{Sr} \text { in plastic bags }\end{array}$ & $\begin{array}{l}\text { Contartinated } \\
\text { combustibles }\end{array}$ & - & WESF BIO \\
\hline & & 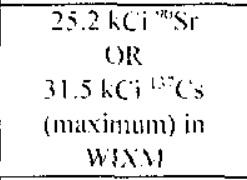 & $\begin{array}{l}\text { Stromtium lluride or } \\
\text { cesium chloride }\end{array}$ & 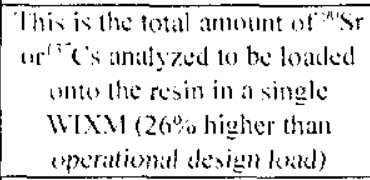 & $\begin{array}{l}\text { WINMSARP' } \\
(1 \mathrm{NE}, 199 \mathrm{~d})\end{array}$ \\
\hline Direct Radiation & $\begin{array}{l}\text { See locations for } \\
\text { radioactive } \\
\text { material, above }\end{array}$ & $\begin{array}{l}\text { See quantities for } \\
\text { radioactive } \\
\text { materials, above }\end{array}$ & $\begin{array}{c}\text { Beta }\left({ }^{137} \mathrm{Cs},{ }^{90} \mathrm{Sr},{ }^{90} \mathrm{Y}\right) \\
\text { Gamma }\left({ }^{137 \mathrm{ma}}\right)\end{array}$ & -- & -- \\
\hline \multirow[t]{7}{*}{ Toxic material } & $\begin{array}{c}\text { AMU } \\
\text { flammable storage } \\
\text { cabinet }\end{array}$ & Neolube $^{\text {TM }}$ & Dry & $\begin{array}{l}\text { A dry film conductive } \\
\text { lubricant used during wire } \\
\text { pulls }\end{array}$ & -- \\
\hline & $\overline{\mathrm{AMU}}$ & Absorb-It & Dry & Clay absorbent & WESF BIO \\
\hline & $\overline{A M U}$ & $\begin{array}{l}\text { Trisodium } \\
\text { phosphate }\end{array}$ & Dry/solution & Decontamination solution & WESF BIO \\
\hline & Truckport & $\begin{array}{l}280 \mathrm{~kg}(615 \mathrm{lb} .) \\
\text { Amerite } \\
\text { Purolite })\end{array}$ & $\begin{array}{l}\text { Dry resin as finte beidds } \\
\text { (similar to sand) }\end{array}$ & $\begin{array}{l}\text { Sulfanaled div inylberlaend } \\
\text { styrue copolymer or } \\
\text { monomer beatls }\end{array}$ & $\begin{array}{l}\text { WIXM SARP } \\
\text { (HNF. 1998d) } \\
\text { MSDS \#15012: MSDS \#29805 }\end{array}$ \\
\hline & $225 \cdot \mathrm{BCi}$ & $\begin{array}{c}728 \mathrm{~kg}(1605 \mathrm{lb} .) \text { or } \\
610 \mathrm{l}(160 \mathrm{gal}) \\
\text { Citric Acid }\end{array}$ & Liçuid & liscol tu adjust pht & MSDS $\# 56688$ \\
\hline & $225.13 \mathrm{Gj}$ & $\begin{array}{l}422 \mathrm{~kg}(930 \mathrm{bs}) \text { or } \\
4101(110 \mathrm{gal}) \\
\text { Spectrus NX1106 }\end{array}$ & liquid & $\begin{array}{l}\text { Water-based microbiat control } \\
\text { agent }\end{array}$ & MSDS $\$ 56+90$ \\
\hline & $225-130$ & $\begin{array}{c}456 \mathrm{~kg}(1005 \mathrm{bb}) \mathrm{or} \\
330)(88 \mathrm{gal})\end{array}$ & liguid & Conrosion inhibitor/dispersant & MSDS $\$ 12956$ \\
\hline
\end{tabular}


HNF-SD-WM-BIO-002 REV 1

Table 3-3. Hazard Identification Results for WESF.

\begin{tabular}{|c|c|c|c|c|c|}
\hline Hazard & Location & Quantity & Form & Remarks & Ref. \\
\hline & & Dianudie DN300 & & & \\
\hline Carcinogen & $\cdots$ & None & - & -- & - \\
\hline Biohazard & $\overline{--}$ & None & -. & - & -- \\
\hline Asphyxiant & -- & None & - & -- & 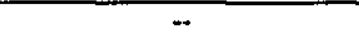 \\
\hline \multirow[t]{4}{*}{ Flammable material } & Truckport & $\begin{array}{l}30 \text { (max) bags of } \\
\text { low level solid } \\
\text { waste }\end{array}$ & $\begin{array}{l}\text { mixed cellulosic } \\
\text { material and plastic }\end{array}$ & - & Nertz 1908 \\
\hline & $\begin{array}{l}\text { Truckport } \\
\text { (wixM vesiel) }\end{array}$ & $280 \mathrm{~kg}(615 \mathrm{lb})$. & $\begin{array}{l}\text { Dry resin (Amerlite(i) } \\
\text { or Purolite(i) as finc } \\
\text { beads (similar to sand) }\end{array}$ & $\begin{array}{l}\text { Ignition temperature of } 427^{\circ} \mathrm{C} \\
\left(800^{\circ} \mathrm{F}\right)\end{array}$ & $\begin{array}{l}\text { WINM SARP } \\
\text { (HNH. 19OSd) } \\
\text { VISOS } \# 15012: \text { MSDS } \# 29805\end{array}$ \\
\hline & Hot cells & $\begin{array}{l}200 \mathrm{~kg} \text { in A Cell. } \\
\text { See section } \\
3.4 .2 .3 .1 \text { for B-E } \\
\text { Cells. F and G } \\
\text { Cells contain none } \\
\text { (except in-use } \\
\text { manipulator boots) } \\
\text { when capsules } \\
\text { exposed and } \\
\text { portcover block } \\
\text { removed. }\end{array}$ & $\begin{array}{l}\text { mixed cellulosic } \\
\text { material and plastic }\end{array}$ & -- & Mertz 1998 \\
\hline & $\begin{array}{c}\text { AMU } \\
\text { flammable storage } \\
\text { cabinet }\end{array}$ & $\begin{array}{c}\text { Neolube }{ }^{\text {TM }} 453.6 \mathrm{~g} \\
(1 \mathrm{lb})\end{array}$ & Dry & $\begin{array}{l}\text { A dry film conductive } \\
\text { lubricant used during wire } \\
\text { pulls }\end{array}$ & 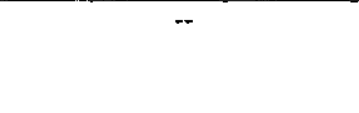 \\
\hline Reactive material & $\overline{--}$ & None & - & $\overline{--}$ & - \\
\hline \multirow[t]{5}{*}{ Explosive material } & Pool cell area & - & Hydrogen & $\begin{array}{l}\text { Generated by radiolytic } \\
\text { decomposition of water }\end{array}$ & Síemer 1995 \\
\hline & $\mathrm{K}-3$ filter housing & -- & Hydrogen & $\begin{array}{l}\text { Generated by radiolytic } \\
\text { decomposition of water if the } \\
\text { filter housing is flooded. }\end{array}$ & Siemer 1995 \\
\hline & TK-100 & -- & Hydrogen & Same as K-3 filter housing. & Siemer 1995 \\
\hline & $\begin{array}{l}\text { Truckport } \\
\text { (WIXN1 Vessel) }\end{array}$ & $\begin{array}{c}\text { (of) mlihr } \\
\text { (bounding - based } \\
\text { on } 20 \mathrm{~h}\left(\mathrm{i}^{\text {*ot }} \mathrm{si}\right)\end{array}$ & Ilygatroggen & $\begin{array}{l}\text { Gencraled by radiolytic } \\
\text { decomponstion of resin/water }\end{array}$ & $\begin{array}{l}\text { WIXM SARP } \\
\text { (IINF, 1998d) }\end{array}$ \\
\hline & All areas & Variable & Flammable gases & $\begin{array}{l}\text { Flanimable gas cylinders are } \\
\text { used for welding, gasoline or } \\
\text { propane might be present in } \\
\text { the Truckport }\end{array}$ & Siemer 1995 \\
\hline $\begin{array}{l}\text { Incompatible } \\
\text { chemical reaction } \\
\text { products }\end{array}$ & -- & None & - & -- & $\overline{--}$ \\
\hline \multirow[t]{2}{*}{ Electrical energy } & -- & $\begin{array}{l}\text { Normal electrical } \\
\text { distribution }\end{array}$ & - & -- & -- \\
\hline & Hot cell windows & -- & Static electricity & - & WESF BIO \\
\hline \multirow[t]{3}{*}{ Thermal energy } & Single pool cell & $149 \mathrm{~kW}$ & \multirow[t]{3}{*}{$\begin{array}{l}\text { Thermal heat output } \\
\text { from capsules, includes } \\
\text { gamma rays. }\end{array}$} & $\begin{array}{l}\text { See } 3.4 .2 .7 \text { for conditions } \\
\text { bounded. }\end{array}$ & $110 y 1999$ \\
\hline & All pools & $403 \mathrm{~kW}$ & & & \\
\hline & F or $\mathrm{G}$ Cell & $4.5 \mathrm{~kW}$ & & See 3.4.2.4.2 for application. & WHC $1996 \mathrm{c}$ \\
\hline
\end{tabular}


HNF-SD-WM-BIO-002 REV 1

Table 3-3. Hazard Identification Results for WESF.

\begin{tabular}{|c|c|c|c|c|c|}
\hline Hazard & Location & Quantity & Form & Remarks & Ref. \\
\hline & $\begin{array}{l}\text { Truckpont } \\
\text { (WIXNI ressel) }\end{array}$ & $\begin{array}{l}193 \mathrm{~W} \\
\text { (maximum) }\end{array}$ & -- & $\begin{array}{l}26 \% \text { greater than one-lourth of } \\
\text { the heat from the maximum } \\
\text { strontium capsule (1his borthds } \\
\text { the maximum cesim capsuls) } \\
\text { This value is conservative } \\
\text { because it is based on } 1990 \\
\text { data. }\end{array}$ & Hey 1999 \\
\hline \multirow[t]{10}{*}{ Kinetic energy } & $\begin{array}{l}\text { Pool cells } \\
1, \text { and } 8-11\end{array}$ & $\begin{array}{l}3 \text { cover blocks on } \\
\text { each cell (except } \\
\text { Cell } 1 \text { has only } 1 \text { ) }\end{array}$ & $\begin{array}{l}6.35 \text { t ( } 7 \text { tons) each, } 76- \\
\mathrm{cm}(30-\text { in. }) \text { thick, high } \\
\text { density concrete }\end{array}$ & -- & Siemer 1995 \\
\hline & $\begin{array}{l}\mathrm{A}, \mathrm{B}, \mathrm{C} \text {, and } \mathrm{F} \text { Hot } \\
\text { Cells }\end{array}$ & $\begin{array}{l}2 \text { cover blocks on } \\
\text { each cell }\end{array}$ & $\begin{array}{l}10 \text { to } 13 \mathrm{t}(11 \text { to } 14 \\
\text { tons), } 89-\mathrm{cm} \text { ( } 35 \text {-in.) } \\
\text { thick high density } \\
\text { concrete }\end{array}$ & - & Siemer 1995 \\
\hline & $\begin{array}{l}\mathrm{D} \text { and } \mathrm{E} \text { Hot Cells } \\
\text { combined }\end{array}$ & $\begin{array}{l}5 \text { total for both hot } \\
\text { cells }\end{array}$ & $\begin{array}{l}9.5 \text { to } 13 \mathrm{t}(10.5 \text { to } 14 \\
\text { tons), } 89-\mathrm{cm} \text { ( } 35 \text {-in.) } \\
\text { thick high density } \\
\text { concrete }\end{array}$ & - & Siemer 1995 \\
\hline & G Hot Cell & 4 cover blocks & $\begin{array}{l}8 \text { to } 11 \text { t ( } 9 \text { to } 12 \text { tons), } \\
89-\mathrm{cm}(35-\text { in. }) \text { thick } \\
\text { high density concrete }\end{array}$ & - & Siemer 1995 \\
\hline & Truckport & 2 cover blocks & $13.6 \mathrm{t}(15$ tons $)$ & - & Siemer 1995 \\
\hline & & BUSS $^{(1)}$ Cask & $\begin{array}{l}\text { cylindrical cask, } \sim 1.52 \\
\mathrm{~m}(-5 \mathrm{ft}) \text { in diameter } \\
\text { and } \sim 2.13 \mathrm{~m}(\sim 7 \mathrm{ft}) \\
\text { high, } 16.8 \mathrm{t}(18.5 \text { tons })\end{array}$ & -- & Siemer 1995 \\
\hline & & ('hเుı-Nuc cash & 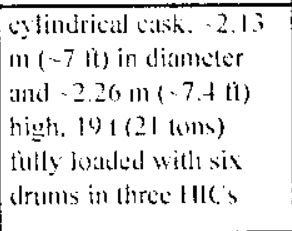 & 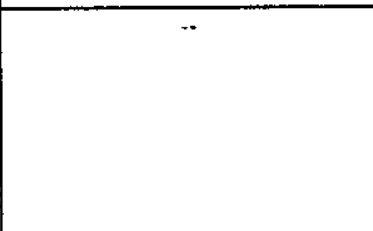 & $10(0-912-052$ \\
\hline & Pool cell area & $\begin{array}{l}1 \text { cover block } \\
\text { overhead }\end{array}$ & $6.8 \mathrm{t}(7.5$ tons $)$ & $\cdots$ & Siemer 1995 \\
\hline & K-3 Filter Pit & 9 cover blocks & $\begin{array}{l}.91 \text { to } 7.7 \mathrm{t}(1 \text { to } 8.5 \\
\text { tons }), 51-\mathrm{cm}(20-\mathrm{in} .) \\
\text { thick structural } \\
\text { concrete }\end{array}$ & -- & Siemer 1995 \\
\hline & TK-100 Vault & 3 cover blocks & $\begin{array}{l}7.3 \text { t }(8 \text { tons) each, } 61- \\
\mathrm{cm}(24 \text {-in.) thick } \\
\text { structural concrete }\end{array}$ & -- & Siemer 1995 \\
\hline High pressure & $\begin{array}{l}\text { Truckport } \\
\text { (WIXM vessel) }\end{array}$ & $\begin{array}{l}\text { Soc quantitiss for } \\
\text { radionative } \\
\text { malerials ahove }\end{array}$ & Comtaminated wet resin & $\begin{array}{l}\text { Pressure buildup due to } \\
\text { hydrogen generation in } \\
\text { contaminated WLXM resscl }\end{array}$ & $\cdots$ \\
\hline Lasers & -- & None & -- & -- & $\cdots$ \\
\hline Potential energy & $\cdots$ & None & -- & -- & - \\
\hline Accelerators & -- & None & $\cdots$ & $\cdots$ & - \\
\hline X-ray machines & - & None & - & $\cdots$ & $m$ \\
\hline
\end{tabular}

TM - Product of Huron Industries, Inc., P.O. Box 610104, Port Huron, MI. 


\section{HNF-SD-WM-BIO-002 REV 1}

Since beginning operations in the 1970s, WESF has not experienced an accidental release of hazardous material outside of the facility. However, many operational events and unusual occurrences (described in anecdotal fashion, technical reports, and occurrence reports) can be summarized in the following categories; capsule upsets, facility near-accident events, and unusual occurrences. The following discussion is not intended to be an exhaustive documentation effort pertaining to the past upset conditions of the facility. It fulfills the requirements of DOE-STD-3009-94, which specifies the need to discuss major facility events so as to provide an insight into the nature of the types of events experienced at the facility.

At present, the only direct experience with a leaking capsule comes from the Radiation Sterilizers, Inc. (RSI) facility in Decatur, Georgia (DOE 1990). The capsules in the Decatur facility were used for dry air operation-water storage irradiation. The capsules were frequently raised into the air for irradiator operations and then returned to a water pool when not in use. The temperature of the capsules would subsequently increase when raised into the air and decrease when placed back into the water. Thermal cycling is thought to be responsible for the single capsule failure and bulging of several other capsules in the same facility. The mechanism of thermal cycling and bulging is not expected to occur in the relatively static storage conditions at WESF. Therefore, the Decatur incident is not necessarily representative of the type of leaking capsule which might occur at WESF.

A leak in an outer capsule was detected at WESF. This event was discovered by operating personnel when the inner capsule failed to pass the inner capsule movement test and upon visual examination, was observed to be leaking steam from a series of microfissures in the area of the end cap weld. This capsule has since been placed in a Type W overpack.

Facility near-accident events are those events which might resemble an accident condition, such as a fire, but which resulted in only operational consequences. Such events include:

- A partial flood of a K-3 filter housing through the filter washdown system, which resulted in an operational upset to the $\mathrm{K} \cdot 3$ system.

- During the processing period when encapsulation of cesium and strontium was occurring in the hot cells, fires inside the hot cells were reported. Such fires were small and adequately controlled by movement of other combustibles away from the location of the fire. This agrees with operational experience which involved elevated temperatures.

- A hot cell was flooded when the processing water feed valve inside the hot cell was inadvertently left open. The water level in the hot cell reached approximately half way up the cerium window. This also agrees with operational experience which involved the use of water to decontaminate inner and outer capsules.

The final category of facility events includes unusual occurrences which includes spread of contamination, facility worker hazards (electrical, falls, etc.), equipment failures, operator and management errors, etc. These occurrences are documented in the Occurrence Reporting and Processing System (ORPS) database maintained for all of the facilities in the DOE Complex, for events occurring after approximately 1990.

The ORPS database was reviewed for events occurring at WESF and the results of that review are summarized in Table 3-4. The columns in the table show: 1) the root cause category which was used by the ORPS database to categorize each event, and 2) the consequence of the event. Most events did not result in any consequences, but several resulted in a minor spread of contamination or a spill of hazardous waste within the facility. The most prevalent root causes of minor contamination spread were defective or failed equipment, inattention to detail by facility workers, and violations of procedure by personnel. The most prevalent cause of hazardous waste spills were defective or failed equipment, inattention to detail by facility workers or errors by facility personnel. None of the events in the database resulted in a release of hazardous material outside the facility. 
Table 3-4. ORPS Abnormal Occurrences and Consequences.

\begin{tabular}{|c|c|c|c|c|}
\hline \multirow[t]{2}{*}{$\begin{array}{l}\text { Root Cause } \\
\text { Category }\end{array}$} & \multicolumn{3}{|c|}{$\begin{array}{l}\text { Number of Occurrences in } \\
\text { Consequence Category }\end{array}$} & \multirow[t]{2}{*}{$\begin{array}{l}\text { Total Number of } \\
\text { Occurrences }\end{array}$} \\
\hline & No Consequence & Contamination(s) & $\begin{array}{c}\text { Hazardous } \\
\text { Waste Spill(s) }\end{array}$ & \\
\hline Inadequate admin. control & 6 & 2 & 1 & 9 \\
\hline $\begin{array}{l}\text { Defective/ } \\
\text { failed part }\end{array}$ & 36 & 6 & 6 & 48 \\
\hline Inattention to detail & 11 & 6 & 5 & 22 \\
\hline $\begin{array}{l}\text { Weather/ } \\
\text { Ambient condition }\end{array}$ & 3 & 2 & - & 5 \\
\hline Contamination & 40 & - & - & 40 \\
\hline $\begin{array}{l}\text { Inadequate or defective } \\
\text { design }\end{array}$ & 11 & 3 & 2 & 16 \\
\hline $\begin{array}{l}\text { Violation of requirement or } \\
\text { procedure }\end{array}$ & 1 & 6 & - & 7 \\
\hline Power loss & 4 & - & - & 4 \\
\hline Personnel error & 13 & 2 & 6 & 21 \\
\hline Contamination spread & 1 & - & - & 1 \\
\hline $\begin{array}{l}\text { Inadequate or defective } \\
\text { procedure }\end{array}$ & 10 & 1 & - & 11 \\
\hline $\begin{array}{l}\text { work org./planning } \\
\text { deficiency }\end{array}$ & 7 & 4 & 1 & 12 \\
\hline $\begin{array}{l}\text { error in equipment or } \\
\text { material selection }\end{array}$ & 1 & $\cdot$ & - & 1 \\
\hline Management error & $\overline{6}$ & 4 & - & 10 \\
\hline Vandalism/sabotage & 1 & - & - & 1 \\
\hline
\end{tabular}

All of the hazards summarized in this section are used as input into the hazards evaluation, accident selection, and accident analysis processes. This is done using the WESF HAZOP (Siemer 1995) and hazards evaluation (Hey 1999). The HAZOP and hazards evaluation systematically examines the hazards in the context of their existence within the facility.

By far the most significant hazards at WESF arise from the radioactive isotopes ${ }^{137} \mathrm{Cs}$ and ${ }^{90} \mathrm{Sr}$ that are contained in capsules in both the pool cells and possibly F and G Cells, and as contamination in the hot cells, K-3 exhaust duct, K-3 filters, and Truckport (as low-level waste [LLW] or in a contaminated WIXM). The radioactive materials represent both dispersal (and subsequent dose) hazards and direct radiation hazards. The remaining hazards, such as fires and explosions, serve as energy sources which might disperse the radioactive materials.

The inventory data report used to specify the location and quantity of the ${ }^{137} \mathrm{Cs}$ and ${ }^{90} \mathrm{Sr}$ is in Supporting Calculations and Documentation for the WESF Basis for Interim Operation, HNF.SD-WM-TI-733 (Hey 1999). The values contained in the report were developed by facility personnel and represent a combination of maximum allowable inventories and estimated 


\section{HNF-SD-WM-BIO-002 REV 1}

actual or maximum conditions. The inventories specified for the Truckport. the WIXM. and the K-3 filters, shown in Table 3-3, are the expected maximum inventories for these areas. These values were selected based on the desire to provide an upper bound for the inventory under which the facility can effectively operate. The low-level contamination associated with the wastes stored in the Truckport is generated from manipulator shop activities, canyon clean-up activities, and routine facility maintenance. The contamination on the K-3 filters originates in the hot cells and the K-3 exhaust duct, with the maximum value based on accident analysis assumption.

The inventories specified for the K-3 exhaust duct, the hot cells, and the pool cells are conservative estimates of the radioactive materials that are estimated to be actually present in those areas. These inventories are bounding because operations which might introduce additional contamination are no longer performed, such as encapsulation activities, and are outside the scope of this BIO. For the K-3 exhaust duct, the inventory data are based on records of dose rates taken in the exhaust duct, which is why two possible isotopic distributions are provided. This contamination is present from former processing activities in the hot cells. In the accident analysis, the distribution that would result in the greatest dose consequences is used. For the hot cells the inventory data represent estimates of residual contamination on equipment and surfaces within the hot cell, based on historical operations within each cell. For the pool cells, the accident analysis uses maximum storage conditions which includes all uncut capsules produced at WESF. The inventory number used for the capsules bounds the additional seven powder and pellet Type W overpack capsules received at WESF in 1998. This kind of analysis serves to bound the potential consequences of accidents and allows the facility greater flexibility in storage of the capsules.

Although predominantly used in the process of hazards evaluation, the WESF HAZOP, performed by plant personnel, is also helpful in the process of identifying facility hazards. Because the HAZOP systematically reviewed WESF operations for potential deviations from normal operating conditions, the hazards inherent in the facility operations and materials were identified. An example would be the identification of the potential, under some process deviations, to generate and accumulate hydrogen.

Potential fire hazards have been identified and evaluated in the FHA performed for WESF (Meriz 199\$). The results of the FHA identified significant combustible loadings in the facility Truckport area and hot cells that present fire hazards for dispersal of radioactive material. These hazards are carried forward in the hazards evaluation and accident analysis.

The kinetic energy hazards identified for WESF consist of the pool cell and canyon cranes, the various cover blocks used in the facility, and the shipping casks used for high-activity solid waste and capsules. The pool cell and canyon cranes are large bridge cranes and would represent a significant force if one failed and fell into a hot cell (canyon crane) or a pool cell (pool cell crane). The various cover blocks used in the facility are intended to provide both confinement of radioactive materials and radiation shielding. There are cover blocks on the hot cells, Truckport, K-3 Filter Pit, TK-100 pit, Pool Cell Area and inactive pool cells. Cover blocks were formerly in place over active pool cells, but an IOSR control is in place for moving a cover block over an active pool cell. There are two types of casks used in the facility, the waste cask for outgoing shipments of the higl-iactivity solid waste drums from A Cell and the BUSS cask for receipt of capsules. Both casks are designed to provide significant shielding for their respective payloads and, as a result, pose significant drop hazards. All of these kinetic energy hazards are addressed in the hazards evaluation and accident analysis as appropriate.

The March 14, 1996 WESF OSHA/Emergency Planning and Community Right-to-Know Act Inventory, Hazardous Material Inventory Database was reviewed ( $\mathrm{Hey}$ 1999), for toxic materials stored in WESF that could potentially be released during an accident and expose the onsite and offsite individuals above the toxic chemical risk guidelines identified in WHC-CM-4-46, Section 7.0, "Risk" (now contained in HNF-PRO-704). Except for trisodium phosphate crystals $\left(\mathrm{Na}_{3} \mathrm{PO}_{4}\right)$, WIXM Amberlite(B or Purolite(B) resin beads and a clay absorbent (Absorbs-It') (MSDS No. 010179), the quantities of materials identified in the database for use in WESF are extremely low (i.e., $18.93 \mathrm{~L}$ [5 gal] of floor wax, $36.74 \mathrm{~kg}$ [81 lb] of floor cleaner). Most of the materials are in use for general housekeeping purposes and are in quantities used for the typical household but are certainly not in greater quantities than found in institutions, e.g., schools, hospitals, hotels/motels, etc. Only one material, Neolube ${ }^{2}$, is not used for general housekeeping purposes and is reviewed along with trisodium phosphate (MSDS

\footnotetext{
'Absorbs-It is a trademark of Excel-Mineral company, 111 S. La Patera Lane, Goleta, California, 93117.

${ }^{2}$ Neolube is a trademark of Huron Industries, Inc., P. O. Box 610104, Port Huron, MI 48061.
} 
No. 042124), WIXM Amberlite or Purolite (MSDS No. 15012: MSDS No. 29805) resin beads and Absorbs-It' in the following discussion.

Trisodium phosphate is used as a decontamination agent in WESF. The dry material is a nonvolatile, noncombustible alkaline dust. The crystals are mixed with water and typically heated to form a 0.4 to $1 \mathrm{wt} \%$ solution. The trisodium phosphate vapor pressure from the 0.4 to $1 \mathrm{wt} \%$ solution would be negligible, and the solution would primarily be considered a potential skin and eye irritant with some potential for respiratory irritation should misting occur. There are no exposure limits for trisodium phosphate in either the American Conference of Governmental Industrial Hygienists (ACGIH 1991) or the National Institute of Occupational Safety and Health (NIOSH 1990). However, exposure to the dry dust would be limited to a $3 \mathrm{mg} / \mathrm{m}^{3}$ (respirable) 8-hour TWA (ACGIH-particulate not otherwise classified). A spill of this material would not result in detectable concentrations at $100 \mathrm{~m}(328 \mathrm{ft})$ or the Hanford Site boundary.

The WIXM resin is a sulfonated divinylbenzene/styrene copolymer that is slightly toxic and can result in irritation to the eyes and skin on contact. The resin material is not listed in 40 CFR 302.4 as a hazardous substance and. therefore. is not lurther analyzed as a toxic substance. (The physical properties of the resin material are, however, considered further in the analysis from the standpoint of radiological hazards.)

Absorbs-It' is sedimentary opal clay used as a liquid absorbent. The material contains less than $10 \%$ crystalline silica (as quartz), and is nonvolatile and noncombustible. The exposure limit for quartz is $0.1 \mathrm{mg} / \mathrm{m}^{3}$ (respirable) 8-hour TWA (ACGIH), and crystalline silica is considered a possible or reasonably anticipated carcinogen by the National Toxicological Program and the International Agency for Research on Cancer. There is some potential for exposure to employees using the material, but the material is non-toxic to the environment and a spill of this material would not result in detectable concentrations at $100 \mathrm{~m}(328 \mathrm{ft})$ or the Hanford Site Boundary. This material is directly analogous to common sand.

Neolube $^{2}$ is a mixture of isopropanol and natural graphite used when pulling wires through electrical conduit. Employee exposure limits for the Neolube ${ }^{2}$ ingredients are: graphite, $2 \mathrm{mg} / \mathrm{m}^{3}$ (respirable) 8-hour TWA (ACGIH-TLV) and isopropanol, $400 \mathrm{ppm} 8$-hour TWA, $500 \mathrm{ppm}$ STEL (ACGIH-TLV). The Neolube ${ }^{2}$ is stored in the flammable cabinet in the AMU. The material does not pose a significant exposure hazard to employees using the material, and a spill of this material

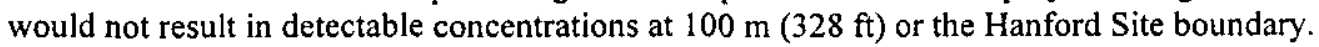

Since the original release of the WESF BIO, the latility has added the Pool Cell Closed Loop Cooling system. 225-BG. Chemicals are added to this system to redace corrosion (Dianodic DN300). eliminate biological growth within the system (Spectrus NX1106), and balance pH (citric acid) as necessary. None of these compounds are considered carcinogenic. none of these compounds are listed in 40 CFR 355 as an extremely hazardous substance. and only the potassium hydroxide (a constituent of Dianodic DN300) is listed in 40) (FR 302.+ as a hazardous substance. There are no regulated constituents present at OSHA thresholds and the CERCI.A/SARA reportable quantity of Diandic DN300 due to the potassium hydroxide is 2,068 gallons and the facility only stores 180 gallons. Hithese chemicals are accidentally mixed (e.g.. failure of the containers). they would neutralize each other but would not create an exothermic reaction. For these reasons, additional analysis will not be performed and the site/facility industrial safety and chemical management programs will ensure worker safety is maintained.

None of the chemicals at WESF pose a credible onsite, $100 \mathrm{~m}$ ( $328 \mathrm{ft}$ ), offsite (Hanford boundary), or environmental risk based on the quantity of material and the dispersion properties due to the physical characteristics of the materials. The materials discussed in some detail above are not considered as having any significant exposure potential outside the immediate spill or work area. The potential for worker exposure to the materials is addressed in the institutional health and safety program identified in Chapter 6.0, Section 6.2, "Hazardous Material Protection."

\subsubsection{Hazard Categorization.}

This section gives the results of the final hazard categorization activity performed as required by DOE Order 5480.23 and in accordance with the guidance provided in DOE-STD-1027-92 (DOE 1992). The preliminary hazard category assigned to WESF is Hazard Category 2 as transmitted to DOE (Reed 1994b). This is the most restrictive category that can be assigned to a DOE non-reactor nuclear facility by the Management and Operations Contractor. DOE-STD-1027-92 also reserves the right to designate facilities as Hazard Category 1 per the direction of the Cognizant Secretarial Officer (CSO) or designee. 
DOE-STD-1027-92 states, "The final categorization is based on an 'unmitigated release' of available hazardous material. For the purposes of hazard categorization, 'unmitigated' is meant to consider material quantity, form, location, dispersibility and interaction with available energy sources, but not to consider safety features (e.g., ventilation system, fire suppression, etc.) which would prevent or mitigate a release."

Other considerations made in this hazard assessment are (1) facility segmentation, (2) treatment of sealed sources, and (3) use of alternative release fractions. Each consideration is discussed below.

Segmentation. Segmentation is used to avoid placing excessive requirements on simple or even trivial co-located operations. The WESF facility is, for all practical purposes, independent of the shutdown B Plant facility. The WESF mission is one of interim storage. It no longer serves as a processing extension of the B Plant complex. The only interaction between the two facilities that increases hazards is the potential failure of the B Plant end wall. Its failure during a seismic event could damage portions of the WESF structure. The interaction has been evaluated in this BIO (see Section 3.4.2.1) and, although a significant hazard, its potential consequences are within risk evaluation guidelines. Other hazardous releases from B Plant, unrelated to WESF, were also evaluated for impact on WESF (see Section 3.4.2.2). Although B Plant accidents have the potential to disrupt WESF operations, none were found that would prevent WESF from carrying out its mission of safe storage.

B Plant deactivation activities should proceed without impacting the WESF safety basis. Therefore, the segmentation of WESF from B Plant for hazard categorization purposes is appropriate and beneficial.

Three seismically independent structures make up WESF; however, many of the service systems are common. All three structures are vital to the WESF storage mission. At this time, no benefit is ascertained from further segmentation of WESF.

Sealed Radioactive Sources. DOE-STD-1027-92 (DOE 1992) states "Sealed radioactive sources that are engineered to pass the special form testing specified by the U.S. Department of Transportation in 49 CFR 173.469 or testing specified by ANSI N43.6, 'Sealed Radioactive Sources, Categorization,' may be excluded from summation of a facility's radioactive inventory." Other documentation and source control requirements are also applicable. The WESF cesium capsules passed all Special Form tests and were qualified as Special Form in 1975 (Nogales 1992), but the sealed radioactive source exclusion will not be taken for the purpose of this hazard analysis for the following reasons.

- A WESF cesium capsule failed on June 1988 at a commercial irradiation facility, RSI, in Decatur, Georgia. Due to concerns for Special Form application to RSI capsules and the desire for expedient recovery, cesium capsules were shipped from the RSI facilities to WESF as Normal Form Material. These same concerns (i.e., the impact of thermal cycling on capsule integrity) remain outstanding for those capsules that were shipped Normal Form and would have to be addressed before Special Form requirements could be formally stated to be met.

- The loss of pool cell water event discussed in Section 3.4.2.7 identifies a way that the encapsulated material could be released. This condition is brought about by the storage configuration and heat buildup of several hundred capsules located within a confined volume. Active human intervention is required in order for this configuration to remain safe. Such a configuration does not meet the intent of DOE-STD-1027-92 (DOE 1992) for passively safe storage of hazardous material.

Alternate Release Fractions. The release fractions used in deriving the radio-isotopic threshold criteria in DOE-STD1027-92 (DOE 1992) were $1.0 \times 10^{-2}$ and $1.0 \times 10^{-3}$ for cesium and strontium, respectively. From an evaluation of the worst case, unmitigated accident sequence (i.e., the loss of pool cell water event discussed in Section 3.4.2.7), a similar release fraction of $3.0 \times 10^{-2}$ results from the release of $110 \mathrm{~kg}$ (out of a total of $3,546 \mathrm{~kg}$ ) of cesium chloride over the first 28 days of the release. (Total cesium capsule net mass is 1,328 capsules times $2.67 \mathrm{~kg}$ net mass per average cesium capsule [Hcy 1999]). Relative to the cesium chloride release, no significant strontium fluoride is released. DOE (1992) allows the threshold quantity to be adjusted by the ratio of the calculated release fraction to the default release fraction. Thus, the detailed analysis of Section 3.4.2.7 provides a basis for decreasing the threshold criteria for ${ }^{137} \mathrm{Cs}$ by a factor of three and excluding consideration of ${ }^{90} \mathrm{Sr}$ from this event hazard. 
WHC-CM-4-46 (which has since been replaced with HNF-PRO-704) provides the following expression for use in determining the final hazard categorization.

$$
\text { SUM of Ratios }=\sum_{i=1}^{j} \frac{\text { Inventory at Risk of Isotope }}{\text { Category } 2 \text { Threshold Quantity of Isotope }}
$$

If the solution to this expression is greater than unity, the analyst is directed to document the facility as Hazard Category 2.

The inventory at risk is the inventory that could become a source of a hazardous release in the event of an accident. As shown in Section 3.4.2.7, considerable WESF inventory meets this definition. From Table 3-3 the inventory at risk is approximately $52 \mathrm{MCi}$ of ${ }^{137} \mathrm{Cs}$. Substituting these values into the above expression with the appropriate adjustments to the DOE-STD-1027-92 (DOE 1992) threshold criteria (based on an alternate release fraction) yields:

Sum of Ratios $=\frac{52 \mathrm{MCi} i^{137} \mathrm{Cs}}{89 / 3 \mathrm{kCi} i^{137} \mathrm{Cs}}=1,750$.

If the original DOE-STD-1027-92 threshold criteria (without adjustment for release fraction and exclusion of Sr-90) had been used, the following result, which is virtually the same, would be obtained

$$
\text { Sum of Ratios }=\frac{52 \mathrm{MCi} i^{137} \mathrm{Cs}}{89 \mathrm{kCi} i^{137} \mathrm{Cs}}+\frac{23 \mathrm{MCi}{ }^{90} \mathrm{Sr}}{22 \mathrm{kCi}{ }^{90} \mathrm{Sr}}=1,630 .
$$

Conclusion. The WESF radioactive inventory exceeds the DOE-STD-1027-92 (DOE 1992) threshold inventory for Hazard Category 2. Based on this comparison and the considerations noted above, a designation of Hazard Category 2 is assigned to WESF.

The unmitigated consequences of the most severe accident sequence, evaluated in Section 3.4.2.7, indicates that the release of radioactive cesium chloride could begin approximately 2 days after water is lost in all pool cells. Such a release could result in a 50-yr committed dose to the maximum public receptor of slightly less than $100 \mathrm{mSv}(10 \mathrm{rem})$ in the first $24 \mathrm{~h}$. Furthermore, sufficient radioactive material and energy are available to continue releasing radioactive cesium chloride for several weeks.

\subsubsection{Hazard Evaluation Results.}

This section contains a summary of the results of the hazards evaluation effort performed for WESF. The hazards evaluation results are shown in detail in a supporting document (H ley 1999).

As discussed in Section 3.3.1.2, the hazards evaluation for WESF consisted of two primary efforts. The first is the WESF HAZOP performed in 1994 and issued in 1995 (Siemer 1995). The HAZOP identifies and partially evaluates hazards and potential system and operating deviations that might result in adverse consequences. The second effort is shown in a supporting document (Hey 1999) and determines frequencies and challenged safety barriers for the purposes of the BIO. The WIXM HIAZOP was completed in a single effort and was incorporated into l ley(1999).

The results of the HAZOPs consisted of a number of postulated accident scenarios that were ranked by the HAZOP team members with respect to assigned consequences. The qualitative consensus estimates of the safety severity of the consequences were ranked as S0 (operational issues), S1 (worker safety issues), S2 (onsite consequences), and S3 (offsite consequences).

There were a total of 326 deviations identilied to have potential consequences associated with the 27 HAZOP nodes shown in Table 3-5. Details on each these deviations including the assigned Consequence Rank (S0. SI or S3) and Freguency Rank (F0, F1, or F3) are contained in Table A-2 and A-2a in the Hey (1999). In some cases, deviations of a parameter 


\section{HNF-SD-WM-BIO-002 REV 1}

associated with one node would cause another deviation of a parameter associated with a second node (e.g., high flow through a feed line node might cause a high level in the destination vessel). There were also several instances in the HAZOP where an accident scenario caused by a particular deviation has more than one consequence ranking (S1/S2 or S2/S3) depending on the state of associated equipment or process parameters. In some cases, the cause and consequences of a particular deviation at a node are identical to a deviation at another node. These are cross-referenced in the HAZOP tables and are not generally included in the count as separately ranked accident scenarios.

There were several deviations postulated as having S0 consequences (operational concerns only). These deviations, having been brought to the attention of management, are documented in a supporting document (Hey 1999). S( deviations will not be evaluated further.

The S1 deviations identified in the HAZOP studies have been combined and summarized in Table 3-6. The institutional safety programs that are designed to address worker safety issues at WESF are identified in Chapter 6.0, "Safety Management Programs." Identification in the HAZOP and summarization in this section, are sufficient to define the interface between safety analysis issues and worker safety issues for WESF. Therefore, S1 deviations are not evaluated further.

The S2 deviations have been combined and summarized in Table 3-7. All S2 deviations identified in the HAZOPs are included in the full hazards evaluation and accident selection processes, and Table 3-7 is provided only as a summary of the hazards evaluation results.

The S3 deviations have been combined and summari<ed in Table 3-8. All S3 deviations are included in the full hazards evaluation and accident selection processes, and Table 3-8 is provided only as a summary of the hazards evaluation results.

In addition to the WESF HAZOP, a hazards evaluation identifying barriers to the postulated consequences and assigning frequencies to the deviations of interest was performed for WESF and is documented in Hey (1999). This effort used the HAZOP as the basis to further evaluate S2 and S3 deviations. The hazards evaluation results, shown in Hey (1999),

Table A-2 lable A-2a, are used in the accident selection process detailed in Hey (1999), Table A-3 Table A-3a; and Section 3.3.2.3.5 of this document.

The risk rank; for each deviation is shown in Hey (1999), Table A-3 and Table A-3a. The risk rank is the primary input into the accident selection process. For deviations that were assigned a combination of consequence categories (S1/S2 or S2/S3), the higher consequence category was assumed unless noted otherwise in the remarks column of Hey (1999),

Table A-2 lable A-2a.

\subsection{Planned Design and Operational Safety Improvements.}

There are currently no significant design or operational improvements planned for WFSF.

\subsection{Defense-In-Depth.}

This section discusses the results of the hazards identification and evaluation efforts for the purpose of evaluating the existence of defense-in-depth at WESF. Defense-in-depth is both a philosophy and a reference to "uncredited" barriers. The philosophy is that, when possible, reliance should not be placed on a single barrier to prevent unacceptable consequences. An "uncredited" barrier means that the SSC could act as a barrier to unacceptable consequences; however, it is not credited as safety significant or safety class. In practice, SSCs can be credited to control some, but possibly not all events. To present a consistent summary, Table 3-10 broadly includes any and all SSCs which could act as a barrier to unacceptable consequences. Reliance on them as safety class, safety significant, or merely defense-in-depth is also denoted along with their relationship to the accident analysis. 
HNF-SD-WM-BIO-002 REV 1

Table 3-5. Nodes Analyzed in WESF HAZOP.

\begin{tabular}{|c|c|}
\hline l & WESF Truckport \\
\hline 2 & Cask Transport Vehicle (Corklift or truck) \\
\hline 3 & $13.61(15-t o n)$ crane \\
\hline 4 & Shipping cask \\
\hline 5 & G-Cell capsule handling area \\
\hline 6 & Hot cell manipulators \\
\hline 7 & Capsule transier cart \\
\hline 8 & Pool cell and transfer aisle tongs \\
\hline 9 & Pool cell cranc \\
\hline 10 & Capsule (cesium or strontium) \\
\hline 11 & F-Cell capsule decontamination and storage \\
\hline 12 & Water supply to pool cells \\
\hline 13 & Pool cell water thow through heat exchanger to ion-exchange bleed of \\
\hline 14 & CDL discharge \\
\hline 15 & lon-exchange loop \\
\hline 16 & Pool cell \\
\hline 17 & Pool Cell Araa \\
\hline 18 & Piping from pool cell drain system \\
\hline 19 & $\begin{array}{l}\text { Low level waste piping from lot cell drain to B Plant TK-39-1 (this system was } \\
\text { deactivated in 1998) }\end{array}$ \\
\hline 20 & TK-100 low level licpuid waste system \\
\hline 21 & Piping from B Plant TK-100 to TK-39-1 (this system was deactivated in 1998) \\
\hline 22 & 208-1, (55-gal) solid waste drum from hot cells \\
\hline 23 & Currently unused hot cells $(A-E)$ \\
\hline 24 & $\begin{array}{l}\text { K-3 supply from intake to cell (the K-3 system is used to represent "typical" } \\
\text { events from all ventilation systems) }\end{array}$ \\
\hline 25 & K-3 supply to typical cell \\
\hline 26 & K-3 cxhaust duct to stack \\
\hline 27 & WIXM \\
\hline
\end{tabular}


HNF-SD-WM-BIO-002 REV I

Table 3-6. Summary of HAZOP S1 Deviations.

\begin{tabular}{|c|c|c|}
\hline Spread of Contamination & Hazardous Material/Radiation Exposure & Industrial Concerns \\
\hline $\begin{array}{l}\text { Release of contaminated pool cell water (during } \\
\text { transfer to B Plant } \mid[\text { Plant like intictivated in } \\
\text { 1998 [) } \\
\text { Waste water backflow from B Plant|(13 plant line } \\
\text { inactivaled in }|948| \\
\text { TK-100 flood, leak, or rupture } \\
\text { TK-100 fire (leaked fuel from Truckport) } \\
\text { Non-routine maintenance for TK-100 } \\
\text { Solid waste container failure (explosion, fire, } \\
\text { reaction, etc.) } \\
\text { Hazardous materials entering facility from outside }\end{array}$ & 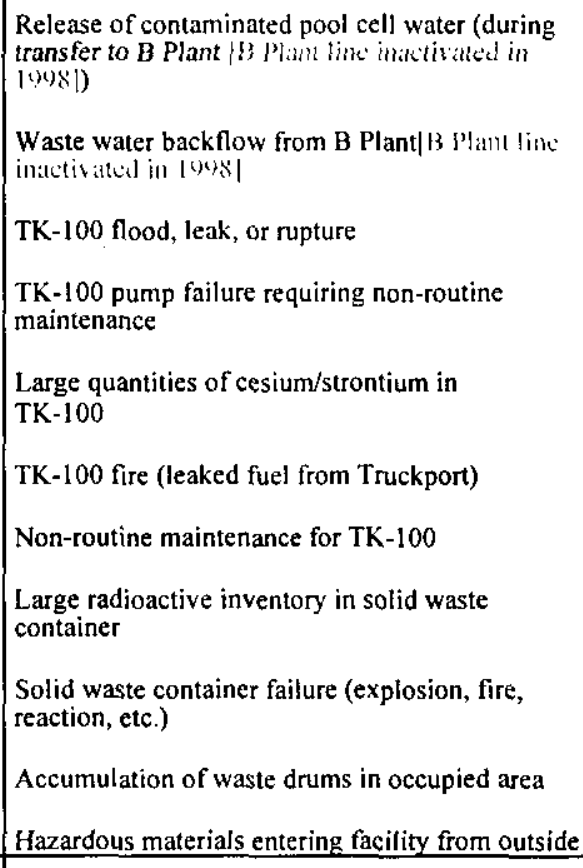 & $\begin{array}{l}\text { Heavy solid waste container } \\
\text { Solid waste container failure (explosion, fire, } \\
\text { reaction, etc.) }\end{array}$ \\
\hline $\begin{array}{l}\text { Combustim of } \mathrm{W}, X \mathrm{X} / \mathrm{resin} \text { and release of } \\
\text { ladiogactive smoke }\end{array}$ & 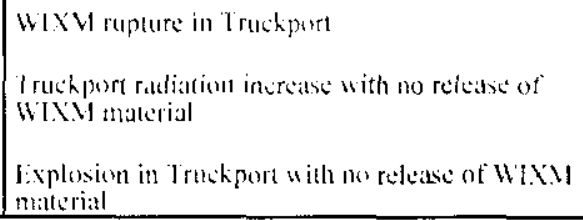 & Increase in HIXVI temperature \\
\hline
\end{tabular}


Table 3-7. Summary of HAZOP S2 Deviations.

\begin{tabular}{|c|c|}
\hline & Deviation \\
\hline 1 & $\begin{array}{l}\text { Contamination spread from Truckport fire caused by leaking fuel from gasoline or diesel } \\
\text { engine igniting radioactive waste }\end{array}$ \\
\hline 2 & Contamination spread from shipping cask damaged due to impact of misplaced cover block \\
\hline 3 & $\begin{array}{l}\text { Cask damage due to placement on cover block rather than canyon floor. (Possibility of failing } \\
\text { cover block because the structural strength is less than the canyon floor; cover block cannot } \\
\text { support cask weight) }\end{array}$ \\
\hline 4 & Spread of contamination broken loose from K-3 exhaust system overwhelming the filter system \\
\hline 5 & $\begin{array}{l}\text { Spread of contamination broken loose from K-3 exhaust system transferred unmonitored to the } \\
\text { environment through the } 296-\mathrm{B}-12 \text { steam jet ( } \mathrm{K}-3 \text { sleam jet has since been removed) }\end{array}$ \\
\hline 6 & Breach of capsule and/or pool cell leak caused by cover block drop into pool cell \\
\hline 7 & $\begin{array}{l}\text { Spread of contamination after capsule structural failure due to high temperature caused by loss } \\
\text { of pool water }\end{array}$ \\
\hline 8 & $\begin{array}{l}\text { Spread of contamination after hydrogen explosion in hot cell due to increased radiolytic } \\
\text { hydrogen concentration resulting from loss of cell ventilation }\end{array}$ \\
\hline 9 & $\begin{array}{l}\text { Radiation dose from uncovered capsules caused by structural failure of pool cell allowing water } \\
\text { to drain }\end{array}$ \\
\hline 10 & $\begin{array}{l}\text { Large release from overheating of capsules in drained pool causing melting and/or multiple } \\
\text { capsule failure }\end{array}$ \\
\hline 11 & $\begin{array}{l}\text { Under cover block hydrogen explosion. (Not applicable since cover blocks have been } \\
\text { removed) }\end{array}$ \\
\hline 12 & $\begin{array}{l}\text { Contamination spread from hydrogen explosion in TK-100 due to transfer of excess strontium } \\
\text { or cesium to tank (increasing radiolysis) }\end{array}$ \\
\hline 13 & Contamination spread due to leak of material from TK-100 to soil \\
\hline 14 & Increased direct radiation dose from TK-100 due to $\mathrm{K}-3$ filter flush \\
\hline 15 & Contamination spread from fire in waste drum \\
\hline 16 & Contamination spread from chemical reaction in waste drum \\
\hline 17 & Release of contamination to the environment from $\mathrm{K}-3$ filter due to flooding \\
\hline 18 & Contamination spread from fire in $\mathrm{K}-3$ filter \\
\hline 19 & Contamination spread from fire in hot cell. \\
\hline 20 & Release of fine spray in Truckport due to WIXM overpressure \\
\hline
\end{tabular}


HNF-SD-WM-BIO-002 REV 1

Table 3-8. Summary of HAZOP S3 Deviations.

\begin{tabular}{|c|c|}
\hline & Deviation \\
\hline$\overline{1}$ & Contamination spread from cask damage due to cover block drop \\
\hline 2 & $\begin{array}{l}\text { Contamination spread from hydrogen explosion in hot cell due to } \\
\text { increased radiolytic hydrogen concentration resulting from loss of } \\
\text { cell ventilation }\end{array}$ \\
\hline 3 & $\begin{array}{l}\text { Contamination spread from damage to filters (K-3 system) caused } \\
\text { by water from cell flooding }\end{array}$ \\
\hline 4 & Contamination spread from hydrogen explosion in pool cell \\
\hline 5 & $\begin{array}{l}\text { Contamination spread due to capsule structural failure due to loss of } \\
\text { pool cell water and failure to replenish water }\end{array}$ \\
\hline 6 & Contamination spread due to $\mathrm{K}-3$ filter fire \\
\hline 7 & Contamination spread due to fire in hot cell \\
\hline 8 & $\begin{array}{l}\text { Contamination spread from damage to capsules caused by drop of } \\
\text { heavy object. }\end{array}$ \\
\hline 9 & Contamination spread dele to deflagration detonation in WIXM \\
\hline
\end{tabular}

Table 3-9 summarizes the WESF and WIXM specific hazard evaluation effort. The entries in Table 3-9 were obtained from Table $\Lambda-3$ and lable $\Lambda-3$ a of 1 ley (1999) and represent the number of deviations in Table A-2 and Table $A-2 a$ of Hey (1999) which were assigned a particular combination of frequency and consequence. Table $3-2$ of the BIO demonstrates how frequency and consequence rank result in a particular risk rank. Note that the total number of deviations in Table 3-9 is not equal to the total number of deviations in Table A-2 Table A-2a of Hey (1999). Several of the WESF HAZOP deviations were equivalent and were not counted multiple times in the risk rank summary.

Table 3-9. Risk Rank Results Matrix.

\begin{tabular}{|c|c|c|c|}
\hline & RI Deviations & $\mathrm{R} 2$ Deviations & R3 Deviations \\
\hline WESF IHAKOP' & 30 & 40 & 23 \\
\hline WIXM HAZOP & 8 & 2 & 1 \\
\hline Total & 38 & 42 & 24 \\
\hline
\end{tabular}


Table 3-10. Summary of SSCs Having a Safety Function.

\begin{tabular}{|c|c|c|c|}
\hline Feature & Defense-in-depth function & $\begin{array}{l}\text { Relevant } \\
\text { accidents }\end{array}$ & $\begin{array}{l}\text { Level of } \\
\text { protection }\end{array}$ \\
\hline Diesel generator & Provide backup power & 3.4 .2 .13 .4 .2 .2 & DD \\
\hline Area 2 (hot cell) structure & $\begin{array}{l}\text { Structural confinement of residual contamination and } \\
\text { capsules; shielding. }\end{array}$ & $\begin{array}{l}3.4 .2 .1 \\
3.4 .2 .3 \\
3.4 .2 .4\end{array}$ & $\begin{array}{l}\text { SC } \\
\text { SC } \\
\text { WS }\end{array}$ \\
\hline Pool cell water quality & Limit liner and capsule corrosion; maintain visibility & 3.4 .2 .63 .4 .2 .7 & DD \\
\hline Pool cell level control & Maintain capsule cooling and shielding & 3.4 .2 .7 & IOSR \\
\hline Pool cell level instrumentation & Maintain capsule cooling and shielding & 3.4 .2 .7 & $\mathrm{SC}$ \\
\hline Pool cell liners & Maintain capsule cooling and shielding & 3.4 .2 .7 & DD \\
\hline Pool cell leak detection sump & Maintain capsule cooling and shielding & 3.4 .2 .7 & DD \\
\hline $\begin{array}{l}\text { Area } 3 \text { (Pool Cell Area structure including pool } \\
\text { cell concrete walls and floor) }\end{array}$ & Maintain capsule cooling and shielding & 3.4 .2 .7 & $\mathrm{SC}$ \\
\hline 296-B stack and K-3 exhaust ducting & Provide for elevated release of material in event of a DBE & 3.4 .2 .1 & SC \\
\hline Capsule movement procedures & Maintain capsule shielding & N/A & WS \\
\hline Pool cell heat load limits & Maintain capsule cooling and shielding & 3.4 .2 .7 & IOSR \\
\hline Pool cell temperature alarms & Maintain capsule cooling and shielding & 3.4 .2 .7 & DD \\
\hline Pool cell water circulation piping & Retain pool cell water & 3.4.2.7 & $\mathrm{SC}$ \\
\hline Pool cell normal water makeup & $\begin{array}{l}\text { Maintain capsule cooling and shielding; provide makeup } \\
\text { water for decontamination }\end{array}$ & 3.4 .2 .63 .4 .2 .7 & DD \\
\hline Pool cell emergency water makeup & $\begin{array}{l}\text { Provide long term emergency water source for capsule } \\
\text { cooling and shielding }\end{array}$ & 3.4 .2 .7 & $\mathrm{SC}$ \\
\hline Transfer ports normally closed & $\begin{array}{l}\text { Provides assurance that loss of water in one pool cell does } \\
\text { not result in loss of water in other pool cells }\end{array}$ & 3.4.2.7 & DD \\
\hline Water in inactive pool cells & $\begin{array}{l}\text { Provide short term seismically qualified water source for } \\
\text { capsule cooling and shielding }\end{array}$ & 3.4 .2 .7 & $\mathrm{DD}$ \\
\hline Area radiation monitoring in the Pool Cell Area & Alarm for elevated dose rates in the Pool Cell Area & 3.4 .2 .63 .4 .2 .7 & $\begin{array}{l}\text { SS } \\
\text { SC }\end{array}$ \\
\hline K-3 Filter Pit structure & $\begin{array}{l}\text { Protect filter housing from NPHs, shielding of } \mathrm{K}-3 \\
\text { contamination }\end{array}$ & $\begin{array}{l}3.4 .2 .1 \\
3.4 .2 .4\end{array}$ & $\begin{array}{l}\text { SC } \\
\text { WS }\end{array}$ \\
\hline K-3 exhaust duct drain-line and dam & Prevent filter housing water accumulation & 3.4 .2 .4 & DD \\
\hline K-3 filter housing sump and steam jet & Collect and remove filter housing water & 3.4 .2 .4 & DD \\
\hline K-3 filter housing sump liquid detection & Alarm for water in the filter housing, hydrogen dilution & 3.4 .2 .4 & DD \\
\hline $\begin{array}{l}\text { K-3 filter housing sump liquid removal } \\
\text { procedures }\end{array}$ & Prevent hydrogen buildup. & 3.4 .2 .4 & DD \\
\hline K-3 filter inventory limits & Prevent safety class consequences from hydrogen explosion & 3.4 .2 .4 & IOSR \\
\hline
\end{tabular}


HNF-SD-WM-BIO-002 REV 1

Table 3-10. Summary of SSCs Having a Safety Function.

\begin{tabular}{|c|c|c|c|}
\hline Feature & Defense-in-depth function & $\begin{array}{l}\text { Relevant } \\
\text { accidents }\end{array}$ & $\begin{array}{l}\text { Level of } \\
\text { protection }\end{array}$ \\
\hline Truckport low-level solid waste inventory limits & Limit releases from Truckport accidents & 3.4 .2 .3 & IOSR \\
\hline Truckport radiation surveys and detectors & Contamination and radiation field alarms & 3.4.2.3 & $\begin{array}{l}\text { DD } \\
\text { WS }\end{array}$ \\
\hline Chem-Nuc waste cask & Shielding for waste drums & 3.4 .2 .3 & WS \\
\hline BUSS cask & $\begin{array}{l}\text { Shielding, and containment for capsules (including fire and } \\
\text { impact protection) }\end{array}$ & 3.4 .2 .3 & $\begin{array}{l}\text { DD } \\
\text { Ws }\end{array}$ \\
\hline TK- 100 walls and pit structure & Shielding and containment of contamination & 3.4 .2 .4 & EP \\
\hline TK-100 level instrumentation & Prevent overflow into K-3 system & 3.4 .2 .4 & $\begin{array}{l}\text { DD } \\
\text { WS } \\
\text { EP }\end{array}$ \\
\hline Pool cell storage racks & Control capsule storage configuration and protect liner & 3.4 .2 .1 & DD \\
\hline$K-1$ and $K-4$ ventilation systems & $\begin{array}{l}\text { Dilution of fuel fumes in Truckport; prevent hydrogen } \\
\text { buildup in Pool Cell Area. provide cooling of structure if } \\
\text { water lost. }\end{array}$ & $\begin{array}{c}3.4 .2 .3 \\
3.4 .2 .4 \\
3.4 .2 .53 .4 .2 .7\end{array}$ & DD \\
\hline Stack radiation monitors & Monitor and alarm for contamination release & 3.4 .2 .4 & $\mathrm{DD}$ \\
\hline 208-L (55-gal) drums & Confinement of solid waste in A Cell & 3.4 .2 .3 & IOSR \\
\hline Hot cell capsule storage limits & $\begin{array}{l}\text { Thermal protection for safety class structure (IOSR); limits } \\
\text { capsule corrosion (DD) }\end{array}$ & 3.4.2.4 & IOSR \\
\hline Capsules & Primary containment barrier & 3.4 .2 .63 .4 .2 .7 & DD \\
\hline Solid waste bags & Solid waste containment & 3.4 .2 .1 & WS \\
\hline $\begin{array}{l}\text { Truckport fire detection and suppression system } \\
\text { (Nute: this tire suppression system was formerly } \\
\text { SS but has been chanded to DD due to a } \\
\text { (cedtution in drtm inventory) }\end{array}$ & Protect chem-Nuc waste cask in the event of fire & 3.4.2.3 & D) \\
\hline $\begin{array}{l}\text { Vehicle maintenance and waste cask movement } \\
\text { procedures }\end{array}$ & Minimize the possibility for a fire involving the waste cask & 3.4.2.3 & DD \\
\hline $\begin{array}{l}\text { Procedures for transfer from TK-100 to tanker } \\
\text { lruck }\end{array}$ & Prevent high radiation fields; prevent hydrogen buildup & 3.4.2.4 & $\begin{array}{l}\text { WS } \\
\text { EP }\end{array}$ \\
\hline Hot cell fire detection and suppression system & Alarm and extinguish fire in $F$ and $G$ cells & 3.4 .2 .3 & DD \\
\hline $\begin{array}{l}\text { Restriction on combustibles in } \mathrm{B}-\mathrm{F} \text { : Cells } \\
\text { Restriction on combustibles in F and G Cells }\end{array}$ & $\begin{array}{l}\text { Prevent tiilure ol h-j HI:P Pilter } \\
\text { Precludes fire when capsules are present and port } \\
\text { plugs/cover blocks are open }\end{array}$ & 3.4 .2 .3 & IOSR \\
\hline Maximum of $200 \mathrm{~kg}$ of combustibles in A Cell & Minimize fire in A Cell & 3.4.2.3 & IOSR \\
\hline $\begin{array}{l}\text { Plug ports and cover blocks must remain in place } \\
\text { for } B \text { through } E \text { Cells }\end{array}$ & Minimize fise in $B$ through $E$ Cells & 3.4 .2 .3 & IOSR \\
\hline $\begin{array}{l}\text { Hot cell to hot cell pass-throughs (with doors) } \\
\text { remain normally closed }\end{array}$ & Minimizes the possibility of spread of hot cell fire & 3.4.2.3 & IOSR \\
\hline
\end{tabular}


HNF-SD-WM-BIO-002 REV 1

Table 3-10. Summary of SSCs Having a Safety Function.

\begin{tabular}{|c|c|c|c|}
\hline Feature & Defense-in-depth function & $\begin{array}{l}\text { Relevant } \\
\text { accidents }\end{array}$ & $\begin{array}{l}\text { Level of } \\
\text { protection }\end{array}$ \\
\hline K-3 HEPA filters & $\begin{array}{l}\text { Confinement of contamination from hot cells and } \mathrm{K}-3 \\
\text { system }\end{array}$ & $\begin{array}{l}3.4 .2 .3 \\
3.4 .2 .4\end{array}$ & $\mathrm{SC}$ \\
\hline Truckport housekeeping procedures & Minimize loose combustibles & 3.4 .2 .3 & DD \\
\hline Hot cell surveillance and water removal & Prevent hot cell flooding and hydrogen buildup & 3.4 .2 .4 & IOSR \\
\hline Hot cell sumps with liquid detectors & Prevent hot cell flooding and hydrogen buildup & 3.4 .2 .4 & DD \\
\hline $\mathrm{K}-3$ ventilation airflow & $\begin{array}{l}\text { Prevent hot cell and K-3 system hydrogen buildup; provide } \\
\text { cooling in hot cells. }\end{array}$ & 3.4 .2 .4 & DD \\
\hline Packaging requirements for waste drums & Prevent hydrogen generation in waste drums & 3.4 .2 .3 & $\begin{array}{l}\text { DD } \\
\text { WS }\end{array}$ \\
\hline TK $\cdot 100$ bubbler & Control hydrogen buildup & 3.4 .2 .4 & $\begin{array}{l}\text { DD } \\
\text { WS } \\
\text { EP }\end{array}$ \\
\hline Pool cell cover block & Emergency shielding & 3.4 .2 .63 .4 .2 .7 & $\mathrm{DD}$ \\
\hline Heavy object lift restrictions & Prevent a heavy object from falling into a pool cell & 3.4 .2 .63 .4 .2 .7 & IOSR \\
\hline Hot Cell structures & Shielding and confinement & 3.4 .2 .3 & WS \\
\hline Truckport cover block & Shielding and confinement & $\mathrm{N} / \mathrm{A}$ & WS \\
\hline $\begin{array}{l}\text { Hot Cell and Truckport cover block lift } \\
\text { procedures }\end{array}$ & Prevent cover block drop & $\mathrm{N} / \mathrm{A}$ & $\begin{array}{l}\text { DD } \\
\text { WS }\end{array}$ \\
\hline Pool cell drain line & Retention of pool cell water & 3.4 .2 .7 & SC \\
\hline Pool cell E:MIX' system & Pool cell decontamination & 3.4 .2 .6 & $\mathrm{DD}$ \\
\hline Electrical supply system redundancies & $\begin{array}{l}\text { Prevent loss of electric power due to single component } \\
\text { failures. }\end{array}$ & 3.4 .2 .2 & DD \\
\hline Instrument air & $\begin{array}{l}\text { Essential plant support system (operates DOVs for water } \\
\text { makeup) }\end{array}$ & 3.4 .2 .63 .4 .2 .7 & DD \\
\hline $\begin{array}{l}\text { K-3 system differential pressure monitors and } \\
\text { alarms }\end{array}$ & Alarm for K-3 system upset & $\begin{array}{l}3.4 .2 .3 \\
3.4 .2 .4\end{array}$ & DD \\
\hline $\begin{array}{l}\text { K-3 ventilation system exhaust and supply } \\
\text { interlocks }\end{array}$ & $\begin{array}{l}\text { Interlock deactivates supply fan if exhaust fans fail; } \\
\text { prevents pressurization of contaminated areas. }\end{array}$ & 3.4 .2 .4 & DD \\
\hline K-3 system interlock with $K-1$ and $K-4$ systems & $\begin{array}{l}\text { Interlock deactivates the K-1 and K- } 4 \text { systems in the event } \\
\text { of failure of the K-3 system; prevents ventilation air from } \\
\text { pass between zones }\end{array}$ & 3.4 .2 .4 & DD \\
\hline $\begin{array}{l}\text { Altemate ventilation of Pool Cell Area if the K-l } \\
\text { and } K-4 \text { systems inoperable }\end{array}$ & Prevent hydrogen buildup in the Pool Cell Area & 3.4 .2 .5 & IOSR \\
\hline $\begin{array}{l}\text { Control of highly volatile liquid fuels and } \\
\text { flammable gases }\end{array}$ & Prevent flammable gas explosion in the facility & 3.4 .2 .5 & IOSR \\
\hline Active ventilation of all areas of the facility & $\begin{array}{l}\text { Sweep away any flammable gases or fumes generated by } \\
\text { spills or leaks during facility maintenance or modification } \\
\text { activities }\end{array}$ & 3.4 .2 .5 & DD \\
\hline
\end{tabular}


HNF-SD-WM-BIO-002 REV 1

Table 3-10. Summary of SSCs Having a Safety Function.

\begin{tabular}{|c|c|c|c|}
\hline Feature & Defense-in-depth function & $\begin{array}{l}\text { Relevant } \\
\text { accidents }\end{array}$ & $\begin{array}{l}\text { Level of } \\
\text { protection }\end{array}$ \\
\hline Bridge crane, catwalk, and associated supports & Prevent capsule damage and liner leak due to falling object & $\begin{array}{l}3.4 .2 .6 \\
3.4 .2 .7\end{array}$ & $\mathrm{DD}$ \\
\hline $\begin{array}{l}\text { "Inner capsule movement test" procedures and } \\
\text { equipment }\end{array}$ & Locate leaking capsule & 3.4 .2 .6 & $\mathrm{DD}$ \\
\hline Transfer procedures to G Cell & Isolate leaking capsule & 3.4 .2 .6 & DD \\
\hline $\begin{array}{l}\text { Pool cell water circulation and heat exchange } \\
\text { systems }\end{array}$ & $\begin{array}{l}\text { Route water through ion exchange columns (Pool Cell 11); } \\
\text { route water through emergency ion exchange sistem ; } \\
\text { control water temperature }\end{array}$ & $\begin{array}{l}3.4 .2 .6 \\
3.4 .2 .7\end{array}$ & $\mathrm{DD}$ \\
\hline Pool cell in-line beta monitor system & $\begin{array}{l}\text { Detects and alarms for radioactive contamination in the } \\
\text { pool cell water }\end{array}$ & 3.4 .2 .6 & $\mathrm{DD}$ \\
\hline Pool Cell 11 ion-exchange rad monitor & $\begin{array}{l}\text { Prevents radioactive contamination buildup on unshielded } \\
\text { ion exchangers }\end{array}$ & $\mathrm{N} / \mathrm{A}$ & $\begin{array}{l}\text { DD } \\
\text { WS-ALARA }\end{array}$ \\
\hline Truckponet dorors & 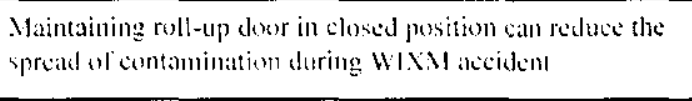 & $\begin{array}{l}3.2 .5 \\
3 .+2.6\end{array}$ & DI) \\
\hline Fiftered WIXU vent & 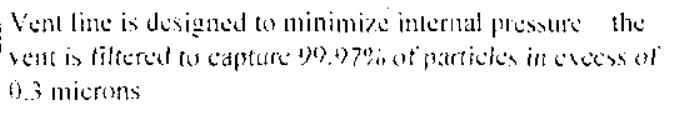 & 3.4 .2 .6 & DI) \\
\hline WIXM design & 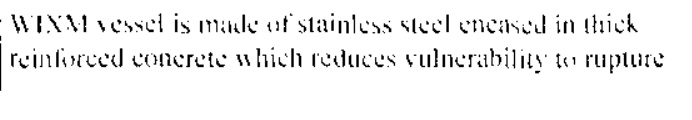 & $\begin{array}{l}3.4 .2 .3 \\
3.4 .2 .6\end{array}$ & $D D$ \\
\hline Trtuckport tire suppression & 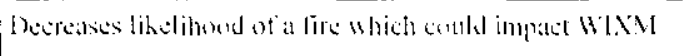 & $3 .+2.3$ & D) \\
\hline Radiation protection program & 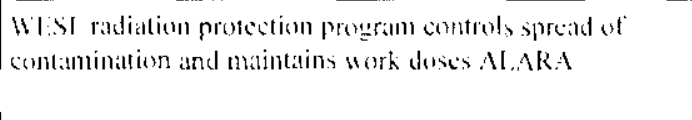 & $\begin{array}{l}3 .+2.5 \\
3+2.6\end{array}$ & $D$ \\
\hline WIXM peparation and shipment procedures & 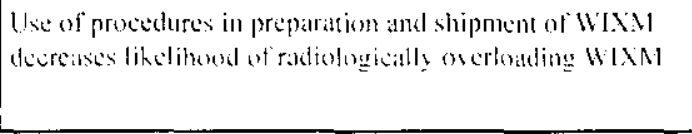 & $\begin{array}{l}3.4 .2 .3 \\
3 .+2.5 \\
3 .+2.6 \\
\end{array}$ & [נ] \\
\hline
\end{tabular}

\footnotetext{
ALARA = as low a reasonably achievable

$\mathrm{DD}=$ Defense-in-depth

DOV $=$ Diaphragm-operated valve

$\mathrm{EP}=$ Environmental protection

IOSR = Interim operational safety requirements

$\mathrm{NPH}=$ Natural Phenomena Hazards

$\mathrm{SC}=$ Safety class

SS = Safety significant

WS $=$ Worker safety.
} 


\section{HNF-SD-WM-BIO-002 REV 1}

The following discussion focuses on each of the significant hazards addressed in Section 3.3.2.1, showing SSCs and administrative controls relied on to control the hazards. The predominant types of hazards identified and evaluated (from Table 3-3) were direct radiation, radioactive materials (includes thermal energies), combustible/flammable materials, explosive materials, and kinetic energy.

Radiation. Direct radiation hazards were identified in the Pool Cell Area, hot cells, K-3 Filter Pit, Truckport, TK-100 pit, and areas where the loaded shipping casks may be located.

For the Pool Cell Area, the radiation hazard stems from the cesium and strontium capsules located in active pool cells. Defense-in-depth for this hazard begins with the capsules themselves, which provide shielding for the beta radiation and containment for the radioactive material. The first barrier for the gamma radiation is the pool cell water and associated systems and controls. Also present are radiation monitors in the Pool Cell Area, the water circulation system, and the ion-exchange columns. All of these features are discussed below.

Radiation produced by the encapsulated materials in the pool cells consists of beta and gamma radiation. The beta radiation will also interact with shielding materials (e.g., capsules) to produce bremsstrahlung radiation, but there is no identified condition at WESF where bremsstrahlung radiation would play a significant role in dose rate estimates. On this basis bremsstrahlung radiation is not considered further. The beta radiation produced by the ${ }^{90} \mathrm{Sr},{ }^{90} \mathrm{Y}$ (the daughter product of ${ }^{90} \mathrm{Sr}$ ), and the ${ }^{137} \mathrm{Cs}$ is shielded by the inner and outer stainless steel capsules. Only in the event of a failed capsule, analyzed in the hazards evaluation and accident analysis, would the beta radiation not be shielded by the capsules. The gamma radiation, predominantly produced by ${ }^{137 \mathrm{~m}} \mathrm{Ba}$ (the daughter product of ${ }^{137} \mathrm{Cs}$ ), is not adequately shielded by the capsules. The water in the pool cells is used to provide the shielding for the gamma radiation. Il sullicient water depth were not available as shielding, the level monitoring would alert facility personnel to low poot cell levels and the area radiation monitoring in the Pool Cell Area would act to alert tacility personel to the presence of elevated dose rates.

Because some of the capsules may be stored near the walls of the pool cells, the water in the active pool cells and the pool cell wall do not provide sufficient shielding to the side. To provide additional shielding. water is maintained in inactive pool cells that are adjacent to active pool cells.

Several features maintain the water as shielding in the active pool cells.

- The pool cell liners, and safety class drain piping and circulation system piping are relied on as the first boundary to contain the water in the pool cells.

- A sump with leak detection capabilities is provided for each pool cell to collect any water that may leak from a liner.

- The safety class pool cell concrete structures under the liners are the second boundary to contain the water in the pool cells.

- When capsules are moved with the hollow pool cell tongs. the capsules are not lifted any higher than necessary and the tongs are filled with water to prevent dose to the facility worker.

- The water level in each active pool cell is monitored and controlled via water level instrumentation.

- The water lost from the pool cells is replaced by water makeup systems. The primary (normal) water makeup system is deionized water. Alternate and emergency water makeup systems include the normal plant sanitary and raw water supplies, two deep wells that can feed the raw water supply loop for WESF, and external water sources.

- The water in each active pool cell is actively cooled by circulation through a heat exchange system. The cooling is performed to maintain water temperature.

- The quality of the pool cell water is maintained by the use of deionized water makeup (above) and periodic circulation 
through ion-exchange columns located in Pool Cell 11 to reduce corrosion.

- Radiation monitoring in Pool Cell Area, circulation system, and ion exchange columns.

- Water transfer from pool cell to pool cell can be performed to provide short-term water supply and cooling.

Radiation monitors are located in the water circulation system and on the ion-exchange column intake. The circulation system for each pool cell is designed to take water from the pool cell, cool it by passing it through a heat exchanger, then return it to the same pool cell. The circulation radiation monitors are designed to detect and alert facility personnel to the presence of radioactive material in the pool cell water. The ion-exchange columns in Pool Cell 11 are used to periodically clean the water in each pool cell by circulating it over ion exchange resin. The radiation monitors associated with the ion-exchange columns in Pool Cell 11 are intended to minimize the radioactive contamination retained on the resin in the event of a leaking or failed capsule in a pool cell. Pool Cell 11 is maintained without water, and the current design does not allow changeout of the resin remotely. Therefore, an interlock between the radiation monitor and the column inlet valve is provided to automatically stop the flow on the outlet side of the columns if elevated radiation levels are detected.

The hazards evaluation also identified a direct radiation hazard associated with the hot cells. This hazard is mitigated by walls, cover blocks, and lead-glass windows. The north and south walls of the hot cells, facing the Operating Gallery and the Service Gallery, respectively, are made of $89-\mathrm{cm}-(35$-in.-) thick, high-density concrete. The east and west walls of A and G Cells are also constructed of $89-\mathrm{cm}$ - (35-in.-) thick, high density concrete so that manned entry may be made into A and G Cells. The hot cells each have stepped cover blocks constructed of 76-cm- (30-in.-) high-density concrete to provide shielding for the canyon (above the hot cells). The hot cell windows, designed to allow operators to view into the hot cells, are constructed of lead glass and provide the equivalent of $89-\mathrm{cm}(35-\mathrm{in}$.) of high-density concrete. The windows have a protective cerium coverglass on the hot cell side and a protective plateglass on the Operating Gallery side.

The hazards evaluation also found a direct radiation hazard which could be associated with the K-3 Filter Pit. Currently, little radioactive material is present in the K-3 filter housings, and it is not anticipated that the filters will ever become significantly contaminated in the future. If the filters did beconle significantly contaminated. they could be taken out of serviee and replaced. however. lilter changeout is currently not allowed under this BIO. Filter radiation monitors would detect the presence of elevated dose rates, or if it were suspected that significant amounts of radioactive material were present on the K-3 filters, as low as reasonably achievable (ALARA) principles and practices would be used to control the direct radiation hazard.

The Truckport was also found to have a direct radiation hazard in the form of low-level solid radioactive wastes stored in plastic bags/wooden boxes or in a loaled WIXM. The features used to control this hazard are limits on the radioactive material inventories allowed for the WIXM; radiation surveys for surface contamination on the bags; a continuous air monitor to detect airborne contamination; and an area radiation monitor to detect elevated dose rates.

The movement of high-activity solid waste from the facility and the receipt and subsequent movement of capsules to the pool cells also present direct radiation hazards. For the high-activity solid waste, the features associated with the hot cells provide the radiation shielding before the waste is removed from A Cell. Once the drum is lifted into the high integrity container (HIC) in the canyon, the $1 \mathrm{IIC}$ provides sumle radiation shielding until the package is placed in the Chem-Nuclear Systems Inc.(Chem-Nuc) cask in the Truckport. The period of greatest dose rates occurs between the time the plug port in the largest of the two A Cell cover blocks is removed (to allow movement of the 208-L [55-gal] drum) and the time when the waste drum is placed in the HIC. During this time, the radiation exiting vertically through the open port is shielded by the roof of the 225-B Building.

For the transport of capsules, the beneficial uses shipping system (BUSS) cask is relied on to provide radiation shielding and additional confinement for the capsule(s) while it is in the Truckport, canyon, and G Cell (until the cover blocks I for G Cell are in place). Once the cask is in G Cell, the cover blocks have been placed into position, and the BUSS cask opened, the radiation shielding features associated with the hot cells (specifically G Cell) are relied on to provide the necessary radiation shielding. Once the capsule has been lowered into Pool Cell 12 from G Cell, the water in Pool Cell 12, and then the other pool cells provide the necessary radiation shielding. 
While in the Truckport, the direct radiation from the casks is controlled by the performance of surveys on the casks and the Truckport radiation monitors. Surface contamination surveys performed on the casks would detect a potential leak of radioactive material and subsequent elevated dose rates from the cask so that facility personnel could take appropriate actions. The radiation monitors would detect airborne contamination and elevated levels of direct radiation.

The radiation hazard identified for TK-100 results from the potential to wash significant quantities of radioactive materials from the K-3 exhaust duct into the tank. TK-100 is located in a concrete-lined, below grade pit approximately $12 \mathrm{~m}$ (40 ft) south of the 225-B Building. The 15,000-L (4,000 gal) capacity tank is used to receive any low-level liquid wastes generated in WESF and transfer them to a tanker truck for disposal. Normal LLLW sent to the tank poses little direct radiation hazard. In the event that significant contamination is introduced to the tank, the tank walls and below grade construction in conjunction with the pit cover blocks, which are $61-\mathrm{cm}-(24-$ in.-) thick structural concrete, are relied on to provide shielding until the waste can be transferred.

For all areas and sources of direct radiation except TK-100 and the $\mathrm{K}-3$ filter, the 225-B Building structure provides a final layer of radiation shielding. Also, many of the radiation hazard barriers discussed above rely on facility-wide support systems. The offsite electric power distribution system has redundant supply lines, switches and motor control centers, and a backup diesel generator. Essential defense-in-depth electrical components include circulation pumps, exhaust and supply fans, radiation monitors, and pool cell instrumentation.

Radioactive Material (includes thermal energy hazards). Radioactive material hazards were identified for the pool cells, hot cells, Truckport, TK-100, and the K-3 exhaust system.

The radioactive material hazards identified for the pool cells consists of ${ }^{137} \mathrm{Cs}$ and ${ }^{90} \mathrm{Sr}$. The stainless steel capsules (both normal and Type W capsules) are the first control relied on to contain the radioactive materials in the pool cells. The capsules are held in place vertically, in one layer, by storage racks on the bottom of the pool cell. The storage racks ensure that the capsules are stored in a controlled configuration. The capsules are maintained in the pool cells so that they are stored underwater at all times, which in addition to providing shielding, keeps the capsules cool. Those features that act to retain, maintain, cool, and add water to the pool cells are identified above in the discussion of the direct radiation hazard and are also applicable to the confinement of the radioactive material.

The radiation monitors associated with the Pool Cell Area would detect the presence of radioactive materials that might have escaped confinement. Pool cell water contaminated by a leaking capsule can be transferred to a WFSF ion cxchange module in the Truckport.

A leaking capsule can be detected using the inner capsule movement test (see Section 3.4.2.6.1) and moved to G Cell according to the capsule transfer procedures. The 225-B Building structure is an additional means of confinement, as shown in the loss of pool cell water accident analysis in Sections 3.4.2.7.1 and 3.4.3.3, which would substantially reduce the amount of radioactive material lost from the facility in such an event. The K-1 filters are the final layers of confinement for the radioactive material stored in the pool cells. The K-1 exhaust and K-4 supply systems would act to keep the capsules cool in a loss of water event and would act to filter the air in the pool cell room in the event of a leaking capsule (and subsequent airborne contamination if the contamination is cesium chloride). The stack radiation monitors provide a means of detecting the presence of contamination that might have escaped all prior barriers and would alert facility personnel to the loss of confinement.

The radioactive material present in the hot cells is in the form of contamination on equipment, solid waste, and interior surfaces. The hot cells in general are maintained at a negative pressure with respect to the canyon and to the Operating Gallery by the K-3 ventilation system. In-cell high-efficiency particulate air (HEPA) filters exist on the ventilation outlets in the hot cells. However, these filters are not regularly maintained or tested and cannot be relied on for providing confinement of the radioactive material in the hot cells. Since the hot cells are ventilated by the K-3 system, the K-3 HEPA filters ensure that any migration of contamination from the hot cells is controlled. The K-3 system differential pressure monitors and alarms act to detect and alarm in the event of an upset in the K-3 system. An interlock exists between the K-3 exhaust and supply fans so that failure of the exhaust fans results in deactivation of the supply fans, so that pressurization of the hot cells does not occur. Another interlock exists between the K-3 system and the K-1 and K-4 systems, so that failure of the K-3 system deactivates the K-1 and K-4 systems, preventing airflow from the hot cells to operating areas. The K-3 system represents two 


\section{HNF-SD-WM-BIO-002 REV 1}

stages of HEPA filtration within each of two filter housings that are in parallel (normally one filter housing is operating and the other is on standby). Additional controls that prevent the release of the radioactive materials from the hot cells are the hot cell sumps and associated liquid detectors and sump pumps. Any contamination that might bypass the in-cell and K-3 HEPA filters would be detected by the stack radiation monitors, which would alert facility personnel to the loss of confinement.

A Cell is used to collect and store solid combustible wastes generated by cleaning other hot cells. The radioactively contaminated waste from the other cells is passed through connecting ports until it gets to the A Cell hood. There it is placed in 208-L (55-gal) drums and moved into A Cell until it can be shipped out of the facility. Thus, in addition to the confinement provided by the K-3 ventilation system, the radioactive material in A Cell is further confined by the 208-L (55-gai) drums.

F Cell and or ( $B$ Cell is used to store suspect and known leaking capsules. Suspect capsules are those which for some reason have questionable integrity. These capsules, which may only be singly encapsulated, are stored in the hot cells to avoid possible contamination of the pool cell water. These capsules are limited to $1.8 \mathrm{~kW}$ in total power (assuming no ventilation) and are stored in a vertical and spaced ( $20 \mathrm{~cm}[7.9 \mathrm{in}$.] apart) array to allow for sufficient heat transfer to the surrounding heat sinks (WHC 1996c). This limits the salt/capsule interface temperature to minimize the potential for accelerated corrosion of the capsule wall. The K-3 ventilation system, in addition to providing the general confinement function identified for all hot cells, also acts to cool the capsules in $\mathrm{F}$ and ( $i$ Cells. Finally, the capsules themselves, although suspect, also act to prevent the dispersal of the radioactive materials.

The radioactive material hazards identified for the Truckport area arise from the low-level solid wastes stored in the Truckport. the WIXM and the movement of the Chem-Nuc waste cask and BUSS cask through the Truckport. The low-level solid waste is confined in plastic bags within the Truckport, while the high-activity solid waste in the Chem-Nuc waste cask is confined by the 208-L (55-gal) drums inside the HIC(s) inside the cask. In the BUSS cask, the capsules provide the primary confinement function with the cask itself providing additional confinement. In the WIXM. a stainless steel vessel encased in reinfored concrete contines the radioactive material. There is also a thermal hazard associated with the WIXM due to radioactive decay. Controlling the amount of radioactive material allowed to accumulate in the WIXM controls the thermal hazard. The additional features used to control these radioactive materials are the $\mathrm{K}-1$ filters, Truckport continuous air monitoring system and ARM, and surveys performed for surface contamination.

TK-100 also stores radioactive material. Potentially contaminated water, normally designated as LLI.W, is stored in TK-100 until it can be transferred to a lemporary holding lanh or tanker touch for disposal. The tank itself is the primary method for controlling the contaminated water. If the tank overflowed or a fitting leaked, the contaminated water would be contained in the concrete pit.

As with the contamination in the hot cells, migration of the radioactive material in the K-3 exhaust duct is controlled by the K-3 HEPA filters and by differential pressure monitors and alarms designed to protect those filters. The stack radiation monitors would detect any radioactive material that might bypass the K-3 filters. In addition, interlocks between the K-3 exhaust and supply fans and between the $\mathrm{K}-3$ system and the $\mathrm{K}-1$ and $\mathrm{K}-4$ systems would prevent inadvertent migration of contamination within the facility.

Combustible/Flammable Materials. Combustible/flammable materials are stored in various locations throughout WESF. The WESF FHA, in addition to the hazards evaluation, indicates that the areas where combustibies/flammables might impact hazardous materials are the hot cells and Truckport. The BIO tire accident analyses are consistent with the analyses performed in the WFSF FHA (Mertz. 1998)

The hot cells contain, or could potentially contain, solid combustibles in the form of manipulator boots, cleaning pads, plastics, etc. These combustibles represent an energy source that could adversely impact any radioactive materials in the hot cells. To control this hazard, there is the following series of defense-in-depth controls and SSCs for the hot cells.

- A Cell has the following controls and SSCs:

- $\quad$ K-3 HEPA filters

- Limit of $200 \mathrm{~kg}(441 \mathrm{lb})$ of solid combustible wastc

- Solid combustible waste in A Cell must be packaged (i.e., 208-L [55-gal] drum or equivalent) 
- B through E Cells have the following controls and SSCs:

- $\quad$ K-3 HEPA filters

- Plug ports and cover blocks must remain in place at all times

- Cell pass-throughs with doors are closed at all times except during an ongoing operation, which requires one to be open

- Limit of $18 \mathrm{~kg}(37 \mathrm{lb}$ ) for solid transient combustibles (this limit already accounts for hot cell window oil)

- F and G Cells have the following controls and SSCs:

- No combustibles (except for the in-use manipulator boot) are allowed in either hot cell when capsules are present and the coverblock is removed, except for capsules in the BUSS cask when the lid to the cask is still in place

The Truckport is used to temporarily store low-level solid waste and is the location where the WIXM. Cheni-Nuc waste cask and the BUSS cask enter and exit the facility. The solid waste is stored in plastic bags and possibly wooden boxes and could represent a significant combustible loading. The BUSS cask, used to receive capsules at the facility, is designed to withstand severe fires, which bound the fires postulated at WESF (SNL 1991) and its payload would not be impacted by a fire 1 in the Truckport. The WESF Chem-Nuc cask, however, does not have the same design documentation as the BUSS cask, and its capability to withstand a fire in the Truckport is unknown. In addition to the solid waste in the Truckport, during Truckport activities a truck (diesel-powered) and diesel-powered forklift might be present. These sources of fuel increase the combustible material loading of the area.

The features relied on in the Truckport to control fires are personnel actions and practices, the fire detection and suppression systems, the response of the Hanford Fire Department, and to a limited extent, the K-1 ventilation system. Facility personnel minimize the loose combustibles in the Truckport through good housekeeping, so as to minimize the potential for a Truckport fire. In addition, operating procedures and vehicle maintenance, which reduces the likelihood of a fuel leak, reduce the possibility of a Truckport fire during Truckport activities. The Truckport fire suppression system is designed to automatically detect and activate in the event of a fire. Activation of the system would alert facility personnel and the Hanford | Fire Department (HFD). The WESF FHA (Mert 1998 ) shows that the fire suppression system in the Truckport is adequate to keep exposed surfaces, such as structural components and a cask, cool but would not extinguish a fuel fire.

Explosive Materials. The hazards evaluation identified the potential for the generation and accumulation of hydrogen gas (through radiolytic decomposition of water) in several locations in the facility. The Pool Cell Area, because of the capsules stored underwater, is the only location where significant quantities of hydrogen are generated during normal operations. The hot cells, K-3 filters, TK-100. and WIXM might also be locations where hydrogen is generated and accumulated, but not normally in quantities of any significance.

Hydrogen generation and accumulation in the Pool Cell Area have been analyzed in Liljegren and Terrones (1996) and are considered in the hazards evaluation and accident analysis. Hydrogen is generated in the pool cell water by the radiation from the capsules and moves from the water into the atmosphere of the Pool Cell Area. If the hydrogen were allowed to accumulate in the Pool Cell Area in flammable concentrations, a subsequent explosion could cause the failure of the Pool Cell Area structure. Such a structural failure represents a significant hazard to the integrity of the capsules and the pool cell liners. Features normally relied upon to control accumulation of hydrogen in the Pool Cell Area are the K-1 and K-4 ventilation systems or opening the north door if the ventilation system is inoperable.

The potential for hydrogen generation and accumulation in a hot cell was identified in the hazards evaluation in Hey (1999). Water is not normally used in the hot cells and has been isolated to all celts but $F$ and (i Celts.: The first control over this hazard is attained by an IOSR against water remaining or accumulating in the hot cells without ventilation. Periodic I surveillances of the hot cells support this control. $\Gamma$ and G Cells have pumps to remove water from the hot cells.

The high-activity solid waste drums typically stored in A Cell were evaluated in Hey (1999) for potential buildup of hydrogen. Packaging requirements for solid wastes preclude the addition of free liquids to a drum, reducing the possibility of 


\section{HNF-SD-WM-BIO-002 REV 1}

generation of significant quantities of hydrogen. and water has been isolated to A Cell.

Generation and accumulation of hydrogen in the K-3 filter housings could occur following a flood of the filter housings. However, this is only a significant hazard if the source of the flood is a hot cell with subsequent flooding of the K-3 exhaust duct and then the filter housing (see Section 3.4.2.4.3). There are numerous controls and SSCs that prevent hydrogen accumulation in a K-3 filter housing. Since the hazard is only realized in the event of a hot cell flood severe enough to block ventilation flow, a periodic surveillance of the hot cells would detect the event and allow facility personnel ample opportunity

to respond (only $f$ and $G \mathrm{C}$ ells have potential water sources). If a hot cell were to become flooded and subsequently release water to the K-3 exhaust duct, a $5-\mathrm{cm}(2-\mathrm{in}$.) drain line with a $2.5-\mathrm{cm}(1-\mathrm{in}$.) dam would divert water to TK-100 before it entered the K-3 filter housing. If the drain were somehow blocked or bypassed and water entered the K-3 filter housing, the liquid detection, alarm, and removal systems would be available to detect the event and remove the water. If the facility did not want to remove the water, airflow through the filter housing, through normal ventilation or the liquid detection system (air bubbler), would ensure that any hydrogen generated could not accumulate.

TK-100 is used to receive low kevel liquid waste from WTSS. Hydrogen generation and accumulation in TK-100 could occur if significant contamination were introduced into the tank and the K-3 ventilation (i.e., the TK-100 bubbler) were lost. . As described above in the discussion of direct radiation hazards, TK-100 has the potential to receive the contamination present in the K-3 exhaust duct. This contamination could result in the generation of hydrogen in the tank, with subsequent ignition of the hydrogen and tank failure. The control of the contamination allowed in the tank, through control of water sources and knowledge of waste streams, is the first control for this event. Additional controls are the small but significant amount of ventilation provided by the TK- 100 bubbler used for level indication and timely transfer of the tank contents so that hydrogen does not have time to accumulate.

Ilydrogen is also gererated inside a loaded WIXM due to radiolytic decomposition of water. A filtered vent is installed on the WIX.V to prevent overpressurization. however. his vent is not large enough fo prevent the hy drogen concentration from exceding the lower flammability limit of $4^{\prime \prime}$. To minimize the potential conseguences due to a hydrogen explosion in a WIXM, ignition sources are isolated and the liee volume in the WIXM is tilled with iner resin.

The hazards identification also found the possibility of accumulation of flammable gases (non-hydrogen) within the facility. Two general sources of flammable gases are highly volatile liquid fuels, such as gasoline, and gases contained in cylinders or tanks. The highly volatile liquid fuel is most likely to enter the facility in the form of a vehicle in the Truckport. The gas tanks or cylinders could be brought into any area of the facility for facility maintenance or modification.

The WESF FHA (MteItz 1998) found that the pressure increase associated with a propane explosion in the Truckport was sufficient to cause catastrophic structural failure. While the FHA calculation did not account for possible venting of combustion gases out of the Truckport doors, other areas do not have large vent pathways. The implications of the analysis are that a large flammable gas explosion in the facility could cause catastrophic structural failure, possibly impacting capsule storage and Hot Cell structural integrity. Section 3.4.2.5.2 contains an analysis for a possible flammable gats explosion. as well as the basis lor the controls applied to flammable gas sources.

The primary barrier to a possible flammable gas explosion is the prohibition against bringing any such gases, or highly volatile fuels, into the facility. This prohibition includes gasoline, propane, and other flammable gases, such as acetylene. These materials are entirely banned from the facility in all quantities, and no activities involving these materials are allowed in the facility. To support the prohibition of materials into the facility, WESF personnel are trained in IOSR compliance and cognizant of the control. If a project or activity postulated use of such a material, WESF personnel would immediately be aware of the conflict and would take actions to ensure that the material is not brought into the facility.

If the control against bringing flammable gases into the facility were to fail and flammable gases in tanks or cylinders were inadvertently brought into the facility, a secondary barrier is the standard industrial controls associated with flammable gases and flammable gas cylinders. Such controls include equipment inspections, leak tests, fire watches, and surveillances, as well as operator training requirements. In some cases, mechanical ventilation in addition to the normal area ventilation, must be used to prevent worker exposure to fumes. This mechanical ventilation would also tend to disperse any flammable gas fumes which might leak. 


\section{HNF-SD-WM-BIO-002 REV 1}

Kinetic energy. The hazards evaluation identified several kinetic energy hazards that are non-routine in nature. These hazards arise from the pool cell, hot cell, Truckport, and Pool Cell Area cover blocks; the pool cell and canyon cranes; the pool cell catwalk; the shipping casks used to transport waste drums and capsules; and manipulators. These objects represent a potential hazard to the confinement and containment of radioactive materials and direct radiation.

The pool cell cover blocks are designed to rest on top of the pool cells, side-by-side, with three cover blocks over each pool cell. The cover blocks are stepped so they will not fall into the pool cell and so that they interlock with each other. The width and the length of the cover blocks is greater than the width of the pool cells, so that the only way for a cover block to fall into a pool cell is on edge.

The pool cell cover blocks are lifted and moved within the Pool Cell Area by the pool cell crane. The crane and related SSCs undergo regular maintenance and inspection activities to ensure that it is in proper working order. The crane and cover blocks are both designed for a cover block lift and movement. A cover block lift is performed in accordance with DOE-RL (1995a), Hanford Site Hoisting and Rigging Manual. In addition, there is an administrative control that prevents moving a cover block over an active pool cell except in the case of an emergency.

The hot cell, Truckport, and canyon cover blocks, except for the lifting bails, serve as an integral part of the canyon floor. There are two cover blocks on A, B, C, and F Cells, five on D and E Cells combined, four on G Cell, two on the Truckport, and one that allows access to the Pool Cell Area from the canyon. In general, the lifting and movement of a cover block in the canyon is very rare. The Truckport, A and G Cell cover blocks are the most frequently removed because of the necessity to bring the BUSS cask into G Cell through the Truckport and canyon and to remove packaged waste from A Cell.

The cover blocks are lifted and moved within the canyon by the canyon crane. Both the crane and the cover blocks are designed for cover block lifts. The canyon crane and associated SSCs undergo regular maintenance to ensure that they are in proper working condition. A cover block lift in the canyon, like a pool cell cover block lift, is performed in accordance with DOE-RL (1995a).

The shipping casks used in WESF operations are the WESF Chem-Nuc cask and the BUSS cask (SNL 1991). Both casks represent kinetic energy hazards of the same magnitude as the cover blocks discussed above. Both the canyon crane and shipping casks are designed for cask lifts. The BUSS cask has been evaluated and found to be sturdy enough to survive the impact of a dropped Truckport cover block (McCormick 1993).

\subsection{Worker Safety.}

This section is intended to provide a general overview of the SSCs and administrative controls germane to worker safety, identify controls to ensure worker safety, and demonstrate that worker safety is an integral part of the overall facility safety. Where this discussion overlaps the discussion provided in Section 3.3.2.3.2, Defense-In-Depth, a summary of the hazard and related facility feature(s) is provided, followed by a reference to Section 3.3.2.3.2.

Additional programmatic and institutional controls applicable to the facility are discussed in Chapter 6 , Safety Related Programs and Controls.

To be consistent with the discussion in Section 3.3.2.3.2, the following discussion of worker safety is organized by type of hazard and then by specific hazards within the facility. The types of hazard addressed are direct radiation, radioactive materials, combustible/flammable materials, explosive materials, kinetic energy, and electrical hazards.

Radiation. Direct radiation hazards were identified in the Pool Cell Area, hot cells, K-3 Filter Pit, Truckport, TK-100, and areas where loaded casks may be located.

The most significant hazard present at WESF for the facility workers is the doubly encapsulated and stored underwater ${ }^{137} \mathrm{Cs}$ and ${ }^{90} \mathrm{Sr}$ capsules in the pool cells. The beta radiation is shielded by the capsules themselves, while the gamma radiation is shielded by water in the pool cells. In addition to shielding, the water also controls the temperature of the capsules. The support features relied on to retain the water in the pool cells consists of several SSCs and administrative controls. These features and controls are as follows: 
- Pool cell liners and safety class drain piping and circulation piping

- Under-liner sump and leak detection

- Pool cell structures

- Minimum water depth over capsules

- Water level monitors and alarms

- Water makeup systems

- Water temperature monitors and alarms

- Water cooling systems

- Minimum levels of water quality

- Radiation monitoring in the Pool Cell Area, in the circulation system, and on the ion exchange columns

- Cell-to-cell water transfer capability

- Maximum height that the capsules can be lifted from the bottom of the pool cell

- Inner capsule movement test.

These features are intended to provide control of every aspect of the direct radiation hazard posed by the capsules. These features are also identified as relevant to defense-in-depth and discussed more fully in Section 3.3.2.3.2.

The contamination in the hot cells also represents a radiation hazard for the facility worker. For the hot cells, radiation shielding is provided by the hot cell structures, including the windows and cover blocks. These features are discussed in Section 3.3.2.3.2.

As the K-3 HEPA filters collect contamination that has migrated from the hot cells and K-3 exhaust duct, the direct radiation hazard associated with the K-3 filters increases. The features used to control the radiation are an administrative limit on the allowable radioactive material inventory associated with the filters, the below grade design of the K-3 filter pit, and the K-3 filter pit cover blocks. The inventory limit is based on the need to limit accident consequences, but also has the effect of limiting worker doses when the filters must be changed out. The K-3 filter pit design provides radiation shielding because it is below grade. The K-3 filter pit cover blocks are in place to provide shielding as well as to provide protection from weather. Section 3.3.2.3.2 provides additional discussion of the features used to control the radiation hazard associated with the K-3 HEPA filters.

The direct radiation hazard associated with the Truckport is from the collection of low-level solid waste in plastic bags and the WIXM. An administrative limit on the WIXM radioactive material inventories and the requirement for radiation monitoring ensures that facility workers are protected from uncontrolled radiation exposure. Section 3.4.2.6.3 provides additional discussion.

The movement of high-activity solid waste from the facility and the receipt and subsequent movement of capsules to the pool cells, also present direct radiation hazards to facility workers. For the high-activity solid waste typically removed from A Cell, the HICs and Chem-Nuc cask is used to provide shielding. For the short duration that A Cell is open (the plug port), the canyon structure provides shielding for the radiation exiting A Cell vertically. 


\section{HNF-SD-WM-BIO-002 REV 1}

For the movement of capsules outside of F and G Cells and the pool cells, the BUSS cask is used to provide shielding. A more detailed discussion of these features is provided in Section 3.3.2.3.2.

The radiation hazard potentially arising from TK-100 is the result of flushing the contamination from the K-3 exhaust duct into the tank. This potential hazard is controlled by the walls and below grade construction of the tank in conjunction with the pit cover blocks. Knowledge of the tank contents, through tank instrumentation and control of water sources, and timely transfer of the contents also help control this hazard. This hazard and the facility features used to control it are discussed in more detail in Section 3.3.2.3.2.

The 225-B Building offers the final measure of shielding for all of the identified direct radiation sources, except those located outside of the building, such as the K-3 HEPA filter area and TK- 100 .

Radioactive Material. Radioactive material hazards were identified for the pool cells, hot cells, Truckport, TK-100, and the K-3 exhaust system.

Each of the Cs and Sr capsules in the pool cells (excluding the Type W overpacks) consist of two stainless steel capsules, one inside the other. To enable the capsules to confine the radioactive material, the capsules are held in storage racks and the pool cell water and associated support systems and controls cool the capsules. In addition, the 225-B Building structure and the K-1 filters provide layers of confinement. A more detailed discussion on the mechanism by which these features provide control of the radioactive material in the pool cells is provided in Section 3.3.2.3.2.

The radioactive material in the hot cells is controlled by negative pressures created by the $\mathrm{K}-3$ ventilation system, incell HEPA filtration of hot cell ventilation exhaust, manipulator boots, and the K-3 HEPA filters. In A Cell the radioactive material is further confined by the $208-\mathrm{L}$ (55-gal) waste drums in which the waste is placed. For F Cell, which is used to store capsules, further control of the radioactive materials is provided by an administrative limit on the number and configuration of capsules, the action of the K-3 system to provide cooling for the capsules, and the capsules themselves. A more detailed discussion of the radioactive material confinement functions provided by the hot cells is provided in Section 3.3.2.3.2.

Migration of the radioactive material out of the K-3 exhaust duct is controlled by the K-3 HEPA filters. This source of contamination has less significance for the facility worker because there is little potential for the material to migrate back into the facility areas.

TK-100 pit is located away from the 225-B Building structure, is below grade, and does not require routine maintenance. Under normal conditions, the levels of radioactive materials present in the tank are extremely low, and manned access to the tank has been allowed. Given that personnel access to TK-100 is non-routine, the accepted radiation work controls and surveys are sufficient to control the radioactive material hazards to facility workers.

Combustible/Flammable Materials. Combustible/flammable materials are stored in various locations throughout WESF. The WESF FHA (Mertz 1998) provides the analysis of the fire hazards at WESF. In addition, the potential for fire to impact the hazardous materials in WESF has been addressed in the hazards evaluation in Hey (1997), the defense-in-depth discussions in Section 3.3.2.3.2, and the accident analysis in Section 3.4.2. Normal institutional controls pertaining to fire protection at WESF are sufficient to control this hazard from the standpoint of worker safety (see Chapter 6.0).

Explosive Materials. The hazards evaluation identified the potential for the generation and accumulation of hydrogen gas (through radiolytic decomposition of water) in several locations in the facility. The Pool Cell Area, because of the capsules stored under water, is the only location where significant quantities of hydrogen is generated during normal operations. Other areas, the hot cells, K-3 HEPA filter housings, TK-100, and WIXM have the potential to generate hydrogen in the event of a flood. A hydrogen explosion in any of these areas could lead to adverse impacts to facility workers because of the energy of the explosion, the exposure of elevated dose rates, or the inhalation of airborne radioactive particles.

The controls relied on to prevent and mitigate hydrogen explosions are addressed in the accident analysis for each area of the facility where this is a hazard. Section 3.4.2.5 addresses the Pool Cell Area; Section 3.4.2.4.3 addresses the K-3 
filter housings; Section 3.4.2.4.4 addresses TK-100; and Section 3.4.2.4.5 addresses the hot cells; and Section 3.4.2.5.3 addresses the WIXM.

The possibility of a flammable gas (non-hydrogen) explosion was also discovered in the hazards identification. Highly volatile liquid fuels, or tanks and cylinders of flammable gases, could be associated with facility operations. Gasolineand propane-powered vehicles, acetylene cylinders, and other sources of flammable gases might be associated with facility operations. The controls relied upon to prevent a flammable gas explosion are discussed in the accident analysis in Section 3.4.2.5.2.

Kinetic Energy. Kinetic energy has been identified in the hazards evaluation as a significant hazard because of its potential to disperse radioactive materials. From the standpoint of the worker safety, the kinetic energy hazards are bounded by those found in industry.

\subsection{Environmental Protection.}

This section summarizes the facility features that reduce the potential for large releases of hazardous (radioactive) materials to the environment. The discussion in this section relies on much of the discussion provided in Section 3.3.2.3.2. However, this section focuses only on the control of radioactive material with regard to the pathways for uncontrolled releases to the environment. In all cases, the features relied on to contain and control the radioactive materials are specified in Section 3.3.2.3.2 and are not repeated in this section.

The hazards evaluation in Iley (1999) identifies several pathways for a release of radioactive materials to the environment. The pool cells, K-3 exhaust duct and filters, hot cells, and TK-100 were all identified as potentially contributing to a release to the environment.

By far the most significant source of radioactive material that could potentially be released to the environment is located in the pool cells. The pathways by which the radioactive material could enter the environment are airborne and water transport. The airborne pathway could be significant following a loss of pool cell water and subsequent capsule failure as a result of elevated temperatures. Groundwater contamination could result if radioactive material were released from one or more capsules and the water were to leak during transfer out of the facility or leak from the pool cell. A cover block drop might also provide a means for the contents of damaged capsules to leak through openings in the liner. Controls to prevent a cover block drop are based on the event evaluated in Section 3.4.2.6.2. A leak from a pool cell is prevented by those features discussed in Section 3.4.2.7.

The radioactive materials present in the hot cells represent an airborne release hazard and, to a lesser degree, a hazard to the groundwater. Several mechanisms were identified in the hazards evaluation that could result in airborne dispersion of the material in the hot cells. The K-3 ventilation system would provide the motive force for the dispersion of any material in the hot cells that might become airborne. The material in the hot cells might reach the groundwater by a hot cell flood and subsequent washing of material into TK- 100 or the K-3 HEPA filters. Failure of the confinement features in these areas could then lead to a release of the contaminated water to the groundwater.

The radioactive materials present in the K-3 exhaust duct and filter housings could be released through the same pathways as the material in the hot cells. The only exception would be the radioactive material on the filters themselves, which would not be subject to release to the groundwater. The K-3 HEPA filters are separated in the K-3 HEPA filter housing from the washdown system and the sump in such a way that no water flood of the filter media is possible. A release to the groundwater is possible if a leak developed in the filter housing sump or fittings and contaminated water leaked into the $\mathrm{K}-3$ Filter Pit. In that event the K-3 Filter Pit would also act as a barrier to the release of the radioactive material.

A leak of the tank contents into the pit would be similar to a leak of contaminated water into the K-3 Filter Pit. However, the leak from TK-100 would have larger consequences and be more likely than a leak from a K-3 HEPA filter housing because of the larger capacity of the tank and its more frequent use for storage of contaminated water. The airborne release from TK-100 could take the form of a spray leak from the tank into the pit which has been analyzed in Section 3.4.2.4.4. 


\section{HNF-SD-WM-BIO-002 REV 1}

\subsection{Accident Selection.}

This section describes the method and results of the accident selection process. Although not described in detail below, the accident selection process for the separate WIXM safety analysis was identical to the one described in this section. The hazard evaluation table is contained in Hey (1999).

\subsection{Selection Methodology.}

A subset of accidents from the hazards evaluation in Section 3.3.2.3 and Hey (1999) was selected for detailed analysis. Information in Hey (1999), Table A-2, formed the basis for the selection process. It should be noted that Tables 3-6, 3.7, and 3-8 are provided to summarize the results of the hazard evaluation but were not used in the accident selection process. I Table A-3, Iley (1999) was used for the formal accident selection process.

To carry out the selection process, accidents from the hazards evaluation were grouped according to the physical phenomena involved in the accident. These groupings are shown in the second and third columns of Table A-3 in Hcy (1999) labeled "category" and "type," respectively. For accidents in the "internally initiated operational events" category of Table A-3, the initial accident selection was made within each type (e.g., facility fire) by choosing the accident(s) with the highest risk rank. For accidents in the "natural phenomena" and "externally initiated manmade events" categories, all accidents within each category were treated as a single group for accident selection (i.e., accident types were not separated, and the highest risk rank accident(s) was selected from among all the accidents in that category). Most accidents were not selected because they did not represent the highest risk rank for that type and were not otherwise unique accidents. If the highest qualitative risk rank was found for two or more accidents in the same type, a judgment was made concerning which accident represents the higher risk within the qualitative risk rank. If, however, the accident selected is estimated to have lesser consequences than some other accident challenging the same barrier (but with the same or lower risk rank), the higher consequence accident is analyzed in addition to the original selection. This ensures that an accident with a potentially higher consequence but lower risk (among all accidents challenging a certain safety system or control) is not overlooked. As in the risk ranking performed in the hazards evaluation, only accidents with S2 or S3 consequences were considered. Furthermore, accidents with frequencies estimated by the hazard evaluation to be in the "F0" category (beyond extremely unlikely) were dropped from consideration in the accident selection.

In some cases, it was found that a series of similar accidents (see "K-3 HEPA filter flood" or "loss of pool cell water" in the accident selection summary in Section 3.3.2.3.5.2) with the highest risk rank resulted in similar consequences. Since safety class and IOSR determination depends only on the consequences of the accident, all members of this set of similar accidents were included in the same accident analysis. This ensures that all relevant safety SSCs are accounted for in the accident analysis. For example, several kinds of Truckport fires were evaluated in Hcy (1999) and all were grouped as a single "Truckport fire" accident and bounded by the accident analysis. This helps to ensure that the controls necessary to prevent or mitigate the accident encompass all of the similar sequences identified.

Exceptions to the accident selection scheme described above were made in two cases: in order to include accidents that have a unique impact on facility SSCs or administrative controls, and where lesser risk-ranked events may not be bounded by other events and have the potential to result in significant dose consequences.

In summary, the accidents were selected within each category and type according to the following criteria:

- Highest risk rank

- Unique accident with potential for significant consequences, regardless of risk rank

- Unique accident that challenges a particular barrier and has the potential for significant consequences

- Unique accident that is not bounded by another accident and has the potential for significant consequences.

\subsection{Summary of Selected Accidents.}

As discussed previously, accidents were categorized into several types depending on the physical phenomena, barriers, and consequences involved. From each accident type a subset of accidents was selected for a more detailed 
evaluation. A summary of the accident(s) chosen for each type is provided in Table 3-11.

Table 3-11. Summary of Accident Selection Results.

\begin{tabular}{|c|c|}
\hline Accident type/section & Accidents selected \\
\hline 1) Natural Phenomena/3.4.2.1 & $0.25 \mathrm{~g} \mathrm{DBE}$ \\
\hline \multirow[t]{4}{*}{ 2) Externally Events/3.4.2.2 } & Loss of electric power \\
\hline & Accidents at adjacent facilities \\
\hline & Aircraft impact \\
\hline & Truck impact \\
\hline \multirow[t]{2}{*}{ 3) Fire/3.4.2.3 } & Hot cell fire \\
\hline & Truckport fire \\
\hline \multirow[t]{5}{*}{ 4) Loss of Confinement/3.4.2.4 } & High flow in K-3 ventilation system \\
\hline & Loss of $\mathrm{K}-3$ ventilation flow \\
\hline & K-3 system water accumulation \\
\hline & High activity in TK- 100 \\
\hline & Hydrogen accumulation in hot cells \\
\hline \multirow[t]{2}{*}{ 5) Facility Explosions/3.4.2.5 } & Flammable gas explosion \\
\hline & Hydrogen explosion in pool cell area \\
\hline \multirow[t]{3}{*}{ 6) Loss of Containment/3.4.2.6 } & Underwater capsule failure due to corrosion \\
\hline & Underwater capsule failures due to drop impacts \\
\hline & Rupture of WIXM \\
\hline \multirow[t]{2}{*}{ 7) Loss of Pool Cell Water/3.4.2.7. 3.4.3.3 } & Loss of water from a single pool cell \\
\hline & Loss of water from all pool cells \\
\hline
\end{tabular}

The categorization and interrelationship of the accident sequences chosen for detailed analysis is depicted in Figure-3-1. The top row of rectangular boxes identilies the categories into which the accidents were grouped (accident types). Directly connected to the accident types are events in rectangular boxes, which illustrate the accidents chosen for analysis. Each accident is further defined by one or more ovals or hexagons. An oval represents a condition analyzed in the accident while a hexagon references an analysis elsewhere. The beyond design basis accidents (BDBAs) are the only exception to this format.

The accident types are somewhat interdependent since the individual accidents may be causally connected. The various sequences of accident events found in the hazard evaluation are not uniquely resolvable using the typical categories of phenomena recommended by DOE (1994). For example an extended loss of ventilation flow in the K-3 system is classified as a loss of confinement event. If, however, the cause of the ventilation failure is due to the presence of water in the K-3 filter box, then hydrogen may accumulate in the filter box and cause an explosion. Such an event might be labeled as "loss of confinement" or "hydrogen explosion" (included as loss of confinement in this analysis). 
A detailed narrative description of each accident type follows:

Natural Phenomena. Accidents of this type are seismic events, high winds, wind-driven missiles, tornadoes, floods, snowfall, and ash fall up to, but not exceeding, design basis loads. Beyond design basis events are considered in Section 3.4.3. The effect of lightning is considered in the loss of electric power event discussed in Section 3.4.2.2.

High winds of $145 \mathrm{~km} / \mathrm{h}(90 \mathrm{mi} / \mathrm{h})$ were considered in the original design basis of WESF. The most recent study performed on the ability of WESF to withstand natural phenomena forces (Wagenblast, et al. 1999) indicates that the facility structure will easily withstand a high-wind event. Since the primary structure, the 225-B Building, will survive the effects of a high-wind event, no release of contamination is postulated. High winds could result in a loss of electrical power should the backup diesel generator fail to function. A loss of electrical power is evaluated in Section 3.4.2.2.

The possibility of a wind-driven missile impacting WESF is not expected to result in significant consequences. The facility structure encloses all of the contamination present in the facility, except for the K-3 HEPA filter and TK-100 pits. The facility and the cover blocks over both pits are capable of withstanding the design-basis missile impact defined in SDC 4.1, Rev. 11 (DOE-RL 1989). The WESF facility has no external tanks, waste storage pads, or other aboveground locations where contamination might be present. Therefore, wind-driven missiles are not a significant hazard for WESF. A wind-driven missile could result in a loss of electric power, which is evaluated in Section 3.4.2.2.

Tornadoes represent a very low likelihood hazard to facilities at the Hanford Site and are exempt from the design basis of non-reactor nuclear facilities. As such, a tornado impacting WESF is a beyond design basis event and is bounded by the BDBE analyzed in Section 3.4.3.

The flood event was evaluated in the B Plant accident analysis (WHC 1996a) and was found to have negligible risk of impacting facilities in the 200 Areas.

Dead and live loads were considered in the original design basis of WESF. The primary facility structure, the 225-B Building, will survive the design basis combined snow and ashfall loading (Wagenblast, et al. 1999). Since the facility will survive these events, no release of contamination from WESF is postulated. B Plant load capacity is not known. Thus, this event is assumed in WHC (1996a) to result in a collapse the B Plant canyon roof. Its impact on WESF is discussed in Section 3.4.2.2.

A $0.25 \mathrm{~g}$ earthquake is evaluated in Section 3.4.2.1. This event involves analyzing the facility-wide response to the design basis earthquake (DBE). All areas of the facility are evaluated for SSC failures, inventory response, and the resulting movement of contamination. In Hey (1999), Table A-3, this event was noted as a potential cause of multiple system failures including pool cell crane or catwalk drop in a pool cell, pool cell cover block drop, loss of pool cell water due to structural failure of the pool cell liner and walls, and failure of pool cell drain or circulation piping. Upon further examination (Wagenblast, et al. 1999), structural failures from the $0.25 \mathrm{~g}$ earthquake were found to be prevented by design, except in the case of the K-3 filter housing-to-duct connections. B Plant interactions with WESF during and following a seismic event are also considered. The consequences of structural failure for loads exceeding the 0.25g DBE are evaluated in Section 3.4.3.

External Events. Accidents of this type are manmade and external to WESF. Specific events include accidents at nearby facilities, loss of electric power (LOEP), aircraft crash, and ground vehicle accidents. Each of these events was evaluated for their adverse impact on WESF.

The identification of accidents at nearby facilities and their potential impacts to WESF was aided by a review of the safety analysis documentation for the B Plant (WHC 1996a). Several events of interest are discussed in Section 3.4.2.2. Although some of these B Plant accidents were initiated by natural phenomena, the accident type is considered to be external with respect to WESF.

Commercial airline flights and general aviation were evaluated in Muhlestein (1994). This type of aircraft crash into WESF is considered to be incredible based on this information. However, there is no means to justify the frequency of intentional overflights for other purposes. Therefore, an aircraft crash into WESF is addressed in Section 3.4.2.2. 


\section{HNF-SD-WM-BIO-002 REV 1}

This page intentionally left blank. 


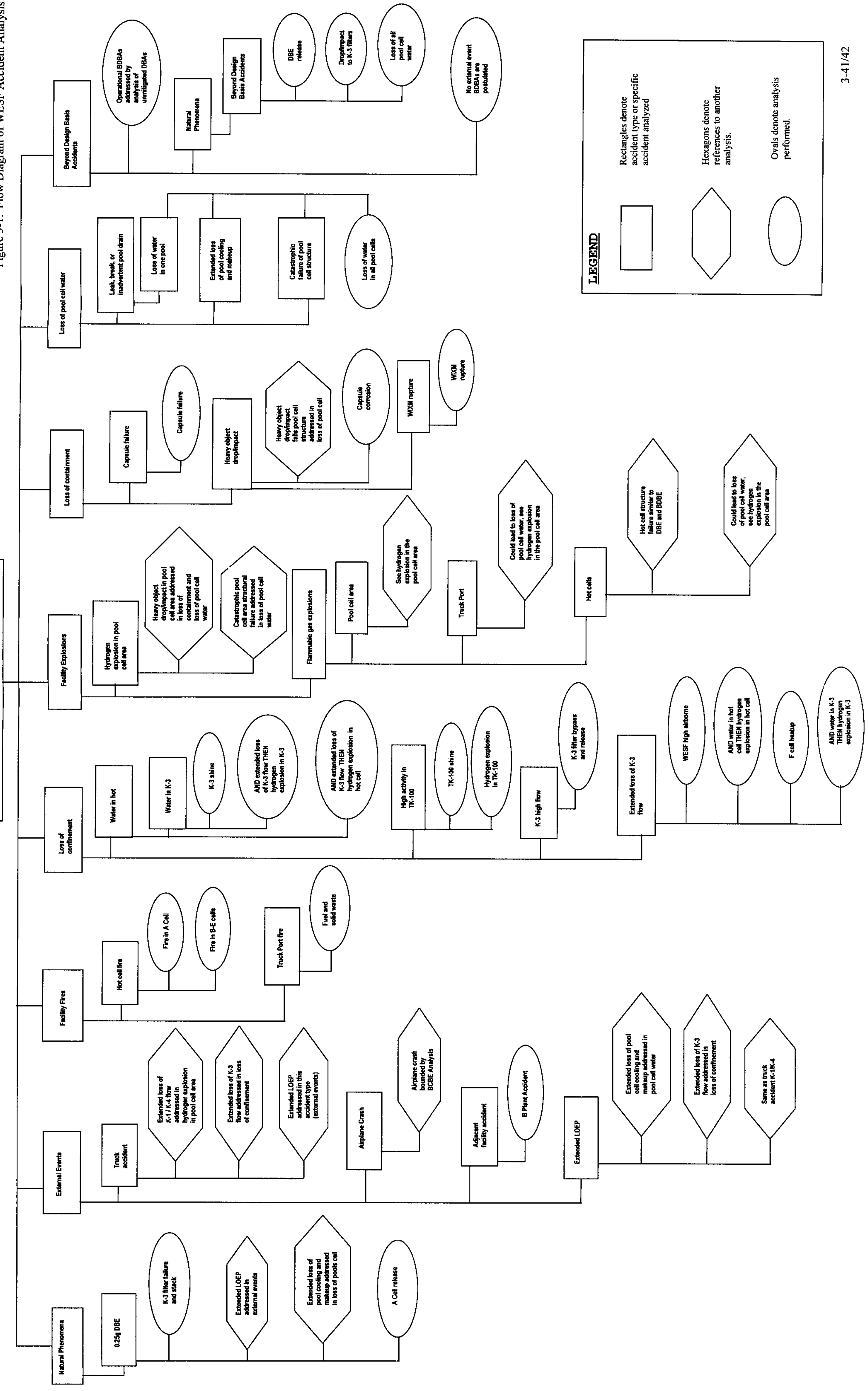


A truck impacting the Truckport could result in minor contamination spread of solid waste stored inside the Truckport. This accident is considered bounded by the evaluation of a fire in the Truckport. In the Pool Cell Area, the 20-25 $\mathrm{cm}(8-12 \mathrm{in}$.) solid concrete walls make significant damage to this area unlikely. Furthermore, no radioactive contamination is readily dispersable. The K-3 fans are located aboveground and could be impacted by a ground vehicle, rendering the K-3 fans inoperable. Loss of the K-3 fans is evaluated in Section 3.4.2.4. A loss of power, which could also be caused by a ground vehicle accident, is evaluated in Section 3.4.2.2.

A backup diesel generator is located at WESF in the event of an LOEP to the facility. An LOEP could be the result of an external or natural phenomena event. Failure of the diesel generator to perform its function would impact several systems throughout the plant. As with the seismic event, the LOEP is modeled in terms of a facility-wide response to the event. Some of the system failures are identified in Table A-3, Hey (1999), including failure of the K-1 and K-3 ventilation systems. The LOEP scenario does not result in any direct dose consequences. However, it is an initiator to secondary failures that could result in releases. These are discussed in Section 3.4.2.2.

Facility Fires. This accident type includes all possible fires identified in the hazards evaluation in Hey (1999). Hydrogen explosions are evaluated separately, either in Sections 3.4.2.5 or 3.4.2.4. All of the fires identified can be grouped into Truckport fires, hot cell fires, waste drum fire (A Cell), and K-3 HEPA filter fires.

A Truckport fire addresses the possibility of a fire impacting solid waste and/or a shipping cask/loaded WIXM in the Truckport area. This includes consideration of gasoline, diesel, and propane fuel, solid waste accumulation, solid waste drum(s), and the possibility of impacting capsules contained in a cask. These hazards are evaluated in Section 3.4.2.3. The possibility of an explosion resulting from propane or gasoline fumes is considered under Facility Explosions, Section 3.4.2.5.

A fire in a hot cell is addressed in Section 3.4.2.3. This analysis considers the potential for a fire in all hot cells, including a waste drum fire.

A K-3 HEPA filter fire was originally identified in the WESF HAZOP (Siemer 1995) as a possibility. On further examination (Mert $\angle 1998$ ), the mechanism originally thought to cause this event (i.e., hot cell fire) was found to generate insufficient heat to cause the K-3 HEPA filter to burn. However, other impacts, such as plugging of the K-3 HEPA filters, are considered.

Loss of Confinement. Loss of confinement accidents refer mostly to K-3 ventilation system upsets. These include: loss of differential pressure control, extended loss of flow, higher than normal flow, high temperature, water in the system, and high radiation levels in the filter housing. Also included as a loss of confinement is high activity in TK-100. Many of these anomalies could be related, as discussed below.

Loss of differential pressure control might occur due to flow path changes when doors are opened or cover blocks removed. Such an event could allow backflow from the hot cells to inhabited operating areas and eventually to the environment. Consequences would be limited to the facility worker. This accident was not considered for detailed analysis due to its low risk rank in the hazards evaluation.

In addition to the consequences of loss of differential pressure, and depending on the number of capsules stored dry in F Cell, an extended loss of K-3 ventilation flow would result in an increased temperature in the hot cell, potentially challenging capsule integrity. The WESF HAZOP (Siemer 1995) indicated that a leaking capsule in F Cell is expected to pose no significant risk outside the facility. A thermal analysis, supporting the maximum number of capsules that could be safely stored in F Cell over a long period of time, is presented in Section 3.4.2.4.

In order to ensure that the K-3 HEPA filter function is appropriately controlled, an accident scenario involving the resuspension of material currently contained in the K-3 ductwork is evaluated. Such a resuspension could be the result of a high flow condition in the K-3 ventilation system. This event was selected for consequence assessment despite its lesser risk rank due to the unique physical challenge to the K-3 system. Higher than normal flow might be caused by flow balance upsets such as inadvertent removal of a hot cell cover block, or two fans operating simultaneously. This accident is evaluated in Section 3.4.2.4. 
The K-3 HEPA filter could be adversely effected due to high temperature gasses entering the ductwork from failure of the chiller units, a hot cell fire. or a steam leak during sump jening. A hot cell fire was judged to be the most severe of the high-temperature events and is analyzed in Section 3.4.2.3.

Water in the K-3 system presents several potential hazards. The event includes consideration for the following items from Table A-3 in Hey (1999): actuation or leak of the fire suppression system, the deionized water used for decontamination wash in hot cells, actuation of the steam supply system with the steam jet valve open ( $k-3$ stean jet las since been removed), overflow from TK-100 from rain, spill into Truckport drain, K-3 HEPA filter flush, loss of tank level instrumentation, failure to calibrate level instrumentation correctly, and failure of the TK-100 pump. This accident is modeled as the entry of water into the K-3 ducting and either bypassing or overflowing TK-100. These conditions could cause higher than allowable radiation fields above the filter or pit cover blocks; and, if left unmitigated for several months, a buildup of hydrogen gas at either location. These events are evaluated in Section 3.4.2.4. TK-100 leaks were not considered for separate analysis because leaks from the tank will flood the TK-100 pit, and a leak is bounded by the analysis of high activity in TK-100, Section 3.4.2.4.4.

A buildup of hydrogen gas and a potential for hydrogen explosion could exist in a hot cell containing radiation if water were present in combination with an ignition source and an extended loss of hot cell ventilation flow. The permanent draining of water from capsule storage tank TK-F5 in F Cell substantially reduced the potential for accumulation of hydrogen in a hot cell. Underwater storage of capsules in a hot cell are specifically excluded from the scope of this document and are not analyzed.

Facility Explosions. Facility explosions include possible flammable gas buildups in various locations in the facility. Specific analyses include possible propane, gasoline fume, and flammable gas cylinder explosions, as well as a possible | hydrogen explosion in the pool cell area. Potential hydrogen accumulation and explosion in the WIXM. hot cells and in the $\mathrm{K}-3$ filters is addressed in loss of confinement.

Flammable gases (other than hydrogen) may be used or generated in the facility from the use of gasoline-powered trucks, propane-powered forklifts, and compressed gas cylinders. For the use of gasoline-powered trucks, the event analyzed addresses the possibility that a gasoline spill could generate an explosive gasoline-air mixture within the confines of the truckport. The analysis also encompasses the use of compressed, flammable gases within the facility for such purposes as welding.

This accident type also considers a hypothetical hydrogen explosion in the Pool Cell Area occurring after an extended outage (i.e., 10 days or more) of the K-1 and K-4 ventilation systems. Although natural infiltration rates would make this event very unlikely, if not impossible, analysis with the proper basis in facility specific leakage areas and meteorological data has not been performed. This event does not directly cause a release of radioactive material, however, the structural damage potential identifies this event as an initiator for a loss of water in one or more capsule storage pools. The sequence is evaluated in Section 3.4.2.5.

Loss of Containment. In this document, loss of containment refers to a breach of those components certified or commonly considered to be containment barriers. These are the WESF cesium chloride or strontium fluoride capsules, shipping casks, compressed gas bottles, 208-L (55-gal) waste drums, WVIXN, tanks and piping. Due to the special hazards of a loss of pool cell water, which might lead to capsule failures, these events are analyzed separately in Section 3.4.2.7, "Loss of | Pool Cell Water".

A heavy object drop on a capsule or shipping cask in the hot cells (possibly due to a canyon crane failure or cover block drop) was considered in the hazard evaluation but was judged to have low risk rank and was not selected for analysis. Also, the BUSS cask is designed to survive such a drop with no failure of the capsules within. Capsules stored in $F$ Cell are vulnerable, but such an event was not expected to generate large quantities of radioactive aerosols. In addition, the hot cell and canyon structure and the $\mathrm{K}-3$ ventilation system were thought to provide adequate confinement of any radioactive aerosols generated.

Since suspect or failed capsules are stored dry in F Cell, loss of capsule integrity in this location is not considered an 
accident, since it is the intended purpose of the hot cell and ventilation system to serve as a confinement boundary in the absence of a containment. As discussed in Section 3.4.2.4, inventory and storage requirements are specified for F Cell capsules to minimize this challenge. On the other hand, a failed capsule in a storage pool is a distinct possibility and poses special problems for failed capsule identification and isolation. There are two potential mechanisms for underwater capsule failure. These are (1) failure due to internal corrosion, most likely involving a capsule that has already suffered some degradation since manufacture, and (2) mechanical failure due to impact. These are discussed further below.

A capsule failure, possibly due to corrosion, is considered in Section 3.4.2.6. Since there is no basis with which to predict the characteristics of such a failure, a spectrum of leak rates is evaluated. It should be stressed, however, that the failure mechanism in Decatur, Georgia is thought to have been caused by thermal cycling (i.e., thermal ratcheting), which is not the condition at WESF. Capsule leaks would pose no danger outside the facility but is evaluated in order to determine the importance of controls used to mitigate such an event.

A heavy object drop into the pool cell could be the result of a cover block drop due to operator error or mechanical failure of the bridge crane. It could also be the result of catastrophic structural failure of the 225-B Building as discussed in Section 3.4.2.5 or fall of the motorized catwalk into the pool cell. Unlike a capsule failure due to corrosion, mechanical impact could result in the release of large quantities of radioactive salt to the pool in a relatively short time. The heavy object drop could also cause a liner puncture and contaminated water leakage into the pool cell sump system. The direct radiation hazard to the facility worker and the suspension of particulates from the contaminated water are both addressed by this accident in Section 3.4.2.6.

Compressed gas bottles in the Pool Cell Area were also included in the hazard evaluation. The consequences of a rupture of one of these bottles was judged in the hazard evaluation to have low severity, bounded by the mechanical failure of a capsule due to cover block drop, and adequately covered by safety management controls. Note that this only addresses the potential physical impact caused by the cylinder. The possibility of flammable gases being released into the facility is addressed in Facility Explosions, Section 3.4.2.5.

A rupture and leak of TK-100 was also considered in the hazard evaluation. Leaks from TK-100 would end up in the concrete pit and possibly the surrounding soil, potentially causing environmental contamination. Consequences from airborne radioactivity were also estimated by the hazard evaluation to be small, since release pathways from the pit are limited to construction joints and cover block mating joints. The consequences of such an event, however, is bounded by the analysis in Section 3.4.2.4.4.

A rupture of a loaded WIXM was considered in a separate hazard evaluation. A rupture in the WIXM could result in a spread of resin and contaminted waler inside the Truckport or outside the lacility. Consequences of a release of radioactive material from a ruptured WIXM are addressed in the analysis in Section 3.2.4.6.3.

A Cell stores 208-L (55-gal) drums containing contaminated waste. A drum failure could cause a spread of contamination inside the hot cell and might damage the cerium window between A Cell and the Operating Gallery. However, the hazard evaluation judged the consequences to be low severity, and the event is not considered for further analysis.

Loss of Pool Cell Water. This accident type is specifically directed to those sequences that could lead to the total loss of water from one or more active capsule storage pools. Initiators are heavy object drop, inadvertent pool drain, catastrophic failure of the pool cell retention structure, and extended loss of pool cooling and makeup. In addition to the loss of pool cell water accident discussed in Section 3.4.2.7 and 3.4.3.3, other accident types that could lead to one of the above initiators are discussed in Sections 3.4.2.2, 3.4.2.5, and 3.4.3.

Due to the differences in the initiators, the likelihood of occurrence, and the consequences, two loss of pool cell water accidents are considered. These are the loss of water from a single pool and the loss of water from all active pools. In terms of dose consequences, this accident type is the most severe of all the accidents analyzed for WESF.

Beyond Design Basis Accidents. A final category for accident selection is beyond design basis accidents (BDBAs). DOE-STD-3009-94 (DOE 1994) does not require the evaluation of beyond design basis external events since the external event itself (e.g., aircraft impact) is usually beyond the design basis. Beyond design basis natural phenomena are considered to 
be acts of nature having a larger magnitude and lower return frequency than their design basis counterparts. Thus, a wind greater than $245 \mathrm{~km} / \mathrm{h}(90 \mathrm{mi} / \mathrm{h})$, roof loads of greater than $0.96 \mathrm{kPa}\left(20 \mathrm{lb} / \mathrm{ft}^{2}\right)$ dead load plus live load, or seismic spectra more severe than the DBE are considered BDBAs for WESF. Of these events, a beyond design basis earthquake is selected as a bounding representation of the BDBAs. This is discussed in Section 3.4.3. The rapid loss of pool cell water accident caused by failure of the drain circulation line in the pipe tunnel has also been added to the BDBA section of the BIO. See Section 3.4.3.3.

The purpose of the BDBA is threefold. First, it ensures that important risks are not disregarded by classifying them as "incredible." Second, it is a measure of the residual risk of facility operation and provides a basis for the selection of additional controls if their implementation would be relatively easy in comparison to the risk involved. Third, it is a bounding measure of the risk to the public, which is also discussed in Section 3.3.2.2.

\subsection{ACCIDENT ANALYSIS}

\subsubsection{Methodology}

This section summarizes the methods used to quantify the consequences of the accidents selected in Section 3.3.2.3.5. The methods addressed include development of the accident scenario, source term, and consequence estimate. In addition, the I application of risk evaluation guidelines is also discussed.

In general, the quantitative analysis of accidents involves the investigation of both unmitigated and mitigated consequences in order to ascertain the importance of the facility barrier(s) challenged by the design basis accident (DBA). If the unmitigated accident consequences exceed the offsite and/or onsite risk evaluation guidelines, then credit is taken for one or more facility barriers until the consequences drop below the risk evaluation guidelines. Those barriers are then summarized for input into Chapter 4.0, "Safety, Systems, Structures, and Components," and Chapter 5.0, "Derivation of Interim Operational Safety Requirements." The predominant exception to this methodology is the seismic event analysis where it is assumed that all structures and piping that are seismically qualified to levels equal to or greater than the seismic DBA levels, either by design or by later analysis, survive the seismic DBA.

The values selected for parameters in the quantitative analyses are consistently chosen as conservative values. This conservative approach provides bounding accident scenarios to define the envelope of facility operations and for the selection of controls.

\subsubsection{Accident Scenario Development Methodology.}

Each accident analysis begins with a qualitative discussion of the accident scenario. This includes basic information pertaining to the hazard (form, quantity, etc.), the location and process associated with the hazard, one or more initiating events and their relationships, and a step-by-step progression of the accident sequence, including facility/operator actions, until the consequences of interest are reached. The scenario development establishes the groundwork for the source term and consequence models that follow.

In order to maintain a proper perspective of the accident, an effort is made to discuss the many barriers that would have to fail in order for the event to progress. Not all such barriers are credited as the controlling SSC or administrative control but are rather defense-in-depth barriers discussed in the context of the scenario. The credited SSCs and controls are clearly identified by definitions of unmitigated and mitigated conditions for the accidents. 


\subsubsection{Source Term Modeling Methodology.}

The source term models arise from the scenario development discussion. Using the inventory, the physical characteristics associated with each hazardous material, and any applicable environmental conditions, such as high temperature or high flow, the amount of each hazardous material which is made airborne at the site of the accident is estimated. The amount of each material made airborne is estimated by either an airborne release fraction (ARF) or an airborne release rate (ARR) from DOE-HDBK-3010-94 (Mishima 1994).

The amount of each hazardous material initially made airborne is adjusted by the respirable fraction (RF) associated with the release mechanism being analyzed. The RF is the fraction of the material made airborne and considered to be readily inhalable, which is a particle size of $10 \mu \mathrm{m}$ aerodynamic equivalent diameter (AED) or less. Generally, the RF is applied at the same time as the ARF and ARR, the combination of which is denoted in the form ARF:RF and ARR:RF, respectively. All $A R F, A R R$, and RF values used in the accident analysis are shown in Table 3-12.

The respirable amount made airborne at the accident location is multiplied by the leak path factor (LPF). The LPF takes into account any mechanisms that reduce the amount of material escaping the accident location and being released outside the facility. The LPF would take into account, for example, the plate-out of material as it passes through ventilation ducting and the effects of HEPA filtration. The LPFs used in the accident analysis are shown in Table 3-12.

Table 3-12. ARF, ARR, RF, and LPF Values Used in the Accident Analysis.

\begin{tabular}{|c|c|c|c|c|c|}
\hline $\begin{array}{l}\text { Accident type/ } \\
\text { Section location }\end{array}$ & \multicolumn{2}{|c|}{ Applicable accident } & $\begin{array}{l}\text { ARF:RF or } \\
\text { ARR:RF }\end{array}$ & $\mathrm{LPF}$ & Basis \\
\hline $\begin{array}{l}\text { Natural phenomena/ } \\
\text { 3.4.2.1 }\end{array}$ & \multicolumn{2}{|c|}{$0.25 \mathrm{~g}$ Earthquake } & $1.0 \mathrm{E}-03: 1.0$ & 1.0 & $5.3 .3 .2 .2^{\mathrm{a}}$ \\
\hline \multirow{4}{*}{$\begin{array}{l}\text { External } \\
\text { Events/3.4.2.2 }\end{array}$} & \multicolumn{2}{|c|}{ Loss of electric power } & \multicolumn{3}{|c|}{$\mathrm{N} / \mathrm{A}$} \\
\hline & \multicolumn{2}{|c|}{ Adjacent facility accident } & \multicolumn{3}{|c|}{$\mathrm{N} / \mathrm{A}$} \\
\hline & \multicolumn{2}{|l|}{ Truck impact } & \multicolumn{3}{|c|}{ N/A } \\
\hline & \multicolumn{2}{|c|}{ Aircraft impact } & \multicolumn{3}{|c|}{$\overline{\mathrm{N} / \mathrm{A}}$} \\
\hline \multirow[t]{4}{*}{ Facility Fire/3.4.2.3 } & \multirow[t]{2}{*}{ Hot cell fire } & A Cell & $5.0 \mathrm{E}-04: 1.0$ & 1.0 & $5.2 .1 .1^{\mathrm{a}}$ \\
\hline & & $\begin{array}{l}\mathrm{B} / \mathrm{C}, \mathrm{D} / \mathrm{E} \\
\text { Cells }\end{array}$ & $1.0 \mathrm{E}-02: 1.0$ & 1.0 & $5.2 .1 .2^{\mathrm{a}}$ \\
\hline & \multirow[t]{2}{*}{ Truckport fire } & Solid waste & $1.0 \mathrm{E}-02: 1.0$ & 1.0 & $5.2 .1 .2^{\mathrm{a}}$ \\
\hline & & $\begin{array}{l}\text { 208-L }(55- \\
\text { gal) Drum }\end{array}$ & $5.0 \mathrm{E}-04: 1.0$ & 1.0 & $5.2 .1 .1^{2}$ \\
\hline \multirow{5}{*}{$\begin{array}{l}\text { Loss of } \\
\text { Confinement/ } \\
3.4 .2 .4\end{array}$} & \multirow{2}{*}{\multicolumn{2}{|c|}{$\begin{array}{l}\text { High flow in K-3 ventilation } \\
\text { system }\end{array}$}} & $1.9[-03: 1.0$ & $\begin{array}{c}1.0 \\
\text { (unmitigated) }\end{array}$ & $5.3 .4^{\mathrm{a}}$ \\
\hline & & & & $\begin{array}{c}1.0 \text { E-03 } \\
\text { (mitigated) }\end{array}$ & \\
\hline & \multicolumn{2}{|c|}{ Loss of K-3 ventilation flow } & \multicolumn{3}{|c|}{ N/A } \\
\hline & \multicolumn{2}{|c|}{$\begin{array}{l}\text { K-3 system water } \\
\text { accumulation }\end{array}$} & $1.0 \mathrm{E}-02: 1.0$ & 1.0 & $5.4 .2 .2^{\mathrm{a}}$ \\
\hline & \multicolumn{2}{|c|}{ High activity in TK-100 } & $1.0 \mathrm{E}-04: 1.0$ & 1.0 & $3.2 .2 .3 .1^{\mathrm{a}}$ \\
\hline
\end{tabular}




\section{HNF-SD-WM-BIO-002 REV 1}

Table 3-12. ARF, ARR, RF, and LPF Values Used in the Accident Analysis.

\begin{tabular}{|c|c|c|c|c|}
\hline $\begin{array}{l}\text { Accident type } / \\
\text { Section location }\end{array}$ & Applicable accident & $\begin{array}{l}A R F: R F \text { or } \\
A R R: R F\end{array}$ & LPF & Basis \\
\hline & $\begin{array}{l}\text { Hydrogen accumulation in hot } \\
\text { cells }\end{array}$ & \multicolumn{3}{|c|}{ N/A } \\
\hline \multirow{2}{*}{$\begin{array}{l}\text { Facility } \\
\text { Explosions/3.4.2.5 }\end{array}$} & Flammable gas explosion & \multicolumn{3}{|c|}{$\overline{\mathrm{N} / \mathrm{A}}$} \\
\hline & $\begin{array}{l}\text { Hydrogen explosion in Pool } \\
\text { Cell Area }\end{array}$ & \multicolumn{3}{|c|}{ N/A } \\
\hline \multirow{2}{*}{$\begin{array}{l}\text { Loss of } \\
\text { Containment/ } \\
3.4 .2 .6\end{array}$} & $\begin{array}{l}\text { Underwater capsule failure } \\
\text { due to corrosion }\end{array}$ & \multirow[t]{2}{*}{$1.45 E-10 / \mathrm{h}: 1.0^{(\mathrm{b})}$} & \multirow[t]{2}{*}{ N/A } & \multirow[t]{2}{*}{ Orme 1981} \\
\hline & $\begin{array}{l}\text { Underwater capsule failures } \\
\text { due to drop impact }\end{array}$ & & & \\
\hline \multirow{2}{*}{$\begin{array}{l}\text { Loss of Pool Cell } \\
\text { Water } \\
3.4 .2 .7\end{array}$} & $\begin{array}{l}\text { Loss of water from a single } \\
\text { pool cell }\end{array}$ & \multirow{2}{*}{\multicolumn{2}{|c|}{$\mathrm{N} / \mathrm{A}^{(\mathrm{c})}$}} & \multirow[t]{2}{*}{ WHC $1996 \mathrm{~b}$} \\
\hline & $\begin{array}{l}\text { Loss of water from all pool } \\
\text { cells }\end{array}$ & & & \\
\hline
\end{tabular}

(a) Mishima (1994)

(b) Orme (1981) evaporative release fraction (would equate to 7.7 E-06Cith assuming a maximum cesium capsule of $53.2 \mathrm{kCi}$. Actual dose conseguences were not calculated because of the very small source term and long release time.

${ }^{(c)}$ Release for these accidents were not calculated using a fixed ARF, RF, and LPF.

Note: Release fraction data in Mishima (1994) is typical for uranium and plutonium compounds. These compounds have greater bulk densities so that lighter strontium or cesium compounds may become airborne more easily. However, this is of fset by use of bounding ARF, RF, and LPF values. In addition, no release fraction data exists specifically for strontium and cesium compounds.

\subsubsection{Consequence Analysis Methodology.}

The consequence analysis combines the results of the source term, atmospheric dispersion, and International Commission on Radiological Protection (ICRP) reference man dose models to estimate radiological consequences to onsite and offsite individuals.

The dispersion model accounts for the movement of each hazardous material from the facility to the location of the individual and is characterized by a Hanford Site-specific atmospheric dispersion coefficient $(\chi / Q)$. The derivation of the $\chi / Q$ I values used in the accident analysis is summarized here and is detailed in Hey (1999). The $\chi / \mathrm{Q}$ is specific to the Hanford Site through the use of Hanford Site meteorological data documented in Schreckhise et al. (1993).

The $\chi / Q$ values calculated for the accident analysis represent conservative distances to receptors and extreme atmospheric conditions conducive for the transport of hazardous materials. The basic dispersion model used is the straight line continuous gaussian plume model as implemented in the GXQ computer code, with options to include the effects of plume meander, building wake, and elevated release height.

The GXQ computer code, documented, validated, and verified in Hey (1995a and 1995b), was used to implement the basic gaussian plume model in addition to the corrections for plume meander, building wake, and elevated release height. The basic gaussian model calculated $\chi / Q$ values for a point-source, ground-level release. The plume meander correction accounts 


\section{HNF-SD-WM-BIO-002 REV 1}

for the lateral (side-to-side) movement of the plume about its average centerline and is applicable when the release is approximately constant and has a duration of at least $1 \mathrm{hr}$. The building wake correction accounts for the dispersion of the plume in the turbulence on the downwind side of a structure. The inputs for the building wake correction are the smallest

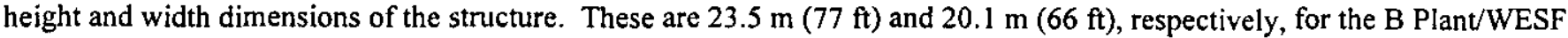
structure as taken from Chapter 2. The elevated release height accounts for releases through the 296-B-10 stack and is used only in the DBE analysis. The elevated release height is not used in the offsite calculations because the corrections at large receptor distances are not significant.

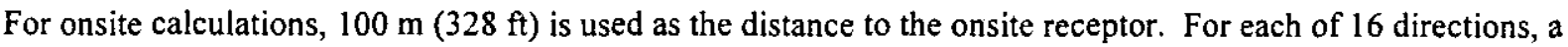
$99.5 \% \chi / \mathrm{Q}$ (meaning that the $\chi / \mathrm{Q}$ is exceeded only $0.5 \%$ of the time) is calculated along with a $95 \%$ site-wide $\chi / \mathrm{Q}$ (which considers all directions at the same time). The greatest of the 17 values is selected as the onsite $\chi / Q$.

For offsite calculations, two Hanford Site boundary definitions are evaluated. These are the current Hanford Site boundary (i.e., the fence line) and an alternate site boundary which is bounded by the near bank of the Columbia River to the north and east, the Wye barricade to the southwest, and Highway 240 to the west and south. The distances in each of 16 compass sectors are shown in Table 3-13 for both boundary definitions (Hey 1999). The $99.5 \% \chi / \mathrm{Q}$ values are compared for each of the 16 directions with the greatest value selected as the offsite $\chi / Q$. Potential dose consequences are evaluated at both boundary definitions for each of the accidents quantified. In general, consequences at the alternate site boundary are $40 \%$ higher than at the fence line.

The onsite and offsite $\chi / Q$ values that are representative of the dispersion between the WESF release point and the receptor locations under various release conditions are shown in Table 3-14. The particular $\chi / Q$ value used in an accident analysis is determined based on the physical phenomena associated with the accident. For example, in the loss of pool cell water accident, both plume meander and building wake are applicable because the facility structure is present and the release duration is constant and longer than $1 \mathrm{hr}$. For the hydrogen explosion in the K-3 Filter Pit, however, plume meander is not applicable because of the short duration of the release. For the stack release in the DBE, it is appropriate to use an elevated release model.

The unit dose factors used in the accident analysis are taken from the assumptions and calculations document and summarized here (l ley 1999). They represent the 50-yr committed dose per unit curie of released material and are calculated from the information provided in Table 3-15.

Note that the $\chi / Q$ s in Table 3-15 are corrected for building wake only, and are used for all analyses except loss of pool cell water and the stack release associated with the DBE analysis. For a loss of pool cell water, which results in a release over several days, it is appropriate to adjust the $\chi / Q$ for plume meander and building wake as shown in Table 3-16. For this event it is also convenient to develop a dose per unit $\mathrm{kg}$ release since the release quantities are expressed in mass instead of activity. The average salt specific activity is taken from the WESF Encapsulation Database System (EDS) as discussed and documented in Hey (1999).

The average salt specific activity is the ratio of the total uncut capsule activity as of January 1,1996 over the total net weight of uncut capsule contents, excluding fabricated metallic parts. The 50-yr committed dose per unit kilogram of average WESF cesium salt released is calculated from the information provided in Table 3-16.

The final dose consequence is found by taking the sum of the dose consequences arising from each isotope. For each isotope, the dose consequence is calculated by multiplying the source term for the isotope and the dose per unit release 
according to the following equation.

$$
\begin{gathered}
D=Q C \\
\text { where: } \\
D=\text { dose (rem) } \\
Q=\text { source term }(\mathrm{C} i) \\
C=\text { dose per unit curie release }(\mathrm{rem} / \mathrm{C} i)
\end{gathered}
$$

The dose per unit curie release, $C$, should be taken from Table 3-15 to represent the 50-yr committed effective dose through the inhalation pathway. The plume submersion dose (i.e., the external dose received from radiation emitted in the enveloping plume), in comparison to the inhalation pathway dose, is insignificant (Hey 1999). Other possible dose pathways, such as ground shine and ingestion, which might occur long after the release, are specifically excluded from acute, accidentbased consequence analysis.

Table 3-13. Site Boundary Distances Used in Offsite Dispersion Calculations (Hey 1999).

\begin{tabular}{|c|r|r|}
\hline Transport direction & $\begin{array}{r}\text { Fence-line distance } \\
(\mathrm{km})\end{array}$ & $\begin{array}{c}\text { Alternate site boundary } \\
\text { distance }(\mathrm{km})\end{array}$ \\
\hline S & 19.31 & 8.94 \\
\hline SSW & 16.64 & 8.26 \\
\hline SW & 18.08 & 8.26 \\
\hline WSW & 19.29 & 9.71 \\
\hline W & 18.89 & 11.04 \\
\hline WNW & 19.39 & 14.36 \\
\hline NW & 19.81 & 11.49 \\
\hline NNW & 19.55 & 11.33 \\
\hline N & 22.78 & 12.99 \\
\hline NNE & 25.45 & 14.01 \\
\hline NE & 19.88 & 12.27 \\
\hline ENE & 17.04 & 12.14 \\
\hline E & 16.87 & 13.65 \\
\hline ESE & 21.04 & 20.88 \\
\hline SE & 25.17 & 14.19 \\
\hline SSE & 21.08 & 11.71 \\
\hline & & \\
\hline & & \\
\hline
\end{tabular}


Table 3-14. Atmospheric Dispersion Coefficients ( $\chi / Q s)$ Used in the Accident Analysis.

\begin{tabular}{|l|c|c|c|}
\hline \multicolumn{1}{|c|}{ Source/receptor description } & $\begin{array}{c}\text { Onsite } 100-\mathrm{m} \chi / \mathrm{Q} \\
\left(\mathrm{s} / \mathrm{m}^{3}\right)\end{array}$ & $\begin{array}{c}\text { Fence-line } \chi / \mathrm{Q} \\
\left(\mathrm{s} / \mathrm{m}^{3}\right)\end{array}$ & $\begin{array}{c}\text { Hwy-240, Wye barricade, } \\
\text { and near river bank } \\
\chi / \mathrm{Q}\left(\mathrm{s} / \mathrm{m}^{3}\right)\end{array}$ \\
\hline $\begin{array}{l}\text { Ground level release, point } \\
\text { source }\end{array}$ & $\begin{array}{c}3.41 \mathrm{E}-02 \\
(\mathrm{E})\end{array}$ & $\begin{array}{c}1.35 \mathrm{E}-05 \\
(\mathrm{E})\end{array}$ & $\begin{array}{c}1.90 \mathrm{E}-05 \\
(\mathrm{NNW})\end{array}$ \\
\hline $\begin{array}{l}\text { Ground level release with plume } \\
\text { meander }\end{array}$ & $\begin{array}{c}1.13 \mathrm{E}-02 \\
(\mathrm{ESE})\end{array}$ & $\begin{array}{c}1.13 \mathrm{E}-05 \\
(\mathrm{E})\end{array}$ & $\begin{array}{c}1.52 \mathrm{E}-05 \\
(\mathrm{NNW})\end{array}$ \\
\hline $\begin{array}{l}\text { Ground level release with } \\
\text { building wake }\end{array}$ & $\begin{array}{c}1.14 \mathrm{E}-02 \\
(\mathrm{E})\end{array}$ & $\begin{array}{c}1.34 \mathrm{E}-05 \\
(\mathrm{E})\end{array}$ & $\begin{array}{c}1.88 \mathrm{E}-05 \\
(\mathrm{~W})\end{array}$ \\
\hline $\begin{array}{l}\text { Ground level release with plume } \\
\text { meander and building wake }\end{array}$ & $\begin{array}{c}8.55 \mathrm{E}-03 \\
(\mathrm{E})\end{array}$ & $\begin{array}{c}1.13 \mathrm{E}-05 \\
(\mathrm{E})\end{array}$ & $\begin{array}{c}1.52 \mathrm{E}-05 \\
(\mathrm{NNW})\end{array}$ \\
\hline Elevated release height & $2.00 \mathrm{E}-04$ & Not calculated & Not calculated \\
\hline
\end{tabular}

Table 3-15. Committed Inhalation EDE per Unit Curie Release of Respirable ${ }^{137} \mathrm{Cs}$ and ${ }^{90} \mathrm{Sr}$.

\begin{tabular}{|c|c|c|c|c|c|}
\hline Receptor & Isotope & $\begin{array}{l}\text { Committed effective } \\
\text { dose equivalent per } \\
\text { unit intake } \\
\mathrm{mSv} / \mathrm{Ci} \\
(\mathrm{rem} / \mathrm{Ci})\end{array}$ & $\begin{array}{c}\chi / Q \\
\left(\mathrm{~s} / \mathrm{m}^{3}\right)^{*}\end{array}$ & $\begin{array}{c}\text { Ref. man } \\
\text { breathing rate } \\
\left(\mathrm{m}^{3} / \mathrm{s}\right)\end{array}$ & $\begin{array}{c}\text { Inhalation dose } \\
\text { per unit release } \\
\mathrm{mSv} / \mathrm{Ci} \\
(\mathrm{rem} / \mathrm{Ci})\end{array}$ \\
\hline Public & $\begin{array}{l}{ }^{90} \mathrm{Sr} \\
{ }^{137} \mathrm{Cs}\end{array}$ & $\begin{array}{c}2.50 \mathrm{E}+06 \\
(2.50 \mathrm{E}+05) \\
3.20 \mathrm{E}+05 \\
(3.20 \mathrm{E}+04)\end{array}$ & $1.34 \mathrm{E}-05$ & $3.3 \mathrm{E}-04$ & $\begin{array}{c}0.011 \\
(0.0011) \\
0.0014 \\
(0.00014)\end{array}$ \\
\hline $\begin{array}{l}\text { Onsite } 100-\mathrm{m} \\
\text { worker }\end{array}$ & $\begin{array}{l}{ }^{90} \mathrm{Sr} \\
{ }^{137} \mathrm{Cs}\end{array}$ & $\begin{array}{c}2.50 \mathrm{E}+06 \\
(2.50 \mathrm{E}+05) \\
3.20 \mathrm{E}+05 \\
(3.20 \mathrm{E}+04)\end{array}$ & $1.14 \mathrm{E}-02$ & same & $\begin{array}{c}9.4 \\
(0.94) \\
1.2 \\
(0.12)\end{array}$ \\
\hline $\begin{array}{c}\text { Onsite } 100-\mathrm{m} \\
\text { worker elevated } \\
\text { release height }\end{array}$ & ${ }^{90} \mathrm{Sr}$ & $\begin{array}{c}2.50 \mathrm{E}+06(2.50 \\
\left.E_{-} 05\right) \\
3.20 E+05(3.20 \\
E+04)\end{array}$ & $2.00 \mathrm{E}-04$ & same & $\begin{array}{c}0.17 \\
(0.017) \\
\\
0.021 \\
(0.0021)\end{array}$ \\
\hline $\begin{array}{c}\text { Alternate site } \\
\text { boundary }\end{array}$ & $\begin{array}{l}{ }^{90} \mathrm{Sr} \\
{ }^{137} \mathrm{Cs}\end{array}$ & $\begin{array}{c}2.50 \mathrm{E}+06 \\
(2.50 \mathrm{E}+05) \\
3.20 \mathrm{E}+05 \\
(3.20 \mathrm{E}+04)\end{array}$ & $1.88 \mathrm{E}-05$ & same & $\begin{array}{c}0.016 \\
(0.0016) \\
0.0020 \\
(0.00020\end{array}$ \\
\hline
\end{tabular}

"Adjusted for building wake, except onsite 100 -m worker elevated release height. 
Table 3-16. Committed Inhalation EDE per Unit Kilogram Release of Respirable WESF CsCI.

\begin{tabular}{|l|c|c|c|c|c|}
\hline Receptor & $\begin{array}{c}\text { Committed } \\
\text { effective dose } \\
\text { equivalent per } \\
\text { unit intake } \\
\mathrm{mSv} / \mathrm{Ci} \\
(\mathrm{rem} / \mathrm{Ci})\end{array}$ & $\begin{array}{c}\text { Specific activity } \\
(\mathrm{Ci} / \mathrm{kg})\end{array}$ & $\begin{array}{c}\chi / \mathrm{Q} \\
\left(\mathrm{s} / \mathrm{m}^{3}\right)^{*}\end{array}$ & $\begin{array}{c}\text { Ref. man } \\
\text { breathing rate } \\
\left(\mathrm{m}^{3} / \mathrm{s}\right)\end{array}$ & $\begin{array}{c}\text { Inhalation dose } \\
\text { per unit release } \\
\mathrm{mS} / \mathrm{kg} \\
(\mathrm{rem} / \mathrm{kg})\end{array}$ \\
\hline Public & $\begin{array}{c}3.2 \mathrm{E}+05 \\
(3.2 \mathrm{E}+04)\end{array}$ & $1.47 \mathrm{E}+04$ & $1.13 \mathrm{E}-05$ & $3.3 \mathrm{E}-04$ & $\begin{array}{c}18 \\
(1.8)\end{array}$ \\
\hline Onsite 100-m Worker & same & same & $8.55 \mathrm{E}-03$ & same & 13,000 \\
$(1,300)$
\end{tabular}

'Adjusted for building wake and plume meander.

\subsubsection{Application of Risk Fvaluation Guidelines.}

The risk evaluation guidelines used in the accident analysis for the determination of Safety Class and Safety Significant (SSCs) and associated IOSRs are taken from WHC-CM-4-46, Chapter 9.0. The guidelines used in the BiO from WHC-CM-4-46 are comsistent with current IINF-PRO-70+ guidelines. The basic risk evaluation guidelines are $5 \mathrm{mSv}(0.5$ rem) for offsite consequences and $50 \mathrm{mSv}(5 \mathrm{rem})$ for onsite consequences.

In cases where the event frequency is well documented the rish evaluation guidelines can be based on frequency (see Table 3-17). This methodology is allowed only for accident scenarios which have well-documented frequencies for the initiating event. In no case was it possible to argue less restrictive controls on the basis of initiating event frequency.

Table 3-17. Risk Evaluation Guidelines Based on Initiating Event Frequency.

\begin{tabular}{|l|c|c|c|}
\hline $\begin{array}{c}\text { Event frequency } \\
\text { category }\end{array}$ & $\begin{array}{c}\text { Event frequency } \\
\left(\mathrm{yr}^{-1}\right)\end{array}$ & $\begin{array}{c}\text { Onsite evaluation guidelines } \\
\text { as effective dose equivalent }\end{array}$ & $\begin{array}{c}\text { Offsite evaluation } \\
\text { guidelines as effective } \\
\text { dose equivalent }\end{array}$ \\
\hline Anticipated & $>1 \mathrm{E}-02$ to $\leq 1$ & $50 \mathrm{mSv}(5 \mathrm{rem})$ & $5 \mathrm{mSv}(0.5 \mathrm{rem})$ \\
\hline Unlikely & $>1 \mathrm{E}-04$ to $\leq 1 \mathrm{E}-02$ & $250 \mathrm{mSv}(25 \mathrm{rem})$ & $50 \mathrm{mSv}(5 \mathrm{rem})$ \\
\hline Extremely unlikely & $>1 \mathrm{E}-06$ to $\leq 1 \mathrm{E}-04$ & $1,000 \mathrm{mSv}(100 \mathrm{rem})$ & $250 \mathrm{mSv}(25 \mathrm{rem})$ \\
\hline
\end{tabular}

The guidelines noted above are used for risk analysis in accordance with WHC-CM-4-46, Chapter 7.0, Rev. 4, for the determination of additional IOSRs which may not be related to SSCs. Therefore, for all accidents that use these values as I risk evaluation guidelines, the requirement to perform risk analyses has been met. All accidents in this BIO fall into this category.

\subsubsection{Safety Class and IOSR Designation Methodology.}

The accident analysis provides the basis for establishing safety significant and safety class SSCs and IOSRs, in accordance with DOE-STD-3009-94 and Chapter 9.0 of WHC-CM-4-46. The guidelines used in the BIO from WIIC-CM-4- 
46 are consistent with current HNF-PRO-704 guidelines. Those accident consequences that exceed, or in some cases approach, the risk evaluation guidelines listed above, will have identified the SSCs and administrative controls credited for mitigation or prevention. These SSCs and administrative controls will be summarized here along with the safety function they provide. A more detailed description of these barriers will be provided in Chapter 4.0, "Safety Class SSCs," and Chapter 5.0, "Derivation of IOSRs."

\subsubsection{Design Basis Accidents}

There is some confusion as to the definition of DBAs and how they apply to existing facilities. To avoid confusion with other definitions of DBA, a brief explanation is appropriate. The DOE-5480.23 (1992) attachment states that DBAs are "accidents that are utilized to provide the design parameters for release barriers and mitigating systems." For an existing facility whose release barriers and mitigating systems are already designed, there is little value in deriving their design parameters. However, for an existing facility, there is value in establishing a safety basis for operation. In this sense, DBA is equivalent to safety basis accident, because it is used to (1) "identify" the existing controls that provide the necessary prevention, detection or mitigation of the accident, or (2) design new controls as appropriate to provide the necessary level of protection.

Regardless of whether the accident is truly an accident (e.g., earthquake) or was considered in facility design before construction (e.g., 0.25g ground acceleration), this document will use DOE-STD-3009-94 (DOE 1994) terminology and refer to all such evaluated events as DBAs.

There are many accidents that could occur in a nuclear facility, but only a few of these accidents need to be analyzed in order to ensure adequate protection of the public and workers through a combination of engineered barriers and administrative controls. There are seven types of DBAs evaluated for WESF. One is labeled natural phenomena, one is labeled external events, and five are various types of operational events internal to WESF. Those events that represent unique, representative, and bounding challenges to barriers against releases are selected for a more detailed deterministic accident analysis. The goal of this accident analysis is to (1) identify the controlling barriers to hazardous releases, (2) determine the importance of those barriers, and (3) identify facility vulnerabilities for application of interim and future controls.

The seven DBA types for WESF are identified in Table 3-11. Several events are shown for each type. Detailed analyses are provided for the selected accidents.

The evaluation of BDBAs is also required by DOE Order 5480.23. The BDBAs are either natural phenomena events having a return frequency less than design basis event or operational DBAs without the benefit of qualified engineered barriers and controls (i.e., unmitigated). Because safety classification and IOSR assignment rely on unmitigated consequence estimates, operational BDBAs are covered in Section 3.4.2 for accident types 3 through 7 (i.e., unmitigated operational accidents). The BDBA, for accident type 1 (natural phenomena), is considered in Section 3.4.3. Accident type 2 events (external events) are specifically excluded from BDBA by DOE-STD-3009-94, and therefore, are not examined.

\subsubsection{Natural Phenomena.}

This section provides the results of accident analyses for design basis natural phenomena events. DOE-STD-1027-92 (DOE 1992) "design basis natural phenomena events include earthquakes, high winds, tornadoes, floods, etc. for which the facility has been (or should have been) designed." Natural phenomena events having forces greater than those used in the design basis (for which the facility was not designed), are considered beyond design basis and are evaluated separately in Section 3.4.3 in accordance with the format provided by DOE-STD-3009-94 (DOE 1994).

\subsection{Survey Results.}

A survey was completed to appraise the ability of the 225-B Building WESF to resist DBE ground motions and other NPH (Wagenblast, et al. 1999). The scope of this survey included a technical review of the original WESF seismic design analysis and review (Blume 197la and 1971 b). Reviews of other available design analyses, the construction drawings, and specifications were made. Inspections were conducted for the 225-B Building and pool cell structures and the systems and equipment required to operate the pool cells. Several engineering reports for inspections and repairs to the reinforced concrete 
225-B Building and the hot cell floor liners were obtained and reviewed. The lateral force resisting systems for the WESF structures were determined.

The configuration, anchorages, and lateral supports for the systems and equipment items were determined.

Evaluations were made on the probability of NPH survival for WESF structures and systems, based on engineering judgments about whether the responses of the items could be expected to be within acceptable limits.

The survey considered three natural phenomena events: (1) DBE ground motions, (2) design basis wind pressures and missiles, and (3) volcanic ashfall and snow loads combined. Tornadoes were not considered because they are not considered in the design basis for non-reactor nuclear facilities at the Hanford Site. The WESF structures and systems appraised by the survey are as follows:

- $\quad$ Structures

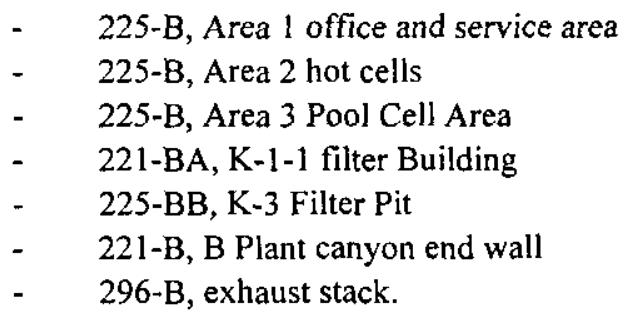

- $\quad$ Systems

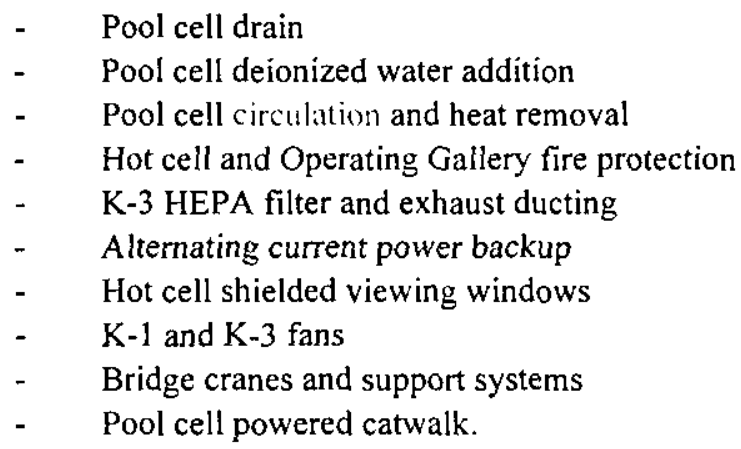

The main conclusions of this survey are summarized as follows:

- Area 1 of the 225-B Building, with the heating, ventilating, and air conditioning (HVAC) room and most of the control and surveillance instrumentation for the pool cells was originally designed for a $0.12 \mathrm{~g}$ operating basis earthquake. Therefore, Area 1 including equipment, exceeds the minimum uniform building code (UBC) seismic and wind provisions in SDC 4.1, Rev. 12 (Wagenblast, et al. 1999) currently required for general use facilities. It is also likely, but not confirmed or credited during the DBE analysis, that Area 1 structure could survive the current Hanford Site DBE (0.20 g) (Wagenblast, et al. J999).

- Areas 2 and 3 of the 225-B Building, the hot cells and storage pool cells, were originally designed for a $0.25 \mathrm{~g}$ earthquake. Although the documentation that remains available is incomplete, it is believed that efforts to pursue a new and complete set of seismic analyses for the 225-B Building would be of limited value for the following reasons. First, based on the expert opinion of the structural engineers who performed the survey, there is a high likelihood that further comprehensive seismic analyses, if conducted, would successfully show these areas adequate for DBE requirements. Therefore, little real gain in facility safety would be realized. Second, the accident analysis results documented here indicate that the more significant vulnerabilities are associated with SSCs that are not qualified for NPH loads. Therefore, new seismic analyses will only confirm the results of existing analyses and do nothing to resolve the vulnerabilities of SSCs not designed for NPH loads. 
- The K-3 HEPA filter housings are unanchored in the K-3 filter pit. This allows them to be remotely changed with ease. However, the filters could be dislodged by seismic motions and the K-3 HEPA filters would not be available for filtration of the exhaust airflow from the K-3 system.

- The DBE seismic motions could interrupt the makeup deionized water for the pool cell and raw water to the circulation system heat exchangers and the WESF fire protection system.

- The 221-B Building west end wall could be damaged by $0.25 \mathrm{~g} \mathrm{DBE}$ motions and cause local structural damage to the east end of the 225-B Building (Area 2, the hot cells). This is remote from the Pool Cell Area.

All of the items listed above are factored into the accident analysis in this BIO.

The scope of analysis in this section is to evaluate worst case consequences from natural phenomena forces up to, but not exceeding, design basis loads. All natural phenomena identified as adversely impacting WESF were examined in the hazards evaluation.

NPHs at the Hanford Site are well known and documented. They include seismic events, high winds, wind-driven missiles, floods, snow fall, and ash fall. The flood event has been found to fall short of impacting facilities in the 200 Areas, considering both local creek flooding and flooding of the major rivers of the area (HNF 1998). The NPHs of high wind, snow and ash fall, and wind-driven missiles have minor impact compared to the hazards of an earthquake. However, these hazards could result in the loss of electrical power. Consequences of this event are evaluated under external events in Section 3.4.2.2. Seismic events are unique in that they could provide a means for common mode failure, including the loss of electrical power, while also providing energy for the release of hazardous material. No other natural phenomena event has such broad implications. For this reason, the seismic event is representative of the worst case NPHs and was selected for quantitative analysis and as the basis for safety controls.

During the hazards survey process, 21 structural design modification recommendations, 1 structural evaluation recommendation, and 6 equipment design modification recommendations were discovered. Of the 21 structural recommendations, 16 had been completed and 5 were not necessary. The single recommendation for further evaluation, pertaining to a stack located on the Area 1 structure, was also not necessary. Of the 6 equipment design recommendations, 3 were performed, 2 were not necessary because of equipment changes, and 1 was not incorporated. The equipment design modification not incorporated is the seismic anchoring of the K-3 filter housings.

\subsection{Design Basis Earthquake.}

Two design basis seismic events were considered in WESF design and construction. The first event, called the operating basis earthquake, has a peak ground acceleration of $0.12 \mathrm{~g}$ and was applied to the office and support areas of the 225-B Building (i.e., Area 1). The second event, called the safe shutdown earthquake, has a peak ground acceleration of 0.25 $\mathrm{g}$ and was applied to those portions of the 225-B Building having a radiological confinement function, such as the hot cells and Pool Cell Area (i.e., Areas 2 and 3, respectively). The seismic event analyzed in this section is the more severe safe shutdown earthquake and will be referred to as the DBE for the remainder of the WESF accident analyses. It is a conservative event with respect to current requirements (Wagenblast, et al. 1999).

A detailed discussion of the individual natural phenomenon that might impact WESF and the selection for quantitative analysis are provided in Section 3.3.2.3.5. For additional details regarding the treatment of design basis seismic, wind, snow and ashfall loads, see Wagenblast, et al. (1999), Blume (1971 a and 1971b), and VITRO (1970).

\subsection{Scenario Development.}

The purpose of this section is to evaluate the facility-wide response to the DBE, including reactions of facility SSCs and hazardous materials. 
Unmitigated Condition. The unmitigated scenario is analyzed in Section 3.4.3. In this scenario all SSCs impacted by the earthquake are assumed to fail. The reader is referred to that section for a discussion of how the approach to the seismic event and external events differ from the other accidents considered.

Mitigated Condition. In the mitigated scenario, certain structures and piping survive the earthquake and continue to function normally. The basis for assuming SSC failure or survival in the DBE is provided in the Natural Phenomenon Hazards | Survey (NPHS) (Wagenblast, et al. 1999). For each SSC, three basic results are given in the NPHS: high likelihood that the SSC would survive the DBE, moderate likelihood that the SSC would survive the DBE, and low likelihood that the SSC would survive the DBE.

The DBE analysis for WESF considers two consequence categories: immediate and delayed. External impacts to WESF due to the interaction of the DBE with adjacent facilities is considered in Section 3.4.2.2. The immediate effects include WESF response to the DBE and the potential hazardous material releases resulting directly from the DBE. Delayed effects considers the degraded condition of WESF systems and the potential for subsequent releases if human intervention does not occur.

Immediate Effects. In the analysis of immediate effects of the DBE, those SSCs that are designated in the NPHS as having a high likelihood for survival (i.e., seismically qualified) are assumed to survive the DBE. Survival of an SSC is defined here as the ability of the SSC to perform its safety function and takes into consideration possible failures of other SSCs. All other SSCs, designated in the NPHS as having a low or moderate likelihood of survival, are assumed to fail in the DBE.

The immediate effects of the DBE arise from the motion of the ground and subsequent motion and failure of facility SSCs. The following SSCs are designed to survive the DBE (Wagenblast, et al. 1999):

- Operating Gallery, hot cells, viewing windows, AMU, canyon bridge crane (including live load), and canyon structures

- Pool cells, Pool Cell Area, and Truckport structures

- Pool cell drain piping, pool cell crane (including live load), and pool cell catwalk

- Pool cell water circulation and heat removal piping

- K-3 Filter Pit (not including the filter housings themselves)

- $\mathrm{K}-3$ ducting all the way into the stack

- 296 B exhaust stack

- $\mathrm{K}-1$ filter building.

The following SSCs are not designed for DBE loads and are assumed to fail in this analysis of the DBE:

- Instrumentation, HVAC, and office area

- 221-B Building end wall, the portion above the 225-B Building roof only

- Electrical backup power supply (diesel generator)

- Deionized water makeup system

- Raw water and deep well water feeds

- Hot cell and Operating Gallery fire suppression systems (pipe failure in office area)

- Hot cell and pool cell instrumentation adjacent to the Operating Gallery

- K-3 HEPA filter housing-to-duct connection

- Sanitary water supply

- Offsite electrical power supply. 


\section{HNF-SD-WM-BIO-002 REV 1}

Given the SSC responses listed above, it is easiest to summarize the immediate effects of the DBE by facility area and then by the reaction of the hazardous materials within those areas. The Operating Gallery, hot cells, and hot cell viewing windows are designed to survive the DBE. However, the process and pool cell instrumentation located in and adjacent to the Operating Gallery are assumed to fail in the DBE even though the structure associated with the Operating Gallery survives. In addition, failure of the 221-B end wall could result in structural damage to the canyon and Service Gallery, failure of the deionized water makeup piping, and possible structural damage to A Cell.

The AMU, Service Gallery, canyon structure, canyon crane and all hot cell cover blocks, being associated with the hot cell structure, are designed to survive the DBE. However, there does exist the potential for structural damage to the canyon from the failure of the B Plant end wall. Except for A Cell, it is assumed that all other cover blocks remain functional and in place during the DBE.

The K-3 Filter Pit structure survives the DBE, but the filter housings themselves are not anchored in place and could be displaced by seismic motions (Wagenblast, et al. 1999), causing the K-3 filters to be bypassed. Although offsite power and the backup diesel generator are not designed for DBE loads, electric power is conservatively assumed to remain intact to the K-3 fans, forcing airflow to sweep resuspended material in the hot cells and K-3 duct out through the 296-B stack. The K-3 exhaust ducting and 296-B stack are also qualified for the DBE (Wagenblast et. al. 1999). No credit is given for the failure of the K-3 fans in limiting the release of materials made airborne in the hot cells and K-3 ducting. Radiation monitors that are located in the stack have not been qualified for DBE loads. Accordingly, no credit is taken for their monitoring function or for operator action to shut the ventilation system down.

The K-1 filter building and ducting are designed to survive the DBE. However, the failure of the wall adjoining B Plant and WESF could result in an uncontrolled opening between the environment, the B Plant canyon, and areas ventilated by both the $\mathrm{K}-\mathrm{l}$ and $\mathrm{K}-3$ ventilation systems. In this circumstance, the capability of the $\mathrm{K}-1$ system to continue to provide for habitability and effective ventilation of the Truckport, Operating Gallery, AMU, and the Pool Cell Area is unknown, even if backup electrical power were available and the exhaust fans continued to operate.

The Pool Cell Area structure is designed for DBE loads. The calculations conservatively account for the increased loads due to hydrodynamic seismic forces (i.e.. stoshing) on the pool cell walls. No credit is titken for the rigidity that the cover blocks would aftord. and removal of the cover blocks bas the elfect of reducing seismic loads. Additionally, no credit is tatken for the additional restraint from the attached foundation between the buildings housing the cannon and pool cells.. The pool cell bridge crane, bridge crane supports, catwalk, catwalk supports, drain piping (in the pipe tunnel), and the circulation system piping are also qualified for DBE loads (Wagenblast, et al. 1999). The pool cell liner is not a structural member, is not exposed to earthquake loads, and would not fail in a DBE. The deionized water, sanitary water, raw water, and deep well water makeup are not designed for NPH loads and are assumed to fail in the DBE. Water initially in the pool cells is retained, but normal water makeup and cooling could be lost. Also, the K-1 ventilation system and circulation pumps could fail due to a loss of electric power, normally supplied offsite, but redundantly supplied by an unqualified backup diesel generator. The pool cell controls, located adjacent to the Operating Gallery, could be inaccessible due to failure of the office area structure (i.e., Area 1).

The Truckport, as part of the Pool Cell Area structure, is designed to survive the DBE. As described earlier, however, the Truckport might not be ventilated because of an upset in the K-l ventilation system.

Although not qualified for DBE Loads, it is feasible that one or more detection or makeup systems would be available in the event of an earthquake. Several such systems are present including the level detection instrumentation, area radiation monitors, deionized water makeup, sanitary water makeup, and raw water makeup. In addition, WESF is among the top priorities for the Emergency Preparedness organization so that, if necessary, water may be trucked in from the nearest available water source, including the Columbia River.

The immediate effects of the DBE on the hazardous materials in WESF result in the release from only two areas within the facility. The immediate release is from the suspension of solid radioactive materials in the hot cells and the K-3 exhaust ducting. The radioactive material, ${ }^{137} \mathrm{Cs}$ and ${ }^{90} \mathrm{Sr}$, in the hot cells is present as a result of contamination on equipment and stored solid waste. This contamination may become suspended as a result of the shock of the DBE and the structural 
failure of A Cell, which although highly unlikely because of the 225-B Building roof and the distance from the end wall to A Cell, is assumed to be impacted by the failure of the $221-\mathrm{B}$ Building end wall. The 221-B endwall is assumed to survive a $0.12 \mathrm{~g}$ seismic event (HNF 1998) but fail following the larger $0.25 \mathrm{~g}$ DBE associated with WESF. The same isotopes are present in the K-3 exhaust ducting downstream of the hot cells and would also be subject to the shock-vibration associated with the DBE.

The radioactive material in the Truckport and in capsules located in the pool cells, F Cell, and possibly in the BUSS cask in the Truckport, canyon, or G Cell, are not impacted by the immediate effects of the DBE. The Truckport survives the DBE and the packaging associated with the LLLW that might be present in the Truckport is sufficient to prevent the suspension of contamination. The structures confining the capsules, including the BUSS cask, the hot cells, the Truckport, the canyon, the pool cells, are also assumed to survive the DBE. Thus, the capsules are not impacted by falling objects and, in the absence of such an impact, the capsules are adequately protected from the DBE.

The inventory in the K-3 filter housings, present in the form of contamination on the interior surfaces and on the filter media, might be impacted by the DBE but would not be released to the environment. A certain quantity of the radioactive material could become airborne as a result of shock/vibration of the filter housing. Since the filter media inside the filter housing would not fail in the DBE, the worst-case consequences would arise from displacement of the filter housing itself with a subsequent breach of the inlet and outlet ducting. This breach could result in a bypass of the filter housing so that radioactive material resuspended in the hot cells or K-3 exhaust duct could bypass the K-3 filters. The radioactive material resuspended inside the filter housing, however, would not be subject to release because of a lack of motive force for removal of the airbome material from the filter housing.

In summary, radioactive material may be released from WESF in two ways following the DBE. The first is from A Cell through openings caused by possible impacts from the failed $221-\mathrm{B}$ endwall. This release pathway requires a seismic event of greater than $0.12 \mathrm{~g}$, because the endwall is assumed to survive this lesser event (HNF 199\$). The second release path results from the bypassed K-3 filters. Since the K-3 exhaust ducting and 296-B stack have been shown to survive the DBE and no credit is given for failure of the K-3 exhaust fans, this is a rapid, elevated release.

Delayed Effects. Designated emergency water sources outside the facility (i.e., sanitary and raw water) are also vulnerable to failure in the DBE. Therefore, the DBE could result in failure of both normal and emergency means of providing makeup water. Elapsed time to uncover the capsules due to evaporative losses from the highest heat load pool cell would require at least 5 days (without cooling), and if the transfer ports were opened to at least eight pools, another 17 days (Hcy 1999). Nevertheless, human intervention is required to stop this chain of events. The loss of water from both a single pool cell and all active pool cells is analyzed in Section 3.4.2.7. Those consequences, which occur several days later, could be added to those discussed here if human intervention to restore a means of makeup water did not occur. The delayed consequences of the DBE are not addressed further here since the analysis in Section 3.4.2.7 is sufficient to establish the necessary controls.

Major Assumptions. The following assumptions were made in the scenario development.

- Various SSCs are assumed to survive the DBE (see the list in the scenario description above).

- The packaging associated with the LLLW that might be present in the Truckport is sufficient to prevent the suspension of contamination.

\subsection{Source Term Analysis.}

Unmitigated Condition. The unmitigated scenario source term is analyzed in Section 3.4.3.2.

Mitigated Condition. The source term arising from the DBE can be estimated by modeling the suspension of impacted hazardous material. The scenario development above identifies the radioactive contamination in the K- 3 ventilation system and in certain hot cells as the only hazardous materials impacted by the immediate effects of the DBE.

In general, the source term arising from the DBE is the product of the inventory at risk, ARF:RF value, and LPF 


\section{HNF-SD-WM-BIO-002 REV I}

associated with the accident conditions. For the DBE there are two separate release paths determined in the scenario development, one through the 296-B stack and the other through the failed A Cell structure. A separate source term must be calculated for each release path so that the elevated release through the stack can be distinguished from the ground-level release from A Cell.

For the first release path, through the 296-B stack, the inventories in the affected hot cells and in the K-3 exhaust duct can be combined. The hot cells are ventilated by the K-3 system with air entering from the canyon area and exiting through the hot cell floors into a common hot cell exhaust duct, which in turn goes to the K-3 Filter Pit. The hot cells are separated from the downstream portions of the K-3 ventilation system by a HEPA filter on the hot cell ventilation outlet. These HEPA filters are not regularly tested or changed, and therefore, no credit is taken for them. The inventory which may be present in A Cell would not contribute to a release in this fashion because the waste packaging (55-gal drums) would preclude a release. The inventory in A Cell would only be subject to release if the A Cell structure failed as a result of an impact from the 221-B endwall, which is accounted for separately.

Considering the release through the 296-B stack, the inventory at risk for $\mathrm{B}$ through $\mathrm{G}$ Cells can be found from the inventory data presented in Table 3-3. The $\mathrm{B}$ and $\mathrm{C}$ Cells each contain $7.4 \times 10^{14} \mathrm{~Bq}(20 \mathrm{kCi})$ of ${ }^{90} \mathrm{Sr}$ and $7.4 \times 10^{13} \mathrm{~Bq}(2 \mathrm{kCi})$ of ${ }^{137} \mathrm{Cs}$ as contamination available for release on solid wastes, walls, and other exposed surfaces. The inventory in $\mathrm{D}$ and $\mathrm{E}$ Cells is $7.4 \times 10^{14} \mathrm{~Bq}(20 \mathrm{kCi})$ of ${ }^{137} \mathrm{Cs}$ as contamination similar to that in $\mathrm{B}$ and $\mathrm{C}$ Cells. The $\mathrm{B} / \mathrm{C}$ Cell furnace contains $1.5 \mathrm{x}$ $10^{15} \mathrm{~Bq}(40 \mathrm{kCi})$ of ${ }^{90} \mathrm{Sr}$ in boats and waste pipes. The $\mathrm{F}$ and $\mathrm{G}$ Cell inventories would not be impacted by the DBE as discussed in the scenario development. The exact amount of contamination, and its distribution in $\mathrm{B}$ through $\mathrm{E}$ Cells, is unknown. Therefore, it is assumed that total inventory of the hot cells (B through E Cells) is at risk in the DBE. This results in an inventory at risk in the hot cells (B through E Cells) of $3.0 \times 10^{15} \mathrm{~Bq}(80 \mathrm{kCi})$ of ${ }^{90} \mathrm{Sr}$ and $8.9 \times 10^{14} \mathrm{~Bq}(24 \mathrm{kCi})$ of ${ }^{137} \mathrm{Cs}$.

The inventory at risk in the K-3 exhaust duct is given in Table 3-3. Of the two isotopic distributions presented for contamination in the $\mathrm{K}-3$ ducting, the $7.4 \times 10^{15} \mathrm{~Bq}(200 \mathrm{kCi})$ of ${ }^{90} \mathrm{Sr}$ is conservatively assumed to be the inventory at risk.

The inventory at risk in $\mathrm{B}$ through $\mathrm{E}$ Cells and the $\mathrm{K}-3$ ducting may be combined, for a total of $1.0 \times 10^{16} \mathrm{~Bq}(280$ $\mathrm{kCi})$ of ${ }^{90} \mathrm{Sr}$ and $8.9 \times 10^{14} \mathrm{~Bq}(24 \mathrm{kCi})$ of ${ }^{137} \mathrm{Cs}$. The ARF:RF value for the hot cells and $\mathrm{K}-3$ ducting, shown in Table $3-12$, is $1.0 \times 10^{-3}: 1.0$ from Mishima (1994), Section 5.3.3.2.2 and represents the bounding value for shock-vibration of surface contamination on solid, non-brittle surfaces. The RF value of 1.0 is assumed based on the absence of data pertaining to the particle size distribution of the contamination. This value is conservative for WESF hot cell and K-3 exhaust duct contamination, which has been flooded previously. The resultant form of the contamination is a salt-like material adhering to the surface of the equipment and ducting. Because of the possible continued operation of the K-3 exhaust fans and bypass of the K-3 HEPA filters, the LPF value for the hot cells and K-3 ducting is assumed to be 1.0, resulting in a source term released through the stack of $1.0 \times 10^{13} \mathrm{~Bq}(280 \mathrm{Ci})$ of ${ }^{90} \mathrm{Sr}$ and $8.9 \times 10^{11} \mathrm{~Bq}(24 \mathrm{Ci})$ of ${ }^{137} \mathrm{Cs}$.

For the release from A Cell in the event that the 221-B endwall causes the failure of the A Cell structure, inventory is assumed to be impacted by failed structural components or cover blocks. Such impacts can be modeled by use of the same shock/vibration ARF:RF as was used above for $B$ through $E$ Cells and the $K-3$ exhaust duct. This ARF:RF is $1 \times 10^{-3}: 1.0$. The inventory at risk in A Cell, which is present in the form of contaminated solids in 208 -L (55-gal) drums, is $-5.6 \times 10^{14} \mathrm{~Bq}(15$ $\mathrm{kCi})$ of ${ }^{137} \mathrm{Cs},{ }^{90} \mathrm{Sr}$, or a combination of both. Because of its greater inhalation unit dose, the entire inventory at risk is assumed to be ${ }^{90} \mathrm{Sr}$. The resulting source term from A Cell is $5.6 \times 10^{11} \mathrm{~Bq}(15 \mathrm{Ci})$.

Major Assumptions. The following assumptions were made in the preceding source term analysis.

- The hot cell HEPA filters are assumed to provide no filtration.

- The total inventory of $B$ through E Cells is at risk for a release through the 296-B stack in the DBE. This results in an inventory at risk for this release path of $3.0 \times 10^{15} \mathrm{~Bq}(80 \mathrm{kCi})$ of ${ }^{90} \mathrm{Sr}$ and $8.9 \times 10^{14} \mathrm{~Bq}(24 \mathrm{kCi})$ of ${ }^{137} \mathrm{Cs}$.

- The total inventory at risk in A Cell, and subject to release if the A Cell structure is damaged by failure of the $221-\mathrm{B}$ endwall, is $5.6 \times 10^{i 4} \mathrm{~Bq}(15 \mathrm{kCi})$ of ${ }^{90} \mathrm{Sr}$.

- The inventory at risk in the $\mathrm{K}-3$ ducting is $7.4 \times 10^{15} \mathrm{~Bq}(200 \mathrm{kCi}){ }^{\circ}{ }^{90} \mathrm{Sr}$. 
- The ARF:RF value for all inventories is $1.0 \times 10^{-3}: 1.0$.

- The LPF value for all releases is assumed to be 1.0 .

\subsection{Consequence Analysis.}

Unmitigated Condition. The unmitigated seismic event does not take credit for SSCs that have a high probability of survival due to their seismic resistance. Hence, the importance of these SSCs can be gauged by determining the consequences should they fail. This scenario is no different from the BDBE evaluated in Section 3.4.3.

Mitigated Condition. The dose consequences arising from the DBE (shown in Table 3-18) can be found by multiplying the source term by the dose conversion factors developed in Section 3.4.1.3. Note that the elevated release height is accounted for only in the dose calculations for the onsite receptor. This is because the effects of an elevated release diminish as the receptor distance increases, so that for offsite calculations the effect is insignificant.

Table 3-18. Mitigated and Immediate Design-Basis Earthquake Dose Consequences.

\begin{tabular}{|c|c|c|c|c|}
\hline $\begin{array}{l}\text { Release } \\
\text { Path }\end{array}$ & Isotope & $\begin{array}{l}\text { Source term } \\
\text { (Ci) }\end{array}$ & $\begin{array}{c}\mathrm{DCF} \\
\mathrm{mSv} / \mathrm{Ci}(\mathrm{rem} / \mathrm{Ci})\end{array}$ & $\begin{array}{c}\text { 50-yr Committed } \\
\text { EDE } \\
\mathrm{mSv}(\mathrm{rem})\end{array}$ \\
\hline \multirow[t]{2}{*}{ Stack } & ${ }^{90} \mathrm{Sr}$ & 280 & $0.17(0.017)$ & \multirow[t]{2}{*}{$\begin{array}{l}48(4.8) \text { onsite } \\
100-m \text { worker }\end{array}$} \\
\hline & ${ }^{137} \mathrm{Cs}$ & 24 & $0.021(0.0021)$ & \\
\hline A Cell & ${ }^{90} \mathrm{Sr}$ & 15 & $9.4(0.94)$ & 140 (14) Onsite 100 -m worker \\
\hline \multirow[t]{2}{*}{ Stack* } & ${ }^{90} \mathrm{Sr}$ & 280 & $0.011(0.0011)$ & \multirow[t]{2}{*}{$3.1(0.31)$ public } \\
\hline & ${ }^{137} \mathrm{Cs}$ & 24 & $0.0014(0.00014)$ & \\
\hline A Cell & ${ }^{90} \mathrm{Sr}$ & 15 & $0.011(0.0011)$ & $0.17(0.017)$ public \\
\hline \multirow[t]{2}{*}{ Stack* } & ${ }^{90} \mathrm{Sr}$ & 280 & $0.016(0.0016)$ & \multirow{2}{*}{$\begin{array}{c}4.5(0.45) \\
\text { alternate } \\
\text { site boundary }\end{array}$} \\
\hline & $\begin{array}{l}137 \\
13 s\end{array}$ & 24 & $0.0020(0.00020)$ & \\
\hline A Cell & ${ }^{90} \mathrm{Sr}$ & 15 & $0.016(0.0016)$ & $\begin{array}{c}0.24(0.024) \text { alternate site } \\
\text { boundary }\end{array}$ \\
\hline
\end{tabular}

*Uses conservative ground level release with building wake.

\subsection{Comparison to Guidelines.}

The risk cvaluation guidelines used for the DBE are taken from Section 3.4.1 and Table 3-17. Seismic studies performed for the Hanford Site indicate that a $0.25 \mathrm{~g}$ peak acceleration seismic event has an annual return frequency on the order of $5.0 \times 10^{-4} \mathrm{yr}^{-1}$ (Tallman 1996). However, the K-3 HEPA filter housings are unanchored in the filter pit which could

| cause them to be dislodged by seismic motions, thus causing a HEPA filter bypass (Wagenblast, et al. 1999). Due to the large uncertainty associated with any estimate of a seismic return frequency that could cause this failure, no credit is taken for frequency dependent risk evaluation guidelines in the case of the release through the stack. Thus, the consequences associated with the release through the stack must be compared to the risk craluation guidelines for an anticipated event ( $50 \mathrm{mSv}$ [5 rem] onsite and $5 \mathrm{mSv}[0.5 \mathrm{rem}]$ offsite).

The onsite dose consequence associated with the stack release is $48 \mathrm{mSv}(4.8 \mathrm{rem})$, which is below the onsite 
evaluation guideline of $50 \mathrm{mSv}(5.0 \mathrm{rem})$. The offsite stack release results in $3.1 \mathrm{mSv}(0.31 \mathrm{rem})$ to the offsite receptor which is below the offsite guideline of $5 \mathrm{mSv}(0.5 \mathrm{rem})$. The stack release results in a dose of $4.5 \mathrm{mSv}(0.45 \mathrm{rem})$ at the alternate site boundary.

For the release from A Cell, however, a $0.12 \mathrm{~g}$ seismic event is required (HNF 1998). For the Hanford Site this corresponds to an event frequency of approximately $l \times 10^{-3}$ per year which falls into the range of an unlikely event $\left(1 \times 10^{-2} / \mathrm{yr}\right.$ to $1 \times 10^{-4} / \mathrm{yr}$ ). Thus, for a seismic event large enough to cause a release from A Cell, the appropriate risk evaluation guidelines for an unlikely event are ( $250 \mathrm{mSv}[25 \mathrm{rem}]$ onsite and $50 \mathrm{mSv}$ [5 rem] offsite).

Given a seismic event large enough to cause structural failure of the 221-B endwall, the stack release must also be assumed to occur. Therefore, the stack release consequences must be combined with the $\mathrm{A}$ Cell release consequences for comparison to the risk evaltation guidelines for an unlikely event. The onsite dose consequence is $188 \mathrm{mSv}(18.8 \mathrm{rem})$ which is below the onsite evaluation guideline of $250 \mathrm{mSv}(25 \mathrm{rem})$. The offsite dose is $3.27 \mathrm{mSv}(0.327 \mathrm{rem})$ which is below the offsite evaluation guideline of $50 \mathrm{mSv}(5 \mathrm{rem})$. The dose at the alternate site boundary is $4.74 \mathrm{mSv}(0.474 \mathrm{rem})$.

\subsection{Summary of Safety SSCs and IOSR Controls.}

Credited SSCs. Several SSCs are credited to survive the DBE because they are qualified for those loads. Those SSCs credited as surviving the DBE, qualified to survive the DBE, and whose failure results in exceeding the offsite risk evaluation guidelines of $5 \mathrm{mSv}(0.5 \mathrm{rem})$ are designated "safety class." Those SSCs credited as surviving the DBE, qualified to survive the DBE, and whose failure results in exceeding the onsite risk evaluation guidelines of $50 \mathrm{mSv}(5 \mathrm{rem})$ are designated "safety significant." The basis for their failure consequence is provided in Section 3.4.3.2. These SSCs and their safety functions are as follows.

- Pool cell structure (i.e., Area 3 in structural evaluation)

Safety class function - To retain structural integrity of pool cell water retention and overhead structures in the event of design basis natural phenomena

- Pool cell bridge crane, catwalk, and associated support structures

Safety class function - To maintain support of the bridge crane, maintain the bridge crane load, and maintain support of the catwalk in the event of design basis natural phenomena

- Pool cell drain and circulation piping

Safety class function - To retain pool cell water in the event of $0.25 \mathrm{~g} \mathrm{DBE}$

- K-3 exhaust duct and 296-B-10 stack

Safety significant function - To remain intact and retain structural integrity in the event of a $0.25 \mathrm{~g}$ DBE. This is applicable to the above-ground portion of the K-3 exhaust duct running from the exhaust fans to the stack. Although the duct and stack are required to fulfill a safety significant function, they are designated as safety class for three reasons: (1) they are qualified for safety class natural phenomena loads, (2) future changes to WESF design or mission might require them to be safety class, and (3) maintaining the them to safety class design standards provides a higher level of defense-in-depth.

- K-3 Filter Pit structure

Safety significant function - To protect the K-3 HEPA filter housings from the kinetic energy hazard of a falling K-3 Filter Pit cover block under all design basis natural phenomena (see Section 3.4.3.2). Although this structure is only required to be designated safety significant, WESF will maintain it as a safety class structure for the following reasons: (1) it is qualified for safety class natural phenomena loads, (2) future changes to WESF design 
or mission might require this structure to be safety class, and (3) maintaining the structure to safety class design standards provides a higher level of defense-in-depth.

- Operating Gallery/canyon/hot cell structure (i.e., Area 2 in structural evaluation)

Safety significant function - To confine the radioactive material inventory contained within the hot cells in the form of surface contamination, contaminated combustibles, and capsules in dry storage. This structure is also vulnerable to B Plant end wall interactions that could cause damage to A Cell and the K-l and K-3 ventilation systems. Although this structure is only required to be designated safety significant, WESF will maintain it as a safety class structure for the following reasons: (1) with the exception of B Plant end wall interactions, it is qualified for safety class natural phenomena loads, (2) future changes to WESF design or mission might require this structure to be safety class, (3) the structure performs an important confinement function, especially with respect to the protection of facility workers, and (4) maintaining the structure to safety class design standards provides a higher level of defense-in-depth.

\section{Credited IOSR Controls.}

- None

As stated earlier, the basis for the designation of the SSCs listed above arises from the unmitigated dose consequences calculated in Section 3.4.3. The sole exception is the K-3 exhaust duct and 296-B stack for which no analysis is performed in Section 3.4.3. However, the proper designation for these SSCs can be gleaned from the dose consequences calculated above for the DBE. The DBE consequences do not credit the elevated release to the offsite (or alternate site boundary) receptor and the resulting offsite doses are below risk evaluation guictetines. Therefore, it can be concluded that the exhaust duct and stack do not fulfill a safety class function. However, noting the approximate order-of-magnitude increase in the unit dose factors

from a ground-level to an elevated release, it can be concluded that onsite risk evaluation guticlelines would be exceeded if credit were not given for the survival of the duct and stack.

\subsubsection{External Events.}

This accident type considers the possible effects of events which are man made but external to WESF, that could have an adverse impact on facility safety. These events include loss of electrical power (LOEP), aircraft accidents, vehicle accidents, and accidents at nearby facilities such as B Plant. A more detailed discussion of the accident selection process as it pertains to this accident type is presented in Section 3.3.2.3.5, Accident Selection.

\subsection{Loss of Electric Power.}

\subsection{Scenario Development.}

This section analyzes a facility-wide LOEP accident. The qualitative event frequency assigned in the hazard evaluation process for this event was F2 (i.e., unlikely). The hazard evaluation identifies several consequences as a result of LOEP at WESF. They are as follows:

- Loss of ventilation airflow and subsequent pressure differentials in the hot cells, K-3 exhaust duct, and K-3 filter housings

- Loss of Pool Cell Area ventilation

- The loss of circulation cooling in pool cells.

Unmitigated Condition. Normal electric power to WESF is supplied through the $13.8-\mathrm{kV}$ line from substation $251 \mathrm{~W}$ feeding the 200 Area to substation C8-S26. Substation C8-S26 supplies power to essential WESF circuits through motor control centers in the 225-B and 225-BC Buildings. Additionally, there is a backup power diesel generator that automatically 
picks up loads in case of a normal power failure. After a short delay, the systems supplied with power from the generator are: the $\mathrm{K}-\mathrm{I}$ and $\mathrm{K}-3$ exhaust fans, a vacuum pump for the air monitors, fixed loads, (i.e., instrument power and standby lighting), an air compressor for instrument air, components of the K-5 refrigeration system; the K-5 refrigeration unit itself; and the pool cell circulation pumps. The electrical distribution system for WESF is shown in Chapter 2.0, Figure 2-11.

The LOEP is defined here as a loss of normal power to all essential motor control centers and failure of the backup diesel generator. Power loss to the motor control centers may occur due to failure of the overhead line to substation C8-S26 or multiple failures of feeders, transformers, or circuit breakers within the system. Failure of the backup diesel generator could occur due to failure of the generator to start or run on demand, or failure of the automatic switches (any system component) to bring backup power online.

Facility support systems no longer available under LOEP conditions (including loss of the backup diesel generator) include the following:

- All ventilation supply and exhaust fans

- All pool cell water circulation cooling due to loss of power to circulation pumps

- All CAM alarms, beta monitors, weight factor instrumentation, etc.

Upon failure of the HVAC systems, airborne contaminants in the hot cells, K-3 exhaust duct, and the K-3 filter housings may migrate to other areas within the facility and potentially to the environment. However, this potential spread of contamination has been addressed in Section 3.4.2.4 under a loss of the K-3 ventilation system.

Other concerns arising from a loss of electrical power come from a loss of services in the Pool Cell Area. In the Pool Cell Area there is the potential buildup of hydrogen, which is generated by radiolytic decomposition of the pool cell water. In addition, the ability to remove heat from the pool cell water through the heat exchangers would be lost because the circulation pumps would be inoperable, and the operation of adding makeup water to the pool cells is made more difficult.

Accident progressions for hydrogen accumulation and subsequent explosion in the Pool Cell Area are addressed in Section 3.4.2.5, and for loss of cooling and makeup water are addressed in Section 3.4.2.7. If a hydrogen explosion were to occur, then a loss of pool cell water could be experienced if structural debris fell into a pool cell, or a loss of the ability to provide normal makeup water could be experienced. If hydrogen accumulation did not result in an explosion, then heatup and evaporation of the pool cell water would result if the LOEP continued for a number of days. Accident progression would then be similar to the loss of cooling event described in Section 3.4.2.7, except that all alarms and monitors indicating the state of the pool cells would be disabled. The water level in the pool cells could be maintained in an extended LOEP event by using the normal deionized water makeup (through manual operation of valves). If deionized water was not available or insufficient, then any of the designated sources of makeup water could be used.

The possibility of losing ventilation is addressed in Section 3.4.2.4. The discussion identifies the LOEP as an initiator to a loss of ventilation and indicates that there are no consequences for this event.

Mitigated Condition. Mitigation is provided by the controls for a hydrogen explosion in the pool cell (Section 3.4.2.5), loss of cooling and makeup water (Section 3.4.2.7), and loss of ventilation (Section 3.4.2.4).

Major Assumptions. The following assumptions were made in the scenario development.

- LOEP is defined as loss of normal power to all essential motor control centers and failure of the backup diesel generator.

- Assumptions for the scenario development are provided in loss of confinement, hydrogen explosion in the pool cell, and loss of pool cell water (Sections 3.4.2.4, 3.4.2.5, and 3.4.2.7, respectively). 


\section{HNF-SD-WM-BIO-002 REV 1}

\subsection{Source Term Analysis.}

Unmitigated Condition. As discussed above, there are two possible source terms arising from a LOEP event. The first is the migration of radioactive materials from contaminated areas within the facility. This possibility addresses the loss of confinement in the hot cells, $\mathrm{K}-3$ exhaust duct, and $\mathrm{K}-3$ filter housings and is addressed in Section 3.4.2.4. The conclusion is that no significant consequences outside of the facility would occur. The second source term arises from possible loss of pool cell water from either a hydrogen explosion or a loss of makeup water and cooling. These possibilities are addressed in Section 3.4.2.5 for the hydrogen explosion and Section 3.4.2.7 for the loss of cooling and makeup water.

Mitigated Condition. See the source term analysis for a hydrogen explosion in the pool cell and loss of pool cell water (Section 3.4.2.5).

Major Assumptions. See the assumptions for a hydrogen explosion in the pool cell and loss of pool cell water (Section 3.4.2.5).

\subsection{Consequence Analysis.}

Unmitigated Condition. The consequences of a LOEP event fall into two categories: (1) impacts resulting from loss of confinement in contaminated areas and (2) impacts to capsule storage in the pool cells.

As stated earlier in the accident analysis, the consequences of a loss of ventilation and subsequent loss of confinement is addressed in Section 3.4.2.4. That evaluation concludes that migration of contamination from the effected areas would result in localized consequences within the facility. In addition, for such migration to occur, the ventilation system would need to be inoperable for an extended period of time.

Capsule storage in the Pool Cell Area would be effected by the LOEP event by loss of the K-1 ventilation system and loss of pool cell water cooling capability. The loss of ventilation presents a hydrogen accumulation concern within the Pool Cell Area, which is addressed in Section 3.4.2.5. The loss of cooling for the pool cell water presents several concerns: rapid water loss from high-temperature evaporation and boiling, habitability of the Pool Cell Area because of lack of electrical services (i.e., lighting and the temperatures and humidity from the hot pool cell water; and complications in the process of adding makeup water because of habitability problems in the Pool Cell Area and the increased demand for makeup water.

Mitigated Condition. See the consequence analysis for a hydrogen explosion in the pool cell and loss of pool cell water (Section 3.4.2.5).

\subsection{Comparison to Guidelines.}

Unmitigated Condition. Of the two consequences identified for a LOEP event, only the unmitigated consequences of a loss of pool cell water, resulting from either a hydrogen explosion or loss of cooling and makeup, exceed either the onsite or offsite risk evaluation guidelines. A hydrogen explosion in the Pool Cell Area is analyzed in Section 3.4.2.5. The loss of pool cell water due to failure to provide cooling and makeup is analyzed in Section 3.4.2.7.2.

Mitigated Condition. See the mitigated condition comparison for a hydrogen explosion in the pool cell and loss of pool cell water (Section 3.4.2.5).

\subsection{Summary of Safety SSCs and IOSR Controls.}

Based on the consequences of the LOEP event, the necessary SSCs and IOSR controls pertain to the desire to maintain water in the pool cells. To that end, the possibility of a hydrogen explosion in the Pool Cell Area and loss of cooling and makeup must be controlled. The controls used to prevent and mitigate the consequences of a LOEP event include those items used to prevent or mitigate a hydrogen explosion in the Pool Cell Area, and those items that ensure that makeup water is available during the LOEP. 
Those controls designated as preventing a hydrogen explosion in the Pool Cell Area are discussed in Section 3.4.2.5.5. Those controls are sufficient to prevent a hydrogen explosion in the Pool Cell Area that is initiated by a LOEP event.

The controls necessary to ensure that the makeup water is available to the pool cells are specified in Section 3.4.2.7. Given the severe consequences of a loss of pool cell water, those controls are sufficient to provide makeup water to the pool cells in the event of an LOEP.

\subsection{Adjacent Facilities.}

This section evaluates the direct impact on WESF due to the possible release of hazardous materials and energies from nearby facilities. The closest, and by far the most significant, facility is B Plant. Accidents at B Plant are significant to WESF for two reasons. First, the release at B Plant could initiate a subsequent accident at WESF. Second, a release at B Plant could hamper recovery actions should WESF operating personnel be in the process of responding to a common cause event, (e.g., an earthquake or loss of offsite power). As in the case of natural phenomena events, WESF is prepared for such external and manmade hazards. Adjacent facility hazards were not originally considered in the WESF HAZOP but are considered in this BIO.

\subsection{Adjacent Facility Release from Seismic Event.}

This section addresses a potential impact to WESF recovery operations due to releases from B Plant facilities in the event of a $0.12 \mathrm{~g}$ seismic event. Structural interactions between B Plant and WESF are discussed in Section 3.4.2.1. The current B Plant safety documentation (HNF 1998) indicates that a mitigated dose commitment of several $\mathrm{mSv}$ (rem) is possible to the onsite (i.e., $100 \mathrm{~m}[328 \mathrm{ft}]$ ) receptor due to various causes. It should be noted that the $B$ Plant DBE of $0.12 \mathrm{~g}$ is less severe than the $0.25 \mathrm{~g}$ seismic event that is the accident analysis DBE for WESF. A BDBE for the B Plant is considered to be a seismic event having a horizontal ground acceleration greater than $0.20 \mathrm{~g}$. Unmitigated doses for the B Plant BDBE are several $\mathrm{mSv}(\mathrm{rem})$ to the onsite receptor.

In the event of a WESF DBE (i.e., $0.25 \mathrm{~g}$ ), an unavoidable release is possible from the K-3 HEPA filter system. The WESF post-DBE actions must focus on maintaining water level in the pool cells. The WESF water supply systems are already vulnerable to the WESF DBE. The radiological releases caused by mechanical resuspension from $B$ Plant could cause the evacuation of WESF. However, this plume would be very brief and would not prevent entry of essential personnel back into WESF with the proper protective gear.

\subsection{Adjacent Facility Release from Snow and Ashfall.}

As discussed in Section 3.4.2.1, WESF was divided into three areas for structural design analysis. Area 1, the Support Area, was designed for a live load of $0.96 \mathrm{kPa}\left(20 \mathrm{lb} / \mathrm{ft}^{2}\right)$. Areas 2 and 3, the canyon and Pool Cell Areas, were designed for dead loads plus a live load of $0.96 \mathrm{kPa}\left(20 \mathrm{lb} / \mathrm{ft}^{2}\right)$. All three areas have a high probability of surviving a combined snow and volcanic ashfall loading. However, B Plant satety documentation (HINF 1998) assumes a 221-B Building roof collapse in this event which results in a significant release and dose commitment to the onsite receptor.

Several hours warning would be expected as the snow and ash must accumulate on B Plant roof over a period of time. Additionally, if the 221-B Building roof did collapse, the resulting release would exist for only a brief period of time and would not prevent essential WESF operations such as maintaining pool cell water level. Therefore, no special controls with respect to this hazard are required.

\subsection{Adjacent Facility Release from Operational Accidents.}

Several "operational" accidents are postulated to occur in the B Plant accident analysis (HNF 1998).. None of these events leads to consequences that exceed onsite risk evaluation guidelines. The WESF mission is important and can lead to significant safety consequences if interrupted for a long period of time (i.e., several days). However, none of the B Plant operational accidents mentioned above would prevent WESF essential operations. Therefore, no special controls, with respect to these hazards are required. 


\subsection{Aircraft Impact.}

The potential for an aircraft impact on WESF can be evaluated from analyses performed from other facilities. Muhlestein (1994) performed a frequency analysis for aircraft crashes into sites operated as part of the Multi-Function Waste Tank Facility (MWTF). That analysis encompasses civilian, military, and pesticide/herbicide over-flights of MWTF sites, with the aircraft associated with traffic from all known local airports. The result of the analysis indicates that an aircraft impact into an MWTF site is beyond extremely unlikely (less than $\left.1.0 \times 10^{-6} \mathrm{yr}^{-1}\right)$. This conclusion is conservative with respect to WESF since the area occupied by the MWTF sites $\left(0.04 \mathrm{~km}^{2}\left[0.015 \mathrm{mi}^{2}\right]\right)$ is much larger than the area occupied by WESF $\left(0.001 \mathrm{~km}^{2}\left[0.0005 \mathrm{mi}^{2}\right]\right)$ (see Chapter 2.0$)$. However, this analysis is applicable only to commercial, military flights, and herbicide/pesticide application parameters over which the DOE has only partial control of (width of flight corridors, military flight paths, etc.) and is dependent on a single year of flight data from nearby airfields. Due to the variability of the data used in the calculations, flight data was doubled in an effort to conservatively bound the event frequency.

In addition to Muhlestein (1994), an unreviewed safety question screening was performed to evaluate the likelihood of a helicopter crash impacting the B Plant and WESF during over-flights for radiation detection. The results of the screening showed that the event frequency for this type of aircraft crash is also beyond extremely unlikely. However, this conclusion remains true only for approximately four such flights per year and neglects other over-flights.

Based on the discussion above and the possibility of over-flights for purposes as yet unknown, it is difficult to substantiate either the credibility or incredibility $\left(1.0 \times 10^{-6} \mathrm{yr}^{-1}\right)$ of an aircraft impact at WESF. For that reason, the potential consequences of such an event will be evaluated to provide a better understanding of overall risks to the facility.

An aircraft crash into WESF could result in impacts to the radioactive materials present in the facility. The consequences of such an impact could be similar to those postulated to follow the BDBE analyzed in Section 3.4.3, except that facility damage should be more localized and Hanford Site resources more readily available. Although the aircraft could impact the K-3 and $\mathrm{K}-1$ filters, more severe consequences would be expected if the aircraft impacted the hot cells and/or pool cells in the 225-B Building. By far the worst-case consequences would arise from failed building structural components or aircraft components causing the failure of one or more pool cells with subsequent loss of pool cell water in one or more pool cells. Such an impact could also result in a fire. On the basis of the consequences associated with a loss of pool cell water (Section 3.4.2.7.2), the airspace above WESF is declared a no-flight zone for local, low-level flights.

\subsection{Ground Vehicle Impact.}

The prospect of ground vehicular traffic accidents involving WESF were considered in the hazards evaluation. Those areas of the facility that are particularly vulnerable to vehicle traffic are the $\mathrm{K}-1$ and $\mathrm{K}-3$ ventilation fans, the electrical distribution substation, and the Truckport. WHC-SD-TP-RPT-021, Rev. 0, Hanford Site Truck Accident Rate, 1990-1995, provides a quantitative analysis of the likelihood of truck accidents at the Hanford Site. While the report focuses on trucks carrying radioactive material shipments, all accidents resulting in personnel injury or death, or greater than a specified amount of property damage are considered in estimating the truck accident frequency.

The truck accident rate report indicates that six truck accidents (non-fender benders) occurred at the Hanford Site from 1990 to 1995. Of these six, none involved a truck impact to a stationary object like a building. The truck accident rate is estimated to be less than $2.0 \times 10^{-7}$ accidents per mile. While this analysis is not conducive to determining if a vehicle impact into WESF is either credible or incredible, it provides an insight into the relatively improbable nature of such an event. This value is conservative for application to hazards and safety analyses because many vehicle accidents may occur above the property damage threshold that do not result in impacts to vital facility SSCs.

The consequences that could be expected from a vehicle impact into a facility area lead to a possible loss of electric power (Section 3.4.2.2.1), a loss of K-3 ventilation (Section 3.4.2.4), a loss of K-1 ventilation (Section 3.4.2.5); and a loss of confinement in the Truckport (Section 3.4.2.3.2). 


\section{HNF-SD-WM-BIO-002 REV 1}

\subsubsection{Facility Fires.}

This section includes consideration of all fires identified in the hazards evaluation in fley (1999). These can be grouped into Truckport fires, hot cell fires, waste drum fire (A Cell), and K-3 HEPA filter fires.

The Truckport fire and a hot cell fire impacting the K-3 HEPA filters were selected for quantitative analysis. Due to the wide range in hazardous material inventory and physical configurations, hot cell fires are considered for all hot cells. The possibility of a K-3 HEPA filter fire is combined with the hot cell fire and is not called out for separate analysis. The

1 Truckport fire considers the LLWs stored there and the presence of the WESF hot cell drums or a loided WIXM. A more detailed discussion of the accident selection process pertaining to this accident type is included in Section 3.3.2.3.5.

\subsection{Hot Cell Fire.}

\subsection{Scenario Development.}

The possibility of a facility fire involving the hot cells is identified in the hazards evaluation in Hey (1999) as having an F2 (i.e., unlikely) frequency rank and an S3 (i.e., public impact) severity rank. This results in a risk rank of R3 (i.e., events of major concern). To ensure that the accident analysis envelopes all potential consequences, the fire is modeled based on the fire characteristics presented in the WESF FHA (Mert7 1998) in conjunction with specific considerations for each cell. Impacts to, and reactions of, the hot cell, canyon, and ventilation SSCs are also modeled.

From the analysis of the worst case hot cell fire, the FHA concluded that no significant damage to the hot cell, canyon, or K-3 SSCs would occur. It also concluded that there would be no burn-through of the K-3 HEPA filter due to burning embers. The elevated temperatures associated with the fire could cause lailure of the hot cell windows and a release of the oil inco the cell. The only significant physical impact to facility SSCs arises from potential plugging of the K-3 HEPA filters by the smoke released from the fire. The potential for such plugging is addressed in this accident analysis.

The analysis in this section addresses a potential hot cell fire in the following groups: A Cell, B through E Cells, and F and G Cells.

A Cell. A Cell contains radioactive solid wastes generated in other hot cells. The wastes are packaged in 208-L (55gal) steel drums, which are staged in A Cell until they can be removed for disposal. Because of the 208-L (55-gal) drums, a fire involving this waste would have to be initiated by some phenomena inside a drum, such as ignition of flammable gases (produced as a result of degrading wastes) because of static electricity or mechanical spark. Since no combustibles (other than the in-use manipulator boot) are present in A Cell outside of 208-L (55-gal) drums, the electrical service to the hot cell and mechanical sparks outside of the drums could not initiate a fire that would impact the waste.

If flammable gases were ignited inside the drum, the integrity of the drum could be significantly degraded, resulting in more complete oxidation and venting of combustion gasses. For the purposes of bounding the potential consequences, it is assumed that the entire contents of the drum are consumed in the fire. Also, for the same reason, it is assumed that the drum fire propagates to the other drums in the hot cell. This assumption also encompasses possible operating conditions in which the drums are not sealed or have their lids entirely removed.

In the analysis of a fire in A Cell it is assumed that the plug port or one or both cover blocks has been removed and that the fire burns to completion.

Unmitigated Condition. For the unmitigated scenario, the K-3 HEPA filters are assumed to fail leaving an open flowpath. This would result in smoke, combustion gases, and small amounts of airborne radioactive materials released from the cell, through the K-3 exhaust duct, through the active K-3 filter housing, and out of the facility.

Mitigated Condition. For the mitigated scenario, the K-3 HEPA filters do not suffer structural failure. The release would be filtered until the K-3 HEPA filters became loaded with smoke. Then the release and fire would be limited because of 
the lack of fuel and the lack of motive force for removal of the airborne radioactive material. The $\mathrm{K}-3$ ventilation system response to this condition is discussed below.

Major Assumptions. The following assumptions were made in the A Cell scenario development:

- HEPAs fail in the unmitigated case leaving an open flowpath through the K-3 system

- HEPAs plug with smoke and ventilation flow stops in the mitigated case

- The fire propagates to consume combustibles in all waste drums stored in A Cell

- The plug port and cover blocks are removed.

B through E Cells. B through E Cells were used for strontium (B and C Cells) and cesium (D and E Cells) processing. The radioactive material is in the form of contaminated thoor sweepings in boats pipes. contamination on walls, contamination on equipment, and limited amounts of combustibles. The combustibles are predominantly plastics (neoprene manipulator boots, plastic sheeting, etc.) and cellulosics (rags and wood).

A fire could be initiated in one of B through E Cells by the electrical service to the hot cell or by mechanically generated sparks impacting the solid waste (with subsequent smoldering and then flaming combustion). A fire in B Cell could propagate to $C$ Cell (and from $C$ to $B$ Cell) by an open pass-through connecting them. A fire in D Cell could likewise involve E Cell (and E to D Cell) because these hot cells are essentially one large cell. Therefore, $B / C$ and $D / E$ Cells are treated as single hot cells for the purposes of this analysis.

Unmitigated Condition. If a fire were initiated in $\mathrm{B} / \mathrm{C}$ or $\mathrm{D} / \mathrm{E}$ Cells it is likely that the in-cell ventilation outlet HEPA filter would fail because of the high temperatures associated with the fire. Smoke, combustion gases, and airborne radioactive material would then be transported down the K-3 exhaust duct and into the active $\mathrm{K}-3$ filter housing. Unmitigated, the airbome radioactive material would be released out of the facility through the stack.

Mitigated Condition. For the mitigated scenario, the K-3 HEPA filters act to remove the radioactive material until they eventually became plugged due to smoke loading. The fire would be limited because of a lack of oxygen and a lack of motive force for removal of the airborne radioactive material. Because B through E Cells are not normally accessed through the plug ports or cover blocks, it is assumed in this analysis that they are in place during the fire. This mitigating feature limits combustion.

Since it was found that the onsite risk evaluation guidelines were still exceeded after taking credit for the K-3 HEPA filters and the hot cell cover blocks being in place, a control was placed on the amount of combustibles allowed in the cells to prevent plugging of the $\mathrm{R}-3$ filters.

Major Assumptions. The following assumptions were made in the B through $\mathrm{E}$ Cell scenario development:

- A fire in B Cell propagates to C Cell (and vice-versa). Similarly a fire in D Cell propagates to E Cell (and viceversa).

- The plug ports and cover blocks are in place.

- HEPAs fail in the unmitigated case leaving an open flowpath through the $\mathrm{K}-3$ system.

- HEPAs plug with smoke and ventilation flow stops in the mitigated case.

F and G Cells.

Unmitigated Condition. Cells $\mathrm{F}$ and $\mathrm{G}$ are used to store and handle cesium and strontium capsules. They do not 


\section{HNF-SD-WM-BIO-002 REV 1}

contain appreciable radioactive contamination outside of capsules and normally do not contain significant quantities of combustibles (except in-use manipulator boots). The capsules are resistant to fires as documented in Hammond (1975), Tingey (1985), and Washburn (1989). However, it is anticipated that suspect or known compromised capsules may be stored in $F$ and $G$ Cells and the capacity of these capsules to resist the effects of a fire is unknown. On this basis, an administrative control is required to prevent the concurrent conditions of capsules in the hot cell, loose combustibles in the hot cell, and hot cell cover block or plug removed. Since the BUSS cask has been shown to be able to withstand the effects of a severe fire (SNL 1991) this control does not apply to capsules contained within a secured BUSS cask.

Mitigated Condition. No mitigated condition is analyzed due to the lack of combustibles and consequences discussed above.

Major Assumptions. The following assumptions were made in the F/G Cell scenario development:

- The cells do not contain significant quantities of combustibles.

- Pass-through doors between A and B Cells, C and D Cells, and E and F Cells are normally closed. They may be opened for specific operations but are closed at the conclusion of the operation.

K-3 Ventilation System Response to a Hot Cell Fire. Because of active ventilation, smoke generated in the fire would migrate to and load the K-3 HEPA filters through one of two pathways, depending on the location of the fire. For A Cell, the smoke would exit the hot cell directly into the K-3 exhaust duct beneath the cell and into the canyon through the open plug port or cover block. Both pathways lead to the K-3 filters. For B/C and D/E Cells, the smoke would exit the cell through the $\mathrm{K}-3$ exhaust duct beneath the cells and proceed directly to the K-3 filters.

The WESF FHA indicates that an equivalent mass of $18 \mathrm{~kg}$ of polystyrene in addition to the oil in wo windows is required to effectively plug the K-3 HEPA filters. For the unmitigated case, the K-3 IIEPA filter's are assimed to plug. If the K-3 HEPA filters did not plug they would continue to perform their filtration function resulting in an insignificant release from the facility.

If the filters in the active filter housing were to become sufficiently loaded such that the pressure in the duct upstream from the filters approaches atmospheric, a series of responses is triggered in the $\mathrm{K}-3$ system. The pressure sensor in the $\mathrm{K}-3$ exhaust duct, just downstream from $\mathrm{G}$ Cell, would initiate the following actions:

- Alarms in the Operating Gallery and supervisory panel would be activated

- The K-3 supply fan would be deactivated

- The second K-3 HEPA filter housing would be activated

- The $\mathrm{K}-1$ exhaust fans would be deactivated, leading to deactivation of the $\mathrm{K}-1$ supply and $\mathrm{K}-4$ fan (as the pressure in the $\mathrm{K}-1$ exhaust duct approaches atmospheric)

- The $\mathrm{K} \cdot 2$ system would be deactivated

- The standby K-3 exhaust fan would be activated following a time delay.

If the activation of the second filter housing and standby exhaust fan were to provide sufficient duct vacuum at the location of the pressure sensor, a time delay would be initiated, which, when completed, would return the second K-3 HEPA filter housing to its offline condition. This would cause a restart of the system response (except that the standby K-3 exhaust fan would already be running) and subsequent surging of the system until the filters in the second filter housing also became loaded with smoke.

In this condition, when the HEPA filters become increasingly loaded, the pressure differential across the filters would 


\section{HNF-SD-WM-BIO-002 REV 1}

continue to increase up to the static fan shutoff pressure. The potential for filter failure in this condition can be determined by comparing known filter failure data to the maximum pressure differential across the filters. Mishima (1994), Section 5.4.2.2, indicates that high flow rate HEPA filters (greater than $28.32 \mathrm{~m}^{3} / \mathrm{min}\left[1,000 \mathrm{ft}^{3} / \mathrm{min}\right]$ ) failed in the range of 9 to $15.9 \mathrm{kPa}$ ( 187.97 to $332.08 \mathrm{lb} / \mathrm{ft}^{2}$ ). The maximum pressure that is realized across the filters can be found from an examination of the system operation and characteristics. The maximum static pressure of the exhaust fans is $7.7 \mathrm{kPa}\left(160.82 \mathrm{lb} / \mathrm{ft}^{2}\right)$, which would be the pressure exerted on the filters if they were completely plugged (no flow). This pressure is below $9 \mathrm{kPa}\left(187.97 \mathrm{lb} / \mathrm{ft}^{2}\right)$, the smallest pressure observed to cause filter failure, and thus the fans would not be expected to cause failure of the K-3 filters. Backflow through the K-3 exhaust fans would limit the differential pressure across the filters to approximately the K-3 fan static pressure differential. In this condition the exhaust fans would be operating in a negative flow regime for which no flow and pressure data exists. However, inspection of the fan curves for the exhaust fans shows that for the relatively small backwards flow (approximately $10 \%$ of the normal forward flow) it is anticipated that little deviation would be realized from the maximum static pressure of $7.7 \mathrm{kPa}\left(160.82 \mathrm{lb} / \mathrm{ft}^{2}\right)$.

\subsection{Source Term Analysis.}

The source term analysis is divided into models corresponding to the scenario development for $\mathrm{A}$ Cell and $\mathrm{B} / \mathrm{C}$ plus D/E Cells. F and G Cells, as stated in the scenario development, are controlled such that a fire impacting the capsules stored there is not possible, and therefore, no source term analysis is performed for these cells.

A Cell. A fire in A Cell is assumed to occur during an operation in which the plug port or a cover block has been removed so that an open flowpath exists between the canyon and the hot cell. The source term model for such an occurrence can be derived from the scenario development in Section 3.4.2.3.1.1, in conjunction with appropriate values for the radioactive inventory, ARF:RF, and LPF.

Unmitigated Condition. The inventory used in the analysis for A Cell is the same for both the unmitigated and mitigated conditions. From Table 3-3 it is assumed that $5.6 \times 10^{14} \mathrm{~Bq}(15 \mathrm{kCi})$ of either ${ }^{90} \mathrm{Sr}$ or ${ }^{137} \mathrm{Cs}$ exists in A Cell. For the purposes of bounding the potential consequences, it is assumed that the maximum inventory of ${ }^{90} \mathrm{Sr}$ is present in the hot cell ${ }^{\left({ }^{90} \mathrm{Sr}\right.}$ has a greater unit dose than $\left.{ }^{137} \mathrm{Cs}\right)$. Although the cesium chloride has a greater volatility than the strontium fluoride at higher temperatures, the choice of release fraction bounds both compounds.

The ARF:RF value used to estimate the source term is $5 \times 10^{-4}: 1.0$ from Mishima (1994), Section 5.2.1.1, for packaged wastes. This value is appropriate for wastes in 208-L (55-gal) drums and is used for both the unmitigated and mitigated conditions.

The LPF varies from the unmitigated to the mitigated condition. For the unmitigated condition, the fire would go to completion with the smoke, combustion products, and airborne radioactive material exiting the facility through the K-3 ventilation system. In this case the LPF is 1.0 and the resulting source term is the product of the inventory and ARF:RF, or $2.8 \times 10^{11} \mathrm{~Bq}(7.5 \mathrm{Ci})$ of ${ }^{90} \mathrm{Sr}$.

Mitigated Condition. For the mitigated condition, credit is taken for the confinement afforded by the canyon structure. The K-3 HEPA filters would become plugged from smoke, eliminating the primary motive force (the K-3 system) for the removal of the airborne radioactive material. With the cessation of ventilation airflow, the primary motive force for the release of material becomes the generation of hot combustion gasses within the facility. The most significant path for release of these gasses would be through the K-3 supply duct entering the canyon (after the gases enter the canyon through the opening). Less significant pathways would be from the hot cell to the Operating Gallery; from the canyon to the Truckport, AMU, Service Gallery, and Pool Cell Area, and from the canyon to the environment through an external personnel access door. To account for the releases from such paths, an analysis of the motive forces and flowpaths available is performed.

Two types of releases would occur from the facility during and following such an event: a release because of internal facility pressurization caused by the fire, and migration of contamination caused by natural forces (e.g., wind). The latter is discussed in Section 3.4.2.4 and represents extremely low motive forces that would take long periods of time to develop. The former, however, would provide a significant motive force for the release of material in a relatively short period of time. Based on these considerations, the contribution of natural migration is assumed to be negligible and the release from an A Cell fire is based on the characteristics of the fire. 
To determine the amount of airborne contamination released from the facility, it is assumed that the volume increase associated with the high temperature of the fire and the creation of combustion products causes a commensurate increase in pressure within the facility. This internal pressure is then relieved by venting the increased volume of gas from the facility.

Of the various flowpaths from the facility, the ventilation inlet in the canyon is the most direct. All other flowpaths (e.g., the Truckport and Operating Gallery) require contamination to travel through at least two additional airspaces, and/or through very small openings before exiting the facility. Therefore, for the sake of conservatism, it is assumed that the hot combustion gases and airborne radioactive material enter the canyon through the open plug port or cover block, with the subsequent pressure increase vented through the ventilation inlet.

The volume of the canyon can be found from the description provided in Chapter 2.0, Section 2.4. The canyon is

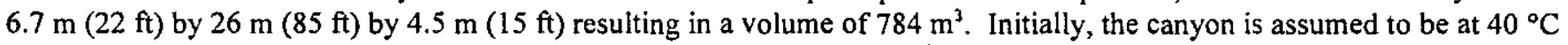
$\left(104^{\circ} \mathrm{F}\right)$ and $1 \mathrm{~atm}$, so that the density of the air is approximately $1.1 \times 10^{3} \mathrm{~g} / \mathrm{m}^{3}$. Thus, initially there is approximately $8.6 \times 10^{5} \mathrm{~g}$ of air in the canyon, or $3.0 \times 10^{4} \mathrm{~mol}$ (using a molecular weight of 29 ).

Following the fire, the increase in volume can be found from the increase in the moles of gases in the canyon and the increase in temperature in the canyon. The hot cell fire analysis in Revision I of the WESF FHA (Mert7. 1997) estimated the canyon temperature to be approximately $180^{\circ} \mathrm{C}\left(356^{\circ} \mathrm{F}\right)$ assuming a combustible loading ol $200 \mathrm{k} g$ in $\mathrm{A}$ Coll. The hot cell fire analysis in the current WESF FHA, Revision 2, (Mert7. 1998) is based on a fire in G Cell itssterd of A Cell and uses a different method of performing the fire analysis. Instead of assuming a combustible loading of $200 \mathrm{~kg}$ in $\mathrm{A}$ Cell. the analysis modeled several different heat release rates from $250 \mathrm{~kW} \mathrm{to} 7.500 \mathrm{~kW}$. The information in Revision 1 of the fHA is still valid and will continue to be used as a relerence in this accident analy sis.

The number of moles of gases generated by the fire is more difficult to ascertain but can be found from the combustion reaction that constitutes the fire.

The primary combustible constituents of the fire are plastics (neoprene manipulator boots) and cellulosics (cloth, wood, etc.). To determine the number of moles of combustion gases created during the fire, some arbitrary assumptions must be made. However, since the accident analysis must be bounding, the sensitivity of the results to these assumptions is examined and the important assumptions highlighted. The plastics are modeled using the chemical formula for neoprene, $\mathrm{C}_{8} \mathrm{H}_{8} \mathrm{OCl}_{2}$, and the cellulosics are modeled as cellulose with a chemical formula of $\mathrm{C}_{6} \mathrm{H}_{10} \mathrm{O}_{5}$. Neoprene is used because it is the primary constituent of the manipulator boots and is conservative because it neglects any non-combustible filler materials. To depict the overall reaction, the two chemical formulas can be combined with the assumption that one-half of the combustibles (by mass) is plastic and one-half is cellulose. An approximate effective chemical formula is then $\mathrm{C}_{7} \mathrm{H}_{9} \mathrm{O}_{3} \mathrm{Cl}$, resulting in an overall combustion reaction of

$$
2 \mathrm{C}_{7} \mathrm{H}_{9} \mathrm{O}_{3} \mathrm{Cl}(\mathrm{s})+15 \mathrm{O}_{2}(\mathrm{~g}) \rightarrow 14 \mathrm{CO}_{2}(\mathrm{~g})+8 \mathrm{H}_{2} \mathrm{O}(\mathrm{g})+2 \mathrm{HCl}(\mathrm{g})
$$

For every 2 mol of combustibles consumed in the A Cell fire, approximately $15 \mathrm{~mol}$ of oxygen are also consumed and $24 \mathrm{~mol}$ of gases are produced. Thus, for every $2 \mathrm{~mol}$ of combustibles consumed in the fire, a net of 9 mol of gases are produced. Other elements in the combustion formula presented above would have a relatively minor impact on the moles of gas produced.

It is assumed that $200 \mathrm{~kg}$ of combustibles are burned in the fire, which is slightly greater than the value used in the WESF FHA (Mertz 1998). The effective molecular weight of the combustibles is $177 \mathrm{~g} / \mathrm{mol}$ (the molecular weight of $\mathrm{C}_{7} \mathrm{H}_{9} \mathrm{O}_{3} \mathrm{Cl}$ ), yielding $1.1 \times 10^{3} \mathrm{~mol}$ of combustibles. Following combustion, the resulting amount of gases entering into the canyon is $5.0 \times 10^{3} \mathrm{~mol}$. The quantity of gases already in the canyon plus the quantity of gases entering the canyon from the fire is $3.0 \times 10^{4}+5.0 \times 10^{3}=3.5 \times 10^{4} \mathrm{~mol}$.

Given the increase in temperature and moles of gases, the increase in volume can be estimated by using the ideal gas law for the conditions before and following the fire: 


\section{HNF-SD-WM-BIO-002 REV 1}

$$
\begin{gathered}
\frac{P_{1} V_{1}}{P_{2} V_{2}}=\frac{n_{1} R T_{1}}{n_{2} R T_{2}} \\
\text { where: } \\
P_{1}=P_{2}=\text { canyon pressure } \\
V_{1}=\text { initial volume of gases in canyon }\left(784 \mathrm{~m}^{3}\right) \\
V_{2}=\text { final effective volume of gasses in canyon }(\text { unknown }) \\
n_{1}=\text { initial gas moles in canyon }\left(3.0 \times 10^{+} \mathrm{mol}\right) \\
n_{2}=\text { final effective gas moles in canyon }\left(3.5 \times 10^{+} \mathrm{mol}\right) \\
R=\text { universal gas constant } \\
T_{1}=\text { initial temperature of gases in canyon }\left(313^{\circ} \mathrm{K}\left[40^{\circ} \mathrm{Cl}\right)\right. \\
T_{2}=\text { final temperature of gases in canyon }\left(450^{\circ} \mathrm{K}\left[180^{\circ} \mathrm{C}\right] \text { from } \mathrm{FHA}\right)
\end{gathered}
$$

The pressure is the same before and after the fire because the building will not retain pressure, and the universal gas constant is the same so that these parameters cancel. Solving the equation for $\mathrm{V}_{2}$ and substituting the appropriate values yields.

$$
\begin{aligned}
V_{2} & =V_{1} \cdot\left(\frac{n_{2} T_{2}}{n_{1} T_{1}}\right) \\
=\left(784 \mathrm{~m}^{3}\right) \cdot( & \left(\frac{\left(3.5 \times 10^{+} \mathrm{mol}\right)\left(450^{\circ} \mathrm{K}\right)}{\left(3.0 \times 10^{+} \mathrm{mol}\right)\left(313^{\circ} \mathrm{K}\right)}\right) \\
& =1,300 \mathrm{~m}^{3}
\end{aligned}
$$

The total quantity of radioactive material made airborne in the A Cell fire is the same value as calculated for the source term in the unmitigated case above and is $2.8 \times 10^{11} \mathrm{~Bq}(7.5 \mathrm{Ci})$ of ${ }^{90} \mathrm{Sr}$. Assuming that the material is uniformly mixed and that all the material enters the canyon, the concentration of radioactive material in the $1,300 \mathrm{~m}^{3}$ volume is $2.2 \times 10^{8} \mathrm{~Bq} / \mathrm{m}^{3}$ of ${ }^{90} \mathrm{Sr}$.

The volume of gases that must exit the canyon (through the $\mathrm{K}-3$ supply duct) is approximately $516 \mathrm{~m}^{3}\left(1,300 \mathrm{~m}^{3}\right.$ $\left.784 \mathrm{~m}^{3}\right)$. The source term from the facility is then $516 \mathrm{~m}^{3}$ times the concentration of radioactive materials, or

$$
\begin{gathered}
\text { Source } \text { Term }_{A \text { Cell, }{ }^{00} S r}=\left(516 \mathrm{~m}^{3}\right) \cdot\left(2.2 \times 10^{8} \frac{\mathrm{Bq}}{\mathrm{m}^{3}}\right) \\
=1.1 \times 10^{11} \mathrm{~Bq}(3.0 \mathrm{Ci})
\end{gathered}
$$

Major Assumptions. The following assumptions were made in the preceding A cell source term development:

- The radioactive inventory is $15 \mathrm{kCi}$ of ${ }^{90} \mathrm{Sr}$.

- The ARF:RF value is $5 \times 10^{-4}: 1.0$ from Mishima (1994), Section 5.2.1.1 for packaged wastes.

- The LPF value is 1.0 for the unmitigated scenario corresponding to no HEPA filtration.

- For the mitigated scenario, natural migration of contamination is assumed to play a minor role compared to the 
contamination spread caused by hot gases generated during the fire.

- The initial temperature of the canyon is $40^{\circ} \mathrm{C}\left(104^{\circ} \mathrm{F}\right)$.

- To calculate combustion gas generation, manipulator boots are assumed to be neoprene, $\mathrm{C}_{8} \mathrm{H}_{8} \mathrm{OCl}_{2}$, and the cellulosics are modeled as cellulose with a chemical formula of $\mathrm{C}_{6} \mathrm{H}_{10} \mathrm{O}_{5}$.

- One-half of the combustibles (by mass) is plastic and one-half is cellulose.

- $200 \mathrm{~kg}(441 \mathrm{lb})$ of combustibles are burned in the fire (Mertz 1998).

Of the latter three assumptions, only the assumption of $200 \mathrm{~kg}(441 \mathrm{lb})$ of combustibles had a significant impact on the results of the analysis. The assumptions concerning the types and percentages of combustibles are approximations which have very little influence on results of the calculations.

\section{$\underline{B / C}$ and D/E Cells}

Unmitigated Condition. An unmitigated fire initiated in either $\mathrm{B} / \mathrm{C}$ or $\mathrm{D} / \mathrm{E}$ Cells would follow the same progression of events as an unmitigated A Cell fire (assuming that the cover blocks and plug ports are in place but the filters have failed). The source term for such an event would be different, however, because of different inventory and ARF:RF values.

The inventory in $\mathrm{B} / \mathrm{C}$ Cell and furnace is given in Table $3-3$ and is $3.0 \times 10^{15} \mathrm{~Bq}(80 \mathrm{kCi})$ of ${ }^{90} \mathrm{Sr}$ and $1.5 \times 10^{14} \mathrm{~Bq}$ $(4 \mathrm{kCi})$ of ${ }^{137} \mathrm{Cs}$. The inventory in $\mathrm{D} / \mathrm{E}$ Cell is $7.4 \times 10^{14} \mathrm{~Bq}(20 \mathrm{kCi})$ of ${ }^{137} \mathrm{Cs}$. Because ${ }^{90} \mathrm{Sr}$ has a greater unit dose consequence than ${ }^{137} \mathrm{Cs}$, the fire is assumed to occur in $\mathrm{B} / \mathrm{C}$ Cell so as to bound the calculated dose consequences.

Also, since the wastes in B/C and D/E Cells are unpackaged, the appropriate ARF:RF of $1 \times 10^{-2}: 1.0$ from Mishima (1994), Section 5.2.1.2 for the burning of uncontained, contaminated, largely cellulosic combustibles is used. This value can be compared with $6 \times 10^{-3}: 0.01$ for the heating of contaminated, non-combustible surfaces (Mishima 1994) which would be appropriate for modeling the release from walls, equipment, and other non-combustible surfaces. However, the distribution of the contamination within the hot cell is unknown, and for the sake of conservatism, it is assumed that all of the contamination is present on the combustibles. The ARF:RF of $1 \times 10^{-2}: 1.0$ also bounds the release of cesium chloride, which has a greater volatility than the strontium fluoride at higher temperatures.

The unmitigated source term for a fire in $\mathrm{B} / \mathrm{C}$ Cell (which bounds $\mathrm{D} / \mathrm{E}$ Cell) is the product of the inventory and the ARF:RF, or $3.0 \times 10^{13} \mathrm{~Bq}(800 \mathrm{Ci})$ of ${ }^{90} \mathrm{Sr}$ and $1.5 \times 10^{12} \mathrm{~Bq}(40 \mathrm{Ci})$ of ${ }^{137} \mathrm{Cs}$. This source term would be released through the $\mathrm{K}-3$ system and stack, assuming failure of the K-3 filters.

Mitigated Condition. For the mitigated case, credit is taken for the K-3 HEPA filters and the normally installed plug ports and cover blocks on B through E Cells. In the early stages of the fire, the K-3 HEPA filters would act to filter any airborne radioactive materials, essentially eliminating a release outside of the facility. In the later stages of the fire, the filters would become loaded with smoke and the K-3 system would respond as discussed in the scenario development (resulting in cessation of ventilation airflow). With the loss of ventilation airflow and the absence of a significant influx of oxygen, the fire would halt flaming combustion at approximately $19 \%$ oxygen (by volume) and would smolder until the concentration of oxygen reached approximately $11 \%$ and then would be extinguished. This assumption is supported by the WESF FHA, which shows that for a fire in A Cell with the personnel access door closed and the cover blocks and plug ports in-place, the heat release rate from the fire ceases after approximately $300 \mathrm{~s}$ (Mertz 1998). However, for the purposes of simplicity of calculation and conservatism, it is assumed that the fire proceeds to complete consumption of all available oxygen.

The analysis below indicates that after taking credit for the K-3 HEPA filters and the in-place plug ports and cover blocks, the onsite dose consequences still exceed the appropriate risk evaluation guidelines. Therefore, an additional control is necessary to further mitigate or prevent the hot cell fire in B through E Cells. For that reason, a control is placed on the amount of combustible allowed to be stored in the hot cells (including the oil in the hot cell window). 
The methodology used to calculate the source term exiting the facility in the mitigated case is complicated by the necessity of modeling the release as it progresses from the hot cell to the canyon and finally to the environment. The methodology used for the $\mathrm{B} / \mathrm{C}$ Cell fire is summarized in the following steps:

1. Estimate the quantity of airborne radioactive material entering the canyon from the hot cell, including the following:

- The volume increase in the hot cell gases due to the temperature rise and production of combustion gases

- The concentration of radioactive material in the total volume of hot cell gases.

2. Estimate the quantity of airborne radioactive material exiting the canyon to the environment, including modeling the mixing of the canyon air and the gases exiting the hot cell which must account for the following:

- The resulting mixture temperature

- The volume increase in the canyon due to elevated temperature and an increase in the quantity of gases

- The concentration of airborne radioactive material in the canyon.

3. Account for the prevention of the release due to the control of combustible loading the hot cells.

No ARF:RF data could be found to distinguish between flaming and smoldering combustion, so it is assumed that the ARF:RF used for the unmitigated case applies to the mitigated case until the fire is extinguished at $11 \%$ oxygen. Further, since the distribution of the radioactive material in the hot cells is unknown, it is assumed that the entire inventory is impacted by the fire. The amount of contamination made airborne in the hot cell is then the product of the inventory and the ARF:RF (the same as the unmitigated case), or $3.0 \times 10^{13} \mathrm{~Bq}(800 \mathrm{Ci})$ of ${ }^{90} \mathrm{Sr}$ and $1.5 \times 10^{12} \mathrm{~Bq}(40 \mathrm{Ci})$ of ${ }^{137} \mathrm{Cs}$.

Unlike the unmitigated case, however, the only significant motive force for the removal of airborne radioactive materials is the high temperature in the hot cell and the creation of combustion products. The temperature in the hot cell is taken from the FHA for the A Cell fire case where the cell is closed (i.e., plug, cover block, and personnel access door is in place). In that case, the FHA shows that the maximum temperature reached in the hot cell is approximately $400^{\circ} \mathrm{C}\left(752^{\circ} \mathrm{F}\right)$ (Mertz 1998).

The quantity of combustion gases created in the fire can be estimated using the same methodology as presented in the source term analysis for the A Cell fire. Instead of the combustibles acting as the limiting component of the fire, the available oxygen will limit the fire. From Chapter 2.0, Section 2.4, the internal dimensions of B and C Cells results in a total volume of $44 \mathrm{~m}^{3}$. This volume of air is $4.8 \times 10^{4} \mathrm{~g}$ of air (density of $1.1 \times 10^{3} \mathrm{~g} / \mathrm{m}^{3}$ ), or $1.7 \times 10^{3} \mathrm{~mol}$ (molecular weight of 29 ).

Assuming an ideal gas, the volume percent is equal to the mole percent so that the number of moles of oxygen initially in the cell is $21 \%$ of the total number of moles, or $357 \mathrm{~mol}$ of oxygen. As shown in the source term analysis for an A Cell fire, 24 mol of combustion gases are produced for every $15 \mathrm{~mol}$ of oxygen consumed so that $357 \mathrm{~mol}$ of oxygen would produce a net of $571 \mathrm{~mol}$ of combustion products.

As with the A Cell source term analysis above, the high temperature and additional gases can be accounted for by assuming that the additional volume of gases are vented through the path of least resistance. Given that the plug port and cover blocks are in place, the single largest flowpath from the hot cell is the K-3 ventilation inlet that leads to the canyon. The other possible flowpaths out of the hot cell are around the closed pass-throughs to other hot cells, manipulator penetrations into the Operating Gallery, and gaps around the cover blocks leading to the canyon. The K-3 exhaust system has already been assumed to be plugged so the release could not follow this path. In addition, it is conservative to assume that all the radioactive material exits the facility in the same path because this maximizes the calculated release.

As in the case of the A Cell fire, the additional volume of gases generated as a result of the fire can be calculated using the ideal gas law, as was done for the A Cell fire. The ratio of the number of moles and temperature before and after the fire yields $a V_{2}$ of 


$$
\begin{gathered}
V_{2}=V_{1} \cdot\left(\frac{n_{2} T_{2}}{n_{1} T_{1}}\right) \\
=\left(44 \mathrm{~m}^{3}\right) \cdot\left(\frac{(2271 \mathrm{~mol})\left(673^{\circ} \mathrm{K}\right)}{(1,700 \mathrm{~mol})\left(313^{\circ} \mathrm{K}\right)}\right) \\
=127 \mathrm{~m}^{3} \\
\text { Where: } V_{1}=\text { initial gas volume } \in \text { the hot cells }\left(44 \mathrm{~m}^{3}\right) \\
V_{2}=\text { final, effective volume of gasses (unknown) } \\
n_{1}=\text { initial number of moles of gases in the hot cells }(1700 \mathrm{~mol}) \\
n_{2}=\text { final effective number of moles of gases }(2271 \mathrm{~mol}) \\
T_{1}=\text { initial temperature of the hot cell gases }\left(313^{\circ} \mathrm{K}\left(40^{\circ} \mathrm{CJ}\right)\right. \\
T_{2}=\text { final temperature of gases in canyon }\left(673^{\circ} \mathrm{K}\left[400^{\circ} \mathrm{CJ} \text { from } \mathrm{FHA}\right)\right.
\end{gathered}
$$

The concentration of radioactive materials in the generated volume can be calculated by assuming that all of the contamination made airborne (estimated above from the inventory and ARF:RF value) is well mixed in the generated volume. This is very conservative because some of the airborne material would have migrated in the K-3 exhaust system before plugging the K-3 HEPA filters. Because these factors are difficult to predict and a bounding analysis is desired, the total amount made airborne $\left(3.0 \times 10^{13} \mathrm{~Bq}\right.$ of ${ }^{90} \mathrm{Sr}$ and $1.5 \times 10^{12} \mathrm{~Bq}$ of ${ }^{137} \mathrm{Cs}$ calculated above $)$ results in a concentration of radioactive materials in the generated volume of $2.4 \times 10^{11} \mathrm{~Bq} / \mathrm{m}^{3}$ of ${ }^{90} \mathrm{Sr}$ and $1.2 \times 10^{10} \mathrm{~Bq} / \mathrm{m}^{3}$ of ${ }^{137} \mathrm{Cs}$.

The net volume exiting the hot cell into the canyon is $83 \mathrm{~m}^{3}\left(127 \mathrm{~m}^{3}-44 \mathrm{~m}^{3}\right)$, for a total release of radioactive material to the canyon of $2.0 \times 10^{13} \mathrm{~Bq}$ of ${ }^{90} \mathrm{Sr}$ and $1.0 \times 10^{12} \mathrm{~Bq}$ of ${ }^{137} \mathrm{Cs}$ (the product of the concentration and the net volume increase).

Upon entering the canyon, the combustion products, smoke, and airborne radioactive materials would cause gases to exit the canyon in a manner similar to that described in the source term analysis for the A Cell fire. As was found in that analysis, gases in the canyon could easily exit through the $\mathrm{K}-3$ supply duct to the environment. Because the driving force for the release from the canyon is small, the gases from the hot cell would have ample opportunity to mix with the canyon atmosphere.

Because of the cooling of the gases from the hot cell, the volume increase in the canyon is less than the $83 \mathrm{~m}^{3}$ calculated for the hot cell. The temperature resulting from mixing the gases together can be found (from any text on thermodynamics) by:

$$
\begin{gathered}
\rho_{\text {cell }} V_{\text {cell }} C_{p}\left(T_{f}-T_{\text {cell }}\right)=\rho_{\text {canyon }} V_{\text {canyon }} C_{p}\left(T_{\text {canyon }}-T_{f}\right) \\
\text { where: } \\
\rho_{\text {cell }}=\text { density of gases exiting hot cell } \\
\text { (modeled as air at } \left.400^{\circ} \mathrm{C}\left[752^{\circ} \mathrm{F}\right]\right)(0.52 \mathrm{~kg} / \mathrm{m}) \\
\rho_{\text {canyon }}=\text { density of air in Canyon at } 40^{\circ} \mathrm{C}\left(104^{\circ} \mathrm{F}\right)\left(1.1 \mathrm{~kg} / \mathrm{m}^{3}\right) \\
V_{\text {cell }}=\text { volume of gases exiting hot cell }\left(83 \mathrm{~m}^{3}\right) \\
V_{\text {caryon }}=\text { volume of gases in Canyon }\left(784 \mathrm{~m}^{3}\right) \\
C_{p}=\text { heat capacity of gases }(\text { term cancels }) \\
T_{f}=\text { final equilibrium temperature }(\mathrm{K}) \\
T_{\text {cell }}=\text { temperature of gases exiting hot cell }\left(673^{\circ} \mathrm{K}\left[752^{\circ} \mathrm{FJ}\right)\right. \\
T_{\text {cunpon }}=\text { initial temperature of Canyon air }\left(313 \mathrm{~K}\left[104^{\circ} \mathrm{F}\right]\right)
\end{gathered}
$$

Inserting the appropriate values and solving for $T_{\mathrm{f}}$ yields a final temperature in the canyon of $330 \mathrm{~K}\left(135^{\circ} \mathrm{F}\right)$. The initial quantity of gases in the canyon is $3.0 \times 10^{4} \mathrm{~mol}$ (from the A Cell fire source term calculations) and the quantity of gases 


\section{HNF-SD-WM-BIO-002 REV 1}

produced by the fire is $571 \mathrm{~mol}$ (calculated above).

The ideal gas law can be used to calculate the increase in volume in the canyon, as was done for the hot cell above.

$$
\begin{gathered}
V_{2}=V_{1} \cdot\left(\frac{n_{2} T_{2}}{n_{1} T_{1}}\right) \\
=\left(784 \mathrm{~m}^{3}\right) \cdot\left(\frac{(3.06 E+04 \mathrm{~mol})\left(330^{\circ} \mathrm{K}\right)}{(3.0 \mathrm{E}+04 \mathrm{~mol})\left(313^{\circ} \mathrm{K}\right)}\right) \\
=840 \mathrm{~m}^{3}
\end{gathered}
$$

The concentration is calculated by dividing the quantity of airborne radioactive material exiting the hot cell $\left(2.0 \times 10^{13} \mathrm{~Bq}\right.$ of ${ }^{90} \mathrm{Sr}$ and $1.0 \times 10^{12} \mathrm{~Bq}$ of $\left.{ }^{137} \mathrm{Cs}\right)$ by the total volume of $840 \mathrm{~m}^{3}$. This concentration is $2.4 \times 10^{10} \mathrm{~Bq} / \mathrm{m}^{3}$ of ${ }^{90} \mathrm{Sr}$ and $1.2 \times 10^{9} \mathrm{~Bq} / \mathrm{m}^{3}$ of ${ }^{137} \mathrm{Cs}$.

The source term exiting the facility can then be calculated as the product of the concentration of airborne radioactive material in the canyon by the volume increase in the canyon $\left(840 \mathrm{~m}^{3}-784 \mathrm{~m}^{3}\right)$ of $56 \mathrm{~m}^{3}$. Thus, the source term from the facility in the mitigated condition is $1.3 \times 10^{12} \mathrm{~Bq}(35 \mathrm{Ci})$ of ${ }^{90} \mathrm{Sr}$ and $6.7 \times 10^{10} \mathrm{~Bq}(1.8 \mathrm{Ci})$ of ${ }^{137} \mathrm{Cs}$.

Giving consideration for the control which limits the amoun of combustibles in the cells, thereby preventing the K-3 HEPA filter from plugging, the release of radioactive material is prevented. In this case, no dose consequences are calculated because the release is prevented.

Major Assumptions. The following assumptions were made in the preceding B through E Cell source term development:

- The LPF value is 1.0 for the unmitigated scenario corresponding to no HEPA filtration.

- For the mitigated scenario, natural migration of contamination is assumed to play a minor role compared to the contamination spread caused by hot gases generated during the fire.

- The initial temperature of the canyon is $40^{\circ} \mathrm{C}\left(104^{\circ} \mathrm{F}\right)$.

- The maximum temperature of the hot cell reaches $400^{\circ} \mathrm{C}\left(752^{\circ} \mathrm{F}\right)$

- The inventory in $\mathrm{B} / \mathrm{C}$ Cell is given in Table $3-3$ and is $3.0 \times 10^{15} \mathrm{~Bq}(80 \mathrm{kCi})$ of ${ }^{90} \mathrm{Sr}$ and $1.5 \times 10^{14} \mathrm{~Bq}(4 \mathrm{kCi})$ of ${ }^{137} \mathrm{Cs}$.

- A fire in B/C Cell bounds the consequences of a fire in D/E Cell.

- For both the unmitigated and mitigated scenarios, the ARF:RF value of $1 \times 10^{-2}: 1.0$ was used from Mishima (1994), Section 5.2.1.2, for the burning of uncontained, contaminated, largely cellulosic combustibles).

- All of the contamination is present on the combustibles, thus maximizing the calculated release.

- For the mitigated case, credit is taken for normally installed plug ports and cover blocks on B through E Cells.

- For the mitigated case, complete consumption of all available oxygen is assumed.

- For the mitigated case, credit is taken for the control ol combustible loading in B through E Cells. 


\subsection{Consequence Analysis.}

The consequence analysis is divided into the same groups as the source term analysis above.

\section{A Cell}

Unmitigated Condition. The unmitigated dose consequences arising from the A Cell fire can be found by multiplying the source term by the dose conversion factors developed in Section 3.4.1.3 (see Table 3-19).

Mitigated Condition. The mitigated dose consequences arising from the A Cell fire can be found by multiplying the source term by the dose conversion factors developed in Section 3.4.1.3 (see Table 3-20).

Table 3-19. Unmitigated A Cell Fire Event Dose Consequences.

\begin{tabular}{|c|c|r|r|}
\hline Isotope & Source term (Ci) & $\begin{array}{c}\text { DCF } \\
\mathrm{mSv} / \mathrm{Ci}(\mathrm{rem} / \mathrm{Ci})\end{array}$ & $\begin{array}{c}50 \text {-yr Committed } \\
\text { EDE } \\
\mathrm{mSv}(\mathrm{rem})\end{array}$ \\
\hline${ }^{90} \mathrm{Sr}$ & 7.5 & $9.4(0.94)$ & $\begin{array}{c}71(7.1) \text { onsite } \\
100-\mathrm{m} \text { worker }\end{array}$ \\
\hline${ }^{137} \mathrm{Cs}$ & -- & $1.2(0.12)$ & $\begin{array}{c}0.083(0.0083) \\
\text { public }\end{array}$ \\
\hline${ }^{90} \mathrm{Sr}$ & 7.5 & $0.011(0.0011)$ & $\begin{array}{c}0.12(0.012) \\
\text { alternate site boundary }\end{array}$ \\
\hline${ }^{137} \mathrm{Cs}$ & -- & $0.0014(0.00014)$ & $0.016(0.0016)$ \\
\hline${ }^{90} \mathrm{Sr}$ & 7.5 & $0.0020(0.00020)$ & \\
\hline
\end{tabular}

$\mathrm{DCF}=$ dose conversion factor.

Table 3-20. Mitigated A Cell Fire Event Dose Consequences.

\begin{tabular}{|c|c|r|r|}
\hline Isotope & Source term (Ci) & $\begin{array}{c}\text { DCF } \\
\mathrm{mSv} / \mathrm{Ci}(\mathrm{rem} / \mathrm{Ci})\end{array}$ & $\begin{array}{c}50 \text {-yr Committed } \\
\text { EDE } \\
\mathrm{mSv}(\mathrm{rem})\end{array}$ \\
\hline${ }^{90} \mathrm{Sr}$ & 3.0 & $9.4(0.94)$ & $\begin{array}{c}28(2.8) \text { onsite } \\
100-\mathrm{m} \text { worker }\end{array}$ \\
\hline${ }^{137} \mathrm{Cs}$ & -- & $1.2(0.12)$ & $\begin{array}{c}0.033(0.0033) \\
\text { public }\end{array}$ \\
\hline${ }^{90} \mathrm{Sr}$ & 3.0 & $0.011(0.0011)$ & $\begin{array}{c}0.048(0.0048) \text { alternate } \\
\text { site boundary }\end{array}$ \\
\hline${ }^{137} \mathrm{Cs}$ & -- & $0.0014(0.00014)$ & $0.016(0.0016)$ \\
\hline${ }^{90} \mathrm{Sr}$ & 3.0 & $0.0020(0.00020)$ & \\
\hline
\end{tabular}




\section{$\underline{B / C}$ and $D / E$ Cells}

Unmitigated Condition. The unmitigated dose consequences arising from the B through E Cell fire can be found by multiplying the source term by the dose conversion factors developed in Section 3.4.1.3 (see Table 3-21).

Mitigated Condition. The partially mitigated dose consequences (taking credit for the K-3 HEPA filters and the inplace plug ports and cover blocks) arising from the B through E Cell fire can be found by multiplying the source term by the dose conversion factors developed in Section 3.4.1.3 (see Table 3-22).

Table 3-21. Unmitigated B/C Cell Fire Event Dose Consequences (Bounding Over D/E Cell).

\begin{tabular}{|c|r|r|r|}
\hline Isotope & $\begin{array}{c}\text { Source term } \\
\text { (Ci) }\end{array}$ & $\begin{array}{c}\text { DCF } \\
\mathrm{mSv} / \mathrm{Ci}(\mathrm{rem} / \mathrm{Ci})\end{array}$ & $\begin{array}{c}\text { 50-yr Committed } \\
\text { EDE } \\
\mathrm{mSv}(\mathrm{rem})\end{array}$ \\
\hline${ }^{90} \mathrm{Sr}$ & 800 & $9.4(0.94)$ & $\begin{array}{c}7600(760) \text { onsite } \\
100 \text {-m worker }\end{array}$ \\
\hline${ }^{137} \mathrm{Cs}$ & 40 & $1.2(0.12)$ & $8.8(0.88)$ \\
public
\end{tabular}

Table 3-22. Mitigated with Coverblocks B/C Cell Fire Event Dose Consequences (Bounding Over D/E Cell).

\begin{tabular}{|c|c|r|r|}
\hline Isotope & $\begin{array}{c}\text { Source term } \\
\text { (Ci) }\end{array}$ & $\begin{array}{c}\text { DCF } \\
\mathrm{mSv} / \mathrm{Ci}(\mathrm{rem} / \mathrm{Ci})\end{array}$ & $\begin{array}{c}\text { 50-yr Committed } \\
\text { EDE } \\
\mathrm{mSv}(\mathrm{rem})\end{array}$ \\
\hline${ }^{90} \mathrm{Sr}$ & 35 & $9.4(0.94)$ & $\begin{array}{c}330(33) \text { onsite } \\
100-\mathrm{m} \text { worker }\end{array}$ \\
\hline${ }^{137} \mathrm{Cs}$ & 1.8 & $1.2(0.12)$ & 0.41 (0.041) \\
public
\end{tabular}

For the fully mitigated condition, which controls the combustible loading (including the window oil) to prevent plugging of the K-3 filters, the release is prevented and no dose consequences are calculated.

In addition to the calculated onsite and offsite dose consequences, a hot cell fire could result in the spread of contamination within the facility. The analyses show that the worst case release would occur through the canyon, but other 
pathways exist. A fire in A Cell could release contamination into the Service Gallery, while a fire in any of the hot cells could release contamination into the Operating Gallery through the manipulator penetrations.

\subsection{Comparison to Guidelines.}

Although the event frequency rank of unlikely (i.e., F2), was assigned to this event in the hazards evaluation in Hey (1999) only well-defined initiating event frequencies may be used. Since the possible initiating event frequencies for this accident are not considered well-defined, no credit is taken for the reduced frequency of the scenario.

\section{A Cell.}

Unmitigated Condition. The unmitigated consequences of a fire in A Cell, $71 \mathrm{mSv}(7.1 \mathrm{rem})$ onsite and $0.08 \mathrm{mSv}$ $(0.008 \mathrm{rem})$ offsite ( 0.01 at the alternate site boundary), are above the onsite risk evaluation guids lines ( $50 \mathrm{mSv}$ [ 5 rem]) but below the offsite risk evaluation guidelines $(5 \mathrm{mSv}[0.5 \mathrm{rem}])$.

Mitigated Condition. The mitigated dose consequences, having taken credit for the K-3 HEPA filters, are below both the onsite and offsite dose guidelines.

\section{B/C and D/E Cells.}

Unmitigated Condition. The unmitigated consequences of a fire in $\mathrm{B} / \mathrm{C}$ Cell (bounding D/E Cell), 7,600 mSv (760 rem) onsite and $8.8 \mathrm{mSv}(0.88 \mathrm{rem})$ offsite $(13 \mathrm{mSv}[1.3 \mathrm{rem}]$ at the altemate site boundary), are above both the onsite | rish evaluation guidelines ( $50 \mathrm{mSv}$ [ $5 \mathrm{rem}])$ and the offsite risk evaluation guidelines ( $5 \mathrm{mSv}$ [0.5 rem]).

Mitigated Condition. The mitigated dose consequences of a fire in $\mathrm{B} / \mathrm{C}$ Cell (bounding $\mathrm{D} / \mathrm{E}$ Cell), having taken credit for the K-3 HEPA filters and the normally installed plug ports and cover blocks, are $330 \mathrm{mSv}$ ( $33 \mathrm{rem}$ ) onsite and $0.41 \mathrm{mSv}$ $(0.041 \mathrm{rem})$ offsite $(0.56 \mathrm{mSv}$ [0.056 rem] at the alternate site Boundary). These consequences are above the onsite guideline but below the offsite guideline. Therefore, an additional control is required to further reduce the consequences of a hot cell fire in B through E Cells.

The additional control is the $18 \mathrm{~kg}$ limit placed on the combustible loading (conservatively assumed to be polystyrene) allowed in B through $\mathrm{F}$. Cells. This limit was determined as follows:

- Volume of mineral oil in one hor cell window is approximately 1 to gatlons

- Density of mineral oil is $0.871 \mathrm{~g} / \mathrm{cm}^{3}$ (MSDS 33915 )

- There are 12 individual filters in K-3 system

- Mass of polystyrene required to plug one individual filter is 2-kg (Merz 1998)

- Mass of white mineral oil required to plug one individual filter is 5-kg (Mertz. 1998)

These combustible limits will apply to $\mathrm{B} / \mathrm{C}$ Cells combined and $\mathrm{D}$ : $\mathrm{F}$. Cells combined since a fire can easily propasate between these cells. There are two windows therelore which could be subjected to the fire and fail. In rality, it is very unlikely that fire in B'C Cells or D't. Cells could fail both windows.

Mass of mineral oil in two windows in B/C Cells and DE cells equals:

() me window: $\left.2 \mathrm{gal})\left(2785 \mathrm{~cm}^{3} / \mathrm{gal}\right)\left(0.87 / \mathrm{g}^{2} \mathrm{~cm}^{3}\right) \mathrm{ll} \mathrm{kg} / 000 \mathrm{~g}\right)-6.6 \mathrm{~kg}$

Two windows: $(6.6 \mathrm{~kg})(2)-13 \mathrm{~kg}$

Number of filters potentially plugged by the window oil equals:

$(13 \mathrm{~kg}) /(5 \mathrm{~kg} f$ fllor $)-2.6$ filters 
which lecres 12 fillers -2.6 fillers $=9.4$ fillors remaining

Mass of polystyrene recuired to plug remaining filters ecuals:

(9.t fillers) $2 \mathrm{~kg}$ filler) $-18.8 \mathrm{~kg}$

The combustible loading in $\mathrm{B}: \mathrm{C}$ Cells and D/E Cells must remain below $18 \mathrm{~kg}$.

\subsection{Summary of Safety SSCs and IOSR Controls.}

\section{Credited SSCs.}

- K-3 HEPA filters.

Safety Class Function - To maintain a barrier to the unrestricted release of radioactive material being swept into the K-3 system during a hot cell fire. The K-3 system is not expected or required to maintain $100 \%$ confinement because the HEPA filters would be expected to load up with ash and smoke particulates, eventually reducing ventilation flow. However, in the event the K-3 HEPA filters did plug up, they would be relied on to maintain a passive barrier to the unrestricted release of radioactive material out the 225-B stack. It should be noted that the K-3 HEPA filters provide only a safety significant function in the event of a fire in A Cell.

\section{Credited IOSR Controls.}

- The radioactive material inventory in A Cell is limited to that presented in Table 3-3.

- Solid wastes in A Cell are stored in packaging so that the selection of the ARF:RF value is not invalidated. Packaging must preclude the free flow of air up through the combustible material. An open 208-L (55-gal) steel drum is adequate.

- Because the analysis for A Cell depends on the quantity of combustibles present, a limit of $200 \mathrm{~kg}(441 \mathrm{lb})$ of total combustibles is an initial condition.

- Cell-to-cell pass-throughs that have doors must remain closed except when an active operation requires that they be opened.

- The plug ports and cover blocks on B through E Cells must remain in-place when combustibles (other than in-use manipulator boots) are present in the cell(s).

- There is a combustible waste limit equivalent to $18 \mathrm{~kg}$ polystyrene for $\mathrm{B} / \mathrm{C}$ Cells and $\mathrm{D}$ E Celis [this number already accounts for the hot cell window oill.

- For $\mathrm{F}$ and $\mathrm{G}$ Cells, an IOSR control will prevent the concurrent conditions of capsules in the cell, combustibles in the cell, and cell cover block or plug removed. In-use manipulator boots on the manipulators are excepted. Capsules in the BUSS cask are excluded from this control when the cask lid is secure.

\subsection{Truckport Fire.}

\subsection{Scenario Development.}

The Truckport, located at the west end of the WESF building, provides confinement for cask and low-level solid 
waste loading and unloading. A diesel-powered forklift is used to load and unload casks and solid waste burial boxes in the Truckport transfer area. The WESF FHA analyzes the possibility of a diesel-powered transport truck being present inside the Truckport at the same time as the forklift (Mertz 1998).

The hazards evaluation in Hey (1999) indicates that a Truckport fire involving the fuel from the forklift or truck has a frequency rank of $F 3$ (i.e., anticipated) and a severity rank of S2 (i.e., onsite impacts), resulting in a risk rank of R3 (i.e., major concern). Of the potential causes of a fire in the Truckport, the fuel fire is the most likely and has the greatest potential to spread to the solid waste stored in the Truckport.

The use of gasoline or propane in the Truckport has been identified as possible cause for an explosion as well as a fire. The consequences arising from an explosion is likely bounded by the fire analyzed here, except for potential impacts to the wall adjoining the pool cell area. The response of the Pool Cell Area structure has not yet been ascertained but the possibility exists that failure of structural components could impact the capsules or underlying pool cell structure. A more detailed analysis of a potential explosion in the Truckport is addressed in Section 3.4.2.5, Facility Explosions.

The Truckport acts as a potential accumulation area for plastic bags of low-level solid waste material generated during normal operations of the facility. Part of this waste consists of combustible material, such as cleaning materials, plastic sheets used to control contamination, materials used to take smear samples, and other miscellaneous materials. The plastic bags are loaded into wooden solid waste burial boxes and transferred to an appropriate storage or disposal facility. This material has very little contamination (typically less than $1 \mathrm{mR} / \mathrm{hr}$ ) and provides an inconsequential source term in comparison to the A Cell waste ransferred through the Truckport.

The BUSS cask, containing one or more capsules, might be present during Truckport operations. The BUSS cask is a Type B containment device conforming to 10 CFR 71 and designed to safely contain from 1 to 16 WESF capsules. The BUSS cask has a well known design basis and can withstand effects of the Truckport fire postulated here (SNL 1991). Therefore, the capsule(s) within the BUSS cask would not contribute to the release of contamination in a Truckport fire. In addition, the capsules themselves have been tested in a simulated fire where the test chamber atmosphere was heated to $870^{\circ} \mathrm{C}\left(1,600^{\circ} \mathrm{F}\right)$ and maintained for 90 minutes. The capsules suffered minor damage but did not lose their integrity (Hammond 1975).

The WESF Chem-Nuc cask containing $\wedge$ Cell waste drums or a plywood waste box (which is later placed inside a stecl box lor shipment) containing A Cell waste drums could also be present during Truckport operations, but not at the same time as the BUSS cask (the facility can only handle one cask at a time). The Chem-Nuc cask. which can contain up to six 208L (55-gal) drums. and the hot cell waste box. which can contain up to tive 208 - L (55-gal) drums, are used to transfer highly radioactive solid waste from the hot cells to an appropriate disposal area outside the WESF complex. The Chem-Nuc cask and the hot cell waste box have approved safety analysis reports for packaging, which allows onsite transfers from the WESF facility to a disposal site (Flanagin 1997. Smith 1999). However, unlike the BUSS cask, the Chem-Nuc cask and waste box may not be able to withstand a fuel fire in the Truckport. On this basis, the possibility of involving the Chem-Nuc cask or the waste box in a fuel fire is addressed in this accident analysis.

A loaded WIXM may also be present during Truckport operations, but not at the same time as the BUSS cask. ChemNuc cask, or hot cell waste box (the facility can handle only one al a lime). A WIXM is used to remove ${ }^{137} \mathrm{Cs}$ or ${ }^{*} \mathrm{Sr}$ from pool cell water in the event of a capsule leak or from the low level ficquid waste if the concentration is too high to allow disposal. The WIXM has an approved safety analysis report for packaging which allows onsite transfers to a disposal site (Clemments 1998). The ability of the WIXM to withstand a fire is addressed in this accident analysis. The consecpuences to the WIXM from the fire analyzed are very conservative. The Truckport lire analyzed in the FHA (Mertz 1998) assuned that there was fuel from both a forklift and a truck located in the Tructiport. With the WIXM in place, a forklift and truck cannor plysically tir into the Truckport.

The characteristics of the Truckport fire modeled in this accident analysis are based on the Truckport fire postulated in the WESF FHA (Mert7. 1998). The FHA considered the maximum potential fire to be associated with a fuel fire involving the forklift and truck. It is postulated in the FHA that a flammable liquid leak, either diesel, or hydraulic fluid, is ignited in one of four possible operating configurations: with the cover block to the canyon off and the Truckport roll-up door closed; with the cover block in place and roll-up door open; with the cover block removed and the roll-up door open; and with the cover block in-place and the roll-up door closed. Although propane and gasoline are not allowed in the facility (see 


\section{HNF-SD-WM-BIO-002 REV 1}

Section 3.4.2.5, Facility Explosions), diesel or hydraulic fluid have similar energies of combustion and would yield similar consequences.

For the purposes of the accident analysis, it is assumed that the worst case conditions from the FHA exist in the Truckport fire. This condition is with the roll-up doors open and the cover block from the Truckport to the canyon removed. Although the cover block and roll-up door are not opened simultaneously (operational restriction only) because of operational impacts to the K-3 ventilation system, it is possible that the roll-up door could be opened following initiation of the fire for the purposes of evacuation or access by the Hanford Fire Department. In addition, this condition allows substantial quantities of air to the fire, allows an unfiltered path from the Truckport, and results in impacts to the K-3 ventilation system.

Unmitigated Condition. The unmitigated condition applies to the case where the suppression system, in addition to emergency response actions, fails to extinguish the Truckport fire, which is allowed to continue to its natural conclusion. The unmitigated condition for this operational event encompasses the requirements for BDBA analysis provided in Section 3.4.3.

In the unmitigated condition, the Truckport fire and opening of the roll-up door would initiate several events.

- As the roll-up door opens, the negative pressure maintained in the canyon would be lost initiating the following: a pressure sensor in the canyon would register the loss of negative pressure and deactivate the K-3 supply fan and the K-2 system, another pressure sensor in the canyon would further open the dampers in the canyon ventilation outlet duct which leads directly to the K-3 filter housings.

- The smoke entering the canyon from the Truckport could plug the HEPA filters on the hot cell ventilation inlets, effectively isolating the hot cells and K-3 exhaust duct leading from the hot cells. Because the exhaust duct leading from the canyon directly to the K-3 filter housings joins the exhaust duct from the hot cells before entering the filter housings, the K-3 exhaust fans would not be able to create sufficient vacuum in the hot cells to cause the failure of the plugged inlet HEPA filters.

- The smoke entering the canyon could also travel to the K-3 filter housings through the canyon exhaust duct (which leads directly to the housings) and begin to plug the K-3 HEPA filters. The K-3 system would respond as described in the hot cell fire analysis in Section 3.4.2.3.1, with the exception that the system would not "surge" as in the hot cell fire. That response of the system is to activate the second K-3 filter housing and the standby K-3 exhaust fan. If the $\mathrm{K}-3$ supply fan, $\mathrm{K}-1$ exhaust fans, and $\mathrm{K}-2$ system have not yet been deactivated, then they would be deactivated as the K-3 filter becomes increasingly plugged. However, the filters would survive, resulting in a no-flow condition.

- Although the K-1 exhaust fans cannot maintain a negative pressure in the Truckport when the roll-up door is open, any smoke that is drawn into the K-l exhaust system either before or after the door was opened would cause the $\mathrm{K}-1$ HEPA filters to plug. The ability of the K-1 filters to withstand the pressure differential caused by the K-1 exhaust fans is unknown and is not necessary to determine the accident progression because of the potential for an unfiltered release through the roll-up door.

In summary, the Truckport fire is assumed to occur during WIXM activities or shipment activities involving highly radioactive solid waste (WESF Chem-Nuc cask or hor cell waste box), and the roll-up door is opened before, or during the fire. The unmitigated condition further assumes that the fire suppression system in the Truckport is unavailable or fails. The potential releases include the 208-L (55-gal) drums of radioactive solid waste in the WESF Chem- Nuc cask hot cell waste box or the contaninated resin from the WIXN. I he radioactive material in the hot cells and K-3 filter housings would not be impacted by a Truckport fire, even if the cover blocks between the canyon and the Truckport were removed.

Mitigated Condition. No mitigated condition is considered since the umnitigated scenario consequences lall below the risk evaluation guidelines as discussed below.

Major Assumptions. The following assumptions were made in the scenario development.

- The worst case conditions from the FHA exist in the Truckport fire. This condition is with the roll-up doors open 


\section{HNF-SD-WM-BIO-002 REV 1}

and the cover block from the Truckport to the canyon removed.

- The unmitigated condition assumes that the fire suppression system in the Truckport is unavailable or fails.

\subsection{Source Term Analysis.}

Given the scenario development above, only three sources of radioactive material could be potentially impacted by a Truckport fire: the 208-L (55-gal) drums of radioactive waste in the WESF Chem-Nuc cask hot cell waste box, cesium and strontium capsule(s) in the BUSS cask, and a loaded WIXM. Each of these sources of radioactive material is addressed in the source term analysis in this section.

Unmitigated Condition. One of the possible sources of radioactive material in the Truckport is the 208-L (55-gal) drums of highly radioactive waste in the WESF Chem-Nuc cask or the plywood waste box. The waste in the drums is generated in the hot cells from cleaning, decontamination, or maintenance activities and typically moved into the A Cell hood, placed in a 208-L (55-gal) drum, and stored in A Cell. The Chem-Nuc holds the most drums, six, and will be used as the bounding condition for this analysis. Two 208-L (55-gal) drums are loaded into one of the HIC's stored in the WESF canyon. Three HICs are loaded into the Chem-Nuc cask located in the Truckport and removed from the facility.

The drums trom the hot cells are 208 -L (55-gat) polyethylene lined drums with lid baits. The HICs are polyethylene material manufactured as medium sized overpacks for standard drums. The certified shipping container is the Chem-Nuc cask. The cask is a steel cylinder with outside dimensions of $2.2 \mathrm{~m}$ ( $7 \mathrm{ft}+\mathrm{in}$.) high and $2.1 \mathrm{~m}(7 \mathrm{ft}$ ) in diameter with inner dimensions of $2 \mathrm{~m}$ ( $6 \mathrm{ft} 8 \mathrm{in}$ ) high and $2 \mathrm{~m}$ ( $6 \mathrm{ft} .5 \mathrm{in}$ ) wide. $\wedge$ stainless steel inner wall is seal welded along all sides and an outer steel wall encapsulates lead shielding. Given the temperatures of the Truckport fire postulated in the FHA, it is unknown if the cask would provide a sufficient thermal barrier for the solid waste in the 208-L (55-gal) drum. On this basis. and to bound operations with the hot cell waste box. it is assumed that the cask would not prevent the release from the waste drum in the event of a fire in the Truckport.

The Truckport fire would cause the solid combustibles within the drum to hydrolyze in the absence of oxygen, causing a pressure increase within the drum and subsequent drum failure. The radioactive material in the drum would be subject to release by destruction of the solid waste substrate and venting of the generated gases.

The inventory at risk in the 208-L (55-gal) drum can be found from the Chem-Nuc cask SARP (Flanagian 1997) to be $9.79 \times 10^{17} \mathrm{Bc}(2.64 \mathrm{kCi})$ of ${ }^{137} \mathrm{Cs},{ }^{90} \mathrm{Sr}$, or a combination of both. The Chem-Nuc inventory bounds the inventory allowed in the hot cell waste box (Smith. 1999). To be conservative in this analysis. the inventory will be doubled to $1.85 \times 10^{11} \mathrm{Bc}\left(\mathrm{s}^{5}\right.$ $\mathrm{kCi}$ of ${ }^{17} \mathrm{Cs}$. ${ }^{x / 1} \mathrm{Sr}$, or a combination ol boh. Because of its greater inhalation unit dose, the entire inventory at risk is assumed to be ${ }^{90} \mathrm{Sr}$.

The ARF:RF value used for the release from the 208-L (55-gal) drum is $5.0 \times 10^{-4}: 1.0$ from Mishima (1994), Section 5.2.1.1, for the burning of contaminated solid combustibles in packages. This value is very conservative for the release from the 208-L (55-gal) drum in the cask because of the nature of the experiments used to derive the value. The most substantial packaging used in the experiments consisted of plastic bags of combustibles inside of a cardboard box. The experimental procedure consisted of adding fuel to the package and igniting it so that the entire package was consumed in the fire. By comparison, the 208-L (55-gal) drum would not be consumed in the fire but would only vent the hydrolyzed gases into the cask, which would, in turn, release the gases to the Truckport where they would burn.

The source term resulting from the 208-L (55-gal) drum is calculated by multiplying the inventory at risk and the selected ARF:RF value. The resulting source term is $9.25 \times 10^{1 / 1} \mathrm{~Bq}(2.5 \mathrm{Ci})$ of ${ }^{90} \mathrm{Sr}$.

The BUSS cask is used for receipt of up to 16 capsules through the Truckport. This cask has approximately the same likelihood of being in the Truckport during a fuel fire as the waste cask, but the design of the BUSS cask is substantially more robust. As discussed in the scenario development for this accident analysis, the radioactive materials in the BUSS cask would not be impacted by a fire in the Truckport.

The last possible source of radionctive material in the Truckport is the WIXM. A fire in the Truckport could have a 


\section{HNF-SD-WM-BIO-002 REV 1}

direct impact on WIXM safety if the resin beads ignite and release airborne radiological contamination into the Truckport. The WIXM resin beads are conbustible. although the ignition temperature is estimated on the material safety data sheets at approximately $427^{\circ} \mathrm{C}\left(800^{\circ} \mathrm{F}\right)$, and could decompose at lemperatures as low as $330^{\circ} \mathrm{C}\left(625^{\circ} \mathrm{F}\right)(\mathrm{Cohen}$. 1989$)$. Combustion or decomposition of the contaminated resin beads could possibly release ${ }^{1: 4} \mathrm{Cs}$ or ${ }^{\circ} \mathrm{Sr}$ into the Truckport atmosphere given a leak path in the WIXM itself. A likely leak path for such a release would be throngh the WIXM vent. The vent is filtered with an activated carbon filter. however it is likely that a Truckport tire severe enough to ignite the resin material would cause failure of the filter.

The WESF FHA (Mertz. 1998) analyzes a Truckport tire using fucl from a forkliti and a transport truck as the primary combustible material. The maximum fires in those analy ses are used as the basis for a thermal analy sis performed for the WIXM and documented in HNF (1998a). The WIXM thermal analy sis uses the maximum tire characteristics and the maximum internal themal load (decay heat) in the WIXM to alssess the possibility of heating and igniting the resin.

The maximum decay heat load used in the thermal analysis corresponds to a WIXiM completely full of resin with the maximum quantity of contamination. The design capacity of the WIXM is approximately one-fourth of the maximum strontium capsule or une-half of the maximum cesium capsule (based on 1998 decay values). As of January 1. 1996. the maximum decay heal associated with a strontitm capsule was $615 \mathrm{~W}$ (Hey, 1999), and for a cesium capsule was $255 \mathrm{~W}$. Using 1996 decay heat loads is conservative because it neglects approximately wo years of radionctive decay. One-fourth of the maximum strontium capsule $(154 \mathrm{~W}$ ) is greater than one-half of the maximum cesium capsule (128 W). This heat load, however, would be atssociated with the intended operating level of the resin bed within the WIXN1. where the WIXM is loaded to a depth of $35 \mathrm{in.} \mathrm{of} \mathrm{resin.} \mathrm{The} \mathrm{full} \mathrm{depth} \mathrm{of} \mathrm{the} \mathrm{vessel} \mathrm{is} 4.4 \mathrm{in}$, which is a $26^{\circ} \mathrm{u}$ increase in deptl. If the vessel were treated as a cylinder. which is conservative because it overpredicts the volume for the rounded top and botton of the vessel. the increase in volume, and subsequent heat load would also be $26 \%$. Thus, the heal load assumed lor the thermal analysis is $26 \%$ greater than $154 \mathrm{~W}$ which equates to approximately $193 \mathrm{~W}$.

The results of the thermal analysis determine the maximum resin temperature would be $187^{\circ} \mathrm{C}$ for steady-state (nonlire) and $203^{\circ} \mathrm{C}$ following the Truckport lire. This is well below both the decomposition and ignition temperatures for the resin. and does not include any preventative or mitigative features.

The concrete associated with the WIXM would suffer some external surface damage as a result of the elevated temperatures associated with the fire. The thermal model shows that the allowable concreve temperature to maintain shielding and structural integrity is exceeded only near the external surface for most sides in both the short and long term fire scenarios. The exception is the boltom surlace in long term tire. The concrete is potentially impacted up to a depth of 10 inches from the external surface. This amount of degradation of the concrete does not impact the structural function of the concrete, which is to hold the ion exchange vessel in place and provide shiekding. The degradation of the shiclding would not result in a source term of radioactive material from the WIXM, but could increise the dose rates near the WIXM. Since some shielding remains after the fire, the direct beta dose rates $\left({ }^{(*)} \mathrm{Sr}\right.$ and ${ }^{\text {W/ }} \mathrm{Y}$ ) would be negligible. The gamma direc dose raes could increase, but would be bounded by the loss of containment analysis.

The thermal analysis in HNF (1998) did not examine the case where water is present in the WIXM so as to bound the temperature rise associated with the resin. If water were present, the resin would dissipate heat better (the interstitial void volume in the resin was modeled as air, which is less effective for heat dissipation) and significant energy would be absorbed by heating and then vaporising the water. Since it is possible to have water in the WIXM during a Truckport fire and the response of the water is unknown, the possibility that water is present and vaporized by the heat (both due to decay and fire) nust be considered.

The source term from the water is dependent upon the concentration of contamination in the water and the volume of the water. The strontium fluoride dissolves very slowly, while cesium chloride will completely dissolve quickly in a storage pool. Thus, pool water contaminated witl cesium chloride would have a higher contamination concentration. For this analysis, however, scrontium fluoride is conservatively assuned to mix in the pool water resulting in a contamination concentration higher than that of cesium chloride. Strontium is used because it hats a greater dose conversion factor than cesium. The dimensions of the smallest storage pool as $1.3 \mathrm{~m}$ wide by $6.6 \mathrm{ml}$ long by $5.5 \mathrm{~m}$ deep, with a normal operating water level of $156 \mathrm{in}$. (4.0 $\mathrm{m})$. This yiclds a water volume of $34.3 \mathrm{~m}^{3}$. Given that the maximum strontium capsule contains approximately $3.4 \times 10^{15} \mathrm{~Bq}(91 \mathrm{kCi}$ ) (decayed to January 1,1996$)$, the concentation of contamination is approximately 


\section{HNF-SD-WM-BIO-002 REV 1}

$2,700 \mathrm{Ci} / \mathrm{m}^{3}$ which converts to $2.7 \mathrm{Ci} / \mathrm{L}$ if all the contents of the leaking capsule escape and dissolve in the pool water. Section 2.4.2.3.2 calculates the total volume of the WIXM vessel of $312 \mathrm{~L}$ (including vent, inlet, and outlet lines). For simplicity, and to bound the estimated consequences, it is assumed that the entire volume of the WIXM vessel contains water (neglecting the volume of the resin and any gas volume that might be present). Thus, the bounding contamination at risk is the product of the WIXM volume and the concentration of contamination, or approximately $3.1 \times 10^{1.3} \mathrm{Bg}(840 \mathrm{Ci})$.

For the released steam, DOE-HDBK-3010-94 reports two possible release models. The first model represents the conditions inside the heated vessel as an aqueous solttion near or just at its boiling point where steam is being released, but no vigorous boiling exists (no bubbles breaking at the liquid surlace). The second model is applicable to vigorous boiling with bubbles breaking at the liquid surface, and has an ARF:RF value approximately two orders of magnitude greater than case without vigorous boiling. The first model would be applicable to the water present in the resin matrix and the second model would be applicable to any water which might be present in the void volume above the resin bed. However, the depth of resin in the WIXM could vary and so the volume of water for which the larger ARF:RF value is applicable is unknown. To bound the possible release, the ARF:RF for vigorous boiling is applied to the entire volume of water. The vigorous boiling $A R F ; R F$ is $2 \times 10^{-3}: 1.0$, resulting in a source 10 rm of $6.3 \times 10^{111} \mathrm{~Bq}(1.7 \mathrm{Ci})$.

The total unmitigated source term arising from the Truckport fire will either be the 208-L (55-gal) drums of highactiv ity waste or the WIXM (the BUSS cask would not contribute to the release during a Truckport fire) multiplied by the LPF for the event. The LPF for the event is assumed to 1.0 based on the possibility of the roll-up door of the Truckport being open. The resulting total source term is $9.25 \times 10^{16} \mathrm{~Bq}(2.5 \mathrm{Ci})$ of ${ }^{90} \mathrm{Sr}$ from the Chem-Nuc cask or $6.3 \times 10^{16} \mathrm{~Bq}(1.7 \mathrm{Ci})$ of ${ }^{-60} \mathrm{Sr}$ from the WIXM.

Mitigated Condition. No mitigated condition is considered since the unmitigated scenario consequences fall below the risk evaluation guidelines as discussed below.

Major Assumptions. The following assumptions were made in the preceding source term analysis.

- The LPF is assumed to be 1.0 because of the possibility that the ventilation flows might be interrupted and the Truckport door open.

- The inventory at risk in the 208-L (55-gal) drums is $1.85 \times 10^{11} \mathrm{BC}(5 \mathrm{kCi})$ of ${ }^{90} \mathrm{Sr}$.

- The inventory at risk in the WIXM is $3.1 \times 10^{13} \mathrm{~Bq}(840 \mathrm{Ci})$ of ${ }^{\text {"h }} \mathrm{Sr}$.

- The ARF:RF value used for the release from the 208-L (55-gal) drum is $5.0 \times 10^{-4}: 1.0$ from Mishima (1994), Section 5.2.1.1 for the burning of contaminated solid combustibles in packages.

\subsection{Consequence Analysis.}

Unmitigated Condition. The unmitigated dose consequences arising from the Truckport fire can be found by multiplying the source term by the dose conversion factors developed in Section 3.4.1.3 given in Table 3-23 and Table 3-24. 
Mitigated Condition. No mitigated condition is considered since the unmitigated scentrio consequences fall below the rish evaluation guidelines as discussed below.

Table 3-23. Unmitigated Truckport Fire Event Dose Consequences (Chem-..uc Cask).

\begin{tabular}{|c|r|r|c|}
\hline Isotope & $\begin{array}{c}\text { Source term } \\
(\mathrm{Ci})\end{array}$ & $\begin{array}{c}\text { DCF } \\
\mathrm{mSv} / \mathrm{Ci}(\mathrm{rem} / \mathrm{Ci})\end{array}$ & $\begin{array}{c}50 \text {-yr Committed EDE } \\
\mathrm{mSv}(\mathrm{rem})\end{array}$ \\
\hline${ }^{90} \mathrm{Sr}$ & 2.5 & $9.4(0.94)$ & $\begin{array}{c}23.5(2 .+1) \text { onsite } \\
100-\mathrm{m} \text { worker }\end{array}$ \\
\hline${ }^{90} \mathrm{Sr}$ & 2.5 & $0.011(0.0011)$ & $\begin{array}{c}0.028(0.0028) \\
\text { public }\end{array}$ \\
\hline${ }^{90} \mathrm{Sr}$ & 2.5 & $0.016(0.0016)$ & $\begin{array}{c}0.04(0.004) \\
\text { alternate } \\
\text { site boundary }\end{array}$ \\
\hline
\end{tabular}

Table 3-24 Unmitigated Truckport Fire Event Dose Consecjuences (WIXM).

\begin{tabular}{|c|c|c|c|}
\hline Isotope & $\begin{array}{c}\text { Source term } \\
(\mathrm{Ci})\end{array}$ & $\begin{array}{c}\text { DCF } \\
\mathrm{mSv} / \mathrm{Ci}(\mathrm{rem} / \mathrm{Ci})\end{array}$ & $\begin{array}{c}50-\mathrm{yr} \text { Committed EDE } \\
\mathrm{mSv}(\mathrm{rem})\end{array}$ \\
\hline${ }^{90} \mathrm{Sr}$ & 1.7 & $9.4(0.94)$ & $\begin{array}{c}16(1.6) \\
\text { onsite } \\
100-\mathrm{m} \text { worker }\end{array}$ \\
\hline${ }^{90} \mathrm{Sr}$ & 1.7 & $0.011(0.0011)$ & $\begin{array}{c}0.019(0.0019) \\
\text { public }\end{array}$ \\
\hline${ }^{90} \mathrm{Sr}$ & 1.7 & $0.016(0.0016)$ & $\begin{array}{c}0.027(0.0027) \\
\text { alternate } \\
\text { site boundary }\end{array}$ \\
\hline
\end{tabular}

\subsection{Comparison to Guidelines.}

No credit is taken for the frequency of the initiating event of this accident because such a frequency is not well | known. Therefore, the risk cvaluation guidelines used for this accident are those associated with the anticipated frequency range, $50 \mathrm{mSv}(5 \mathrm{rem})$ onsite and $5 \mathrm{mSv}(0.5 \mathrm{rem})$ offsite.

Unmitigated Condition. The unmitigated onsite dose for the Chem-Nuc is $24 \mathrm{mSv}$ ( $2.4 \mathrm{rem}$ ) and the dose for the WIXM is $16 \mathrm{mSv}(1.6 \mathrm{rem})$, both of which are below the onsite rish evaluation guideline of $50 \mathrm{mSv}$ ( $5 \mathrm{rem})$. The unmitigated offsite dose for the Chem-Nuc is $2.8 \times 10^{-2} \mathrm{mSv}\left(2.8 \times 10^{-3} \mathrm{rem}\right) 14.0 \times 10^{-2} \mathrm{mSv}\left(4.0 \times 10^{-3} \mathrm{rem}\right)$ for the alternate site boundary $]$ and the dose for the WIXM is $1.9 \times 10^{-2} \mathrm{mSv}\left(1.9 \times 10^{-6} \mathrm{rem}\right)\left[2.7 \times 10^{-2} \mathrm{mSv}\left(2.7 \times 10^{-5}\right.\right.$ rem $)$ for the allernate site boundary |, both of which are substantially below the offsite risk evaluation guideline of $5 \mathrm{mSv}(0.5 \mathrm{rem})$.

Mitigated Condition. No mitigated condition is considered since the unmitigated scenario consequences fall below the I risk evaluation guidelines.

\subsection{Summary of Safety SSCs and IOSR Controls.}

\section{Credited SSCs.}

None 


\section{Credited IOSR Controls.}

- Radioactive solid waste contained inside the WESF Chem-Nuc cask and waste boxes is limited to $1.85 \times 10^{14} \mathrm{~Bq}$ $(5 \mathrm{kCi})$ of ${ }^{90} \mathrm{Sr}$ andior ${ }^{137} \mathrm{Cs}$.

- To keep operations within the bounds of the analysis, the quantity of radioactive materials present in the WIXM assembly must be no greater than $25,200 \mathrm{Ci}$ of ${ }^{90} \mathrm{Sr}$ or $31,500 \mathrm{Ci}$ of ${ }^{137} \mathrm{Cs}$. For combinations of isotopes, where ${ }^{90} \mathrm{Sr}$ and ${ }^{137} \mathrm{Cs}$ are present at the same time, it is noted that the method of controlling the inventories is by limiting the quantity of cation resin in the WIXM vessel. Limiting the resin places a physical limit on the inventory, and since ${ }^{90} \mathrm{Sr}$ is bounding over ${ }^{137} \mathrm{Cs}$, any combination where ${ }^{137} \mathrm{Cs}$ takes the place of ${ }^{90} \mathrm{Sr}$ is bounded by the case where all of the contamination is ${ }^{90} \mathrm{Sr}$.

\subsubsection{Loss of Confinement.}

This section considers the range of upset conditions associated with TK-100 and the K-3 ventilation system, which are addressed in the hazards evaluation in Hey (1999). These conditions include high flow in the K-3 system ductwork, loss of K-3 ventilation flow, K-3 system water accumulation, failure of the K-3 filters, high activity in TK-100, and hot cell hydrogen accumulation.

All of these conditions are evaluated quantitatively. Failure of the K-3 HEPA filters, in and of itself, is not considered by the hazards evaluation to have significant consequences outside of the facility. However, failure of the filters is considered in other accidents in two cases: where accident conditions are such that the filters would not survive the accident, and where the filters are relied on to mitigate the release so as to determine the importance of their function. A more detailed discussion of the accident selection process as it pertains to this accident type is provided in Section 3.3.2.3.5.

Sections 3.4.2.4.3 3.4.2.4.4, and 3.4.2.4.5 all address the potential for the generation and accumulation of hydrogen in various areas of the facility. The models used in these analyses are similar in nature. To avoid unnecessary repetition, the first analysis where particular models are used shows the basis of the models, equations used, and appropriate references. Later use of the models references this initial development but does not repeat it.

\subsection{High Flow in K-3 Ventilation System.}

\subsection{Scenario Development.}

The hazards evaluation in Hey (1999) indicates that a high-flow event in the K-3 ventilation system has a frequency rank of F2 (i.e., unlikely), with S2 (i.e., onsite worker) consequences. The frequency rank was assigned based on the necessity that a flow rate high enough to dislodge significant quantities of contamination in the quantities postulated must be sustained. The resulting risk rank is $\mathrm{R} 2$ (events of moderate concern). This event is selected for quantitative analysis based on its unique challenge to the K-3 HEPA filters.

Under normal operations, one of the two K-3 ventilation system fans is operating at all times. If the pressure differential in any of the ventilated zones is unsatisfactory (i.e., duct pressure approaches atmospheric) due to failure of the online fan or overload of the system, the standby fan starts automatically.

High airflow through the K-3 ventilation system could be caused by instrumentation failure, allowing multiple fans to run simultaneously, or could be a result of opening a flow path, such as the removal of the Truckport cover block (leading to the canyon) while the Truckport is open to environment. Although these transients have occurred in the past and the system is designed to accommodate the maximum flow, contamination in the exhaust duct could break loose under sustained high flow rates.

event.

Unmitigated Condition. The unmitigated condition considers the failure of the K-3 HEPA filters to mitigate the 
Mitigated Condition. The mitigated case considers the success of the K-3 HEPA filters in mitigating the consequences of the event. The filters are shown to be able to survive the high-flow event in the source term analysis below.

Major Assumptions. The following assumptions were made in the scenario development:

- Both K-3 exhaust fans are operating

- Contamination in the exhaust duct breaks loose under sustained high flow rates

- The K-3 HEPA filters fail in the unmitigated scenario

- The K-3 HEPA filters function normally in the mitigated scenario.

\subsection{Source Term Analysis.}

This event assumes sustained high flow rates in the K-3 ventilation system. The potential source term arising from this event can be estimated based on the facility SSC response and the radioactive materials impacted.

The radioactive materials that could be impacted by the high flow event are the contamination present in the hot cells, K-3 exhaust duct, and K-3 HEPA filter housings. The contamination in the hot cells would not be susceptible to appreciable suspension because the size of the hot cells is such that even though the volumetric flow rate would be higher than normal, the velocity of the airflow parallel to the contaminated surfaces is low. Therefore, no significant source term would arise from the hot cells in a K-3 high flow event.

The inventory in the K-3 exhaust duct is provided in Table 3-3. Two isotopic splits for the contamination in the duct are provided. Since the isotopic split is uncertain, the contamination is conservatively assumed to be $100 \%{ }^{90} \mathrm{Sr}\left[7.4 \times 10^{15} \mathrm{~Bq}\right.$ $(200 \mathrm{kCi})]$ because this yields the greatest dose consequences.

The inventory in the K-3 filter housing may also be impacted by the high flow event. The resuspension of radioactive particles from the HEPA filters is bounded by the postulated resuspension of particles in the K-3 exhaust duct. Therefore, the inventory assumed to be present in the K-3 filter housing can be added to the inventory in the K-3 exhaust duct. From Table 3-3 the inventory associated with the K-3 HEPA filter housing is $8.9 \times 10^{12} \mathrm{~Bq}(240 \mathrm{Ci}){ }^{137} \mathrm{Cs}$ and $6.7 \times 10^{14} \mathrm{~Bq}(18 \mathrm{kCi}){ }^{90} \mathrm{Sr}$.

The total inventory impacted by the high-flow event is the sum of the inventory in the K-3 exhaust duct and the K-3 HEPA filter housing. This sum is $8.9 \times 10^{12} \mathrm{~Bq}(240 \mathrm{Ci}){ }^{137} \mathrm{Cs}$ and $8.1 \times 10^{12} \mathrm{~Bq}(218 \mathrm{kCi}){ }^{90} \mathrm{Sr}$.

The resuspension of the inventory at risk is modeled below as the resuspension of particulates in a crosswind. Section 5.3.4 of Mishima (1994) provides a lengthy discussion of the phenomenon of particulate resuspension from solid, unyielding, noncombustible surfaces under ventilation flow conditions. Reviews of the experimental data in this area indicate very small values of the resuspension rate. The conclusion is that this phenomenon is bounded by the values recommended for the resuspension of powders from a heterogeneous bed under ventilation flow conditions for which an ARR:RF of $4 \times 10^{-5} / \mathrm{h}: 1.0$ is used.

It is assumed that the high-flow condition lasts 48 hours before being corrected, resulting in an ARF:RF of $1.9 \times 10^{-3}: 1.0$. This duration is chosen as an upper bound considering time to detect the high-flow condition and rectify its cause.

Unmitigated Condition. The unmitigated source term, corresponding to no HEPA filtration (LPF $=1.0)$ can be found by multiplying the total inventory impacted by the ARF:RF. The resulting source term is $1.5 \times 10^{13} \mathrm{~Bq}(414 \mathrm{Ci})$ of ${ }^{90} \mathrm{Sr}$ and $1.7 \times 10^{10} \mathrm{~Bq}(0.46 \mathrm{Ci})$ of ${ }^{137} \mathrm{Cs}$.

Mitigated Condition. The response of the K-3 HEPA filters to a high-flow event can be bounded by an analysis of 
the filter response to the maximum pressure differential that could be induced by the $\mathrm{K}-3$ exhaust fans. The maximum pressure that can be applied to the filters is in a no-flow condition such as a plugged filter. While the event under analysis is a high-flow condition, if the filters can be shown to survive a no-flow condition (maximum pressure differential) then they can survive any high-flow condition (lesser pressure differential).

The analysis for a hot cell fire, Section 3.4.2.3.1, examines a no-flow condition for the K-3 filter system and shows that the filters would survive. Since a no-flow condition represents the maximum pressure that can be applied across the filters, the filters would survive any high-flow condition.

For the mitigated condition where credit is taken for HEPA filtration, the LPF is taken to be $1.0 \times 10^{-3}(99.9 \%$ overall efficiency) resulting in a mitigated source term of $1.5 \times 10^{10} \mathrm{~Bq}(0.414 \mathrm{Ci})$ of ${ }^{90} \mathrm{Sr}$ and $1.7 \times 10^{7} \mathrm{~Bq}\left(4.6 \times 10^{-4} \mathrm{Ci}\right)$ of ${ }^{137} \mathrm{Cs}$.

Major Assumptions. The following assumptions were made in the preceding source term analysis.

- The $\mathrm{K}-3$ duct inventory is no greater than $200 \mathrm{kCi}$ of ${ }^{90} \mathrm{Sr}$ or $5.1 \mathrm{kCi}$ of ${ }^{137} \mathrm{Cs}\left({ }^{90} \mathrm{Sr}\right.$ is used as the bounding case). These value are taken from the inventory data in Table 3-3.

- The K-3 HEPA filter housing inventory is no greater than $18 \mathrm{kCi}$ of ${ }^{90} \mathrm{Sr}$ and $240 \mathrm{Ci}$ of ${ }^{137} \mathrm{Cs}$. These value are taken from the inventory data in Table 3-3.

- The ARR:RF values for both the unmitigated and mitigated scenarios are $4 \times 10^{-5} / \mathrm{h}: 1.0$.

- The LPF value for the unmitigated scenario is 1.0 corresponding to no HEPA filtration.

- The LPF value for the mitigated scenario is $1.0 \times 10^{-3}$ corresponding to normal HEPA filtration.

- The high-flow condition lasts 48 hours before being corrected. This duration is chosen as an upper bound.

\subsection{Consequence Analysis.}

Unmitigated Condition. The unmitigated dose consequences arising from the K-3 high flow event can be found by multiplying the source term by the dose conversion factors developed in Section 3.4.1.3 (see Table 3-25).

Mitigated Condition. The mitigated dose consequences arising from the K-3 high flow event can be found by multiplying the source term by the dose conversion factors developed in Section 3.4.1.3 (see Table 3-26).

Table 3-25. Unmitigated K-3 High Flow Event Dose Consequences.

\begin{tabular}{|c|c|r|r|}
\hline Isotope & Source term (Ci) & $\begin{array}{c}\text { DCF } \\
\mathrm{mSv} / \mathrm{Ci}(\mathrm{rem} / \mathrm{Ci})\end{array}$ & $\begin{array}{c}50 \text {-yr Committed EDE } \\
\mathrm{mSv}(\mathrm{rem})\end{array}$ \\
\hline${ }^{90} \mathrm{Sr}$ & 414 & $9.4(0.94)$ & $\begin{array}{c}3900(390) \\
\text { onsite } 100 \text {-m worker }\end{array}$ \\
\hline${ }^{137} \mathrm{Cs}$ & 0.46 & $1.2(0.12)$ & $\begin{array}{r}4.6(0.46) \\
\text { public }\end{array}$ \\
\hline${ }^{90} \mathrm{Sr}$ & 414 & $0.011(0.0011)$ & $\begin{array}{r}6.6(0.66) \text { alternate } \\
\text { site boundary }\end{array}$ \\
\hline${ }^{137} \mathrm{Cs}$ & 0.46 & $0.0014(0.00014)$ & \\
\hline${ }^{90} \mathrm{Sr}$ & 414 & $0.016(0.0016)$ & \\
\hline
\end{tabular}


HNF-SD-WM-BIO-002 REV 1

Table 3-26. Mitigated K-3 High Flow Event Dose Consequences.

\begin{tabular}{|c|c|c|c|}
\hline Isotope & $\begin{array}{l}\text { Source term } \\
\text { (Ci) }\end{array}$ & $\begin{array}{c}\text { DCF } \\
\mathrm{mSv} / \mathrm{Ci}(\mathrm{rem} / \mathrm{Ci})\end{array}$ & $\begin{array}{c}\text { 50-yr Committed EDE } \\
\text { mSv (rem) }\end{array}$ \\
\hline${ }^{90} \mathrm{Sr}$ & 0.414 & $9.4(0.94)$ & \multirow[t]{2}{*}{$\begin{array}{c}3.9(0.39) \\
\text { onsite } 100-\mathrm{m} \text { worker }\end{array}$} \\
\hline${ }^{137} \mathrm{Cs}$ & $4.6 \mathrm{E}-04$ & $1.2(0.12)$ & \\
\hline${ }^{90} \mathrm{Sr}$ & $\overline{0.414}$ & $0.011(0.0011)$ & \multirow[t]{2}{*}{$\begin{array}{c}0.0046(0.00046) \\
\text { public }\end{array}$} \\
\hline${ }^{137} \mathrm{Cs}$ & $4.6 \mathrm{E}-04$ & $0.0014(0.00014)$ & \\
\hline${ }^{90} \mathrm{Sr}$ & $\overline{0.414}$ & $0.016(0.0016)$ & \multirow[t]{2}{*}{$\begin{array}{c}0.0066(0.00066) \\
\text { alternate } \\
\text { site boundary }\end{array}$} \\
\hline${ }^{137} \mathrm{Cs}$ & $4.6 \mathrm{E}-04$ & $0.0020(0.00020)$ & \\
\hline
\end{tabular}

\subsection{Comparison to Guidelines.}

No credit is given for reduced frequencies of the accident because the frequency of the initiating event is not well defined. Therefore, the risk evaluation guidelines for the anticipated frequency range of $50 \mathrm{mSv}(5 \mathrm{rem})$ onsite and $5 \mathrm{mSv}(0.5$ rem) offsite are used in this analysis.

Unmitigated Condition. The unmitigated onsite dose is $3,900 \mathrm{mSv}$ (390 rem), which exceeds the onsite risk evaluation guidelines of $50 \mathrm{mSv}(5.0 \mathrm{rem})$. The unmitigated offsite dose is $4.6 \mathrm{mSv}(0.46 \mathrm{rem})$, which approximately equals the offsite rish evaluation guidelines of $5 \mathrm{mSv}(0.5 \mathrm{rem})$. The unmitigated offsite dose for the alternate site boundary is approximately $6.6 \mathrm{mSv}(0.66 \mathrm{rem})$, which exceeds the offsite rist evaluation guidelines.

Mitigated Condition. The mitigated, K-3 HEPA filters, onsite dose is $3.9 \mathrm{mSv}(0.39 \mathrm{rem})$, which is well below the onsite risk evaluation guidelines of $50 \mathrm{mSv}(5.0 \mathrm{rem})$. The offsite dose is $4.6 \times 10^{-3} \mathrm{mSv}\left(4.6 \times 10^{-4} \mathrm{rem}\right)$, which is well below the offsite risk evaluation guidelines of $5.0 \mathrm{mSv}(0.5 \mathrm{rem})$. Likewise, the offsite dose for the alternate site boundary, $6.6 \times 10^{-3}$ $\mathrm{mSv}\left(6.6 \times 10^{-4} \mathrm{rem}\right)$, is also well below the offsite risk evaluation guidelines of $5.0 \mathrm{mSv}(0.5 \mathrm{rem})$.

\subsection{Summary of Safety SSCs and IOSR Controls.}

In reviewing the assumptions used to develop the accident analysis model, it can be seen that the dominant assumption is the performance of HEPA filtration during the event. All other assumptions, such as the release rate and duration of the high-flow condition, are unimportant to the conclusions of the analysis. For example, if the entire quantity of contamination in the exhaust duct $\left[7.4 \times 10^{15} \mathrm{~Bq}(200 \mathrm{kCi})\right]$ were resuspended in the high-flow condition, the ARF were assumed to be 1.0 , and the HEPA filtration functions as designed, the onsite dose would be $19 \mathrm{mSv}(1.9 \mathrm{rem})$ and the offsite dose would be $2.2 \times 10^{-2} \mathrm{mSv}\left(2.2 \times 10^{-3} \mathrm{rem}\right)\left(3.1 \times 10^{-2} \mathrm{mSv}\left[3.1 \times 10^{-3} \mathrm{rem}\right]\right.$ at the alternate site boundary $)$. These consequences still fall below the onsite and offsite risk cvaluation guidelines and cannot be exceeded. Thus, regardless of the other assumptions made in the analysis, when the HEPA filters function as designed, sufficient mitigation for the high flow condition is attained.

\section{Credited SSCs.}

- K-3 HEPAs filters.

Safety Class Function - To provide a combined filter efficiency of $99.9 \%$ in the event that radioactive particulates are resuspended from the hot cell and/or K-3 duct work during operational events such as a high-flow condition. 
HNF-SD-WM-BIO-002 REV 1

\section{Credited IOSR Controls.}

- The K-3 HEPA filter housing inventory is no greater than $18 \mathrm{kCi}$ of ${ }^{90} \mathrm{Sr}$ and $240 \mathrm{Ci}$ of ${ }^{137} \mathrm{Cs}$.

\subsection{Loss of K-3 Ventilation Flow.}

Loss of K-3 ventilation flow under accident conditions is identified and addressed in Sections 3.4.2.1, 3.4.2.2, 3.4.2.3, and 3.4.2.4.3. The analysis of those accidents addresses the failure of the $\mathrm{K}-3$ ventilation system as it pertains to the particular accident phenomena. They do not address the general consequences associated with a loss of ventilation and potential subsequent migration of contamination.

\subsection{Scenario Development.}

K-3 ventilation could be lost as a result of several events identified in the hazards evaluation in Hey (1999). In addition to those mentioned above, the following events were also identified as causing a loss of K-3 ventilation:

- Supply air system failure (dampers or clogged filters)

- Exhaust system failure (fans, clogged filters, or dampers)

- Breach in ducting

- Stack collapse.

Considering only the effects of a loss of K-3 ventilation and not the dominating effects of some of the initiating events (e.g., facility fires), these events are bounded by the F2 (i.e., unlikely) frequency category and an S1 or S2 (i.e., facility worker or onsite impact) consequence ranking (from Hey 1999 ).

The loss of K-3 ventilation, by itself, could result in migration of contamination and a temperature increase in $\mathrm{F}$ Cell (capsule storage). A prolonged increase in capsule/salt interface temperature could result in accelerated corrosion of the capsule wall, but no release outside the facility would occur. Of more importance for F Cell is the protection of the safety class structure of the hot cell from degradation because of sustained high-thermal loads.

Spread of Contamination. The spread of contamination in the event of a loss of K-3 ventilation was found in the hazards analysis to have consequences only within the facility. Since no appreciable contamination would exit the facility except at a very low rate over a long period of time, no source term or consequence analysis is performed.

The loss of the K-3 ventilation system would result in a loss of air flow in the canyon, hot cells, and K-3 ducting. If the initiating event were not obvious, the no-flow condition would be detected by differential pressure monitors associated with the areas ventilated by the K-3 system (i.e., the K-3 HEPA filter housings, canyon, and hot cells). Once ventilation flow is lost, the negative pressures maintained in those areas would be lost and the contamination present could migrate slowly into uncontaminated areas.

Of all the ventilated areas, the hot cells, $\mathrm{K}-3$ exhaust duct, and K-3 HEPA filter housings are the locations where a contamination spread might originate. Contamination from any of these areas could eventually migrate into the canyon, Operating Gallery, and Service Gallery. Contamination that enters the canyon could eventually migrate to other parts of the facility (e.g., the Pool Cell Area and Truckport), through gaps and spaces around cover blocks, doors, etc.

The primary motive forces that cause migration of contaminants include pressure differentials caused by wind and barometric pressure fluctuations around the facility, temperature differences between areas within the facility and the environment, and ventilation failures. Wind blowing across the stack and around the facility causes small pressure differentials and subsequent airflows from one area to another within the facility. Fluctuations in the barometric pressure could also result in pressure differentials between the facility and the environment. In addition, the temperature differences within the facility and the surrounding environment would add to the airflow caused by wind around the facility. Ventilation failures could result in migration of contamination in two cases: failure of the K-3 exhaust fans while the K-3 supply fan 
continues operation, and failure of the K-3 system while the $\mathrm{K}-1$ and $\mathrm{K}-4$ systems continue to operate. In either case, contamination could migrate between areas of the facility.

The operation of other ventilation systems within the facility are interlocked to the K-3 system to prevent ventilation air from being drawn from contaminated areas into uncontaminated areas of the facility in the event of K-3 system shutdown. In addition, the K-3 exhaust fans are interlocked with the K-3 supply fan so that if the exhaust fans fail, the supply fan is deactivated. This interlock helps to prevent pressurization of contaminated areas.

Given the limited pathways and relatively minor motive forces, the migration of contamination following a loss of $\mathrm{K}-3$ ventilation would result in very low consequences within the facility and would take substantial time to be realized.

Storage of Capsules in F Cell. The HAZOP relied on as the basis for the hazards evaluation in Hey (1999) indicates that a leaking capsule in F Cell has an S1 (i.e., facility worker) consequence rank, which would not normally be considered for quantitative accident analysis. However, it is realized that leaking capsules are undesirable, even if safely stored in F Cell, and it is prudent to define the conditions by which capsules could be stored in F Cell without unduly challenging their integrity or the integrity of the surrounding structure.

The capsules to be stored in F Cell would include known and suspected leakers, with F Cell providing out-of-poolcell dry storage and confinement. The unrestricted storage of any number of capsules in F Cell could lead to high salt/metal interface temperatures and a potential for accelerated corrosion of the capsule wall. This section provides a conservative basis for an F Cell capsule storage configuration and inventory that limits the interface temperature. Calculated temperatures are based on work documented in the thermal analysis report (WHC 1996c). Temperature limits are based on concerns for both capsule corrosion and concrete strength. The analysis also considers the possible loss of ventilation flow in F Cell.

WHC-SD-WM-TI-771 (WHC 1996c) presents a thermal analysis of dry capsule storage in the F Cell. The intent is to determine if the predesignated capsule spacing (in it ack $20 \mathrm{~cm}$ off the fluor) can be used to store capsules in F Cell without exceeding a set of thermal limits. These limits are as follows:

- Long-term concrete temperatures should not exceed $66^{\circ} \mathrm{C}\left(151^{\circ} \mathrm{F}\right)$ generally and should not exceed $93^{\circ} \mathrm{C}(199$ $\left.{ }^{\circ} \mathrm{F}\right)$ locally (ACI 1987).

- Under normal conditions, capsule interface temperature must not exceed $270^{\circ} \mathrm{C}\left(518^{\circ} \mathrm{F}\right)$, based on accelerated corrosion concerns.

- Under loss of ventilation conditions, capsule interface temperature must not exceed $450^{\circ} \mathrm{C}\left(842{ }^{\circ} \mathrm{F}\right)$.

- Under loss of ventilation conditions, concrete surface temperatures should not exceed $177^{\circ} \mathrm{C}\left(351^{\circ} \mathrm{F}\right)(\mathrm{ACI} 1987)$.

The Thermal limits are based on two considerations. First are accelerated corrosion concerns at the capsule cesium chloride-stainless steel interface, and second are standard temperature limits for concrete.

The $270^{\circ} \mathrm{C}\left(518^{\circ} \mathrm{F}\right)$ limit comes from Bryan (1989) and is the lowest melting point of a mixture of cesium chloride and impurities, $3 \% \mathrm{FeCl}_{3}$, studied. The $450^{\circ} \mathrm{C}\left(842{ }^{\circ} \mathrm{F}\right)$ limit also comes from Bryan (1989) and is the test temperature (considered for geologic disposal of WESF capsules) for which inner-capsule through-wall corrosion was estimated to occur in 15 to 21 yr. Bryan (1989) also acknowledges the many uncertainties associated with such predictions but they provide a conservative basis for storage of capsules in F Cell. Therefore, the lower limit is used here for normal storage conditions and the greater limit is used for upset conditions (i.e., ventilation failure).

The temperature limit for the concrete is used here to protect the hot cell structure. Since the structure is relied upon as the primary means of confinement and shielding, and is designated as safety class, it must be protected from thermal degradation. The temperature limit of $177^{\circ} \mathrm{C}\left(351^{\circ} \mathrm{F}\right)$ ensures that the hot cell structure is not unduly challenged.

The computer code used for the thermal analysis was derived lrom the Modular Accident Analysis Program version 4 


\section{HNF-SD-WM-BIO-002 REV 1}

(MAAP4) (WHC 19966) originally created to analyze thermal-hydraulic and radionuclide phenomena during nuclear severe accidents. The MAAPt routine contains extensivety validated hear transfer, mass transfer. fletid tlow. and aerosol trace gas transport and deposition models. For the F Cell thermal analy sis (WHC 1996c). MAAP4 provided a room model to calculate $f$ Cell gas space and heat sink temperatures. given a heat input. $\wedge$ capsule model, which provided this heat input to the $F$ Cell gas space and heat sinks, was linked to the balance of the MAAP4 code. The capsule model also calculated capsule wal! temperature and cesium chloride stainless steel interface temperature based on boundary conditions fron the MAPA room model.

Assuming a hot cell ventiation thowrate of $250 \mathrm{~cm}$ and using conductive and convective heal loss, the thermal analy sis concluded that 24 average capsules $(+.5 \mathrm{~kW})$ could be stored in a rack $\mathrm{f}$ Cell without exceeding long term temperature limits for concrete of $66^{\circ} \mathrm{C}$ generally and $93^{\circ} \mathrm{C}$ locally. Even under a loss of ventikation condition, the temperatures would not exceed the short-term temperature limit of $177^{\circ} \mathrm{C}$ for concrete. In lieu of maintaining a ventilation airflow of $250 \mathrm{ctm}$ through the cell, the thermal load can be reduced to $1.8 \mathrm{~kW}$ to operate within the analyzed conditions and not exceed long tem temperature limits. The $1.8 \mathrm{~kW}$ value was determined by assuming no convective heat transfer and using only conductive heat transter.

The capsule interface temperatures were also calculated in the thermal analysis for normal operating conditions (ventilation airflow of $250 \mathrm{cfm}$ ) and accident conditions (loss of ventilation). The average capsule interfice temperature remains well below the $270^{\circ} \mathrm{C}$ lim it during normal operating conditions and only reaches $250^{\prime \prime} \mathrm{C}$ during accident conditions. The thermal analysis did show that using worst case assumptions. if the maximum power capsule were placed in the middle of the rack, the interface temperature could be as high as $294^{\prime \prime} \mathrm{C}$. This would not necessarily indicate any real accelerated corrosion, however. because of the conservatisms in the interface criteria.

\section{Major Assumptions.}

- Wind, barometric pressure changes, and temperature induced pressure differentials within the facility do not result in a significant spread of contamination outside the facility in the event of a loss of ventilation.

- For the storage of capsules in a hot cell, the temperature criteria are based on protection of the hot cell structure and on the capsule/salt interface.

\subsection{Source Term Analysis.}

No release of airborne radioactive material is expected as a result of any failure experienced by capsules stored in any WESF hot cell. However, the surrounding hot cell structure is safety class owing to the potential consequences of their destruction as described in Section 3.4.3. Therefore, controls necessary to protect this structure from thermal and other types of degradation are prudent.

\subsection{Consequence Analysis.}

A loss of ventilation event, by itself, causes no consequences beyond those discussed above. Human habitation both onsite and offsite are not threatened by this event.

\subsection{Comparison to Guidelines.}

For the reasons discussed above, no comparison to guidelines is made.

\subsection{Summary of Safety SSCs and IOSR Controls.}

The controls derived from this analysis are intended to protect capsule integrity and the hot cell structure. Protection of capsule integrity is a prudent and reasonable operational prerogative. The unintentional defeat of capsule integrity could be costly in terms of cleanup and maintenance. The capsule containment also provides an added barrier against the accidental release of dispersable material and as such, should be considered defense-in-depth. It is not, however the credited barrier 


\section{HNF-SD-WM-BIO-002 REV 1}

against the uncontrolled release of hazardous material. This task is reserved for the WESF hot cell. The safety class function of the WESF hot cell must be protected against long-term degradation that unspecified and uncontrolled storage of capsules could cause. The following controls are based on the thermal analysis of storage of capsules within a hot cell as shown in WHC-SD-WM-TI-771 (WHC 1996c) and summarized in 3.4.2.4.2.1. The credited IOSR controls are designed to protect the hot cell structure and are based on no ventilation airflow through the hot cell. The additional defense in depth controls are designed to prevent accelerated corrosion of the capsules.

Credited SSCs. None. The capsules are not credited as a barrier since the integrity of capsules stored in the hot cell is unknown. The hot cell structure was designated a safety class barrier in Section 3.4.2.4.1 and requires protection as indicated below.

\section{Credited IOSR Controls.}

- Total capsule stored wattage in any one hot cell is maintained at less than $1.8 \mathrm{~kW}$ assuming no hot cell ventilation or $4.5 \mathrm{~kW}$ with an airllow of $250 \mathrm{~cm}$.

The corresponding ${ }^{1: 7} \mathrm{Cs}$ activity for $4.5 \mathrm{~kW}$ is $941 \mathrm{kCi}$ or 24 average cesium capsules. Calculations indicate that the maximun direct gamma-ray shine in the Operating Gallery would be less than a $0.03 \mathrm{mR}$ h (Hey 1999). This control ensures that the hot cell structure is protected and that accelerated capsule corrosion does not occur.

- Capsules are located a minimum of $20 \mathrm{~cm}$ (7.9 in.) from any hot cell structural surface. This control ensures that the hot cell structure is protected.

\section{Additional Defense-in-Depth.}

The following controls, also based on the thermal analysis, ensure that accelerated capsule corrosion does not occur. Since these controls protect capsule integrity, they contribute to defense-in-depth.

- Capsules are spaced a minimum of $20 \mathrm{~cm}(7.9 \mathrm{in}$.) apart.

- Capsules are supported $20 \mathrm{~cm}$ (7.9 in.) off the bottom, vertically oriented, with a free flowing air gap through the base.

- Maximum capsule power is less than $255 \mathrm{~W}$ (this corresponds to the maximum power uncut cesium capsule as of 01/01/96).

- Capsules with very high power (greater than $220 \mathrm{~W}$ ) should not be placed in the center of the storage rach.

- The capsules are of standard WESF design (i.e., Type 1,2, or 3), either singly or doubly encapsulated.

- The ventilation airflow through the hot cell is at least $250 \mathrm{cfm}$.

\subsection{K-3 System Water Accumulation.}

This scenario addresses the potential for inadvertent accumulation of water in the K-3 ventilation system. Potential consequences are a buildup of hydrogen gas, increased radiation exposure rates in the vicinity of the K-3 Filter Pit (radioactive material could be washed into the filter housing), and blockage of the K-3 airflow resulting in a loss of facility ventilation.

The hazards evaluation in Iley (1999) assigned an F2 (i.e., unlikely) frequency of occurrence to this event. The frequency rank, combined with the $\mathrm{S} 2$ (i.e., onsite impacts) consequence rank, results in a risk rank of R2 (i.e., moderate concern) for this accident. 
HNF-SD-WM-BIO-002 REV 1

\subsection{Scenario Development.}

This assessment examines the conditions necessary to generate and accumulate significant amounts of hydrogen in the hot cells. The time required to accumulate $4 \%$ by volume (which is the lower flammability limit [LFL] for hydrogen in air) is also estimated.

The K-3 system provides ventilation for the WESF canyon and hot cells (see Section 2.6.1). The ventilation air first enters the canyon and exits through the hot cells and through an exhaust duct directly to the K-3 HEPA filters. The ventilation air that passes through the hot cells flows into a common hot cell exhaust duct after passing through two banks of HEPA filters, one on the hot cell inlet and one on the hot cell outlet. The ventilation outlets for the hot cells are located in vertical ducting that penetrates the floor of each hot cell. The outlet HEPA filter is located at the top of each outlet duct with the filter about $1 \mathrm{~m}$ above the floor. Each outlet duct is connected to the common duct which is encased in concrete below the hot cells. The common duct receives filtered exhaust air from all of the hot cells and leads to the K-3 HEPA filters. Prior to entering the K-3 Filter Pit, the hot cell common duct is joined with the canyon outlet duct. The K-3 exhaust duct, after the point where canyon and hot cell exhaust ducts join, contains a drain line to TK-100 (also known as the TK-100 vent line) where any water in the K-3 exhaust duct normally drains. A $2.5-\mathrm{cm}$ ( 1 -in.) dam just downstream of the drain line provides a barrier in the ducting to prevent relatively small water flows from bypassing the drain and entering the active K-3 filter housing.

The hazards evaluation in Hey (1999) identified several mechanisms by which water could inadvertently enter and flood the K-3 HEPA filter housing. The possible sources of water can be divided into three groups: hot cell water, TK-100 water, and the $\mathrm{K}-3$ filter washdown water.

Hot Cell Flood. Water sources have been isolated lrom A through E Cells. The sources of water to F Cell are deionized water. fire suppression (also deionized water) and tri-sodium phosphate (TSP) lines. The sources of water to G Cell are deionized waler, fire suppression (raw water) and TSP. The hite suppression system for $F$ and (f Cells are separate so that the system in one hot cell can be activated without activation in the other hot cell.

If operationial controls associated with the sources of water failed, water could flood a hot cell, exceed the level of the ventilation bypass or outlet duct, and exit into the K-3 exhaust duct. Upon entering the K-3 exhaust duct, the water would travel until it reached the drain line leading to TK-100. At that point, the water would be diverted to the drain line, and subsequently, to TK-100 by a $2.5-\mathrm{cm}(1-\mathrm{in}$.) dam just downstream from the drain line opening. If the drain line were plugged, TK-100 overflowing, or the water flow rate were sufficiently high, the $2.5-\mathrm{cm}(1-\mathrm{in}$.) dam could be overwhelmed, and the water could proceed to the active K-3 HEPA filter housing sump. Potential causes of a plugged drain are objects carried by the water (from the duct or the hot cell) and blocking the drain opening, although in photographs of the duct interior, no debris were seen. In addition, overflow of TK-100 could occur if the tank were already full or nearly full such that the tank could not handle the capacity of the flood event. See Figure 3-2 for the isometric view of the K-3 exhaust ducting, K-3 filter pit, and TK-100.

Once water begins to enter the active filter housing (see Figure 2-10), it would be collected in the filter housing sump where it would initiate alarms through the liquid detection system and could be subsequently transferred to TK-100 by the liquid removal system. The water detection system associated with the filter housing sump consists of an air bubbler and remote alarm systems. The injection of air to the filter housing through the bubbler system also acts to dilute any hydrogen that might be generated.

If the source of the flood was controlled or the water drained into TK-100, the normal ventilation air passing through the filter housing would prevent the accumulation of any hydrogen that might be generated. The water in the filter housing sump could then be removed or allowed to evaporate depending on the quantity of water and operational expediency.

If the source of water were not identified and controlled and the drain to TK-100 failed, the water level in the filter housing sump would continue to rise. Because of the filter housing design, a high water level in the sump would restrict and then halt airflow through the filter housing. As the airflow became increasingly restricted, the response of the K-3 ventilation system would be similar to that discussed in Section 3.4.2.3.1.1, Hot Cell Fire. As a part of that analysis it is assumed that the K-3-filters become plugged from smoke accumulation thereby restricting and then halting the airflow through the filter housing. In summary, the reduced airflow would cause the activation of the standby K-3 filter housing and exhaust fan while 
Figure 3-2. Isometric View of K-3 Exhaust Ducting, K-3 Filter Pit, and TK-100

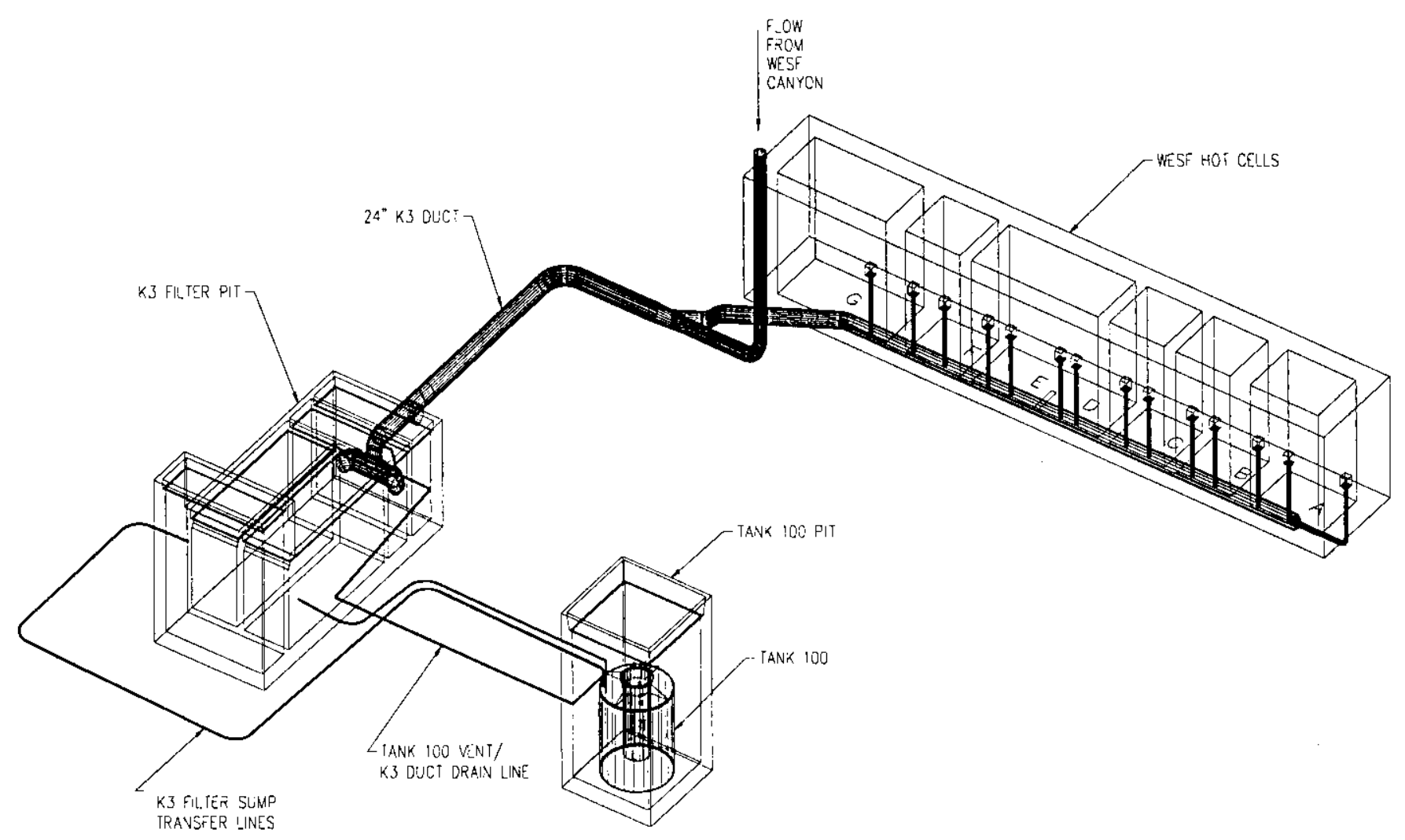


also shutting down the $\mathrm{K}-3, \mathrm{~K}-1$, and $\mathrm{K}-4$ supply fans and all other facility ventilation systems. By opening the standby filter housing, the K-3 system could temporarily restore sufficient airflow and system pressures, causing deactivation of the standby filter housing. Switching back to the flooded filter housing would cause a loss of system airflow again and reactivation of the standby filter housing. Thus, the K-3 ventilation would "surge" until the standby filter housing also became flooded (from water entering from the K-3 exhaust duct or backed up from the other filter housing).

If the standby filter housing became flooded, the airflow through the K-3 system would be halted and the K-3 exhaust fans would be operating in a no-flow condition.

Once the flood condition is detected (by the ventilation system responses) water can be removed from one or both filter housing sumps through the steam jet located there. The jet is designed to move water from the filter housing sump to TK-100 and can be operated by manually aligning valves. Reducing the water level in the sump would allow ventilation air to pass through the filter housing.

If the sump jet is inoperable or if there is a simultaneous loss of general institutional control at the facility (i.e., facility personnel do nothing and allow the condition to persist indefinitely), hydrogen could begin to accumulate in one or both filter housings. The hydrogen would be produced as a result of radiolysis of water in the sump, with the energy coming from radioactive material potentially washed into the sump with the water and from radioactive material present on the filters. To bound the progression of events, it is assumed that one filter housing, containing the maximum possible radioactive material inventory dissolved in the water and present on the filters, is involved in the explosion. This maximizes the potential consequences and provides the bounding time required to achieve the lower flammability limit (LFL) inside the filter housing.

TK-100 Overflow. TK-100 is used to collect and stage batches of potentially contaminated low-level liquid waste before transfer to a tanker truck for disposal. In addition to acting as the receiver tank for the K-3 exhaust duct drain line, TK-100 also receives water from numerous floor drains throughout the facility, including the Service Gallery and Truckport.

If water diverted to TK-100 (not from the K-3 exhaust duct, which is addressed in the flood of a hot cell above) exceeded its storage capacity, the tank would overflow into one or more of the following places: 1) through the 5 - $(\mathrm{cm}$ (2-in) sump line and into the TK-100 pit, 2) through the 5-cm (2-in.) K-3 duct drain line and into the K-3 exhaust duct. and or 3 ) through the $5-\mathrm{cm}(2-\mathrm{iu})$ vent line into the K-3 filter housing. No substantial amount of contamination would be washed into the filter housing trom any ol these paths since the water in TK-100 does not contain significant contamination. To prevent such a flood and allow facility personnel to halt the flow of water, the tank has level monitoring instrumentation and alarms to show the level of liquid in the tank and provide a high-level alarm should the liquid level exceed a specified value.

If the TK-100 level monitors and alarms failed or if facility personnel could not identify and halt the flow of water into the tank, water could eventulally back up into the the active K-3 filter housing. The progression of events from this point is identical to those described for the hot cell flood with two exceptions. The first exception is the complication of TK-100 already being full so that water cannot be transferred out of the filter housing sump. Some of the contents of TK-100 would have to be transferred per normal operating procedures before draining the filter housing sumps. This complication is more than offset by the second exception, which is the greatly reduced radioactive material inventory assumed to be dissolved in the water. Since the TK-100 source of water is essentially uncontaminated, the energy available for radiolysis of water is greatly reduced resulting in a much longer time available for recovery.

The possible overflow of TK-100 is developed here because it is a possible source of water entering the K-3 filter housings, and as such, must be evaluated. However, the source term analysis below, Section 3.4.2.4.3.2, demonstrates that insufficient radioactive material would be present in a flooded filter housing following this event to cause an appreciable generation rate of hydrogen. Therefore, no mitigated or unmitigated conditions are developed for a possible TK-100 overflow scenario.

K-3 Filter Washdown System Activation. The filter washdown system in each of the K-3 filter housings is comprised of fixed-head spray nozzles above the pre-filter equipment in the filter housing. The system is designed to allow washing (for decontamination purposes) of the in-line heaters, moisture separators, and other exposed surfaces upstream of the HEPA filters. The water from the washdown system is collected in the $\mathrm{K}-3$ filter housing sump and is separated from the filter media by a steel wall across the interior of the filter housing. The water from the washdown system never contacts the filter media. 
When the washdown system is not in use, quick-disconnects and two valves are used to keep the filter housings isolated from the source of water. A filter washdown flood has already partially occurred in a 1994 event in which inadvertent alignment of the two valves (with the disconnects connected) caused one of the filter housings to become partially flooded. In that event, the K-3 system responded to the decreasing airflow as noted above and facility personnel were able to recover from the event before the complete cessation of airflow. The water was removed from the filter housing sump by the sump jet.

In addition to the flood of the active filter housing, which would have a similar progression of events to that already described for the hot cell and TK-100 floods, the washdown system could also flood the inactive filter housing. This progression of events would not result in K-3 system upsets and thus would be more difficult to detect. If the inactive filter housing were inadvertently flooded, the liquid detector in the sump, and associated alarm systems, would alert facility personnel to the flooded condition. Facility personnel could then identify and isolate the source of water and remove the water from the filter housing. If the liquid detector or alarms failed or there was a general loss of institutional control (i.e., no response to alarms) in conjunction with significant radioactive material on the filters, hydrogen could be generated and accumulated in the inactive filter housing. Given sufficient time the LFL concentration could be reached and the hydrogen ignited sometime later.

The possible actuation of the filter washdown system is developed here because it is a possible source of water entering the K-3 filter housings, and as such, must be evaluated. However, the source term analysis below, Section 3.4.2.4.3.2, demonstrates that insufficient radioactive material would be present in a flooded filter housing following this event to cause an appreciable generation rate of hydrogen. Therefore, no mitigated or unmitigated conditions are developed for a possible filter washdown system flood scenario.

Unmitigated Condition. The unmitigated condition for a K-3 filter flood scenario is based on the hot cell flood scenario discussed above. The scenarios for a TK-100 overflow and actuation of the filter washdown system were found to have insufficient hydrogen generation potential to be of concern (see Section 3.4.2.4.3.2). Therefore, the unmitigated condition assumes that control of a water source to a hot cell is lost, resulting in a flood of a hot cell, and highly contaminated water bypassing the exhaust duct drain line (to TK-100). In addition, ventilation airflow through the filter housing is assumed to be lost and the water in the filter housing is not detected or removed in time to prevent accumulation of hydrogen in concentrations greater the LFL. This hydrogen is then ignited within the filter housing resulting in direct impact to the radioactive material assumed to be present on the K-3 HEPA filters.

Mitigated Condition. For the mitigated condition, it is assumed that surveillance of the hol cells for flooding prevents a hydrogent explosion in the $K-3$ filters. It takes approximatel. 73 days to accumulate 4 , o hydrogen in the $k-3$ filters following a tlood in the hot cells. Lacking the radioactive material potentially carried by a hot cell flood, a flood of just the K-3 filter housing is not a hazardous condition (see Section 3.4.2.4.3.2). Therefore, the potential accumulation of hydrogen within a filter housing, and subsequent explosion hazard, is prevented.

Major Assumptions. The following assumptions were made in the scenario development:

- The hot cell ventilation bypass seals would not prevent water in the hot cells from entering the K-3 duct

- One filter housing, containing the maximum possible radioactive material inventory dissolved in the water and present on the filters, is involved in a hydrogen explosion as a result of the $\mathrm{K}-3$ flooding event. One housing is assumed instead of both because this maximizes the calculated consequences while minimizing the time required to reach $4 \%$ hydrogen

\subsection{Source Term Analysis.}

The source term analysis is based on the three sources of water for a K-3 filter housing flood: a hot cell, TK-100, or the filter washdown system. The details of each source of water are discussed below to ascertain the bounding length of time to achieve the LFL concentration in the filter housing. In addition, the potential radioactive material source term released from a hydrogen explosion in a filter housing is calculated. 


\section{HNF-SD-WM-BIO-002 REV 1}

The general methodology for calculating the length of time required to reach $4 \%$ (by volume) of hydrogen in the volume of a filter housing is listed in the following steps:

- Estimate the ionizing energy given off from the radioactive materials present (this is calculated from the inventory present and any relevant physical characteristics, e.g., shielding)

- Calculate the rate at which hydrogen gas is produced from the absorbed energy (i.e., radiolysis)

- Given the rate of hydrogen generation and the volume to be filled, calculate the time required to reach $4 \%$ concentration. found from

The ionization energy given off from the radioactive materials that could potentially be absorbed by the water is

$$
\begin{aligned}
& E_{T}=E_{\text {Filter }}+E_{C s, H_{2} O}+E_{B a_{1} H_{2} O} \\
& \text { where: } \\
& E_{T}=\text { total ionization energy emission rate }(\mathrm{eV} / \mathrm{s}) \\
& E_{\text {fiter }}=\text { energy from filters }(\mathrm{eV} / \mathrm{s}) \\
& E_{C s, H_{2} \mathrm{O}}=\text { energy from }{ }^{137} \mathrm{Cs} \text { in water }(\mathrm{eV} / \mathrm{s}) \\
& E_{B a, H_{i} O}=\text { energy from }{ }^{13 \% m} \mathrm{Ba} \text { in water }(\mathrm{eV} / \mathrm{s})
\end{aligned}
$$

The contribution from each particular source of ionization energy is estimated from the inventory by

$$
E_{\text {location }}=s_{i} x_{i}
$$

where:

$s_{i}=$ source inventory of isotope $i(B q)$

$x_{i}=$ ionizing energy emitted by isotope $i(\mathrm{eV})$

The generation rate of the hydrogen, $R_{H_{2}}$, is then estimated the same as Hey (1999) using

$$
R_{H_{2}}=E_{T} F G C
$$

where:

$E_{T}=$ total ionization energy emission rate $(\mathrm{eV} / \mathrm{s})$

$F=$ energy fraction deposited in water (assumed 1.0)

$G=$ material $\mathrm{H}_{2}$ generation characteristic

( 0.45 molecules $\mathrm{H}_{2}$ per $\left.100 \mathrm{eV}\right)$

$\mathrm{C}=$ conversion factor $\left(3.72 \times 10^{-23} \mathrm{~L} /\right.$ molecule $\mathrm{H}_{2}$ [Hey 1996])

The time required to reach $4 \%$ hydrogen is then calculated by 


$$
\operatorname{time}(4 \%)=(0.04) \cdot\left(\frac{V}{R_{H 2}}\right)
$$

where:

$$
\begin{gathered}
0.04=\text { volume fraction of interest }(4 \%) \\
V=\text { free volume of filter box }(L)
\end{gathered}
$$

Hot Cell Flood. The maximum amount of radioactive material that could possibly enter the filter housing in a hot cell flood is from a flood or washdown of the $\mathrm{K}-3$ exhaust duct. The inventory from the hot cells is not used in this analysis since water to A through $\mathrm{F}$. Cells has been isolated and there is no appreciable inventory in $f$ and $\mathrm{G}$ Cells outside of the capsules. The inventory data in Table 3-3 for the K-3 exhaust provides two possible mixtures of ${ }^{90} \mathrm{Sr}$ and ${ }^{137} \mathrm{Cs}$. In this accident, it is assumed that the contamination in the exhaust duct consists entirely of ${ }^{337} \mathrm{Cs}, 1.9 \times 10^{14} \mathrm{~Bq}(5 \mathrm{kCi})$ to maximize the amount of soluble radioactive material assumed to be carried into the filter housing. The only source of water entry into the K-3 exhaust duct is from a flood of a hot cell. This water source will not result in a fast-flowing, turbulent washing of the entire circumference of the duct. The water would form a shallow stream in the bottom of the duct and flow smoothly down its length. It is expected that very little, if any, strontium fluoride would be dislodged by this action. In addition, the contamination in the exhaust duct has experienced several years of continuous air passage and only the material that would dissolve in water would be expected to be washed away by a flood event. Therefore, the total amount of radioactive material assumed to be dissolved in the water during a flood of the $\mathrm{K}-3$ filter housing is $1.9 \times 10^{1+} \mathrm{Bq}\left(5 \mathrm{kC}\right.$ ) of ${ }^{137} \mathrm{Cs}$.

In addition to the radioactive material dissolved in the water, the inventory assumed to be present on the K-3 HEPA filters could also add to the hydrogen generation rate. The contamination assumed to be present on the K-3 filters is assumed to be $8.9 \times 10^{12} \mathrm{~Bq}(240 \mathrm{Ci})$ of ${ }^{137} \mathrm{Cs}$ and $6.7 \times 10^{14} \mathrm{~Bq}(18 \mathrm{kCi})$ of ${ }^{90} \mathrm{Sr}$. This assumption is subject to inventory control for the K-3 filters.

It is conservatively assumed that all of the energy from the material in the water, which includes the ${ }^{137} \mathrm{Cs}$ and its daughter product ${ }^{137 \mathrm{~m}} \mathrm{Ba}$, is absorbed by the water. The energy from the material on the filter, however, is shielded except for the gamma energy from the ${ }^{137_{m}} \mathrm{Ba}$.

The peak decay energy for beta particles $\left({ }^{137} \mathrm{Cs}\right)$ is $0.552 \mathrm{MeV} / \mathrm{dis}$ with the average decay energy one-third of the peak, or $0.184 \mathrm{MeV} / \mathrm{dis}$. The decay energy for the gamma particles is $0.662 \mathrm{MeV} / \mathrm{dis}$. Using these values and the inventory values stated above, the energies can be calculated as

$$
\begin{gathered}
E_{\text {Ba fitter }}=\left(8.9 \times 10^{12} \mathrm{~Bq}\right) \cdot\left(0.662 \frac{\mathrm{MeV}}{\mathrm{dis}}\right) \\
=5.9 \times 10^{12} \frac{\mathrm{MeV}}{\mathrm{s}} \\
E_{C s, H 2 O}=\left(1.9 \times 10^{\prime \prime} \mathrm{Bq}\right) \cdot\left(0.184 \frac{\mathrm{MeV}}{\mathrm{dis}}\right) \\
=3.5 \times 10^{13} \frac{\mathrm{MeV}}{\mathrm{s}} \\
E_{B a, H 2 O}=\left(1.9 \times 10^{\prime 4} \mathrm{~Bq}\right) \cdot\left(0.662 \frac{\mathrm{MeV}}{\mathrm{dis}}\right) \\
=1.3 \times 10^{14} \frac{\mathrm{MeV}}{\mathrm{s}}
\end{gathered}
$$

The total energy is $1.7 \times 10^{14} \mathrm{MeV} / \mathrm{s}$, or $1.7 \times 10^{20} \mathrm{eV} / \mathrm{s}$. Thus, the generation rate of hydrogen is 


$$
\begin{aligned}
R_{H_{2}}=\left(1.7 \times 10^{20} \frac{\mathrm{eV}}{\mathrm{s}}\right) \cdot(1.0) & \left(\frac{0.45 \mathrm{molec} \cdot \mathrm{H}_{2}}{100 \mathrm{eV}}\right) \cdot\left(3.72 \times 10^{-23} \frac{\mathrm{L}}{\text { molec. } \mathrm{H}_{2}}\right) \\
& =2.8 \times 10^{-5} \frac{\mathrm{L}}{\mathrm{s}}
\end{aligned}
$$

The free volume of the filter housing is $4,417 \mathrm{~L}\left(156 \mathrm{ft}^{3}\right)$ based on water in the sump up to the level of the ventilation duct inlet. To achieve $4 \%$ (volume) of hydrogen it would take

$$
\begin{aligned}
\operatorname{time}(4 \%) & =(0.04) \cdot\left(\frac{\left.4,417 \frac{L}{2.8 \times 10^{-5} \frac{L}{s}}\right)}{}\right) \\
& =6.3 \times 10^{6} \mathrm{~s} \\
& =73 \text { days }
\end{aligned}
$$

This simplistic hand calculation is conservative because it assumes that all of the hydrogen enters the filter housing whereas some of the hydrogen would exit through the K-3 duct leading both to and from the filter housing. In addition, the calculation does not account for the presence of oxygen, which is also generated, albeit at one-half the rate of the hydrogen.

TK-100 Flood and Filter Washdown System. The time required to reach $4 \%$ hydrogen in the filter housing for these sources of water is estimated using the same equations as shown above for the hot cell flood. Because neither of these sources of water would contain appreciable amounts of radioactive contamination, the energy available for radiolytic decomposition of water is much less than was assumed for a hot cell flood.

The energy deposited in the water from the inventory on the K-3 HEPA filters, $\mathrm{E}_{\text {filter, }}$ is calculated above to be $5.9 \times 10^{12} \mathrm{MeV} / \mathrm{s}$, or $5.9 \times 10^{18} \mathrm{eV} / \mathrm{s}$. Since there is no contamination in the water, this energy is the total energy absorbed by the water for the purposes of generating hydrogen. This is a very conservative value because it assumes $100 \%$ of the gamma energy produced by the inventory goes to the water. This assumption is used for two reasons: (1) in the case of the hot cell flood (above), the value is negligible when compared to the other energy sources, and (2) in the case of the TK-100 and washdown system floods, its use demonstrates the very long time period available for detection and recovery (calculated below) even using such conservative values.

With this energy, the generation rate in the filter housing for these two sources of water is bounded by $9.9 \times 10^{-7} \mathrm{~L} / \mathrm{s}$. Using the same methodology (and same conservative assumptions) from the hot cell flood analysis (above), this generation rate results in a time to reach $4 \%$ hydrogen in the filter housing of $1.8 \times 10^{8}$ seconds, or 2,100 days (6 years).

Unmitigated Condition. The unmitigated condition assumes that control of a source of water to a hot cell was lost and the secondary controls (e.g., maintaining airflow through the filter housing) failed. In this condition it is postulated that hydrogen is produced by radiolysis of the highly contaminated water in the filter housing sump and then accumulated in the filter housing air space. If a hydrogen explosion were to occur within the filter housing, initiated by an energy source within the filter housing, such as from one of the in-line electrical heaters or static electricity, the potential exists for failure of the housing and filter media because of internal overpressurization. Two models from Mishima (1994) were considered for this event. The first was a shock event impacting the filter media. The second was a blast event impacting the filter media. The blast model was chosen due to its greater conservatism. From Mishima (1994), Section 5.4.2.2, the bounding ARF:RF for a blast impact to a HEPA filter is $1 \times 10^{-2}: 1.0$.

Applying this release fraction to the inventory assumed to be on the HEPA filters, $8.9 \times 10^{12} \mathrm{~Bq}(240 \mathrm{Ci})$ of ${ }^{137} \mathrm{Cs}$ and $6.7 \times 10^{14} \mathrm{~Bq}(18 \mathrm{kCi})$ of ${ }^{90} \mathrm{Sr}$, results in a source term of $8.9 \times 10^{10} \mathrm{~Bq}(2.4 \mathrm{Ci})$ of ${ }^{137} \mathrm{Cs}$ and $6.7 \times 10^{12} \mathrm{~Bq}(180 \mathrm{Ci})$ of ${ }^{90} \mathrm{Sr}$. 
The radioactive material from the exhaust duct, assumed to be dissolved in the water inside the filter housing sump, would not be released as a result of the explosion. The damper on the outlet ventilation duct would likely fail before a structural failure of the filter housing itself, so that no contaminated water would be released. This differs from the analysis of the potential hydrogen explosion in TK-100 (Section 3.4.2.4.4.2) where it is assumed that the pressure from the explosion is vented below the liquid level. Given the unknowns associated with the two analyses, the seeming discrepancy is explained by the desire to provide a bounding estimate of the potential consequences of each accident. In the case of TK-100, the bounding dose consequences arise from a tank failure and subsequent spray leak. In the case of the K-3 filter housing, the bounding dose consequences arise from the direct path to the environment (failed damper) in conjunction with a high-energy impact to the filter media (and ${ }^{90} \mathrm{Sr}$ ).

Mitigated Condition. The mitigated condition assumes that surveillance of the hot cells for flooding is performed. Barring a hot cell flood, water accumulation in a K-3 filter housing is not a hazardous condition. Thus, in the mitigated condition. a hydrogen explosion in a K-3 filter housing is prevented.

The accident progressions for a TK-100 and for a filter washdown system flood are not carried further, and no controls are developed for them. Given the nature of the existing facility operations, described in Chapter 2.0 , it is incredible that a filter housing at or near its maximum allowable contamination levels would sit idle for the long period of time required to generate a combustible mixture of hydrogen gas. Deliberate abandonment of a filter housing, because of operational or other considerations, is outside of the scope of this BIO.

Major Assumptions. The following assumptions were made in the preceding source term analysis:

- Contamination in the exhaust duct consists entirely of ${ }^{137} \mathrm{Cs}, 1.9 \times 10^{14} \mathrm{~Bq}(5 \mathrm{kCi})$ and is washed into a $\mathrm{K}-3$ filter housing

- The contamination present on the K-3 filters is assumed to be $8.9 \times 10^{12} \mathrm{~Bq}(240 \mathrm{Ci})$ of ${ }^{137} \mathrm{Cs}$ and $6.7 \times 10^{14} \mathrm{~Bq}$ $(18 \mathrm{kCi})$ of ${ }^{90} \mathrm{Sr}$

- For the hot cell flood scenario, all of the energy from the material in the water flooding the filter pit is absorbed by the water

- All hydrogen generated remains in the filter housing

- The ARF:RF values of $1 \times 10^{-2}: 1.0$ for the unmitigated hot cell flood were chosen for a blast impact to a HEPA filter

- The explosion is vented through the most direct and conservative route from the $\mathrm{K}-3$ filter housing

\subsection{Consequence Analysis.}

Unmitigated Condition. The unmitigated dose consequences arising from a hydrogen explosion in the K-3 filter housing can be found by multiplying the source term by the dose conversion factors developed in Section 3.4.1.3 and given in Table 3-27.

1 Mitigated Condition. No consequences are generated by the mitigated hot cell flood scenario since the explosion is prevented. Also, no mitigated scenario is required for the TK-100 and filter washdown flood scenarios since all conditions necessary for a combustion event were considered outside the scope of this BIO.

To provide a more complete assessment of potential effects of this inadvertent water accumulation in the K-3 HEPA filter housing, the gamma-ray shine from the $1.9 \times 10^{14} \mathrm{~Bq}\left(5 \mathrm{kC}(\mathrm{i}){ }^{137} \mathrm{Cs}\right.$ assumed to be in the filter housing can be estimated. The unit exposure rate (1ley .1999) of $5.0 \times 10^{-2} \mathrm{mR} / \mathrm{h} / \mathrm{Ci}$ would give an exposure rate of about $250 \mathrm{mR} / \mathrm{h}$ on the K-3 filter pit cover blocks. 
HNF-SD-WM-BIO-002 REV 1

Table 3-27. Unmitigated Dose Consequences from Hydrogen Explosion in the K-3 HEPA filter Housing.

\begin{tabular}{|c|c|r|c|}
\hline Isotope & Source term $(\mathrm{Ci})$ & $\begin{array}{c}\text { DCF } \\
\mathrm{mSv} / \mathrm{Ci}(\mathrm{rem} / \mathrm{Ci})\end{array}$ & $\begin{array}{c}\text { 50-yr Committed } \\
\text { EDE } \\
\mathrm{mSv}(\mathrm{rem})\end{array}$ \\
\hline${ }^{90} \mathrm{Sr}$ & 180 & $9.4(0.94)$ & $\begin{array}{c}1700(170) \\
\text { onsite } 100-\mathrm{m} \text { worker }\end{array}$ \\
\hline${ }^{137} \mathrm{Cs}$ & 2.4 & $1.2(0.12)$ & $\begin{array}{c}2.0(0.20) \\
\text { public }\end{array}$ \\
\hline${ }^{90} \mathrm{Sr}$ & 180 & $0.011(0.0011)$ & $\begin{array}{c}2.9(0.29) \\
\text { alternate site boundary }\end{array}$ \\
\hline${ }^{137} \mathrm{Cs}$ & 2.4 & $0.0014(0.00014)$ & $0.016(0.0016)$ \\
\hline${ }^{90} \mathrm{Sr}$ & 180 & $0.0020(0.00020)$ & \\
\hline
\end{tabular}

\subsection{Comparison to Guidelines.}

No credit is taken for a reduced frequency of the event because the frequency of the initiating event is not well known. Therefore, the risk evaluation guidelines used in this analysis are those associated with the anticipated frequency range, $50 \mathrm{mSv}(5.0 \mathrm{rem})$ onsite and $5 \mathrm{mSv}(0.5 \mathrm{rem})$ offsite.

Unmitigated Condition. The unmitigated onsite dose is $1,700 \mathrm{mSv}(170 \mathrm{rem})$, which is above the onsite risk evaluation guideline of $50 \mathrm{mSv}(5.0 \mathrm{rem})$. The unmitigated offsite dose is $2 \mathrm{mSv}(0.20 \mathrm{rem})$, which is below the offsite risk evaluation guideline of $5 \mathrm{mSv}(0.5 \mathrm{rem})$. In addition, the offsite dose for the alternate site boundary definition is $2.8 \mathrm{mSv}$ $(0.28 \mathrm{rem})$, is also below the offsite risk evaluation guideline.

Mitigated Condition. No consequences were generated by the mitigated condition.

\subsection{Summary of Safety SSCs and IOSR Controls.}

Credited SSCs. None. The visible condition of water in a hot cell, a loss of K-3 ventilation, and the several days ( 73 days) available before hydrogen accumulation becomes a concern, makes engineered barriers unnecessary.

\section{Credited IOSR Controls.}

- An initial condition in this analysis is the limiting inventory of $8.9 \times 10^{12} \mathrm{~Bq}(240 \mathrm{Ci})$ of ${ }^{137} \mathrm{Cs}$ and $6.7 \times 10^{14} \mathrm{~Bq}$ $(18 \mathrm{kCi})$ of ${ }^{90} \mathrm{Sr}$ on either of the K-3 HEPA filter trains. The assumption is necessary to maintain unmitigated offsite dose consequences below safety class guidelines.

- An IOSR is needed to detect and take subsequent actions for flooding of a hot cell. This control consists of the following elements:

- A periodic surveillance of all hot cells to detect possible water leaks into the hot cell. A surveillance interval of at least once per 60 days ensures that water accumulated in the K-3 filter housing would not result in a hydrogen concentration greater than $4 \%$.

- On detection of water in a K-3 HEPA filter housing, ensure that 1) water did not originate from a hot cell, or 2) ventilation flow through the affected filter train is maintained, or 3) water from the filter 
housing is removed within 60 days from the last surveillance.

\subsection{High Activity in TK-100.}

This scenario addresses the possibility of ${ }^{137} \mathrm{Cs}$ and ${ }^{90} \mathrm{Sr}$ contamination accumulating in $\mathrm{TK}-100$ and remaining for an extended period of time. The source of contamination could be water from the K-3 ductwork. Consequences are a buildup of hydrogen gas and a potential for increased radiation exposure rates in the vicinity of the TK-100 pit.

The hazards evaluation in Hey (1999) identifies a potential large accumulation of radioactive material in TK-100 as having a frequency rank of unlikely, F2 (i.e., unlikely), with a severity of S2 (i.e., onsite worker). This frequency rank is based on the likelihood of flushing significant quantities of contamination into the tank and then failing to dispose of its contents for an extended period of time. The combination of severity and frequency ranks results in a risk rank of R2 (i.e., moderate concern).

\subsection{Scenario Development.}

Unmitigated Condition. Accumulation of contaminated liquid in TK-100 from the K-3 ductwork is possible in two ways: (1) liquid enters the K-3 exhaust duct and carries contamination into the $5-\mathrm{cm}$ (2-in.)-diameter vent/drain line to TK-100, and (2) liquid enters the exhaust duct and carries the contaminated material into the K-3 HEPA filter housing where it

| is jetted from the sump into TK-100. In addition, liquid from any of 225-B Building areas drained by the LLLW system will drain to TK-100.

The liquid entering the $\mathrm{K}-3$ duct as in the first instance above (1) would be coming from the hot cells. Such a flow could occur from the causes already discussed in Section 3.4.2.4.3.1 of the K-3 system water accumulation scenario development. The water from this source could have high activity as soluble ${ }^{137} \mathrm{Cs}$ is assumed to be dissolved in the drainage. The liquid entering TK-100 as identified in the second instance above (2) would have the same activity expected as described in the first instance since it has the same origin. If the $5-\mathrm{cm}(2-\mathrm{in}$.)- diameter vent/drain line is open and the water flow is sufficient to overwhelm the $2.5-\mathrm{cm}$ (1-in.) dam in the duct, these events could occur simultaneously. Removal of this water would likely be in conjunction with water removal from a K-3 HEPA filter housing, and therefore, the high activity and the potential for hydrogen accumulation would be well known by facility personnel. The potential for significant activity going to

| TK-100 is, however, slight in the case of the LLLW system since all of the locations draining to TK-100 have manned access and as such are not significantly contaminated. Section 2.6.2.2 lists all of the facility locations that drain to TK-100.

Barriers to this event include those discussed in Section 3.4.2.4.3 in addition to a small (i.e., $0.03 \mathrm{~m}^{3} / \mathrm{h}$ [1 $\mathrm{ft}^{3} / \mathrm{h}$ ]) but significant amount of ventilation flow provided by the level monitoring bubbler system within TK-100. TK-100 head space gas pressure is equalized through the 5 -cm (2-in.) vent line to the K-3 ductwork upstream of the HEPA filters. An additional control is provided by transfer of the contaminated water out of the tank in a timely fashion.

Mitigated Condition. No mitigated condition is considered since the unmitigated scenario consequences fall below the risk evaluation guidelines as discussed below. condition:

Major Assumptions. The following assumptions were made in the scenario development for the unmitigated

- Hydrogen is generated in the tank

- A gas explosion occurs.

\subsection{Source Term Analysis.}

The methodology used to model the generation and accumulation of hydrogen in TK-100 is similar to that used in Section 3.4.2.4.3.2. However, in the analysis for TK-100 diffusion through a 2 -in. vent line is taken into consideration, whereas diffusion was not modeled in the K-3 analysis. The methodology for TK-100 is as follows: 
- The energy absorbed by the water and subsequent generation rate of hydrogen are calculated in the same fashion as presented in Section 3.4.2.4.3.2 (K-3 analysis)

- Using the hydrogen generation rate and an estimated diffusion rate of hydrogen from the tank, the theoretical equilibrium concentration of hydrogen within the tank is estimated

- Using the theoretical equilibrium concentration of hydrogen within the tank, the time required to reach a concentration of $4 \%$ is calculated

The diffusion of hydrogen from the tank is calculated in a fashion similar to that used in Liljegren and Terrones (1996) for the K-1 duct leading from the Pool Cell Area.

The equation used in that analysis is

$$
\begin{gathered}
Q_{\text {vemt }}=D_{H_{2} \text { air }} \cdot\left(\frac{A}{L}\right) \\
\text { where: } \\
Q_{\text {vem }}=\text { rate of diffusion }\left(\mathrm{cm}^{3} / \mathrm{s}\right) \\
D_{H_{2}, \text { air }}=\text { diffusion coefficient for } \mathrm{H}_{2} \text { in air } \\
\left(0.711 \mathrm{~cm}^{2} / \mathrm{s} \text { at } 25^{\circ} \mathrm{C}[\text { Liljegren, et. al } 1996]\right) \\
A=\text { vent area normal to flow }\left(\mathrm{cm}^{2}\right) \\
L=\text { length of vent line to } K-3 \text { exhaust duct }(\mathrm{cm})
\end{gathered}
$$

The diffusion rate is then used as input into the equilibrium concentration calculation, which is also given by Liljegren and Terrones (1996) as:

$$
\chi_{H_{2}}=\left(1+\frac{R_{O_{2}}+Q_{v e n t}}{R_{H_{2}}}\right)^{-1}
$$

$$
\text { where: }
$$

$\chi_{\mathrm{H}_{2}}=$ hydrogen volume fraction in filter housing

$$
R_{O_{2}}=\text { generation rate of oxygen }(L / s)
$$

$$
=0.5 \text { of } R_{H_{2}}
$$

$R_{H_{2}}=$ generation rate of hydrogen $(L / s)$

$Q_{\text {vent }}=$ hydrogen diffusion rate through vent $(L / s)$ 
From Liljegren and Terrones (1996), the time required to reach a specified concentration when given the equilibrium concentration can be estimated by

$$
\begin{gathered}
\chi_{H_{2}}(t)=\left(\chi_{H_{2}}(0)-\chi_{H_{2}, \text { equil }}\right) e^{-\frac{t}{\tau}}+\chi_{H_{2}, \text { equit }} \\
\text { where: } \\
\chi_{H_{2}}(t)=0.04, \text { volume fraction of interest } \\
\chi_{H_{2}}(0)=0, \text { initial hydrogen concentration } \\
\chi_{H_{2}, \text { equit }}=\text { calculated equilibrium concentration } \\
t=\text { time (s) } \\
\tau=\text { time constant } \\
\tau=\frac{V_{\text {head }}}{R_{H 2}} \chi_{H 2, \text { equil }}
\end{gathered}
$$

where:

$V_{\text {head }}=$ headspace in tank $(L)$

$R_{H_{2}}=$ hydrogen generation rate $(L / s)$ in TK-100.

Unmitigated Condition. Following the introduction of water into the $\mathrm{K}-3$ exhaust duct, hydrogen could accumulate

The total ionization energy, E, is identical to that calculated in Section 3.4.2.4.3.2 for the flood of the K-3 filter housing except for the energy contributed from the K-3 HEPA filters. The energy from the contamination in the water is $3.5 \times 10^{13} \mathrm{MeV} / \mathrm{s}$ (for the ${ }^{137} \mathrm{Cs}$ ) and $1.3 \times 10^{14} \mathrm{MeV} / \mathrm{s}$ (for the ${ }^{137 \mathrm{~m}} \mathrm{Ba}$ ). This energy accounts for the entire $\mathrm{K}-3$ exhaust duct inventory, $1.9 \times 10^{14} \mathrm{~Bq}(5 \mathrm{kCi})$ of ${ }^{137} \mathrm{Cs}$. The total energy is then $1.7 \times 10^{14} \mathrm{MeV} / \mathrm{s}$, or $1.7 \times 10^{20} \mathrm{eV} / \mathrm{s}$.

Using the stated values for $\mathrm{E}\left(1.7 \times 10^{20} \mathrm{eV} / \mathrm{s}\right), \mathrm{F}(1.0), \mathrm{G}\left(0.45\right.$ molecules $\mathrm{H}_{2}$ per $\left.100 \mathrm{eV}\right)$, and $\mathrm{C}\left(3.72 \times 10^{.23}\right.$ $\mathrm{L} /$ molecule $\mathrm{H}_{2}$ ), the rate of generation of hydrogen, $\mathrm{R}_{\mathrm{H} 2}$, is $2.8 \times 10^{-.} \mathrm{L} / \mathrm{s}$.

The diffusion of the hydrogen from TK-100 through the 5-cm (2-in.) drain line, $\mathrm{Q}_{\text {vent }}$, can be estimated from the diffusivity of hydrogen in air $\left(0.711 \mathrm{~cm}^{2} / \mathrm{s}\right.$ at $\left.25 \mathrm{C}\right)$, the cross-sectional area of the duct $\left(20 \mathrm{~cm}^{2}\right)$, and the length of the duct (approximately $3,000 \mathrm{~cm}$ ). Using these values and the equation presented above, $Q_{\text {vent }}$ is $4.7 \times 10^{-3} \mathrm{~cm}^{3} / \mathrm{s}$, or $4.7 \times 10^{-6} \mathrm{~L} / \mathrm{s}$.

Substituting the values of the hydrogen generation rate and diffusion rate into the equilibrium concentration equation, and using $R_{O_{2}}=0.5 R_{H_{2}}$, yields an equilibrium concentration of

$$
\begin{gathered}
\chi_{H 2}=\left(1.5+\frac{4.7 \times 10^{-6} \frac{L}{s}}{2.8 \times 10^{-5} \frac{L}{s}}\right)^{-1} \cdot 100 \% \\
=60 \%
\end{gathered}
$$

Given the sequence of events required to lead to this equilibrium concentration and sufficient time, it is possible that the hydrogen could accumulate in the headspace of the tank in concentrations greater than the lower flammable limit of $4 \%$. To determine the time required to reach a $4 \%$ concentration of hydrogen, the values for the time constant, $\tau$, and the equilibrium concentration are substituted into the time equation shown above. Of the parameters associated with the time equation, the only unknown value is the free volume in the tank, $V_{\text {head }} . V_{\text {head }}$ is assumed to be one-quarter of the volume of the 


\section{HNF-SD-WM-BIO-002 REV 1}

tank, or $2.8 \mathrm{~kL}$ ( $750 \mathrm{gal}$ ). This volume is used as a conservative value because it minimizes the time required to reach the lower flammable limit but still allows sufficient hydrogen to cause damage to the tank if ignited. Substituting these values into the time equation above and solving for $t$ yields

$$
\begin{gathered}
t=-\tau \cdot \ln \left(1-\frac{\chi_{H 2(1)}}{\chi_{H, \text { equil }}}\right) \\
=-\left(\frac{2,800 \mathrm{~L}}{2.8 \times 10^{-5} \frac{\mathrm{L}}{\mathrm{s}}}\right) \cdot(0.60) \cdot \ln \left(1-\frac{0.04}{0.60}\right) \\
=4.2 \times 10^{6} \mathrm{~s} \\
=48 \text { days }
\end{gathered}
$$

Thus, if the entire K-3 exhaust duct inventory were dissolved and carried into TK-100 and the tank bubbler system were inoperable, it would take approximately 48 days to reach $4 \%$ of hydrogen in one-quarter of the tank volume.

If a $4 \%$ concentration of hydrogen is attained in the tank, an ignition source capable of igniting the mixture is not readily apparent. There are no intrusive activities performed in the tank, and the pump associated with transfers of the tank contents is located outside the tank. It is conceivable that static electricity or a lightning strike could cause ignition of the hydrogen. However, these ignition sources have diminishing likelihoods.

The release mechanism associated with a TK-100 explosion can best be modeled as venting of a pressurized vessel. If the hydrogen were ignited, the resulting combustion would be an explosion with subsequent increase in pressure, but would not have the shock wave characteristics associated with a detonation. The increase in pressure could lead to failure of the tank and release of contaminated water into the pit. The most conservative approach to modeling such releases is to treat it as a pressurized spray leak because this results in the greatest estimates of airborne releases.

There is a noted difference in the release mechanism modeled for the hydrogen explosion in the K-3 filter housing, Section 3.4.2.4.3.2, and the release mechanism just postulated for a hydrogen explosion in TK-100. This difference is because of the desire to provide a bounding estimate of the potential consequences associated with the event under analysis. For the K-3 filter housing explosion, the maximum impact to the filter media (and assumed contaminant loading) provided the greatest dose consequences and was the most likely failure mechanism. For the TK-100 explosion, while not the most likely failure mechanism, the rupture below the liquid level and hypothetical spray leak comprise the bounding release mechanism which could be experienced by the contents of the tank.

Based on the graded approach, which dictates that the rigor and detail of an analysis be based upon the magnitude of the potential consequences, sophisticated modeling of the spray leak is not performed. Instead, a bounding ARF:RF of $1 \times 10^{-}$ ${ }^{4}: 1.0$ from Mishima (1994), Section 3.2.2.3.1, is used. This ARF:RF is taken from data on the droplets formed from commercial spray nozzles. This model is extremely conservative for the TK-100 explosion because it assumes that the entire contents of the tank are sprayed from the leak at high pressures. In reality, if the explosion were to happen at all, it would likely rupture the tank above the liquid level and result in a spill in the pit with little detectable contamination spread outside of the pit.

The application of this $A R F: R F$ to the radioactive material assumed to be present in the tank, $1.9 \times 10^{14} \mathrm{~Bq}(5.1 \mathrm{kCi})$ of ${ }^{137} \mathrm{Cs}$ from the K-3 exhaust duct, results in a source term of $1.9 \times 10^{10} \mathrm{~Bq}(0.5 \mathrm{Ci})$ of ${ }^{137} \mathrm{Cs}$ (the ${ }^{137 \mathrm{~m}} \mathrm{Ba}$ daughter product is accounted for in the dose calculations). No credit is taken for the pit providing confinement of the release material resulting in an LPF of 1.0 . 


\section{HNF-SD-WM-BIO-002 REV 1}

Mitigated Condition. No mitigated condition is considered since the unmitigated scenario consequences fall below the risk evaluation guidelines as discussed below.

Major Assumptions. The following assumptions were made in the preceding source term analysis:

- The tank is assumed to be $75 \%$ full of liquid. This volume also minimizes the time required to reach $4 \%$ hydrogen in the tank while allowing sufficient energy to cause failure of the tank.

- Hydrogen diffuses through the $5 \mathrm{~cm}(2$ in.) vent line according to the linear diffusion model in Liljegren and Terrones (1996).

- As a result of the explosion, the bottom of the tank ruptures resulting in a spray leak of the entire tank contents.

- The ARF:RF associated with the spray leak is $1 \times 10^{-4}: 1.0$.

- The pit and cover blocks do not provide any confinement of the released material resulting in an LPF of 1.0.

\subsection{Consequence Analysis.}

Unmitigated Condition. The unmitigated dose consequences arising from a hydrogen explosion in TK-100 is estimated below by multiplying the source term by the dose conversion factors developed in Section 3.4.1.3 and given in Table 3-28.

$$
1
$$

While dose consequences are within risk evaluation guiclelines, the force of any hydrogen explosion in TK-100 could cause displacement of the pit cover block. Worker safety in the immediate vicinity would be jeopardized by any such displacement.

Also, to provide a more complete assessment of potential effects of this inadvertent accumulation of high activity in TK-100, the dose rate from the $1.9 \times 1014 \mathrm{~Bq}(5.1 \mathrm{kCi}){ }^{137} \mathrm{Cs}$ assumed to be washed into TK-100 can be estimated. The unit exposure rate (1ley 1999) of $1.0 \times 10^{-2} \mathrm{mR} / \mathrm{h} / \mathrm{Ci}$ would give an exposure rate of about $50 \mathrm{mR} / \mathrm{h}$ above the pit cover block.

Mitigated Condition. No mitigated condition is considered since the unmitigated scenario consequences fall below the risk evaluation guidelines as discussed below.

Table 3-28. Unmitigated Dose Consequences from Hydrogen Explosion in TK-100.

\begin{tabular}{|c|c|c|c|}
\hline Isotope & $\begin{array}{c}\text { Source term } \\
(\mathrm{Ci})\end{array}$ & $\begin{array}{c}\text { DCF } \\
\mathrm{mSv} / \mathrm{Ci}(\mathrm{rem} / \mathrm{Ci})\end{array}$ & $\begin{array}{c}50 \text {-yr Committed } \\
\text { EDE } \\
\mathrm{mSv}(\mathrm{rem})\end{array}$ \\
\hline${ }^{137} \mathrm{Cs}$ & 0.5 & $1.2(0.12)$ & $\begin{array}{c}0.6(0.06) \\
\text { onsite } 100-\mathrm{m} \text { worker }\end{array}$ \\
\hline${ }^{137} \mathrm{Cs}$ & 0.5 & $0.0014(0.00014)$ & $\begin{array}{c}0.0007(0.00007) \\
\text { public }\end{array}$ \\
\hline${ }^{137} \mathrm{Cs}$ & 0.5 & $0.0020(0.00020)$ & $\begin{array}{c}0.001(0.0001) \\
\text { alternate site boundary }\end{array}$ \\
\hline
\end{tabular}

\subsection{Comparison to Guidelines.}

Because the frequency of the initiating event in this analysis is not well known, the rish evaluation guidelines associated with the anticipated frequency range are used. 
Unmitigated Condition. The calculated onsite dose of $0.6 \mathrm{mSv}(0.06 \mathrm{rem})$ is well below the onsite risk evaluation guideline of $50 \mathrm{mSv}(5.0 \mathrm{rem})$ and the calculated offsite dose of $7.0 \times 10^{-1} \mathrm{mSv}\left(7.0 \times 10^{-5} \mathrm{rem}\right)$ is well below the offsite risk evaluation guideline of $5 \mathrm{mSv}(0.5 \mathrm{rem})$. In addition, the dose at the alternate site boundary is $1.0 \times 10^{-3} \mathrm{mSv}\left(1.0 \times 10^{-4} \mathrm{rem}\right)$, which is also well below the offsite risk evaluation guideline.

Mitigated Condition. No mitigated condition is considered since the unmitigated scenario consequences fall below the risk evaluation guidelines as discussed below.

\subsection{Summary of Safety SSCs and IOSR Controls.}

Given the extremely conservative nature of the accident analysis in conjunction with dose consequences below the most conservative risk evaluation guidelines, no safety class SSCs, safety significant SSCs, or IOSR controls are necessary to prevent or mitigate a hydrogen explosion in TK-100. The potential worker safety and environmental impacts arising from high activity in TK-100 is accounted for in the institutional controls governing the operation of the WESF facility (see Chapter 6.0).

\subsection{Hydrogen Accumulation in Hot Cells.}

This assessment examines the conditions necessary to generate and accumulate significant amounts of hydrogen in the hot cells. The time required to accumulate $4 \%$ by volume (which is the LFL for hydrogen in air) is also estimated in order to estimate the response time necessary to prevent the occurrence.

The hazards evaluation in Hey (1999) assigned an F1 (i.e., extremely unlikely) frequency of occurrence to this event. The frequency rank, combined with the S2 (i.e., onsite impacts) consequence rank, results in a risk rank of R1 (i.e., minor concern) for this accident.

The methodology used to calculate the time required to reach $4 \%$ hydrogen in the hot cells is identical to that presented in Section 3.4.2.4.4.2 for TK-100. The equations developed in that section are not derived again here for the hot cells analysis.

\subsection{Scenario Development.}

\section{Unmitigated Condition.}

Conditions Pertaining to All Hot Cells. In order for hydrogen to accumulate to a concentration of $4 \%$ (the LFL for hydrogen in air) within a hot cell, three conditions must be met: (1) the cell must contain ionizing radiation for radiolysis to occur, (2) water must be added to the hot cell and remain for the duration of the event, and (3) ventilation airflow through the hot cell must cease for the duration of the event.

The radioactive material inventory for each hot cell is given in Table 3-3. The second requirement to generate and accumulate hydrogen in a hot cell is the addition of water to the cell. Water sources are only available to F and $\mathrm{G}$ Cells. There are three possible sources of water in these hot cells. They are fire suppression water, deionized water feeds, and TSP lines. Each of these sources of water is discussed in detail in the analysis for water accumulation in a K-3 filter housing, Section 3.4.2.4.3.1.

The third requirement to generate and accumulate hydrogen in a hot cell is to halt ventilation airflow through the cell. The normal ventilation airflow to each hot cell is from the canyon through two HEPA filtered and dampered inlet ducts (usually only one in operation at a time) that enter the cells through the wall near the ceiling of the cell. Each cell has two HEPA filtered and dampered exhaust ducts (usually only one in operation at a time) that exit the cell through the floor, with the exhaust ducts rising vertically from the cell floor approximately $1 \mathrm{~m}$. 
A loss of ventilation could occur in three ways.

- The K-3 ventilation system could be in a general no-flow configuration that is independent of inadvertent and undetected water flow into a hot cell. Such a general system shutdown could be from such causes as truck impact of the system exhaust fans, loss of electrical power, or other failure of critical components. Such a general system shutdown would not be unnoticed and has no operational relation to cell water usage.

- The second way that the ventilation flow to an individual cell could be stopped is by manually closing of the dampers on either the inlet or exhaust ducts to the cell. The inlet dampers are motor operated while the exhaust dampers are manually operated by means of a key type rod that is connected to the damper control shaft by insertion into the cell wall and rotation by hand. This no-flow condition, as with the general K-3 system no-flow condition, has no connection with inadvertent water introduction and subsequent water retention necessary for potential hydrogen accumulation.

- The third way that ventilation airflow could be stopped relates to the inadvertent water introduction and retention within a hot cell. In this scenario, water could be inadvertently introduced through the opening of both the cell process water supply shutoff valves (in the hot cell and in the Service Gallery). In conjunction with this inadvertent water introduction the water would have to flow unnoticed, even though there is a leak detection sump and alarm in each cell, and accumulate to a depth a depth of about $1 \mathrm{~m}$ and start to overflow through the exhaust duct filters. Introduction of water that overflows the outlet vent path could, depending on the flow rate, also cause water to flow into the K-3 HEPA filter housing. Unabated, the flow into the K-3 HEPA filter housing could block flow in both of the K-3 HEPA filter housings as described in Section 3.4.2.4.3.1 and could be the cause of a no-flow condition in the $\mathrm{K}-3$ ventilation system.

Hydrogen Accumulation in A through F. Cells. There are no water sources available to $A$ through $\mathrm{F}$ Cells, therefore. no lurther analysis is required for these hot cells.

Hydrogen Accumulation in F Cell. While use of water in F Cell is unlikely, the potential storage of 24 capsules makes $\mathrm{F}$ Cell the hot cell that would reach $4 \%$ hydrogen in the shortest time, if the maximum allowed inventory were present.

F Cell contains very little contamination as an activity source for hydrogen generation. The activity for hydrogen generation is that of the 24 capsules assumed to have the average loading per capsule of $39.2 \mathrm{kCi}{ }^{137} \mathrm{Cs}$ per capsule (Hcy 199()), which because of shielding effects of encapsulation, reduces somewhat the energy emitted to the water. The energy emitted by capsules and absorbed by the water in the storage pools was estimated by $\mathrm{Hey}(1999)$ and that estimate is conservatively used to represent the ratio for the F Cell case. The value in lley (1999) is $0.148 \mathrm{MeV}$ absorbed by the water for each $0.662 \mathrm{MeV}$ photon. The following values were used in the time estimate calculations.

$$
\begin{array}{ll}
\text { Activity encapsulated } & =3.48 \times 10^{16} \mathrm{~Bq}\left(9.4 \times 10^{5} \mathrm{Ci}\right) \\
\text { Absorbed energy of activity } & =5.15 \times 10^{21} \mathrm{eV} / \mathrm{s} \\
\text { Hydrogen generation rate, } \mathrm{R}_{\mathrm{H} 2} & =8.61 \times 10^{-4} \mathrm{~L} / \mathrm{s} \\
\text { Diffusion rate, } \mathrm{Q}_{\text {vent }} & =2.21 \times 10^{-4} \mathrm{~L} / \mathrm{s} \\
\text { Equilibrium fraction of } \mathrm{H}_{2}, \chi_{\mathrm{H} 2} & =0.57 \\
\text { Volume of air in F Cell, } \mathrm{V}_{\text {cell }} & =16,000 \mathrm{~L} \\
\tau & =1.1 \times 10^{7} \mathrm{~s}
\end{array}
$$

By a simple conversion of units, the energy rate contribution of the ${ }^{137} \mathrm{Cs}$ is

$$
3.48 \times 10^{16} \mathrm{~Bq} \cdot\left(0.148 \frac{\mathrm{MeV}}{\mathrm{dis}}\right)=5.15 \times 10^{15} \frac{\mathrm{MeV}}{\mathrm{s}}
$$


The subsequent hydrogen generation rate $R_{H_{2}}$ is calculated as follows:

$$
\begin{gathered}
R_{H_{2}}=\left(5.15 \times 10^{21} \frac{\mathrm{eV}}{\mathrm{s}}\right) \cdot(1.0) \cdot\left(\frac{0.45 \mathrm{molec} . \mathrm{H}_{2}}{100 \mathrm{eV}}\right) \cdot\left(\frac{3.72 \times 10^{-23} \mathrm{~L}}{\text { molec. } \mathrm{H}_{2}}\right) \\
=8.61 \times 10^{-4} \frac{\mathrm{L}}{\mathrm{s}}
\end{gathered}
$$

The diftusion of the hydrogen from the hot cell through the inlet duct leading to the canyon is estimated from the diffusivity of the hydrogen, the duct cross-sectional area, and the duct length. The duct leading fiom the canyon to the cell is $15 \mathrm{~cm}(6 \mathrm{in}$.) in diameter and about $572 \mathrm{~cm}$ (225 in.) in length. The filter media is assumed to provide no resistance to the diffusion of the hydrogen from the tilter housing. The specilic diffusion rate is

$$
\begin{gathered}
Q_{\text {vert }}=\left(0.711 \frac{\mathrm{cm}^{2}}{\mathrm{~s}}\right) \cdot\left(\frac{178 \mathrm{~cm}^{2}}{572 \mathrm{~cm}}\right) \\
=2.21 \times 10^{-1} \frac{\mathrm{cm}^{3}}{\mathrm{~s}} \\
=2.21 \times 10^{-4} \frac{\mathrm{L}}{\mathrm{s}}
\end{gathered}
$$

The equilibrium concentration associated with the estimated generation rate and flow rate from $\mathrm{B}$ or $\mathrm{C}$ Cell is then calculated as

$$
\chi_{\text {H.equil }}=\left(1.5+\frac{2.2 \times 10^{-4} \frac{L}{S}}{8.61 \times 10^{-4} \frac{L}{s}}\right)^{-1} \cdot 100 \%=57 \%
$$

Given this high equilibritum concentration, it is possible that the hydrogen could accunulate in the cell(s) in concentrations greater than the I.FL of $4 \%$.

For the time equation, the values of $R_{H_{2}}$ and $\chi_{H_{2}, \text { equil }}$ have already been calculated and are $8.61 \times 10^{-4} \mathrm{~L} / \mathrm{s}$ and 0.57 $(57 \%)$. respectively. $\chi_{\mathrm{H}_{2}}(t)$ is the concentration of interest, $4 \%$, which is the lower flammable limit of hydrogen. $\chi_{\mathrm{H}_{2}}(0)$ is the initial concentration of hydrogen in the cell, which is zero. The volume of the cell. $V_{\text {well }}(16,000 \mathrm{~L})$. is calculated from the $\mathrm{B}$ or C Cell dimensions that are $2.4 \mathrm{~m}$ ( $8 \mathrm{it})$ by $2.4 \mathrm{~m}$ ( $8 \mathrm{ft}$ ) by $4 \mathrm{~m}$ ( $12 \mathrm{it} 10 \mathrm{in}$.). The cell is assumed to be flooded to a depth of $122 \mathrm{~cm}$ ( $48 \mathrm{in}$.) based on the approximate height above the floor of the ventilation outlet (the water level could not get higher). Substituting these values into the time constant and time equations and solving for $t$ yields. 


$$
\begin{gathered}
t=-\tau \cdot \ln \left(1-\frac{\chi_{\text {Hzi(i) }}}{\chi_{\text {H2.equit }}}\right) \\
t=-\left(\frac{16,000 L}{8.61 \times 10^{-4} \frac{L}{s}}\right) \cdot(0.57) \cdot \ln \left(1-\frac{0.04}{0.57}\right) \\
=7.7 \times 10^{5} s \\
=9 \text { days }
\end{gathered}
$$

The time to reach $4 \%$ hydrogen in $\mathrm{F}$ Cell using these values is approximately 9 days.

Hydrogen Accumulation in G Cell. G Cell is normally an uncontaminated cell used for capsule decontamination, temporary storage of capsules and transfer activities. Flooding of the cell is not possible due to the presence of a floor penetration, which is a chute leading into Pool Cell 12 (the transfer aisle). Decontamination solution (i.e., TSP solution or deionized water) is used in a single pass through the scrubber and does not remain in the cell. Radiolytic decomposition of water is not considered further.

Mitigated Condition. Water in the affected hot cell will be removed before a flammable gas mixture can be generated, thereby preventing a gas combustion.

Major Assumptions. The following assumptions were made in the scenario development:

- The cell in question is assumed to be flooded to the depth of the ventilation outlet ducts

- The fraction of gamma-ray energy deposited in the water flooding F Cell is $0.148 \mathrm{MeV}$ for each $0.662 \mathrm{MeV}$ photon

- The activity encapsulated in $\mathrm{F}$ Cell does not exceed $3.48 \times 10^{16} \mathrm{~Bq}\left(9.4 \times 10^{5} \mathrm{Ci}\right){ }^{137} \mathrm{Cs}$

\subsection{Source Term Analysis.}

Unmitigated Condition. F Cell has been analyzed to store as many as 24 capsules without causing thermal degradation to the hot cell structure. The capsules stored in F Cell could be defective such that their containment function is no longer relied upon, hence their isolation and storage in $\mathrm{F}$ Cell.

A hydrogen explosion in a hot cell could potentially damage the hot cell structure, lift the cover block, fail the shielded window, fail the manipulator boot and seal, and release radioactive material into occupied areas of the facility. Although capsules stored in F Cell are suspect leakers, a hydrogen combustion event in the cell would not significantly impact the ${ }^{137} \mathrm{Cs}$ or ${ }^{90} \mathrm{Sr}$ inside the capsules. however. a loss of shielding in $\mathrm{F}$ Cell has worker safety implications. Therefore, on the basis of worker safety and defense-in-depth, easily implementable IOSR controls are developed below to preclude the possibility of accumulating hydrogen in a hot cell.

Mitigated Condition. No mitigated source term analysis was developed for this accident, see the discussion above.

\subsection{Consequence Analysis.}

Unmitigated Condition. No unmitigated consequence analysis is provided for this event. See source term discussion.

Mitigated Condition. No mitigated consequence analysis was necessary for this accident since a gas combustion is 
HNF-SD-WM-BIO-002 REV 1

prevented by the controls discussed below.

3.4.2.4.5.4 Comparison to Guidelines. No comparison is provided for this event.

\subsection{Summary of Safety SSCs and IOSR Controls.}

Although no consequences are expected outside the facility for this event, for the purposes of worker safety and defense-in-depth, easily implementable IOSR controls are developed in this section to preclude a hydrogen explosion in a hot cell.

Credited SSCs. None. The visible condition of water in a hot cell, a loss of K-3 ventilation, and the several days available before hydrogen accumulation becomes a concern, makes engineered barriers unnecessary.

\section{Credited IOSR Controls.}

- An IOSR is needed to detect and take subsequent actions for flooding of a hot cell. This control consists of the following elements:

- A periodic surveillance of $F$ Cell to detect possible water leaks into the hot cell. A surveillance interval of at least once per 9 days ensures that water accumulated in $\mathrm{F}$ Cell would not result in a hydrogen concentration greater than $4 \%$.

\subsubsection{Facility Explosions.}

This section discusses the potential for explosions within the facility. This includes consideration of welding gases, gasoline fumes, propane, and hydrogen generation in the pool cell area as well as the WIXM located it the Truckport. This analysis excludes those events already discussed in Sections 3.4.2.4 relating to hydrogen accumulating in the $\mathrm{K}-3$ ventilation system, hot cells, and TK-100.

This accident type, Facility Explosions, is not taken directly from the hazards evaluation documented in Hey (1999). In the hazards evaluation, the accident type considered was hydrogen deflagration. After completion of the hazards evaluation, however, it became evident that a more general type of explosion event was possible because of the periodic or operationally desired use of flammable gases and highly volatile fuels. Such uses might include a propane-powered forklift or welding operations associated with a facility modification. Therefore, the accident type Hydrogen Deflagration was expanded to include potential explosions from all flammable gases.

\subsection{Hydrogen Explosion in the Pool Cell Area.}

This section analyzes a hydrogen explosion event in the Pool Cell Area.

\subsection{Scenario Development.}

The hazard evaluation identified a hydrogen combustion in the Pool Cell Area due to failure of the Pool Cell Area ventilation as a frequency F2 (i.e., unlikely) and severity S3 (i.e., public). The severity rank is assigned because of the potential for facility structural damage from the combustion event leading to capsule or pool cell structural damage and subsequent loss of pool cell water. The resulting risk rank for this accident is R3 (items of major concern).

Radiolysis of water in the pool cells generates hydrogen during normal operation (Hey 1999). With ventilation supplying and exhausting air in the Pool Cell Area, approximately $140 \mathrm{~m}^{3} / \mathrm{min}\left(5,000 \mathrm{ft}^{3} / \mathrm{min}\right)(\mathrm{Hey} 1999)$, it has been shown wit! calculations and actual samples that the maximum hydrogen concentration, which occurs at the surface of the pool cell water, is substantially less than $1 \%$ (Liljegren and Terrones 1996). Therefore, accumulation of hydrogen and subsequent combustion in the Pool Cell Area is not possible unless the K-1 and K-4 ventilation systems fail or are not operating. 


\section{HNF-SD-WM-BIO-002 REV 1}

Unmitigated Condition. The hydrogen generation rate in the Pool Cell Area was calculated to be $5 \mathrm{cth}$ (Hey 1999). A value of $52.05 \mathrm{MCi}{ }^{15} \mathrm{Cs}$ (see Table $3-3$ ) was used in the calculations since only the gamma emitted from ${ }^{15}$ Ba contributes signiticantly to the ionicing radiation escaping the capsule. The contribution from "sr or its daughter product is negligible.

Using a hydrogen generation rate of $5 \mathrm{cth}$ and the following equation, a graph was developed in Liljegren and Terrones (1996) which identified the length of time reguired to acculnulate 4"o hydrogen with ventilation inoperable and the Pool Cell Area north door both open and closed.

$\chi_{H_{2}}(t)=\left(\chi_{H_{2}}(0)-\chi_{H_{2} . \text { equil }}\right) e_{t}^{-t}+\chi_{H_{2} \cdot \text { equt }}$

where :

$\chi_{H},(t)=0.04$, volume fraction of interest

$\chi_{H_{2}}(0)=0$, initial hydrogen concentration

$\chi_{H_{1}, \text { equil }}=$ calculated equilibrium concentration

$t=$ time $(s)$

$\tau=$ time constant

$\tau=\frac{V_{\text {WESF }}}{R_{H 2}} \chi_{H 2 . \text { equit }}$

where :

$V_{\text {WESF }}=$ roomvolume $(L)$

$R_{H_{2}}=$ hydrogen generation rate $(L / s)$

If the ventilation system fails and the Pool (wh Area north door ( $2 \mathrm{~m}^{2}\left[21 \mathrm{hi}^{-}\right]$) were opened, the hydrogen concentration would not accumulate above $1 \%$.

If the ventilation system fails and the Pool Cell Area north door $\left(2 \mathrm{~m}^{2} 121 \mathrm{ft}^{2}\right)$ were closed, it would reçuired at least 226 hours ( 9 days) to accumulate a flammable concentration of hydrogen in the Pool Cell Area. The model did not account for the natural ventilation caused by barometric pressure changes and pressure differentials across the building as a result of wind or infiltration. The natural draft from the exhaust ventilation stack would be limited because the dampers on the K-1 inlet fail closed if the exhaust system fails.

In the past, cover blocks were placed over pool cells for shielding, and there was a possibility of excess hydrogen buildup in a localized area between the cover blocks and the surface of the pool cell water. However, cover blocks are presently removed from all active cells, and Liljegren and Terrones (1996) shows that without cover blocks in place, natural convective forces within the pool cell will prevent a localized region of high hydrogen concentration above the surface of the pool cells during an extended loss of ventilation. Personnel could reduce the buildup of hydrogen in the Pool Cell Area to acceptable levels by opening the Pool Cell Area north door during a ventilation failure.

Nevertheless, assuming that a flammable concentration does build up and ignite after a number of days without ventilation, the walls and ceiling of the Pool Cell Area may collapse from pressurization caused by the combustion products or the shock wave created by a detonation (Mer1 1998). There are several penetrations in the Pool Cell Area walls and ceiling to provide blow-down pathways that would lessen the severity of a pressurization event: (I) four inlet ducts for the K-4 ventilation system, (2) three steel doors, (3) the K-1 exhaust duct, (4) the window to the Operating Gallery, and (5) the seismic joint between the canyon and Pool Cell Area and the Service Gallery and the Pool Cell Area (structural areas 2 and 3 ).

| However, no credit is taken for these penetrations in the FHA (Mcrt 1998). A detonation in the Pool Cell Area is very unlikely due to the low energy ignition sources and open geometry of the area. Potential ignition sources in the Pool Cell Area are the circulation pump motors, electrical switches associated with monitoring devices or automatic valves, and the $\mathrm{K}-1$ and K-4 fan motors. If ignition occurs in the exhaust or inlet ventilation ducts (from restart of fans or mechanical sparks from the movement of dampers), the combustion event is more likely to progress to a detonation because the narrow duct geometry 


\section{HNF-SD-WM-BIO-002 REV 1}

would tend to enhance the propagation of the flame front. Operations personnel entering the Pool Cell Area might cause an ignition source from static or mechanical sparks, but these are relatively minor energy sources and unlikely to proceed to detonation.

If the walls and ceiling of the Pool Cell Area do not collapse, there is still a possibility that more limited damage will occur and essential piping or equipment in the Pool Cell Area will fail, especially if a detonation occurs (Mert7. 1998). If several heat exchangers or associated piping were damaged, the accident could progress in a manner similar to the loss of water accident described in Section 3.4.2.7.2. The difference between the general loss of cooling capability described in Section 3.4.2.7.2 and the loss of cooling following a hydrogen explosion is that recovery of cooling following the hydrogen explosion may be hampered because of equipment failures. However, once the pool cells begin to heat up from loss of cooling, the risk of further hydrogen combustion would be diminished by the addition of moisture to the pool cell air. There is also a possibility that the pool cell crane could be dislodged from its support rail due to movement of the area walls. If so, accident progression from the point of crane failure could proceed in a manner similar to the object drop/impact accident discussed in Section 3.4.2.6.2.

If the building does collapse, large structural members could fall into the pool cells, damaging capsules and possibly the pool cell liner and underlying structure. Further accident progression from this point would be similar to the falling object accident discussed in Section 3.4.2.6.2 and the loss of pool cell water in Section 3.4.2.7.2 with the exception of the failure of the building structure allowing free heat exchange and aerosol release to the atmosphere.

Mitigated Condition. Following a loss of the Pool Cell Area ventilation, gas combustion is prevented by restoring active or passive ventilation before a flammable gas mixture can be generated.

Major Assumptions. The following assumptions were made in the scenario development (also, see the major assumptions in the source term subsections for the sudden capsule failure analysis, Section 3.4.2.6.2, and the loss of all pool cell water analysis, Section 3.4 .2 .7 .2 ):

- Normal ventilation flow in the Pool Cell Area is approximately $140 \mathrm{~m}^{3} / \mathrm{min}\left(5,000 \mathrm{ft}^{3} / \mathrm{min}\right)$

- In the event of ventilation failure, there is no natural draft or air leakage in the Pool Cell Area for the unmitigated scenario

- No cover blocks are placed over active pool cells

- An ignition source is present in the Pool Cell Area

- A gas combustion will conservatively result in a detonation which will cause the walls and ceiling to collapse for the unmitigated event

- The maximum inventory in the Pool Cell Area is $52.05 \mathrm{MCi}$ of ${ }^{137} \mathrm{Cs}$. The gamma energy deposited in the water by the ${ }^{137 \mathrm{~m}} \mathrm{Ba}$ (daughter product of ${ }^{137} \mathrm{Cs}$ ) is the only ionizing radiation energy not shielded by the capsules.

\subsection{Source Term Analysis.}

Unmitigated Condition. For a hydrogen explosion in the Pool Cell Area, two basic release mechanisms have been identified. The failed structural components following the explosion could result in capsule failure or loss of pool cell water. The analysis of a sudden capsule failure, including consideration for failed building structural components, is contained in Section 3.4.2.6.2. The analysis of a loss of all pool cell water without ventilation is contained in Section 3.4.2.7.2.

The source term for the loss of all pool cell water (no ventilation) is calculated based on maximizing the possible consequences of such an accident. The calculations assume survival of the building structure so that heat transfer from the capsules is limited for some time after the accident. If the building fails or a flow path to the environment is opened early in the accident, the temperatures of the capsules, and subsequent consequences, are greatly reduced. Therefore, the source term 


\section{HNF-SD-WM-BIO-002 REV 1}

calculated in the loss of all pool water accident analysis bounds a hydrogen explosion in the Pool Cell Area.

The source term for capsule rupture due to drop impact is provided in Section 3.4.2.6.2. This source term is based on the direct radiation and minor airborne contamination associated with elevated cesium chloride concentration in a pool cell.

Mitigated Condition. No source term is calculated for the mitigated condition, since a gas combustion is prevented by the restoration of ventilation.

Major Assumptions. See the major assumptions in the source term subsections for the sudden capsule failure analysis (Section 3.4.2.6.2) and the loss of all pool cell water analysis (Section 3.4.2.7.2).

\subsection{Consequence Analysis.}

Unmitigated Condition. The consequences of this accident are bounded by the consequences calculated in the loss of all pool cell water (without ventilation) analysis, Section 3.4.2.7.2 for the case where pool cell water and/or cooling is lost. The consequences of rupturing capsules in a pool cell are analyzed in Section 3.4.2.6.2.

Mitigated Condition. No consequences are calculated for the mitigated condition, since a gas combustion is prevented by the restoration of ventilation.

\subsection{Comparison to Guidelines.}

Unmitigated Condition. As shown in Section 3.4.2.7.2, the unmitigated consequences associated with the loss of all pool cell water (without ventilation) exceeds both the onsite and offsite risk evaluation guldelines. For the case of sudden capsule failure, as from failed building structural components, no comparison to guidelines is made because the loss of pool cell water in the same event already drives the requirement to have safety class SSCs and IOSR controls.

Mitigated Condition. No comparison is made since no consequences are generated by the mitigated condition.

\subsection{Summary of Safety SSCs and IOSR Controls.}

Credited SSCs. None. The obvious condition of a Pool Cell Area ventilation failure, and the several days available before hydrogen accumulation becomes a concern, makes engineered barriers unnecessary. The risk is easily mitigated by the controls credited below.

\section{Credited IOSR Controls.}

- The controls necessary to prevent a hydrogen explosion in the Pool Cell Area are predicated upon providing adequate ventilation for the area. Liljegren and Terrones (1996) have shown that opening a single personnel access door to the environment (located in the north wall of the Pool Cell Area) within 9 days following the loss of ventilation is sufficient to preclude the accumulation of hydrogen. While this action would open an area considered as having possible contamination to the environment, the ventilation system is assumed to be inoperable so that the area has already lost its confinement function.

\subsection{Flammable Gas Explosions.}

This section addresses the possibility of a flammable gas explosion (other than hydrogen) in all areas of the facility. Based on potential impacts to the pool cell area structure and subsequent loss of water, all scenarios identified in this section are assigned an S3 (i.e., public) severity rank. The frequency rank of F2 (i.e., unlikely) is assigned based on the small number of welding and truckport operations performed at WESF. The resulting risk rank for these scenarios is R3 (i.e., items of major concern).

The flammable gases explicitly considered in this analysis include acetylene, propane, and gasoline fumes; however, 


\section{HNF-SD-WM-BIO-002 REV 1}

the analysis is prepared such that it is bounding for all flammable gases which may be brought into the facility.

\subsection{Scenario Development.}

The possibility of a flammable gas explosion (non-hydrogen) in the facility can be divided into two cases: highly volatile liquid fuels and flammable gas cylinders.

The first case, highly volatile liquid fuels, relates to the Truckport area only. During normal operations any trucks associated with Truckport operations are diesel-powered. However, facility operations may find it expedient to use a gasolinepowered truck. A spill of gasoline may result in a fiammable gas hazard not realized with the use of diesel fuel. In addition, a diesel-powered forklift is used in normal Truckport operations, but a propane-powered forklift is an optional backup to the diesel forklift.

The second case, related to the use of flammable gas cylinders, applies to all areas of the facility, including the Truckport. Such cylinders may be used for facility maintenance and modification activities, such as welding.

Unmitigated Condition. For the highly volatile fuels which may be used in the Truckport, the unmitigated condition would consist of a fuel leak or spill, generation of flammable gases, and subsequent explosion. Any resulting fire in the Truckport would be bounded by the analysis provided in Section 3.4.2.3.2.

For the case involving flammable gas cylinders, the unmitigated condition would be gas leaking from the cylinder or the cylinder failing catastrophically. The gas would then be ignited resulting in an explosion.

For all flammable gas explosion scenarios, the bounding consequences would result from the pressure increase associated with the explosion. The actual pressure resulting from an explosion is dependent on the geometry of the area, quantity of gas, vent pathways, possibility of detonation, and other factors. The WESF FHA provides a simplistic calculation f for a propane explosion in the Truckport area (Mcrk 199\$). That calculation, which does not consider venting of the explosion gases through the rollup and folding doors, shows that the potential pressure increase would cause failure of the Truckport structure. From this analysis it can be assumed that a flammable gas explosion in any area of the facility could cause significant structural damage. In addition, an explosion in virtually any area of the facility has the potential to impact the Hot Cell and Pool Cell Area structures which contain the only radioactive materials vulnerable to this event. For example, an explosion in the Operating Gallery could directly impact the Hot Cell structure and the adjoining Pool Cell Area wall.

The responses of the structural areas of the facility to an explosion are unknown. Impacts to the hot cells could result in cover block failure, loss of structural integrity, and subsequent suspension of radioactive material, as well as a loss of shielding. Structural failure in the Pool Cell Area could result in a heavy object drop into an active pool cell and possible capsule impacts and loss of pool cell water. A more detailed discussion of the ramifications of an explosion in the Pool Cell Area can be found in Section 3.4.2.5.1.1, the scenario development for a hydrogen explosion in the Pool Cell Area. Heavy object drops in the facility are discussed in Section 3.4.2.6, Loss of Containment.

Mitigated Condition. As stated above, an explosion in the facility would have unknown impacts to facility structures. Because of the possibility of impacts to the Pool Cell Area and hot cells, the mitigated condition takes credit for a control which restricts all highly volatile fuels and flammable gases from the facility.

\subsection{Source term.}

Unmitigated Condition. As discussed in the scenario development, the bounding consequences associated with a flammable gas explosion are possible impacts to capsules and loss of pool cell water (heavy object drop into a pool cell) and structural failure of the hot cells.

The source term arising from a loss of pool cell water is calculated in Section 3.4.2.5.7. The source term arising from structural failure of the hot cells can be found in Section 3.4.2.1.2, Design Basis Earthquake for A through E Cells and Section 3.4.3.2, Beyond Design Basis Earthquake for F Cell. The earthquake source term analyses are applicable to a 


\section{HNF-SD-WM-BIO-002 REV 1}

flammable gas explosion because both types of events model structural failure of the hot cells and physical shock/vibration of the radioactive materials.

Because these source terms are so large and result in obviously unacceptable consequences, no additional analysis is provided to show the combined hot cell and pool cell source terms. In addition, a heavy object drop onto the hot cells is bounded by the consequences associated with a heavy object drop in the Pool Cell Area.

In addition; to the possible source term arising from heavy object drops, another source term would also arise if the explosion resulted in a fire in the Truckport or Hot Cells. These potential source terms would be bounded by the facility fire analyses in Section 3.4.2.3.

Mitigated Condition. Since a flammable gas explosion is prevented in the mitigated condition, there is no source term.

\subsection{Consequence Analysis.}

Unmitigated Condition. The dose consequences for the unmitigated condition can be found in Section 3.4.2.7 for the loss of pool cell water and Sections 3.4.2.1.2 and 3.4.3.2 for the hot cells. Although the hot cell consequences are not explicitly presented for the DBE in Section 3.4.2.1.2, the consequences associated with a loss of pool cell water are overwhelming. Since the consequences are clearly beyond any risk evaluation guidelines, no further analysis of a hypothetical release from the hot cells is performed. prevented.

Mitigated Conditions. There are no consequences arising from the mitigated condition because the explosion is

\subsection{Comparison to Guidelines.}

Unmitigated Condition. The consequences calculated for a loss of pool cell water (Section 3.4.2.7) are clearly above all risk evaluation guidclines. Because the consequences associated with a loss of pool cell water are dominating, no explicit comparison to guidelines is made for the potential release from the hot cells.

Mitigated Condition. Because the consequences are prevented, no comparison to guidelines is made for the mitigated condition.

\subsection{Summary of Safety SSCs and IOSR Controls.}

The control specified in this analysis, and defined below, is intended to be an interim measure because of the necessity of welding and cutting as part of facility maintenance and modification activities. Further analysis of the explosion hazard posed by the use of flammable gases will be performed and, based on the results of that analysis, this control will be reevaluated and modified, as appropriate.

Credited SSCs. None.

\section{Credited IOSR Controls.}

- Flammable gases, such as propane and acetylene, and highly volatile fuels, including gasoline but excluding diesel fuel, are not allowed anywhere in the facility at any time.

\subsection{WIXM Explosion.}

\subsection{Scenario Development.}

As the resin in a WIXM becomes loaded with radioactive material, the ioniring radiation results in radiolysis of the 


\section{HNF-SD-WM-BIO-002 REV 1}

resin/water and produces hydrogen and oxygen gases. If hydrogen were to accumulate inside the WIXM vessel in quantities of 4 percent volume or more, the hydrogen carn become flammable and eventualfy detonable if it continues to increase. Such a combustion event could result in the release of contaminated resin and water. This event bounds a spray release from use of the EMIX system.

For such accident conditions to exist, the WIXM vessel would be drained (allowing a void volume for the hydrogen to accumulate) and likely would be undergoing preparation for transport. The resin material would be water-soaked with the hydrogen originating from the water trapped within the resiu bed. Hydrogen would then accumulate in the head space of the vessel above the resin bed. The $\mathrm{G}$ value is defined as the number of molecules formed or disassociated per $100 \mathrm{eV}$ energy absorbed. The $\mathrm{G}$ values used to determine the hydrogen generation rate in the WIXM were based on a moisture content of $55 \%$. The lully-swollen, dewatered resin has $55.58 \%$ water content. (HNF, 1998d)

In order for the hydrogen to ignite, an energy source would have to be present in the WIXM. This could potentially be provided by a static charge inside the vessel or possibly by a spark introduced into the hydrogen-containing vent or inler pipe from some outside activity (e.g., a worker's tool). The worst case would be ignition of the hydrogen at the end of the inlet pipe because the flame fron could propagate down the inlet pipe, transition into a detonation, enler the WIXM and impact the resin bed with the maximum force. The detonation pressure pulse would impact the resin/water surface and rebound upward, possibly rupturing the WIXM assenbly and ejecting some resin, radioaclive material, and water into the Truckport.

In addition to the release from the explosion, the resin/water remaining in the WIXM after the explosion could heat up, resulting in decomposition or burning of some resin. This possibility is addressed in the following source term analysis section.

\subsection{Source Term Analysis.}

It is known that hydrogen gas will be generated inside the WIXM if it contains both radioactive material and water. To ascertain if the hydrogen could potentially build up to llammable concentrations in a reasonable period of lime (4\% hydrogen is the fower thammability limit), the hydrogen concentrition as a function of time can be modeled.

The diffusion of liydrogen from the WIXM is calculated in a fashion sintilar to that used in 3.4.2.4.4 for the K-1 ducl leading from the Pool Cell Area. The basic equations used to model the polential hydrogen accumulation are presented below. The equation used in Section 3.4.2.4.4.2 to estimate the rate of diffusion of bydrogen out of a vent is

$$
\begin{gathered}
Q_{\text {vent }}=D_{H_{2}, a i r} \cdot\left(\frac{A}{L}\right) \\
\text { where: } \\
Q_{\text {vent }}=\text { rate of diffusion }\left(\mathrm{cm}^{3} / \mathrm{s}\right) \\
D_{H_{2}, \text { air }}=\text { diffusion coefficient for } \mathrm{H}_{2} \text { in air } \\
\left.\left(0.711 \mathrm{~cm}^{2} / \mathrm{s} \text { at } 25^{\circ} \text { C [Liljegren, Terrones } 1996\right]\right) \\
A=\text { vent area normal to flow }\left(\mathrm{cm}^{2}\right) \\
L=\text { length of vent line }(\mathrm{cm})
\end{gathered}
$$

For the WIXM, the diffusivity of hydrogen is $0.711 \mathrm{~cm}^{2} / \mathrm{s}$ at $25 \mathrm{C}$, the cross-sectional area of the vent (nominal 0.5 in. schedule 40 steel pipe has an internal diameter of $0.622 \mathrm{in}$.) is $2.0 \mathrm{~cm}^{2}$, and the length of the vent pipe is approximately $55 \mathrm{in.}(140 \mathrm{~cm})$.

The rate of diffusion out of the WIXM vent line is 


\section{HNF-SD-WM-BIO-002 REV 1}

$$
\begin{gathered}
Q_{\text {vent }}=\left(0.711 \frac{\mathrm{cm}^{2}}{\mathrm{~s}}\right) \cdot\left(\frac{2.0 \mathrm{~cm}^{2}}{140 \mathrm{~cm}}\right) \\
=0.01 \frac{\mathrm{cm}^{3}}{\mathrm{~s}} \\
=1.0 \times 10^{-5} \frac{\mathrm{L}}{\mathrm{s}}
\end{gathered}
$$

This diffusion rate is then used as input into the equilibrium concentration calculation, which is also given by Section 3.4.2.4.4.2 as:

$$
\chi_{H_{2}}=\left(1+\frac{R_{O_{3}}+Q_{v e m t}}{R_{H_{2}}}\right)^{.1}
$$

where:

$\chi_{\mathrm{H}_{2}}=$ hydrogen volume fraction in WLXM

$R_{O_{2}}=$ generation rate of oxygen $(L / s)$

$$
=0.5 \text { of } R_{H_{2}}
$$

$R_{H_{2}}=$ generation rate of hydrogen $(L / s)$

$Q_{\text {vent }}=$ hydrogen diffusion rate through vent $(L / s)$

For the WIXM, the rate of hydrogen generation is taken to be the maximum rate indicated in the WIXM SARP (HNF, 1998d) of $601 \mathrm{~cm}^{3} / \mathrm{he}\left(1.67,10^{-4} \mathrm{~L} / \mathrm{s}\right)$. The resulting equilibrium concentration is

$$
\begin{gathered}
\chi_{H 2}=\left(1.5+\frac{1.0 \times 10^{-5} \frac{L}{s}}{1.67 \times 10^{-1} \frac{L}{s}}\right)^{-1} \cdot 100 \% \\
=64 \%
\end{gathered}
$$

From Section 3.4.2.4.4.2, the time required to reach a specilied concentration when given the equilibrium concentration, can be estimated by

$$
\begin{aligned}
& \chi_{H_{2}}(t)=\left(\chi_{H_{2}}(0)-\chi_{H_{2}, \text { equil }}\right) e^{\frac{-t}{r}}+\chi_{H_{2}, \text { equil }} \\
& \text { where: } \\
& \chi_{H_{2}}(t)=0.04, \text { volume fraction of interest } \\
& \chi_{H_{2}}(0)=0 \text {, initial hydrogen concentration } \\
& \chi_{H_{2} \text {,equil }}=\text { calculated equilibrium concentration } \\
& t=\text { time (s) } \\
& \tau=\text { time constant }
\end{aligned}
$$




$$
\begin{gathered}
\tau=\frac{V_{\text {head }}}{R_{H 2}} \chi_{H 2, \text { equil }} \\
\text { where: } \\
V_{\text {head }}=\text { headspace in } W L X M(L) \\
R_{H_{3}}=\text { hydrogen generation rate }(L / s)
\end{gathered}
$$

For the WIXM, the volume in the head space of the vessel could vary because there is no administrative control on the height of resin loaded into the vessel. Thus, the volume could be nearly as large as the entire vessel or very small. For the purposes of this caliculation, which is to determine if flammable concentrations of hydrogen could be reached in a credible period of time, the anticipated WIXM operating conditions are assumed.

The total volume of the WIXM vessel is approximately equal to a cylinder with the same dimensions. The vessel is a 44 in. long nominal 24 in. diameter schedule 10 pipe. with nominal 24 in. (schedule 10 stainless steel) rounded pipe caps on the top and bottom. Nominal $24 \mathrm{in}$. pipe of this nature has a wall thickness of $0.25 \mathrm{in}$. Treating the vessel as a cylinder (the actual volume is slightly less because of the rounded top and bottom ends), the total volume of the vessel is approximately $312 \mathrm{~L}$.

The planned operations using the WIXM that result in the specified hydrogen generation rate are associated with a resin depth of $35 \mathrm{in}$. in the vessel. This depth of resin would occupy approximately $80 \%$ of the vessel volume (35 in/43.5 in), or $250 \mathrm{~L}$. The remaining volume of the vessel is $60 \mathrm{~L}$, which is assumed to be the volume available within the vessel to accumulate hydrogen. Using this volume into the time equation above yields

$$
\begin{gathered}
t=-\tau \cdot \ln \left(1-\frac{\chi_{\text {Hziti }}}{\chi_{\text {Hz,equil }}}\right) \\
=-\left(\frac{60 L}{1.67 \times 10^{-4} \frac{L}{s}}\right) \cdot(0.64) \cdot \ln \left(1-\frac{0.04}{0.64}\right) \\
=1.5 \times 10^{4} \mathrm{~s} \\
=4.1 \text { hours }
\end{gathered}
$$

Thus, it is possible, under the maxinum design load of radioactive material, to obtain flammable concentrations in the WIXM in relatively short periods of time.

Since it is possible to obtain flammable hydrogen concentrations inside the WIXM, two source terms are calculated for a possible hydrogen deflagmation/explosion, the unmitigated source term and the mitigated source term. Each of these source terms is comprised of two components, the release of resin (and adhering contamination) and the release of water (and dissolved contamination).

All of the releases are modeled using data and approaches from DOE-HDBK-3010-94. The handbook indicates that for explosions, a bounding ARF:RF of 1.0 times the TNT equivalence of the explosion (in $\mathrm{kg}$ ) is bounding if a mass ratio (MR) of 1 is assumed. The MR is defined as the ratio of the mass inpacted by the explosion (resin/water) to the force of the explosion (measured as TNT equivalence). The handbook draws the conclusion on the bounding nature of this ARF:RF based on experimental evidence in which dry powders were subject to detonation forces. 


\section{HNF-SD-WM-BIO-002 REV 1}

Assuming an MR of 1 models the release from the explosion by assuming that the material released is equal to the TNT equivalent mass of the explosion, and that all the material is comprised of respirable particles. The DOE handbook indicates that this assumption provides greater ARF:RF values over the case where larger quantities of material are assumed to become airborne but with lower respirable fractions.

To calculate the ARF:RF. the TNT kilogram equivalence of the hydrogen explosion must be calculated. For the unmitigated event, no controls are postulaled on the WIXM operations. Thus, the free volume and contamination inside the WIXM can be varied and any free water drained without filling the void space in the vessel. For the mitigated event, an administrative control is credited with filling the void space in the vessel as part of the draining operation. Eliminating or drastically reducing the void space in the vessel reduces the calculated bounding consequences below risk evaluation guidelines.

Unmitigated Source Term. Since the source term increases with the amount of hydrogen involved in the explosion, the entire volune of the WIXM vessel and the inlet pipe is assumed to contain hydrogen gas in the unmitigated event. This assumption overpredicts the amount of hydrogen involved, and is not physically possible, but adequately bounds the estimation of the explosive force. As stated in the scenario developmen, the volume of the inlet pipe is used because it is larger than the vent line, thus maximizing the explosive potential.

The total volume of the WIXM vessel is calculated above as $312 \mathrm{~L}$. and the volume of the inlet pipe can be found from the facility drawings. The length of the pipe is approximately $55.25 \mathrm{in}$, and the pipe is 1.5 -in. nominal, scledule 40 stecl. Schedule 40, nominal 1.5 -in. steel pipe has an internal diameter of 1.61 in., resulting in a volume of the inlet pipe of $108 \mathrm{in}^{3}(1.8 \mathrm{~L})$. Thus, the maximum possible volume involved in the explosion is $314 \mathrm{~L}$.

To estinate the matss of hydrogen involved, it is assumed that the entire volume of the WIXM and outlet pipe are filled with a stoichiometric mixture of hydrogen and oxygen. The assumption of a stoichiometric concentration is bighly conservative considering diffusion of hydrogen through the vent line. the initial presence of inert gases (i.e., nitrogen), and the generation of water vapor from the resin bed. A stoichiomeltic mixture of hydrogen and oxygen is $2 / 3$ hydrogen and $1 / 3$ oxygen, resulting in a volume of hydrogen of

$$
\begin{gathered}
\text { Maximum Possible HydrogenVolume }=\left(\frac{2}{3}\right) \bullet(314 \mathrm{~L}) \\
=210 \mathrm{~L}
\end{gathered}
$$

The density of hydrogen at room temperature and atmospheric pressure is $0.0899 \mathrm{~g} / \mathrm{L}$. resulting in a maximum mass of hydrogen of

$$
\begin{gathered}
\text { Maximum Mass of Hydrogen }=(210 \mathrm{~L}) \cdot\left(0.0899 \frac{\mathrm{g}}{\mathrm{L}}\right) \\
=18.9 \mathrm{~g} \\
=0.019 \mathrm{~kg}
\end{gathered}
$$

NUREG-1320 (NUREG, 1988) indicaltes that the TNT equivalency of hydrogen involved in a vapor cloud explosion is approximately $28.7 \mathrm{~kg} \mathrm{TNT} / \mathrm{kg} \mathrm{H}$, based on a heat of detonation of TNT of $4,187 \mathrm{~kJ} / \mathrm{kg}$ and low heat value of hydrogen of $120 \mathrm{MJ} / \mathrm{kg}$. Thus, a mass of hydrogen of $0.019 \mathrm{~kg}$ is equal to $0.55 \mathrm{~kg} \mathrm{TNT}$.

The source term from the explosion can be estimated from the contributions of the water and the resin. Assuming an MR of I, the total mass of material released is equat to the TNT equivalence, resulting in a total mass released of $0.55 \mathrm{~kg}$ of resin and water (and associated radioactive material). The WIXM SARP (HNF. 1998d) indicares that prior to use, the bulk resin volume is approximately $40 \%$ air and $60 \%$ resin beads. It is assumed that the air is displaced by water when the WIXM is placed into operation so that $40 \%$ of the material made airborne is contaminated water $(0.22 \mathrm{~kg})$, and $60 \%$ is conlaminated resin $(0.33 \mathrm{~kg})$. 
HNF-SD-WM-BIO-002 REV 1

The maximum contamination of the water is calculated in Section 2.4 .2 .2 .2 as $2.6 \mathrm{Ci} / \mathrm{L}$. The density of water at room temperature and atmospheric pressure is approximately $1.0 \mathrm{~kg} / \mathrm{L}$ so that the source lerm from the water is

Water Source Term $=(0.22 \mathrm{~kg}) \cdot\left(\frac{2.6 \frac{\mathrm{Ci}}{\mathrm{L}}}{1.0 \frac{\mathrm{kg}}{\mathrm{L}}}\right)$
$=0.57 \mathrm{CiSr}-90$

The WIXM SARP (HNF, 1998d) indicates that the amount of resin mixture required to remove $20,000 \mathrm{Ci}$ of ${ }^{\text {"r }} \mathrm{Sr}$ results in a weight of $387 \mathrm{lb}(176 \mathrm{~kg})$. To provide an adequate bound of potential operations, the number of curies is increased by $26 \%$ 10 $25.200 \mathrm{Ci}$. as discussed in Section 2.4.2.1.5. To bound the operating conditions with this analyses, it is assumed that $25.200 \mathrm{Ci}$ can be deposited on $100 \mathrm{~kg}$ of resin mixrure (controlled via an Administrative Control). This results in a maximum unit activity of $(25,200 \mathrm{Ci}) /(100 \mathrm{~kg})=252 \mathrm{Ci} / \mathrm{kg}$ of resin. Thus, the source term from the resin is

$$
\begin{gathered}
\text { Source Term }=(0.33 \mathrm{~kg}) \cdot\left(252 \frac{\mathrm{Ci}}{\mathrm{kg}}\right) \\
=75.6 \mathrm{Ci} \mathrm{Sr}-90
\end{gathered}
$$

The total source term from the explosion is then $76.2 \mathrm{Ci}$ of ${ }^{\text {wi }} \mathrm{St}$.

To arrive at this source term it was assumed that the entire volume of the IVIXM vessel was available to accumulate hydrogen, neglecting the volume laken up by the resin and water. In reality, the factors affecting the source term have competing effects. An increase in the volume of hydrogen increases the explosive forces, but decreases the source term available for release. Increasing the resin and water volumes (which decreases the free volume) would tend to increase the material at risk, but decrease the explosive effect. According to the source term model used, the maximum source term occurs when total mass of the material at risk is equal to the TNT equivalent mass of the hydrogen (i.e., there is just enough resin and water to be completely released by the explosion). This maxinizes the explosive force and maximizes the material at risk. To ascertain if use of the entire WIXM vessel volume for hydrogen accumulation is overiy conservative for the unmitigated case, the volume occipied by the material at risk can be estimated. The mass of water released in the maximum explosion was estimated to be $0.22 \mathrm{~kg}$ and the mass of resin released was $0.33 \mathrm{~kg}$. Assuming that these were the total masses of material in the WIXM vessel, they woukd occupy a volume of $0.22 \mathrm{~L}$ for the water and $0.28 \mathrm{~L}$ for the resin (assuming a resin density of $1.17 \mathrm{~kg} / \mathrm{L}$ ). Therefore, the cotal volume oecupied by the resin and water would be $0.50 \mathrm{~L}$, which is negligible compared to the total WIXM vessel volume of $312 \mathrm{~L}$ (calculated earlier in this source term analysis). Ideally, the volume of the resin and water could then be subtracted from the free volume and a new resin and water mass calculated. This iterative calculation could be repeated until the exact balance between resin and water mass and free volume is achieved. However, the small volume occupied by the releasable mass $(0.5 \mathrm{~L})$ compared to $312 \mathrm{~L}$ vessel volume indicates that the use of the entire WIXM vessel volume for hydrogen accumulation would only slightly exceed the possible worsi-case configuration.

It is also possible that the explosion could raise the lemperature of the resin remaining in the WIXM. causing a resin fire. To ascertain if this is a hazard, the anount of energy released by the explosion can be estinated.

The scenario development for this accident indicated that following the explosion, the resin and water remaining in the WIXM vessel could be heated, which could Jead to decomposition or burning of the resin. To determine if this is a hazard, the energy released by the explosion can be compared to the energy required to evaporate water. The maximum energy of the explosion postulated in this analysis is associated with $0.019 \mathrm{~kg}$ of hydrogen. Using the low beat value for hydrogen of $120,000 \mathrm{~kJ} / \mathrm{kg}$ as given in NUREG-1320 (NUREG, 1988), the energy of the release is 2,280 kJ. Before the resin temperature could be raised to ignition temperatures, any water present must be heated and then vaporized. A WIXM containing $100 \mathrm{~kg}$ (based on Administrarive Control 2.5.2) of fully-swollen, drained resin contains approximately $55 \mathrm{~L}$ of 


\section{HNF-SD-WM-BIO-002 REV 1}

water (HNF, 1998d). Ignoring the energy reguired to heat the water, the latent heat of vaporization of water is approximately $2,440 \mathrm{~kJ} / \mathrm{kg}$, so that $2,280 \mathrm{~kJ}$ would vaporize $0.93 \mathrm{~kg}(0.93 \mathrm{~L})$ of water. This calculation assumes that all of the energy of the explosion is absorbed by the resin/water matrix. This quantity of water being vaporized would result in negligible quantities of resin being exposed to elevated temperarures and potentially heated to combustion. Theretore, no source term is estimated from the resin remaining in the WIXM following the explosion event.

Mitigated Source Term. To determine the source term for the mitigated casc, the effects of an administrative control associated with loading the WIXM with resin are modeled. The administrative control credited is the requirement to fill the space above the resin bed with an uncontaminated, inert material after WIXM operations have been terminated. The inert material is added as a slurry as part of the draining process whereby the bulk free water is removed from the WIXM. Enough inert material is added to till the space above the bed to the extent possible.

If hydrogen were generated within the WIXM following addition of the inert material, only four possible volumes exist where the hydrogen might accumulate in tlammable concentrations: the vent line, the inlet line, a possible small gap at the top of the WIXM vessel, and the outles line.

Any hydrogen which might collect in llammable concentrations in the upper portions of the WIXM assembly (the vent line, the inlet line, and a possible gap at the top of the vessel) would not impact significant quantities of radioactive material if combusted. The vent and inle lines connect to the WIXM vessel at the top so that any combustion of hydrogen gas in the lines would impact residual surfice contanination on the interior of the lines, and the inert material on top of the resin bed. The level of contamination in the lines, remaining from contact with contamination in the water, does not pose a significant material at risk. Likewise, the inert material on the top of the resin bed is uncontaminated, so that the potential release is negligible.

The outlet pipe comes out of the WIXM from the bottom of the resin bed, where an inert material cannot be placed. Thus, the contaminated resin would still be in direct contact with any hydrogen accunulating in the outlet pipe. Ignition of hydrogen in the oule pipe is the worst-case scenario for the fulty mitigated event.

The volume of the outlet pipe is essentialty the same as the inle pipe, which is calculated above as $1.8 \mathrm{~L}$. Using this volume in the source model developed for the unnitigated case results in a source term as follows.

The volume of hydrogen is

$$
\begin{gathered}
\text { Hydrogen Volume }=\left(\frac{2}{3}\right) \cdot(1.8 \mathrm{~L}) \\
=1.2 \mathrm{~L}
\end{gathered}
$$

The resulting mass of hydrogen is

$$
\begin{gathered}
\text { Mass of Hydrogen }=(1.2 \mathrm{~L}) \cdot\left(0.0899 \frac{\mathrm{g}}{\mathrm{L}}\right) \\
=0.108 \mathrm{~g} \\
=1.08 \times 10^{-1} \mathrm{~kg}
\end{gathered}
$$

The TNT equivalent mass is

$$
\begin{aligned}
\text { TNT Equivalent Mass } & =\left(1.08 \times 10^{-4} \mathrm{~kg} \mathrm{H}\right) \cdot\left(28.7 \frac{\mathrm{kg} \mathrm{TNT}}{\mathrm{kg} \mathrm{H}}\right) \\
& =0.0031 \mathrm{~kg} \mathrm{TNT}
\end{aligned}
$$


The source term from the water is

Water Source Term $=(0.0031 \mathrm{~kg}) \cdot(0.40) \cdot\left(\frac{2.6 \frac{\mathrm{Ci}}{\mathrm{L}}}{1.0 \frac{\mathrm{kg}}{\mathrm{L}}}\right)$

$=0.0032 \mathrm{CiSr}-90$

The source term from the resin is

Resin Source Term $=(0.0031 \mathrm{~kg}) \bullet(0.60) \bullet\left(252 \frac{\mathrm{Ci}}{\mathrm{kg}}\right)$

$=0.47 \mathrm{CiSr}-90$

Thus, the fully mitigated source term is $0.47 \mathrm{Ci}$ of ${ }^{(0)} \mathrm{Sr}$.

\subsection{Consequence Analysis.}

Unmitigated Consequences. The unmitigated dose consequence can be found by multiplying the source term by the dose conversion factors developed in Section 3.4.1.3 (see Table 3-28a).

Mitigated Consequences. The unmitigated dose consequence can be found by multiplying the source term by the dose conversion factors developed in Section 3.4.1.3 (see Table 3-28b).

Table 3-28a. Unmitigated Dose Consequences from WIXM Explosion.

\begin{tabular}{|c|c|c|c|}
\hline Isotope & $\begin{array}{l}\text { Source term } \\
\text { (Ci) }\end{array}$ & $\begin{array}{c}\mathrm{DCF} \\
\mathrm{mSv} / \mathrm{Ci}(\mathrm{rem} \mathrm{Ci})\end{array}$ & $\begin{array}{c}50-y \mathrm{rCommitted} \\
\text { EDE } \\
\mathrm{mSv}(\mathrm{rem})\end{array}$ \\
\hline${ }^{40} \mathrm{Si}$ & 76.2 & $9.4(0.94)$ & $\begin{array}{c}720(72) \\
\text { onsite } 100-\mathrm{ml} \text { worker }\end{array}$ \\
\hline " $\mathrm{Sl}$ & 76.2 & $0.011(0.0011)$ & $\begin{array}{l}0.8(0.08) \\
\text { public }\end{array}$ \\
\hline${ }^{4 / 4} \mathrm{Sr}$ & 76.2 & $0.016(0.0016)$ & $\begin{array}{c}1.2(0.12) \\
\text { alternate site boundary }\end{array}$ \\
\hline
\end{tabular}

Table 3-28b. Mitigated Dose Consequenees from WIXM Explosion.

\begin{tabular}{|c|c|c|c|}
\hline Isotope & $\begin{array}{c}\text { Source term } \\
\text { (Ci) }\end{array}$ & $\begin{array}{c}\text { DCF } \\
\mathrm{mSv} / \mathrm{Ci}(\mathrm{rem} / \mathrm{Ci})\end{array}$ & $\begin{array}{c}50-\mathrm{yr} \text { Committed } \\
\text { EDE } \\
\mathrm{mSv}(\mathrm{rem})\end{array}$ \\
\hline${ }^{\mathrm{in}} \mathrm{Sr}$ & 0.47 & $9.4(0.94)$ & $\begin{array}{c}4.4(0.44) \\
\text { onsite } 100-\mathrm{m} \text { worker }\end{array}$ \\
\hline $\mathrm{Sr}$ & 0.47 & $0.011(0.0011)$ & $\begin{array}{c}0.005(0.0005) \\
\text { public }\end{array}$ \\
\hline${ }^{\mathrm{in} / \mathrm{Sr}}$ & 0.47 & $0.016(0.0016)$ & $\begin{array}{c}0.007(0.0007) \\
\text { alternate site boundary }\end{array}$ \\
\hline
\end{tabular}




\section{HNF-SD-WM-BIO-002 REV 1}

\subsection{Comparison to Guidelines.}

The most conservative onsite evaluation guideline of $5 \mathrm{rem}$ and the most conservative offsite evaluation guideline of $0.5 \mathrm{rem}$ is used.

Unmiligated Consequences. The unmitigated source term is $76.2 \mathrm{Ci}$ of ${ }^{\text {*1 }} \mathrm{Sr}$, resulting in a dose to the onsite receptor of $720 \mathrm{mSv}$ (72 rem). and a dose to the of fsite receptor of $0.8 \mathrm{mSv}(0.08$ rem) with all alternate boundary offsite dose of $1.2 \mathrm{mSv}(0.12 \mathrm{rem})$. The onsite dose consequence exceeds the risk evaluation guidelines but the offisite dose consequences are well below the risk evaluation guidelines.

Mitigated Conseguences. The fully mitigated source term is $0.47 \mathrm{Ci}$ of ${ }^{\text {(h) }} \mathrm{Sr}$, resulting in a dose to the onsite receptor of $4.4 \mathrm{mSv}(0.44 \mathrm{rem})$, and a dose to the olisite receptor of $5.0 \times 10-3 \mathrm{mSv}\left(5.0,10^{-6} \mathrm{rem}\right)$ with an alternate boundary offsite dose of $7 \times 10-3 \mathrm{mSv}\left(7.0 \times 10^{-4} \mathrm{rem}\right)$. Both the onsite and ofl'site dose consequences are well below risk evaluation guiclelines.

\subsection{Summary of Safety SSCs and IOSR Controls.}

The analysis of the unmitigated conseguences of this event identificd the need to have a control to prevent or mitigate the dose to the onsite receptor. Prevention or mitigation of this event is a safety significant function.

\section{Credited SSCs.}

None.

\section{Credited IOSR Controls.}

- WIXM operations must be controlled in the following tashion: prior to. or as part of draining the bulk water from the WIXM, an uncontaminated. inert solid material must be added so as to fill the free volume above the resin bed to the extent possible. The type of inert material and the procedure for adding it must consider the physical properties of the resin bed and incrt material (wet packing. total masses, relative densities, etc.) so that no atpreciable void volume exists or is created at some point in the future in the WIXM vessel.

\subsubsection{Loss of Containment.}

This section considers all of the loss of containment accidents identified in the hazards evaluation in Hey (1999). Included in these events are underwater capsule failure due to corrosion, underwater capsule failures due to drop impact, a leak from the pool cell sump, a leak in TK-100, canyon crane failure, cover block drop in a hot cell and failure of a 208-L (55-gal) waste drum in A Cell. This section also considers the WIXM loss of containment accident.

Of these events, underwater capsule failure due to corrosion and underwater capsule failures due to drop impact are selected for quantitative analysis. A leak in the pool cell sump was considered to have low risk because of relatively small consequences combined with a small frequency. A leak in TK-100, failure of a 208-L (55-gal) waste drum in A Cell, canyon crane failures or a cover block drop into F Cell were likewise found to be low consequence, low risk events. A more detailed discussion on the accident selection process as it pertains to this accident type is provided in Section 3.3.2.3.5.

\subsection{Underwater Capsule Failure .}

\subsection{Scenario Development.}

The hazards evaluation in $\mathrm{Hey}(1999)$ identifies and qualitatively evaluates several different causes for a loss of containment of a strontium or cesium capsule in a pool cell. All causes resulted in an S2 (i.e., onsite worker) consequence ranking and either an F2 (i.e., unlikely) or F3 (i.e., anticipated) likelihood ranking, resulting in either an R1 or R2 risk rank, 
respectively.

In the absence of stress and in the mild storage pool environment maintained at WESF, corrosion induced failure of a strontium or cesium capsule would be a slow and progressive event. Essentially all of the strontium capsules, and approximately $40 \%$ of the cesium capsules stored at WESF have remained at the facility since manufacture and have been stored underwater at relatively constant ambient temperature. These capsules have never experienced conditions outside their design limits and present little risk of failure. The balance of capsules have at one time been stored and used at various laboratories and irradiation facilities around the country. Some of these capsules have been exposed to conditions which exceeded their design with respect to thermal cycling. Although not showing any evidence of degradation, their operating history would place them in a category of higher risk of failure. Via the EDS and a unique identifier on the top of each outer capsule, WESF management has knowledge and keeps track of the exact location and associated history of every capsule stored at WESF.

Unmitigated Condition. The capsule failure analyses assumes that the capsule involved is a cesium capsule located in any one of the active storage pools. Cesium chloride is assumed instead of strontium fluoride for the sake of conservatism. Cesium chloride is very soluble in water, with detectable subsequent airborne concentrations, while strontium fluoride is very insoluble and would not be expected to migrate from the pool cell. In addition, ${ }^{137} \mathrm{Cs}$ has a significantly greater direct radiation dose rate than ${ }^{90} \mathrm{Sr}$, resulting in greater consequences. In all cases, using a strontium capsule in this analysis would result in lower consequences.

Capsule corrosion is thought to be the most likely mechanism for a single capsule failure. The details of accident progression for a leaking capsule are heavily dependent on the time development of the capsule's structural failure and the resulting time dependence of the cesium leak rate. The physical mechanisms of corrosion and dissolution of cesium into the pool cell water are complex and have not been studied in depth.

At present, the only direct experience with a leaking capsule comes from the Radiation Sterilizers, Inc. (RSI) facility in Decatur, Georgia (DOE 1990). The capsules in the Decatur facility were used for dry air operation-water storage irradiation. The capsules were frequently raised into the air for irradiator operations and then returned to a water pool when not in use. The temperature of the capsules would subsequently increase when raised into the air and decrease when placed back into the water. Thermal cycling is thought to be responsible for the single capsule failure and bulging of several other capsules in the same facility. Over the course of this incident, the leak rate from the capsule was predominantly $50{ }_{\mu} \mathrm{Ci} / \mathrm{h}$ until approximately 4 months after the leak was detected, at which time it went up to a peak rate of $600 \mu \mathrm{Ci} / \mathrm{h}$. Over the next several days following the peak, the rate decreased and stabilized at $150 \mu \mathrm{Ci} / \mathrm{h}$.

The mechanism of thermal cycling and bulging is not expected to occur in the relatively static storage conditions at WESF (see further comments in the discussion of inner capsule movement test below). Therefore, the Decatur incident is not necessarily representative of WESF leaks nor should it be taken to bound possible leaks at WESF.

The time necessary to dissolve the entire contents of a cesium capsule could be considerable. In order to evaluate the effectiveness of controls, it is assumed that a corrosion leak begins and cesium dissolves into the pool cell water at a constant rate until the capsule contents are completely dissolved. Such an accident progression might be envisioned as resulting from microfissures or a pinhole in the capsule wall or weld that is formed at a certain time and is thereafter static and unchanged. (Note, this is probably not realistic since any corrosion-induced crack or weld failure would become progressively worse with time, especially for small leak rates resulting in a capsule that leaks for years before completely dissolving.) As a result of the crack, water then seeps into the capsule and contacts the cesium chloride salt within (the inner capsule may have failed previously). The salt dissolves until the water is saturated and diffuses through the small defect in the capsule into the essentially zero concentration environment of the pool cell water. As long as water within the capsule remains saturated with salt, diffusion through the static crack will be time-independent. Since cesium chloride dissolves readily in water, it is assumed here that any water in the capsule would remain saturated for all leak rates considered. The results of this model are provided in Table 3-29.

\section{Mitigated Condition.}

Radioactive material from a leaking capsule would be carried through the pool cell circulation and heat exchange 


\section{HNF-SD-WM-BIO-002 REV 1}

system. The first sign of contamination would likely come from either periodic water samples drawn from the pool cells or the

| inline beta monitors in the circulation system. The water samples are sent to an analytical laboratory where it is tested for, among other things, the presence of contaminants. The inline beta monitors are designed to detect the presence of beta radiation emitted by ${ }^{90} \mathrm{Sr}$ and ${ }^{137} \mathrm{Cs}$. The inline beta monitors are very sensitive and capable of detecting low concentrations of radioactive contamination such that no hazard is present to a worker entering the Pool Cell Area. Which of these two monitoring systems first detects the contamination depends on the time of leak initiation and the leak rate. The length of time at which certain activity concentrations and dose rate fields would be observable is shown in Table 3-29 as a function of leak rate.

The time periods in Table 3-29 represent minimum values. No correction is made for the effects of cesium decay (with the exception that certain dose rates are not possible for small leaks due to decay). For large leak rates, the exact timing of the in situ concentration is uncertain since it depends on the details of the flow patterns and diffusion in the pool cells that occur on timescales of minutes.

Table 3-29. Example WESF Cesium Capsule Leak Scenarios. ${ }^{(2)}$

\begin{tabular}{|c|c|c|c|c|c|c|c|}
\hline \multirow[t]{2}{*}{ Event } & \multicolumn{7}{|c|}{ Leak rate $(\mathrm{Ci} / \mathrm{h})$} \\
\hline & 0.00005 & 0.0006 & 0.01 & 0.1 & 1 & 10 & 100 \\
\hline $\begin{array}{l}\text { In situ concentration } \\
\text { of } 1.0 \mathrm{E}-3 \mu \mathrm{Ci} / \mathrm{mL}\end{array}$ & 1 month & 2 days & $4 \mathrm{~h}$ & $21 \mathrm{~min}$ & $\min$ & $\min$ & $\min$ \\
\hline $\begin{array}{l}0.01 \mathrm{mR} / \mathrm{h} \text { on west } \\
\text { wall }^{(b)}\end{array}$ & $1 \mathrm{yr}$ & 1 month & 2 days & $4 \mathrm{~h}$ & $24 \mathrm{~min}$ & $\min$ & $\min$ \\
\hline $\begin{array}{l}\text { Dose rate } 1 \mathrm{~m} \\
(3.3 \mathrm{ft} \text { ) above pool } \\
\text { surface is } 100 \mathrm{mR} / \mathrm{h} \\
\text { (i.e., } 0.32 \mu \mathrm{Ci} / \mathrm{ml})^{(\mathrm{c})}\end{array}$ & $26 \mathrm{yr}$ & $2 \mathrm{yr}$ & 1.5 months & 4 days & $11 \mathrm{~h}$ & $1 \mathrm{~h}$ & $\min$ \\
\hline $\begin{array}{l}3 \mathrm{mR} / \mathrm{h} \text { on west } \\
\text { wall }^{(\mathrm{b})}\end{array}$ & $\begin{array}{l}\text { Beyond } \\
\text { facility } \\
\text { lifetime }\end{array}$ & $20 \mathrm{yr}$ & $1 \mathrm{yr}$ & 2 months & 5 days & $12 \mathrm{~h}$ & $1 \mathrm{~h}$ \\
\hline $\begin{array}{l}400 \mathrm{mR} / \mathrm{h} \text { on west } \\
\text { wall }^{(\mathrm{b})}\end{array}$ & \multicolumn{3}{|c|}{ Beyond facility lifetime } & $16 \mathrm{yr}$ & $2 \mathrm{yr}$ & 2 months & 7 days \\
\hline $\begin{array}{l}\text { Maximum capsule } \\
\text { fully dissolved (i.e., } \\
1,500 \mu \mathrm{Ci} / \mathrm{ml} \text { ) }\end{array}$ & \multicolumn{4}{|c|}{ Beyond facility lifetime } & $6 \mathrm{yr}$ & 7 months & 1 month \\
\hline
\end{tabular}

(a)Elapsed time calculated assuming a 9,330-gal pool with no decontamination and constant curie per hour leak rate. (b)This is the approximate location of the ARM located on the west wall of the capsule storage area (i.e., $18 \mathrm{ft}$ north of Pool Cell $5 \mathrm{centerline}$ and $6 \mathrm{ft}$ above floor). Orme (1981) indicates $1 \mu \mathrm{Ci} / \mathrm{mL}=1 \mathrm{mRh}$ at this location.

(c) Based on p. 139 of Orme (1981) which indicates an exposure rate of $8.8 \mathrm{mR} / \mathrm{hr}$ would result, $1 \mathrm{~m}$ above the center of a pool containing $1 \mathrm{Ci}$ of dissolved Cs-137.

In the event of failure or discontinuance of water testing and failure of the inline beta monitors, ARMs would detect elevated dose rates in the Pool Cell Area. The ARMs, two located on the east wall and one located on the west wall of the Pool Cell Area, are designed to detect the presence of gamma and beta radiation.

The radiation monitor associated with the ion-exchange columns in Pool Cell 11 also present an opportunity to detect contamination in an active pool cell. The water in each active pool cell is periodically sent through the ion-exchange columns to remove impurities in the water. The columns have a radiation monitor to alert facility personnel to the presence and possible buildup of radioactive materials on the ion-exchange resin. 


\section{HNF-SD-WM-BIO-002 REV 1}

In the event that all of these detection mechanisms fail, the presence of ${ }^{137} \mathrm{Cs}$ could eventually be detected by personnel radiation monitoring devices and by radiation monitors associated with the $\mathrm{K}-1$ filters. Cesium chloride in water has been known to lead to a spread of contamination by suspension of the cesium chloride in air. In the Decatur incident, ${ }^{137} \mathrm{Cs}$ contamination was found on personnel and facility equipment outside of the Pool Cell Area (DOE 1990). At WESF, all personnel entering the facility are required to exit through one of the radiation monitoring devices located at the facility exits, ensuring that a spread of contamination would be detected. In addition, the K-1 filters have radiation monitors that would detect airborne radioactive material that may accumulate there.

Inadvertent storage of a compromised capsule, one that is received at WESF in a degraded condition such that it is more susceptible to failure, is minimized by capsule receipt tests. The two primary tests are a ring gauge test and an ICM test. Further description and capability of the ICM test is included in the sections below. The ring gauge test is performed by passing the capsule through a ring of known size to detect possible deformities in the outer capsule. Failing either of these tests results in the capsule being labeled as suspect. Suspect capsules are either isolated in Pool Cell 1 or placed in dry storage in F Cell.

Once detected, the hazards of a capsule leak can be controlled by any combination of three methods: decontamination of pool cell water using the WIXM, placement of cover blocks, and isolation of the leaking capsule. Placement of cover blocks over the affected pool cell would serve to control radiation fields in the pool cell area and allow continued access to the area. Isolation of the capsule includes performance of the ICM test (discussed in detail below) and removal of the capsule to $G$ Cell.

If the detection mechanisms were to fail, two predominant concerns are apparent. The first is possible elevated dose rates to facility workers. The second is the inaccessibility of the pool cell area. The worker safety concerns are addressed in the analysis below. The inaccessibility of the pool cell area, however, is not a safety concern because it does not impact the ability of facility personnel to maintain the pool cell water levels. For an extended period of time the facility could be operated from outside the pool cell area by using normal deionized water makeup. If no actions were taken to recover, eventually normal water makeup could be lost due to lack of maintenance of SSCs within the pool cell area. In that case, the water levels in the pool cell could still be maintained indefinitely by adding water through the emergency fill pipe. Such deliberate long term abandonment of the safe storage mission is not within the scope of this BIO and is not addressed further.

The mitigated scenario takes credit for the ARMs to detect elevated levels of radiation and alert facility personnel prior to unacceptable worker doses. Although a number of other SSCs and programmatic controls are available and contribute to defense-in-depth, none are required to prevent unacceptable dose consequences to the facility worker, onsite worker, or the public.

ICM Test. The ICM test is used at WESF to identify a failed capsule. To perform this test, operators stand over the affected pool cell on the catwalk and clamp a set of tongs with a long tubular handle to the capsule being tested. The capsule is quickly raised and lowered above its normal position in the rack. For a normal capsule, the operator should be able to feel the inner capsule impact the bottom of the outer capsule after being displaced during the downward acceleration. If the inner capsule is swollen such that the inner capsule cannot slide within the outer capsule, then the inner capsule movement will not be felt. Also, if water is present in the annular space between the inner and outer capsule, the impact will be "sluggish" compared to a normal capsule. If either symptom is independently observed by two operators during the ICM test, operators are instructed to remove the capsule to G Cell.

There is some historical experience with ICM testing for capsule abnormalities related to failure in addition to the leaking capsule (Capsule 1502) at RSI discussed above. After the contamination event at RSI, ring gauge tests, ICM tests, and visual inspections were performed on all capsules at both RSI facilities in Decatur, Georgia, and Westerville, Ohio. Twelve capsules failed the ICM test and were removed for further testing. These capsules were confirmed by gamma scanning to have experienced inner capsule bulging and, in some cases, outer capsule bulging as well. Gamma scanning revealed that several of the bulged capsules also experienced salt compaction (reduction of the void space within the salt and increase in density). Gardner and Oakley (1989) concluded that the likely cause of capsule bulging and the failure of Capsule 1502 was salt compaction and expansion due to the repeated thermal cycling experienced by the capsules in use at RSI. The above evidence suggests that the ICM test would successfully locate a capsule that failed due to inner capsule bulging. 
In the static storage conditions at WESF, capsules would not experience thermal cycling and bulging. Gardner and Oakley (1989) also observed that any capsules that had experienced thermal cycling and were subsequently placed in static storage conditions did not become more bulged. The capsule storage environment at WESF is a stable storage condition. All capsules stored underwater at WESF have successfully passed the ring gauge and ICM test.

A pre-existing flaw or corrosion-induced failure of a capsule might be possible at WESF. A weld failure has already occurred (1993) in the outer capsule of Capsule 1592 stored at WESF. During a routine ICM test of capsules at WESF, it was found that Capsule 1592 did not impact normally, and it was removed from storage for further examination. Visual examination revealed microfissures in the area of the weld on one end of the capsule from which steam was escaping due to the elevated capsule temperature while in dry storage. Apparently water had seeped into the annular space between the inner and outer capsule causing the capsule to impact abnormally. While the inner capsule did not fail and no contamination was released, the event provides evidence that the ICM test could detect a failed outer capsule.

Considering the potential cesium chloride contamination made airborne above the pool cell, this pathway is an insignificant hazard as discussed in Section 3.4.2.6.2.

Maior Assumptions. The following assumptions were made in the scenario development.

- The leaking capsule is a cesium capsule.

- The rate at which activity leaks from a failed capsule is constant.

- For the mitigated scenario, the facility worker is protected by the ARMs in the pool cell area.

\subsection{Source Term Analysis.} performed.

As this event produces no significant airborne releases (see Section 3.4.2.6.2), a source term analysis is not

\subsection{Consequence Analysis.}

Unmitigated Condition. This section provides a bounding consequence estimate for the total dissolution of the maximum uncut cesium capsule. This scenario, by itself, has no consequences outside the facility and would not normally be included in a quantitative accident analysis. However, the dose consequences to facility workers and the potential for a leaking capsule to hamper operations because of increased dose rates in the Pool Cell Area are important considerations.

The unmitigated consequences of the leaking capsule scenario are shown in Figure 3-3. The values calculated are based on the source term of $53.2 \mathrm{kCi}$ released to the pool cell water containing $9,330 \mathrm{gal}$ of water and an exposure rate value of $8.8 \mathrm{mR} / \mathrm{h} / \mathrm{Ci}$ of ${ }^{137} \mathrm{Cs}$ dissolved in the pool (Orme 1981). This dose rate is associated with a point $1 \mathrm{~m}(3.3 \mathrm{ft}$ ) above the center of the pool cell without a cover block in place. Other areas of high local dose rates, such as near the pool cell water circulation piping or the ion-exchange columns (assuming the contaminated water is sent through the columns) may also be present but are not calculated.

The exposure rate could be as high as $470 \mathrm{R} / \mathrm{h}$ directly above the affected pool cell if the entire contents of a $53.2-\mathrm{kCi}$ maximum cesium capsule dissolved completely. It is not likely that this condition could be reached through a corrosion process because the environmental conditions within the WESF pool cells are mild and the stainless steel capsule material is highly resistant to corrosion. However, it is instructive to evaluate the bounding consequences in order to gain an appreciation for the hazards involved and the importance of mitigative features. The dose rates at various other locations of interest are shown in Figure 3-3, assuming the affected cell is Pool Cell 5. These values were taken from page 144, Figure 5 of Orme (1981), with dose rates scaled down to represent a pool containing $53.2 \mathrm{kCi}$ of ${ }^{137} \mathrm{Cs}$.

As will be discussed in Section 3.4.2.6.2, doses through the inhalation pathway are insignificant, even for a fully dissolved cesium capsule.

Mitigated Condition. For the mitigated scenario, unacceptable doses to facility workers are prevented by the ARMs. 
Figure 3-3. Eye Level Dose Map of Pool Cell Area with $53.2 \mathrm{kCi}^{137} \mathrm{Cs}$ Dissolved in Pool Cell 5

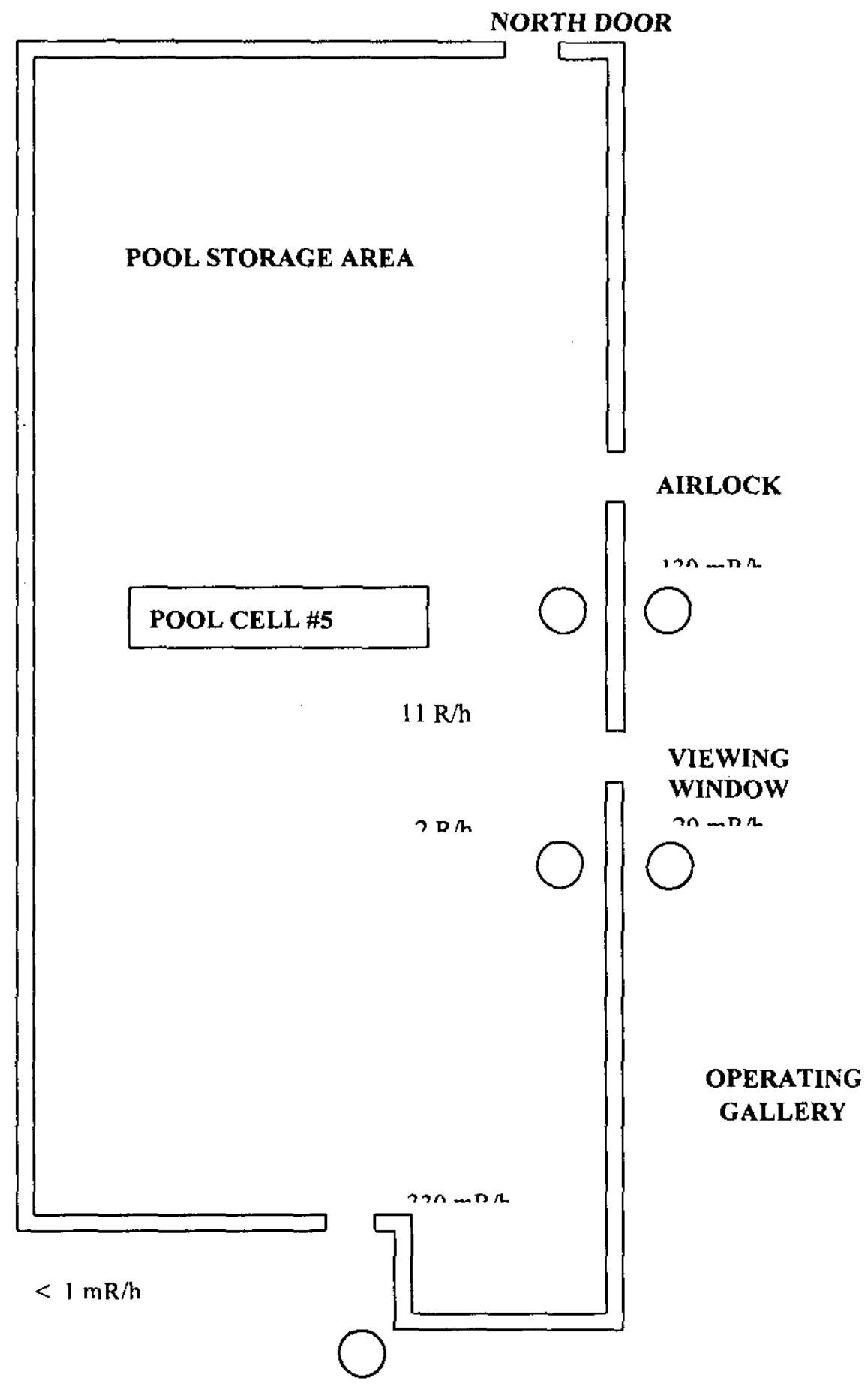

TRUCK PORT 


\section{HNF-SD-WM-BIO-002 REV 1}

\subsection{Comparison to Guidelines.}

Unmitigated Condition. This analysis examined the potential localized dose fields that could arise from a failed capsule in a pool cell. No direct onsite or offsite consequences are expected from this event.

Mitigated Condition. See Unmitigated Condition above.

\subsection{Summary of Safety SSCs and IOSR Controls.}

Although the immediate dose consequences of this event are very small outside the facility, uncorrected, a leaking capsule could lead to high gamma-ray dose fields above the pools, or require the placement and maintenance of cover blocks over the affected pool for an extended period.

The worst case above pool exposure rate from a fully dissolved capsule is $470 \mathrm{R} / \mathrm{h}$. An undetected dose field of this magnitude could result in a prompt (as opposed to latent cancer) worker fatality after an hour exposure or more. SSCs relied on to provide this detection function must be classified as safety significant.

Inner capsule status, WESF salt makeup, the effect of impurities on salt/metal corrosion phenomena, and concerns with capsule end cap welds are not understood well enough to provide a technically justifiable limit on a potential leak rate or size. Therefore, it is prudent to develop before hand, WESF response and design capability necessary to mitigate such an event. WESF has the capability to respond to both ${ }^{90} \mathrm{Sr}$ and ${ }^{137} \mathrm{Cs}$ capsule leaks.

Although the elevated dose rates in the pool cell area would hamper operations, the safe storage of the capsules is not jeopardized because water makeup can be provided remotely. Only maintenance of the SSCs in the pool cell area would suffer, and water makeup could still be performed even in the event of failure of these SSCs. In addition, such a progression of events would take years to develop and would have to be a deliberate decision to take no actions to recover. As discussed in the scenario development for the unmitigated condition, such decisions and actions are outside the scope of this BIO.

\section{Credited SSCs.}

- At a minimum two pool cell areat radiation monitors must be operable.

Safety Significant Basis - The potential dose field in the Pool Cell Area from a fully dissolved cesium capsule could be fatal to a facility worker if exposed for 1 hour or more. The area radiation monitors provide WESF workers with the necessary warning to take protective actions.

\section{Credited IOSR ControIs}

$$
\text { None. }
$$

\subsection{Underwater Capsule Failures Due to Drop Impacts.}

As of this writing, no reasonable basis has been identified for limiting the number of damaged capsules possible in a drop accident. Therefore, consequences are quantified for the single most active cesium capsule (i.e., $53.2 \mathrm{kCi}$ ). This is not to say that the consequences reported here are in any way limiting. But, based on the high dose fields and low airborne concentrations of a single underwater capsule failure, it should be evident that worker doses and accident recovery is the primary concern and not the immediate effects to onsite workers or the public. Since the consequences of failing to recover from this accident could eventually present a hazard to onsite workers and the public (if multiple capsules are ruptured), this accident is considered here in order to aid in the development of those controls.

Regardless of the success of accident recovery, this accident also presents a potential environmental concern with the unlikely leakage of contaminated water to the ground. No attempt is made here to perform ground transport studies or to 
quantify doses through this pathway. It is simply acknowledged that there is a potential for environmental damage and that such damage is unacceptable. Further quantification for the sake of developing controls should not be necessary. No further discussion on this subject is made.

\subsection{Scenario Development.}

The frequency of a heavy object drop in a pool cell is given in the hazards evaluation as unlikely, frequency rank F2, for each of the objects that could result in capsule damage. The frequency rank combined with the S2 (i.e., onsite worker) consequence for capsule leakage in a pool cell results in a risk rank of $R 2$ (i.e., moderate concern).

Unmitigated Condition. A drop and resulting impact of a heavy object is a mechanism that could result in simultaneous damage to several capsules. This event has the potential to lead to a very rapid increase in the concentration of radioactive material in a pool cell. It also has the potential to simultaneously damage the pool cell liner and structure and cause a leak of contaminated water to the ground, which in turn could lead to capsules being uncovered.

An object drop into a pool cell could lead to the following consequences:

- A breach of the pool cell liner and structure

- Mechanical damage to one or more capsules

- Damage to the pool cell heat exchanger and circulation piping

- Flooding of the Pool Cell Area due to raw water leaking from a damaged heat exchanger.

A breach of the pool cell liner and possible damage to the pool cell floor structure are discussed in Section 3.4.2.7.1 as a potential means for water leakage out of the pool cell. The response of the pool cell floor structure to a cover block drop has not been quantified. Additionally, the integrity of the pool sump confinement boundary is not a known or testable feature. As a result of these uncertainties, a cover block drop could lead to pool cell leakage.

It is not known, nor has an attempt been made, to quantify the number of capsules that might suffer mechanical damage as a result of a drop impact. However, it can be shown by the calculation of the resulting dose field from a single cesium capsule failure and subsequent dissolution of its contents, the magnitude of the consequences. The dose field and the number of capsule contents released are related in a linear fashion.

1. An additional concern with the drop accident is the potential for damage to the heat exchanger and circulation piping located in the pool cell. The consequences of damage to the heat exchanger could lead to (1) disruption of portable ionexchanger operation, which takes suction immediately downstream of this piping, and (2) flooding of the Pool Cell Area due to a breach in heat exchanger raw water lines.

The objects that pose a potential drop hazard identified in the hazards evaluation are the pool cell crane, the motorized catwalk, the pool cell cover blocks, and the Pool Cell Area structural components following an explosion in the facility. All overhead structures, including the bridge crane and motorized catwalk, are designed to withstand the $0.25 \mathrm{~g} \mathrm{DBE}$ (Section 3.4.2.1). The possible means by which a drop impacting the pool cells could occur are as follows:

- Falling structural members following an explosion in the facility

- Falling structural members following an aircraft impact

- Falling structural members following a BDBE

- Heavy object drop (e.g.,cover block, bridge crane failure, catwalk overload). 
The first three initiating events are discussed in Sections 3.4.2.5, 3.4.2.2, and 3.4.3, respectively. The consequences discussed below are applicable to all four initiators, but are not necessarily the only consequences. The referenced sections should be referred to for a complete understanding of the event consequence.

Pool cell cover blocks were formerly installed over all active pool cells to provide shielding and limited confinement in the event of loss of pool cell water. They also prevent falling objects from entering a pool cell. Because of concerns over dropping a cover block, they were removed from active pool cells. Inactive pool cells are allowed to have cover blocks in place. Active pool cells may have cover blocks replaced under certain emergency conditions.

The hoisting of a cover block over an active pool cell would imply either a failure of an administrative control or an emergency condition necessitating cover block placement. A second failure of the hoist system would also have to occur in order to have a potential drop. Since the cover blocks are necessarily wider than the pool cell, capsule impact may yet be prevented by the rigidity of the cover block. No structural steel is provided in the lip of the cover block, which rests upon the pool cell wall.

A capsule failure resulting from an object drop would release radioactive salt into the pool cell water. In addition to the high energy gamma-ray from the ${ }^{137 \mathrm{~m}} \mathrm{Ba}$ daughter product, cesium chloride salt is far more soluble than strontium fluoride and is the overriding concern. The dose rates associated with such a release could be sufficient to prevent personnel entry into the Operating Gallery or Pool Cell Area. Controls necessary to mitigate this event must consider this environment. The failure of recovery actions leads to the consequences discussed in Section 3.4.2.7.1.

Mitigated Condition. The mitigated scenario assumes that the movement of cover blocks over active cells is prevented by administrative controls, thereby eliminating the possibility of a cover block drop. Also, structural failure of the crane or catwalk is prevented by controls that require structural components of these items to be qualified for all design basis loads. In the mitigated scenario, capsule damage is prevented by these controls.

Major Assumptions. The following assumptions were made in the scenario development:

- Pool cell concrete floor and sump will not act as a containment barrier for water leaking from a ruptured liner.

- For the mitigated scenario, controls exist to prevent a cover block drop or structural failure of the pool cell crane or catwalk.

\subsection{Source Term Analysis.}

Unmitigated Condition. From the discussion above, the only causes for a sudden capsule failure are object drops into an active pool cell. These same object drops have also been identified as a means to breach the pool cell liner and potentially cause leakage of pool cell water. For the source term resulting from a loss of pool cell water, the reader should refer to Section 3.4.2.7.1. The unique gamma-ray and airborne source terms associated with the dissolution of a single cesium capsule are considered below.

This analysis assumes that the capsule involved is a cesium capsule located in active storage Pool Cell 5. Pool Cell 5 is centrally located and the dose fields reported are conservative with respect to the rest of the pools. Cesium chloride is assumed instead of strontium fluoride for the sake of conservatism. Cesium chloride solubility is 4.5 to 6.8 times more soluble in water than table salt (i.e., at 0 and $100^{\circ} \mathrm{C}\left[212^{\circ} \mathrm{F}\right]$, respectively) while strontium fluoride is very insoluble and would not be expected to migrate from the pool cell. A single pool cell contains sufficient water to easily dissolve the entire encapsulated cesium chloride inventory. In addition, the ${ }^{137} \mathrm{Cs}$ daughter product ${ }^{137 \mathrm{~m}} \mathrm{Ba}$ has a significantly greater direct radiation dose rate than ${ }^{90} \mathrm{Sr}$, resulting in greater direct dose rates. In all cases, using a strontium capsule in this analysis would result in lower consequences.

This case is modeled as the sudden underwater failure of the single highest activity cesium capsule manufactured at WESF, which is yet in existence as of January 1, 1996. The release of the entire contents of the maximum cesium chloride capsule is assumed (i.e., $53.15 \mathrm{kCi}$ of ${ }^{137} \mathrm{Cs}$ ) $(\mathrm{Hey} \mathrm{1999)}$ ). The cesium chloride is assumed to be released so rapidly that no intervening actions are possible to halt the release. In addition, the cesium chloride is assumed to immediately form a uniform 


\section{HNF-SD-WM-BIO-002 REV 1}

mixture in the pool cell and in the pool circulation system. This assumption should be valid for the condition where the circulation pump is running, and conservative for a stagnant pool condition where the higher concentration salt water would initially seek the lower levels in the pool cell.

The contamination in the pool cell can be expected to lead to small quantities of cesium chloride made airborne in the Pool Cell Area. Orme (1981) indicates that entrainment of ${ }^{137} \mathrm{Cs}$ from a contaminated pool can be characterized by an entrainment rate fraction (ERF), which is governed by the evaporation of water from the pool. The ERF is the fraction made airborne of the total amount of dissolved contamination in the pool cell. The airborne release rate from the pool cell can be found by multiplying, the ERF by the total amount of ${ }^{137} \mathrm{Cs}$ dissolved in the pool. When the cover blocks are removed, Orme (1981) calculated an ERF of $1.45 \times 10^{-10} \mathrm{~h}^{-1}$, assuming a bulk water temperature of $50^{\circ} \mathrm{C}\left(122^{\circ} \mathrm{F}\right)$.

Using the ERF of $1.45 \times 10^{-10} \mathrm{~h}^{-1}$ (Orme 1981), the airborne release rate associated with $53.2 \mathrm{kCi}$ of ${ }^{137} \mathrm{Cs}$ dissolved in a pool cell is approximately $2.5 \times 10^{5} \mathrm{~Bq} / \mathrm{h}\left(7.7 \times 10^{-6} \mathrm{Ci} / \mathrm{h}\right)$, or $7.9 \times 10^{1} \mathrm{~Bq} / \mathrm{s}\left(2.1 \times 10^{-9} \mathrm{Ci} / \mathrm{s}\right)$. With an approximate flow rate through the Pool Cell Area of approximately $140 \mathrm{~m}^{3} / \mathrm{min}\left(5,000 \mathrm{ft}^{3} / \mathrm{min}\right)$, this results in an average concentration in the Pool Cell Area of $34 \mathrm{~Bq} / \mathrm{m}^{3}\left(9.2 \times 10^{-10} \mathrm{Ci} / \mathrm{m}^{3}\right)$.

Mitigated Condition. The mitigated condition takes credit for the prevention of a heavy object drop into a pool cell.

Major Assumptions. The following assumptions were made in the preceding source term analysis:

- Leaking capsule is a cesium chloride capsule in Pool Cell 5.

- The entrainment rate fraction for cesium dissolved in a pool cell is $1.45 \times 10^{-10} \mathrm{~h}^{-1}$, assuming a bulk water temperature of $50^{\circ} \mathrm{C}\left(122^{\circ} \mathrm{F}\right)$.

- The ventilation flow rate is approximately $140 \mathrm{~m}^{3} / \mathrm{min}\left(5,000 \mathrm{ft}^{3} / \mathrm{min}\right)$.

\subsection{Consequence Analysis.}

Unmitigated Condition. The direct radiation dose rate associated with a pool cell contaminated with the contents of the maximum capsule, $53.2 \mathrm{kCi}$ of ${ }^{137} \mathrm{Cs}$, can be found using the same exposure rate as above from Orme (1981). That value is $8.8 \mathrm{mR} / \mathrm{h} / \mathrm{Ci}$ leaked into the pool, for a total exposure rate at $1 \mathrm{~m}(3.3 \mathrm{ft})$ above the center of the pool of approximately $470 \mathrm{R} / \mathrm{h}$.

The dose consequences associated with the airborne contamination are not calculated because of the very small source term and long release time. The insignificant nature of the dose consequences associated with the release of airborne contamination can be illustrated by calculating the length of time required to reach an onsite dose of $50 \mathrm{mSv}(5.0 \mathrm{rem})$, which is the onsite evaluation guideline. The exposure time, $t_{e}$, can be determined by

$$
t_{e}=\frac{D}{Q^{\prime} R \frac{\chi}{Q^{\prime}} C}
$$

where:

$$
\begin{gathered}
D=\text { dose of interest }(\mathrm{rem}) \\
Q^{\prime}=\text { release rate }(\mathrm{Ci} / \mathrm{s})
\end{gathered}
$$

$R=$ reference man breathing rate $\left(\mathrm{m}^{3} / \mathrm{s}\right)$

$\chi / Q^{\prime}=$ atmospheric dispersion coefficient $\left(\mathrm{s} / \mathrm{m}^{3}\right)$

$C=$ dose per unit curie inhaled $(\mathrm{rem} / \mathrm{Ci})$

The dose of interest is $50 \mathrm{mSv}\left(5.0 \mathrm{rem}\right.$ ) (the onsite risk evaluation guidelines), the release rate is $2.1 \times 10^{-9} \mathrm{Ci} / \mathrm{s}$, 
(calculated above), the breathing rate is $3.3 \times 10^{-4} \mathrm{~m}^{3} / \mathrm{s}$ (Section 3.4.1.3), the $\chi / \mathrm{Q}$ is $1.13 \times 10^{-2} \mathrm{~s} / \mathrm{m}^{3}$ (Section 3.4.1.3), and the unit dose for ${ }^{137} \mathrm{Cs}$ is $3.2 \times 10^{5} \mathrm{mSv} / \mathrm{Ci}\left(3.2 \times 10^{4} \mathrm{rem} / \mathrm{Ci}\right)$ (Section 3.4.1.3). Substituting these values in the equation above yields

$$
\begin{aligned}
t_{e}=\frac{5 \mathrm{rem}}{\left(2.1 E-09 \frac{\mathrm{Cl}}{\mathrm{s}}\right)\left(3.3 E-04 \frac{\mathrm{m}^{3}}{\mathrm{~s}}\right)\left(1.13 E-02 \frac{\mathrm{s}}{\mathrm{m}^{3}}\right)\left(3.2 E+04 \frac{\mathrm{rem}}{\mathrm{Ci}}\right)} \\
=2.0 \mathrm{E}+10 \mathrm{~s} \\
\approx 630 \mathrm{yr}
\end{aligned}
$$

Thus, in order to reach the onsite risk evaluation guidelines this release would have to occur unmitigated for approximately $630 \mathrm{yr}$. This calculation does not account for the natural decay of the ${ }^{137} \mathrm{Cs}$, which has a half-life of $30.17 \mathrm{yr}$, nor does it account for filtration in the K-1 system.

The dose field at various locations in and around WESF resulting from the dissolution of the maximum cesium capsule is provided in Figure 3-3. condition.

Mitigated Condition. No mitigated consequences are analyzed since the drop accident is prevented in the mitigated

\subsection{Comparison to Guidelines.}

Unmitigated Condition. As stated at the beginning of this accident scenario, no basis is available which would limit the number of capsules damaged in a drop accident. However, it can be seen from the low airborne concentrations and dose fields outside the facility, and the high dose fields inside the facility, that the overriding concern is accident recovery. Failing to recover from this accident could eventually lead to the more serious consequences of a loss of pool water as discussed in Section 3.4.2.7. Therefore, the controls identified to prevent or mitigate this accident should be considered in light of the more serious consequences. Furthermore, any recovery actions should consider the adverse environment that this accident could cause. The dose fields estimated above are not necessarily limited to those of a single capsule as reported.

DOE-STD-3009-94 (DOE 1994) also requires the consideration of adverse environmental impact. A cover block drop could potentially cause such an impact by causing both capsule leakage and leakage of contaminated water to the soil. Although a significant dose from this pathway would take many years to develop, the magnitude of the environmental damage and risk to ground water sources is large.

Mitigated Condition. No comparison is made since the mitigated scenario has no consequences.

\subsection{Summary of Safety SSCs and IOSR Controls.}

\section{Credited SSCs}

- Bridge crane, catwalk and associated support structures.

Safety Class Function - Must be capable of carrying design loads under all conditions.

\section{Credited IOSR Controls}

- IOSR protected control prevents, except in the case of an emergency response, the lifting of heavy objects over active pool cells that have the potential to damage capsules or the pool cell liner. 


\subsection{WIXM Loss of Containment}

\subsection{Scenario Development.}

This accident analysis addresses a loss of WIXM containment. The WIXM ion exchange colunn is completely encased in reinforced concrete on all sides which is at least $3 !$ inches thick. It is very unlikely that the WIXM can be ruptured. however, to bound operations, it is assumed that the WIXM is breached and results in a release of the contents. In the source term and consequence analyses, the release mechanisms are modeled such that all of the events are bounded.

Events identitied which could possibly rupture the WIXM include earthquake, vehicular collision, and rupture due to overpressurization from hydrogen buildup. The WIXM is contained in reinforced concrete and is a large monolithic structure not prone to tipping caused by a seismic event or vehicle impact. Vehicle impacts would also be of very slow speed and not likely to damage the WIXM structure at all.

If the WIXM were not vented (i.e., vent line mistakenly capped), the generation of hydrogen within the WIXM could eventually cause an overpressurization. Due to the pressure buildup and the potentially high temperatures generated inside the WIXM. the water remaining in the WIXM could flash to steim once the pressure is released. This could cause release of resin material and flying projectiles (i.e., cap and/or rod inserted in inlet and outlet lines) which could cause injury to the facility worker.

These events have similar release mechanisms in that they result in failure of the WIXM containment boundary and spill or ejection of material into the Truckport.

\subsection{Source Term Analysis.}

The resin beads are similar in size to sand. The top of the resin bed is approximately 87 in. off the ground giving the resin sufficient potential energy to spill onto the Truckport floor (assuming the structure was breached). The wet resin would be limited in movement once il exits the WIXM and would have too much mass to become airborne. As stated in the hazards evaluation, the contamination on the resin is subject to release only in the event of burning of the resin or severe shock that pulverizes the resin beads (such as an explosion). Thus, a spill of the WVIXM contents would not result in a respirable release from the resin.

A spill of material followed by impact of the WIXM assembly or a vehicle would not result in a significant quantity of crushed resin or a release of significant airborne contanination. Exposure of the unslielded resin material, however, would result in an increase in direct radiation levels in the Truckport.

For the BIO WIXM accident analyses. a radiological source term greater than the operating limit was desired in order to bound operations. The heat load assumed for the thermal analysis ( $19+\mathrm{W}$ ) is $26 \%$ greater than one-fourth the maximum strontium capsule $(154 \mathrm{~W})$ [see Section 3.4.2.3.2]. Therefore, to bound operating conditions, the source term of $25,200 \mathrm{Ci}{ }^{90} \mathrm{Sr}$ or $31,500 \mathrm{Ci}{ }^{13} \mathrm{Cs}$ was used for all accident analyses. This equates $1026 \%$ greater than the SARP operating limits of $20,000 \mathrm{Ci}$ ${ }^{\text {"I }} \mathrm{Sr}$ or $25.000 \mathrm{Ci}{ }^{1.7} \mathrm{Cs}$. The facility implementing procedures comply with the SARP limits; the BIO limits were developed to bound lacility operations.

\subsection{Consequence Analysis.}

The airborne release of contamination trom a spill of the WIXM contents is negligible, as discussed in the scenario development. Therefore, inhalation dose is not of concern.

The $S \wedge R P$ calculated the dose rate for $20,000 \mathrm{Ci}$ of ${ }^{\prime \prime} \mathrm{Sr}$. The maximum potential direct radiation dose rate from ${ }^{\infty} \mathrm{Sr}^{\prime \prime \prime} \mathrm{Y}$ was calculated as $1.04 \times 10^{\prime} \mathrm{rem} / \mathrm{hr}$ (whole body) for beta and $5.5 \mathrm{ren} / \mathrm{hr}$ for gamma at $3 \mathrm{~m}$ in Section B4.7.5 of the WIXM SARP (IINF, 1998d). 


\section{HNF-SD-WM-BIO-002 REV 1}

These beta/ganuna dose rates are associated with the WIXM design loading of $20.000 \mathrm{Ci}$ of ${ }^{21)} \mathrm{Sr}$. To provide a bounding case, the quantities of radioactive material is increased by $26 \%$ to $25,200 \mathrm{Ci}$ of ${ }^{\text {(h) }} \mathrm{Sr}$. Increasing the inventories by $26 \%$ results in an equivalent increase in the estimated dose rates. Thus, the dose rates are $1.31 \times 10^{\circ} \mathrm{rem} / \mathrm{hr}$ (whole body) for beta and $6.6 \mathrm{rem}$ hr for gamma.

The direct dose rate for a resin spill containing $25,000 \mathrm{Ci}$ (design load) or $31.500 \mathrm{Ci}$ ( $26^{\circ} \circ$ higher than design load) of ${ }^{n} \mathrm{Cs}$ was not calculated, however, because ${ }^{17} \mathrm{Cs}$ is primarily gamma, it can be intuitively concluded that this type of spill would also result in a significant dose to the worker.

Due to the WIXM design and operational controls, it is very unlikely that it will completely rupture and spill its contents. However, to protect the worker, radiation monitoring capabilities will be required. A vent line will also be required for worker protection to prevent overpressurization of the WIXM.

\subsection{Comparison to Guidelines.}

The most conservative onsite evaluation guideline is $5 \mathrm{rem}$ and the most conservative oft site evaluation guideline is $0.5 \mathrm{rem}$ due to inhalation of radiological contanination. Neither of these guidelines explicitly applies to direct radiation doses, however, some qualitative judgements can be made. The direct dose rate associated with the "Sr. whether the design load or $26 \%$ increase, clearly impacts worker safety. The direct dose associated with the ${ }^{137} \mathrm{Cs}$, whether the design load or the $26 \%$ increase, would also represent a significant threat to worker safety.

\subsection{Summary of Safety SSCs and IOSR Controls.}

\section{Credited SSCs.}

None.

\section{Credited IOSR Controls.}

- To keep operations within the bounds of the analysis. the quantity of radioactive materials present in the WIXM assembly must be no greater than $25,200 \mathrm{Ci}$ of ${ }^{(1)} \mathrm{Sr}$ or $31,500 \mathrm{Ci}$ of ${ }^{157} \mathrm{Cs}$. For combinations of isotopes. where ${ }^{90} \mathrm{Sr}$ and ${ }^{1: 7} \mathrm{Cs}$ are present at the same time. it is noted that the method of controlling the insentories is by limiting the quantily of cation resin in the WIXM vessel. Limiting the resin places a plyysical limit on the inventory, and since ${ }^{\text {"xh }} \mathrm{Sr}$ is bounding over ${ }^{1.77} \mathrm{Cs}$, any combination where ${ }^{177} \mathrm{Cs}$ takes the place of ${ }^{81} \mathrm{Sr}$ is bounded by the case where all of the contamination is ${ }^{90} \mathrm{Sr}$.

- Anytime a WIXM is contaminated with ${ }^{137} \mathrm{Cs}$ and/or ${ }^{90} \mathrm{Sr}$, radiation monitoring capabilities inust be present. Such monitoring must alarm locally to alert personnel of elevated radiation levels if the WIXM breached

- A vent line is also required for the WIXNt to prevent overpressurization.

\subsubsection{Loss of Pool Cell Water.}

This accident type is specifically directed to those sequences that could lead to the total loss of water from one or more active pools cells, as identified in the hazards evaluation in Hey (1999). Initiators are: heavy object drop, failure to add makeup water with or without a loss of cooling, and inadvertent pool drain. The maintenance of capsule water cover is necessary and sufficient to prevent capsule failure.

\subsection{Scenario Development.}

Unmitigated Condition. Each pool cell is designed for independent monitoring and cooling. Makeup and draw down are also controlled by valving to affect one pool at a time. The initiators listed above would not be expected to effect the 


\section{HNF-SD-WM-BIO-002 REV 1}

integrity of another pool. In this evaluation, it is assumed that other systems servicing other pools remain intact. For this reason, the pool cooling systems for unaffected pools are assumed to remain functional for the duration of the event. Also, water level in each of these other pools is assumed to remain at their nominal levels. This is done for both simplicity and to evaluate the thermal and source term consequences of draining a single pool, independent of consequences from other pools

Pool Cell Liner Leak Due to Corrosion. The pool cell liner is constructed of 16-gauge type 304 stainless steel at the sides and 14-gauge type 304 stainless steel flooring. This material is highly resistant to corrosion, especially at the temperatures and pressures of the WESF pool cells. If corrosion did occur, it would require an extended period of degraded pool cell water quality. Water is routed through the ion-exchange columns on a regular basis, and degraded water quality will not go undetected unless controls to monitor the pool cell water also fail.

If a small leak in a pool cell liner developed, water would leak into the corresponding sump. Each pool cell sump is

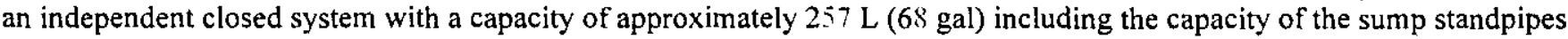
(leak detector lines) up to the $396 \mathrm{~cm}$ (156 in.) level (Iley 1999). This is equivalent to $2.5 \mathrm{~cm}$ ( 1 in.) of water level in Pool Cells 2 through 11. A conductivity probe is provided in each sump for indication of water accumulation. A water level drop of more than $2.5 \mathrm{~cm}(1 \mathrm{in}$.) would require a breach in the concrete pool structure or the letak detector line. Concrete around the drain line and circulation pipe penetrations was poured in place, precluding significant leakage into the pipe tunnel through penetrations. The leak detector lines are seismically qualitied to a WLSF DBt. (Wigenblast, et al. 1999).

Pool Cell Liner Leak Due to Object Drop/Impact. One possible mechanism for causing a high leak rate is to drop something heavy into the pool cell. Two potential initiators for this event are a crane lift accident or a catastrophic structural failure such as that discussed in Sections 3.4.2.5 and 3.4.3. Wagenblast, et al. (1999) concluded that none of the overhead structures and components such as the 225-B roof, cover blocks (when installed), bridge crane, or catwalk, had the potential for failing under design basis loads.

One object heavy enough to cause this event and readily available is a pool cell cover block. Pool cell cover blocks are $76-\mathrm{cm}$ - (30-in.-) thick and weigh 6,600 to $6,800 \mathrm{~kg}(14,500$ to $15,000 \mathrm{lb})$. A drop could easily cause a puncture or rip in the liner. The possibility of a breach in the $53-\mathrm{cm}-(2 \mathrm{l}$-in.-) thick concrete floor beneath the pool cells or of a pre-existing leak path through the floor structure requires this event to be considered a potential leak initiator.

A unique aspect of this accident is the potential high radiation field that would quickly result from catastrophic capsule failure. Unfortunately, it is not possible to determine beforehand how many capsules will fail, but the severity of the event can be gauged from a single cesium capsule failure and the dissolution of $100 \%$ of the salt contents (i.e., $53.2 \mathrm{kCi}$ maximum). As discussed in Section 3.4.2.6.2.3, the direct radiation exposure rate $1 \mathrm{~m}(3.3 \mathrm{ft}$ ) above a pool cell would be 470 $\mathrm{R} / \mathrm{h}$. Therefore, potential damage to the pool cell water retention structure caused by a cover block drop could quickly preclude manned entry into the Pool Cell Area. Section 3.4.2.6.2 contains additional discussions of drop accidents, their causes and consequences. The potential for contaminated water leakage is also considered there.

Inadvertent Draining. The following pathways exist by which a pool cell could be inadvertently drained. These are (1) through the circulation cross connect, and (2) through the transfer port valves and transfer aisle. The following paragraphs discuss these drain pathways.

(1) The inadvertent draining of water from an active pool cell could occur through the cross connect to the ionexchange system located in Pool Cell 11 . Normally a stream of $11 \mathrm{~L} / \mathrm{min}(3 \mathrm{gal} / \mathrm{min})$ is diverted from the heat exchanger return line to the purification system. After purification the stream is returned directly to the pool cell. A valve alignment error could divert this flow to another pool cell or $1 \mathrm{~K}-100$ during use of the emergency ion exchange system. Since the flow to the ion-exchange column is diverted from the circulation line, the water level of the pool cell could not be reduced to less than the $350 \mathrm{~cm}$ ( $138 \mathrm{in}$.) level because this is the level of the circulation pump inlet. A water level drop of $2.5 \mathrm{~cm}(1 \mathrm{in}$.) in Pool Cells 2 through 11 is equivalent to a water volume of 60 gal. Thus, it would take 6 hours for the level to drop from the nominal value of approximately $396 \mathrm{~cm}(156 \mathrm{in}$.) to the $350-\mathrm{cm}(138$-in.) level.

(2) The second pathway for partially draining a pool cell is through the transfer aisle. A normal means of water addition to a pool cell is through transfer aisle equalization. This is accomplished by opening the transfer port valve for the desired pool cell and adding water to the transfer aisle. If the transfer port to an empty pool cell were also opened, all three 


\section{HNF-SD-WM-BIO-002 REV 1}

pools would equalize to a water level of $254 \mathrm{~cm}(100 \mathrm{in}$.). This assumes that the transfer aisle was originally at $254 \mathrm{~cm}$ ( $100 \mathrm{in}$.) and the active pool cell wals originally at $3.30 \mathrm{~cm}(130 \mathrm{in}$.). A further decrease in water level is not possible without additional errors or failures. In this analysis and in the hazards evaluation in Hey $(1999)$, it is assumed that the facility configuration is for all of the transfer ports to be normally closed. The transfer ports are assumed to be open only for predefined operations or as part of an emergency action.

Failure to Add Makeup Water. The WESF operating experience indicates $<1$ to 6 in. per week evaporative losses from a pool cell are normal, depending on ambient conditions that control cooling water temperature on the tube side of the heat exchanger. Should pool cooling be lost, the bulk boiling temperature assuming worst case capsule configuration could be reached in no less than 11 hours (Hey 1999). The rate of level drop at this point would be a maximum of $2.5 \mathrm{~cm} / \mathrm{h}(1 \mathrm{in} / \mathrm{h})$ or

$4 \mathrm{~L} / \mathrm{min}(1 \mathrm{gal} / \mathrm{min})$. This is illustrated in Figure 3-4. These estimates are based on an initial pool temperature of $50^{\circ} \mathrm{C}\left(122^{\circ} \mathrm{F}\right)$, a pool level of 130 in. and a thermal pool heat generation of $149 \mathrm{~kW}$, and neglects conduction to the ground or adjacent pools. Potential causes of heat removal failure are as follows:

- Circulation pump or motor mechanical failure, instrument failure, loss of instrument air

- Loss of raw water cooling, loss of electrical power to the circulation pumps

- Low water level.

The first failure mechanisms are unlikely to result in a total loss of heat removal capability from all pools since each pool has its own circulation system. The exception is a loss of instrument air, which would result in a low water level reading for all pool cells and, in turn, cause the circulation pumps to be shut off. The second set of failure mechanisms could result from a seismic event since neither the raw water source nor electrical power supplied to WESF is qualified for seismic loads. However, the existence of a diesel driven raw water pump and a backup diesel generator make their failure less likely. A low water level in a pool cell could also cause a loss of cooling if the water level were to drop below the setpoint of an interlock or the inlet for the circulation system. The interlock would act to deactivate the circulation pump to protect it from damage.

The total thermal output of all uncut cesium chloride and strontium fluoride capsules as of January 1, 1996, is 403 $\mathrm{kW}$ (this value bounds the ly pe W orerpack capsules brought to WHSF in 1998). Without pool cooling, a conservative estimate of the evaporative loss associated with this thermal power is approximately $11 \mathrm{~L} / \mathrm{min}(3 \mathrm{gal} / \mathrm{min})$. Therefore, the emergency makeup requirement is minimal and could easily be supplied by the flow rate from a standard garden hose or one tanker truck per day. In this case, potential emergency sources of water addition are as follows:

- Sanitary water addition from fire hydrant

- Raw water addition from fire hydrant

- Opening the transfer port valve between the active pool and the transfer aisle

- Tanker truck (only applicable for loss of pool cell cooling: not applicable for a rapid loss of pool cell water).

The first three are vulnerable to seismic failure since, like the deionized water system (see Section 3.4.2.1), neither the sanitary or raw water sources are seismically qualified. However, it is feasible that one or both systems could remain functional following a seismic event. In addition, the pool cells provide a source of water that is qualified for seismic loads up to the $0.25 \mathrm{~g}$ DBE. If makeup water and pool cooling were lost for an extended period, opening the transfer port valves of Pool Cells 1 through 8 would lower the evaporation loss to $0.8 \mathrm{~cm} / \mathrm{h}(0.32 \mathrm{in} / \mathrm{h})$ and triple the response time available to restore water makeup capability and the time at which capsule water coverage would be lost. II Pool Cells 1 and 3 through 7 transfer port valves were opened, the evaporation loss would be $1.0 \mathrm{~cm}$ hr $(0.38 \mathrm{in} / \mathrm{hr})$ |lley 1999). This is illustrated in Figure 3-4.

In either case, several days are available for placement of cover blocks. This action would limit the dose fields in and around the Pool Cell Area to acceptable levels for implementation of recovery actions. The direct gamma-ray exposure rate from 715 uncovered cesium capsules beneath cover blocks would be in the range of $5 \mathrm{mR} / \mathrm{h}$ (Hey 1999).

From the discussions provided above, a credible means for the pools cells to experience evaporation without pool cooling in conjunction with a simultaneous loss of normal and emergency makeup water systems, is a seismic event. With the exception of the water retained in the pool cells themselves, no seismically qualified water supply is available to WESF. However, the success of alternative water supplies (tanker truck, new well, etc.) or repair of failed water supplies is made more likely when more time is available for recovery. Time is afforded by the use of the limited supply of water retained in the pool 
cells, all of which are seismically qualified, and the capability to place cover blocks over the pool cells to ensure facility access is not prevented in the short term. The success of the recovery actions is dependent on the time available and the preparations made. From Figure 3-4, it should be evident that at least 2 and possibly 8 days are available to place the cover blocks over the Pool Cells. All structures and bridge cranes necessary to support cover block placement are seismically qualified, but electrical power is not. This short term action would extend the recovery period from a minimum of 5 days and, depending on the pool cell water supply, to as many as 22 days (Hey 1999). Restoration of makeup water within this time frame is adequate to prevent capsule damage.

Figure 3-4. Capsule Storage Pool Water Level Versus Evaporation Time (Single Pool with $149 \mathrm{~kW}$, Six Pools with $403 \mathrm{~kW}$, Eight Pools with $403 \mathrm{~kW}$ )

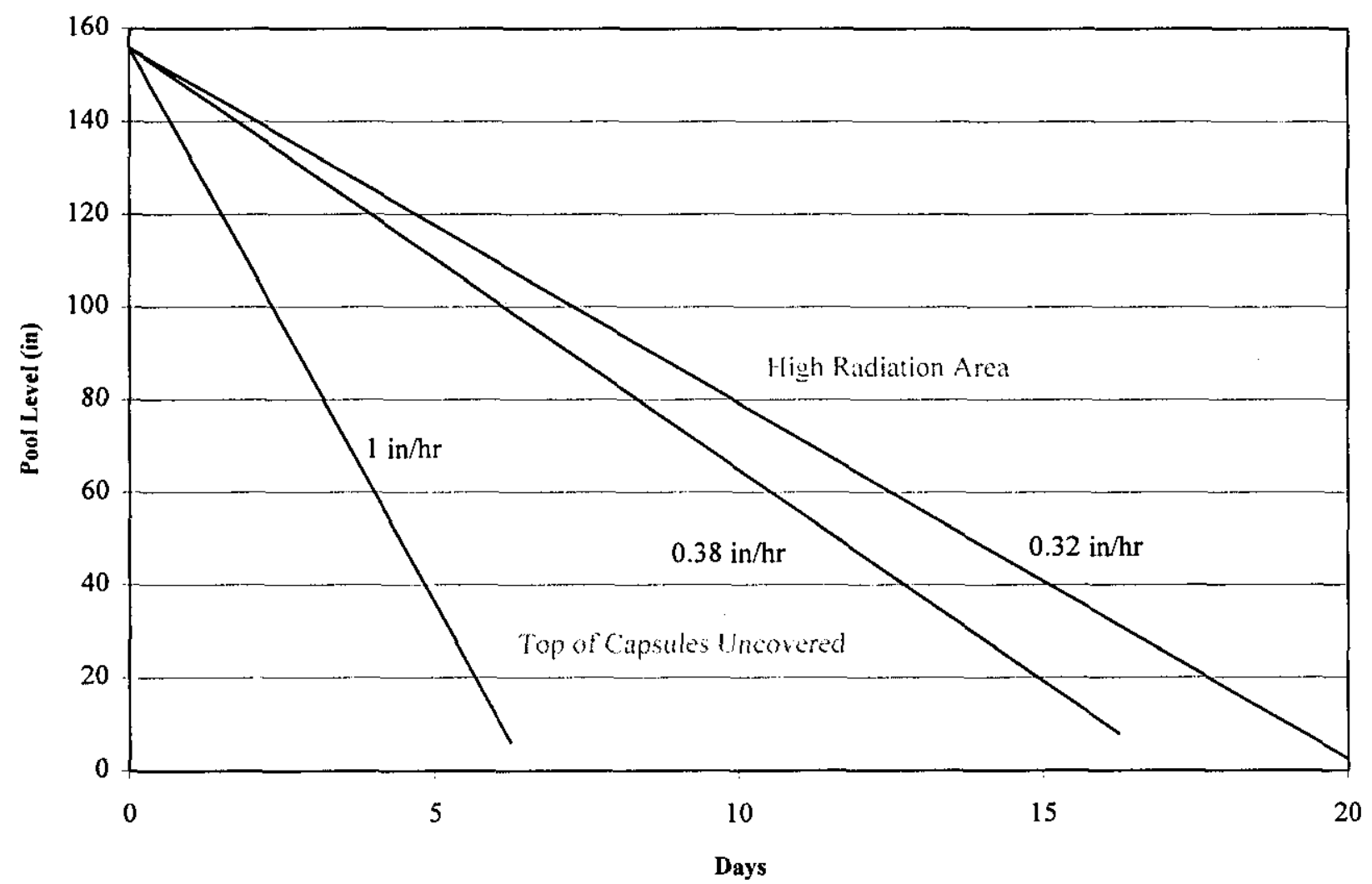




\section{HNF-SD-WM-BIO-002 REV 1}

Pool Cell Drain L,ine (or Circulation Line) Failure. Fach pool cell is provided with a 5 -cm (2-in.-) diameter. schedule 10S stainless steel, water removal pipe (drain line) extending from an open end at $1.3-\mathrm{cm}(1 / 2 \mathrm{in}$.) above the pool cell floor. through the pool cell liner and wall into the pipe tunnel. and through the pipe tunnel ceiling into the pipe trench to a flange connection at $15 \mathrm{~cm}(6 \mathrm{in}$.) below the Pool Cell Area lloor grating. Each water removal pipe penetrates the pool cell liner and wall into the pipe tunnel at an elevation of $91 \mathrm{~cm}$ ( $36 \mathrm{in}$.) above the pool cell floor. extends horizontally $2.3 \mathrm{in}(7.5 \mathrm{ft}$ ) to the exterior wall, then vertically up $2.7 \mathrm{~m}(9 \mathrm{di})$ where it penetrates the pipe tunnel ceiling. Each pool cell is also provided with a 7.6-con $(3-\mathrm{in})$ diameter circulation line that penetrates the pool cell liner and walt into the pipe tunnel at an elevation of $91 \mathrm{~cm}$ (36 in.) above the pool cell hoor, extends horizontally $91 \mathrm{~cm}$ (. fil). then vertically up $2.7 \mathrm{~m}$ (9 it) where it penetrates (skeved) the pipe tunnel ceiling. If the pool cell drain or circulation line were to mupture in the pipe tunnel. the pool cell would be in jeopardy of draining to just below the $91-\mathrm{cm}$ (36-in.) level (centerline of $5 \mathrm{~cm}$ [2-in.] pipe is at $91 \mathrm{~cm}[36 \mathrm{in}$.]).

Revision 0 of the WESF BIO accident analyses used existing nuclear industry data and conservatively determined the frequency of a pipe leak in the pipe tunnel to be $1.3 \times 10^{-3} / \mathrm{yr}^{\mathrm{r}}$ and a pipe break to be $4.4 \times 10^{5} / \mathrm{yr}$ (1ley 1999). It has since been determined that this data was for piping under dynamic loading and is not applicable to the unused drain lines and lowpressure circulation lines in the pipe tunnel.

There is currently no credible means identified to fail the drain and circulation lines in the pipe tunnel. These lines are stainless steel and are of all welded construction: there are no operations performed in the pipe tunnet which could physically inpact the lines; only deionized water has been used in these lines: video pictures taken in 1995 showed no evidence of water leaking in the pipe tunnel: and these lines have been evaluated in Wagenblast, et al. (1999) and lound io be structurally capable of withstanding DBE loads without exceeding allowable stress levels.

Due to the significant consequences associated with this event (see Section 3.4.3.3). 1.imiting Condition for Operation (LCO) 3.1 "Pool Cell Level" and Administrative Control (AC) 5.8 "Pool Cell Water Maheup" were developed and satety class SSCS were identified as mitigative features. Fiven thougl there is currently no credible initiator to this event and the accident analy sis has been moved to the Beyond Design Basis Accident section (Section 3.4.3). the controls will be maintained until additional evaluation is performed during the next WFSt $B 1 O$ update.

Mitigated Condition. The mitigated condition assumes that any loss of pool cell water is prevented or mitigated such that the capsule cooling function of the pool cell water is maintained at all times. Certain initiators discussed above in the unmitigated scenario may be prevented by controls. Other loss of water events may be mitigated by detection and addition of water before the accident can develop into a complete loss of pool cell water.

Major Assumptions. The following assumptions were made in the scenario development:

- In the case of liner failure, the concrete pool cell structure provides a containment barrier against water loss.

- Pool cells, other than the cell losing water, continue to function normally throughout the accident.

- Transfer ports between the pool cells and the transfer aisle are only opened for predefined operations and emergency actions. They are kept closed at all other times.

- The total thermal output of all remaining uncut cesium and strontium capsules as of 01 01/96 is $40.3 \mathrm{~kW}$ (Hey 1999) [this value bounds the Type W' overpack capsules brought to WESF in 1998].

- The rapid loss of pool cell water accident caused by drain line lailure is still being used as the bounding accident analysis for loss of pool cell water.

\subsection{Source Term Analysis.}

Unmitigated Condition. The rapid loss of pool cell water accident callsed by drain line fallure is still being used as the bounding accident analysis tor a loss of pool cell water event. SCe BDBA. Sections 3.4.3.3.1.2 (single pool cell) and 
| 3.4.3.3.2.2 (all pool cells), for unmitigated source term analysis associated with a rapid loss of pool cell water.

Mitigated Condition. The rapid loss of pool cell water accident caused by drain line failure is still being used as the bounding accident analysis for a loss of pool cell water event. Sec BDBA. Sections 3.4.3.3.1.2 (single pool cell) and 3.4.2.2.2.2 (all pool cells). for mitigated source term analysis associated with a rapid loss of pool cell water.

Major Assumptions. The rapid loss of pool cell water accident caused by drain line failure is still being used as the bounding accident analysis for a loss of pool cell water event. See BDBA, Sections 3.4.3.3.1.2 (single pool cell) and 3.4.2.2.2.2 (all pool cells). for major assumptions associated with a rapid loss of pool cell water.

\subsection{Consequence Analysis.}

Unmitigated Condition. The rapid loss of pool cell water accident caused by drain line failure is still being used as the bounding accident analysis for a loss of pool cell water event. See BDBA, Sections 3.4.3.3.1.3 (single pool cell) and 3.4.2.2.2.3 (all pool cells), for unmitigated consequence analysis associated with a rapid loss of pool cell water

Mitigated Condition. The rapid loss of pool cell water accident caused by drain line lailure is still being used as the bounding accident analysis for a loss of pool cell water event. See BDBA, Sections 3.4.3.3.1.3 (single pool cell) and 3.4.2.2.2.3 (all pool cells), for mitigated consequence analysis associated with a rapid loss of pool cell water.

\subsection{Comparison to Guidelines.}

Unmitigated Condition. The rapid loss ol pool cell water accident caused by drain line lälure is still being used as the bounding accident analysis for a loss of pool cell water event. See BDBA. Sections 3.4.3.3.1.4 (single pool cell) and 3.4.2.2.2.4 (all pool celis), for comparison of unmitigated dose consequences to guidelines associated with a rapid loss of pool cell water.

Mitigated Condition. The rapid loss of pool cell water accident caused by drain line failure is still being used as the bounding accident analysis for a loss ol pool cell water event. See BDBA, Sections 3.4.3.3.1.4 (single pool cell) and 3.4.2.2.2.4 (all pool cells), for comparison of mitigated dose consequences to guidelines associated with a rapid loss of poo! cell water.

\subsection{Summary of Safety SSCs and IOSR Controls.}

The following controls are defined for the bounding rapid loss of pool cell water event described in Section 3.4.3.3. Even though these controls are based on a $B D B \wedge$, they bound all other loss of pool cell water accidents identified in this section and are therefore included here. These controls will be maintained until further evaluation is performed in the next B1O updiste.

\section{Credited SSCS}

- Rapid water loss detection system (i.e.. level instrumentation and ARMs).

Safery Class function - The rapid water loss detection system is a required engineered barrier needed to prevent complete loss of pool cell water in the event of a drain line or circulation line failure in the pipe tunnel. Its safety class function is to alarm on detection of rapid loss of water from the pool cell to initiate emergency response actions. Level instrumentation and ARMs act together as a redundant and diverse means of alarming on detection of a rapid loss of water. Seismic qualification is not required since the system is not required to respond to the DBE. Environmental conditions in the Pool Cell Area during this event are the same as those during normal operating conditions. 


\section{HNF-SD-WM-BIO-002 REV 1}

- Emergency makeup lill pipe.

Salety Class Function - To allow water to be added to the pool cells remotely in the event of a rapid loss of pool cell water without exposing response personnel to a dose of greater than $50 \mathrm{mSv}$ (5 rem).

- Area i structure.

Safety Class Function - To retain water over the capsules so that radiation fields and capsule temperatures are limited to safe storage conditions.

\section{Credited IOSR Controls.}

- Control of a single WESF storage pool capsule thermal inventory below $149 \mathrm{~kW}$ is required to remain within the analyzed condition.

- The requirement to maintain sufficient water over the capsules stored in pool cells requires an IOSR control.

- Fxcept in the case of emergency response, the litting of heavy objects over active pool cells that have the potential to dimage capsules is prohibited.

\subsubsection{Beyond Design Basis Accidents}

\subsubsection{Introduction.}

DOE 5480.23 requires the evaluation of accidents beyond the design basis.

Each of the events evaluated in Section 3.4.2 necessarily involves an unmitigated scenario and consequence assessment. This analysis provides at least the consequence portion of the BDBA analysis. The accidents considered there are as follows:

- $\mathrm{DBE}$

- LOEP

- Hot cell fire (plus impact on the K-3 ventilation system)

- Truckport fire

- Excessive flow in the K-3 ventilation system

- Loss of K-3 ventilation (including impacts to capsules in F Cell)

- Hydrogen explosion in the K-3 HEPA filter housing

- Hydrogen explosion in TK-100

- Hydrogen explosion in the Pool Cell Area

- Flammable gas explosion in the facility

- Capsule failure in a pool cell

- Loss of pool cell water.

Of the three basic types of events, natural phenomena, external, and operational, all of the accidents listed above, except for the DBE and LOEP, are considered operational accidents. The analysis of operational accidents in Section 3.4.2 already considers the more severe consequences from equipment failures, and, according to DOE-STD-3009-94 (1994), consideration of such unmitigated accidents is sufficient for the BDBA analysis for operational events. DOE-STD-3009-94, Section 3.4.3, provides the example of an analysis of a DBA taking credit for HEPA filters, assuming the filters would survive the accident condition postulated, while the corresponding BDBA does not take credit for the HEPA filters. Thus, since the analyses of operational events in Section 3.4 .2 consider unmitigated source terms and consequences, the corresponding BDBA analyses have already been performed. For each operational accident, see the appropriate subsection in Section 3.4.2 to find a 
discussion of unmitigated consequences.

The DBE and LOEP events are treated differently than operational events. External events are specifically excluded from BDBA analysis by DOE-STD-3009-94. Natural phenomena are not excluded, and the DBE analysis in Section 3.4.2.1.1 does not consider consequences BDBE, and thus, does not include the BDBA analysis as the operational events did. This section considers the facility response and potential consequences of a BDBE. Additionally, post accident, or accident recovery issues are addressed relating to an extended loss of water from one or more pool cells.

\subsubsection{Beyond Design Basis Earthquake.}

The BDBE analyzed here utilizes new analysis in combination with source terms and consequences already calculated. The new analysis accounts for the failure of the F Cell structure and subsequent impact to capsules stored there, and the potential for dropping a cover block into the K-3 filter pit. The analyses referenced for source terms and consequences are from Sections 3.4.2.1.1 and 3.4.2.7.2. The BDBE herein has the same format and content of the accident analyses in Section 3.4.2, excluding the comparison to guidelines and summary of SSCs and IOSRs subsections.

In general, it will not be assumed in the BDBE analysis that failure of an SSC or administrative control will provide prevention or mitigation of potential accident consequences. This is the same principle used in the development of the DBA analyses.

\subsection{Scenario Development.}

The analysis of the DBE in Section 3.4.2.1.1 evaluates facility response based on survivability of SSCs to DBE loads. The BDBE is similar with the exception that SSCs designed to survive the DBE now fail in whatever configuration causes the greatest consequence.

For the purposes of the analysis, the likelihood of the BDBE can be found from the design of the facility and the seismic hazard curves for the Hanford Site. Specifically, Areas 2 and 3 of WESF were designed for a seismic event having a

| peak ground acceleration of $0.25 \mathrm{~g}$ (Wagenblast, et al. 1999), which according to Tallman (1996) corresponds to an annual frequency of $5.0 \times 10^{-4} \mathrm{yr}^{-1}$. This frequency is in the range of "unlikely" (frequency rank of $\mathrm{F} 2$ in the hazards evaluation), which results in a risk rank of R3 (i.e., major concern) when combined with the S3 severity (i.e., impacts to the public).

Most of the facility areas are designed to maintain their integrity following the DBE. For the BDBE, the assumption is made that all SSCs react in the failure mode, which results in the greatest dose consequences. No postulated failure, other than the presence of structural debris, is assumed to prevent the release of radioactive material.

Failure of the hot cells would result in exposure of the interior of the cells to the environment. Migration of contamination through openings in the hot cell and Operating Gallery structures, in addition to elevated direct radiation dose rates, would be expected. Any capsules stored in F Cell would be impacted by structural debris or a cell cover block and would add to the spread of contamination and direct radiation doses. It is not expected that the capsules will significantly increase in temperature because of restrictions in the airflow from failed structural components. Similar confined circumstances are present, without undue temperature increase, when up to 16 capsules are transported in the BUSS cask, which affords no ventilation.

Failure of the 225-B Building structure could cause the confinement failure of the Truckport area. Failure of the Truckport structure may impact any solid waste stored there, as well as any shipments in progress. The LLLW stored in bags or wooden boxes, however, would produce a negligible spread of contamination compared to the possible releases elsewhere in the facility. For shipping activities which might be in progress during the BDBE, the WESF waste cask may not withstand the failed structure and is assumed to fail, releasing its contents. The BUSS cask, because of its designed capabilities (SNL. 1991 ) is sufficient to withstand the impacts of the failed structure.

Failure of the canyon confinement, in and of itself, would not result in a significant spread of contamination. However, the canyon failure would present a flow path to the environment for the radioactive materials contained in the hot cells under the canyon. 


\section{HNF-SD-WM-BIO-002 REV 1}

The K-3 ventilation exhaust system is assumed to be effected in a fashion similar to that postulated in the DBE analysis. Contamination in the exhaust duct is suspended and carried out the ventilation system through the exhaust flowpath. In addition, the K-3 HEPA filters are assumed to be impacted by one or more failed cover blocks, adding to the source term and opening a direct flowpath from the filter pit to the environment.

In the Pool Cell Area, the BDBE could result in effects similar to those postulated in the hydrogen explosion in the Pool Cell Area event in Section 3.4.2.5.3. The BDBE could cause the complete failure of the roof panels and structural supports resulting in substantial impacts and mechanical failure of several capsules. However, as shown in the loss of pool cell water accident analysis, the effects of failure of the structure may be cooling of exposed capsules by allowing natural convective heat removal from the capsules. As general principle, it will not be assumed that failure of an SSC or administrative control will mitigate potential accident consequences, so it is assumed that the Pool Cell Area structure survives the BDBE and provides a temporary confinement function. The pool cell liners and underlying concrete foundations fail, so that all pool cell water is lost in a short period of time. All cooling and makeup water is likewise lost, and because of the rapid loss of all pool cell water and subsequent high dose rates, no makeup water from an external source can be added to the pool cells. The subsequent events pertaining to capsule heatup resemble the loss of all pool cell water event discussed in Section | 3.4.3.3.

While not qualified for DBE loads, it is feasible that one or more detection or makeup systems would be available in the event of an earthquake. Several such systems are present including the level detection instrumentation, area radiation monitors, deionized water makeup, sanitary water makeup, and raw water makeup.

The remaining areas of WESF, the office, AMU, manipulator shops, etc., could also be expected to fail in the BDBE. These areas contain only small quantities of hazardous materials, however, and would cause little spread of contamination.

It could also be expected that all utilities and support systems are lost in the BDBE. This includes raw, sanitary, and deionized water, electrical power (including the backup diesel generator), instrument air, control instrumentation, and radiation monitoring and alarms.

\section{Maior Assumptions.}

- All facility SSCs and support services fail in the BDBE in whatever configuration provides the worst-case consequences (i.e., the failure of an SSC is not credited for preventing or mitigating the potential consequences of the BDBE).

\subsection{Source Term.}

The source term arising from the BDBE can be estimated as the combination of the source terms from the DBE, loss of all pool cell water, impacts to capsules in F Cell, and cover block impacts to the K-3 filters.

The source term calculated for the DBE in Section 3.4.2.1.2.2 is the combination of the release through the stack (B through E Cells plus the K-3 exhaust duct) and the release from A Cell. In the DBE analysis, the stack release was treated separately from the A Cell release because the 296-B stack was shown to survive the DBE. For the BDBE, however, the stack does not survive and the releases postulated for $A$ through $E$ Cells can be combined for a total source term of $9.5 \times 10^{12} \mathrm{~Bq}$ $(260 \mathrm{Ci})$ of ${ }^{90} \mathrm{Sr}$ and $8.9 \times 10^{11} \mathrm{~Bq}(24 \mathrm{Ci})$ of ${ }^{137} \mathrm{Cs}$. The source term from A through E Cells would be the same for the BDBE as for the DBE because of similar physical phenomena. Both model shock/vibration of the radioactive material. The BDBE postulates a greater level of structural damage, but the $A R F: R F$ used in the analysis encompasses impacts from such structural damage.

The source term arising from the loss of all pool cell water would not arise immediately following the BDBE. Although the pool cell water would be lost immediately, the capsules require time to heat up to temperatures where failures would be expected and molten cesium chloride released. In addition, the source term following heat up of the capsules is developed in Section 3.4.2.7.2 as a mass release rate, with calculations showing the release after 24 hours for the offsite receptor and 8 hours for the onsite receptor. The source term arising from a loss of all pool cell water following the BDBE, 
therefore, is presented in the same fashion. This source term is $1.3 \mathrm{~kg}$ of cesium chloride salt released to the onsite receptor and $3.8 \mathrm{~kg}$ of cesium chloride salt released to the offsite receptor (see Section 3.4 .3 .3 ).

The source term arising from the potential impact to the capsules stored in F Cell can be estimated in the same fashion as the source term for the DBE. Although in the DBE the capsules were assumed to survive the shock/vibration, in the BDBE the capsule could be failed by physical impacts from cell structural components and/or cover blocks. The resulting impact to the capsules can be modeled with the same shock/vibration ARF:RF as was used in the DBE, $1 \times 10^{-3}: 1.0$. The material in capsules, however, is similar to a monolithic structure with significant cohesive forces between particles which must be overcome by the force of the postulated impacts. Mishima (1994) reduces the RF from a value of 1.0 to 0.1 for cases where "clumps/piles" of contamination exist and deagglomeration of the powder must occur to make respirable particles (Section 4.4.3.3.1 of Mishima [1994]). This is applicable to the material in the capsules in F Cell, and so with an RF of 0.1 the total release fraction of respirable material is $1 \times 10^{-4}$. The inventory in 24 capsules (with an average of $1.5 \times 10^{12} \mathrm{~Bq}[39.2$ $\mathrm{kCi}$ ] per capsule) is $3.48 \times 10^{16} \mathrm{~Bq}(941 \mathrm{kCi})$ of ${ }^{137} \mathrm{Cs}$ per capsule for a source term of $3.48 \times 10^{12} \mathrm{~Bq}(94.1 \mathrm{Ci})$.

The source term arising from the cover block drop into the K-3 filter pit can be modeled as an impaction stress on an unenclosed (failed filter housing) HEPA filter as given in Section 5.4.4.2 of Mishima (1994). The appropriate ARF:RF value is $1 \times 10^{-2}: 1.0$ and the inventory (assuming that only one of the filters is loaded with radioactive material) is $8.9 \times 10^{12} \mathrm{~Bq}$ $(240 \mathrm{Ci})$ of ${ }^{137} \mathrm{Cs}$ and $6.7 \times 10^{14} \mathrm{~Bq}(18 \mathrm{kCi})$ of ${ }^{90} \mathrm{Sr}$. The resulting source term from the impact to the $\mathrm{K}-3$ filters is $8.9 \times 10^{10} \mathrm{~Bq}(2.4 \mathrm{Ci})$ of ${ }^{137} \mathrm{Cs}$ and $6.7 \times 10^{12} \mathrm{~Bq}(180 \mathrm{Ci})$ of ${ }^{90} \mathrm{Sr}$. Only one filter box is assumed to be loaded in this analysis because the only source of contamination is from the hot cells and $\mathrm{K}-3$ exhaust duct. Both of these sources have already been accounted for in the BDBE and it is bounding to assume that a K-3 HEPA filter is present at its maximum allowed loading without decreasing the inventories in the hot cells and the K-3 exhaust duct.

The total source term from the BDBE is the summation of the source terms above, or $4.5 \times 10^{12} \mathrm{~Bq}(121 \mathrm{Ci})$ of ${ }^{137} \mathrm{Cs}$ and $1.6 \times 10^{13} \mathrm{~Bq}(435 \mathrm{Ci})$ of ${ }^{90} \mathrm{Sr}$ in addition to $1.3 \mathrm{~kg}$ of cesium chloride exposure to the onsite receptor and $3.8 \mathrm{~kg}$ of cesium chloride exposure to the offsite receptor.

\subsection{Consequence Analysis.}

The dose consequences arising from the $\mathrm{BDBE}$ are the combination of the dose consequences arising from the source terms developed above. Tables 3-36 and 3-37 show the source terms from the previous section and the subsequent onsite and offsite dose consequences. The source term for the loss of pool cell water is reported for an 8 -hr period for the onsite receptor exposure and for a $24-\mathrm{hr}$ period for the offsite receptor exposure (Scction 3.4.3.3). 
Table 3-36. Beyond Design Basis Earthquake Onsite 100-m Worker Dose Consequences

\begin{tabular}{|c|c|c|c|}
\hline Release mechanism & Source term & DCF & $\begin{array}{l}\text { 50-yr EDE } \\
\mathrm{mSv} \text { (rem) }\end{array}$ \\
\hline DBE source term & $\begin{array}{l}260 \mathrm{Ci}^{90} \mathrm{Sr} \\
24 \mathrm{Ci}^{137} \mathrm{Cs}\end{array}$ & $\begin{array}{c}9.4 \mathrm{mSv} / \mathrm{Ci} \\
(0.94 \mathrm{rem} / \mathrm{Ci}) \\
1.2 \mathrm{mSv} / \mathrm{Ci} \\
(0.12 \mathrm{rem} / \mathrm{Ci})\end{array}$ & $\begin{array}{l}2,500 \\
(250)\end{array}$ \\
\hline $\begin{array}{l}\text { Failed hot cell structure crushing stored cesium } \\
\text { capsules }\end{array}$ & $94.1 \mathrm{Ci}^{137} \mathrm{Cs}$ & $\begin{array}{c}1.2 \mathrm{mSv} / \mathrm{Ci} \\
(0.12 \mathrm{rem} / \mathrm{Ci})\end{array}$ & $\begin{array}{l}110 \\
(11)\end{array}$ \\
\hline $\begin{array}{l}\text { Failed K-3 Filter Pit structure and cover block } \\
\text { impact on filter housing }\end{array}$ & $\begin{array}{l}180 \mathrm{Ci}^{90} \mathrm{Sr} \\
2.4 \mathrm{Ci}^{137} \mathrm{Cs}\end{array}$ & $\begin{array}{c}9.4 \mathrm{mSv} / \mathrm{Ci} \\
(0.94 \mathrm{rem} / \mathrm{Ci}) \\
1.2 \mathrm{mSv} / \mathrm{Ci} \\
(0.12 \mathrm{rem} / \mathrm{Ci})\end{array}$ & $\begin{array}{l}1,700 \\
(170)\end{array}$ \\
\hline $\begin{array}{l}\text { Thermally failed cesium capsules (release over } 8 \mathrm{~h} \\
\text { period two days into event) }\end{array}$ & $1.3 \mathrm{~kg}$ & $\begin{array}{l}13,000 \mathrm{mSv} / \mathrm{kg} \\
(1,300 \mathrm{rem} / \mathrm{kg})\end{array}$ & $\begin{array}{l}17,000 \\
(1,700)\end{array}$ \\
\hline $\begin{array}{l}\text { Direct gamma-ray shine from empty pools }(4 \mathrm{R} / \mathrm{h} \\
\text { over } 8 \mathrm{~h} \text { period) }\end{array}$ & $55 \mathrm{MCi}$ & $\mathrm{N} / \mathrm{A}$ & $\begin{array}{l}320 \\
(32)\end{array}$ \\
\hline \multicolumn{3}{|c|}{ Total onsite dose ( $100 \mathrm{~m}[328 \mathrm{ft}]$ receptor) } & $\begin{array}{l}22,000 \\
(2,200)\end{array}$ \\
\hline
\end{tabular}

Table 3-37. Beyond Design Basis Earthquake Alternate Site Boundary Dose Consequences.

\begin{tabular}{|l|c|c|c|}
\hline \multicolumn{1}{|c|}{ Release mechanism } & Source term & DCF & $\begin{array}{c}\text { Alternate site } \\
\text { boundary 50-yr } \\
\text { EDE } \\
\mathrm{mSv}(\mathrm{rem})\end{array}$ \\
\hline DBE source term & & & 4.2 \\
& $260 \mathrm{Ci}^{90} \mathrm{Sr}$ & $0.016 \mathrm{mSv} / \mathrm{Ci}$ & $(0.42)$ \\
& & $(0.0016 \mathrm{rem} / \mathrm{Ci})$ & \\
& & $0.0020 \mathrm{mSv} / \mathrm{Ci}$ & \\
\hline $\begin{array}{l}\text { Failed hot cell structure crushing stored cesium } \\
\text { capsules }\end{array}$ & $94.1 \mathrm{Ci}^{137} \mathrm{Cs}$ & $0.0020 \mathrm{mSv} / \mathrm{Ci}$ & 0.19 \\
& & $(0.00020 \mathrm{rem} / \mathrm{Ci})$ & $(0.019)$ \\
\hline $\begin{array}{l}\text { Failed K-3 Filter Pit structure and cover block } \\
\text { impact on filter housing }\end{array}$ & $180 \mathrm{Ci}^{90} \mathrm{Sr}$ & $0.016 \mathrm{mSv} / \mathrm{Ci}$ & 2.0 \\
& $2.4 \mathrm{Ci}{ }^{137} \mathrm{Cs}$ & $(0.0016 \mathrm{rem} / \mathrm{Ci})$ & $(0.29)$ \\
\hline $\begin{array}{l}\text { Thermally failed cesium capsules (release over } \\
\text { 24-h period 2 days into event) }\end{array}$ & & $0.0020 \mathrm{mSv} / \mathrm{Ci}$ & \\
\hline \multicolumn{2}{|c|}{ Total offsite dose } & $(0.00020 \mathrm{rem} / \mathrm{Ci})$ & \\
\hline
\end{tabular}

The dose at the alternate site boundary described in Section 3.4.1.3 would be $99 \mathrm{mSv}$ (9.9 rem). 


\subsubsection{Rapid Loss of Pool Cell Water.}

Rapid loss of pool cell water caused by a break in the drain line (or circulation line) located in the pipe tumnel has been classified as a BDBA. However. until further analysis is performed, this accident is still considered the bounding loss of pool cell water event and controls have been identified to mitigate/prevent this accident.

\subsection{Loss of Water from a Single Pool Cell}

\subsection{Secnario Development}

Each pool cell is provided with a 5 -cm (2-in.-) diameter, schedule $10 \mathrm{~S}$ stainless steel, water removal pipe (drain line) extending from an open end at $1.3-\mathrm{cm}(1 / 2 \mathrm{in}$. above the pool cell floor, through the pool cell liner and wall into the pipe tunnel, and through the pipe tumnel ceiling into the pipe trench to a flange connection at $15 \mathrm{~cm}(6 \mathrm{in}$.) below the Pool Cell Area floor grating. Fach water removal pipe penetrates the pool cell liner and wall into the pipe tunnel at an elevation of $91 \mathrm{~cm}$ (36 in.) above the poof cell thoor, extends horizontally $2.3 \mathrm{~m}$ (7.5 fi) to the exterior wall, then vertically up 2.7 in (9) fi) where it penetrates the pipe tunnel ceiling. Each pool cell is also provided with a $7.6-\mathrm{cm}$ ( 3 -in) diameter circulation line that penetrates the pool cell liner and wall into the pipe tunnel at an elevation of $91 \mathrm{~cm}(36 \mathrm{in}$.) above the pool cell floor, extends horizontally $91 \mathrm{~cm}(3 \mathrm{ft}$ ), then vertically up $2.7 \mathrm{~m}(9 \mathrm{ft}$ ) where it penetrates (sleeved) the pipe tunnel ceiling. The drain and circulation lines in the pipe tumnel are of all welded construction

If the drain or circulation line were to rupture above the pipe tunnel ceiling, the pool cell would not be in jeopardy of draining as the pipe rupture would be above the nominal water level in the pool cell. If the pool cell drain or circulation line were to rupture in the pipe tunnel. the pool cell would be in jeopardy of draining down to just below the $91-\mathrm{cm}(36$-in.) level since the $5 \mathrm{~cm}(2-\mathrm{in}$.$) pipe centerline is at 91 \mathrm{~cm}(36 \mathrm{in}$.). The drain line would offer the least resistance to gravity flow due to a sparger distributor on the circulation line.

A complete break of the $5 \mathrm{~cm}(2$-in.) drain line at its lowest level outside the pool cell could drain the pool down to the $91-\mathrm{cm}$ (36-it.) level in a little over 1 hour (1ley 1999). There is also the possibility that the severed end of the pipe could dethet downward, resulting in a siphon drain of the pool cell to a kevel lower than the $91-\mathrm{cm}(36-i n$.) level. The cause of the downward deflection could be the force associated with the pipe failure and water flow, but could not be from impact because of the lack ol non-qualitied SSC s over the pipe. The possible dellection that might occur at pipe failure has been addressed in Wagenblast. et. al. (1997). The maximum deflection would be approximately $0.69 \mathrm{~cm}(0.27 \mathrm{in}$.). which is negligible. In approximately 20 minutes. the exposure lield at the operating deck level and in direct view of the capsules could be on the order of $100 \mathrm{R} / \mathrm{h}$. Thus, it would not be possible for an operator to open the transfer port valve in the transfer aisle at this point. Initially the 170 rate would be about $757 \mathrm{~L} / \mathrm{min}(200$ gal min), which is currently in exess of the deionized water makeup system capability. Once at the $91 \mathrm{~cm}(36-\mathrm{in}$.) level, there woukd be slighrly less than $20 \mathrm{~cm}$ ( $8 \mathrm{in}$.) of water shielding above the capsules, complicating recovery actions because of elevated radiation tields (sce Table 3-32). Once the $91 \mathrm{~cm}$ (36-in.) level is reached. further level drop would occur due to evaporation. Evaporative losses could be as high as $2.5 \mathrm{~cm} / \mathrm{h}$ (1 in $/$ h).

No mechanism for simultaneous failure of multiple drain lines has been identified. Barriers to this event are drain line piping integrity, level alarms, and timely human intervention to terminate the leak.

Mitigated Condition. The mitigated condition assumes that a rapid loss of pool cell water is mitigated by detection and water addition such that the capsule cooling function of the pool cell water is maintained at all times.

An emergency litl pipe is instalied through the north wall of WESF. This pipe has a standard fire hose connector such that a fire hose could be used to add water to the transfer aisle (Cell 12) without the necessity of opening the Pool Cell Area north door. This capability provides some additional benelit in the shielding afforded by the noth building wall and roof. However, the north door, located with in $0.3 \mathrm{~m}(\mathrm{l} \mathrm{ft})$ of the fire hose connector, provides minimal shielding from uncovered capsules. The gamma-ray dose rate at the focation of the fire hose connector could be in the range of $200-1,200$ $\mathrm{m} S \mathrm{v} / \mathrm{h}(20-120$ rem/h) (Hey 1999). depending on the water levet in the pool cell at the time the hose connection is made. 


\section{HNF-SD-WM-BIO-002 REV 1}

Major Assumptions. The following assumptions were made in the scenario development:

- In the case of liner failure, the concrete pool cell structure provides a containment bartier against water loss.

- Pool cells, other than the cell losing water. continute to function normally throughout the accident.

- A drain pipe failure in the pipe tunnel is assumed to be a break at the point where the pipe enters the wall.

- Transfer ports between the pool cells and the transfer aisle are only opened for predefined operations and emergency actions. They arekept closed at all other times.

\subsection{Thermal and Souree Term Analysis.}

Unmitigated Condition. Thermal and souree term analyses for hypothetical WESF Pool Cell Area pool drain accidents were performed (WIIC 1996b). Thermal analyses were performed in order to understand the transient temper:ature response of the capsules and surrounding structures. Used in conjunction with capsule and structural failure criteria, these analyses provide a basis for a conservative estimate of capsule failure and potential source term.

Thermal Analysis. Two cases were considered in the thermal and source term evaluation for draining a single pool cell. In the thermal analysis report (WHC 1996b) these are called Cases 3 and $t$. Case 3 represents an unmitgated sequence where no safety system operation or response is credited. Since none of the four initiators of liner corrosion. drop. pipe tailure, or operator crror would altect more than one pool cell, the remaining unallected pool cells are assumed to operate nonnally. This includes the continued operability of the ir heat exchangers. Which have ample capacity to carry the additional heat load of an adjacent uneooled storage pool. Case thoks at the same sequence but wilh Pool Cell Area ventilation llow of approximately $140 \mathrm{~m} / \mathrm{min}\left(5.000 \mathrm{ft}^{\mathrm{i}} \mathrm{mmin}\right)$ credited. The purpose of this latter cisse was to determine the benefit and potential mitigation that the HVAC systems would provide. Whether the HVAC svstem could survive this environment was outside the scope of the themal analysis report (WIIC 1996).

A detailed capsule atrity heatup model was developed. considering matural convection with in the drained pool and radiation to the surroundings, in order to lind the capsule average and peat kemperatures for a gis en anbiem gas lemperature. $A$ facility response model was also employed. considering circulation of gases with in Wr.St. exchange flows to the cnviroment, and heatup of structures. in order to provide the gas and structure temperature boundary conditions for the detailed capsule model.

The capsule storage contiguration assumed in this analysis consisted of 494 cesium capsules (i.e.. one $17 \times 13$ array and one $21 \times 13$ array) and 169 strontium capsules (i.c. one $13 \times 13$ array). Heat generated in the pool was assumed to be $110^{\circ} \%$ of what this configuration would generate if all capsules had an average thermal power as of 01/01/96. This corresponds to a thermal heat generation rate of $149 \mathrm{~kW}$. which includes the energy ol emitted ganma radiation. A simple statistical analysis (1)ey 1999) of the capsule thermal power distribution among all existing WESF mantfactured and uncut capsules as of January 1, 1996 showed this to be adequately conservative for the following reasons. The analysis showed that 494 of the highest power cesium chloride capsules could not exceed $110 \%$ of the average for the entire population of cesium capsules. For strontium capsules there was a $0.55 \%$ probability that the average power for a random sample of 169 capsules could exceed the $110 \%$ of the average power of the total population of 600 strontium capsules. Thus. the combination of the two indicates that the probability that this assumption would not be exceeded is greater than $99.5 \%$. As time passes and radioactive decay occurs, this assumption will become more conservative.

$\Lambda$ thermal power of $149 \mathrm{~kW}$ is also conservative for the following storage contigurations.

- The condition of having the four most westerly rows of the cesium rack also loaded with cesium capsules. The thermal analysis is conservative by a margin of $2 \%$. The release soure term results of the themal analysis report (WHC 1996b) should be increased by $10^{\circ}$ in to account for the larger number of cesium capsules. 


\section{HNF-SD-WM-BIO-002 REV 1}

- A pool loaded with 715 cesium capsules, the maximum number physically possible in the current rack design. The thermal analysis is conservative by a margin of $10^{\circ}$. The release source term results of the thermal analysis report (WHC 1996b) shoild be increased by $40 \%$ to account for the larger number of cesium capsules.

The thermal analysis bounds all conditions where $149 \mathrm{~kW}$ or less is generated in the storage poof. Storage of significantly more than 169 strontium capsules in a single pool has the potential to exceed this thermal limit.

Source 'Term Analysis. Two tailure mechanisms were considered for high temperature challenges to WH.SF capsutes: (1) failure due to stress caused by thermal expansion of the salt and (2) internal corrosion. The corrosion model used in the thermal analysis report (WHC 1996b) provides an extremely conservative failure criterion. Bryan (1989) states three reasons for this: (1) the data points were selected to show maximum corrosion, (2) the interface temperature decreases over time along with decreasing capsule decay heat, and (3) the corrosion rate should decrease over time as the concentration of reactints decreases (i.e., impurities are consumed during the corrosion process). Also, the capsule surtace temperature model takes into account ratial conduction, but not axial vatiations. and overstates the temperature at the weahest points in the inner and outer capsules (the top and bottoms).

As a further simplification to the source term analysis. it was noted from the capsule transient temperature response that 2 days were recuired for the maximum centerline cesium silt temperature to exceeded $700^{\circ} \mathrm{C}\left(1.292{ }^{\circ} \mathrm{F}\right)$. From the data presented in $\mathrm{Hey}(1999)$ and WHC (1996b), no significant releases would be expected in this short time frame. Aller 2 days. capsule failures could begin to occur due to stress rupture and later by corrosion. The rate of corrosion was modeled by way of an Arrhenius plot (Sasmor et al. 1988). Failure was assumed to occur if the corrosion could exceed the capsule wall thickness in less than 10 days. Wall thickness was minimized by taking into consideration the thinnest sections at the top and bottom of the capsules.

An evaluation of the thermal response of cesium chloride capsules (Hey 1999) indicates that an average $0.1 \mathrm{~kg}$ of salt would be released per failed capsule in order to relieve stress. Additional salt coukl escape due to the entrapped gals contained in the capsule annulus. In contrast, each capsule lailing due 10 corrosion is assumed to release its cntire contents of $2.9 \mathrm{~kg}$ salt. This is the average net weight of existing uncut cesium capsules. A complete release is assumed due to the uncertainty of capsule corrosion phenomena and the nature of the lailure. To simplify the source term analysis, all capsule lathes were treated as corrosion failures. This conservatively overstates the annount of cesium chloride released.

Results indicate that 42 cesium capsules could fail by corrosion and 9 by stress rupture for a rotal of 51 failed capsules. The maximum centerline temperatures of the cesium and strontium capsules were 740 and 1110 . C (1364 and 2030 $\left.{ }^{\circ} \mathrm{F}\right)$ respectively. Since the melting point of Sif: is $\left(1477^{\circ} \mathrm{C}\left|2691^{\circ} \mathrm{F}^{\circ}\right| \mathrm{N} A \mathrm{~S} \wedge 1993\right)$, no release of SrF, would be expected.

A steady-state temperature in the Pool Cell $A$ rea of $94^{\circ} \mathrm{C}\left(201^{\circ} \mathrm{F}\right)$ is attained in 5 to 10 days. Based on the evaluation documented in Appendix E of Hey(1999), no structural failures are expected as a result of this event. However, the unmitigated consequence estimate takes no credit for IIVAC or HIPA filter operation. Therefore. over a 28 day period a small release of $3.2 \times 10^{-7} \mathrm{~kg}$ cesium chloride salt to the enviromment is calculated to occur through leakage paths such as those present around doors and seismic wall and ceiling joints (Wagenblast, et al. 1999). Most of the salt released as vapor is collected in the adjacent pool cells that are water filled. If all of the sall released as vapor were to escape the building, then the release to the environment over the same period of time coukl be as high as $1.2 \times 10^{-3} \mathrm{~kg}$. The release rate is assumed to be constant, but the actual release rate and overall quantity would depend on the buikding leak rate, which is unknown and dependent on local meteorological conditions.

A source term was calculated for two scenarios associated with the draining of a single WESF pool cell. Results are ratioed in order 10 account for a worst case pool containing 715 cesium capsules. The lirst scenario takes no credit for the cooling or filtering of air in the Pool Cell Area. Small leakage atreas are modeled such that the building does not presstrize. This leakage area does not provide any significimt amount of cooling and neglects any natural building infiltration that might be caused by wind or other elements. The second scenario places an upper bound on the first scenario results by assuming all vaporized salt escapes into the environment. The results of this seenario place an absolute upper bound on the consequences. Fxpected consequences would be much lower because (1) deposition with in the building would occur and (2) infilltration would provide additional cooling, which would both reduce the number of lailed capsules and lower the cesium salt vapor pressure. Source terms for the three scenarios are summarized in Table 3-30. 
HNF-SD-WM-BIO-002 REV 1

Table 3-30. Single Pool Water Loss Event Sourec Terms.

\begin{tabular}{|c|c|c|c|c|}
\hline Scenario description & $\begin{array}{l}\text { Fstimated release } \\
\text { to environment } \\
\text { (WHC 1996b) (kg) }\end{array}$ & $\begin{array}{l}\text { Release period } \\
\text { (WHC 1996b) }\end{array}$ & $\begin{array}{c}\text { Ratio of } 715 \text { to } 494 \\
\text { cesium capsules }\end{array}$ & $\begin{array}{l}\text { Adjusted source } \\
\text { term }(\mathrm{kg} / \mathrm{h})\end{array}$ \\
\hline $\begin{array}{l}\text { No HVAC but minimal } \\
\text { buitding leakage (WHC } \\
\text { 1996b, Case 3) }\end{array}$ & $3.2[-07$ & 28 days & 1.4 & $6.7 \mathrm{E}-10$ \\
\hline $\begin{array}{l}\text { Absolute upper bound } \\
\text { consequence (WHC 1996b, } \\
\text { Case } 4 \text { stuck on filter) }\end{array}$ & $1.25-03$ & 13 days & 1.4 & 5.4 F- -06 \\
\hline
\end{tabular}

Post Accident Mitigation Concerns. Post accident mitigation concens are addressed in Section 3.4.3.3.

Mitigated Condition. No nitigated source term is calculated since capsule damage is prevented in the mitigated scenario.

Major Assumptions. The following assumplions were made in the preeding source term analysis.

- The pool cell inventory assumed in thermal analysis consisted ol $49+$ cesium capsules (i.e., one $17 \times 13$ array and one $21 \times 13$ array) and 169 strontium capsules (i.e.. one $13 \times 1.3$ array). This configuration provided a conservative estimate of the heat load in a pool cell.

- For the source term analysis, the poot cell inventory was assumed to be alt cesium capsules to bound the potential relealse.

- The thermal hear generated in the pool was assumed to be $149 \mathrm{~kW}$. This represents $110 \%$ of the heat that would be generated it the pool cell inventory noted above consisted ol average power capsules based on their decay power as of January I. 1996.

- Capsule failure by corrosion was assumed to occur if cortosion exceeded the minimum capsule wall thickness.

- No strontium was released since the maximum centerline temperature of the strontium capsules does not exceed the melting point of strontium fluoride.

- Cesium capsules failing due to corrosion or stress (from sall expansion) were assumed to release $2.9 \mathrm{~kg}$ of salt. This is the average net weight of existing uncut cesiun capsules.

- The unmitigated conseguence estimate takes no credit for IIVAC flow, cooling. or IIt.PA filtration.

- Small leakage areas are modeled such that the building does not pressurize for the unmitigated scenario.

- The release rate was assumed to be constant.

\subsection{Consequence Analysis.}

Unmitigated Condition. Three consecuences are considered in this section. The first is the dose to the public and onsite workers. The second is the dose field at locations where recovery actions miglat require personnel entry. The third is the potential adverse radiation environment and its impact on equipment. 


\section{HNF-SD-WM-BIO-002 REV 1}

Dose Consequence to the Public and Onsite Workers. Two dose pathways dominate the hazard to anyone within a few hunded meters of WESF during this event. The lirst and largest is the direct gamma-ray shine and backscalter from the WESF structure and atmosphere. This hazard would occur immediately on loss of shielding water. Analyses documented in Hey (1999) indicate that the dose rate due to the direcl gamma-ray shine at a receptor $100 \mathrm{~m}$ (328 fi) from the nearest WESF outside wall would be $20 \mathrm{mSv} / \mathrm{h}$ ( $2 \mathrm{rem} / \mathrm{h}$ ). Direct shine to the nearest public receptor would be insignificant in comparison to the potential inhalation dose.

The second dose pathway is through inhalation of airborne radioactive particulates. This hazard could begin to exist 2 days after an unmitigated pool dryout. In comparison to the direct shine it is a minor hazard to anyone located within a 100 m (328 it) of the lacility. For an offisite receptor it is the only significant dose pathway.

Dose consequences from the two pathways of direc shine and inhalation are considered. A plume submersion dose is not calculated since it is not significant in comparison to the inhalation dose. The worst case release is $5.4 \times 10^{\text {ti }} \mathrm{kg} / \mathrm{h}$. Since this scenario involves a continuous shine and, after 2 days, a contintous release of radioactive material, some assumption for duration of exposure must be made in order to calculate a total dose. A reasonable exposure duration of 8 hours for the onsite receptor and 24 hours for the public receptor is chosen (see Table $3-31$ ).

From a comparison of the two dose pathways, it is obvious that the direct shine is lar more hazardous to nearby workers than any inhalation hazard. The dose at the alternate site boundary described in Section 3.4.1.3 would be $3.1 \times 10^{-3}$ $\mathrm{mSv}\left(3.1 \times 10^{-4} \mathrm{rem}\right)$ and therefore, would not change the conclusion arrived at from this analysis.

Dose Field at Recovery Locations. Dose hield estimales (documented in Hey [1999] at various locations in and around WESF) that could hamper recovery activities are provided in Table 3-32.

Table 3-31. Unmitigated Single Pool Water Loss Event Consequence.

\begin{tabular}{|c|c|c|c|c|c|}
\hline Receptor & $\begin{array}{l}\text { Adjusted } \\
\text { source term } \\
(\mathrm{kg} / \mathrm{h})\end{array}$ & $\begin{array}{l}\text { Dose per unit } \\
\text { release } \\
\text { mSvikg } \\
\text { (remkg) }\end{array}$ & $\begin{array}{l}\text { Exposure } \\
\text { duration (h) }\end{array}$ & $\begin{array}{l}\text { Commilted dose } \\
\text { from inhalation } \\
\text { mSv (rem) }\end{array}$ & $\begin{array}{l}\text { Dose due to direct } \\
\text { gamma-ray shine } \\
\text { (rem) }\end{array}$ \\
\hline $\begin{array}{l}\text { Onsite 100-m } \\
\text { worker }\end{array}$ & salne & $\begin{array}{l}13,000 \\
(1.300)\end{array}$ & 8 & $\begin{array}{c}5.6[\mathrm{E}-01 \\
(5.6 \mathrm{E}-02)\end{array}$ & 16 \\
\hline Public & $5.4 E-06$ & $\begin{array}{c}18 \\
(1.8)\end{array}$ & 24 & $\begin{array}{c}2.3 E-03 \\
(2.3+-04)\end{array}$ & 0 \\
\hline $\begin{array}{l}\text { Altemate site } \\
\text { boundary }\end{array}$ & same & $\begin{array}{c}24 \\
(2.4)\end{array}$ & 24 & $\begin{array}{l}3.1 \mathrm{E}-03 \\
(3.11-04)\end{array}$ & 0 \\
\hline
\end{tabular}


HNF-SD-WM-BIO-002 REV 1

Table 3-32. Dose Fields Within and Near WESF (Pool Cell 7 with 715 Cesium Capsules or $31 \mathrm{MCi}^{137} \mathrm{Cs}$ )

\begin{tabular}{|c|c|c|c|}
\hline Condition & location & $\begin{array}{l}\text { Dose rate } \\
m \text { Svh }(\text { rem } h)\end{array}$ & Reference \\
\hline $\begin{array}{l}\text { Nominal water level of } 396 \mathrm{~cm} \\
\text { (156 in.) }\end{array}$ & $\begin{array}{l}5.5 \mathrm{~m}(18 \mathrm{ft}) \text { Ovel center of pool } \\
\text { coll floor }\end{array}$ & $\begin{array}{l}4.45-05 \\
(4.45,-06)\end{array}$ & \multirow[t]{3}{*}{$\begin{array}{l}\text { Hey(1999) } \wedge p p, B \\
\text { Microshicld }\end{array}$} \\
\hline $\begin{array}{l}\text { Water Level at } 279 \mathrm{~cm} \\
\text { (110 in.) }\end{array}$ & $\begin{array}{l}5.5 \mathrm{~m}(18 \mathrm{ft}) \mathrm{Over} \text { Center of Pool } \\
\text { Cell Floor }\end{array}$ & $\begin{array}{c}0.57 \\
(0.057)\end{array}$ & \\
\hline \multirow[t]{2}{*}{ Water Level at $163 \mathrm{~cm}(6+$ in. $)$} & $\begin{array}{l}5.5 \mathrm{~m} \text { ( } 18 \text { it) Over Center of Pool } \\
\text { Cell Floor }\end{array}$ & $\begin{array}{l}4.700 \\
(470)\end{array}$ & \\
\hline & Airloch Door & $\begin{array}{c}13 \\
(1.3)\end{array}$ & $\begin{array}{l}\operatorname{Hev}(1999) \text { App. B } \\
8 M 730-K E I 1-96-01\end{array}$ \\
\hline \multirow{3}{*}{$\begin{array}{l}\text { Water level at } 91 \mathrm{~cm} \text { (36 in.) } \\
\text { (i.e., at drain line penetration } \\
\text { level) }\end{array}$} & $\begin{array}{l}5.5 \mathrm{~m} \text { ( } 18 \text { li) Over Center of Pool } \\
\text { Cell Floor }\end{array}$ & $\begin{array}{l}490.000 \\
(49.000)\end{array}$ & \multirow[t]{3}{*}{$\begin{array}{l}\text { Hcy }(1999) \text { App. B } \\
8 M 730-\text { KEH-96-03 }\end{array}$} \\
\hline & Airtock Door & $\begin{array}{l}2,600 \\
(260)\end{array}$ & \\
\hline & Just Outside North Door & $\begin{array}{l}290 \\
(29)\end{array}$ & \\
\hline $\begin{array}{l}\text { Water level at } 74 \mathrm{~cm}(29 \mathrm{in} .) \\
\text { (i.e.. at top of capsules) }\end{array}$ & $\begin{array}{l}5.5 \mathrm{~m}(18 \text { tit) over Center of Pool } \\
\text { Ceil flor }\end{array}$ & $\begin{array}{l}830,000 \\
(83,000)\end{array}$ & $\begin{array}{l}\text { Hey }(1999) \text { App. B } \\
\text { Microshield }\end{array}$ \\
\hline \multirow[t]{8}{*}{ Dry pool } & $\begin{array}{l}5.5 \mathrm{~m}(18 \mathrm{ft}) \mathrm{Over} \text { Center of Pool } \\
\text { Cell rloor }\end{array}$ & $\begin{array}{r}620.000 \\
\{62.000(1) \\
\end{array}$ & \multirow[t]{3}{*}{$\begin{array}{l}11 \mathrm{ey}(1999) \text { Аpp. B } \\
8 \mathrm{M} 730-\mathrm{kEH}-96-03\end{array}$} \\
\hline & Airloch Door & $\begin{array}{l}10,000 \\
11,000) \\
\end{array}$ & \\
\hline & Just Outside North Door & $\begin{array}{l}1.200 \\
(120) \\
\end{array}$ & \\
\hline & $5 \mathrm{~m}(16 \mathrm{ft})$ from external wall & $\begin{array}{l}200 \\
(20)\end{array}$ & \multirow[t]{5}{*}{$\begin{array}{l}\text { Hes(1999) App. B } \\
\text { KEH-8D 150-94-01 } \\
\text { results divided by } 2^{\text {th }}\end{array}$} \\
\hline & $10 \mathrm{mi}(3 ; \mathrm{fi})$ tiom sxternal wall & $\begin{array}{l}200 \\
20)\end{array}$ & \\
\hline & $50 \mathrm{~m}$ ( $16+\mathrm{ft})$ fiom exlornal wall & $\begin{array}{l}50 \\
(5)\end{array}$ & \\
\hline & $\begin{array}{l}100 \text { in }(328 \mathrm{nt}) \text { fiom extemal } \\
\text { wall }\end{array}$ & $\begin{array}{l}20 \\
(2) \\
\end{array}$ & \\
\hline & $\begin{array}{l}200 \mathrm{~m}(656 \mathrm{ft}) \text { from external } \\
\text { wall }\end{array}$ & $\begin{array}{c}4 \\
(0.4)\end{array}$ & \\
\hline
\end{tabular}

"Microshicld (Negin and Worke 1092) calculations appear to be conservative by a factor of 2 compared to MCNP (Cartel 1996) calculations. This is caused by simplitied homogeneous treatment of capsule array materials.

thish calculation did not account for the self-shielding provided by the capsule array and may be conservative by a tactor of 51010. 


\section{HNF-SD-WM-BIO-002 REV 1}

Exposure Conseguence to Equipment. Plastic insulation is the most susceptible material in the Pool Cell Areat to radiation damage. A threshold of $5.0 \times 10^{\prime \prime}$ rad is given in the Reactor Handbouk (Blizzard 1962). There is nothing in the pool that could be harmed. and the dose rate of $1.200,000 \mathrm{mSv} / \mathrm{h}(120.000$ rem h) directly above a dry pool would indicate electrical insulation in direct view of the uncovered capsules (such as the catwalk motor) could survive for approximately 2 days. Components not in direct view of the capsules would be subject to backseatter doses off the ceiling. Doses from this scattered radiation would be a couple of orders of magnitude lower than the direct contribution. Condensation from water released from rapid pool cell evaporation'boiling could cause electrical components to fail.

Mitigated Condition. No consequences are analyzed for the mitigated scenario sine capsule damage is prevented by the controls discussed below.

\subsection{Comparison to Guidelines.}

Unmitigated Condition. Unmitigated dose consequences for the lirst 30 days of the event are far below the risk evaluation guidelines used for the public. On the other hand, onsite worker doses can culickly exceed the risk evaluation guidelines for safety signilicant $S \mathrm{SCS}$, even at $100 \mathrm{~m}$ (328 it). The scenario also has the potential for leading into the more severe consequences of a loss of water from all active pools. Safety class features and IOSR controls are required to prevent these more severe consequences.

Mitigated Condition. No comparison is made for the mitigated condition since there are no consequences.

\subsection{Summary of Safety SSCs and IOSR Controls.}

Controls are compiled in Section 3.4.2.7.1.5.

\subsection{Loss of Watter from All Pool Cells.}

\subsection{Scenario Development.}

This section analyzes aecidents that were identified in the hazards evaluation, Section 3.3.2.3, as resulting in a total loss of water in all pool cells. The potential cibuses analyzed here are loss of water in a single pool cell and catastrophic pool cell structural failure. Three initiators lor catastrophic pool cell structural failure are a BDBE. aircralt impact, and cxplosion in the facility.

Unmitigated Condition. The following paragraphs describe in detail the unmitigated scenarios leading to total loss of all pool cell water.

\section{Loss of Water in a Sirgle Poot Cell}

As discussed in Section 3.4.3.3.1, the rapid loss of water from a single pool çell creates fatal dose fields within the Pool Cell Area and a field of approximately $120 \mathrm{R} / \mathrm{h}$ immediately outside the 225-B structure. Dose fields in the Operating Gallery have not been calculated, but are presumed to prevent continued habitation. Currently there is no control which could be relied upon to terminate this event once capsules have been uncovered. Thus, facility control is effectively lost.

Continued progression of the event leads to gradual cvaporalive loss of water in the remaining pool cells and thermally induced failure of uncovered capsules. Fven though relatively little in the way of airborne releases would be expected from capsules intially tailed in the singte poot the loss of facility controt requires that this event be considered as an initiator to the more severe consecuences of loss of water from all pool cells.

Catastrophic Pool Cell Structural Failure. Seismic analysis of the 225-B Building was performed by Blume (197l) and reviewed by Wagenblast, et al. ( 1999$)$. This analysis provides the basis for qualification of the pool cell sructure to the 


\section{HNF-SD-WM-BIO-002 REV 1}

$0.25 \mathrm{~g}$ DBE. The calculations conservalively account for the increased loads due to hydrodynamic seismic forces (i.c.. sloshing) on the cell walls. No credit is taken for the rigidity that the cover blocks would afford. and removal of the cover blocks bas the effect of reducing seismic loads. Additionally, no credit is taken for the additional restraint from the attached foundation between the buildings housing the canyon and poof cells. The pool cell liners are not structural elentents and would not be subject to signilicant seismic stresses.

The 225-B Building is not qualified for seismic phenomena greater than that represented by the $0.25 \mathrm{~g}$ DBE. Furthermore, no analysis of the forces imposed on the pool cefls from at hydrogen explosion or aircraft impact have been pertormed. No attempt is made here to calculate the forces necessary to breach the conlinement boundary. The uncertainties associated with such analyses would likely result in extreme conservatism and a high likelihood that pool cell structural damage would be shown possible. For simplicity, it is assumed that such challenges could lead to a direct loss of pool cell water through failed structural components.

The frequency of an aircraft impact or facility explosion. without preventive controls. are thought to be very low but not incredible. Litiewise, a BDBE, by delintion, is a seismic event larger than the $0.25 \mathrm{~g}$ DBE. Mitigation could be hampered by facility structural damage. loss of confinement boundary. potential failure of support systems. spread of radioactive material, and competition for emergency resoures. Further discussion of the ramifications of a BDBE is provided in Section 3.4.3.2. Obviously. such events must be prevented or mitigated with a commensurate application of controls. The importance of these controls are made evident belou.

Mitigated Condition. In the mitigated condition, the controls discussed in section 3.4.2.7.1.5 prevent or mitigate a total loss of all pool cell water such that all active pool cells maintain sufficient cooling capability to prevent any capsule damage.

Major Assumptions. The following assumption was made in the scenario development: The total thermal output of all remaining uncut cesium and strontium calpsules as of 01.0196 is $403 \mathrm{~kW}$ ( Hey 1999).

\subsection{Thermal and Source Term Analysis.}

Unmitigated Condition. Thermal and source term analyses for a hypothetical WtSF pool drain accident were performed (W'HC 1996h). Thermal analyses were performed in order to understand the transien temperature response of the capsules and surrounding structures. Used in conjunction with capsule and structural failure criteria. these analyses provide a basis for a conservative estimate of capsule lailure and potential source term.

Themal Analysis. The thermal analy sis report (WHC 1996b) andyzed an unmitigated sequence where no salety system operation or response is credited.

A detailed capsule arraly heatup model was developed. considering latural convection within the drained pool and radiation to the surroundings, in order to find the capsule average and peak temperatures for a given ambient gas temperature. A facility response model was also employed. considering circulation of gases within WFSF. exchange flows to the cuviromment, and heatup of structures, in order to provide the gas and structure temperature boundary conditions for the detailed capsule model.

The capsule storage configuration assumed in this analysis consisted of 1.328 cesium capsules and 601 strontium capsutes. The tolal heat generation decayed to $01 / 01 / 96$ is $403 \mathrm{~kW}$. which includes the energy of emitted gamma adiation. These numbers represented all the uncut capsules manufactured at WESF. In 1998. the facility received seven Type W overpack capsules containing cesium powder and pellets from former WESF capsules which had been cut open. These seven lype $W$ overpack capsules result in an inconsequential increase in totat inventory and are bounded by the numbers assumed in the analyses.

Source Term Analysis. Two lailure nechanisms were considered for high temperature challenges to WESF capsules. these were failure due to stress caused by themal expansion of the salt or by internal corrosion. The corrosion model used in WHC (1996h) provides an extrencly conservative failure criterion. Bryan (1989) states three reasons for this: (1) the data points were selected to show maximum corrosion. (2) the interface temperature decreases over time along with decreasing 
capsule decay heat, and (3) the corrosion rate should decrease over time as the concentration of reactants decreases (i.e.. impurities are consumed during the corrosion process). Also. the capsule surface temperature model takes into account radial conduction. but not axial variations, and overstates the emperature at the weakest points in the inner and outer capsules (the top and bottom).

$\Lambda s$ a further simplification to the source term analysis. it was noted from the capsule transient temperature response that 2 days were required for the maximum centerline cesium salt temperature to excecded $700^{\circ} \mathrm{C}\left(1292^{\circ} \mathrm{F}\right)$. From the data presented in Hey (1999) and (WHC 19966), no significant releases would be expected in this short time frame. After 2 days. capsule failures could begin to occur due to stress rupture and later by corrosion. The rate of corrosion was modeled by way of an Arrhenius plot (Sasmor et al. 1988). Failure was assumed to occur if the corrosion conld exceed the capsule wall thickness in iess than 10 days. Wall thickness was minimized by taking into consideration the thinnest sections an the top and bottom of the capsules.

An evaluation of the thermal response of cesium chloride calpsules (lley 1999) indicates that an average $0.1 \mathrm{~kg}$ of salt would be released per tailed capsule in order to relieve stress. Additional salt could escape dee to the entrapped gas contained in the capsule annulus. In contrast. each capsule failing due to corrosion is assumed to release its entire contents of $2.9 \mathrm{~kg}$ salt. This is the average net weight of existing uncul cesium capsules. A complete release is assumed due to the uncertainty of capsule corrosion phenomena and the nature of the failure. To simplify the source term analysis, all eapsule failures were treated as corrosion failures. This conservatively overstates the amount of cesium chloride released.

Worst case results indicate that 1,162 cesium capsules could fail by a combination of corrosion and stress rupture. The maximum centerline temperatures of the cesium and strontium capsules were 1210 and $1565^{\circ} \mathrm{C}\left(2210\right.$ and $2849^{\circ} \mathrm{F}$ ) respectively. Since the melting point of strontium fluoride is $3477^{\circ} \mathrm{C}\left(2691^{\circ} \mathrm{F}\right)$ (NASA 1993 ), some failed strontum capsules could be expected.

On a mass basis. inhaled strontium salt is 5.6 times more madiologically hazardous than inhaled cesium salt. However, the liquid phase strontium fluoride is several orders of magnitude less dispersable than cesiun chloride. The hazards of failing WESF strontium capstles die to high temperature is discussed further below.

The release of strontium fluoride from failed capsules is not expected to contribute significantly to radionuclide releases. The melting point of strontium fluoride $\left(1477^{\circ} \mathrm{C}\left[2691^{\circ} \mathrm{F}\right]\right.$. [NASA 1993]) is much higher than the melting point of pure cesium chloride. which suggests that at a given temperature, the mass of volatile strontium fluoride will be far less than the mass of volatile cesium cliloride. The centerline temperature tor the maximum power strontium fluoride capsule exceeds the strontium fluoride melting point in Case 1 only. Since the tabulated temperature value is for the maximum strontium capsule power $(615 \mathrm{~W}$. as apposed to an average strontium capsule power of $25+\mathrm{W})$. lhe vast majority of strontium thuoride capsules will suffer little or no melting in Case I. Although some struntium fluoride melting could be expected in Case 1 . it is not significant when compared to the extent of cesium chloride melting.

Strontium tluoride vapor pressure data are limited, but Orme (1981) reports a vapor pressure of $8.5 \mathrm{~mm}$ mercury at $1822^{\circ} \mathrm{C}\left(3312^{\circ} \mathrm{F}\right)$. Considering that the reported boiling point of cesium chloride is about $1300^{\circ} \mathrm{C}\left(2372^{\circ} \mathrm{F}\right)$, the vapor pressure of strontium fluoride is clearly negligible in relation to cesium chloride. The release model, therefore, does not account for strontium fluoride.

The thermal analyses results in WHC (1996b) (assuming all pool cells drained and no IrVAC) show that the temperature throughout the interior of the pool cell building reaches $350^{\circ} \mathrm{C}\left(662{ }^{\circ} \mathrm{F}\right)$ in 5 days. In this event, it is estimated that the structure would not continue to provide confinement ( $\Lambda$ ppendix E. Hey 1999). Over a 25-day period. a release of 2.4 $\mathrm{kg}$ cesium chloride salt to the environment is calculated to occur through openings either pre-existing or caused by the thermal degradation of the structure.

A source term was calculated for four scenarios associated with the draining of all Wt:SF pool cells. The first scenario atakes no credit for filtration by the K-1 HEPA filters. The second, third, and fourth, scenarios present the results of a patametric study of the effect of building leakage areas to the environment. No credit is taken for any forced ventilation or filtration. A very small building leakage area will minimize the leah rate to the environnent but will increase the steady state temperature and salt vapor pressure. A very large building leakage area will increase the leak rate to the environment but also 


\section{HNF-SD-WM-BIO-002 REV 1}

increase the amount of natural convective cooling and lower the salt vapor pressure. The worst case evaluated was a moderate building leakage area equivalent to a $0.1 \mathrm{~m}^{2}\left(1 \mathrm{ft}^{2}\right)$ opening in both the roof and a side wall. Results for all four scenarios are provided Table $3-33$.

Table 3-33. All Pool Water Loss Event Source Terms. *

\begin{tabular}{|c|c|c|c|}
\hline Scenario description & $\begin{array}{c}\text { Fstimated release } \\
\text { to environment } \\
(\mathrm{kg})\end{array}$ & Release period & Source term $(\mathrm{kg} / \mathrm{h})$ \\
\hline $\begin{array}{l}\text { With } 140 \mathrm{~m} / \mathrm{min}(5,000 \mathrm{ft} / \mathrm{min}) \text { unfillered } \\
\text { IIVAC flow (WIIC 1996b. Case } 2 \text { stuck on filter) }\end{array}$ & $1.9 \mathrm{E}-(0) 2$ & 13 days & $6.1 \mathrm{E}-05$ \\
\hline $\begin{array}{l}\text { No HVAC but large building leakage (WHC } \\
\text { 1996b. Case I w/ I } \mathrm{m}^{2} \text { opening) }\end{array}$ & $2.4 E+00$ & 28 days & $3.6 \mathrm{E}-03$ \\
\hline $\begin{array}{l}\text { No HVAC but small building leakage (WHC } \\
\text { 1996b. Case } 1 \mathrm{w} / 0.02 \mathrm{~m}^{2} \text { opening) }\end{array}$ & $6.6 E+01$ & 28 days & $1.0 \mathrm{E}-01$ \\
\hline $\begin{array}{l}\text { No HVAC but moderate building leakage (WHC } \\
\text { 1996b. Case } 1 \mathrm{w} / 0.1 \mathrm{~m}^{2} \text { opening) }\end{array}$ & $1.1 E+02$ & 28 days & $1.6 \mathrm{E}-01$ \\
\hline
\end{tabular}

The source term used in the analysis is the worst-case value of $0.16 \mathrm{~kg}$. 1 .

\section{Post Accident Mitieation Concerns. Post accident mitigation concerns are addressed in Section 3.4.3.4.}

Mitieated Condition. No source term was analy zed for the miligated seenario since capsule danage is prevented by the controls discussed in Section 3.4.3.7.1.5.

Major $A$ ssumptions. The following assumptions were made in the preceding source term analysis.

- The worst case unmitigated scenario was a moderate building leakage area equivalent to a $0.1 \mathrm{~m}^{2}\left(1 \mathrm{ft}^{2}\right)$ opening in both the roof and a side wall.

- The capsule storage conliguration assumed in this analysis consisted of 1.328 cesiun capsules and 600 strontium capsules.

- The total hear generation decayed to January 1.1996 is $40.3 \mathrm{~kW}$.

- Capsule failure by corrosion was assumed to occur if corrosion exceeded the minimum capsule wall thickness.

- In comparison to the cesium chloride. negligible strontium fluoride would be relealsed.

- Cesium capsules failing due to corrosion or stress (from salt expansion) were alssumed to release $2.9 \mathrm{~kg}$ of salt. This is the average net weight of existing uncut cesium capsules.

- The unmitigated consequence estimate takes no credit for HVAC How, cooling, or HEPA hiltration.

- Simatl leakage areas are modeled such that the building does not pressurize for the unmitigated scenatio.

- The transter ports between the pool cells and the transfer aisle are normally closed except as part of a predelined operation or an emergency response action. 


\section{HNF-SD-WM-BIO-002 REV 1}

\subsection{Consequence Analysis.}

Unmitigated Condition. As in the loss of single pool consequence assessment, two dose pathways dominate the hazard to anyone within a few hundred meters of WESF during this event. The direct gamma-ray shine and backscatter from the WF SF structure and armosphere would occur immediately on loss of shielding water. Analyses documented in lley (1999) indicate that the dose rate due to the direct gamma-ray shine at a receptor $100 \mathrm{~m}$ ( $328 \mathrm{ft}$ ) from the nearest WESF outside wall would be $40 \mathrm{mSv} / \mathrm{h}(\mathrm{rem} / \mathrm{h})$. Direct shine to the nearest public receptor would be insignificant in comparison to the potential iwhalation dose.

An inhalation dose pathway could begin to exist 2 days after the loss ol water event. This pathway has the potential to overshadow the direct shine dose to all potential receptors, for an offsite receptor it is the only significant dose pathway.

Dose consequences fiom the two pathways of direct shine and inhalation are considered. A plume submersion dose is not calculated since it is not signilicant in comparison to the inhalation dose. From Table $3-33$, the worst case release is 0.16 $\mathrm{kg} / \mathrm{h}$. Since this scenario involves a continuous shine and. after 2 days. a continuous release of radioactive material. some assumption for duration of exposure must be made in order to calculate a total dose. A reasonable exposure duralion of 8 hours for the onsite receptor and 24 hours for the public receptor is used. This results in at total release of $1.3 \mathrm{~kg}$ to the onsite receptor and $3.8 \mathrm{~kg}$ to the oflsite receptor. The resulting conseguences are presented in Table $3-34$.

Table 3-34. Unmitigated All Pool Water Loss Event Consequence.

\begin{tabular}{|c|c|c|c|c|c|}
\hline Receptor & $\begin{array}{l}\text { Source term } \\
(\mathrm{kg} / \mathrm{h})\end{array}$ & $\begin{array}{l}\text { Dose per unit } \\
\text { release } \\
\text { mSytig } \\
(r e m k g)\end{array}$ & $\begin{array}{c}\text { Fxposure } \\
\text { duration (hrs) }\end{array}$ & $\begin{array}{l}\text { Committed dose } \\
\text { from inhalition } \\
m S v(r e m)\end{array}$ & $\begin{array}{c}\text { Dose due to direct } \\
\text { gamma-ray shine } \\
\text { (rem) }\end{array}$ \\
\hline $\begin{array}{l}\text { Onsite } 100 \mathrm{~m} \\
\text { worker }\end{array}$ & $1.65 .-01$ & $\begin{array}{l}13.000 \\
(1,300)\end{array}$ & 8 & $\begin{array}{c}1.7 \mathrm{E}+04 \\
(1.7[+03)\end{array}$ & 32 \\
\hline Public & same & $\begin{array}{c}18 \\
(1.8)\end{array}$ & 24 & $\begin{array}{c}69 \\
(6.9)\end{array}$ & 0 \\
\hline $\begin{array}{l}\text { Aftermate site } \\
\text { boundary }\end{array}$ & same & $\begin{array}{l}24 \\
(2.4)\end{array}$ & 24 & $\begin{array}{c}92 \\
(9.2)\end{array}$ & 0 \\
\hline
\end{tabular}

The dose at the alternate site boundary described in Section 3.4.1.3 would be $92 \mathrm{mSv}(9.2$ rem) and would not change any conclusion arrived at from this analysis.

Dose Field at Recovery Locations. The dose lield estimates at various locations in and around WESF that could hamper recovery activities are shown in Table 3-35 (1 tey 1999).

Exposure Conseguence to Equipment. The exposure conseguence to equipment would not be significantly different than that analyzed for a single pool loss of water event.

Mitigated Condition. The mitigated scenario has no consequences since capsule damage is prevented by the controls in Section 3.4.2.7.1.5. 
HNF-SD-WM-BIO-002 REV 1

Table 3-35. Dose Fields Within and Near WESF (All Pools Drained $55 \mathrm{NCi}^{137} \mathrm{Cs}$ ).

\begin{tabular}{|c|c|c|c|}
\hline Condition & Location & $\begin{array}{c}\text { Dose rate mSvh } \\
\quad(\text { rem } h)\end{array}$ & Reference \\
\hline \multirow[t]{8}{*}{ Dry pool } & $\begin{array}{l}5.5 \mathrm{~m} \text { (18 fit) over center of pool } \\
\text { cell floor }\end{array}$ & $\begin{array}{l}620.000) \\
(62.000)\end{array}$ & $\begin{array}{l}\text { Hey(1999) App. B 8M730- } \\
\text { KEH-96-03 }\end{array}$ \\
\hline & Airlock door & $\begin{array}{l}50,000 \\
(5,000)\end{array}$ & \multirow[t]{7}{*}{$\begin{array}{l}\text { Hey (1999) App. B KEH- } \\
\text { 8D150-94-01 }\end{array}$} \\
\hline & Just outside north door & $\begin{array}{r}17.000 \\
(1.700)\end{array}$ & \\
\hline & $5 \mathrm{~m}(16$ lt) from external wall & $\begin{array}{l}400 \\
(40)\end{array}$ & \\
\hline & $10 \mathrm{~m}$ (33 li) from external wall & $\begin{array}{l}400 \\
(40)\end{array}$ & \\
\hline & $50 \mathrm{~m}$ (164 hi) from external wall & $\begin{array}{l}100 \\
(10)\end{array}$ & \\
\hline & $100 \mathrm{~m}$ (328 ft) from external wall & $\begin{array}{l}40 \\
(4)\end{array}$ & \\
\hline & $200 \mathrm{~m}(656 \mathrm{ft})$ lrom extemal wall & $\begin{array}{r}7 \\
(0.7)\end{array}$ & \\
\hline
\end{tabular}

(a) This calculation did not account for the self-shielding provided by the capsule array and appears conservative by a lactor of 51010.

\subsection{Comparison to Guidelines.}

Unmitigated Condition. From the consequences estimated above, it is cleall that both onsite and offsite rish evaluation guidelines could be exceeded if water from all pool cells were lost. A more conservative calculation or longer exposure durations would not change this conclusion. The confinement boundary is not qualified to withstand the cnvironmental conditions this event causes. Therefore, mitigation ol consequences once the capsules are uncovered is not an option and the event must be prevented. Safety class SSCS and IOSR controls are necessary to prevent the loss of water cover over the capsules.

Mitigated Condition. No comparison is made since there are no conseguences.

\subsection{Summary of Safety SSCs and IOSR Controls.}

Controls are compiled in Section 3.4.2.7.1.5.

\subsubsection{Post Loss of Pool Cell Water Accident Concerns.}

The question of whether or not to add water to a pool after capsules have been uncovered for a period of time was also addressed in the thermal analysis report (WHC 1996b). The particular concerns addressed were: (1) the potential for 


\section{HNF-SD-WM-BIO-002 REV 1}

thermal stresses causing new capsule failures, (2) molten salt-water interactions potentially damaging capsules or the pool, or increasing the source term by mechanical aerosol generation, (3) water reacting with cesium chloride to create new trace species that exacerbate the source term, and (4) contaminated water leakage through failed confinement boundaries. Items 2 , 3 , and 4 are relevant only if capsule failures have occurred, but Item 1 is relevant anytime a pool cell is drained.

The WESF capsule thermal shock tests (Kenna 1982) can be compared to the calculated surface temperatures provided in the thermal analysis report (WHC 1996b). To meet ANSI N542 Class 6 requirements, a test capsule was heated to $800^{\circ} \mathrm{C}\left(1472^{\circ} \mathrm{F}\right)$ and rapidly cooled to $20^{\circ} \mathrm{C}\left(68^{\circ} \mathrm{F}\right)$, ten times. The test capsule maintained its integrity and exceeded the ANSI N542 Class 6 requirement (one thermal shock of $800^{\circ} \mathrm{C}$ to $20^{\circ} \mathrm{C}\left[1472{ }^{\circ} \mathrm{F}\right.$ to $\left.68^{\circ} \mathrm{F}\right]$ ). This thermal shock loading appears to bound the conditions evaluated here since none of the capsule surface temperatures ever approach $800^{\circ} \mathrm{C}$ $\left(1472^{\circ} \circ \mathrm{F}\right)$.

In summary, the rack average temperatures show that capsule failure due to the thermal shock of water addition should not be a concern. The thermal shock used in WESF capsule test conditions described above greatly exceeds the thermal shock that water addition into a drained pool cell might create. The conclusion from this evaluation is that; although a few capsules may suffer further degradation from the addition of water, the majority of capsules will benefit from the cooling and avert failure.

Molten salt-water interactions present new concerns such as vapor explosions. This issue is relevant only after capsule failure. It is not relevant if accident management actions take place with a day or so after pool cell drainage. Rack average temperature plots presented in the thermal analysis report (WHC 1996b) show that during the first few days after drainage, capsule surface temperatures will not be high enough to cause failures.

Vapor explosions generate vapor at a rate faster than the surrounding medium can accommodate acoustically or inertially. Experiments have demonstrated that vapor explosions (steam explosions in this instance) can occur if a cold fluid is poured into hot fluid, or vice versa. Hohmann (1979 and 1982) observed steam explosions when water was poured on an $8 \mathrm{~cm}$ deep layer of molten thermite. The many steam explosion observations in the literature suggest that pouring water onto molten cesium chloride presents similar concerns. A steam explosion on the pool cell floor could potentially damage the intact capsules or the pool cell liner, and disperse cesium chloride into airborne particles.

For Cases 3 and 4, the rack average temperature and temperature of the salt on the floor are well below the melting point of cesium chloride. Even if the effect of impurities lowering the cesium chloride melting point is taken into account, the salt on the floor has little likelihood of thoroughly mixing with incoming water.

Steam and cesium chloride can react to form cesium hydroxide and hydrochloric acid:

$$
\mathrm{CsCl}+\mathrm{H}_{2} \mathrm{O}-\mathrm{CsOH}+\mathrm{HCl}
$$

Hydrochloric acid is extremely corrosive and dangerous, but it is not a radiological concern. Only prolonged exposure to hydrochloric acid would have any significant deleterious effects on the SSCs in the pool cell area. Cesium hydroxide is much more volatile than cesium chloride and creates a new source term concern.

In summary, quenching cesium chloride debris might produce cesium hydroxide and hydrochloric acid, both of which exacerbate the accident. Heat transfer calculations in the thermal analysis report (WHC 1996b) show, however, that the production would be transitory. Potential cesium hydroxide and hydrochloric acid production should not deter accident management schemes to quench cesium chloride debris as long as a sufficient water supply is available. The only stipulation is that adding small amounts of water without ever quenching the salt could cause sustained cesium hydroxide generation. Accident management schemes can avoid this situation by verifying sufficient flow rates into the pool cell(s)

Leakage from a failed pool cell can transport cesium chloride from WESF to the soil. Cesium chloride is three times more soluble than table salt and water leaking from the failed cell can take cesium chloride along with it. Accident management schemes must weigh the relative benefits of preventing airborne releases against the drawbacks of contaminating the underlying soil. This issue is not considered here in further detail, but is the sole concern that would prevent water addition after capsule failures. 


\section{HNF-SD-WM-BIO-002 REV 1}

This page intentionally left blank. 


\subsection{SAFETY STRUCTURES, SYSTEMS, AND COMPONENTS}

The purpose of this chapter is to provide details on the Waste Encapsulation Storage Facility (WESF) structures, systems, and components (SSCs) that are necessary to satisfy the evaluation guidelines, provide defense-in-depth, or contribute to worker safety or facility control as identified in Chapter 3.0 "Hazard and Accident Analyses."

\subsection{INTRODUCTION}

The WESF facility has been designated a Hazard Category 2 nuclear facility, and may be expected to have the potential for an accident resulting in significant onsite consequences and may also have offsite consequences. Hazard Category 2 facilities usually have associated safety-significant designated SSCs to provide protection to the $100-\mathrm{m}$ (328-ft) onsite individual and as appropriate, safety-class designated SSCs to provide protection to the offsite public. Generally, safety-class SSCs require more formality in establishing functional requirements and performance criteria than safety-significant SSCs due to their public protection function.

During the hazards and accident analysis process documented in Chapter 3.0, each accident section concludes with a summary of safety SSCs and an Interim Operational Safety Report (IOSR) Controls subsection. These subsections provide the basis for this chapter. A summary of the accident analysis results, including the designated safety-class and safety-significant SSCs, is exhibited in Table 3-1.

Safety class and safety significant SSCs are defined in this section. Safety-class SSCs prevent or mitigate releases to the public that would otherwise exceed the offsite radiological evaluation guidelines, or prevent accidental nuclear criticality. Safety-signilicant SSCS prevent or mitigate releases of radiological materials to onsite workers and toxic chemicals to the offsite public and onsite workers. This includes barriers that are judged to substantially contribute to defense-in-depth independent of quantitative analysis. Safety signiticant also describes worker sately SSCS that protect the facility worker from serious injury due to hazards not controlled by institutional safety programs. The criteria for assigning a safety class and safery signiticant SSC's is contained in HNF-PRO-7()4. 19991.

The safety-class and safety-significant SSCs identified are compiled in the facility safety equipment list (SEL) [Covey

\subsection{REQUIREMENTS}

This section identifies the design codes, standards, regulations, and DOE Orders that are required specifically for this chapter to establish the safety basis of WESF.

Hanford Plant Standards SDC 4.1, Rev. 12 (1993)

DOE Order $5480.7 \mathrm{~A}$

DOE Order 6430.1A

National Fire Protection Association (1991)

Uniform Building Code (1991)

\subsection{SAFETY SYSTEMS, STRUCTURES, AND COMPONENTS}

The following is addressed in this chapter for each safety-class or safety-significant designated SSC identified in Chapter 3.0 to prevent or mitigate a hazard or accident:

- Identification of the safety SSC and related accident 


\section{HNF-SD-WM-BIO-002 REV 0}

- Description of the safety SSC safety function

- Description of the safety SSC and how it performs its safety function

- Identification of the functional requirements necessary for the safety SSC to perform its safety function

- Identification of the performance criteria necessary to provide reasonable assurance that the functional requirements will be met

- Identification of assumptions needing IOSR coverage.

The WESF safety-class and safety-significant SSCs discussions are assembled in this chapter in the following manner with reference to the Chapter 3.0 accident-specific section in parentheses:

4.3.1 WESF Structures and Systems

(3.4.2.1.2 Design Basis Earthquake)

(3.4.2.6.2 Underwater Capsule Failures Due to Drop Impacts)

(3.4.2.7 Loss of Pool Cell Water)

4.3.2 K-3 HEPA Filter System

(3.4.2.3.1 Hot Cell Fire - A Cell)

(3.4.2.3.1 Hot Cell Fire - B through E Cells)

(3.4.2.4.1 High Flow in K-3 Ventilation System)

4.3.3 Pool Cell Area ARMs

(3.4.2.6.1 Underwater Capsule Failure Due to Corrosion)

4.3.4 Pool Cell Water Loss Detection System

(3.4.2.7 Loss of Pool Cell Water)

4.3.5 Pool Cell Emergency Makeup Water System

(3.4.2.7 Loss of Pool Cell Water)

The safety-class and safety-significant SSCs for the accidents will be addressed in the order of the analyses in Chapter 3.0 for ease of identification. A list of the combined safety-class and safety-significant SSCs and a summary of the above information is shown in Table 4-1.

\subsubsection{WESF Structures and Systems}

Section 3.4.2.1.2 "Design Basis Earthquake," identifies the Area 3 structure; pool cell bridge crane, catwalk, and associated support structures; and the pool cell drain and circulation piping as safety-class SSCs. Section 3.4.2.1.2, also identifies the K-3 filter pit structure, the 296-B stack, and the Area 2 structure as safety-significant SSCs. Section 3.4.2.6.2 "Underwater Capsule Failures Due to Drop Impacts," identifies the pool cell bridge crane, catwalk, and associated support structures as a safety-class SSC. Section 3.4.2.7 "Loss of Pool Cell Water," identifies the Area 3 Structure as a safety-class SSC. 
Table 4-1. Safety Class and Safety Significant Systems, Structures, and Components Summary List

\begin{tabular}{|c|c|c|c|c|c|c|}
\hline \multirow{2}{*}{$\begin{array}{l}\text { Accident } \\
\text { (Chapter } 3.0 \\
\text { Section) }\end{array}$} & \multicolumn{3}{|c|}{$\begin{array}{c}\text { Safety Structures, Systems, \& } \\
\text { Components }\end{array}$} & \multirow[t]{2}{*}{ Safety Function } & \multirow[t]{2}{*}{ Functional Requirements } & \multirow[t]{2}{*}{ Related IOSR Controls } \\
\hline & Description & SC & SS & & & \\
\hline \multicolumn{7}{|c|}{ NATURAL PHENOMENA (3.4.2.i) } \\
\hline \multirow[t]{6}{*}{$\begin{array}{l}\text { Design Basis } \\
\text { Earthquake } \\
(3.4 .2 .1 .2)\end{array}$} & Area 3 Structure & $\mathrm{x}$ & & \multirow[t]{6}{*}{$\begin{array}{l}\text { Retain structural integrity } \\
\text { for a seismic event having } \\
\text { a peak horizontal ground } \\
\text { acceleration of } 2.5 \mathrm{~m} / \mathrm{s}^{2} \\
\text { (0.25 gravity) to provide } \\
\text { confinement for water- } \\
\text { stored }{ }^{137} \mathrm{Cs} \text { and }{ }^{90} \mathrm{Sr} \\
\text { capsules and/or } \\
\text { contamination }\end{array}$} & \multirow[t]{6}{*}{$\begin{array}{l}\text {-To meet original WESF DBE } \\
\text { criteria: } \\
\text {-Peak ground acceleration of } 2.5 \\
\mathrm{~m} / \mathrm{s}^{2} \text { (0.25 gravity) } \\
\text {-Damping up to } 5 \%\end{array}$} & \multirow[t]{6}{*}{$\begin{array}{l}\text { IOSR design features (see section } \\
5.6)\end{array}$} \\
\hline & $\begin{array}{l}\text { Pool Cell Bridge } \\
\text { Crane, Catwalk, and } \\
\text { Associated Support } \\
\text { Structures }\end{array}$ & $\mathbf{X}$ & & & & \\
\hline & $\begin{array}{l}\text { Pool Cell Drain and } \\
\text { Circulation Piping }\end{array}$ & $X$ & & & & \\
\hline & $\begin{array}{l}\text { K-3 Filter Pit } \\
\text { Structure }\end{array}$ & $x$ & & & & \\
\hline & 296-B Stack & $x$ & & & & \\
\hline & Area 2 Structure & $\mathrm{X}$ & & & & \\
\hline \multirow{2}{*}{\multicolumn{7}{|c|}{$\begin{array}{l}\text { EXTERNAL EVENTS }(3.4 .2 .2)- \\
\text { No safety-class or safety-sígnificant SSCs required }\end{array}$}} \\
\hline & & & & & & \\
\hline \multicolumn{7}{|c|}{ FACILITY FIRES (3.4.2.3) } \\
\hline $\begin{array}{l}\text { Hot Cell Fire - } \\
\text { A Cell } \\
(3.4 .2 .3 .1)\end{array}$ & K-3 HEPA Filters & & $X$ & $\begin{array}{l}\text { To retain structural } \\
\text { integrity after the } \\
\text { plugging of the HEPA by } \\
\text { smoke and debris to } \\
\text { provide a passive barrier } \\
\text { (confinement) to the } \\
\text { unrestricted release of } \\
\text { radioactive material } \\
\text { resulting from a fire in the } \\
\text { hot cell(s) }\end{array}$ & $\begin{array}{l}\text { Retain structural integrity under the } \\
\text { environmental conditions of a } \\
400^{\circ} \mathrm{C}\left(752^{\circ} \mathrm{F}\right) \text { hot cell fire }\end{array}$ & $\begin{array}{l}\text { - The K-3 HEPA filter system will } \\
\text { remain intact when subjected to a hot } \\
\text { cell fire } \\
\text { - Testing of the K-3 HEPA filter is } \\
\text { current }\end{array}$ \\
\hline $\begin{array}{l}\text { Hot Cell Fire - B- } \\
\text { E Cells } \\
(3.4 .2 .3 .1)\end{array}$ & K-3 HEPA Filters & $\mathrm{X}$ & & $\begin{array}{l}\text { See Hot Cell Fire - A } \\
\text { Cell, in this Table }\end{array}$ & $\begin{array}{l}\text { See Hot Cell Fire - A Cell, in this } \\
\text { Table }\end{array}$ & $\begin{array}{l}\text { See Hot Cell Fire - A Cell, in this } \\
\text { Table }\end{array}$ \\
\hline \multicolumn{7}{|c|}{ LOSS OF CONFINEMENT (3.4.2.4) } \\
\hline $\begin{array}{l}\text { High Flow in K-3 } \\
\text { Ventilation } \\
\text { System } \\
(3.4 .2 .4 .1)\end{array}$ & K-3 HEPA Filters & $\mathrm{X}$ & & $\begin{array}{l}\text { To provide a combined } \\
\text { filter efficiency of } 99.9 \% \\
\text { to prevent or mitigate the } \\
\text { release of radioactive } \\
\text { material. }\end{array}$ & $\begin{array}{l}\text { Remove at least } 99.9 \text { percent of } 0.3 \\
\mu m(11.8 \mu \mathrm{in} .) \text { particles of an } \\
\text { approved test aerosol }\end{array}$ & $\begin{array}{l}\text { - The K-3 HEPA filters are in place } \\
\text { - Testing of the K-3 HEPA filter } \\
\text { system is current. } \\
\text { - Minimum } 99.9 \% \text { efficient. }\end{array}$ \\
\hline
\end{tabular}


HNF-SD-WM-BIO-002 REV 0

\begin{tabular}{|c|c|c|c|c|c|c|}
\hline \multirow{2}{*}{$\begin{array}{l}\text { Accident } \\
\text { (Chapter } 3.0 \\
\text { Section) }\end{array}$} & \multicolumn{3}{|c|}{$\begin{array}{l}\text { Safety Structures, Systems, \& } \\
\text { Components }\end{array}$} & \multirow[t]{2}{*}{ Safety Function } & \multirow[t]{2}{*}{ Functional Requirements } & \multirow[t]{2}{*}{ Rilatid IOSR Controls } \\
\hline & Description & $\mathrm{SC}$ & SS & & & \\
\hline \multicolumn{7}{|c|}{$\begin{array}{l}\text { HYDROGEN EXPLOSION IN THE POOL CELL AREA (3.4.2.5) - } \\
\text { No safety-class or safety-significant SSCs required }\end{array}$} \\
\hline \multicolumn{7}{|c|}{ LOSS OF CONTAINMENT $(3.4 .2 .6)$} \\
\hline $\begin{array}{l}\text { Underwater } \\
\text { Capsule Failure } \\
\text { Due to Corrosion } \\
(3.4 .2 .6 .1)\end{array}$ & $\begin{array}{l}\text { Pool Cell Area } \\
\text { ARMs }\end{array}$ & & $\mathrm{x}$ & $\begin{array}{l}\text { To alarm the presence of } \\
\text { elevated radiation levels } \\
\text { in the Pool Cell Area and } \\
\text { evacuate facility } \\
\text { personnel from the Pool } \\
\text { Cel! Area }\end{array}$ & $\begin{array}{l}\text { - At a minimum, two ARMs must } \\
\text { be operable } \\
\text { - Provide an audible and visual } \\
\text { alarm both locally and remotely } \\
\text { upon detection of radiation in the } \\
\text { Pool Cell Area exceeding a preset } \\
\text { level }\end{array}$ & $\begin{array}{l}\text { - At a minimum two ARMs are } \\
\text { operable } \\
\text { - Testing of the Pool Cell Area } \\
\text { ARMs is current } \\
\text { - Alamm will result upon system loss } \\
\text { of power }\end{array}$ \\
\hline \multicolumn{7}{|c|}{ LOSS OF POOL CELL WATER (3.4.2.7) } \\
\hline $\begin{array}{l}\text { Loss of Water } \\
\text { From All Pool } \\
\text { Cells } \\
(3.4 .2 .7 .2)\end{array}$ & $\begin{array}{l}\text { Rapid Water Loss } \\
\text { Detection System } \\
\text { (level } \\
\text { instrumentation and } \\
\text { ARMs) }\end{array}$ & $\mathrm{X}$ & & $\begin{array}{l}\text { To detect the rapid loss of } \\
\text { water from the pool cells } \\
\text { and alarm the condition to } \\
\text { initiate a response to } \\
\text { prevent total loss of pool } \\
\text { cell water }\end{array}$ & $\begin{array}{l}\text { - Have an operable level } \\
\text { monitoring system for Pool Cells } 1 \text { - } \\
8 \text { and } 12 \\
\text { - Provide an audible and visual } \\
\text { alarm for the level monitoring } \\
\text { system upon detection of water } \\
\text { loss exceeding a preset level } \\
\text { - At a minimum, one operable } \\
\text { ARM } \\
\text { - Provide an audible and visual } \\
\text { alarm both locally and remotely for } \\
\text { the ARM upon detection of } \\
\text { radiation in the Pool Cell Area } \\
\text { exceeding a preset level }\end{array}$ & $\begin{array}{l}\text { - The pool cell water loss detection } \\
\text { system is operable } \\
\text { - Testing of the pool cell water loss } \\
\text { detection system is current and in } \\
\text { accordance with IOSR requirements } \\
\text { - Alarms will result upon loss of } \\
\text { power or compressed air to the } \\
\text { system }\end{array}$ \\
\hline & $\begin{array}{l}\text { Pool Cell } \\
\text { Emergency Makeup } \\
\text { Water I:ill Pipce }\end{array}$ & $\mathrm{x}$ & & $\begin{array}{l}\text { To provide an } \\
\text { unobstructed path for } \\
\text { water delivery to the pool } \\
\text { cells to prevent total loss } \\
\text { of Pool Cell water }\end{array}$ & $\begin{array}{l}\text { - Provide an unobstructed path for } \\
\text { water to Pool Cell } 12 \\
\text { - Be able to connect with a standard } \\
\text { fire hose }\end{array}$ & $\begin{array}{l}\text { - Two independent sources of } \\
\text { emergency makeup water are } \\
\text { available } \\
\text { - Transfer ports and air vents into } \\
\text { Pool Cell } 12 \text { from Pool Cells } 9,10 \text {, } \\
\text { and } 11 \text { are closed } \\
\text { - Water addition occurs at a } \\
\text { minimum flow rate of } 570 \mathrm{~L} / \mathrm{min} \\
\text { (150 gal/min) } \\
\text { - The capacity of the emergency } \\
\text { makeup water supply is a minimum } \\
\text { of } 310,000 \mathrm{~L}(83,000 \text { gal) } \\
\text { - Air vents into Pool cell } 12 \text { from } \\
\text { ative ponl cells shatl remain (spen }\end{array}$ \\
\hline & Area 3 Structure & $\mathrm{X}$ & & $\begin{array}{l}\text { See Design Basis } \\
\text { Earthquake in this Table }\end{array}$ & $\begin{array}{l}\text { See Design Basis Earthquake in } \\
\text { this Table }\end{array}$ & $\begin{array}{l}\text { See Design Basis Earthquake in this } \\
\text { Table }\end{array}$ \\
\hline
\end{tabular}

SC $=$ Safety Class

SS $=$ Safety Significant

HEPA $=$ High Efficiency Air Particulate

DBE = Design Basis Earthquake

OBE $=$ Operating Basis Earthquake

IOSR = Interim Operational Safety Requirement 


\section{HNF-SD-WM-BIO-002 REV 0}

It is noted here that the Area 2 structure performs a safety-significant function in response to natural phenomena hazards (Section 3.4.2.1.2), but is qualified and will be declared a safety-class SSC, not because of prevention or mitigation of offsite dose consequences, but for the following reasons:

- With the exception of vulnerability to B Plant endwall collapse, the Area 2 structure is qualified for safety class seismic loads (Wagenblast, et al., 1999). Collapse of the B Plant endwall will not result in offsite consequences.

- Future WESF design or mission changes may require the Area 2 structure to be designated as safety class.

- The Area 2 safety-class structure provides an important confinement function with respect to facility workers.

- Maintaining the Area 2 structure safety class provides defense-in-depth.

The K-3 filter pit structure and 296-B-10 stack also perform a safety-significant function in response to natural phenomena hazards (Section 3.4.2.1.2), but are qualified and will be declared a safety-class SSC, not because of prevention or mitigation of offsite dose consequences, but for the following reasons:

- Future WESF design or mission changes may require the K-3 filter pit structure or stack to be designated as safety class.

- The K-3 filter pit structure provides an important confinement function with respect to facility workers.

- Maintaining the K-3 filter pit structure and 296-B-10 stack safety class provides defense-in-depth.

\subsubsection{Safety Function.}

The safety function of the safety class Area 3 structure, the safety class pool cell bridge crane, catwalk, and associated support structures, the safety class pool cell drain and circulation piping, the safety class K-3 filter pit structure, and the safety class Area 2 structure is:

- To retain structural integrity for a WESF design basis earthquake (DBE) having a peak horizontal ground acceleration of $2.5 \mathrm{~m} / \mathrm{s}^{2}(0.25$ gravity $)$ to provide confinement for water-stored ${ }^{137} \mathrm{Cs}$ and ${ }^{90} \mathrm{Sr}$ capsules and/or contamination to prevent dose consequences in excess of the offsite evaluation guidelines.

(Section 3.4.2.1.2 "Design Basis Earthquake")

(Section 3.4.2.6.2 "Underwater Capsule Failures Due to Drop Impacts")

(Section 3.4.2.7 "Loss of Pool Cell Water")

\subsubsection{Safety Description}

Area 3 Structure: The Area 3 is a two-story structure. The first story pool cells are below grade. The reinforced concrete roof and pool cell floor slab at grade are supported by reinforced concrete shear walls. The foundation consists of a reinforced concrete mat on undisturbed soil at approximately $4.9 \mathrm{~m}(16 \mathrm{ft})$ below grade and soil retaining shear walls. The concrete foundation for the pool cells is $0.53 \mathrm{~m}$ ( $21 \mathrm{in}$.) thick; for the pipe trench, $0.46 \mathrm{~m}$ ( $18 \mathrm{in}$.) thick; and for the transfer aisle is 0.89 $\mathrm{m}$ (35 in.) thick. The Area 2 and Area 3 foundations are continuous and structurally connected at all common edges below grade. The Area 3 above grade shear walls and roof are separated from Area 2 by a $5.1-\mathrm{cm}(2-\mathrm{in}$.) (seismic) joint. Thus, the Area 3 above grade structure is independent of the adjacent structures for resisting lateral seismic and wind loads and vertical gravity loads including dead, live, snow, and ashfall. The Area 3 below grade structure (Pool Cell Area) is structurally connected to the Area 2 foundation. This will enhance the lateral load capacity for resisting earthquake motions. The Area 3 Structure has been designed to survive the $2.5 \mathrm{~m} / \mathrm{s}^{2}$ (0.25 gravity) WESF DBE. (Wagenblast, et al., 1999)

Pool Cell Bridge Crane, Catwalk, and Associated Supports: In Area 3, a $9.1 \mathrm{t}(10 \mathrm{t})$ overhead crane is located above the pool cells. The electric powered catwalk on rails, also in Area 3 at the deck level, spans the pool cells. The fundamental 
components for the crane are the crane bridge, trolley, hoist, rail girders, and the lifted load. These components are configured and equipped with devices to prevent unrestrained movements of the cranes and derailing if strong seismic motions occur. The crane is original WESF construction and seismic design efforts were conducted for the crane support systems. These systems were evaluated, and additional confirming seismic analyses for the crane supports are provided in a recent evaluation (Wagenblast, et al., 1999). Design analyses were conducted for the rail girders and their anchored supports. These design analyses presumed a 13.6 metric $t(15 \mathrm{t})$ capacity Area 3 pool cell crane. Horizontal and vertical impact loads based on the UBC (1991) seismic provisions were included for seismic design. The lifted load was considered to contribute to the horizontal loads. The investigating engineers conducted additional seismic analyses that confirm that the 9.1 metric $t(10 t)$ crane support system is adequate for the DBE forces. Seismic experts conclude that the pool cell bridge crane and support systems will survive the $2.5 \mathrm{~m} / \mathrm{s}^{2}(0.25$ gravity) WESF DBE. (Wagenblast, et al., 1999)

The catwalk, designed and constructed in 1994, is a bridge-crane-like structure designed for a live load of $36.6 \mathrm{~g} / \mathrm{cm}^{2}$ $\left(75 \mathrm{lb} / \mathrm{ft}^{2}\right)$. The catwalk is stable due to having a low center of gravity and a wide wheel base. The catwalk drive gears restrain movement and the wheels are flanged to prevent derailing if strong earthquake motions occur. The engineers conclude that the catwalk and associated supports will survive the $2.5 \mathrm{~m} / \mathrm{s}^{2}(0.25$ gravity) WESF DBE. (Wagenblast, et al., 1997)

Pool Cell Drain and Circulation Piping: Each pool cell is provided with a $5.1-\mathrm{cm}$ (2-in.) diameter, stainless steel abandoned water removal pipe (drain line). Each drain line penetrates the pool cell liner and wall into the pipe tunnel at an elevation of 0.9 $\mathrm{m}(3 \mathrm{ft})$ above the pool cell floor, extends horizontally $2.3 \mathrm{~m}(7.5 \mathrm{ft})$ to the exterior wall, then vertically up $2.7 \mathrm{~m}(9 \mathrm{ft})$ where it penetrates the pipe tunnel ceiling. The drain tine in the pipe tunnel is all welded pipe having no valves or flange connections. If the drain line were to rupture in the pipe tunnel, the pool cell would be in jeopardy of draining down to the $0.9 \mathrm{~m}$ ( $3 \mathrm{ft}$ ) level. If the water removal pipe were to rupture above the pipe tunnel ceiling, the pool cell would not be in jeopardy of draining since the pipe rupture would be above the water level in the pool cell. A conservative seismic evaluation qualifies the water removal pipes for DBE loads and therefore, they will survive the $2.5 \mathrm{~m} / \mathrm{s}^{2}(0.25$ gravity) WESF DBE. (Wagenblast, et al., 1999)

Each pool cell containing capsules has a water circulation system. The pool cell circulation system pumps heated water out of the top of the pool cells, circulates it through the heat exchangers, and re-injects the cooled water through distribution pipes in the bottom of the pool cells. The heat exchanger secondary or cooling system consists of circulated raw water. There are 7.6-cm (3-in.) diameter stainless steel circulation water pipes from the pumps to the distribution pipes. Each 7.6-cm (3-in.) circulation pipe route penetrates the pipe tunnel ceiling at the center of the tunnel and drops vertically $2.7 \mathrm{~m}(9 \mathrm{ft})$ to $0.9 \mathrm{~m}$ $(3 \mathrm{ft}$ ) above the floor. Then, the pipe route extends horizontally $1.2 \mathrm{~m} \mathrm{(4ft)} \mathrm{to} \mathrm{a} \mathrm{distribution} \mathrm{pipe} \mathrm{embedded} \mathrm{in} \mathrm{the} \mathrm{cell} \mathrm{wall.}$ Similar to the pool cell drain line discussed above, the circulation pipe in the pipe tunnel is all welded pipe having no valves or flange connections. A conservative seismic evaluation qualifies the pipes for DBE loads. therefore, they will survive the $2.5 \mathrm{~m} / \mathrm{s}^{2}$ (0.25 gravity) WESF DBE. (Wagenblast, et al., 1994)

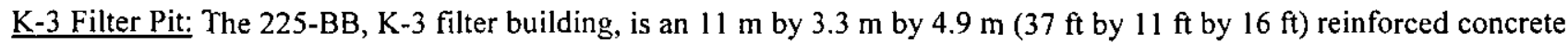
structure. The building is a one-story below grade retaining wall structure or pit with five cells, four of which open at the ground surface and one which opens $1.83 \mathrm{~m}(6 \mathrm{ft})$ above the ground surface. The tops of the cells are normally closed with cover blocks. The foundation is a continuous reinforced concrete slab $3 \mathrm{~m}(10 \mathrm{ft})$ below grade. The $\mathrm{K}-3 \mathrm{filter}$ pit is structurally independent of the adjacent structures. The 225-BB Building, K-3 filter pit design qualifies for the $2.5 \mathrm{~m} / \mathrm{s}^{2}(0.25$ | gravity) WESF DBE. (Wagenblast, et al., 199')

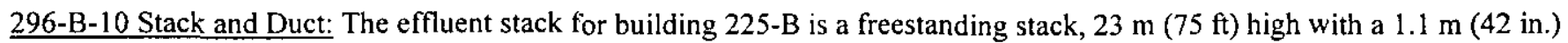
inside diameter, made from glass-fiber-reinforced polyester resin; the base of the stack is fastened to a steel base ring assembly. The steel base ring assembly consists of a $1.3 \mathrm{~cm}(1 / 2 \mathrm{in}$.) thick plate rolled into a cylinder having a $1.1 \mathrm{~m}(44 \mathrm{in}$.) inside diameter (ID) and $.5 \mathrm{~m} \mathrm{(20} \mathrm{in.)} \mathrm{high;} \mathrm{the} \mathrm{cylinder} \mathrm{is} \mathrm{welded} \mathrm{to} \mathrm{a} 2 \mathrm{~cm} \mathrm{(3/4} \mathrm{in.)} \mathrm{thick} \mathrm{ring} \mathrm{plate} \mathrm{having} \mathrm{an} \mathrm{inside} \mathrm{diameter}$ of $1.1 \mathrm{~m} \mathrm{(44} \mathrm{in.)} \mathrm{and} \mathrm{an} \mathrm{outside} \mathrm{diameter} \mathrm{of} 1.4 \mathrm{~m}(53 \mathrm{in}$.), the cylinder and ring are reinforced with sixteen $1 \mathrm{~cm}(3 / 8 \mathrm{in}$.) gusset plates. The base ring assembly is anchored with sixteen $3.2 \mathrm{~cm}(11 / 4 \mathrm{in}$.) diameter by $0.4 \mathrm{~m}(16 \mathrm{in}$.) long anchor bolts embedded in a reinforced concrete foundation $2 \mathrm{~m}(6 \mathrm{ft})$ in diameter and $4.3 \mathrm{~m}(14 \mathrm{ft})$ deep. The stack has two main penetrations: a $0.8 \mathrm{~m}(30 \mathrm{in}$.) penetration for the $\mathrm{K}-1$ and a $0.5 \mathrm{~m}(20 \mathrm{in}$.) penetration for the $\mathrm{K}-3$ exhaust duct connections, as well as several other penetrations ranging between $2.5 \mathrm{~cm}(1 \mathrm{in}$.) and $0.4 \mathrm{~m}(15 \mathrm{in}$.) in diameter. All penetrations are equipped with stainless steel flanges molded into the stack. 
A fiberglass duct having a $0.5 \mathrm{~m}(20 \mathrm{in}$.) ID and $0.6 \mathrm{~cm}(1 / 4 \mathrm{in}$.) wall thickness connects the $0.5 \mathrm{~m}(20 \mathrm{in}$.) flanged stack opening and the K-3 exhaust fan assembly to the west; the duct is $18 \mathrm{~m}(60 \mathrm{ft})$ long, with 6 supports spaced at $3 \mathrm{~m}$ ( $10 \mathrm{ft}$ ) centers. The $0.8 \mathrm{~m}$ ( $30 \mathrm{in}$.) flanged stack opening is connected to the K-1 exhaust fan assembly to the east with a $0.8 \mathrm{~m}(30$ in.) ID, $0.6 \mathrm{~cm}(1 / 4 \mathrm{in}$.) wall thickness, and $3 \mathrm{~m}$ (10 ft) long fiberglass duct; the $0.8 \mathrm{~m}(30 \mathrm{in}$.) duct has one support at the center. The fiberglass ducts are connected to the K-1 and K-3 stainless steel fan outlet ducts that are connected to the fans with flex connection. A conservative seismic evaluation qualifies the stack and duct for DBE loads and therefore, they will survive the $2.5 \mathrm{~m} / \mathrm{s}^{2}$ (0.25 gravity) WESF DBE. (Wagenblast, et al., Appendix $\left.\mathrm{G}, 1999\right)$

Area 2 Structure: The Area 2 is a two-story above grade structure with a reinforced concrete roof and floor slabs supported by reinforced concrete shear walls. The high-density concrete shielding hot cells provide additional shear walls for resisting lateral loads on both the first and second floors. The building foundation consists of continuous and spread footings at a depth of $1.83 \mathrm{~m}(6 \mathrm{ft})$ below the grade slab, bearing on compacted fill. The high-density concrete shielding hot cells have a separate foundation, a continuous base mat slab on compacted fill, $1.83 \mathrm{~m}(6 \mathrm{ft})$ below the grade slab. The east end of the foundation spread footings, grade slab, and floor slab of Area 2 are separated from the 221-B Building by a 0.6-cm $(0.25$-in.) expansion joint. The walls and roof of Area 2 are separated from the 221-B Building by a 5.1-cm (2-in.) gap identified on the design drawings as a seismic joint. The $5.1-\mathrm{cm}(2$-in.) gap, or seismic joint, allows relative motion between the structures without load transfer and prevents impact or seismic pounding. Therefore, Area 2 is structurally independent of the adjacent structures for resisting lateral seismic loads. Seismic analyses for the 221-B Building showed that inelastic stresses will develop in the canyon walls at relatively low north-south seismic accelerations or motions. The unreinforced infill end-wall panels would be forced to comply with the 221-B Building transverse, north-south, deflections. The resulting large diagonal shear forces could fail and collapse the panels. Only the portion of the west end infill wall panel that extends above the 225-B Building roof elevation has the potential to do significant local structural damage to the 225-B Building. The pool cells would be unaffected structurally by a collapse of the 221-B Building end wall. The shielding view windows in the hot cell walls do not appreciably weaken the walls. Horizontal seismic forces on the shielding windows are resisted by the friction developed by the lead shims and compacted lead wool surrounding them. The Area 2 Structure has been designed and qualified to survive the $2.5 \mathrm{~m} / \mathrm{s}^{2}$ (0.25 gravity) WESF DBE. (Wagenblast, et al., 1999)

\subsubsection{Functional Requirements.}

Area 2 structure, Area 3 structure, K-3 filter pit, 296-B-10 stack, pool cell bridge crane, catwalk, and associated supports, and the pool cell drain and circulation piping shall meet the following minimum parameters:

- Peak ground acceleration of $2.5 \mathrm{~m} / \mathrm{s}^{2}(0.25$ gravity $)$

- Damping up to $5 \%$

\subsubsection{System Evaluation.}

Area 3 structure, pool cell bridge crane, catwalk, and associated support structures, pool cell drain and circulation piping, K-3 filter pit structure, stack, exhaust duct, and the Area 2 structure are constructed and designed to survive a WESF DBE (Wagenblast, et al., 1999).

\subsubsection{IOSR Controls.}

The seismic qualifications of the Area 3 structure, pool cell bridge crane, catwalk, and associated support structures, pool cell drain and circulation piping, K-3 filter pit structure, stack, exhaust duct, and the Area 2 structure to a $2.5 \mathrm{~m} / \mathrm{s}^{2}(0.25$ gravity) WESF DBE are included as IOSR Design Features (see Section 5.6).

\subsubsection{K-3 HEPA Filter}

Section 3.4.2.3.1 "Hot Cell Fire" for A Cell, identifies the K-3 HEPA filter system as a safety-significant SSC. Section 3.4.2.3.1 "Hot Cell Fire" for B-E Cells and section 3.4.2.4.1 "High Flow in K-3 Ventilation System," identify the K-3 HEPA filter as a safety-class SSC. 


\subsubsection{Safety Function.}

The safety function of the safety class K-3 HEPA Filter is:

- To retain structural integrity after the plugging of the HEPA by smoke and debris to provide a passive barrier (confinement) to the unrestricted release of radioactive material [resulting from a fire in the hot cell(s)] to prevent dose consequences in excess of the onsite and offsite evaluation guidelines.

(Section 3.4.2.3.1 "A Hot Cell Fire" - SS)

(Section 3.4.2.3.1 "B through E Hot Cell Fire" - safety class)

- To provide a combined filter efficiency of $99.9 \%$ to prevent or mitigate the release of radioactive material to prevent dose consequences in excess of the onsite and offsite evaluation guidelines.

(Section 3.4.2.4.1 "High Flow in K-3 Ventilation System" - safety class)

\subsubsection{Safety Description.}

The K-3 exhaust system consists of two parallel filter housings. One is operating and the other is on standby (under normal operation, only one filter system is online). Each filter housing contains two stages of HEPA filtration in series, with six standard HEPA filters units $(0.61 \mathrm{~m}$ by $0.61 \mathrm{~m}$ [ $2 \mathrm{ft}$ by $2 \mathrm{ft}])$ per stage, see Figure $2-11$. Only the HEPA filter is discussed in this section as either a safety-class or safety-significant SSC.

The HEPA filter is fabricated from a fibrous medium having a particle removal efficiency of at least $99.95 \%$ for $0.3-$ $\mu \mathrm{m}$ (11.8- $\mu \mathrm{in}$.) particles of an approved test aerosol which exceeds the requirement of $99.9 \%$. The fibrous material is mounted and sealed to a frame and the frame provides sealing faces for installation of the filter element into a mounting enclosure. To perform periodic efficiency testing, several taps are used for injection and sampling of an approved tested aerosol.

The HEPA filters are also designed to retain structural integrity during a hot cell fire of $400^{\circ} \mathrm{C}\left(752^{\circ} \mathrm{F}\right)$.

\subsubsection{Functional Requirements.}

The K-3 HEPA filter shall meet the following criteria:

- Retain structural integrity under the environmental conditions of a hot cell fire of $400^{\circ} \mathrm{C}\left(752^{\circ} \mathrm{F}\right.$ ) (in Hot Cell) (Section 3.4.2.3.1 "A Hot Cell Fire" - SS)

(Section 3.4.2.3.1 "B through E Hot Cell Fire" - safety class)

- Remove at least 99.9 percent of $0.3-\mu \mathrm{m}(11.8-\mu \mathrm{in}$.) particles of an approved test aerosol. (Section 3.4.2.4.1 "High Flow in K-3 Ventilation System" - safety class)

\subsubsection{System Evaluation.}

The K-3 HEPA filter system is designed to ASME/ANSI-509, and tested to ASME/ANSI-510, which requires removal of at least 99.95 percent of approved test aerosol particles with particle size having a median diameter less than $1 \mu \mathrm{m}$ (-in.). The testing requirements for the K-3 HEPA filter system are more demanding than the accident analysis requirements to provide HEPA filtration of at least 99.9 percent of $0.3-\mu \mathrm{m}(11.8-\mu \mathrm{in}$.) particles of an approved test aerosol. At the time of its installation and annually thereafter, the K-3 HEPA filters are subjected to an aerosol injection test to verify its operability.

The gas temperatures resulting from the hot cell fire will not breach the K-3 HEPA filters, but the amount of fuel burned could clog the filters. (Mertz 1998) 


\subsubsection{IOSR Controls.}

The implied and stated assumptions of Section 3.4.2.3.1 "Hot Cell Fire" - A Cell, and Section 3.4.2.3.1 "Hot Cell Fire" - B through E Cells, are:

- The K-3 HEPA filters will remain intact when subjected to a hot cell fire

- Testing of the K-3 HEPA filter system is current (i.e., it was tested with an approved aerosol at the time of its installation, and it has been tested annually thereafter).

The implied and stated assumptions of Section 3.4.2.4.1 "High Flow in K-3 Ventilation System," are:

- The K-3 HEPA filters are in place

- Testing of the K-3 HEPA filter system is current (i.e., it was tested with an approved aerosol at the time of its installation, and it has been tested annually thereafter)

- The K-3 HEPA filters will be tested annually and removes at least 99.9 percent of $0.3-\mu \mathrm{m}(11.8-\mu \mathrm{in}$.) particles of an approved test aerosol.

\subsubsection{Pool Cell Area Radiation Monitors (ARMs)}

Section 3.4.2.6.1 "Underwater Capsule Failure Due to Corrosion," identifies the ARMs as a safety-significant SSC. Note: These SSCs perform a safety class finction in conjunction with the pool cell level monitoring SSCS to mitigate the Rapid Loss of Pool Cell Water Accident (see section 4.3.4). The lacility maintains the higher salety class classilication on all pool cell $A$ RMs.l

\subsubsection{Safety Function.}

The safety function of the safety significant ARMs for the capsule failure accident is:

- The ARMS provide WESF workers with the necessary waming to take protective actions. The potential dose freld in the Pool Cell Area from a fully dissolved cesium capsule could be fatal to a lacility worker if exposed for I hour or more. (Section 3.4.2.6.1 "Underwater Capsule Failure Due to Corrosion")

\subsubsection{Safety Description.}

There are three ARMs located in the Pool Cell Area, two located on the east wall and one located on the west wall, set to alarm upon detection of elevated gamma and beta radiation levels in the Pool Cell Area. At a minimum, two ARMs must be operable to detect elevated radiation levels and notify facility personnel to evacuate the Pool Cell Area. The ARMs have local audible and visual alarms.

\section{| 4.3.3.3 Functional Requirements.}

The Pool Cell ARMs shall comply with the following:

- At a minimum, two Pool Cell Area ARMs must be operable (Section 3.4.2.6.1 "Underwater Capsule Failure Due to Corrosion")

- Provide a local audible and visual alarm upon detection of elevated radiation levels in the Pool Cell Area exceeding a preset level (see Section 3.4.2.6.1 "Underwater Capsule Failure Due to Corrosion"). 


\subsubsection{System Evaluation.}

The Pool Cell ARMs and alarms are adequate for their assigned safety function. Upon detecting elevated radiation levels in the Pool Cell Area, an audible and visual alarm will be generated locally. Facility personnel will respond to the alarm and evacuate the Pool Cell Area. Upon verifying a high radiation condition, facility personnel will proceed with appropriate action for recovering a failed capsule (assumed worst-case scenario for this safety function). Recovery actions from a leaking capsule may consist of pool cell water decontamination and isolation of the leaking capsule.

\subsubsection{IOSR Controls.}

The implied and stated assumptions of Section 3.4.2.6.1 "Underwater Capsule Failure" are:

- Two Pool Cell Area ARMs must be operable while personnel are located in the Pool Cell Areat.

\subsubsection{Pool Cell Water Loss Detection System}

Section 3.4.2.7 "Loss of Pool Cell Water," identifies the pool cell rapid water loss detection system (level monitoring and ARM systems) as a safety-class SSC. (Note: The pool cell ARMs also perform a satety significant function to mitigate the Capsule Failure Accident (see section 4.3.3). The facitity maintains the higher safety class ctassification on all pool cell ARMs.]

\subsubsection{Safety Function.}

The safety function of the safety class pool cell Water Loss Detection System (pool cell level monitoring and ARM systems) is:

- To detect the rapid loss of water from the pool cells and alarm the condition to initiate a response that prevents total loss of pool cell water. This function is to prevent loss of facility control and mitigate resulting onsite, offsite, and facility worker dose consequences in excess of the evaluation guidelines.

(Section 3.4.2.7 "Loss of Pool Cell Water")

\subsubsection{Safety Description.}

The pool cell Water Loss Detection System consists of the pool cell level monitoring systems and the pool cell ARM system. The pool cell level monitoring systems and the pool cell ARM system together perform a redundant and diverse means of alarming upon detection of a rapid loss of pool cell water. Pool cell weight factor level monitoring and both local and remote alarms are provided for Pool Cells 1 through 8 and 12. The level indicators are located in the Operating Gallery and have both audible and visual alarms. There are three ARMs located in the Pool Cell Area, two located on the east wall and one located on the west wall, to detect the presence of elevated radiation levels in the Pool Cell Area. At a minimum, one ARM must be operable to alarm elevated radiation levels and notify facility personnel of a rapid water loss. The ARMs have audible and visual alarms both locally and remotely.

\subsubsection{Functional Requirements.}

The pool cell water loss detection system shall comply with the following:

- Have an operable water loss detection system for Pool Cells 1 through 8 and 12 (Section 3.4.2.7 "Loss of Pool Cell Water")

- Provide an audible and visual alarm both locally and remotely for the water loss detection system upon detection of water loss exceeding a preset level (Section 3.4.2.7 "Loss of Pool Cell Water"). 


\subsubsection{System Evaluation.}

The pool cell water loss detection system consists of the pool cell water level monitoring system and the pool cell area ARMs. The system is required to perform the safety class function of alerting facility personnel in the event of a rapid loss of water in an active pool cell.

The pool cell water loss detection system was originally designed and procured when the facility was first planned and built. It met the appropriate design and procurement standards when first installed, and all maintenance and upgrades to the system have also met appropriate industrial standards. The testing performed on the system includes operability testing, surveillance, calibration, and preventative maintenance. A review of past calibration and testing data indicate that the instrumentation is normally within defined tolerances and have routinely passed functional tests.

The single failure criterion and system redundancy are satisfied with the pool cell level monitoring system, however, because this system was not designed to current safety class criteria, the Pool Cell Area ARMs are also included as part of the rapid water loss detection system.

The water level monitoring system visually displays the water level in each active pool cell and provides alarms if the water level falls below a specified value or the system fails. The water levels are periodically checked and recorded so that trending data may be gathered which might provide an indication of system malfunction. The ARMs detect the presence of high gamma radiation fields in the Pool Cell Area. In the event of a rapid loss of pool cell water, the radiation field in the Pool Cell Area would increase causing the ARMs to alarm.

The combination of these two sub-systems, the level monitoring system and the ARMs, provides the overall system redundancy and satisfies the single failure criterion. A loss of electric power to the facility is the only failure mode which has been identified that would render both the level monitoring system and the ARMs inoperable at the same time. The level monitoring system will initiate an alarm on the WESF process monitoring and control system upon a loss of power to the system or facility which will allow compensatory actions to be instituted. An alarm will also result upon a loss of compressed (instrument) air or component failure.

The environment in the pool cell area and control area (adjacent to the operating gallery) during normal operations, system shutdown, and system testing are designed for human habitation and pose no hazards to the system. No accident or upset condition has been identified that would generate an environment which would cause the system to fail when called upon (the system is not required to be operable following a seismic event). There are only two identified abnormal conditions that would result in environmental conditions which could challenge the system. These conditions are inadvertent introduction of steam into the Pool Cell Area or high temperature and high humidity following an extended loss of pool cell cooling. It has been demonstrated through past events that the instrumentation can survive this type of condition.

Regarding the reliability of the systems, significant guidance exists on the use of commercial grade items to fulfill safety class functions in commercial reactors and non-reactor, nuclear facilities (HNF-PRO-268 and EPRI-5652). Of all the methods for accepting commercial grade items as sufficient to fulfill a safety class function, the examination of the documented past performance of the system is relevant to the water loss detection system. Both sub-systems, the water level monitoring system and the ARMs, have an operating record of greater than 20 years and have been maintained in accordance with relevant industrial standards. A review of Occurrence Reports over the last few years (since 1991) and interviews with facility personnel indicate there is no record of any failure of the level monitoring or ARM systems.

The water level monitoring system is bubbler system based on proven technology and has been modified only to the extent necessary to provide modern (digital) readout capabilities. It is a reliable system designed with internal component redundancy and alarmed failsafe modes. The ARMs are also based on proven technology and have been very reliable during the operating history of the facility. Unlike the level monitoring system, which will alarm upon a loss of electrical power to the facility or the entire system, the ARM system will not alarm if power is lost to the entire system.

On the basis of this evaluation, the rapid water loss detection system is adequate to fulfill its intended purpose. 


\subsubsection{IOSR Controls.}

The implied and stated assumptions of Section 3.4.2.7 "Loss of Pool Cell Water" are:

- The pool cell water loss detection system is operable (pool cell level monitoring system, one pool cell ARM system, and all associated alarms)

- Testing of the pool cell water loss detection system is current and in accordance with IOSR requirements

- Alarms will result upon loss of power or compressed air to the system(s).

\subsubsection{Pool Cell Emergency Makeup Water Fill Pipe}

Section 3.4.2.7.2 "Loss of Water From All Pool Cells," identifies the Pool Cell Emergency Makeup Water Fill Pipe as a safety class SSC. There is a related IOSR Administrative Control $(\Lambda C \quad 5.8)$ which supports this requirement by maintaining two water sources available.

\subsubsection{Safety Function.}

The safety function of the safety class Pool Cell Emergency Makeup Water Fill Pipc is:

- To allow water to be added to the pool cells remotely to maintain water over the capsules in the event of a rapid loss of pool cell water, and to restore pool cell water level in active pool cells (containing capsules) to $3.3 \mathrm{~m}$ (130 in.) without exposing response personnel to a dose of greater than 5 rem (Section 3.4.2.7.2 "Loss of Water From All Pool Cells").

\subsubsection{Safety Description.}

The Pool Cell Emergency Makeup Water System consists of a sitety class fill pipe installed through the north wall of the 225-B Building and the supply used to provide makeup water controlled through IOSR Administrative Control AC 5.8.

The fill pipe has a standard fire hose connector so a fire hose can be connected from the outside of the building to provide sanitary or raw water to Pool Cell 12 and ultimately the remaining pool cells. The water overflows through the air difution ports between Pool Cell 12 and the other poot cells and ultimately fills the pool cell losing water. Eventually the water level will equalize between the pool cell losing water and the pipe tunnel. The fill pipe is not required to meet single failure criteria since it is a passive component.

Water for the emergency fill system is provided through one of several independent general service water sources located near WESF. The water supply is connected to the fill pipe by use of standard fire fighting hoses brought to the facility by the response of the Hanford Fire Department (HFD). The HFD trucks are required by law to carry several hundred feet of several hose sizes, including 2.5 -in and 4 -in hoses. If necessary, the flow from the hydrants can also be increased by the pumps located on the HFD truck.

\subsubsection{Functional Requirements.}

The safety class pool cell emergency water lill pipe shall meet the following minimum parameters.

- $6.4 \mathrm{~cm}$ (2.5 in.) diameter fill pipe from exterior of pool cell area to Pool Cell 12

The supporting general service pool cell emergency water sources controlled by Administrative Control AC 5.8 shall met the following minimum parameters.

- Tivo sources of water available 
- Water volume available $310,000 \mathrm{~L}(83,000 \mathrm{gal})$

- Water flow rate of $570 \mathrm{~L} / \mathrm{min}(150 \mathrm{gal} / \mathrm{min})$.

Upon reaching $3.3 \mathrm{~m}$ (130 in.) in all active pool cells, the action of the emergency fill system is complete and the system can be deactivated. Any source of water makeup can then be used to raise the levels of the active pool cells above the $3.3 \mathrm{~m}$ (130 in.) level, as necessary. In addition, during the time that the affected pool cell is being filled to the $3.3 \mathrm{~m}$ ( $130 \mathrm{in}$.) level, the strength of the radiation fields in and near the pool cell area will diminish rapidly. As soon as the dose rates drop to acceptable levels (even if the affected pool cell level has not reached the $3.3 \mathrm{~m}$ [130 in.] level), personnel may enter the pool cell area or control room to provide additional means of water makeup (e.g., opening the transfer ports).

\subsubsection{System Evaluation.}

Fire Hose and Connection. The Pool Cell Water Loss Detection System acts to alert facility personnel to the condition of a rapid loss of pool cell water. In the calculations $(\mathrm{Hey} 1999)$ that provide the basis for the functional requirements it was assumed that the first hour of the event would be response time before water would begin entering Pool Cell 12. Facility personnel would require time to react to the alarm and make notification to the HFD. This is estimated to take $15 \mathrm{~min}$ based on the desire to confirm the alarm and then call for the HFD. The HFD response time to WESF is estimated to be approximately $5 \mathrm{~min}$ with an additional $5 \mathrm{~min}$ to make the necessary hose connections and begin adding water to Pool Cell 12 . The total time elapsed would then be $25 \mathrm{~min}$, which is within the 1 hour response time used in the LCO 3.1.1 (HNF 1997).

Fill Pipe. The fill pipe is a $6.4-\mathrm{cm}$ (2.5-in) diameter pipe running from Pool Cell 12 through the north wall of the Pool Cell Area to a location just west of the personnel access door in the north wall. The total length is less than $2 \mathrm{~m}$ ( $7 \mathrm{ft}$ ) The pipe has no plugs or valves except for a dust cover over a standard fire hose connection on the outside end of the pipe. The standard fire hose connection conforms to NFPA requirements such that a fire hose of any size from the HFD would function with the system. Since the fill pipe is a passive component it is not required to fulfill the single-failure criteria for safety class items. At a flow rate of $570 \mathrm{~L} / \mathrm{min}(150 \mathrm{gal} / \mathrm{min})$ the fill pipe would produce minimal pressure drop and therefore, cause negligible reduction in flow capacity from any of the water supplies evaluated below.

Raw Water Supply. A raw water fire hydrant is located nomth of the 225-B building and is fed from the 282-E reservoir. The gauge pressure is approximately $700 \mathrm{kPa}(100 \mathrm{psi})$. The $180-\mathrm{m}(600 \mathrm{ft})$ of fire hose used in the calculations is adequate to connect the raw water fire hydrant to the emergency fill pipe. Fluid flow analysis (1.1ey 1999) indicates that this water supply would provide a minimum of $1,100 \mathrm{~L} / \mathrm{min}(290 \mathrm{gal} / \mathrm{min})$ of raw water to Pool Cell 12 with essentially unlimited capacity. This exceeds the functional requirements identified above.

Sanitary Water Supply. Sanitary water is produced in the 283-E filter plant which filters and chlorinates raw water and maintains a 1.5 million $\mathrm{L}(400,000 \mathrm{gal})$ supply in an underground clear well system containing two $760,000 \mathrm{~L}(200,000 \mathrm{gal})$ concrete tanks. A sanitary water fire hydrant is located northeast of the 225-B building. The gauge pressure is approximately $550 \mathrm{kPa}(80 \mathrm{psi})$. The assumed $90-\mathrm{m} \mathrm{(300} \mathrm{ft)} \mathrm{of} \mathrm{fire} \mathrm{hose} \mathrm{is} \mathrm{adequate} \mathrm{to} \mathrm{connect} \mathrm{the} \mathrm{sanitary} \mathrm{water} \mathrm{fire} \mathrm{hydrant} \mathrm{to} \mathrm{the}$

emergency fill pipe. Fluid flow analysis (1 ley 1999) indicates that this water supply would provide a minimum of $1,300 \mathrm{~L} / \mathrm{min}$ ( $353 \mathrm{gal} / \mathrm{min}$ ) of sanitary water to Pool Cell 12 with a capacity in excess of $310,000 \mathrm{~L}(83,000 \mathrm{gal})$. This exceeds the functional requirements identified above.

Deep Well Supply. Two diesel-driven deep well pumps identified as \#1 (282-B) and \#2 (282-BA) are located west of 225-B at wells 299-E28-11 and 299-E28-15, respectively. They provide an alternate and redundant emergency makeup water supply to the emergency fill pipe. The assumed $90-\mathrm{m}(300 \mathrm{ft}$ ) of fire hose is adequate to connect the deep well water supply to the emergency fill pipe. Fluid flow analysis (Hey 1999) indicates that this water supply would provide a minimum of $830 \mathrm{~L} / \mathrm{min}$ (220 gal $/ \mathrm{min}$ ) of raw water to Pool Cell 12 with essentially unlimited capacity. This exceeds the functional requirements identified above.

\subsubsection{IOSR Controls.}

The following assumptions require control in an IOSR (See Chapter 5): 
- Two independent sources of emergency makeup water are available

- Transfer ports and air vents into Pool Cell 12 from Pool Cells 9, 10 and II are closed

- Water addition occurs at a minimum flow rate of $570 \mathrm{~L} / \mathrm{min}(150 \mathrm{gal} / \mathrm{min})$

- The capacity of the emergency makeup water supply is a minimum of $310,000 \mathrm{~L}$ ( $83,000 \mathrm{gal}$ ). 


\subsection{DERIVATION OF INTERIM OPERATIONAL SAFETY REQUIREMENTS}

\subsection{INTRODUCTION}

The required preventive and mitigative features determined to be essential in Chapter 3.0, "Hazard and Accident Analyses," and from the designation of safety class and safety significant features in Chapter 4.0, "Safety Structures, Systems, and Components," are identified in this chapter. Information necessary for preparing the separate Interim Operational Safety Requirement (IOSR) document (HNF-SD-WM-IOSR-001, Waste Encapsulation and Storage Facility Interim Operational

| Safety Requirements [HNF 1998c]) required by DOE Order 5480.22, Technical Safety Requirements, is also provided in this chapter.

The IOSRs define acceptable conditions, safe boundaries, and management or administrative controls that ensure safe operation of a nuclear facility and reduce the potential risk to the public and onsite workers from uncontrolled releases of radioactive material or from radiation exposures caused by inadvertent criticality (DOE Order 5480.22). Releases of nonradioactive hazardous material are addressed in Section 5.3.9.

This chapter consists of summaries and references to pertinent sections of the BIO that describe design and administrative control features needed to prevent or mitigate the consequences of an accident. The Safety Limits (SLs), Limiting Control Settings (LCSs), Limiting Conditions for Operation (LCOs), Surveillance Requirements (SRs), Administrative Controls (ACs), and Design Features form the basis of the IOSR document and provide the logical link between the IOSRs and the BIO.

As discussed in Chapter 3.0, a hazard categorization process assessed the WESF radioactive material inventory and determined that WESF is Hazard Category 2. The IOSRs were developed based on the graded approach applied to the hazard and accident analyses and the Hazard Category 2 designation.

Products of this chapter include the following:

- Qualitative and quantitative IOSR selection criteria

- A table that links the hazard and accident analyses, the safety structures, systems, and components (SSCs), and the IOSRs

- A table that provides cross-references to other BIO chapters

- Operational modes that designate distinguishable facility configurations and operational conditions

- Derivation of minimum staffing levels for each operational mode

- A list of Design Features not covered by the IOSRs

- Identification of IOSR interfaces with other Hanford Site facilities and the controls.

\subsection{REQUIREMENTS}

The primary requirements specific for this chapter, the hazard and accident analyses, and the IOSR document are included in the following documents:

- DOE Order 5480.22, Technical Safety Requirements

- WHC-SP-1164, Westinghouse Hanford Company Safety Analysis Reports and Technical Safety Requirements Upgrade Program (replaced by external letter FDH1.9955894 AR2, |Itanson 1999|) 
HNF-SD-WM-BIO-002 REV1

\subsection{INTERIM OPERATIONAL SAFETY REQUIREMENTS COVERAGE}

Corresponding accident analyses discussed in Chapter 3.0 and SSCs identified in Chapter 4.0 as needing IOSR coverage are listed in Table 5-1. The IOSRs required for public safety, significant defense-in-depth, significant worker safety, and maintaining radiological consequences below risk evaluation guidelines are identified as SLs, LCSs, LCOs, ACs, or Design Features. Requirements and detailed guidance for selecting the IOSRs are provided in WHC-CM-4-46, Safety Analysis | Manual, [WIIC-CM-4-46 has since been replaced with IINF-1'RO-700 and HINF-1'RO-704/ and are summarized in Sections 5.3.1 through 5.3.10.

Selection of IOSR control options is based on practicality and ease of implementation. Consideration is given to (1) equipment reliability, availability, and maintainability and (2) human factors.

\subsubsection{Safety Limits}

The SLs are limits on process variables (e.g., temperature, pressure) associated with those physical barriers (e.g., tanks, piping), generally passive, that are necessary for the intended facility function. Exceeding SLs could directly cause the failure of one or more of the barriers that prevent the uncontrolled release of radioactive material. The limits are stated in measurable units such as degrees Celsius and are placed on primary barriers closest to the material source. The SLs, if absolutely necessary, are reserved for a small set of safety requirements to which the facility is committed to protect the integrity of the primary barriers.

Applying the quantitative criteria discussed in Section 5.3.10, SLs are those limits required to maintain radiological consequences to the offsite public below risk evaluation guidelines.

\subsubsection{Limiting Control Settings}

The LCSs are setpoints on safety systems that control process variables to prevent exceeding SLs. The specific setpoints are chosen such that if exceeded, sufficient time is available to automatically or manually correct the condition before exceeding SLs.

The LCSs are combined with their respective LCOs (discussed in Section 5.3.3) with all setpoints and requirements contained within the LCOs. By combining the LCSs with the LCOs, the LCS setpoint (within limits) becomes part of the operability of the system. Furthermore, safety is enhanced by placing the applicability, actions, and surveillances for a system in a single location and the complexity of the IOSR document is reduced.

\subsubsection{Limiting Conditions for Operation}

The LCOs are the lowest functional capability or performance level of SSCs (and their support systems) required for normal, safe operation of the facility. The LCOs are based on keeping the SSCs operable or on maintaining conditions within specified limits. The LCOs are prepared for those SSCs that are identified in the accident analyses as preventing or mitigating accidents or transient events that involve the assumed failure of, or present a challenge to, the integrity of a physical barrier that prevents the uncontrolled release of radioactive material. The LCOs are established only for those mitigative SSCs that are part of the primary success path of an accident sequence analysis (i.e., the assumed sequence of events that leads to the conclusion of an accident for which the risk is judged to be acceptable).

Applying the quantitative criteria discussed in Section 5.3.10, LCOs are established for those preventive and mitigative SSCS or conditions required to maintain radiological consequences to the offsite public and onsite workers below risk evaluation guidelines.

\subsubsection{Surveillance Requirements}

The SRs are requirements relating to testing, calibration, or inspection of SSCs or conditions. The SRs provide assurance that the necessary quality of SSCs is maintained; the facility operation will be within the SLs; and the LCSs and the LCOs will be met. 


\subsubsection{Administrative Controls}

The ACs are the provisions relating to organization and management, procedures, record keeping, reviews, audits, and specific program requirements for risk reduction necessary to ensure safe operation of the facility. The IOSRs (i.e., SLs, LCSs, LCOs, and ACs) establish administrative requirements that ensure IOSR requirements are met in the operation of the facility and the procedures that are followed should an IOSR not be met. The ACs are normally written at the program level and contain key program elements, as applicable. The ACs are established (1) if a safety function is best satisfied by a program instead of a hardware system, (2) if control of a condition is not measured in real-time or near to real-time, (3) if control of a condition is not under the immediate control of the operator, (4) if a condition does not require immediate action and sufficient recovery time exists to permit mitigating action, or (5) if a condition requires an evaluation based on prevalent conditions. The $\mathrm{ACs}$ do not require action statements or surveillances. The SRs necessary to demonstrate compliance with an AC and the actions taken should an $\mathrm{AC}$ requirement not be met are performed according to administrative procedures.

Applying the quantitative criteria discussed in Section 5.3.10, ACs are established for those programs required to maintain radiological consequences to the offsite public and onsite workers below risk evaluation guidelines.

\subsubsection{Design Features}

Design Features are those features not covered elsewhere in the IOSRs and that, if altered or modified, would have a significant effect on safety. Design Features are normally permanently built-in features that do not require, or infrequently require, maintenance or surveillance and are normally not subject to change by operations personnel. The categories of Design Features to be addressed in accordance with DOE Order 5480.22 include the following:

- Vital passive components such as piping, vessels, supports, confinement structures, and containers

- Configuration and physical arrangement of the facility where safety is a concern including site characteristics such as the locations of public access roads, collocated facilities, facility area boundaries, site boundaries, and distances to the nearest residences

- Building materials, if the safe operation of the facility depends on any component being constructed of a particular material.

Changes to Design Features are considered significant modifications. The unreviewed safety question process ensures that changes to Design Features are appropriately analyzed and controlled so that they do not adversely affect safe operation of the facility.

\subsubsection{Significant Defense-in-Depth}

Defense-in-depth is a fundamental approach to hazard control at WESF and is important in determining the safety basis in general. The IOSRs are major contributors to the concept, which includes multiple independent safety provisions, none of which is relied on exclusively for either accident prevention or mitigation. Safety provisions refer to both hardware systems and integrated safety management programs that ensure control and discipline of operations for added prevention. Defense-indepth is reflected in the IOSRs in the form of a hierarchy of limits and controls described in the following paragraphs.

Level 1 - The LCOs keep the SSCs operable or maintain conditions within specified limits to prevent or mitigate radiological consequences to the public and onsite workers to below risk evaluation guidelines. The SRs are tests, calibrations, or inspections designed to help ensure an acceptable level of availability and performance of SSCs and detect deficiencies before they can cause or contribute to accidents. The ACs assumed in the accident analyses to prevent or mitigate radiological consequences to the public and onsite workers below risk evaluation guidelines support the LCOs, maintain the nuclear safety basis as described in the analyses, and ensure compliance with the IOSRs. Taken together, the LCOs, SRs, and ACs are directed toward maintaining operational parameters within normal bounds, and constitute the basic, first level of defense-indepth. Safety management programs at WESF, which are already covered by other orders and regulations, support the defense-in-depth concept and are discussed in Chapter 6.0, "Safety Related Programs and Controls." 
Level 2 - The LCSs and SLs come into play under abnormal or accident conditions in which automatic or manual responses are required before SLs are challenged. An LCS setpoint is part of the operability of a system and, therefore, is combined with the associated LCO. The SLs inherently provide both defense-in-depth and worker safety by protecting the primary physical barrier for the control of radioactive material.

Level 3 - Preventive and mitigative Design Features provide protection of the public and workers even if the first two levels fail. Important Design Features at WESF not covered by the IOSRs are listed in Section 5.6.

\subsubsection{Significant Worker Safety}

Worker safety at WESF is part of the first level of defense-in-depth discussed in Section 5.3.7, and is covered by integrated safety management programs. These programs (discussed in Chapter 6.0) reduce the likelihood and potential impacts of events, and are covered by their respective regulatory and contractual systems of basic requirements. Therefore, these programs are not repeated as AC programs in the IOSR document. The DOE Order 5480.22 requires the IOSR document to include $\mathrm{AC}$ programs for nuclear criticality safety (not applicable to WESF), organization and management (including minimum staffing), and occurrence reporting.

An IOSR may be required if the hazard and accident analyses identify significant worker safety hazards. Significant worker safety hazards involve significant worker exposure, immediate worker fatalities or the hospitalization of multiple workers for hazards that are not already controlled through institutional safety programs that govern standard occupational and health standards.

\subsubsection{Nonradioactive Hazards}

An IOSR may be required for nonradioactive hazards as defined in DOE Order 5480.22 .

\subsubsection{Maintain Consequences Below Evaluation Guidelines}

The review of the hazard and accident analyses to determine whether IOSRs are required uses the risk evaluation guidelines presented in Chapter 3.0. If the "unmitigated" release of available radioactive material from a credible accident exceeds the offsite or onsite risk evaluation guidelines, IOSRs are required. Table 5-1.

A listing of IOSRs required to maintain radiological consequences below risk evaluation guidelines is provided in

\subsection{DERIVATION OF FACILITY MODES}

\subsubsection{Operational Modes}

The operational modes for WESF are derived from the hazard and accident analyses and are used (1) to determine LCO applicability, (2) to determine AC program applicability, (3) to distinguish facility operational conditions, (4) to determine minimum staffing requirements, and (5) to provide an instant facility status report. The modes provide a convenient way of ensuring availability of all pertinent safety functions during relevant facility configurations, as assumed in the analyses. The mode status of WESF is documented and maintained current according to administrative procedures. The modes suggested by DOE Order 5480.22 are generally not applicable for WESF because the WESF mission is the safe storage of cesium and strontium capsules instead of processing waste. Mode definitions for WESF are provided below.

Operation Cesium and strontium capsules are being stored. Receipt, inspection, and decontamination of the capsules are authorized. Routine operational, surveillance, and maintenance activities are authorized.

Restricted Cesium and strontium capsules are being stored. An abnormal facility condition in which only certain restricted activities defined in a recovery plan are authorized. 


\subsubsection{Minimum Staffing Levels}

The minimum staffing in the Operation Mode is one qualified, responsible operator, one support person (backup), and one On-Call Building Emergency Director (OBED). The qualified, responsible operator is trained in facility-specific operating procedures (through an approved training program) that implement (1) LCO requirements, (2) LCO action statements (conditions, required actions, and completion times), (3) Surveillance Requirements and frequencies, (4) AC programs, (5) emergency and alarm responses, and (6) occurtence notification and reporting requirements. The responsible operator is required to be aware of and responsible for the facility status and systems condition and control at all times.

All immediate and short term required actions specified in the LCO action statements can be performed by one responsible operator. One responsible operator can immediately add water to the pool cells or valve in appropriate backup water according to operating procedures should the level drop below LCO limits. One responsible operator can also perform other compensatory measures as required in the LCO action statements if systems are discovered to be inoperable.

Frequent Surveillances (e.g., operator rounds) performed by operators can be performed by one responsible operator within the specified frequencies. The responsible operator is not given duties or operations that could interfere with the completion of these surveillances. Less frequent Surveillances (e.g., system testing) performed by support personnel are adequately planned and scheduled to ensure that the specified frequencies are met.

The support person serves as a backup to the responsible operator and is only required to be responsible to make notifications if the responsible operator is unable in the event of an abnormal or emergency situation. The support person is trained (through an approved training program) in emergency and alarm responses, and occurrence notification and reporting requirements.

The On-Call Building Emergency Director (OBED) is required to be on-call at all times to assist the responsible operator with any emergency response conditions, to assist with system operability determinations or provide IOSR interpretations, as necessary. The OBED is trained (through an approved training program) in the IOSR document, in emergency and alarm responses, and occurrence notification and reporting requirements.

The minimum staffing in the Restricted Mode will be defined in the recovery plan that will be prepared if WESF is placed in this mode. Circumstances leading to placing WESF in the Restricted Mode and the necessary recovery activities could vary widely. Minimum staffing can not be predetermined and therefore, will be based on the prevalent facility conditions.

\subsection{INTERIM OPERATIONAL SAFETY REQUIREMENT DERIVATION}

The derivation of the IOSRs required to ensure safe operation of WESF is based on the hazard and accident analyses in Chapter 3.0, the SSC evaluations in Chapter 4.0, topics required by DOE Order 5480.22, and the contractor's policy on IOSRs

I (WHC-CM-4-46 was used to develop the WESF IOSRs and has since been replaced with HNF-PRO-700 and HNF-PRO-704]). The analyses in Chapter 3.0 conclude that implementation of LCOs, SRs, and ACs is required to protect accident analyses assumptions and to maintain radiological consequences to the offsite public and onsite workers below risk evaluation guidelines. The list of required IOSRs and summary derivation bases are provided in Table 5-1. Expanded bases for the LCOs are provided in HNF-SD-WM-IOSR-001 (HNF 1998c), Appendix A, "Bases."

\subsubsection{Applicable Hazards}

See Table 5-1.

\subsubsection{Limiting Conditions for Operation}

See Table 5-1.

\subsubsection{Surveillance Requirements}

See Table 5-1. 


\subsubsection{Administrative Controls}

See Table 5-1 and Table 5-2.

\subsection{DESIGN FEATURES}

Design Features for WESF that, if altered or modified, would have a significant effect on safe operation are listed below. Selection of the Design Features is based on the criteria in DOE Order 5480.22 as discussed in Section 5.3.6. Descriptions of these Design Features are provided in Chapter 2.0, "Facility Description." The safety functions of Design Features credited in the accident analyses and listed in Table 5-1 are provided in Chapter 4.0.

There are no Design Features identified for the WESF support facilities which include:

- 2l1-BA. Auxiliary Building

- 218-B. Emergency Equipment Storage

- 225-BA, K-1 Filter Building

- 225-BC, WtSF Compressor Building

- 225-BD, WESF Waste Monitor and Sample Building

- 225-Bt. Maintenance Shop

- 225-BF, Utility Building

- 225-BG, WESF Closed Loop Cooling Equipment Building

- 272-B, WLSF Support Building

- 272-BA, Auxiliary Building

- $\quad 272-B B$, Auxiliary Building

- 282-B. Pump House

- 282-BA. Pump House

- 294-B. Raw Water Backflow Preventer Building

- Diesel Gienerator

- TK-50 Pit

- MO-312, Laundry Storage Trailer

Based on the criteria for Design Features in DOE Order 5480.22, passive features only for environmental protection are not listed. Environmental features are, however, discussed in Chapter 3.0, Section 3.3.2.3.4 and listed in Table 3.3.2.3-5. Radioactive and hazardous waste management control features are discussed in Chapter 6.0. Design Features for WESF include the following.

\section{5-B Building}

Design Features for the 225-B Building include the following.

- The Area 2 structures (see Section 4.3.1 for the list) retain structural integrity for a design basis earthquake to provide confinement of airborne radioactive material (see Section 3.4.2.1.2). They also provide shielding from radioactive material.

- The Area 3 structures (see Section 4.3.1 for the list) retain structural integrity for a design basis earthquake to provide water retention for the cesium and strontium capsules (see Sections 3.4.2.1.2 and 3.4.2.7.2).

- The 296-B stack and the exhaust duct between the fans and stack retain structural integrity for a design basis earthquake to prevent a ground level release of radioactive material (see Section 3.4.2.1.2).

- The pool cell drain line and circulation piping retain structural integrity for a design basis earthquake to provide water retention for the cesium and strontium capsules (see Section 3.4.2.1.2).

- The pool cell bridge crane, catwalk, and associated support structures retain structural integrity for a design basis earthquake to preclude mechanical damage to the cesium and strontium capsules from a heavy load drop into active pool cells (see Sections 3.4.2.1.2 and 3.4.2.6.2). 
- The cesium and strontium capsules are double-encapsulated (exciuding Type W overpack capsules), welded, and constructed of stainless steel material for primary containment. The double-encapsulation also provides shielding from beta radiation. Water in the pool cells provides shielding from the gamma radiation.

- An emergency fill standpipe is connected to Pool Cell 12 to provide long-term emergency capability to add pool cell makeup water in the event of loss of water and high radiation in and near the pool cells, without manned entry into the facility (see Section 3.4.2.7.2).

- Personnel entry doors, made of high density concrete, are provided at several locations in the Hot Cell Area and Canyon Area to provide shielding from radioactive material.

- Air locks are provided at several locations and function as an interface to control ventilation zone pressures for contamination control.

- Lead-glass viewing windows are provided in the interior walls of the Canyon for observing Canyon operations from the Aqueous Makeup Area. Lead-glass viewing windows, incorporating a cerium coverglass, are provided for observing hot cell operations from the Operating Gallery. These viewing windows provide shielding from radioactive material.

- Concrete cover blocks are installed in the hot cells and truckport to provide confinement and shielding from radioactive material.

- The Beneficial Uses Shipping System (BUSS) cask provides confinement for capsules (including fire and impact protection) and shielding from radioactive material.

\section{Exhaust Ventilation Systems}

Design Features for the $\mathrm{K}-1$ and $\mathrm{K}-3$ ventilation systems include the following.

- The K-3 Filter Pit structure is below ground to provide shielding from radioactive material. The structure, including concrete cover blocks, retains structural integrity for a design basis earthquake to provide confinement of airbome radioactive material (see Section 3.4.2.1.2).

- The K-3. HEPA filters provide confinement of airborne radioactive material (see Sections 3.4.2.3.1 and 3.4.2.4.1).

- The 296-B stack and the exhaust duct between the fans and the stack prevent a ground release of radioactive material during a design basis earthquake (see Section 3.4.2.1.2).

$\underline{\mathrm{TK}-100}$

- The TK-100 pit structure is below ground to provide shielding from radioactive material. The structure, including concrete cover blocks, also provides confinement of radioactive material.

\section{S.7 INTERFACES WITH IOSRS FROM OTHER FACILITIES}

Physical and administrative interfaces with other Hanford Site facilities exist that affect the WESF safety basis. The facilities, interfaces, and controls are discussed below.

\subsubsection{Utilities.}

This interface involves the reliance of WESF on the Utilities Division to supply emergency raw water and sanitary water for the WESF pool cells. Water is supplied to WESF through the 200 Area Water Distribution System.

The IOSR control established at WESF is as follows: 
- IOSR AC program entitled "Pool Cell Water Makeup."

The purpose of this control is to ensure that adequate supplies of pool cell water makeup are available to keep the cesium and strontium capsules in the pool cells covered with water. Raw water and sanitary water are designated water makeup sources because of their capability to deliver the necessary volume of water to satisfy the safety function of keeping the capsules covered.

\section{7 .2 B Plant.}

WESF has committed to evaluate any USQ screening or degradation data received trom the Environmental Restoration Contractor on the $\mathrm{B}$ Plant end wall to ascertain if there is any impact on the WFSF seismic analysis.

Table 5-1. Hazard and Accident Analyses; Safety Structures, Systems and Components; and Interim Operational Safety Requirement Cross-Reference.

\begin{tabular}{|c|c|c|c|c|c|c|}
\hline \multirow{2}{*}{$\begin{array}{c}\text { Analyzed } \\
\text { Accident } \\
\text { (from Chapter } \\
\text { 3.0) }\end{array}$} & \multirow[t]{2}{*}{$\begin{array}{c}\text { Hazard } \\
\text { (from Chapter 3.0) }\end{array}$} & \multicolumn{3}{|c|}{$\begin{array}{c}\text { Safety Structures, Systems, and } \\
\text { Components } \\
\text { (from Chapter } 4.0 \text { ) }\end{array}$} & \multirow[t]{2}{*}{$\begin{array}{l}\text { Interim Operational } \\
\text { Safety Requirement }\end{array}$} & \multirow[t]{2}{*}{ Derivation Basis } \\
\hline & & Description & SC & $\begin{array}{l}\text { SS } \\
\text { (a) }\end{array}$ & & \\
\hline \multicolumn{7}{|c|}{ NATURAL PHENOMENA (Section 3.4.2.1) } \\
\hline 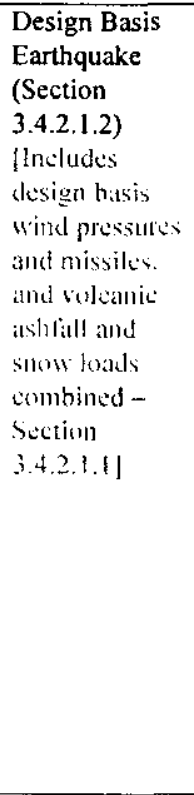 & $\begin{array}{l}\text { Bounding hazardous } \\
\text { condition } \\
\text { K-3 fitter bypass and } \\
\text { radiological release } \\
\text { from material } \\
\text { resuspended in K-3 } \\
\text { exhaust duct. } \\
\text { Initiator to Section } \\
3.4 .2 .7\end{array}$ & $\begin{array}{l}\text { Area } 2 \text { structures: } \\
\text { See Section 4.3.1 for } \\
\text { list of structures } \\
\text { (Design Features) } \\
\text { Area } 3 \text { structures: } \\
\text { See Section 4.3.1 for } \\
\text { list of structures } \\
\text { (Design Features) } \\
\text { K-3 Filter Pit } \\
\text { structure (Design } \\
\text { Feature) } \\
\text { 296-B stack and } \\
\text { exhaust duct between } \\
\text { the fans and stack } \\
\text { (Design Feature) } \\
\text { Bridge crane, } \\
\text { catwalk, and } \\
\text { associated support } \\
\text { structures } \\
\text { (Design Features) } \\
\text { Pool cell drain and } \\
\text { recirculation piping } \\
\text { (Design Features) }\end{array}$ & $\begin{array}{l}\mathrm{x} \\
\mathrm{x} \\
\mathrm{x} \\
\mathrm{x}\end{array}$ & & None & $\begin{array}{l}\text { Design Features } \\
\text { PREVENTIVE: See Section 5.6, Design Features }\end{array}$ \\
\hline \multicolumn{7}{|c|}{ EXTERNAL EVENTS (Section 3.4.2.2) } \\
\hline $\begin{array}{l}\text { Loss of } \\
\text { Electric Power } \\
\text { (Section } \\
3.4 .2 .2 .1 \text { ) }\end{array}$ & $\begin{array}{l}\text { Bounding hazardous } \\
\text { condition } \\
\text { Buildup of hydrogen } \\
\text { in room } \\
\text { Initiator to Sections } \\
3.4 .2 .4 .2,3.4 .2 .5 \text {, and } \\
3.4 .2 .7\end{array}$ & None & None & None & $\begin{array}{l}\text { See Sections } \\
3.4 .2 .4 .2,3.4 .2 .5 \\
\text { and } 3.4 .2 .7\end{array}$ & None \\
\hline $\begin{array}{l}\text { Adjacent } \\
\text { Facilities } \\
\text { (Section } \\
\text { 3.4.2.2.2) }\end{array}$ & $\begin{array}{l}\text { Bounding hazardous } \\
\text { Condition } \\
\text { Release from B Plant }\end{array}$ & None & None & None & None & None \\
\hline
\end{tabular}


HNF-SD-WM-BIO-002 REV1

Table 5-1. Hazard and Accident Analyses; Safety. Structures, Systems and Components; and Interim Operational Safety Requirement Cross-Reference.

\begin{tabular}{|c|c|c|c|c|c|c|}
\hline \multirow{2}{*}{$\begin{array}{c}\text { Analyzed } \\
\text { Accident } \\
\text { (from Chapter } \\
\text { 3.0) }\end{array}$} & \multirow[t]{2}{*}{$\begin{array}{c}\text { Hazard } \\
\text { (from Chapter 3.0) }\end{array}$} & \multicolumn{3}{|c|}{$\begin{array}{c}\text { Safety Structures, Systems, and } \\
\text { Components } \\
\text { (from Chapter 4.0) }\end{array}$} & \multirow[t]{2}{*}{$\begin{array}{l}\text { Interim Operational } \\
\text { Safety Requirement }\end{array}$} & \multirow[t]{2}{*}{ Derivation Basis } \\
\hline & & Description & $\mathrm{SC}$ & $\begin{array}{l}\text { SS } \\
\text { (a) }\end{array}$ & & \\
\hline $\begin{array}{l}\text { Aircraft Impact } \\
\text { (Section } \\
3.4 .2 .2 .3 \text { ) }\end{array}$ & $\begin{array}{l}\text { Bounding hazardous } \\
\text { condition } \\
\text { Potential for pool cell } \\
\text { damage; loss of } \\
\text { contamination control } \\
\text { Initiator to several } \\
\text { events including } \\
\text { Section 3.4.2.7 }\end{array}$ & None & None & None & None & None \\
\hline $\begin{array}{l}\text { Ground } \\
\text { Vehicle Impact } \\
\text { (Section } \\
3.4 .2 .2 .4 \text { ) }\end{array}$ & $\begin{array}{l}\text { Bounding hazardous } \\
\text { condition } \\
\text { Loss of contamination } \\
\text { control; buildup of } \\
\text { hydrogen in Pool Cell } \\
\text { Area; potential for } \\
\text { pool cell damage } \\
\text { Initiator to Sections } \\
\text { 3.4.2.4.2 and 3.4.2.5 }\end{array}$ & None & None & None & $\begin{array}{l}\text { See Sections } \\
3.4 .2 .4 .2 \text { and } 3.4 .2 .5\end{array}$ & None \\
\hline \multicolumn{7}{|c|}{ FACILITY FIRES (Section 3.4.2.3) } \\
\hline $\begin{array}{l}\text { Hot Cell Fire } \\
\text { (Section } \\
3.4 .2 .3 .1 \text { ) }\end{array}$ & $\begin{array}{l}\text { Bounding hazardous } \\
\text { condition } \\
\text { Major radiological } \\
\text { release from hot cells }\end{array}$ & $\begin{array}{l}\text { K-3 HEPA filter } \\
\text { system }\end{array}$ & $\mathrm{x}$ & & $\begin{array}{l}\text { AC 5.7 Source } \\
\text { Inventory } \\
\text { Controls } \\
\text { AC } 5.12 \text { Fire } \\
\text { Protection Program }\end{array}$ & $\begin{array}{l}\text { Administrative Controls } \\
\text { AC 5.7 - PREVENTIVE: The AC program } \\
\text { protects accident analyses inventories and } \\
\text { assumptions required for WESF to remain within } \\
\text { the analyzed bounds. The program in general } \\
\text { protects radioactive material and thermal (heat } \\
\text { load) inventories and assumptions for the hot cells, } \\
\text { pool cells, Truckport, capsules, and K-3 HEPA } \\
\text { filter system. The inventories and assumptions are } \\
\text { in Table 3-3, "Hazard Identification Results for } \\
\text { WESF." } \\
\text { The specific assumptions protected by the } \\
\text { program for this accident are: } \\
\text { - A Cell radioactive material inventory and } \\
\text { combustible waste limit } \\
\text { - Solid waste packaging control (precludes free } \\
\text { flow of air) } \\
\text { AC 5.12- PREVENTIVE/ MITIGATIVE: The AC } \\
\text { program includes specific key elements as part of } \\
\text { the overall fire protection program for WESF. } \\
\text { These elements ensure 1) hot cell to hot cell pass } \\
\text { throughs with doors remain normally closed, 2) } \\
\text { ports/cover blocks in place on Cells B-E when } \\
\text { combustibles present, and } 3 \text { ) no combustibles in } \\
\text { Cells F \& G when capsules are exposed and } \\
\text { port/cover blocks are removed. }\end{array}$ \\
\hline
\end{tabular}


HNF-SD-WM-BIO-002 REV1

Table 5-1. Hazard and Accident Analyses; Safety Structures, Systems and Components; and Interim Operational Safety Requirement Cross-Reference.

\begin{tabular}{|c|c|c|c|c|c|c|}
\hline \multirow{2}{*}{$\begin{array}{c}\text { Analyzed } \\
\text { Accident } \\
\text { (from Chapter } \\
3.0 \text { ) }\end{array}$} & \multirow[t]{2}{*}{$\begin{array}{c}\text { Hazard } \\
\text { (from Chapter 3.0) }\end{array}$} & \multicolumn{3}{|c|}{$\begin{array}{l}\text { Safety Structures, Systems, and } \\
\text { Components } \\
\text { (from Chapter 4.0) }\end{array}$} & \multirow[t]{2}{*}{$\begin{array}{l}\text { Interim Operational } \\
\text { Safety Requirement }\end{array}$} & \multirow[t]{2}{*}{ Derivation Basis } \\
\hline & & Description & $\mathrm{SC}$ & $\begin{array}{l}\text { SS } \\
\text { (a) }\end{array}$ & & \\
\hline $\begin{array}{l}\text { Truckport Fire } \\
\text { (Section } \\
3.4 .2 .3 .2 \text { ) }\end{array}$ & $\begin{array}{l}\text { Bounding hazardous } \\
\text { condition } \\
\text { Radiological release } \\
\text { from Truckport }\end{array}$ & Nont & None & Vente & $\begin{array}{l}\mathrm{AC} 5.7 \text { Source } \\
\text { Inventory Controls }\end{array}$ & $\begin{array}{l}\text { Administrative Controls } \\
\text { AC 5.7- PREVENTIVE: See Section 3.4.2.3.1 } \\
\text { above for general derivation basis. The specific } \\
\text { assumptions protected by the program for this } \\
\text { accident are: } \\
\text { - Solid waste radioactive material inventory in the } \\
\text { Truckport } \\
\text { - WESF hot cell waste cask radioactive material } \\
\text { inventory }\end{array}$ \\
\hline \multicolumn{7}{|c|}{ LOSS OF CONFINEMENT (Section 3.4.2.4) } \\
\hline $\begin{array}{l}\text { High Flow in } \\
\text { K-3 Ventilation } \\
\text { System } \\
\text { (Section } \\
3.4 .2 .4 .1 \text { ) }\end{array}$ & $\begin{array}{l}\text { Bounding hazardous } \\
\text { condition } \\
\text { Resuspension of } \\
\text { contamination in K-3 } \\
\text { exhaust duct }\end{array}$ & $\begin{array}{l}\mathrm{K}-3 \text { HEPA filter } \\
\text { system }\end{array}$ & $x$ & None & $\begin{array}{l}\text { AC } 5.7 \text { Sourc } \\
\\
\text { Controls } \\
\text { AC 5.11 K-3 HEPA } \\
\text { Filter System } \\
\text { Efficiency }\end{array}$ & $\begin{array}{l}\text { Administrative Controls } \\
\text { AC 5.7 - PREVENTIVE: See Section } 3.4 .2 .3 .1 \\
\text { above for general derivation basis. The specific } \\
\text { assumption protected by the program for this } \\
\text { accident is: } \\
\text {-The K-3 HEPA filter inventory. } \\
\text { AC } 5.11 \text { - MITIGATIVE: The AC program } \\
\text { requires a nominal particulate removal efficiency } \\
\text { of } 99.90 \% \text { for each K-3 HEPA filter system which } \\
\text { is a credited assumption in the accident analysis. } \\
\text { The HEPA filter system is required to be } \\
\text { efficiency tested at least annually in accordance } \\
\text { with industry standards. }\end{array}$ \\
\hline $\begin{array}{l}\text { Loss of } \mathrm{K}-3 \\
\text { Ventilation } \\
\text { Flow } \\
\text { (Section } \\
\text { 3.4.2.4.2) }\end{array}$ & $\begin{array}{l}\text { Bounding hazardous } \\
\text { Londition } \\
\text { coss of radiological } \\
\text { confinement } \\
\text { Higher temperature in } \\
\text { hot cell used to store } \\
\text { dry capsules }\end{array}$ & None & None & None & $\begin{array}{l}\mathrm{AC} 5.7 \text { Source } \\
\text { Inventory Controls }\end{array}$ & $\begin{array}{l}\text { Administrative Controls } \\
\text { AC 5.7 - PREVENTIVE: See Section } 3.4 .2 .3 .1 \\
\text { above for general derivation basis. The specific } \\
\text { assumptions protected by the program for this } \\
\text { accident are: } \\
\text { - Heat load of stored capsules in F or G Cell } \\
\text { - Hot cell structural surface to capsule distance } \\
\text { minimum of } 20 \mathrm{~cm} \text {. } \\
\text { The heat load of stored capsules in F or G cell } \\
\text { protects the integrity of the safety class hot cell } \\
\text { structure and against accelerated corrosion of the } \\
\text { capsules. The hot cell surface to capsule } \\
\text { minimum distance assumption protects the } \\
\text { structural integrity of the safety class hot cell } \\
\text { structure. }\end{array}$ \\
\hline $\begin{array}{l}\text { K-3 System } \\
\text { Water Accum. } \\
\text { (Section } \\
\text { 3.4.2.4.3) }\end{array}$ & $\begin{array}{l}\text { Bounding hazardous } \\
\text { condition } \\
\text { Hydrogen buildup in } \\
\text { filter housing. High } \\
\text { radiation field above } \\
\text { cover block. }\end{array}$ & None & $\overline{\text { None }}$ & None & $\begin{array}{l}\text { AC } 5.7 \text { Source } \\
\text { Inventory Controls } \\
\text { AC } 5.9 \text { Hydrogen } \\
\text { Prevention Controls }\end{array}$ & $\begin{array}{l}\text { Administrative Controls } \\
\text { AC 5.7 - PREVENTIVE: See Section } 3.4 .2 .3 .1 \\
\text { above for general derivation basis. The specific } \\
\text { assumptions protected by the program for this } \\
\text { accident are: } \\
\text { - A Cell radioactive material inventory } \\
\text { - Solid waste packaging controls (precludes water } \\
\text { infiltration) } \\
\text { - The K-3 HEPA filter inventory. } \\
\text { AC } 5.9 \text { - PREVENTIVE: See Section } 3.4 .2 .4 .5 \\
\text { below for hydrogen control in the hot cells. } \\
\text { Controls are imposed to uetict flooding in a hot } \\
\text { cell and wibcelucint admission of water into the K- } \\
3 \text { filter housing. }\end{array}$ \\
\hline
\end{tabular}


Table 5-1. Hazard and Accident Analyses; Safety Structures, Systems and Components; and Interim Operational Safety Requirement Cross-Reference.

\begin{tabular}{|c|c|c|c|c|c|c|}
\hline \multirow{2}{*}{$\begin{array}{c}\text { Analyzed } \\
\text { Accident } \\
\text { (from Chapter } \\
3.0 \text { ) }\end{array}$} & \multirow[t]{2}{*}{$\begin{array}{c}\text { Hazard } \\
\text { (from Chapter 3.0) }\end{array}$} & \multicolumn{3}{|c|}{$\begin{array}{c}\text { Safety Structures, Systems, and } \\
\text { Components } \\
\text { (from Chapter 4.0) }\end{array}$} & \multirow[t]{2}{*}{$\begin{array}{l}\text { Interim Operational } \\
\text { Safety Requirement }\end{array}$} & \multirow[t]{2}{*}{ Derivation Basis } \\
\hline & & Description & $S C$ & (a) & & \\
\hline $\begin{array}{l}\text { High Activity } \\
\text { in Tank } 100 \\
\text { (Section } \\
\text { 3.4.2.4.4) }\end{array}$ & $\begin{array}{l}\text { Bounding hazardous } \\
\text { condition } \\
\text { Hydrogen buildup in } \\
\text { TK-100 } \\
\text { High radiation field } \\
\text { above cover blocks }\end{array}$ & None & None & None & None & None \\
\hline $\begin{array}{l}\text { Hydrogen } \\
\text { Accumulation } \\
\text { in Hot Cells } \\
\text { (Section } \\
\text { 3.4.2.4.5) }\end{array}$ & $\begin{array}{l}\text { Bounding hazardous } \\
\text { condition } \\
\text { Hydrogen } \\
\text { accumulation in hot } \\
\text { cells. } \\
\text { Initiator to Section } \\
3.4 .2 .4 .3\end{array}$ & None & None & None & $\begin{array}{l}\text { AC } 5.7 \text { Source } \\
\text { Inventory Controls } \\
\text { AC } 5.9 \text { Hydrogen } \\
\text { Prevention } \\
\text { Controls }\end{array}$ & $\begin{array}{l}\text { Administrative Controls } \\
\text { AC 5.7 - PREVENTIVE: See Section 3.4.2.3.1 } \\
\text { above for general derivation basis. The specific } \\
\text { assumptions protected by the program for this } \\
\text { accident is: } \\
\text { - A and F Cell radioactive material inventory } \\
\text { - Solid waste packaging controls (precludes water } \\
\text { infiltration ) } \\
\text { AC } 5.9 \text { - PREVENTIVE: The AC program } \\
\text { prevents hydrogen buildup in the hot cells by } \\
\text { periodically verifying there is no water leakage in } \\
\text { the hot cells and controlling use of water in the hot } \\
\text { cells. If water is visible, then either airflow must } \\
\text { be established, or watur shall be remowed within } 9 \\
\text { dilys of tilw veritiction }\end{array}$ \\
\hline $\begin{array}{l}\text { Flammable Gas } \\
\text { Explosion } \\
\text { (Section } \\
3.4 .2 .5 \text { ) }\end{array}$ & $\begin{array}{l}\text { Bounding hazardous } \\
\text { condition } \\
\text { Flammable gas } \\
\text { explosion and facility } \\
\text { structural failure. } \\
\text { Initiator to Section } \\
3.4 .2 .7\end{array}$ & None & None & None & $\begin{array}{l}\text { AC } 5.14 \\
\text { Flammable Gas } \\
\text { Controls }\end{array}$ & $\begin{array}{l}\text { Administrative Controls } \\
\text { AC 5.14-PREVENTIVE: The AC prevents the } \\
\text { use and storage of flammable gases, such as } \\
\text { propane and acetylene, and highly volatile fuels, } \\
\text { including gasoline but excluding diesel fuel, in the } \\
225+13 \text { facility at any time. }\end{array}$ \\
\hline \multicolumn{7}{|c|}{ LOSS OF CONTAINMENT (Section 3.4.2.6) } \\
\hline $\begin{array}{l}\text { Underwater } \\
\text { Capsule Failure } \\
\text { Due to } \\
\text { Corrosion } \\
\text { (Section } \\
\text { 3.4.2.6.1) }\end{array}$ & $\begin{array}{l}\text { Bounding hazardous } \\
\text { condition } \\
\text { pool cell water } \\
\text { contamination with } \\
\text { radiation dose to } \\
\text { facility workers }\end{array}$ & $\begin{array}{l}\text { Area Radiation } \\
\text { Monitors (ARMs) }\end{array}$ & None & $\mathrm{X}$ & $\begin{array}{l}\text { AC } 5.15 \text { Pool Cell } \\
\text { Area Radiation } \\
\text { Monitors }\end{array}$ & $\begin{array}{l}\text { Administrative Controls } \\
\text { AC 5.10 - MITIGATIVE: The AC program } \\
\text { requires two radiation monitors in the Pool Cell } \\
\text { Area so that protective actions can be taken for } \\
\text { significant facility worker safety. A capsule leak } \\
\text { could result in the release of radioactive material } \\
\text { into the pool cell water and significant radiation } \\
\text { levels in the Pool Cell Area. }\end{array}$ \\
\hline $\begin{array}{l}\text { Underwater } \\
\text { Capsule } \\
\text { Failures Due to } \\
\text { Drop Impacts } \\
\text { (Section } \\
\text { 3.4.2.6.2) }\end{array}$ & $\begin{array}{l}\text { Bounding hazardous } \\
\text { condition } \\
\text { Heavy object drop } \\
\text { resulting in capsule } \\
\text { and/or pool cell } \\
\text { damage with radiation } \\
\text { dose to facility } \\
\text { workers } \\
\text { Initiator to Section } \\
\text { 3.4.2.7.2 }\end{array}$ & $\begin{array}{l}\text { Bridge crane, } \\
\text { catwalk, and } \\
\text { associated support } \\
\text { structures } \\
\text { (Design Features) }\end{array}$ & $\mathrm{x}$ & None & $\begin{array}{l}\text { AC } 5.10 \text { Heavy } \\
\text { Loads Over Pool } \\
\text { Cells }\end{array}$ & 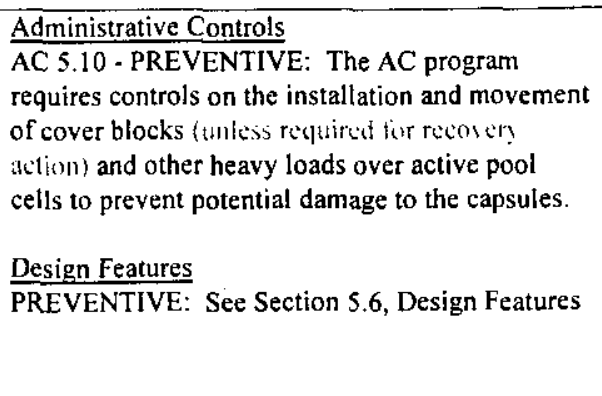 \\
\hline
\end{tabular}


HNF-SD-WM-BIO-002 REV1

Table 5-1. Hazard and Accident Analyses; Safety Structures, Systems and Components; and Interim Operational Safety Requirement Cross-Reference.

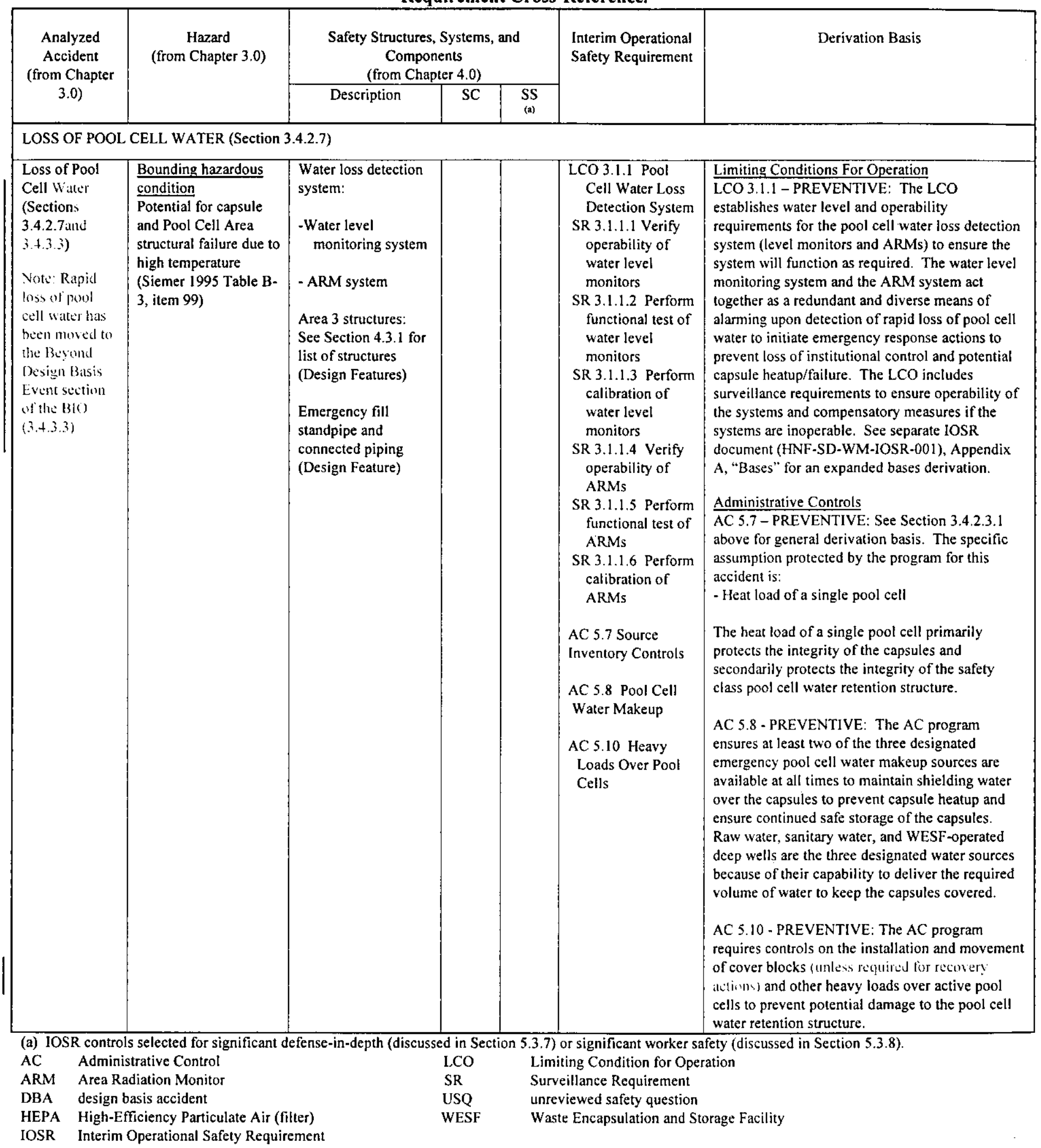


HNF-SD-WM-BIO-002 REV1

Table 5-2. BIO Chapter and Administrative Control IOSR Cross-Reference.

\begin{tabular}{|l|l||}
\hline \multicolumn{1}{|c|}{ BIO Chapter } & \multicolumn{1}{|c|}{ IOSR Administrative Controls ${ }^{(\mathbf{a})}$} \\
\hline Chapter 1 - Introduction and Summary & Not Applicable \\
\hline Chapter 2 - Facility Description & Not Applicable \\
\hline Chapter 3 - Hazard and Accident Analyses & See Table 5-1 \\
\hline Chapter 4 - Safety Structures, Systems, and Components & See Table 5-1 \\
\hline Chapter 5 - Derivation of Interim Operational Safety Requirements & Not Applicable \\
\hline Chapter 6 - Safety Related Programs and Controls & $\begin{array}{l}\text { AC 5.2 - Contractor Responsibility } \\
\text { AC 5.5 - Occurrence Reporting } \\
\text { AC 5.6 - Organization } \\
\text { AC 5.12 - Fire Protection Program }\end{array}$ \\
\hline Chapter 7 - References & Not Applicable \\
\hline
\end{tabular}

(a) The IOSR Administrative Controls in this table are those provisions relating to organization and management, reporting, and health and safety programs for risk reduction necessary to the operational safety of WESF.

BIO Basis for Interim Operation

IOSR Interim Operational Safety Requirement

WESF Waste Encapsulation and Storage Facility 
HNF-SD-WM-BIO-002 REV1

This page intentionally left blank. 


\subsection{SAFETY RELATED PROGRAMS AND CONTROLS}

This chapter provides an overview of the Institutional Safety Programs and Configuration Control System in place at WESF to ensure the safe operation of the facility. The safety related programs and controls at WESF are organized into the following major areas:

- Radiation Protection

- Hazardous Material Protection

- Radioactive and Hazardous Waste Management

- Operational Safety

- Emergency Preparedness

- Procedures and Training

- Initial Testing, In-service Surveillance, and Maintenance

- Quality Assurance

- Management Organization and Institutional Safety Provisions.

The W'FSF Standards/Requirements Identification Document (S/RID), WHC-SD-MP-SRID-007, Rev. 0, (Oldtield $200(1)$ sets forth the Environmental, Safety and Health (ES\&H) standards and requirements that WESF is required to satisfy. The WESF facility is exempt from criticality control according to the Compliance Assessment and Implementation Plan, Statement of Non-Applicability for WESF transmitted in the Transmittal of Implementation Plan for DOE Order 5480.24, Nuclear Criticality Safety (Reed 1994a). .

$\triangle$ list of the Project Ifanford Mandagement Contract (PIMC) site implementing procedures organized by category (e.s. Radiation Protections. Environmental Protection. Configuration Managencul. elc.) is provided on the Hanford Site lntranet (hrtp: apscl01.rl.gov phpp/procedures/index.asp). These procedures will be referred to as IINF-PROs throughout this chapter.

\subsection{RADIATION PROTECTION}

Section 6.1 summarizes the essential features of the radiation protection program as it relates to worker radiological safety at WESF. The WESF radiation protection program is designed and implemented to provide a radiologically safe work place for occupational radiological workers, other facility personnel, and visitors. Additionally, the radiation protection program at WESF supports the mitigation of potential accidents described in Chapter 3.0, "Hazard and Accident Analyses."

Radiation protection requirements are provided in the HNF-PROS; the PHMC Radiological Control Manual (HNF-
5173 ): and WESF procedures.

\subsubsection{Radiation Protection Program and Organization}

The radiation protection program is administered and coordinated at the PIIMC level in order to promote consistency in requirements management, implementation, and to maximize the usefulness in sharing developed applications between Hanford facilities. WESF maintains an active role in decisions relevant to policy matters and implementation details for WESF.

WESF Radiological Control (RadCon) personnel provide technical support for implementation of occupational radiation protection policies and requirements into daily operations at the WESF.

\subsubsection{As Low As Reasonably Achievable Policy and Program}

The comprehensive site and WESF ALARA policy is to minimize human and environmental exposures to radiological or hazardous conditions. The program describes responsibilities for management, facility staff and facility support staff such as the radiation control specialists. Requirements are described for reporting, recording and implementing ALARA into the facility operational activities and training. Each person has specific responsibilities related to achieving and maintaining ALARA goals, appropriate for job categories and facility objectives. 


\subsubsection{Radiological Protection Training}

Standing or long term radiological protection training requirements for personnel working at or near WESF is provided through the Hanford Site training program. The program includes a multi-layered Radiation Protection Training Program that provides a level of training that corresponds to an individual's classification as well as the individual's specific work assignments. Additional radiological training on facility specific requirements (facility radiological orientations) are administered at WESF.

Training is provided to employees with a level of information commensurate with the employee's job assignment and anticipated hazard level of exposure. Basic radiation protection policies, risks and radiation protection applications such as radiological postings, emergency procedures and use of dosimeters are addressed. Supervisors and managers are required to complete training commensurate with their responsibilities and work scope. More detailed training is provided to radiological workers and radiological control technicians and the related management. The training addresses applied radiological work situations typical for various hazard levels of radiological areas.

Continuing training requirements are tracked for each occupational radiological worker assigned to or visiting WESF, at intervals that are assigned to specific training courses. Records are maintained, in particular for those individuals who are required to achieve and maintain occupational radiological worker qualifications.

\subsubsection{Radiation Exposure Control}

The Radiation Exposure Administrative Control Levels are established below the regulatory limits to administratively control and help reduce individual and collective radiation dose. These control levels are multi-tiered with increasing levels of authority required to approve higher administrative control levels or planned special exposures. Procedural requirements for summing internal and external radiation exposures are implemented at WESF, by procurement of centralized dosimetry services, standards, and procedures.

Radiation exposure control at WESF is managed on a daily basis through the implementation of the radiological review process for technical work documents such as operational and maintenance procedures, and work packages for work to be completed in radiological areas. The reviews are conducted by the cognizant facility staff members and assigned radiation control staff who are responsible for supporting the completion of the work assignment.

Radiological areas at WESF are posted with radiological notifications and radiation work permits are issued at WESF according to the WESF radiation protection program.

Access control requirements at WESF are implemented by the Access Control Entry System (ACES) computer based system, which allows verification of critical qualifications prior to radiological area entry authorization, in order to control access to radiological areas. Dosimetry, individual dose tracking, training, personnel protective equipment including respiratory protection equipment, and other key control parameters critical for occupational radiation protection implementation are monitored and administered at WESF by the ACES station operator.

Visitors and vendors are required to have appropriate training before entering WESF.

\subsubsection{Radiological Monitoring, Instrumentation, and Record Keeping}

Radiological monitoring devices and radiological protection instrumentation are provided throughout WESF. Chapter 2.0, Facility Description, provides a description of the monitoring devices and radiological protection instrumentation. Chapters 3.0, "Hazards and Accident Analysis," 4.0, "Safety Structures, Systems, and Components," and 5.0, "Derivation of Interim Operational Safety Requirements," discuss monitoring devices and protection instrumentation that is important for mitigating and/or preventing the analyzed accidents.

Occupational radiological monitoring devices at WESF are generally categorized as fixed (stationary) or portable. The fixed monitoring systems and devices are generally limited to applications within building confines of WESF. The portable monitoring devices are used to monitor both occupational radiological conditions willin the facility and immediately surrounding the facility. 
Fixed radiological monitoring devices at WESF that are used to support the occupational radiation protection program (or to support facility safety) include the following types: area monitoring systems (direct radiation monitor application) and personnel contamination self-survey stations (frisking booths). Portable radiological monitoring devices at WESF that are used to support the occupational radiation protection program include a variety of hand held instrumentation, such as ion chambers, contamination friskers, and air monitoring equipment.

Independent near-facility monitoring, external to the facility, is also conducted by others within the company, to verify and confirm the impacts of WESF operations.

The WESF program includes record keeping of occupational radiation protection program measurements.

\subsection{HAZARDOUS MATERIAL PROTECTION}

This section describes the essential elements of the Hazardous Material Protection program as it relates to the operation of WESF. Hazardous material protection for WESF is obtained through implementation of site and facility specific industrial

hygiene, industrial safety, and environmental chemical management programs. The goal is to protect workers and the environment from exposure to hazardous materials.

Hazardous substances or materials referred to in this section are those nonradioactive materials that pose a hazard to workers or to the public because of their chemical properties. The hazardous materials at WESF are identified in Table 3-3.

\subsubsection{Hazardous Material Protection and Organization}

A sitewide hazardous materials safety program is chartered to accomplish the following:

- Develop and administer industrial health and safety programs and requirements

- Perform independent reviews of activities and documents having potential industrial safety or hygiene implications

- Support facilities safety personnel with safety and health expertise

- Monitor hazardous material and fire safety conditions across the site

- Share information with all the facilities

WESF retains an industrial safely prolessional who coordinates with the Waste Management Project industrial hygienist to cover activities involving hazardous material. Responsibilities include evaluating potential facility hazards, identifying appropriate monitoring procedures to ensure compliance with all pertinent exposure limits, and ensuring that areas with such hazards are properly posted and that access is controlled appropriately.

The WESF organization fulfills its responsibilities for safe operation of the facility by maintaining and coordinating ALARA and safety awareness programs to minimize hazards exposure, increase health and safety awareness, alert personnel to known hazards, and recognize positive safety performance. See Section 6.1.2, for additional discussion of the WESF ALARA program.

\subsubsection{Hazardous Material Training}

Safety training is provided to all WESF employees commensurate with the sitewide training program. The training program consists of courses in general safety awareness, nuclear safety, and courses dealing with hazardous materials and waste.

Employees who routinely work with hazardous chemicals or materials or who may contact hazardous material during a foreseeable emergency, receive general classroom training (i.e., hazard communication and waste management awareness training) as well as facility- or job-specific hazard training. Facility- or job-related hazard training is provided by the manager, supervisor, safety trainer, or other qualified individual. Employees receive on-the-job, area-specific training for the chemical 


\section{HNF-SD-WM-BIO-002 REV1}

hazards they work with or that are present in their work area.

\subsubsection{Hazardous Material Monitoring}

The WESF hazardous material monitoring program meets the requirements for toxic chemical release reporting and hazardous chemical inventories reporting. The hazardous material inventory is updated monthly. This information is provided to a computerized database system that automates sitewide hazardous chemical inventory gathering and reporting. The database includes information about storage location, product name, manufacturer, chemical constituents, physical state, container description, and total quantity for all chemical products stored in facilities that maintain an inventory of hazardous chemicals.

\subsubsection{Hazardous Material Instrumentation}

Hazardous material instrumentation for nonradiological hazardous material is not required at the WESF.

\subsubsection{Hazardous Material Exposure Control, Record Keeping, and Communication}

Records of worker toxicological material exposure, including the results of lab analyses from personal monitoring, are I kept by FH industrial hygiene programs in the Hansord industrial hygiene database.

A written facility specific Hazard Communication Program (HazCom) has been implemented and is maintained for the work areas in the WESF facility. The HazCom and waste management awareness training introduces workers to federal laws governing chemical safety in the workplace.

The WESF respiratory protection program requires that the use of respiratory protection be planned in advance of an activity to protect employees against the inhalation of harmful air contaminants and against oxygen deficient atmospheres. Only respirators approved by the National Institute for Occupational Safety and Health and/or the Mine Safety and Health Administration are used. Employees are medically screened, fit-tested, and trained before using respirators. Respirator and | cartridge selection for non-radiological hazards is performed by an industrial hygienist. An independent annual appraisal of the respiratory protection program is conducted to assess compliance with DOE-mandated standards.

Material Safety Data Sheets (MSDSs) are available for all chemicals used and stored at WESF.

\subsubsection{Occupational Chemical Exposure}

Requirements regurcling occupational exposure to chemicals are addressed in the company controlled procedures (HNF-PROS), and the American Conference of Governmental Industrial Hygienists Threshold Limit Values [ACGIH-TLVS]). These standards define management and personnel requirements and responsibilities for safe handling of these chemicals, including information on training, safe handling, concentration and contamination limits, medical surveillance programs, personal protective equipment and emergency procedures.

\subsection{RADIOACTIVE AND HAZARDOUS WASTE MANAGEMENT} WESF.

This section provides a general overview of the radioactive and hazardous waste management program in place at

\subsubsection{Radioactive and Hazardous Waste Management Program and Organization}

Administrative procedures have been established in the HNE-PROS for all facilities on the Hanford Site to follow in managing their radioactive and hazardous waste.

WESF has developed appropriate operating procedures and training programs for its solid waste management program so that it meets the requirements dictated by all applicable regulations and requirements. All waste generated at WESF is inspected, handled and packaged in accordance with these established procedures. 


\subsubsection{Radioactive and Hazardous Waste Streams and Sources}

The WESF waste sources and streams are described in greater detail in Sections 2.4 and 2.6.

WESF personnel generate routine quantities of solid low-level radioactive waste during radiological work in the WESF hot cells, as well as other contaminated areas in and around the facility. This waste is collected and transferred to an appropriate disposal facility.

WESF also generates radioactive liquid waste from the hot cells and other potentially contaminated areas in WESF. This waste is collected in TK-100, transferred to a tanker truch. and removed from the lacility for ultimate disposal.

\subsection{OPERATIONAL SAFETY}

This section summarizes the WESF conduct of operations, configuration management, and fire protection programs.

\subsubsection{Conduct of Operations}

Cuidance lor conduct of operations at WESF is provided by DOE Order 5480.19 . Conduct of Operatim Requirements

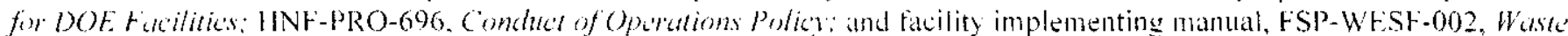
Encapsulution and Storage Ficility Condurt of (operations. The specitic procedure, chapter, and section that implements each part of the 18 chapters of the DOt. Order are defined in the Conduct of Operations Applicability Matrix (Olguin 1999).

Development and implementation of the conduct of operations program as well as monitoring and assessing work performance is the responsibility of the WESF organi zation. The WESF employees are responsible for managing, operating, and maintaining the facility in a safe and efficient manner within the framework of the conduct of operations program.

The WESF conduct of operations program provides effective implementation and control of operating activities through the establishment and communication of written standards and goals in operations; through the performance and communication of periodic inspections, audits, reviews, investigations and self-assessments of operating performance; and by establishing a process for enforcing personnel accountability for performance.

Shift routines, operations turnover, control area activities, aspects of unique operations or processes, and operating practices (including response to emergencies) are specified and communicated to facility personnel.

Communications to personnel at locations other than within WESF is performed by pager, phone, or over the public address system. All areas have adequate coverage for alarms ensuring that employees are notified in case of an emergency.

Procedures are documented and implemented for independent verification, control of equipment and system status, lockouts and tagouts, equipment and piping labeling, and log keeping and recording of operational activities. A system is in place for communicating timely orders to operations personnel.

Additional skill development is provided to facility personnel through operator aid postings, required reading notifications, and on-shift training when required.

\subsubsection{Configuration Management}

I Configuration management is a process for establishing and maintaining consistency of the facility's performance, functional, and physical attributes with its requirements, design, and operational documentation. The Unreviewed Safety Question Process is used to ensure the facility configuration remains within safety basis requirements.

\subsubsection{Operating Configuration.}

Operating configuration is maintaining awareness of the current status of the facility's operating systems. Operating configuration control is achieved through a system of operating procedures, lockout/tagout procedures, communication, work management techniques, and accurate status accounting of variances. 


\subsubsection{Design Configuration.}

Design modifications are controlled by HNF-PROs and ficility procedures, using Engineering Change Notices (ECNs). Work management documentation and other support documentation provide the controls to ensure the plant design configuration is maintained according to requirements and acceptable engineering practices.

Design configuration changes must be reflected in operating, maintenance, and surveillance procedures, and operations and maintenance training. Other considerations are safety analysis documents and safety SSC changes. This ensures minimal impact to facility operation due to design changes.

\subsubsection{Critical Interfaces.}

Critical interfaces occur wherever the work management system interfaces with other systems or when work is performed in a facility by persons who are not part of the work force normally assigned to the facility (non-plant work force). Significant work may require an operations readiness review.

Critical interfaces with the work management system include, but are not limited to:

- The engineering design document control system.

- Various permits and lockout/tagout systems

- Non-plant forces work, such as sub-contractor and service organizations.

\subsubsection{Engineering Design Interface.}

Engineering design interface with work management requires the design work to be completed before work acceptance. This ensures the design work has been completed according to specified instructions and drawings. Upon completion, the equipment is tested to ensure it operates within design parameters. If testing is unsatisfactory, the design will require review and changes to the system or parameters made for acceptance.

\subsubsection{Maintenance History.}

An equipment maintenance history and vendor information program provides historical information for maintenance planning and supports maintenance and performance trending analysis. A maintenance history also supports maintenance activity planning, upgrade programs, equipment performance and reliability.

\subsubsection{Performance Indicators.}

Performance Indicators are used to assess results and evaluate methods for continuous process improvement and are mandated by DOE directives. These management tools provide visual indication on the work management process effectiveness. The work management system shall provide the ability to use performance indicators that characterize the performance of the work management system.

\subsubsection{Fire Hazards Analysis}

A fire hazard analysis (FHA) has been prepared for WESF (Mertz 1998) and was used to develop accident analyses described in Chapter 3.0. The FHA describes the fire hazards present in WESF; the potential extent of fire damage; the impact of candidate fires on the process, employees, and public safety; and the effectiveness of WESF fire protection. The accident analyses provides radiological dose consequences to the onsite worker and offsite population for fire-related accidents.

6.4.3.1 Fire Hazards. The fire protection program is designed to protect against and/or provide direction for responding to those potential fire hazards identified in the WESF FHA and the accident analysis in Chapter 3.0. The potential fire hazards have been identified as follows: 


\section{HNF-SD-WM-BIO-002 REV1}

- Ignition of combustible materials in one or more hot cells (Section 3.4.2.3.1)

- Ignition of fuel from a truck and/or forklift in the Truckport or Truckport transfer area (Section 3.4.2.3.2)

- Facility explosions due to flammable gas and hydrogen concentration buildup, explosion, and subsequent fire in the Pool Cells (Section 3.4.2.5)

- Hydrogen concentration buildup, explosion, and subsequent fire in Tank TK-100 (Section 3.4.2.4.4)

- Hydrogen concentration buildup, explosion, and subsequent fire in the K-3 filters (Section 3.4.2.4.3)

- Hydrogen concentration buildup, explosion, and subsequent fire in the hot cells (Section 3.4.2.4.5).

\subsubsection{Fire Protection Program and Organization.}

The Fire Protection Program is PllMC-wide and involves empolyees in every PHMC company. The responsibilities of each organization are identified in the HNF-PROs and summarized here.

The FDH Industrial Safety and Fire Protection (IS\&FP) organization establishes and interprets tire protection (including l. ife Safety Code and National telectrical Codes) policies. standards and reguirements, and maintains the PHMC fire protection program procedures. IS\&FP also serves as the PHMC technical contact for lire prolection regulations and reviews and approves exemptions'equivalency/deviation recuests from fïre protection standards and recpuirements.

The subcontractor Fire Protection Engineers ( $F$ PFs) participate in design and document reviews to assess compliance with fire protecsion requirements and perform tire protection facility assessments. FPEs provide technical supporl to project organizations to assist with implementation of the fire Protection program and assist line management with fire investigations. resolution of tire system diserepancies and preparation of exemptions/equivalency/devialion requests.

The Hanford Fire Department (HFD) is responsible lor lire system inspection testingmaintenance and repair activities of fire suppression sýstems. hazardous material response and control, fire and life safety permitting. respiratory equipnent servicing and maintenance. emergency rescue and medical response for the Hanford Sile, and administering the fire prevention program. The HFD main tire station is located between the 200 fast and 200 West Areas. The department is staffed on a 24-hr, 7-day basis.

\subsubsection{Combustible Loading Control.}

The WESF management ensures that the use of combustible materials is properly controlled and conforms to ALARA requirements. The combustible loading quantities are provided in Chapter 3.0, Table 3-3 under Flammable Material.

Table 6-I provides a summary of combustible material type and location.

Table 6-1. Waste Encapsulation Storage Facility Combustible Material Type.

\begin{tabular}{|l|l|}
\hline \multicolumn{1}{|c|}{ LOCATION } & \multicolumn{1}{c|}{ TYPE } \\
\hline Truckport/Truckport transfer area & $\begin{array}{l}\text { Truck/forklift diesel fuel, bags of contaminated low-level } \\
\text { mixed cellulose material and plastic }\end{array}$ \\
\hline $\begin{array}{l}\text { Tank TK-100, K-3 filters, hot cells, and } \\
\text { Pool Cells }\end{array}$ & Radiolytic hydrogen \\
\hline Hot cells & Manipulator boots, clothing, plastic, tools, etc. \\
\hline
\end{tabular}

Hazardous material is not permitted in areas routinely accessed by personnel and is stored in containers that comply with the applicable fire protection standards. Accumulations of combustible materials are limited to the quantity required for current needs and they are separated from ignition sources. A ventilation system helps to protect against the accumulation of hydrogen in the K-3 filters, and the Pool Cell Area. An IOSR control has been developed to prevent the addition of flammable gases, such as propane and acetylene, and highly volatile fuels, including gasoline but excluding diesel, in the 


\section{HNF-SD-WM-BIO-002 REV!}

facility to protect against explosions.

\subsubsection{Fire Fighting Capabilities.}

The fire protection system and fire fighting capability at WESF are described in additional detail in the WESF FHA (Mertz 1998) and Chapter 2.0.

The Columbia River provides the source of water for the Hanford Site by the export water system. WESF is served by

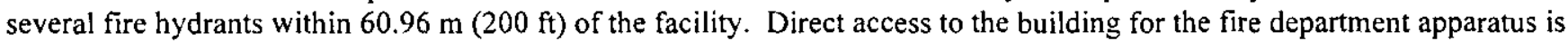
provided. However, if an area is radiologically contaminated, containment cannot be maintained if hoseline access is required.

Portions of the 225-B Building are protected with an automatic wet-pipe sprinkler. When activated, the system provides an alarm within the building and directly to the HFD.

Portable fire extinguishers are located throughout WESF. Smoke and heat detectors are located in portions of the facility as described in the FHA (Mertz 1998).

Manual pull fire alarms are provided at every exit, which activate local WESF alarms and alarms in the HFD dispatching office which is manned continuously. There is an auxiliary annunciator panel outside the dispatcher's office that indicates alarms for WESF fire zones and detector zones.

The WESF employees are provided training in fire notification and response and appropriate use of fire extinguishers. The WESF procedure requires the staff to activate the building fire alarm system, immediately evacuate the building, and report to a designated assembly area.

\subsubsection{Fire Fighting Readiness Assurance.}

Fire fighting readiness assurance is implemented through the HFD Protection Program with primary responsibility residing with the HFD organization.

The HFD performs inspection, testing and maintenance of all fire alarms, and fire suppression and response equipment, and fire suppression systems for WESF. The HFD maintains records of all the inspection, testing, and maintenance activities that are performed. Records are also maintained on system deactivations and reactivations. The HFD is responsible for developing and maintaining inspection, testing, and maintenance schedules and for providing required work control. Schedules are coordinated with WESF. When requested, the HFD performs fire watch services for the WESF.

\subsection{EMERGENCY PREPAREDNESS}

This section provides a summary of the emergency preparedness and response functions including summaries of the major features of the programmatic commitment to the safety basis.

\subsubsection{Summary of Facility Hazards}

Postulated accidents are analyzed in Chapter 3.0 to identify dose consequences to the onsite worker and the offsite general population. The primary operational hazards of concern are: (1) the loss of water over the capsules in the Pool Cells and the resulting direct radiation doses and (2) the consequences of a fire and/or explosion, which would result in unacceptable dose consequences from dispersion of contaminated particulates and in some accident scenarios could lead to loss of Pool Cell water over the capsules as well. Other hazards of concern are natural phenomena (e.g., earthquakes), and incidents involving breaching of facility ventilation systems. Dose consequences for the analyzed accidents are provided in Chapter 3.0, Table 3-1. 


\subsubsection{Summary of Emergency Preparedness Planning Program}

\subsubsection{Emergency Response Organization.}

The DOE maintains the option to assume overall management, direction, and control of any Hanford Site emergency. The Hanford Site emergency response organization has been developed to allow the site contractors to continue their management and operational roles in the event of an emergency.

The Hanford Site emergency response organization comprises two components. The first component consists of Hanford Site contractor response personnel and emergency management teams with the responsibility for responding to and mitigating an emergency on the Hanford Site. The second component consists of the DOE emergency management team that has the responsibility to oversee the onsite response, assess the offsite impacts, and interface with offsite agencies and the public.

The WESF emergency preparedness program is developed, implemented and maintained in coordination with the Hanford Site emergency response organization. The program requires the identification of a Building Emergency Director (BED) and designated alternates. The BED or alternates have overall responsibility for implementing the WESF emergency response plan. The BEDs have the authority to commit all necessary resources (both equipment and personnel) to respond to any emergency. Overall event scene emergency response will be directed by the Incident Commander. The Incident Commander is assisted by the BED and any other designated command system personnel or facility emergeney response organization members.

The objective of the emergency preparedness program is to deal effectively with an event, whether it is an unusual occurrence (which may affect and require notification of only onsite personnel), or an emergency (which may impact and require offsite notification [i.e., alert, site area emergency, general emergency]).

An operational emergency is one of three categories of emergencies. Operational emergencies are significant accidents, incidents, events, or natural phenomena that seriously degrade the safety or security of DOE facilities. There are three emergency event classes: alert, site area emergency, and general emergency.

- An Alert represents events that are in progress or have occurred that involve an actual or a potential substantial degradation of the level of safety at a facility. Any environmental releases of hazardous materials are expected to be limited to fractions of the appropriate protective action guideline. In an alert, the Hanford Site emergency response organization will activate all onsite affected emergency centers and initiate mitigation of the severity of the occurrence or its consequences. Continuous assessments and communications are carried on with all public entities and the pertinent DOE authorities.

- A site area emergency represents events that are in progress or have occurred that involve actual or likely major failure(s) of facility safety or safeguards systems needed for the protection of onsite personnel, the public health and safety, the environment, or national security. Any environmental releases of hazardous materials are expected to exceed the appropriate protective action guideline. In a site area emergency, the Hanford Site emergency response organization activates the response centers and other emergency assets to provide continuous assessment of information for Hanford Site contractor and DOE decision makers, offsite authorities, and other appropriate entities.

- A general emergency represents events that are in progress or have occurred that involve actual or imminent catastrophic failure of facility safety systems with potential for loss of confinement integrity, catastrophic degradation of facility protection systems, or catastrophic failure in safety or protection systems threatening the integrity of a weapon or test device, which could lead to substantial offsite impacts. Any environmental releases of hazardous materials can reasonably be expected to exceed the appropriate protective action guideline ( $10 \mathrm{mSv}$ [1 rem]) or emergency response planning guidelines (ERPG-2) exposure levels at or beyond the Hanford Site boundary. In a general emergency, the Hanford Site emergency response organization activates the response centers and other emergency assets to provide continuous assessment of information and communications with public and DOE authorities and to mitigate the severity of the actual or potential consequences. 


\section{HNF-SD-WM-BIO-002 REV1}

\subsubsection{Assessment Actions.}

An emergency response is activated when the BED has determined that a radiological or hazardous release, fire, or explosion that could threaten human health or the environment has occurred at the facility. An incident requiring evacuation of personnel or the summoning of emergency response units will not necessarily indicate that the plan has been activated.

The emergency response plan is implemented whenever the BED determines that the severity of the incident is or will be a potential to endanger human health or the environment. The WESF organization implements the emergency response plan through specific implementing procedures identified for each postulated incident.

The BED must assess each incident to determine the response necessary to protect personnel, the facility, and the environment. If assistance from patrol, fire, or ambulance units is required, the Hanford emergency response number (911) is used to contact the Patrol Operations Center and request the desired assistance.

The initial response for any emergency is to protect the health and safety of persons in the immediate area. Identification of released radiological or hazardous material is essential to determine appropriate protective actions. Containment, treatment, and disposal assessment are secondary responses.

The WESF assessment approach provides a description of generic incident responses, describes the process for assessing and identifying the hazardous materials and/or dangerous waste, and describes the process for categorizing and classifying an incident.

Consequence assessments evaluate and interpret radiological or other hazardous materials measurements or other information during a declared emergency to provide a basis for decision making. The Unified Dose Assessment Center has the primary responsibility for overall onsite and offsite consequence assessment for the Hanford Site.

\subsubsection{Notification.}

The DOE and site contractor will respond to all emergencies within the Hanford Site boundary. The DOE and its contractors have established arrangements to coordinate responses to emergencies. The DOE identifies the planning and responsibilities for notification and interface with other organizations for an emergency or other incident at the Hanford Site. The DOE has established a number of coordination agreements, or memoranda of understanding, with various agencies to ensure proper response resource availability for incidents involving the Hanford Site. The DOE has also established interface understandings with other federal, tribal, state, local and private organizations.

Notification of an emergency event may be initiated by a WESF staff person who becomes aware of a condition that may affect operations. In some instances the automatic or manual actuation of a facility alarm might be the alerting mechanism. If an alarm is not the initiating action, a staff person calls 911 or 373-3800 and provides his/her name, the nature of the emergency, and exact location of the emergency. The DOE will notify outside agencies and organizations as necessary.

\subsubsection{Emergency Facilities and Equipment.}

The WESF alarm system is designed to alarm in a specific alarming format that identifies the type of response that is required from the employees (e.g., evacuate, take cover). 
Table 6-2 provides a summary description of the emergency communications equipment available at WESF.

Table 6-2. WESF Communications Equipment.

\begin{tabular}{|c|c|c|}
\hline TYPE & LOCATION & CAPABILITY \\
\hline $\begin{array}{c}\text { Public Address System } \\
\begin{array}{c}\text { Hanford Site standard emergency } \\
\text { signals }\end{array}\end{array}$ & Key locations & Internal Communication \\
\hline Crash Alarm Telephone System & WESF Operations Base & Emergency notification to personnel \\
\hline Two-way radios & Key personnel & Internal communications \\
\hline Cellular phones & On-call manager BE:D & External communications \\
\hline
\end{tabular}

Table 6-3, provides a summary of the equipment available to personnel and the equipment location, and functional capabilities.

Table 6-3. WESF Personal Protective Equipment.

\begin{tabular}{|c|c|c|}
\hline Type & Location & Capability \\
\hline PPE & Key locations in the WESF complex & Personnel contamination protection \\
\hline Respirators & 225 -B SWP lobby & Airborne contamination protection \\
\hline
\end{tabular}

PPF = personnel protective equipment.

\subsubsection{Protective Actions.}

Protective actions are taken during an emergency to prevent or minimize actual and/or projected exposure to releases of radioactive and/or nonradioactive hazardous materials. Specific actions are typically in the form of sheltering and/or evacuation, or the use of time, distance, and shielding to reduce exposure to hazardous materials by emergency workers and the public.

Protective action guides are used to determine the appropriate protective actions as identified in DOE-RL 1995b. The WESF BED classifies an event as an operational emergency, using facility emergency action levels. Based on the classification and event, the BED implements initial onsite protective actions and, if necessary, makes initial offsite protective action recommendations. Protective actions at WESF are designed to minimize exposure to workers and the public. The WESF emergency response program provides procedures that describe responses to those operational emergencies that are considered to be potential events that could occur during operation of the facility and in particular those events that have radiological or chemical dose consequences that exceed guidelines.

\subsubsection{Training and Exercises.}

The Hanford Site and WESF emergency preparedness planning program incorporates emergency response training which is conducted at all levels (i.e., the facility, area, and RL Emergency Operations Center). Specialized individual training programs are provided for WESF, Hanford Site contractors, DOE staff, and non-DOE emergency personnel. Emergency drills and exercises are conducted to train workers and evaluate the adequacy of the emergency facilities, equipment, procedures, communication channels, actions of emergency response personnel, and coordination between the organizations. 


\subsubsection{Recovery and Reentry.}

A WESF operations recovery plan is developed when necessary. A recovery plan is needed following an event when further risk could be introduced to personnel, the facility, or the environment through recovery actions and/or to maximize the preservation of evidence. Depending on the magnitude of the event and the effort required to recover from it, recovery planning may involve personnel from DOE and other contractors. If a recovery plan is required, it is reviewed by appropriate personnel and approved by management before facility restart. Restart of operations is performed in accordance with the approved plan.

For emergencies not involving activation of the RL Emergency (Spcrations Center, the WESF BED ensures that conditions are restored to normal before operations are resumed. If the Hanford Site emergency organization was activated and the emergency required evacuation from a facility and/or the Hanford Site, the actions that follow fall into three processes when the emergency has been stabilized. These three processes or activities are emergency event termination, reentry, and recovery.

The emergency can be officially terminated when the event has been stabilized and onsite and protective actions have been implemented. Termination occurs after all the applicable criteria has been met and concurrence between the event contractor and DOE has been obtained. Notification of termination of an event is made to all relevant onsite entities as well as DOE Headquarters and relevant state, county, and offsite agencies.

Reentry is the act of reentering an evacuated area for the purpose of performing emergency activities or to assess facility damage for the purpose of determining if the emergency can be terminated and/or for determining the extent of required recovery activities. Reentry can be performed at any time before termination of the emergency and during recovery activities.

Upon termination of the emergency event, plans are developed to return the affected facility and surrounding areas to normal. Upon completion of the initial reentry team assessment and evaluation activities, the emergency director will designate a manager of recovery operations. The manager of recovery operations will assess the extent of recovery operations necessary and determine the organization needed to implement those operations. Recovering actions include a formal investigation and report.

\subsection{PROCEDURES AND TRAINING}

The WESF procedures are designed to support the safe operation of the WESF facility and support the mitigation and/or prevention of the accidents analyzed in Chapter 3.0.

\subsubsection{Procedure Program}

A program has been implemented at WESF for developing and maintaining operating, maintentuce and administrative procedures that apply to technical work activities directly affecting the operating or design configuration and/or operability or accuracy of the structures, systems, equipment or components.

The WESF procedures include, but are not limited to the following:

- Normal operating procedures

- Planned nonroutine operating procedures

- Alarm response procedures

- Emergency response procedures

- Radiological control procedures

- Maintenance procedures

- Fire protection procedures

- Surveillance procedures 
- Test procedures

- Calibration and testing procedures

- Administrative support procedures

Development and maintenance of the procedures are provided through identification of new activities, periodic reviews of current procedures, and field-identified changes to existing procedures. Responsibility for the implementation of the procedure program resides with the WESF team and to the individual team member assigned specifically to safety-related SSCs and/or to an operations activity. A structured review and approval process is used by the WESF organization for completing new procedures and for revising or upgrading procedures.

\subsubsection{Training Program}

The WESF training program specifies education, experience, and training requirements for personnel; and the records system necessary to document that each individual has and maintains the necessary skills to perform their assignments safely, accurately, and efficiently.

On-shift and classroom training is provided in the following areas as appropriate to an employee's assigned duties:

- Training on safety class and safety significant systems, structures and components (SSC)

- Conduct of normal, abnormal, and emergency operations

- $\quad$ Radiation and hazardous material protection training

- Surveillance, testing, and maintenance training

- $\quad$ Fire protection training

- Quality assurance training

- $\quad$ Emergency preparedness training including drill programs

- Interim operational safety requirements (IOSR) training

- Unreviewed Safety Question (USQ) training.

The WESF training program provides a method of documenting and maintaining records of an individual's training through the use of qualification cards and/or training completion records.

Development, maintenance, and modification of training materials and content are controlled through the implementation of change control procedures covering training programs and methodology.

\subsection{INITIAL TESTING, IN-SERVICE SURVEILLANCE, AND MAINTENANCE}

The testing, in-service surveillance, and maintenance programs and procedures are designed and implemented to support the mitigation of and/or prevention of the accidents analyzed in Chapter 3.0. The detailed programmatic requirements are provided in the HNF-PRO and hacility spocilic procedures.

\subsubsection{Initial Testing}

The initial testing program ensures operability of facility modifications prior to service and ensures that adequate testing is conducted to support facility safety management. If a new system or a significant modification to an existing system is installed, the site program and procedure for operational readiness reviews or readiness assessments will be implemented prior to the startup or restart of the facility. 


\section{HNF-SD-WM-BIO-002 REVI}

Testing is planned, controlled, and documented within the readiness process. Upon approval of the readiness review, testing is initiated and completed. The content of the test program is determined by the size, complexity and technical risk associated with the test. The test document may include but is not limited to:

- Describing measurement and test equipment calibration requirements

- Identification, training, and qualification requirements for test personnel

- Facility identification, status, and condition requirements

- Administration of safety requirements

- Controls for nonconforming items and retest requirements.

Upon identification and training of the test team and execution of the test, the program requires documented review and analysis of the written test results to verify the acceptability of the test SSCs.

\subsubsection{In-Service Surveillance and Maintenance Program}

The WESF in-service surveillance and maintenance program relies primarily on an automated recall system for identifying, changing, reporting and closing out in-service surveillance and maintenance activities. The recall system is a computerized automated database processing system that includes a module designated "preventive maintenance and surveillance." In particular, the recall system identifies surveillance and maintenance activity requirements related to the WESF IOSRs. The IOSR surveillance intervals and maintenance requirements are identified and entered into the recall system.

Information is entered into the recall system through a system-specific form that is completed by appropriate WESF staff. All technical changes require approval of the system engineer. Reports are generated on a regularly scheduled basis and work is planned in advance. Upon completion of the surveillance/maintenance, the recall system is updated to contain evidence of the completed activity.

\subsection{QUALITY ASSURANCE}

The quality policies implemented at WESF apply to all activities that affect the safe and reliable operation and maintenance of the storage facility.

The WESF management coordinates the development and implementation of strategic plans and quality policies. The WESF management is responsible for ensuring that WESF resources are organized to achieve the quality assurance policies.

Implementation of the quality assurance policies is supported by all personncl at WESF.

(Uality assurance reyniruments are documented through the quality policies and supporting quality documents. The activities that affect quality are prescribed by such documents as project management plans and program plans, plant operating procedures, work packages, and instructions or drawings. Records that provide documented evidence of achieved quality and conformance of activities to requirements and specifications are maintained.

The WESF guality assurance program establishes the policy and responsibility to conduct independent assessments. The independent assessment is used to advise and inform management of the implementation and adequacy of the quality systems. The assessments are conducted in the form of audits, assessments, inspections and surveillances. Quality improvements are identified as a result of the review and assessment programs.

Design process control is established for the WESF quality system and provides responsibilities and requirements for controlling the design of SSCs.

The WESF procurement policy establishes requirements and responsibilities for ensuring that purchased items and services conform to design requirements and perform according to specifications. Inspection and acceptance testing requirements are provided in the quality management system for WESF. The program establishes policies, responsibilities and requirements for inspecting and testing incoming, in-process, and finished items, services, and processes and for documenting the result of those inspections and tests. 
HNF-SD-WM-BIO-002 REV1

\subsection{MANAGEMENT ORGANIZATION AND INSTITUTIONAL SAFETY PROVISIONS}

The requirements for management organization and institutional safety provisions are provided in fiacility procedures and HNF-PROs.

\subsubsection{Organizational Structure, Responsibilities, and Interfaces}

The safety culture is achieved through the integration of safety into every operation. Each member of WESF is accountable for safety performance and is responsible for ensuring compliance with established procedures, practices, and planning documents. The Industrial Health and Safety Program is designed to protect the safety, health, and well-being of employees by anticipating, identifying, evaluating, and controlling hazards in the workplace. The WESF organization is required to operate the facility in compliance with appropriate federal, DOE, state, and local statutes, regulations, orders and contractual obligations.

The site contractor is responsible for and supports DOE by supplying technical direction, cost and schedule management, control, integration, quality assurance, applied technology, safety/regulatory compliance support, operations activities, and the Management of Procurement of Government-Furnished Equipment for WESF activities.

WESF is a part of the Fluur Hanford Waste Management Project and the W'FSF Project Nanager reports to the Vice President of the Waste Management Project. The WESF organication consists of the WESF Project Manager, a Project Support Manager. an Fngibeering Manager, a Facility Operations/Maintenance Manager and a Radiological Control/nndustrial Safery Manager. The Projoct Support group provides support in the areas of training. budget, and long term planning: the Enginesring group provides technical engineering and safety basis support: the Operationsinatintenance group is responsible for the day-today operation and maintenance of the lacility: and the Radiological Control Industrial Safely group provides radiological control and industrial safety support.

Other organizations outside the WESF facility provide safety related support to the WESF operation. This support includes the following: perlirming safety analysis and risk assessments for the facilities including radiological dose consequence analyses and shielding analyses; interpreting DOE orders and developing guidance for compliance with applicable regulatory requirements; providing guidance, direction, assessments and audits of facility-specific quality assurance programs and program implementation.

Personnel qualification requirements for employees are based on their qualifications and ability to perform the duties and fulfill the responsibilities of the position. The candidate evaluation includes a total review of the prospective employee's background, including, but not limited to, education, skills, and experience. Minimum staffing levels are defined by the management for the WESF team for operational, engineering, and support staffing levels.

Personnel participate in regular safety and health awareness meetings and on-the-job training. Employee participation in the safety program includes participation on safety committees and task teams, conducting safety inspections, and analyzing routine hazards in each step of a job and/or a process. Employees are involved in preparing or identifying safe work practices or controls to eliminate or reduce exposure, developing or revising sitewide safety and health rules, training (see Section 6.6) both current and newly hired employees, supporting the safety culture by providing programs at safety and health meetings, and participating in accident/incident investigations.

\subsubsection{Safety Management Policies and Programs}

Waste Management Project (W.MP) implements the Project I lanford lntegrated Fnviromment. Salfety and Ilealth Management Sistem (ISMS) within the WMP oryanizations and operations to consure environment. salely, and health are integrated into work performed. WMP implements all applicatble Project llanford policies. plans, antd procedures. The Project Hanford sitew ide procedures (HNE"-PROS) are used diredly where appropriate. and are angmented through the use of WMP/WFSF policies and procedures to provide project or facility-specific direction as necessary. The WMP ISMS Description (HNF-MP-003 Appendia L) refers to policies and procedures as implenenting mechanisms. WESF procedures currently align with Project Ilanford procedures and satisty ISMS principles. For more effective operations in the future. WESF procedures are heing interated wh WMP 


\section{HNF-SD-WM-BIO-002 REV1}

ISMS provides the mechanisms for increasing worker involvement in work planning. including hazard and environmental impact identification. analysis, and control: work execution; and feedback improvement processes. Fffective implementation of ISMS will incorponate the best practices of the Voluntary Protection Program. Enhanced Work Planning. and Responsible Careß as well as orher ES\&ll performance improvement initiatives.

ISMS consists of eleven Guiding Principles and seven Core Functions. The Guiding Principles are ISWS values (e.g. Clear Roles and Responsibilities Detined. Balanced Priorities. Worker Involvement, ele.) that are achieved through execution of the mechanisms. processes. and procedures that implement the Core functions. The Core functions fFiablish tSigl! Policy, Detine Scope of Work, Identify Hazards. Analyze Hazards and Implement Controls. Perform Work within Controls. Feelback and Continuous Improvement. and Management Review). supported by the Guiding Principles, provide the necessary stucure for ans acivities that could potemtially aflect the workers, public. or the envinmment

The safery policy for WESF is: IF IT'S NOT SAFE, DON'T DO IT! All personnel will operate under the premise that a safe plant is a productive plant through which the workforce can provide safe management of the cesium and strontium capsules stored at WESF. The goal of WESF is nothing less than excellence in all aspects of saftet management and performance.

The highest value will be placed on personal stewardship of the facility's radioactive inventory and on actively caring about one's own safety and that of all co-workers. Management will provide equipment. thaning. and encouragement for all employees. Fimployees are empowered to issue "Stop Work" on any activity that they consider to be unsafe. Should any unsale conditions arise, management will take appropriale and timely corrective action. In return, management expects employees to make safety their first priority, to accept responsibility for their own actions, and to help others increase their understanding of and commitment to safe operations.

The WESF Safety Program. defined in FSP-WESF-001 IESF Projet telministrution, addresses the areas of Industrial Safety, Industrial Hygiene. Nuclear Safery, Fire Protection. and Raddological Safety. 


\section{HNF-SD-WM-BIO-002 REV 1}

\subsection{REFERENCES}

10 CFR 71, "Packaging and Transportation of Radioactive Material", Code of Federal Regulations, as amended.

10 CFR 830, "Nuclear Safety Management", Code of Federal Regulations, Part 120, "Quality Assurance Program", as amended.

10 CFR 835, "Occupational Radiological Protection", Code of Federal Regulations, as amended.

29 CFR 1910, "Occupational Safety and Health Standards", Code of Federal Regulations, as amended.

29 CFR 1926, "Safety and Health Regulations for Construction", Code of Federal Regulations, as amended.

40 CFR 117, "Determination of Reportable Quantities for Hazardous Substances", Code of Federal Regulations, as amended.

40 CFR 261, "Identification and Listing of Hazardous Waste", Code of Federal Regulations, as amended.

40 CFR 262, "Standards Applicable to Generators of Hazardous Waste", Code of Federal Regulations, as amended.

40 CFR 264, "Standards for Owners and Operators of Hazardous Waste Treatment, Storage, and Disposal Facilities", Code of Federal Regulations, as amended.

40 CFR 302, "Designation, Reportable Quantities, and Notification", Code of Federal Regulations, as amended.

40 CFR 355, "Emergency Planning and Notification", Code of Federal Regulations, as amended.

40 CFR 372, "Toxic Chemical Release Reporting: Community Right-to-Know", Code of Federal Regulations, as amended.

49 CFR 171, "General Information, Regulations, and Definitions", Code of Federal Regulations, as amended.

49 CFR 172, "Hazardous Materials Table, Special Provisions, Hazardous Materials Communications, Emergency Response Information, and Training Requirements", Code of Federal Regulations, as amended.

49 CFR 173, "Shippers-General Requirements for Shipments, and Packaging", Code of Federal Regulations, as amended.

49 CFR 174, "Carriage by Rail", Code of Federal Regulations, as amended.

49 CFR 175, "Carriage by Aircraft", Code of Federal Regulations, as amended.

49 CFR 176, "Carriage by Vessel", Code of Federal Regulations, as amended.

49 CFR 177, "Carriage by Public Highway", Code of Federal Regulations, as amended.

49 CFR 178, "Specifications for Packaging", Code of Federal Regulations, as amended.

49 CFR 179, "Specifications for Tank Cars", Code of Federal Regulations, as amended.

ACGIH, 1991, 1991-1992 Threshold Limit Values for Chemical Substances and Physical Agents and Biological Exposure Indices, American Conference of Governmental Industrial Hygienists Guidelines, Cincinnati, Ohio. 


\section{HNF-SD-WM-BIO-002 REV 1}

ACl, 1987, ACI Manual of Concrete Practice, Part 4, ACI 349, American Concrete Institute, Detroit, Michigan.

ACI, Building Code for Reinforced Concrete, ACI 318-63, American Concrete Institute, Detroit, Michigan.

Adams, L. L. L., 1984, Waste Encapsulation and Storage facility - Cesium Line Standby/Surveillance, SD-WM-ER014, Rev. 0, Rockwell Hanford Operations, Richland, Washington.

AIChE, 1992, Guidelines for Hazard Evaluation Procedures, American Institute of Chemical Engineers, Center for Chemical Process Safety.

ANSIAWS D1.1-98, Struturd Helding Code- Steel. American Welding Societ, Miami, Florida.

ANSI N14.5, Rudiscactive Walerials - Leakuge Tests on Packuge's for Shipment. American National Standards Institute. New York. New York.

ANSI N43.6, Sealed Radioactive Sources, Categorization, American National Standards Institute, New York, New York.

ANSI N542, Sealed Radioactive Sources, Classification, American National Standards Institute, New York, New York.

ASHRAE, 1993, Heating, Ventilating, and Air-Conditioning Design Guide for Department of Energy Nuclear Facilities, American Society of Heating, Refrigerating and Air-Conditioning Engineers, Inc., Atlanta, Georgia

Black, R. L., 1994, Office of Environmental Management Request for Clarification and Action on the Department's Nuclear Safety Policy, (memorandum to R. S. Scott, EM-20, January 9), U.S. Department of Energy, Washington, D.C.

Blizzard. 1962, Recclor Handhemk, Volume 3. Part B. Shieddins. Feveritt P. Blizzard, Fditor, fohn Wiley and Sons, Inc.. New York. New York, 1962

Blume, J. A., 1971a, Earthquake Analysis of the Waste Encapsulation Facility, RHO-R-22, (JABE-VITRO-01), Westinghouse Hanford Company, Richland, Washington.

Blume, J. A., 1971b, Piping and Equipment Seismic Study, Building 225-B of the Waste Encapsulation Facility, RHO-R-23 (JABE-VITRO-02), Westinghouse Hanford Company, Richland, Washington.

Braden, D. E., 1971, Safety Analysis Report Waste Encapsulation and Storage Facilities (Project HAP-631), ARH1986, Atlantic Richfield Hanford Company, Richland, Washington.

Brehm, J. R., 1996, WESF Interim Safety Basis Project Plan, WHC-SD-WM-PAP-063, Rev. 0, Westinghouse Hanford Company, Richland, Washington.

Bryan, G. H., 1989, Cesium Chloride Compatibility Testing Program - Final Report, PNL-7133, Pacific Northwest National Laboratory, Richland, Washington.

Carlstrom, R. F., 1985a, Waste Encapsulation and Storage Facility Overall Hot Cell Standby/Surveillance, SDWM-ER-024, Rev. 0, Rockwell Hanford Operations, Richland, Washington.

Carlstrom, R. F., 1985b, Waste Encapsulation and Storage Facility Strontium Line Standby/Surveillance, SD-WMER-022, Rev. 0, Rockwell Hanford Operations, Richland, Washington. 


\section{HNF-SD-WM-BIO-002 REV 1}

Carter, L. L., 1996, Certification of MCNP Version 4 A for WHC Computer Platforms, SD-MP-SWD-30001, Rev. 7, Westinghouse Hanford Company, Richland, Washington.

Clemments 1998, Safety Analysis Report for Pakkaging (Onsite) for the Waste Encapsulation and Storage Facility. Ion Exchange Module, HNF-SD-TP-SARP-027. Rev.0-A. Waste Management Federal Services. Inc.. Northwest Operations, Richland WA.

Coats, D. W. and R. C. Murray, 1984, Natural Phenomena Hazards Modeling Project: Seismic Hazard Models for Department of Energy Sites, UCRL-53582, Rev 1, Lawrence Livermore National Laboratory, Livermore, California.

Cohen, 1989. ASME Handbook on Water Techmology for Thermal Pourer Systems, Section 11-5.7.2. American Sociely of Mechanical Engineers, New York, New York.

Covey, 1999. W'uste Encapsulution and Storuge Fa'ility' Sufety. Equipment List, HNF-SD-WM-SEL-008, B \& W Hanford Company, Richland WA.

CRC Handbook of Chemistry and Physics, 64th Edition. CRC Press. Inc.. Boca Raton. Florida.

DOE, 1990, Interim Report of the DOE Type B Investigation Group, Cesium-137: A Systems Evaluation, Encapsulation to Release at Radiation Sterilizers, Inc., Decatur, Georgia, DOE/ORO-914, U.S. Department of Energy, Washington, D.C.

DOE, 1992, Hazard Categorization and Accident Analysis Techniques for Compliance with DOE Order 5480.23, Nuclear Safety Analysis Reports, DOE-STD-1027-92, U.S. Department of Energy, Washington, D.C.

DOE, 1994a, Preparation Guide for U.S. Department of Energy Nonreactor Nuclear Facility Safety Analysis Reports, DOE-STD-3009-94, U.S. Department of Energy, Washington, D.C.

DOE, 1994b, Guidance for Preparation of DOE 5480.22 (TSR) and DOE 5480.23 (SAR) Implementation Plans, DOE-STD-3011-94, U.S. Department of Energy, Washington, D.C.

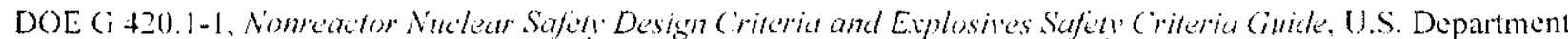
of Energy. Washington, D.C.

DOE Order 4330.4B, Maintenance Management Program, U.S. Department of Energy, Washington, D.C.

DOE Order 5000.3B, Occurrence Reporting and Processing of Operations Information, U.S. Department of Energy, Washington, D.C.

DOE Order 5400.5, Radiation Protection of the Public and the Environment, U.S. Department of Energy, Washington, D.C.

DOE Order 5480.1B, Environmental, Safety, and Health Program for Department of Energy Operations, U.S. Department of Energy, Washington, D.C.

DOE Order 5480.3, Safety Requirements for the Packaging and Transportation of Hazardous Materials, Hazardous Substances, and Hazardous Waste, U.S. Department of Energy, Washington, D.C.

DOE Order 5480.4, Environmental Protection, Safety, and Health Protection Standards, U.S. Department of Energy, Washington, D.C.

DOE Order 5480.7A, Fire Protection, U.S. Department of Energy, Washington, D.C.

DOE Order 5480.10, Contractor Industrial Hygiene Program, U.S. Department of Energy, Washington, D.C. 
DOE Order 5480.11, Radiation Protection for Occupational Workers, U.S. Department of Energy, Washington, D.C.

DOE Order 5480.18A, Accreditation of Performance-based Training for Category A Reactors, U.S. Department of Energy, Washington, D.C.

DOE Order 5480.18B, Nuclear Facility Training Accreditation Program, U.S. Department of Energy, Washington, D.C.

DOE Order 5480.19, Conduct of Operations Requirements for DOE Facilities, U.S. Department of Energy, Washington, D.C.

DOE Order 5480.20A, Personnel Selection, Qualification, and Training Requirements for DOE Nuclear Facilities, U.S. Department of Energy, Washington, D.C.

DOE Order 5480.21, Unreviewed Safety Questions, U.S. Department of Energy, Washington, D.C.

DOE Order 5480.22, 1992, Technical Safety Requirements, Change 1 (1992) and Change 2 (1996), U.S. Department of Energy, Washington, D.C.

DOE Order 5480.23, 1992, Nuclear Safety Analysis Reports, (Change 1 (1994), U.S. Department of Energy, Washington, D.C.

DOE Order 5480.24, 1992, Nuclear Criticality Safety, U.S. Department of Energy, Washington, D.C.

DOE Order 5483.1A, Occupational Safety and Health Program for DOE Contractor Employees at Government-Owned Contractor-Operated Facilities, U.S. Department of Energy, Washington, D.C.

DOE Order 5500.2B, Emergency Categories, Classes, and Notification and Reporting Requirements, U.S. Department of Energy, Washington, D.C.

DOE Order 5500.3A, Planning and Preparedness for Operational Emergencies, U.S. Department of Energy, Washington, D.C.

DOE Order 5700.6C, Quality Assurance, U.S. Department of Energy, Washington, D.C.

DOE Order 5820.2A, Radioactive Waste Management, U.S. Department of Energy, Washington, D.C.

DOE Order 6430.1A, General Design Criteria, U.S. Department of Energy, Washington, D.C.

DOE-RL, 1989, Hanford Plant Standards, Standard Architectural-Civil Design Criteria Design Load for Facilities, SDC 4.1, Rev. 11, U.S. Department of Energy-Richland Operations Office, Richland, Washington.

DOE-RL, 1993, Hanford Plant Standards, Standard Architectural-Civil Design Criteria Design Load for Facilities, SDC 4.1, Rev. 12, U.S. Department of Energy-Richland Operations Office, Richland, Washington.

DOE-RL, 1995a, Hanford Site Hoisting and Rigging Manual, DOE/RL-92-36, U.S. Department of Energy-Richland Operations, Richland, Washington.

DOE-RL, 1995b, Hanford Emergency Response Plan, DOE/RL-94-02, U.S. Department of Energy-Richland Operations Office, Richland, Washington. 
Donnet, V. E., 1980, Waste Encapsulation and Storage Facility Cesium Flowsheet, RHO-F-9, Rockwell Hanford Operations, Richland, Washington.

EPRI, 1998, Guidelines for the Utilization of Commercial Grade Items in Nuclear Safety Related Applications (NCIG-07), EPRI NP-5652, Electrical Power Research Institute, Reading, Pennsylvania.

Flanagan, 1997. Safety Analysis Report for Packaging (Onsite) for Limited Type B Materiut in the CNS 14-215H Cask. HNF-SD-TP-SARP-025. Rev.0. Rust Federal Services Ine Northwest Operations. Richland WA.

Gardner, H. R., and D. J. Oakley, 1989, Interim Report: Cesium Capsule Bulging Phenomena, WHC-SD-WM-TI405, Rev. 0, Westinghouse Hanford Company, Richland, Washington.

GC-LOAD-01, 1996, Design Loads for Facilities, Rev.1, ICF Kaiser Hanford Company (Now Fluor Daniel Northwest, Reference Procedure Deviation SRM 1.2D3), Richland, Washington.

Hammond, J. E., 1975, Cesium Chloride Capsule Testing for Special Form Qualification, ARH-CD-440, Atlantic Richfield Hanford Company, Richland, Washington.

Hanson. R. D., 1999, "Contract Number DE-AC06-96RL13200 - Implementation Plan for DOE Orders 5480.22 and 5480.23," (external letter FDH-9955894AR2 to K. A. Klein, September 22). Fluor Daniel llanford. Inc.. Richland, Washington.

Hey, B. E., 1995a, GXQ Program User $\rrbracket s$ Guide, WHC-SD-GN-SWD-30002, Rev 1, Westinghouse Hanford Company, Richland, Washington.

Hey, B. E., 1995b, GXQ Program Validation and Verification, WHC-SD-GN-SWD-30003, Rev 1, Westinghouse Hanford Company, Richland, Washington.

Hey, B. E., 1999, Supporting Calculations and Documentation for the WESF Basis Interim Operation, HNF-SDWM-TI-733, Rev 1A, B\&W Hanford Company, Richland, Washington.

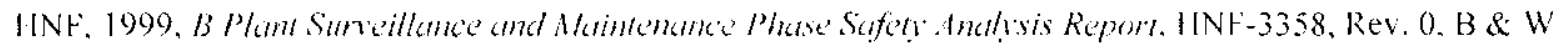
Hantord Company. Ricluland Washington.

HNF, 1998, B Plan Basis for Interim Operation, HNF-SD-WM-BIO-003, Rev. 0. B \& W Hanford Company, Richland Washington.

HNF, 1998a, WIXM Transient Fire and NCT Analyses, HNF-2303, Rev. 0, B\&W Hanford Company, Richland, Washington.

HNF, 1998c, Waste Encapsulation and Storage Facility Interim Operational Safety Requirements, HNF-SD-WMIOSR-001, Rev. 0, B\&W Hanford Company.

IINF. 1998d, Safety Analysis Report for Packaging (Onsite' for W'aste Encupsulation and Storage Facility Ion Exchunge Wedule, HNF-SD-TP-SARP-027, Waste Management Federal Services, Inc., Northwest Operations. Richland Washington.

IINF, 1997d. Specificalion for WESF Ion Fichange Module, HINF-S-0566, Rev. 0-A. Westinghouse Hanford Company, Richland, Washington.

HNF-PRO-704, 1997, Hazard and Accident Andlysis Process. HNF-PRO-704. Rev. 0, Fluor Daniel Hantord Company, Richland Washington. 


\section{HNF-SD-WM-BIO-002 REV 1}

Hohmann, H., et al., 1979, The Effect of Pressure on NaCl-H2O Explosions, 4th CSNI Specialist Meeting on FuelCoolant Interactions in Nuclear Reactor Safety, Bournemouth, United Kingdom, CSNI Report No. 37, pp. 308-323.

Hohmann, H., et al., 1982, Experimental Investigation of Spontaneous and Triggered Vapor Explosions in the Molten Salt/Water System, International Meeting on Thermal Reactor Safety, Chicago, Illinois.

Holten, R. A., 1994, Completion Schedules for Safety Basis (ISB) and Operational Controls as Required by DOE Order 5480.22, Technical Safety Requirements (TSRs) and DOE Order 5480.23, Nuclear Safety Analysis Reports (SARs), (external letter 9402543 B to A. L. Trego, April 28), U.S. Department of Energy Richland Field Office, Richland, Washington.

HSRCM-1, Hanford Site Radiological Control Manual, Hanford Site Contractors, Richland, Washington.

Kenna, B. T., 1982, WESF ${ }^{137}$ CS Gamma Ray Source, SAND82-1492, Sandia National Laboratories, Albuquerque, New Mexico.

Knoll, J. M., 1992, Implementation Plan for DOE Orders 5480.21, 5480.22, and 5480.23, (external letter 9257875 to R. D. Larson, October 28, 1992), Westinghouse Hanford Company, Richland, Washington.

Liljegren, L. M., and G. Terrones, 1996, An Analysis to Determine the Upper Bound on the Hydrogen Mole Fraction in the Pool Area of WESF, PNL-WESF-001, Rev. 1 and Rev. 2, Pacific Northwest Laboratory, Richland Washington.

McCormick, W. A., 1993, BUSS Cask Truck Port Cover Block Drop Analysis, WHC-SD-TP-RPT-009, Westinghouse Hanford Company, Richland, Washington.

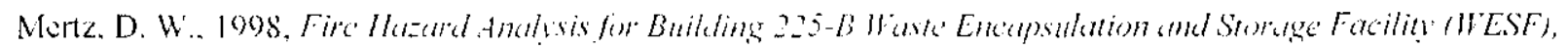
IINF-SD-WM-FIL-019 Rev. 2. B\&W Ilanford Company. Richland. Washington.

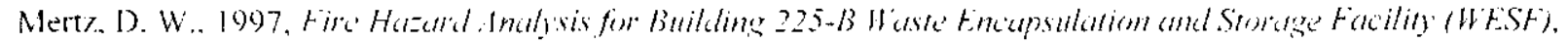
HIN-SD-WiW-FHA-(0)9 Rev. 1. BEW Hantord Compan. Richland. Washington.

MSDS 15012. Material Salety Data Sheet 15012. Amberlite IRN-150 Resin.

MSDS 29805. Material Salety Data Sheet $\$ 29805$. Purolite NRW-37 Jon Exchange Resin.

Miller, C. T., 1993, Westinghouse Hanford Company Conduct of Operations Manual-GOCO Cross Cultivation Committee, WHC-SP-0708, Rev. 1, Westinghouse Hanford Company, Richland, Washington.

Mishima, J., 1994, Recommended Values and Technical Bases for Airborne Release Fractions (ARFs), Airborne Release Rates (ARRs), and Respirable Fractions (RFs) at DOE Non-Reactor Nuclear Facilities, DOEHDBK-3010-94, U.S. Department of Energy, Washington, D.C.

Muhlestein, L. D., 1994, Additional Analysis related to the Multi-Function Waste Tank Facility, WHC-SD-W236AANAL-002, Rev. 0, Westinghouse Hanford Company, Richland, Washington.

NASA, 1993, Coefficients for Calculating Thermodynamic and Transport Properties of Individual Species, NASA4153, Natural Aeronautics and Space Administration, Hampton, Virginia.

Negin, C. A. and G. Worku, 1992, Microshield Version 4 User's Manual, Grove 92-2, Grove Engineering, Inc., Rockville, Maryland.

NFPA 101, 1994, Life Safety Code, National Fire Protection Association, Quincy, Massachusetts. 
NFPA 220, 1992, Standard on Types of Building Construction, 1992 Ed., National Fire Protection Association, Quincy, Massachusetts.

NFPA 253, 1990, Standard Method of Test for Critical Radiant Flux of Floor Covering Systems Using a Radiant Heat Energy Source, National Fire Protection Association, Quincy, Massachusetts

NFPA 255, 1996, Standard Method of Test of Surface Burning Characteristics of Building Materials, 1996 Ed., National Fire Protection Association, Quincy, Massachusetts

NIOSH, 1990, NIOSH Pocket Guide to Chemical Hazards, National Institute for Occupational Safety and Health, Cincinnati, Ohio.

Nogales, M. D., 1992, Technical Assessment of WESF Cesium Capsule Special Form Issue, WHC-SD-WM-TA| 033, Rev. 0, Westinghouse Hanford Company, Richland, Washington.

NRC. 1986 Establishing Ouality Assurance Programs for Packaging Used in the Transpont of Radioutive Material, Regulatory Guide 7.10, U.S. Nuclear Regulatory Commission, Washington. D.C.

NUREG, 1988, Nutear fiel Cych Facility Acciden Analysis Hundhook, NUREG-1320, U.S. Nuclear Regulatory Commission, Washington. D.C.

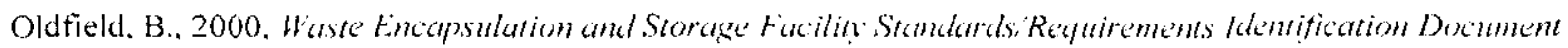
(S:RIDS), HNF-SD-MP-SRID-007, Rev. I, Flour Hanford Company, Richland, Washington.

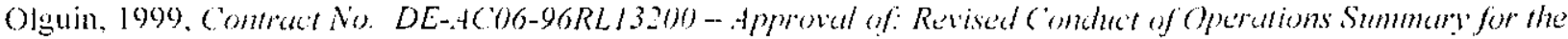
Haste Encapsulation and Storage Facility (letter FDH I-98517.36 RI to A Clark. April 7). B \& W I lanford Company. Riclatand Washington.

Orme, R. M., 1981, A Storage Basin Recovery System for the Waste Encapsulation and Storage Facility, RHO-CD1548, Part 2, Rockwell Hanford Operations, Richland, Washington.

Reed, L. L., 1994a, Transmittal of Implementation Plan for DOE Order 5480.24, Nuclear Criticality Safety, (external letter 9405951BR2 to R. A. Holten, December 30), Westinghouse Hanford Company, Richland, Washington.

Reed, L. L., 1994b, Hazard Categorization of Westinghouse Hanford Company Nuclear Facilities, (external letter 9455200 to R. A. Holten, July 1994), Westinghouse Hanford Company, Richland, Washington.

DOE-RL, 1993, Standard Architectural - Civil Design Criteria, Design Loads for Facilities, Hanford Plant Standard SDC 4.1, Rev. 12, U.S. Department of Energy-Richland Operations Office, Richland, Washington.

Sasmor, D. J., J. D. Pierce, G. L. Tingery, H. E. Kjarmo, J. Tills, and D. C. McKoen, 1988, Characterization of Two WESF Capsules After Five Years of Service, SAND86-2808, Sandia National Laboratories, Albuquerque, New Mexico, and Livermore, California.

Schreckhise, R. G., K. Rhoads, J. S. Davis, B. A. Napier, and J. V. Ramsdell, 1993, Recommended Environmental Dose Calculation Methods and Hanford-Specific Parameters, Westinghouse Hanford Company, Richland, Washington.

Siemer, J. M., 1995, Waste Encapsulation and Storage Facility Hazards and Operability, WHC-SD-WM-PHA-012, Rev. 0, Westinghouse Hanford Company, Richland, Washington.

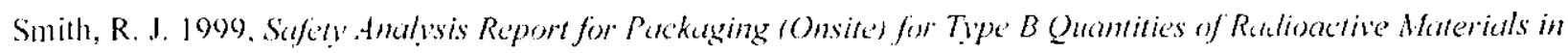


Typo I Boxes. WHC-SD-TP-SARP-018, Rev. 0-t. Waste Management Federal Services. Inc.. Richland Washington.

SNL, 1991, Beneficial Uses Shipping System (BUSS) Cask Safety Analysis Report for Packaging (SARP), SAND830698, TTC-0430, Sandia National Laboratory, Albuquerque, New Mexico.

Tallman, A. M., 1996, Natural Phenomena Hazards of Hanford Site to Support Design Criteria, WHC-SD-GN-ER501, Westinghouse Hanford Company, Richland, Washington.

Terrones, G., 1995, Technical Basis to Justify Hydrogen Probe Location and Estimate of the Maximum Hydrogen Fraction, PNL-IX-IR-0018, Pacific Northwest Laboratory, Richland, Washington.

Tingey, S. M., 1985, WESF Cesium Capsule Behavior at High Temperature or During Thermal Cycling, PNL-5517, Pacific Northwest Laboratory, Richland, Washington.

UBC, 1971, Uniform Building Code, International Conference of Building Officials, Whittier, California.

UBC, 1991, Uniform Building Code, International Conference of Building Officials, Whittier, California.

VITRO, 1970, WESF Structural Design Calculations, WHC-SD-WM-DA-219, Westinghouse Hanford Company, Richland, Washington.

Wagenblast, G., K. C. Tu, and F. R. Vollert, 1999, WESF Natural Phenomena Hazards Survey, HNF-SD-WM-DB034, Rev. 2, Kaiser Engineers, Hanford, Richland, Washington.

Wagoner, J. D., 1994, Office of Performance Assessment Audit of Implementation of DOE Nuclear Safety Orders, March 21 - April 1, 1994, (external letter 9401857 B to A. L. Trego, March 9), U.S. Department of Energy Richland Field Office, Richland, Washington.

Washburn, Sr., D. F., 1989, Interim Report Resolution of Special Form Issues Associated with Cesium Chloride Capsules Manufactured at WESF, WHC-SD-WM-DIC-004, Rev. 0, Westinghouse Hanford Company, Richland, Washington.

WHC, 1993, Hanford Site Solid Waste Acceptance Criteria, WHC-EP-0063-04, Rev. 4, Westinghouse Hanford Company, Richland, Washington.

WHC, 1995a. Quality Assurance Program Plan for the Hazardous Materials Transportation and Packaging Program, WHC-IP-0705. Rev. 1. Westinghouse Hanford Company. Richland, Washington.

WHC, 1996a, B Plant Interim Safety Basis Accident Analysis, WHC-SD-WM-SARR-030, Rev. 0, Westinghouse Hanford Company, Richland, Washington.

WHC, 1996b, FAI/96-I Thermal Analyses of Hypothetical WESF Pool Drain Accidents, WHC-SD-WM-TI-770, Rev. 0, Westinghouse Hanford Company, Richland, Washington.

WHC, 1996c, FAl/96-25 F Cell Thermal Analysis for Cesium Chloride Capsule Storage, WHC-SD-WM-TI-771, Rev. 0, Westinghouse Hanford Company, Richland, Washington.

WHC-CM-4-46, Safety Analysis Manual, Section 2.0, "Safety Analysis Process," Chapter 6.0, "Technical Safety Requirements," and Section 8.0, "Interim Safety Basis,", Rev. 1, Change 1 (1996), Westinghouse Hanford Company, Richland, Washington.

WHC-IP-1182, B Plant/WESF Conduct of Operations, Westinghouse Hanford Company, Richland, Washington. 
HNF-SD-WM-BIO-002 REV 1

WHC-SP-1 131, Quality Assurance Program and Implementation Plan, Rev. 1, Westinghouse Hanford Company, Richland, Washington.

WHC-SP-1164, WHC Safety Analysis Reports and Technical Safety Requirements Upgrade Program, Westinghouse Hanford Company, Richland, Washington.

WMNW. 1997. Specification for WESF lon Exchange Module (WIXM/) Fubrication, Waste Management Federal Services, Inc., Northwest Operations for Fluor Daniel Hantord, Inc., Richland, Washington.

Yamano, N., et al., 1993, Studies on Fuel Coolant Interactions During Core Melt Accident of Nuclear Power Plants, CSNI Fuel-Coolant Interactions Specialist Meeting, (January 5-8), Santa Barbara, California. 
HNF-SD-WM-BIO-002 REV 1

This page intentionally left blank. 
HNF-SD-WM-BIO-002 REV 1

\author{
APPENDIX A \\ Department of Energy Safety Evaluation Report
}

A-1 


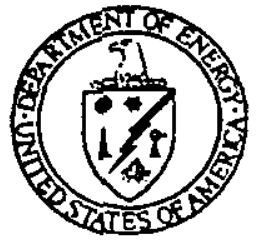

00-ABD-076

\section{Department of Energy \\ Richland Operations Office \\ P.O. Box 550 \\ Richland, Washington 99352}

Mr. R. D. Hanson, President

Fluor Hanford, Inc.

Richland, Washington 99352

Dear Mr. Hanson:

CONTRACT NO. DE-AC06-96RL13200 - WASTE ENCAPSULATION AND STORAGE FACILITY (WESF) BASIS FOR INTERIM OPERATION (BIO)

This is in response to your letter to me dated August 25, 2000, same subject, which submitted Revision 1 of the WESF BIO and Interim Operational Safety Requirements.

$R L$ has reviewed the submitted documents and concluded that they are acceptable. RL hereby approves these documents subject to the conditions contained in the attached Safety Evaluation Report (SER). This SER supercedes all previous SERs and becomes the new SER of record. Please note this in the next revision to the facility Authorization Agreement.

If you have any questions or comments, please contact me, or your staff may contact Jim McCracken, Authorization Basis Division, at (509) 376-4360.

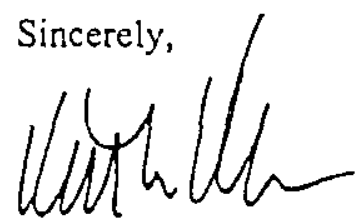

ABD:JJM

Keith A. KJein

Manager

Attachment

cc w/attach:

B. A. Austin, $\mathrm{FHI}$

L. I. Covey, FHI

E. S. Aromi, WMH

D. R. Ellingson, WMH

C. J. Wolfe, WMH 
HNF-SD-WM-BIO-002 REV 1

Attachment
Safety Evaluation Report
for the
Waste Encapsulation and Storage Facility

A-3 
Authorization Basis Division U.S. Department of Energy, Richland Operations Office

Safety Evaluation Report

Date Published: September 2000

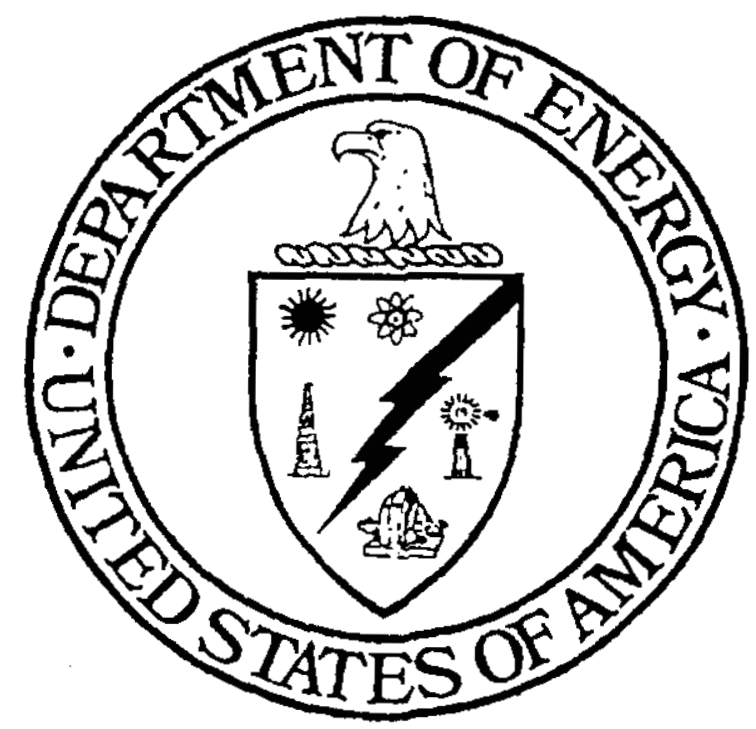

Waste Encapsulation and Storage Facility 
U.S. DEPARTMENT OF ENERGY

RICHLAND OPERATIONS OFFICE

SAFETY EVALUATION REPORT FOR

Waste Encapsulation and Storage Facility September 2000

\section{REVIEW TEAM SIGNATURES}
S.r. un Cine
9120100

J. J. McCracken

Date

Authorization Basis Division

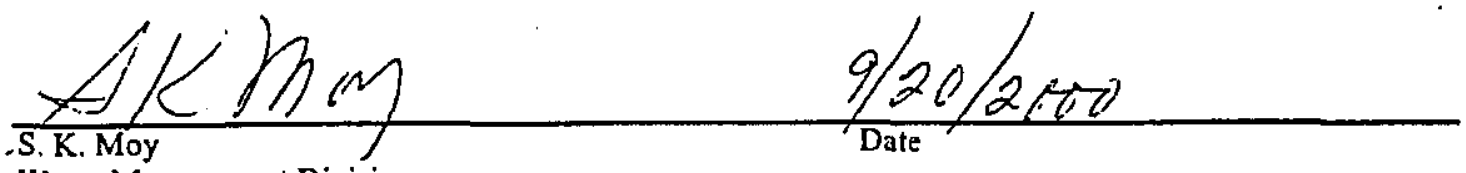

Waste Management Division

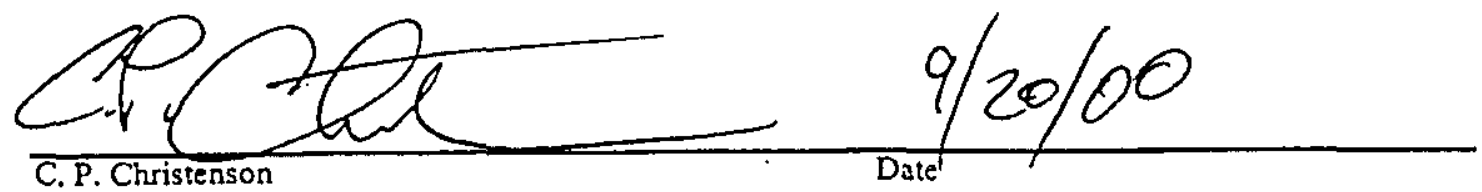

Engineering Safety and Standards Division

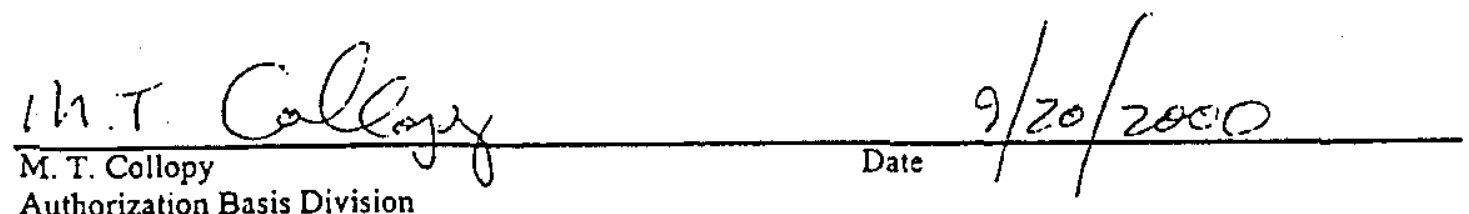

Authorization Basis Division

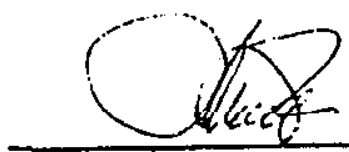

$9 / 21 / 9000$

P. J. Macheth

GSSC

Date

Page 2 of 15 
HNF-SD-WM-BIO-002 REV 1

U.S. DEPARTMENT OF ENERGY

RICHLAND OPERATIONS OFFICE

SAFETY EVALUATION REPORT FOR

Waste Encapsulation and Storage Facility

September $\mathbf{2 0 0 0}$

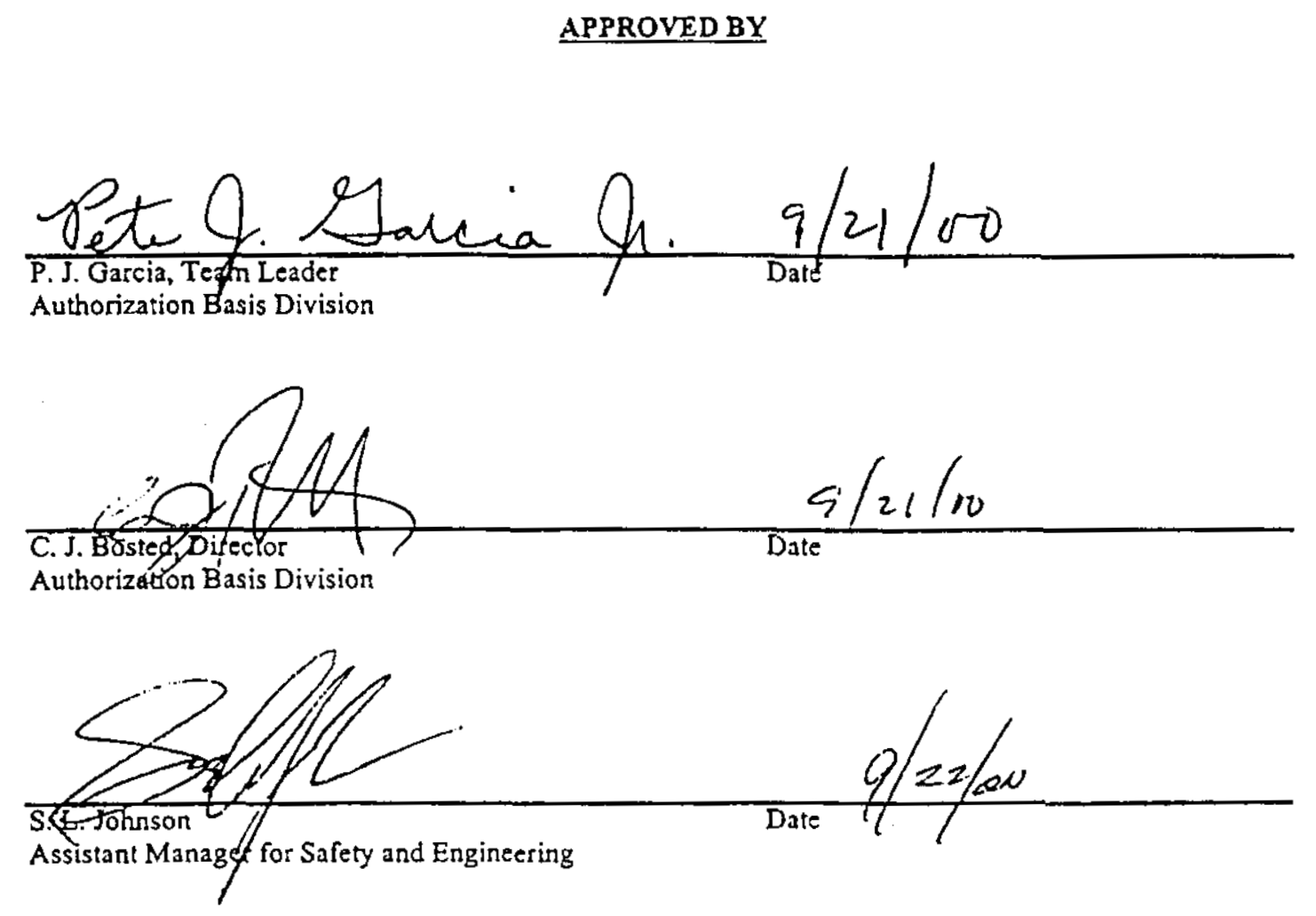

Page 3 of 15 
U.S. DEPARTMENT OF ENERGY

RICHLAND OPERATIONS OFFICE

SAFETY EVALUATION REPORT FOR

Waste Encapsulation and Storage Facility

September 2000

\section{TABLE OF CONTENTS}

Executive Summary

1.0 Introduction

2.0 Review Process

3.0 Base Information

4.0 Hazard and Accident Analyses

5.0 Safety Structures, Systems, and Components

6.0 Derivation of Interim Operational Safety Requirements

7.0 Programmatic Controls

8.0 Conclusion

References 


\section{U.S. DEPARTMENT OF ENERGY \\ RICHLAND OPERATIONS OFFICE \\ SAFETY EVALUATION REPORT FOR \\ Waste Encapsulation and Storage Facility \\ September 2000}

\section{EXECUTIVE SUMMARY}

The U.S. Department of Energy (DOE) Richland Operations Office (RL) has reviewed the Waste Encapsulation and Storage Facility (WESF) Bosis for Interim Operation (BIO), HNF-SD-WM-BIO-002, Revision 1, dated July 2000, and Interim Operational Safety Requirements (IOSR), HNF-SD-WM-LOSR001, Revision 1, dated July 2000, and determined that they meet DOE Order requirements and Standards guidance and are acceptable to RL.

The WESF BIO documents the results of the safery analysis that evaluates and establishes the adequacy of the WESF storage pools and associated support strucrures and systems to safely store, handle, and move the encapsulated sources stored there. The BIO also establishes the envelope within which operations can continue to be performed safely. Storage at WESF has a relatively long-term duration that will conclude with the removal of the stored capsules from WESF for subsequent processing and disposal.

For the analyzed mission, WESF is a Hazard Cateyory 2 facility. The major facility hazards include the radiological and hazardous materials contained in the capsules, natural phenomena (wind, lightning, seismic activity, etc.), man-made activity (aircraft crashes, vehicle accidents, personnel errors, etc.), and the typical hazards associated with an industrial facility. The WESF hazards are unique due to the quantity of radioactive and other hazardous materials present and the proximity to workers and the environment.

The currently approved BIO, as well as proposed Revision 1, is a hybrid document which partially meets the requirements of DOE 5480.23 and the guidance provided in DOE-STD-3009-94, "Preparation Guide for U.S. Department of Energy Nonreactor Nuclear Facility Safety Analysis Reports." At the time of the approval of Revision 0 of the documents, the expectation was that a SAR would be prepared in accordance with the requirements of DOE 5480.23 and the IOSRs revised to meet the requisements for Technical Safety Requirements as specified in DOE 5480.22 by the end of Fiscal Year 2000 . Due to funding issues, Revision 1 of the BIO states that the upgrades of the BIO and IOSRs will be delayed until Fiscal Year 2002.

The BIO examines various accident scenarios. All BIO postulated accidents are calculated to have consequences that are below the onsite and of fsite release limits and evaluation guidelines. These design basis accidents include:

- Natural Phenomena, including the Design Basis Earthquake;

- External Events, including Loss of Electrical Power and Vehicle Impacts;

- Facility Fires in the Hot Cells and Truckport;

- Loss of Confinement;

- Facility Explosions;

- Loss of Containment; and

- Loss of Pool Cell Water.

This Safery Evaluation Report (SER) was prepared following the guidance of DOE-STD-1 104-96, Review and Approval of Nonreactor Facility Safety Analysis Reports.

The WESF accidents as analyzed in the BIO are conservatively developed. Mitigated consequences for analyzed accidents are below DOE and Fluor Hanford, Inc. criteria. Based on the results of the review as summarized within this SER, the RL Review Team recommends approval of the WESF BIO, Revision 1, and WESF IOSRs, Revision 1, subject to the following conditions:

- The contractor shall incorporate into the next annual update of the BIO revised and updated aircraft accident scenarios. 
HNF-SD-WM-BIO-002 REV 1

\section{U.S. DEPARTMENT OF ENERGY RICHLAND OPERATIONS OFFICE SAFETY EVALUATION REPORT FOR Waste Encapsulation and Storage Facility September 2000}

- The contractor sball complete an evaluation of altemative means of mitigation of the tunnel pipe break scenarios, and coordinate the evaluation with $R L$ prior to incorporation into the next annual update of the BIO.

- The contractor shall incorporate into the next annual update of the BIO an updated organizational description of the facility and its management that addresses major programmatic responsibilities described and credited for safety and protection of the environment. 


\section{U.S. DEPARTMENT OF ENERGY \\ RICHLAND OPERATIONS OFFICE \\ SAFETY EVALUATION REPORT FOR \\ Waste Encapsulation and Storage Facility \\ September 2000}

\subsection{INTRODLCTION}

By letter dated August 25, 2000, Fluor Hanford, Inc. (FHI) submitted for U.S. Department of Energy (DOE) Richland Operations Office (RL) review and approval the following Authorization Basis documents pertaining to the Waste Encapsulation and Storage Facility (WESF):

- Basis for Interim Operation, WHC-SD-WM-BIO-002, Revision 1; and

- Interim Operational Safety Requirements, HNF-SD-SNF-IOSR-001, Revision 1

The purpose of this Safety Evaluation Report (SER) is to document the RL review of the Authorization Basis documents and provide a basis for approval of the documents. The WESF BIO and IOSR document had been previously approved by DOE, and this SER addresses BIO Revision 1 and IOSR Revision 1. This SER supercedes all previous SERs issued for WESF.

\subsection{REVIEW PROCESS}

FHI submitted proposed BIO Revision 1 and IOSR Revision 1 to RL as updates to the previously approved documents on March 15, 1999 (Reference 1). An RL Review Team was formed following the RL reorganization in October 1999 to review the submittals. The updated BIO incorporated changes which had been submitted to RL as part of the 1998 and 1999 Unreviewed Safety Question summary reports (References 4 and 5). The documents were reviewed by the Review Team, and review commeats provided informally to FHI. Resolution of all comments was documented in a June 26, 2000 letter (Reference 3), which included as an attachment copies of Review Comment Records signed by Review Team members to indicate agreement with comment resolution. The original submittals were then revised to incorporate the comnent resolutions and resubmitted on August 25, 2000 (Reference 2).

The review was a comprebensive evaluation of Revision 1 of the WESF BIO and the associated IOSRs. The current BIO Review Team's efforts focused on ensuring that the BIO and IOSRs:

- are in compliance with appropriate regulations, DOE Orders, RL instructions or that any deviations are recognized and documented;

- cover the scope of WESF activities sufficiently, or, alterratively, properly identify interfaces with items not included;

- identify and properly address important safety-related technical issues in sufficient detail to permit identification of acceptable controls;

- present and support information in a manner that allows the WESF BIO and IOSRs to be modified using the Engineering Change Notice and the Unreviewed Safety Question (USQ) processes to update the Authorization Basis in response to facility changes; and

- received an appropriate technical review by the Contractor.

The currently approved BIO, as well as proposed Revision 1 , is a hybrid document which partially meets the requirements of DOE 5480.23 and the guidance provided in DOE-STD-3009-94, "Preparation Guide for U.S. Department of Energy Nonreactor Nuclear Facility Safety Analysis Reports." Specifically, Chapters 2, "Facility Description," Chapter 3, "Hazard and Accident Analysis," and Chapter 4, "Safety Structures, Systems, and Components," were prepared using the guidelines of DOE-STD-3009. Chapter 5 of the B1O, "Derivation of Technical Safety Requirements," and the IOSRs were based on DOE 5480.22. At the time of the approval of Revision 0 of the documents, the expectation was that a SAR would be 


\author{
U.S. DEPARTMENT OF ENERGY \\ RICHLAND OPERATIONS OFFICE \\ SAFETY EVALUATION REPORT FOR \\ Waste Encapsulation and Storage Facility \\ September 2000
}

prepared in accordance with the requirements of DOE 5480.23 and the IOSRs revised to meet the requirements for Technical Safety Requirements as specified in DOE 5480.22 by the end of Fiscal Year 2000. Due to funding issues, Revision $I$ of the BIO states that the upgrades of the BIO and IOSRs will be delayed until Fiscal Year 2002.

The proposed Authorization Basis Documents were reviewed against criteria contained in the following:

- DOE-STD-3009-94, "Preparation Guide for U.S. Department of Energy Nonreactor Nuclear Facility Safety Aralysis Reports,"

- DOE-STD-301 1-94, "Guidance for Preparation of DOE 5480.22 (TSR) and DOE 5480.23 (SAR) Implementation Plans," and

- DOE-STD-1027-92, "Hazard Categorization and Accident Analysis Techniques for Compliance With DOE Order 5480.23, Nuclear Safety Analysis Reports."

Finally, this Safety Evaluation Report was prepared using the guidance provided in DOE-STD-1104-96, "Review and Approval of Nonseactor Nuclear Facility Safety Analysis Reports."

\title{
3.0 BASE INFORMATIO.
}

The WESF is located in the northern portion of the 200 East Area adjacent to B Plant. The WESF, built in the early 1970s, was designed and construcled to process, encapsulate, and store long-lived cesium and strontium radionuclides extracted from wastes generated during the chemical processing of defense fuel at Hanford. The facility consists of a large basin subdivided into separale pools for interim underwater storage of capsules containing radioactive cesium and strontium, and the hot cells where the processing and encapsulation was performed using remote manipulators. Hot Cells A-E are being taken out of service, while Hot Cells $F$ and $G$ will remain active.

The current WESF mission involves continuing storage of the capsules, facility maintenance activities, receipt, inspection and decontamination of capsules, and on-going surveillance of stored capsules. No repackaging or other opening of stored capsules is authorized. K-3 HEPA filter changeout is not analyzed nor authorized. No welding or introduction of any other flammable gases into the facility is authorized.

The WESF building consists of three major areas. Area 1 of the WESF is a one-story structure which houses support facilities, including the heating, ventilating and air conditioning system and the Pool Cell Monitoring Area. Area 2 is a two-story structure which contains the hot cells and a canyon which provides access to the hot cells, the pool cells, and the Truckport. Area 3 is a two-story structure which contains the pool cells and the Truckpor.

In general, the WESF BIO contains sufficient background material and fundamental information to support the document. Sufficient base information is present in the BIO to support the review of the technical aspects including the hazards and accident analyses, designation of Safety Structures, Systems, and Components (SSC), derivation of IOSRs and programmatic control over WESF activities. However, the Review Team notes that the information presented could be condensed and edited for clarity in many places, and recommends that additional figures and drawings be provided to supplement the text in future revisions to facilitate understanding of the facility and its current operation. Redundant information and repeated methodology descriptions could be eliminated and the total length of the text reduced to make the BIO more user-friendly.

Page 8 of 15 
HNF-SD-WM-BIO-002 REV 1

\author{
U.S. DEPARTMENT OF ENERGY \\ RICHLAND OPERATIONS OFFICE \\ SAFETY EVALUATION REPORT FOR \\ Waste Encapsulation and Storage Facility \\ September 2000
}

\title{
4.0 KAZARD AND ACCIDENT ANALYSES
}

\subsection{Overview}

The principal purpose of $a$ hazard analysis is to systematically identify hazards, accident potentials, and preventive and mitigative feahures through a comprehensive process of hazard identification and evaluation. As stated in DOE-STD-3009, hazard and accident analysis covers the topics of hazard identification, facility hazard classification, hazard evaluation, and accident analysis. Items to be addressed in the hazard and accident analysis include the following:

- Description of the methodology used for the hazard and accident analyses;

- Identification of hazardous materials and energy sources present by type, quantity, form, and location;

- Facility hazard classification in accordance with DOE-STD-1027-92;

- Identification of the spectrum of potential accidents at the facility and identification of Design Basis Accidents (DBAs) to be assessed further; and

- Accident analysis of DBAs, including estimation of source terms and consequences.

These topics are discussed in more detail below.

\subsection{Facility Classification}

To develop the source term associated with the capsules stored at WESF, the Contractor considered that the capsules contain all of the activity originally packaged without accounting for decay beyond 1995 . Other bounding estimates of accumulated contamination on building surfaces and ventilation system components are used to estimate impacts from accidents involving those systems.

The estimates of the total Cesium-137 and Strontium-90 inventories stored in the WESF pool cells are 52 and 23 million curies, respectively. These values are well in excess of the Hazard Category 2 threshold values contained in DOE-STD-1027-92. WESF is therefore categorized as a Hazard Category 2 nuclear facility.

\subsection{Hazard Analysis}

The WESF hazard evaluation is a structured and systematic examination of the WESF and associated support structures and systems using standard industry hazard evaluation techniques. The hazards analysis includes identification of the hazards associated with WESF design, processes, and operations. Hazards are defined as Material At Risk (MAR) with a potential adverse effect on people or the environment and energy sources that could contribute to the uncontrolled release of that material.

MAR includes both chemicaVtoxicological and radiological species and location of the material. The material may be released in an uncontrolled manner if sufficient energy is deposited in the vicinity of the MAR. At WESF, MAR includes the cesium and strontium stored in capsules, and miscellaneous materials associated with Basin operations such as ion exchange resins and chemicals such as hydraulic fluids and lubricating oils in facility equipment.

Hazards were identified using a variety of techniques, including reviews of WESF safety documents and existing analyses, operating experience at WESF and other DOE facitities, experiences of current and former WESF personnel, and by using standard checklists for MAR and energy sources.

\footnotetext{
$\because$

Page 9 of 15
} 
HNF-SD-WM-BIO-002 REV 1

\author{
U.S. DEPARTMENT OF ENERGY \\ RICHLAND OPERATIONS OFFICE \\ SAFETY EVALUATION REPORT FOR \\ Waste Encapsulation and Storage Facility \\ September 2000
}

The hazard evaluations were based on the hazard identification results, WESF desiga, and operations, test, and maintenance activities. Waste storage and transfer operations within WESF were analyzed by evaluating the operating systems. The analyzed operations and maintenance activities werc comprehensive and accurately sepresented WESF operations.

The BIO Review Team evaluated the WESF hazards analysis, associated development, and underlying assumptions and methodology. After verifying the incorporation of improvements suggested during Review Team meetings, the Review Team accepts the WESF hazards analyses.

\title{
4.4 Accident Analysis
}

Hazardous conditions identified during the hazard evaluation were used to select accidents for detailed quantitative analysis. The aceidents, which were selected to be representative, provide an envelope of accident conditions on which WESF operations can be evaluated. The postulated accidents represent a variety of accident scenarios that involve different types and quantities of MAR. These DBAs include:

- Natural Phenomena, including the Design Basis Earthquake $(0.25 \mathrm{~g})$;

- External Events, including loss of power, ground vehicle impacts, affects from adjacent facilities, and aircraft impacts;

- Facility Fires, in Hot Cells or the Truckport;

- Loss of Confinement, through ventilation system failures;

- Facility Explosions, from fiammable gas accumulations;

- Loss of Containment, from capsule or WIXM failures; and

- Loss of Pool Cell Water, from unspecified leakage.

The final set of accidents evaluated in Chapter 3 of the WESF BIO included those considered "beyond the design basis."

Table 3-1 of the BIO provides a summary of the accidents selected for analysis, the mitigated and unmitigated consequences of each accident, and the credited SSCs and IOSR controls. All DBAs have mitigated consequences below the Risk Evaluation Guidelines contained in HNF-PRO-704, "Hazard and Accident Analysis Process." These guidelines are summarized in Table 3-17 of the BIO.

The Review Team concludes that the contractor had performed an adequate hazard and accident analysis, and agrees with the conclusions reached by the contractor. However, the Review Team notes that the treatment of aircraft impacts is not consistent with current $R L$ policy. Because the probability of this type of accident is low, conditional approval of the BIO is granted with the provision that the airsraft accident scenarios be revised and updated for incorporation into the next annual revision.

In addition, Revision 0 of the BIO committed the facility to completion of an evaluation of alternative means of mitigation of the tunnel pipe break scenarios since they could result in rapid loss of pool cell water. This evaluation has not been completed. The Review Team considers the commitment imporant from a defense-in-depth standpoint, and recommends that completion of the evaluation prior to the next annual update of the BIO be made a condition of approval. 


\author{
U.S. DEPARTMENT OF ENERGY \\ RICHLAND OPERATIONS OFFICE \\ SAFETY EVALUATION REPORT FOR \\ Waste Encapsulation and Storage Facility \\ September 2000
}

\title{
5. SAFETY STRUCTURES, SYSTEMS, AND COMPONENTS
}

BIO Section 4.0 provided a brief summary of the controls selection process that led to identification of Safety Class and Safety Significant SSCs. Per the WESF BIO, Safety Class SSCs prevent or mitigate releases to the public that would otherwise exceed the offsite radiological release limit of $0.5 \mathrm{rem}$ Committed Effective Dose Equivalent. SSCs that support the safety function of a Safety Class SSC are also Safety Class.

As defined in the BIO, Safety Significant SSCs prevent or mitigate releases of radiological materials to onsite workers to below onsite evaluation guidelines, and toxicological materials to the offsite public and onsite workers to below onsite and offsite evaluation guidelines. Safety Significant SSCs also include those safety SSCs that protect the facility worker from serious injury. SSCs which support the safety function of a Safety Significant SSC are also Safety Significant.

Defense-in-Depth, as a fundamental safety philosoghy, has an extensive historical precedent in nuclear safety. Defense-in-Depth builds in multiple layers of defense against a release of hazardous materials so that no single control is completely essential. To compensate for potential human and mechanical failures, Defense-in-Depth relies on several layers of protection with successive barriers to prevent the release of hazardous material to the environment.

The Safety SSCs identified for WESF based on the accident analysis performed are shown on Table 3-10 of the BIO. The table includes SSCs identified as Safety Class, Safety Significant, and Defense-in-Depth. The SSC identified as Safery Class are as follows: the Area 2 (hot cell) structure; pool cell level instrumentation; the Area 3 (pool cell) stnicture; the 296-B stack and K-3 exhaust ducting; the pool cell water circulation piping; pool cell emergency water makeup; pool cell area radiation monitoring; the K-3 Filter Pit structure; the K-3 HEPA filters; the pool cell drain line; and the bridge crane, catwalk, and associated supports.

Based on its review, the Revicw Team concludes that:

- the safety SSCs identified and described in the BIO/IOSRs are consistent with the logic presented in the hazards and accident analysis;

- safery functions for safety SSCs are defined consistently with the bases derived from the hazards and accident analyses;

- functional requirements and system evaluations are derived from the safety function and provide evidence that the safety functions can be performed; and

- the relationship of SSCs and IOSR development is identified.

\subsection{DERIVATION OF INTERIMI OPERATIONAL SAFETY REQUIRENENTS}

\subsection{Overview}

IOSRs define acceptable conditions, safe boundaries, and administrative controls that ensure safe operation of a nuciear facility. Through their implementation, IOSRs also reduce the potential risk to the public and onsite workers from uncontrolled releases of radiological or toxicological materials or from exposures caused by an inadvertent criticality.

. . Page 11 of 15




\section{U.S. DEPARTMENT OF ENERGY \\ RICHLAND OPERATIONS OFFICE \\ SAFETY EVALUATION REPORT FOR \\ Waste Encapsulation and Storage Facility \\ September 2000}

The WESF IOSR controls are considered necessary and sufficient for public safety, significant worker safety, and for maintaining radiological and toxicological consequences below release limits and evaluation guidelines. IOSR level controls are defined in DOE Orders as Safety Limits (SLs), Limit Control Settings (LCSs), Limiting Conditions of Operation (LCOs), Administrative Controls (ACs), and design features.

\subsection{Safety Limits}

There are no SLs for WESF. The uncontrolled release of radioactive material is prevented by maintaining water in pools which have limited leakage potential, and by equipping the hot cell ventilation system with HEPA filters. The limited leakage potential allows sufficient time for automatic or visual detection and provision of makeup capability from alternate sources.

\subsection{Limiting Control Settings}

Because no SL was identified, based on analyzed accidents, an LCS was not included in the IOSR set. LCSs are setpoints or trigger points on safety systems that control process variables to prevent exceeding an SL. The LCS may be combined with an LCO. The combination establishes the LCS setpoint as part of system operability.

\subsection{Limiting Conditions for Operation}

Accidents or hazards, exceeding offsite release limits and evaluation guidelines but not meeting the SL or LCS criteria, are candidates for LCOs or ACs.

An AC is selected instead of an LCO if the control is better managed by a program. LCOs are used to define the functional capability or performance level of Safety SSC required for normal operation. The Contractor's control selection process is consistent with the guidance in DOE-STD-3009-94, Preparation Guide for U.S. Department of Energy Nonreactor Nuclear Facility Safety Analysis Reports. Specific Actions/Activities reviewed include parameter measurements, control of field conditions, response actions, surveillances, and prior control methods. Following this general guidance, LCOs are provided for the following:

- Pool cell water loss detection system; and

- K-3 HEPA filter efficiency.

The safety function of the pool cell water loss detection system is to alert the operator at the start of a rapid water loss situation so that appropriate actions (e.g., begin water makeup) can be taken before loss of institutional control occurs due to an adverse and inaccessible environment. LCO 3.1 establishes requirements for maintenance of minimum water levels in the pool cells, and for provision of water loss detection capability consisting of water level and area radiation monitoring systems. LCO 3.2 requires that a HEPA filter with a particulate removal efficiency of at least $99.9 \%$ be provided for the $\mathrm{K}-3$ ventilation system, which services the hot cells.

\subsection{Administrative Controls}

In addition, the IOSR set provides $17 \mathrm{ACs}$ which follow the control selection methodology. The ACs identify the provisions relating to administration and management, procedures, record keeping, reviews, audits, and specific program requirements for risk reductions necessary to ensure safe operations of the 
HNF-SD-WM-BIO-002 REV 1

\section{U.S. DEPARTMENT OF ENERGY \\ RICHLAND OPERATIONS OFFICE \\ SAFETY EVALUATION REPORT FOR \\ Waste Encapsulation and Storage Facility \\ September 2000}

WESF and associated structures and systems. Section 5.0 of the IOSR document addresses the following:

- Purpose (AC 5.1);

- Contractor Responsibility (AC 5.2);

- Compliance (AC 5.3);

- Interim Operational Safety Requirement Violations (AC 5.4);

- Occurtence Reporting (AC 5.5):

- Organization (AC 5.6);

- Source Inventory Controls (AC 5.7);

- Pool Cell Water Makeup (AC 5.8);

- Hydrogen Prevention Controls (AC 5.9);

- Heavy Loads Over Pool Cells (AC 5.10);

- K-3 HEPA Filter System Efficiency (AC 5.11);

- Fire Protection Program (AC 5.12);

- Pool Cell Steam Jet Operation Controls (AC 5.13);

- Flammable Gas Controls (AC 5.14);

- Pool Cell Area Radiation Monitors (AC 5.15);

- WIXM Radiation Monitoring and Venting (AC 5.16); and

- WIXM Post-Use Filling of Void Space (AC 5.17).

\subsection{Design Features}

Safety SSCs are defined as design features rather than LCOs or ACs when the safety function is to maintain specific design criteria as assumed or implied within the safety analysis. Desiga features are considered IOSR level controls and are managed with appropriate configuration and engineering control processes.

If a design feature was altered or modified, it would have a significant impact on safety. Design features are normally permanently built-in features that do not require, or infrequently require, maintenance or surveillance and are not nomally subject to change by field personnel. Design features include vital passive components such as piping, vessels, supports, confinement structures, and containers. WESF design features include the following: basin structure, basin drain valves, basin superstructure, and transfer bay bridge cranes.

\subsection{IOSR Conclusions}

Page 13 of 15 


\author{
U.S. DEPARTMENT OF ENERGY \\ RICHLAND OPERATIONS OFFICE \\ SAFETY EVALUATION REPORT FOR \\ Waste Encapsulation and Storage Facility \\ September 2000
}

The RL Review Team directed, and the Contractor made, the necessary changes to the WESF IOSR document. The Review Team therefore concludes that Section 5 of the BIO and the IOSR document provide adequate bases for deriving the IOSRs which are consistent with the hazard and accident analyses and the description of Safety SSC contained in Sections 3 and 4 of the BIO.

\title{
7.0 PROGRAMMATIC CONTROLS
}

Programmatic Control encompasses the elements of institutional programs and facility management practices that are necessary to ensure safe operations based on the assumptions of the hazards and accident analyses. Programmatic Control is a product of the hazards and accident analyses, designation of SSCs, and derivation of IOSRs.

Programmatic Controls are maintained as part of the Integrated Safety Management System (ISMS) to minimize the risks to the public, onsite workers, and facility workers, and to ensure the safe operation of WESF and associated SSCs. A number of key program elements support WESF Programmatic Controls. The key elements are included in AC 5.11 .

Section 6.5 of this SER outlined the suite of Administrative Control Programs required to preserve the assumptions of the hazards and accident analysis. The ACs preserve requisite assumptions, and ensure that equipment and programs are available as assumed in the accident analysis. In addition, Section 6 of the BIO addresses additiona! programmatic controls such as radiation safety, radioactive and hazardous waste management, operational safety, emergency preparedness, procedures and training, and quality assurance.

Based on its review of BIO Revision 1, the Review Team concludes that:

- The major programs needed to provide programmatic safery are identified;

- The basic provisions of the identified programs are noted, and references to facility or site program documentation are provided.

The Review Team did note that while the BIO contained general discussions of organizational responsibilities, detailed information was not provided. The Review Team concludes that, because of the importance of the concepts of command and control and ciear channels of communication and designation of authority and responsibility, a condition be incorporated into this approval requiring that the next revision of the BIO contain an updated organizational description of the facility and its management that addresses major programmatic responsibilities described and credited for safety and protection of the environment.

\section{CONCLUSION}

The Review Team has concluded that the revised BIO and $1 O S R$ documents are acceptable, and recommend approval of these documents as the Authorization Basis for WESF subject to the following conditions:

1. The contractor shall incorporate into the next annual update of the BlO revised and updated aircraft accident scenarios.

2. The contracior shall complete an evaluation of alternative means of mitigation of the turnel pipe break scenarios, and coordinate the evaluation with RL prior to incorporation into the next annual update of the BIO. 


\section{HNF-SD-WM-BIO-002 REV 1}

\section{U.S. DEPARTMENT OF ENERGY \\ RICHLAND OPERATIONS OFFICE \\ SAFETY EVALUATION REPORT FOR \\ Waste Encapsulation and Storage Facility \\ September 2000}

3. The contractor shall incorporate into the next annual update of the BIO an updated organizational description of the facility and its management that addresses major programmatic responsibilities described and credited for safery and protection of the eavironment.

\section{REFERENCES}

1. FDH letter to J. C. Hall from R. D. Hanson, "Waste Encapsulation and Storage Facility Basis for Interim Operation 1999 Annual Update," dated March 15, 1999.

2. FHI letter to K. A. Klein from R.D. Hanson, "Waste Encapsulation and Storage Facility Basis for Interim Operation," dated August 25, 2000.

3. FHI letter to G. H. Sanders from E. S. Aromi, "Transmittal of Comment Resolutions on the Waste Encapsulation and Storage Facility Basis for Interim Operation Annual Update," dated June 26, 2000 .

4. FDH letter to S. J. Veitenheimer from E. S. Aromi, "Waste Encapsulation and Storage Facility 1999 Annual Report on Unreviewed Safety Question Evaluations," dated February 1, 2000.

5. FDH letter to P. M. Knollmeyer from L. J. Olguin, "B Plant/Waste Encapsulation Storage Facility 1998 Annual Report on Unreviewed Safety Question Evaluations," dated April 22, 1999. 
00-ABD-076

\section{SEP 292000}

Mr. R. D. Hanson, Presideat

Fluor Hanford, Inc.

Richland, Washington 99352

Dear Mr. Hanson:

CONTRACT NO. DE-AC06-96RL13200 - WASTE ENCAPSULATION AND STORAGE FACILITY (WESF) BASIS FOR INTERIM OPERATION (BIO)

This is in response to your letter to me dated August 25, 2000, same subject, which submitted Revision 1 of the WESF BIO and Interim Operational Safety Requirements.

RL has reviewed the submitted documents and concluded that they are acceptable. RL hereby approves these documents subject to the conditions contained in the attached Safety Evaluation Report (SER). This SER supercedes all previous SERs and becomes the new SER of record. Please note this in the next revision to the facility Authorization Agreement.

If you have any questions or comments, please contact me, or your staff may contact Jim McCracken, Authorization Basis Division, at (509) 376-4360.

ABD:JJM

Sincerely,

ORIGINAL SIGNED BY

Keith A. Klein

Manager

Attachment

cc w/attach:

B. A. Austin, FHI

L. I. Covey, FHI

E. S. Aromi, WMH

D. R. Ellingson, WMH

C. J. Wolfe, WMH

bec:

ABD OFF File

C. J. Bosted, ABD

W. A. Ruhlman, OOD

S. A. Sieracki, PRO

R. P. Carter, WMD

S. K. Moy, WMD

G. H. Sanders, WMD

Record note: This letter approves the new authorization basis documentation for the WESF facility located in the 200 East Area. The review by RL staff is documented in the attached Safety Evaluation Report. This facility is currently scheduled to operate through 2017. This letter completes manager's action item D8413349. Minor edits made $9 / 21 / 00$.

\begin{tabular}{|c|c|c|c|c|c|c|}
\hline \multirow{3}{*}{$\begin{array}{l}\text { Office > } \\
\text { Sumame > } \\
\text { Date > }\end{array}$} & ABO & $A B D$ & AMSE & WMD & AMEW & DMST \\
\hline & MCCRACKEN & BOSTED & JOHNSON & SANOERS & BILSON & KRUGER \\
\hline & $9 / 20 / 00$ & $9 / 21 / 00$ & & & & \\
\hline \multirow{3}{*}{$\begin{array}{l}\text { Office > } \\
\text { Surname > } \\
\text { Date > }\end{array}$} & MGR & & & & & \\
\hline & KLEIN & & & & & \\
\hline & & & & & U1 & \\
\hline \multicolumn{6}{|c|}{ (Please retum to Diana Scolt 6-6004 A5-14/Fed 500 FAX 6-6621) } & ocument \\
\hline
\end{tabular}


00-ABD-076

\section{SEP 292000}

Mr. R. D. Hanson, President

Fluor Hanford, Inc.

Richland, Washington 99352

Dear Mr. Hanson:

CONTRACT NO. DE-AC06-96RL13200 - WASTE ENCAPSULATION AND STORAGE FACILITY (WESF) BASIS FOR INTERIM OPERATION (BIO)

to me datecl

This is in response to your letter of August 25,2000 , same subject, which submitted Revision 1 of the WESF $\mathrm{BIO}$ and Interim Operational Safety Requirements.

$R L$ has reviewed the submitted documents and concluded that they are acceptable. RL hereby approves these documents subject to the conditions contained in the attached Safety Evaluation Report (SER). This SER supercedes all previous SERs and becomes the new SER of record. Please note this in the next revision to the facility Authorization Agreement.

If you have any questions or comments, you may contact me, or your staff may contact Jim McCracken, Authorization Basis Division, at (509) $376-4360$.

ABD:JM

Sincerely,

ORIGINAL SHÉTIÉE BY.

Keith A. Klein

Manager

Attachment

cc: B. A. Austin, FHI

L. I. Covey, FHI

E. S. Aromi, WMH

D. R. Ellingson, WMH

C. J. Wolfe, WMH

bcc:

ABD OFF File

C. J. Bosted, ABD

W. A. Ruhlman, OOD

S. A. Sieracki, PRO

R. P. Carter, WMD

S. K. Moy, WMD

G. H. Sanders, WMD

Record note: This letter approves the new authorization basis documentation for the WESF facility located in the 200 East Area. The review by $\mathrm{RL}$ staff is documented in the attached Safety Evaluation Report. This facility is currently scheduled to operate through 2017. This letter completes manager's action item D8413349.

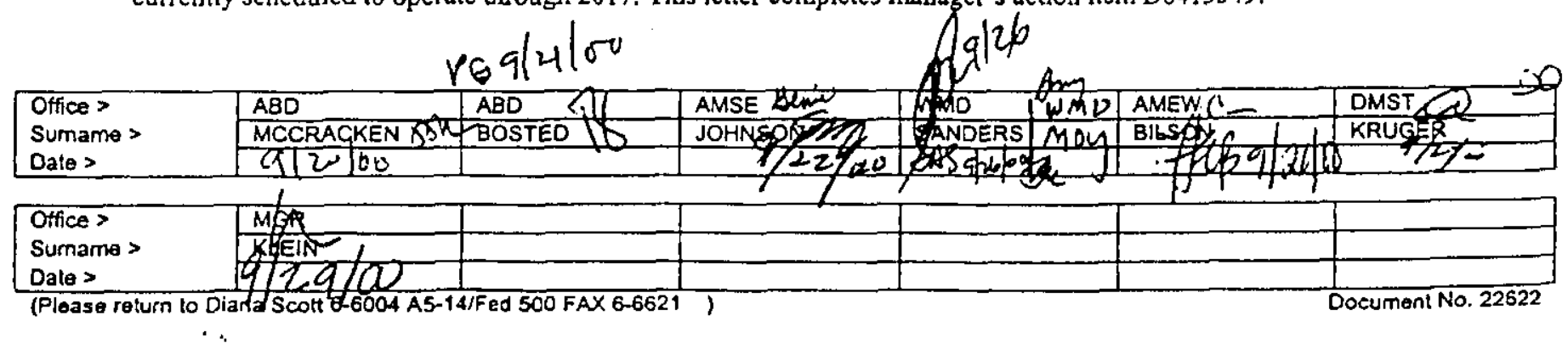




\section{HNF-SD-WM-BIO-002 REV 1}

APPENDIX B

Department of Energy Review Comment Records 


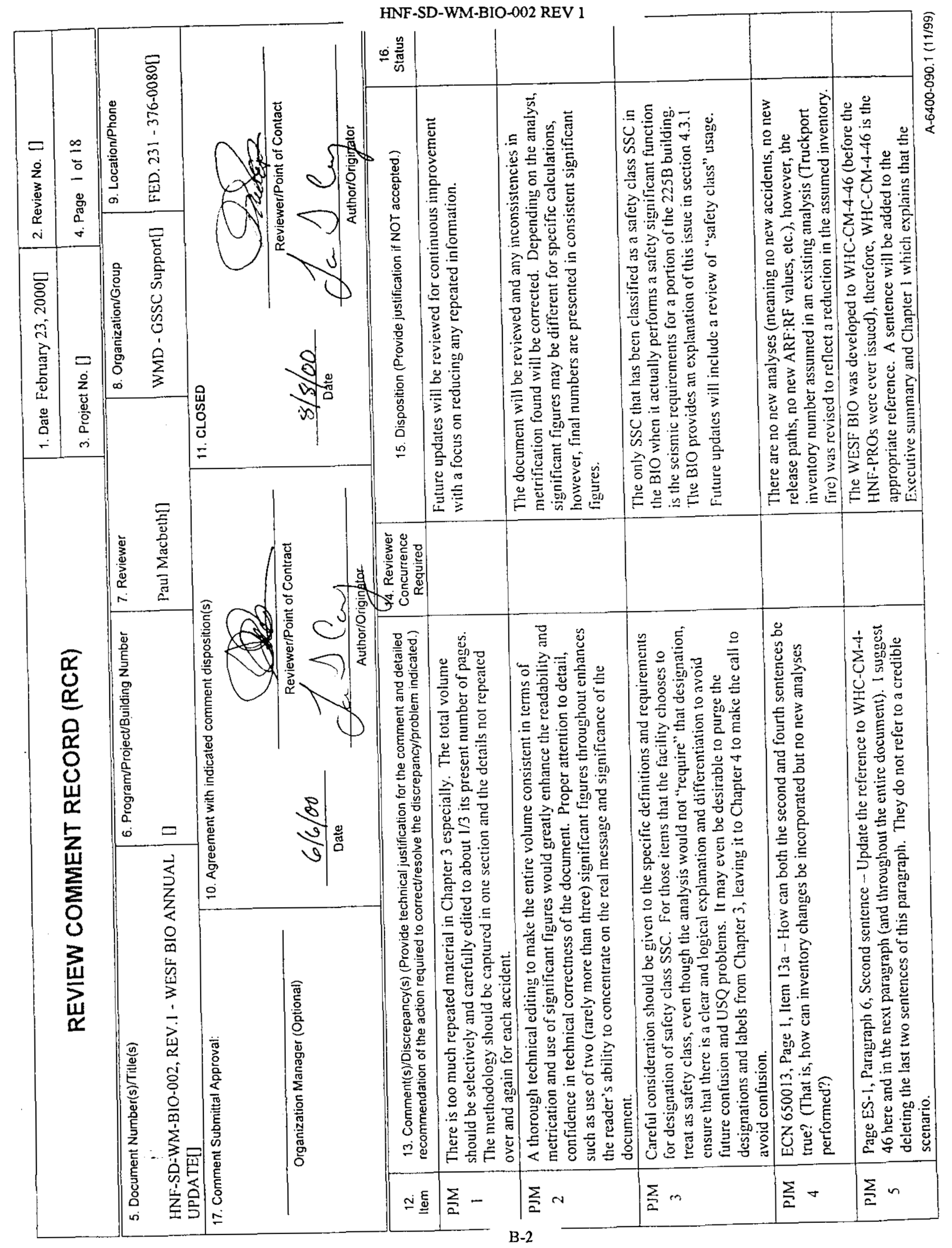


HNF-SD-WM-BIO-002 REV 1

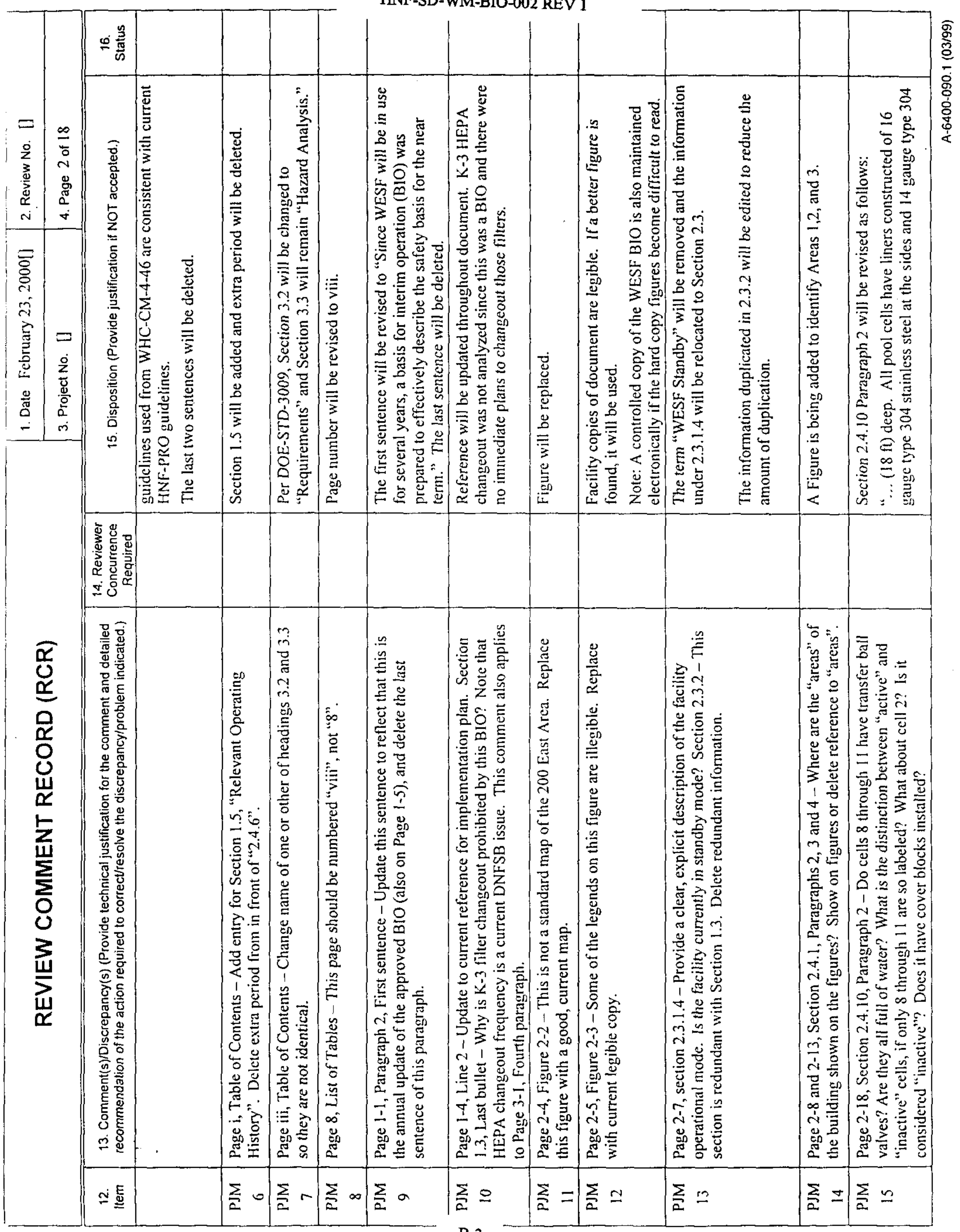


HNF-SD-WM-BIO-OO2 REV 1

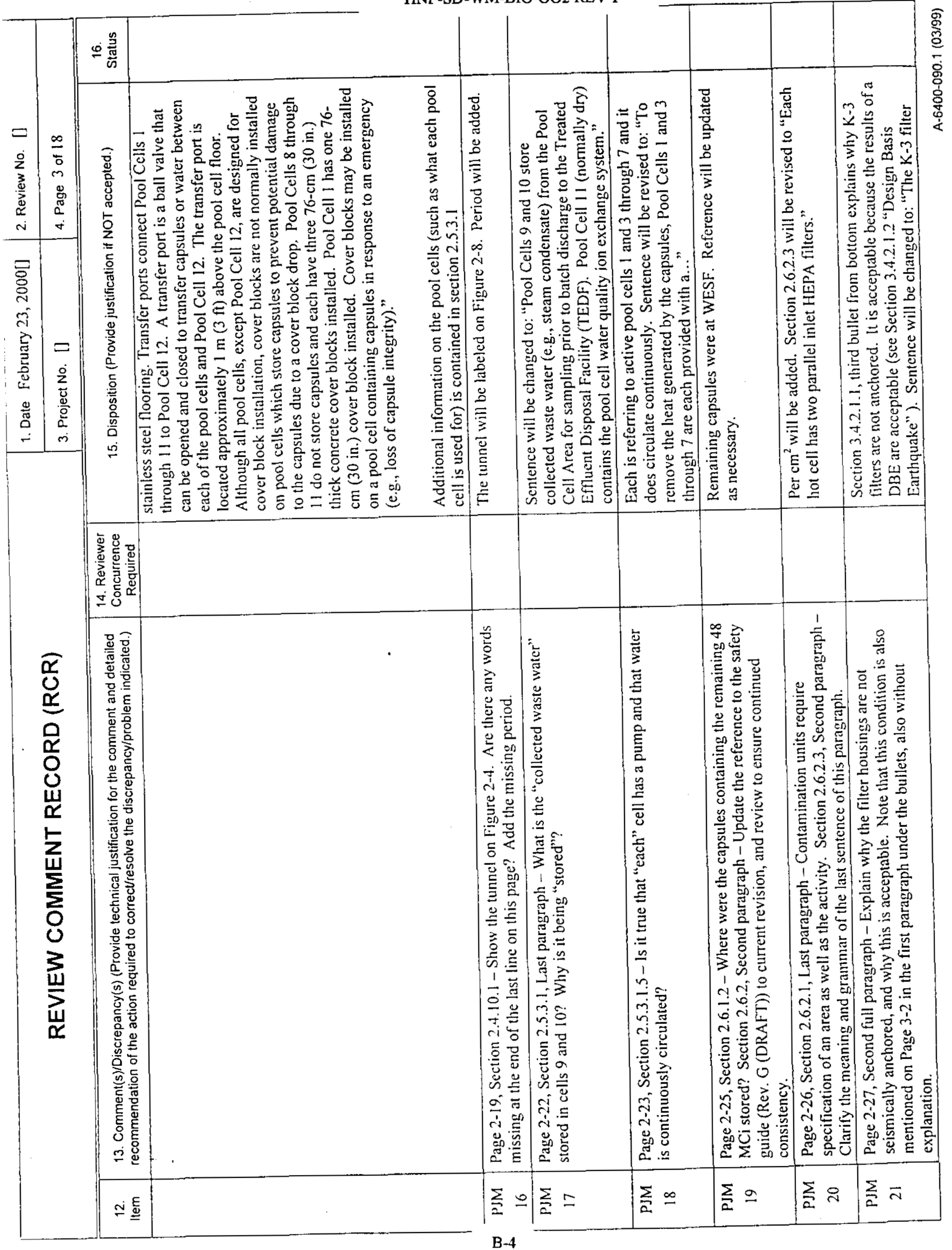


HNF-SD-WM-BIO-002 REV 1

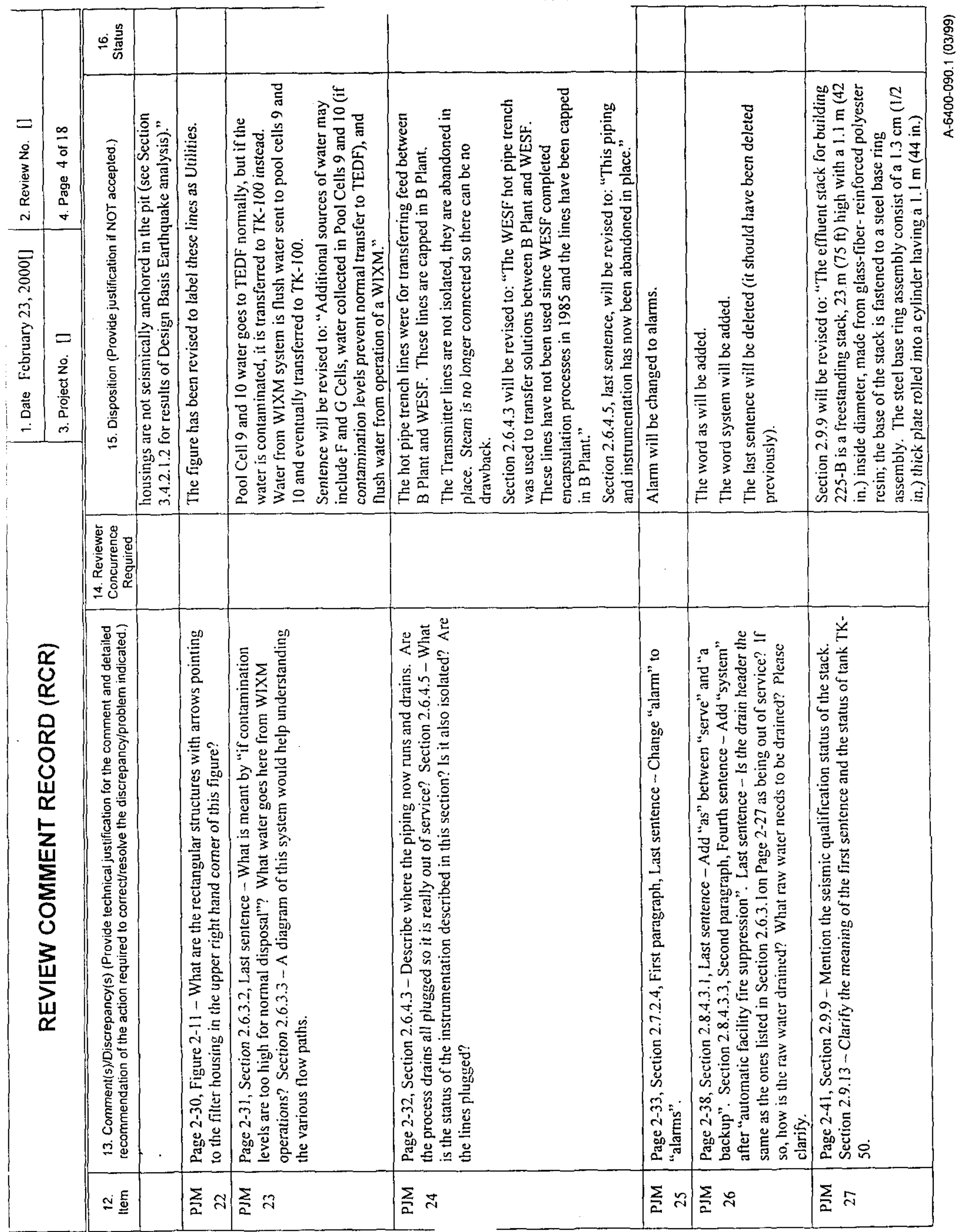


HNF-SD-WM-BIO-OO2 REV 2

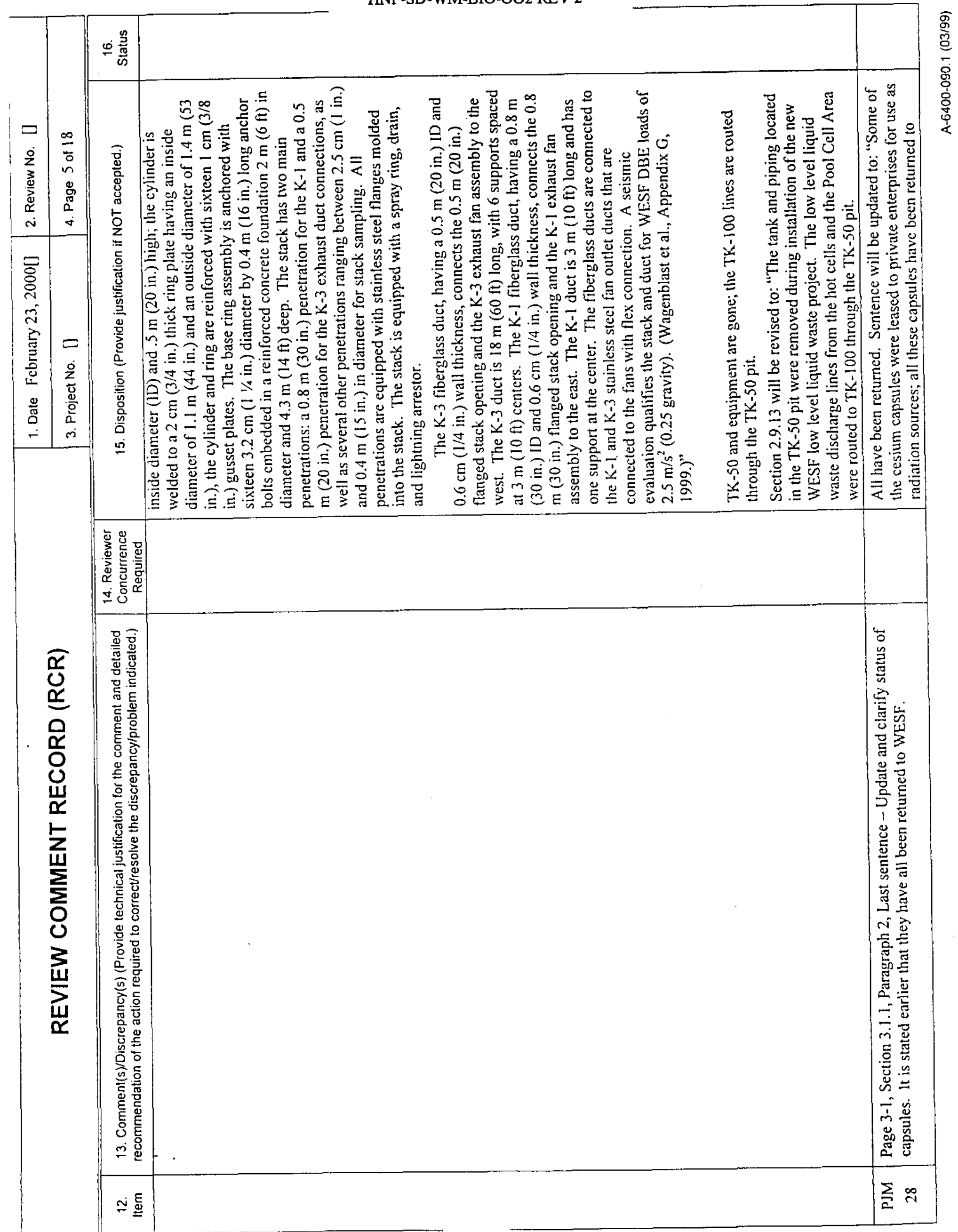


HNF-SD-WM-BIO-OO2 REV 1

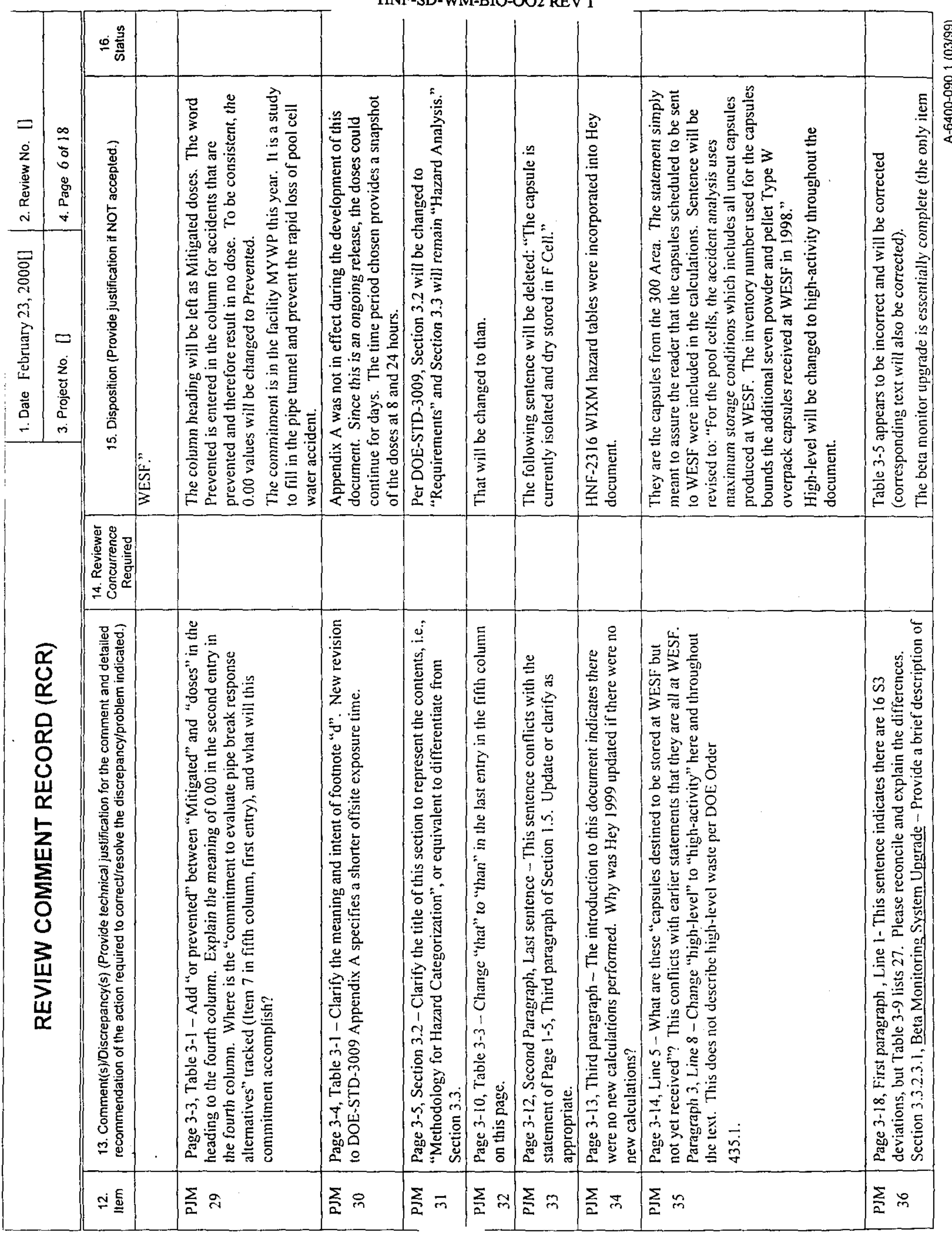




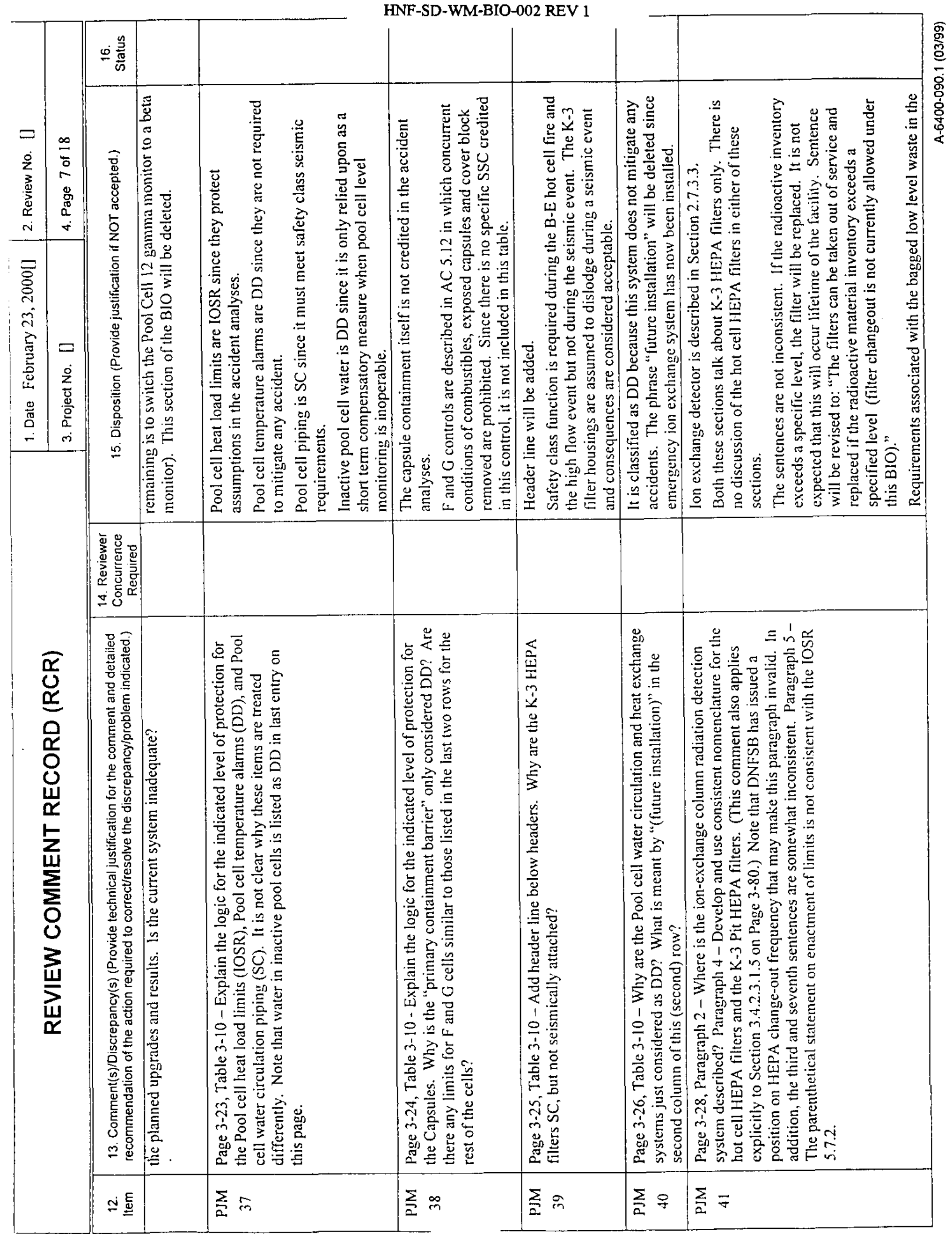


HNF-SD-WM-BIO-002 REV 1

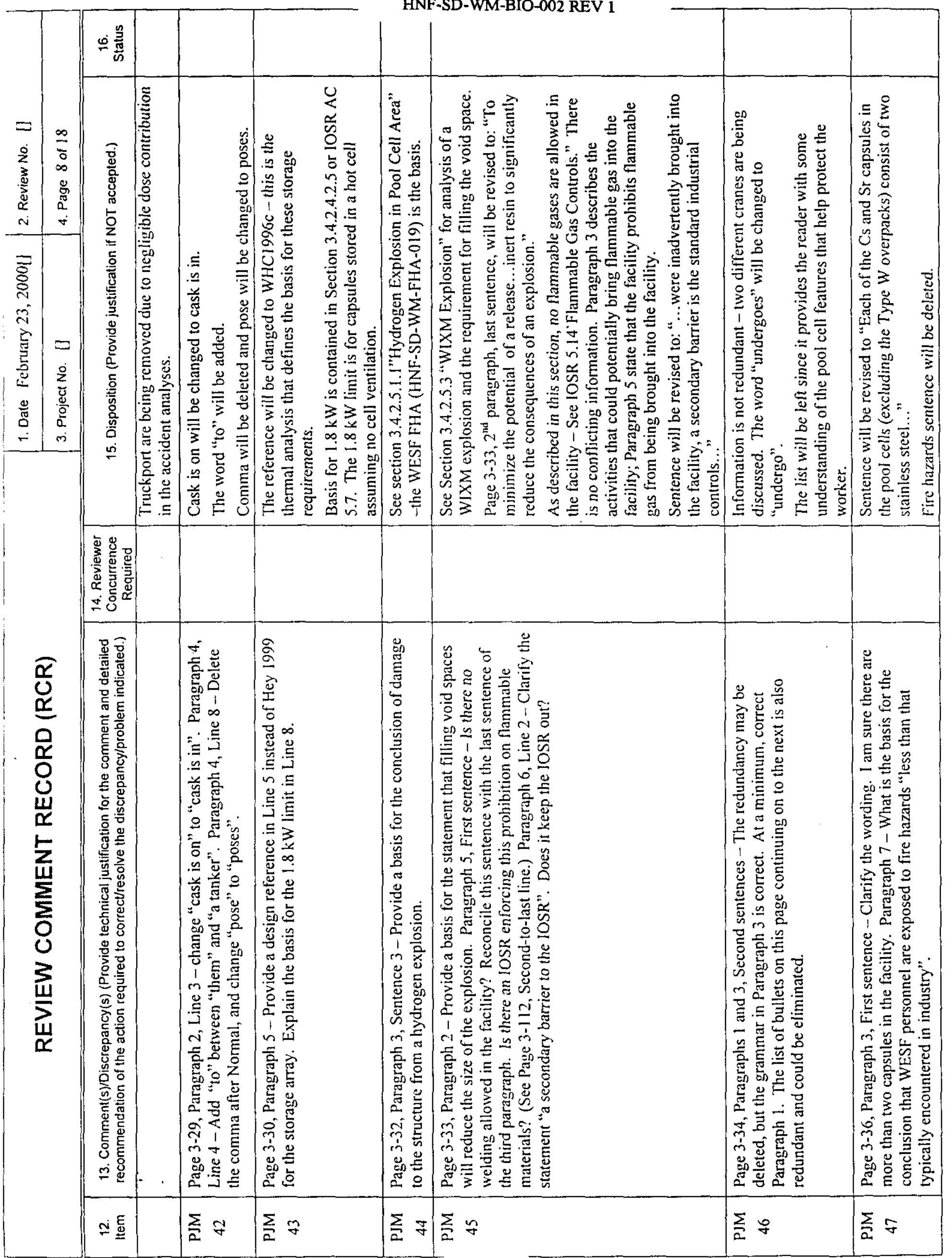




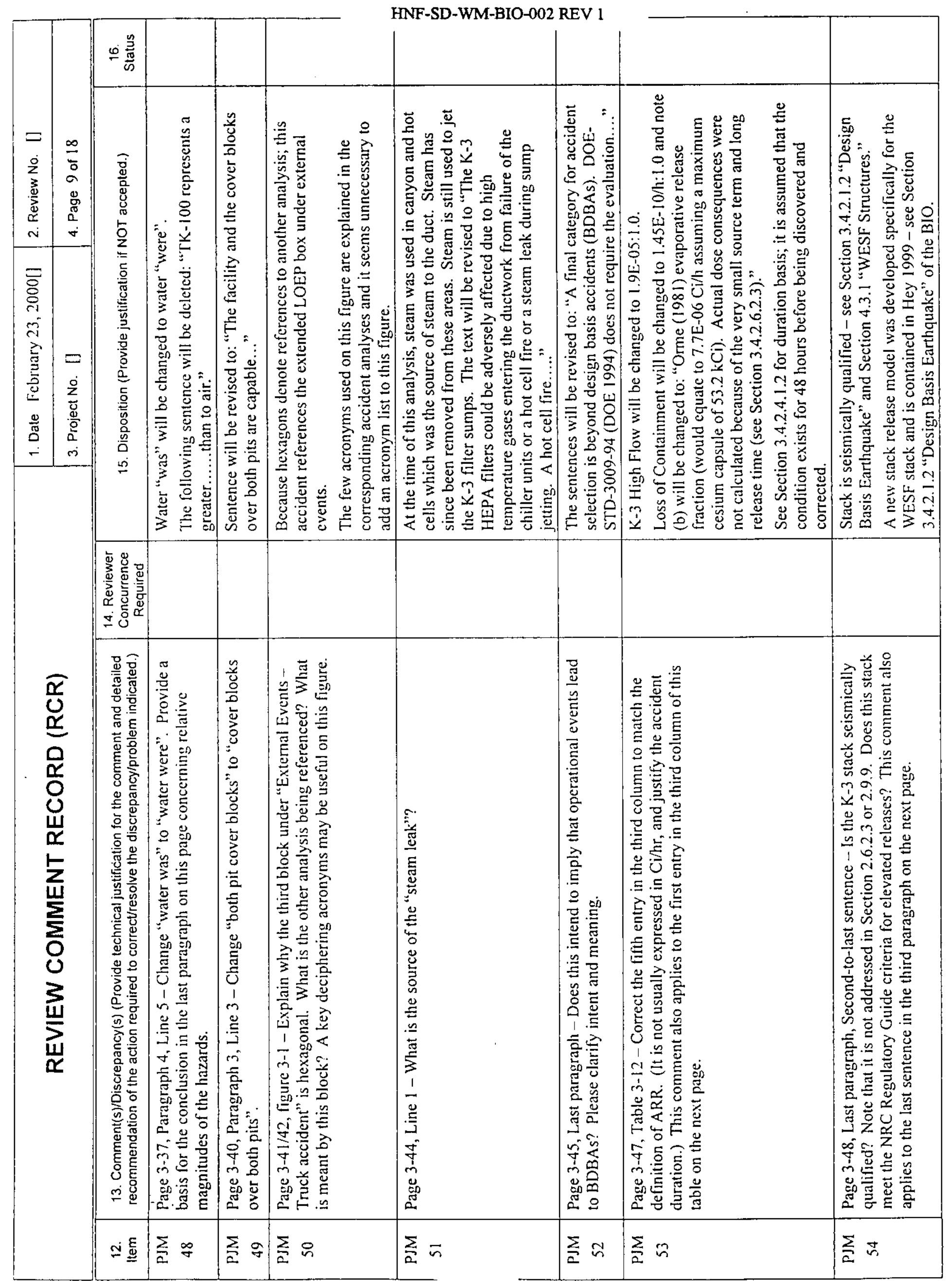




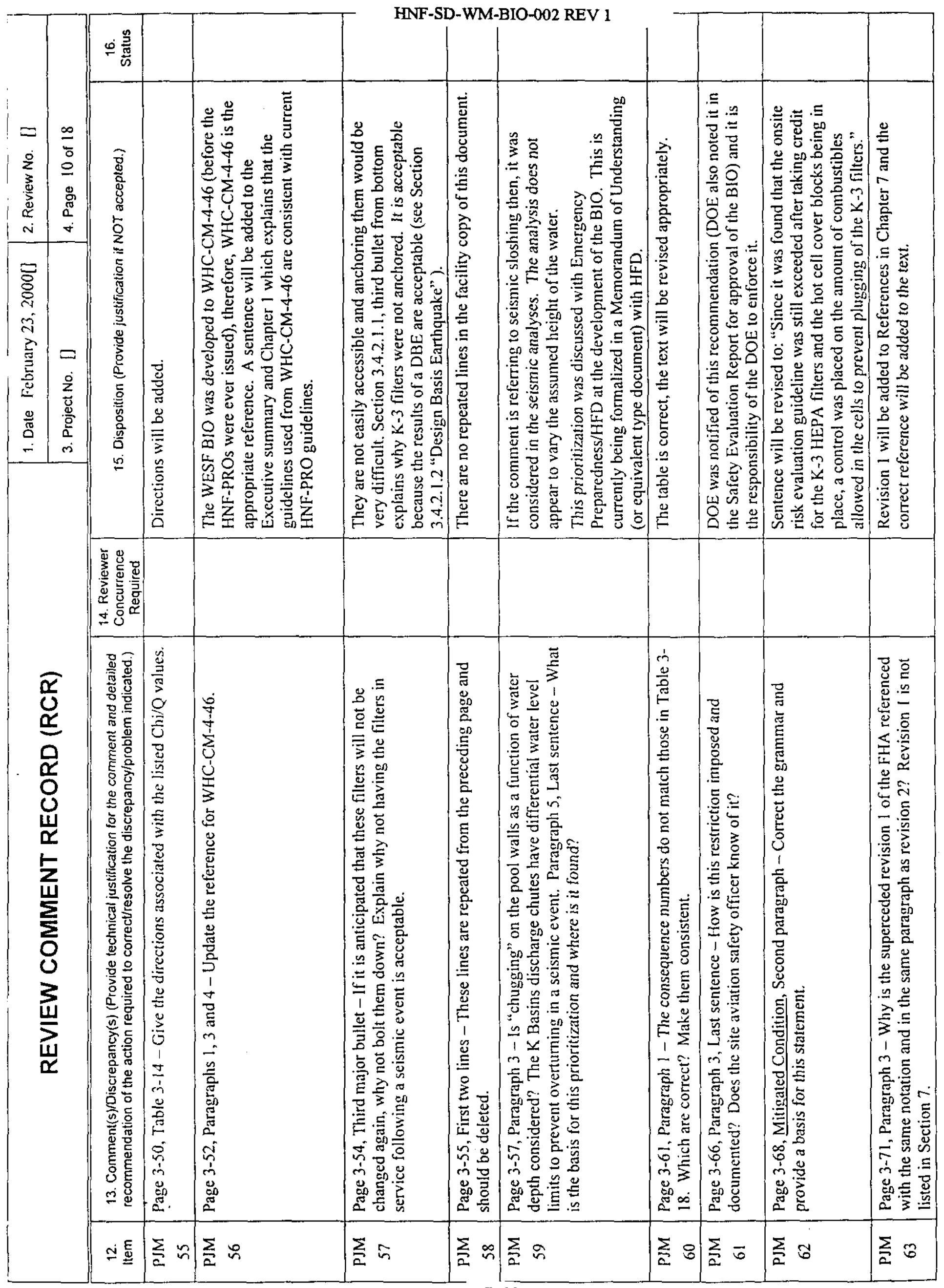




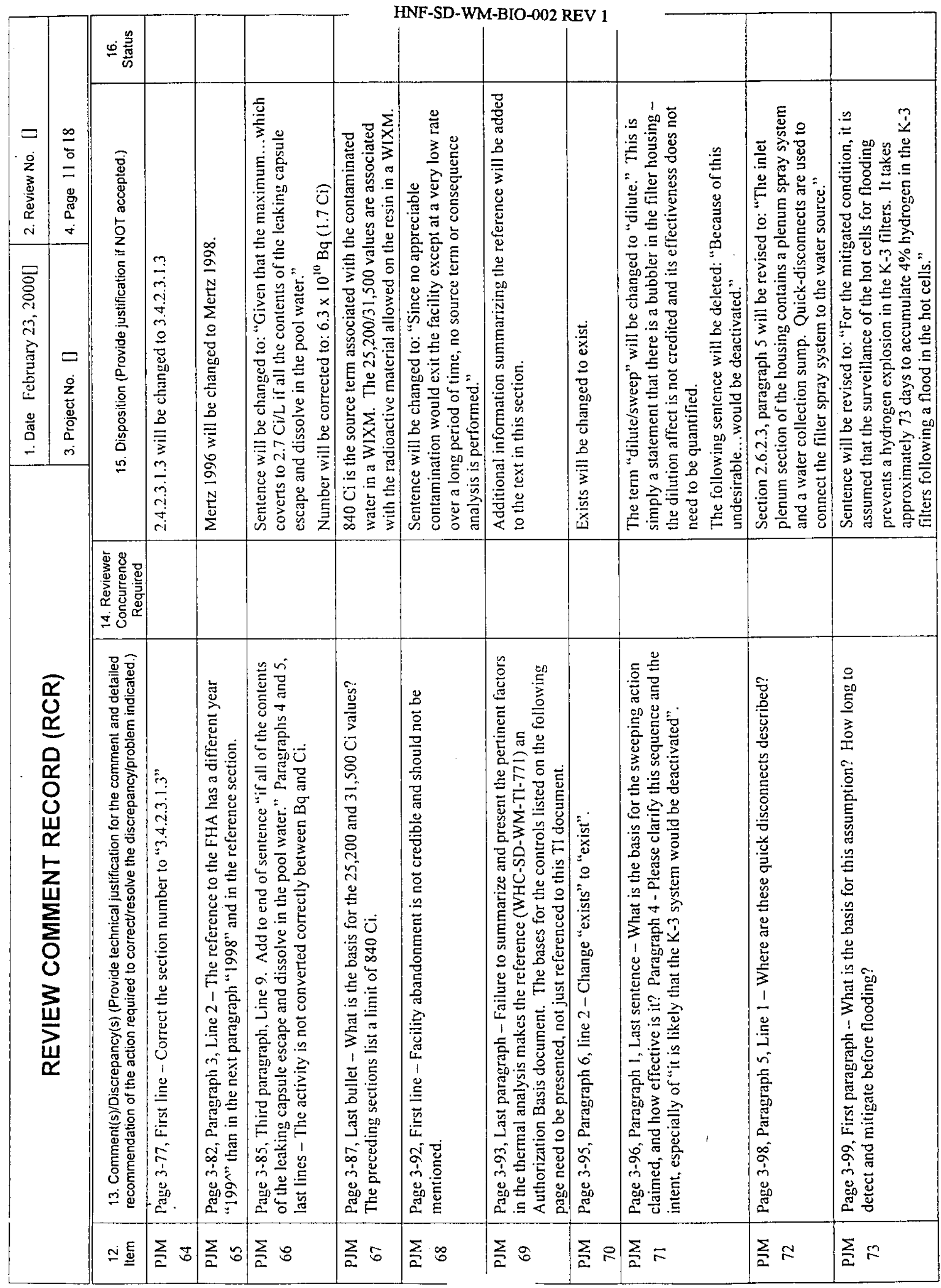




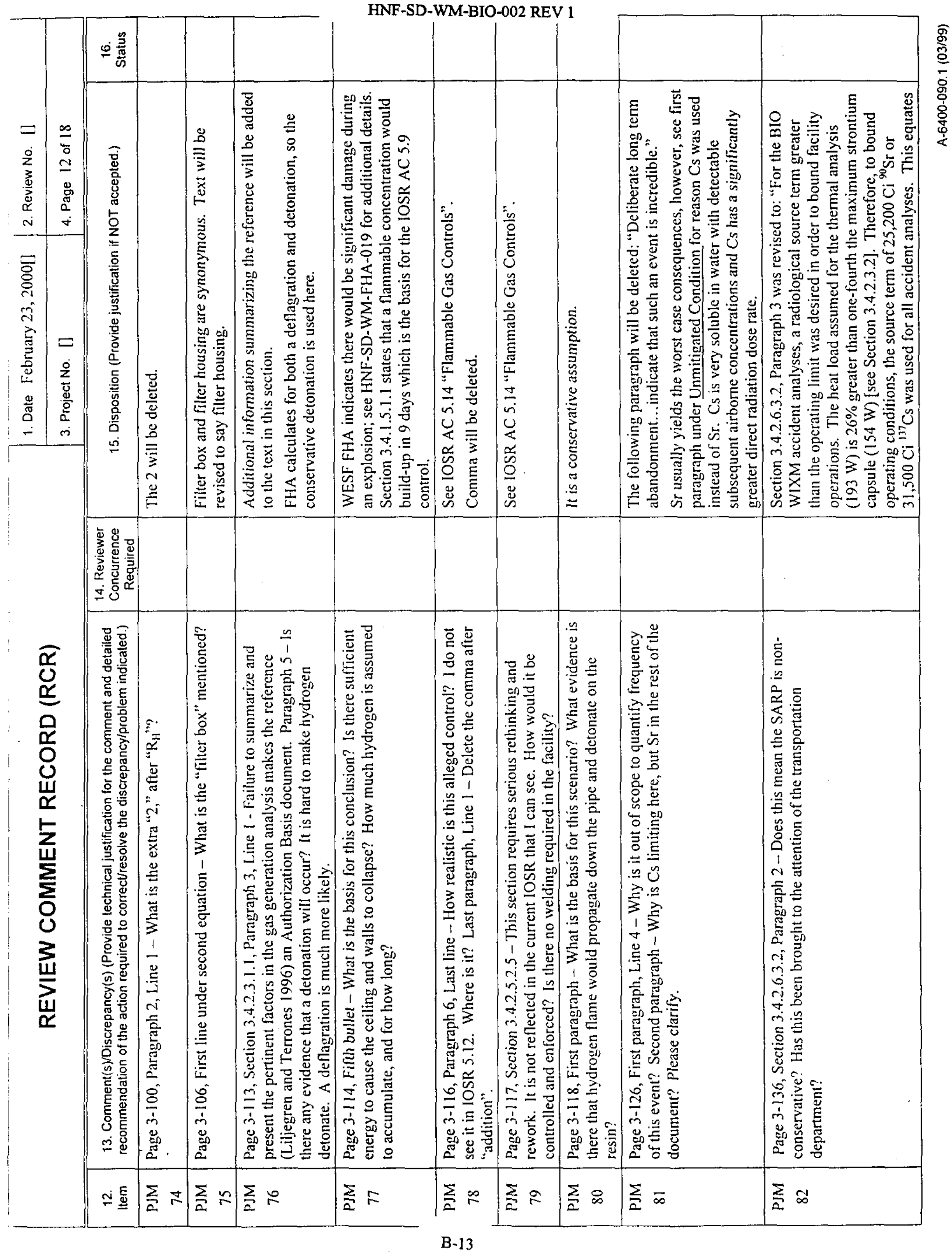


HNF-SD-WM-BIO-002 REV 1

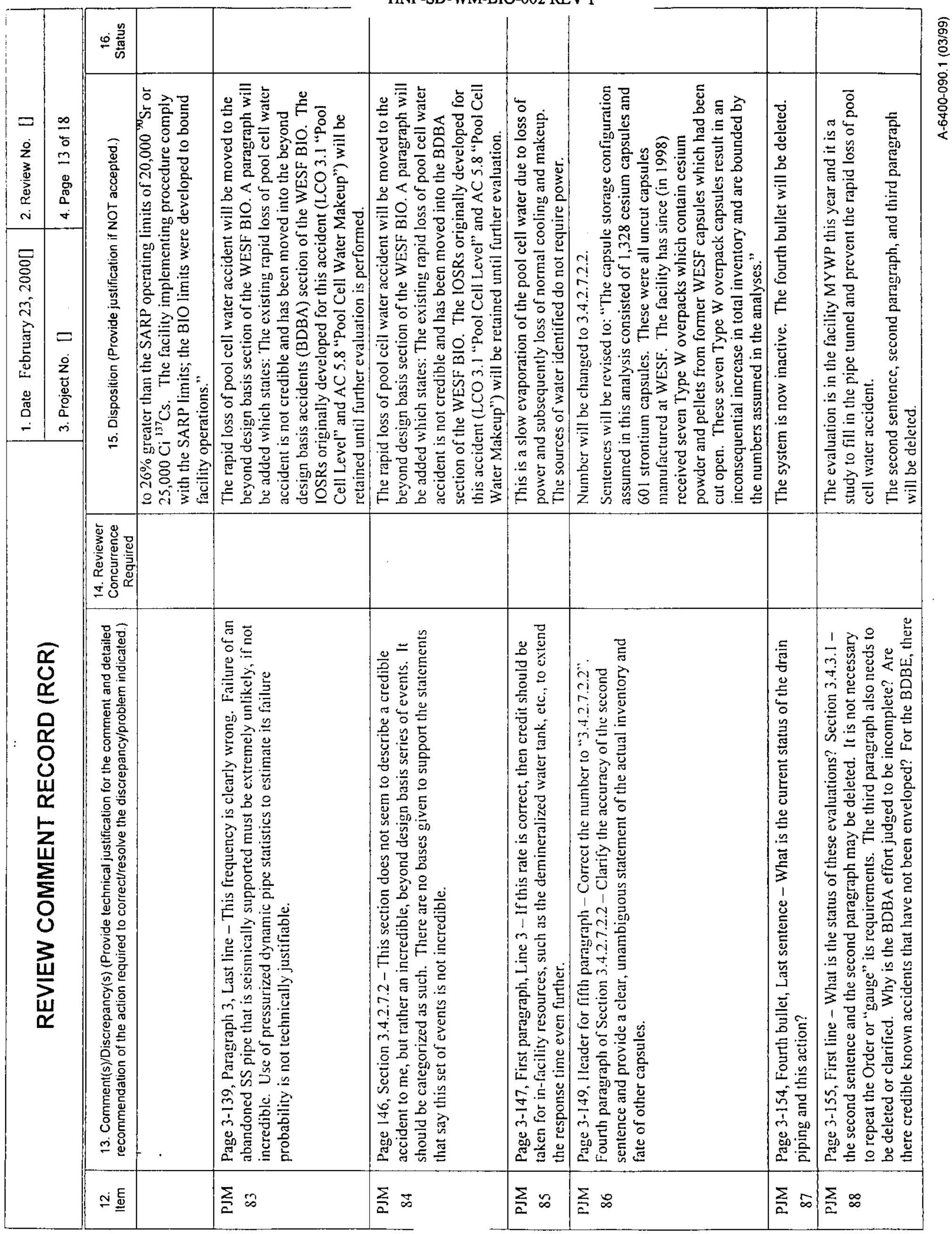




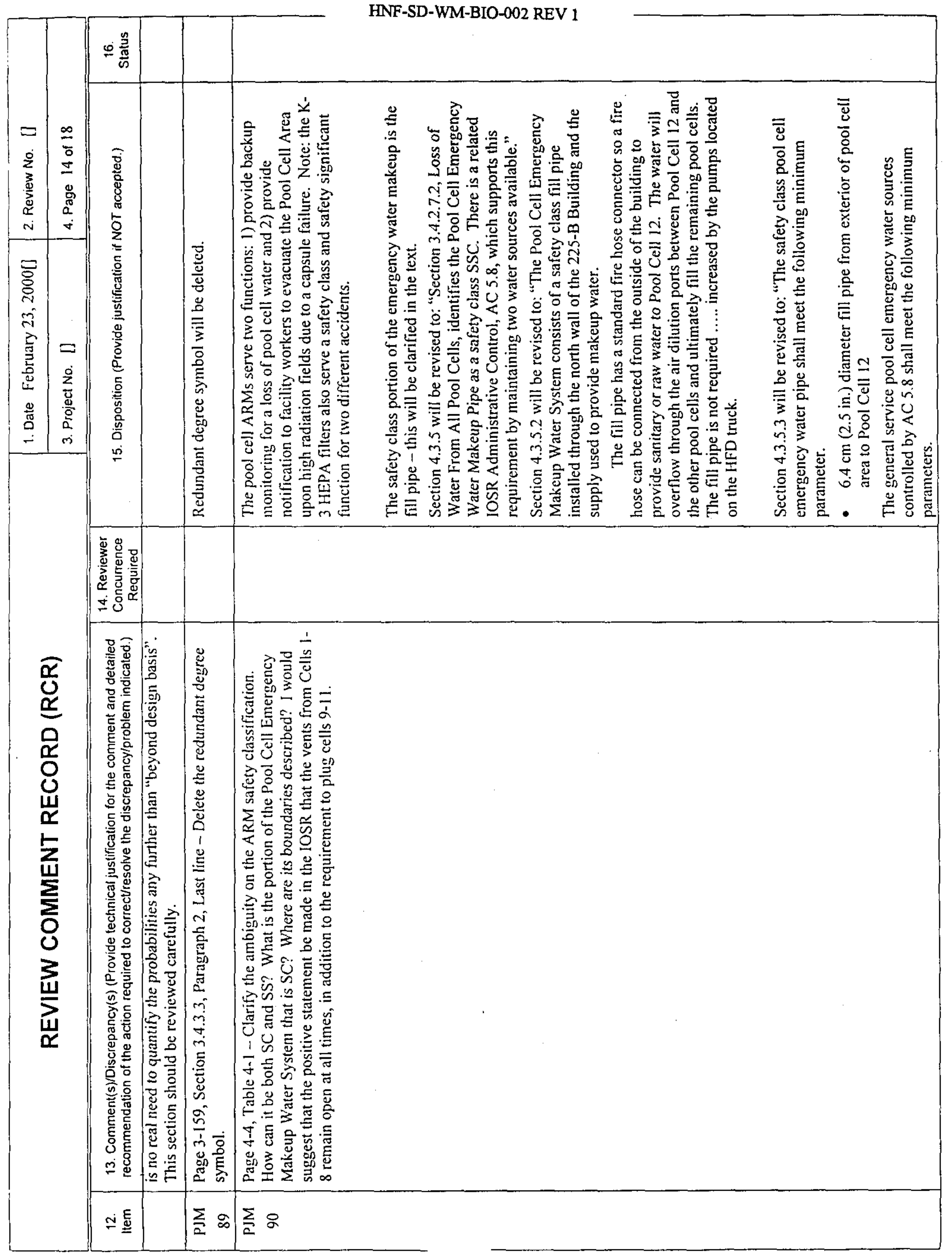




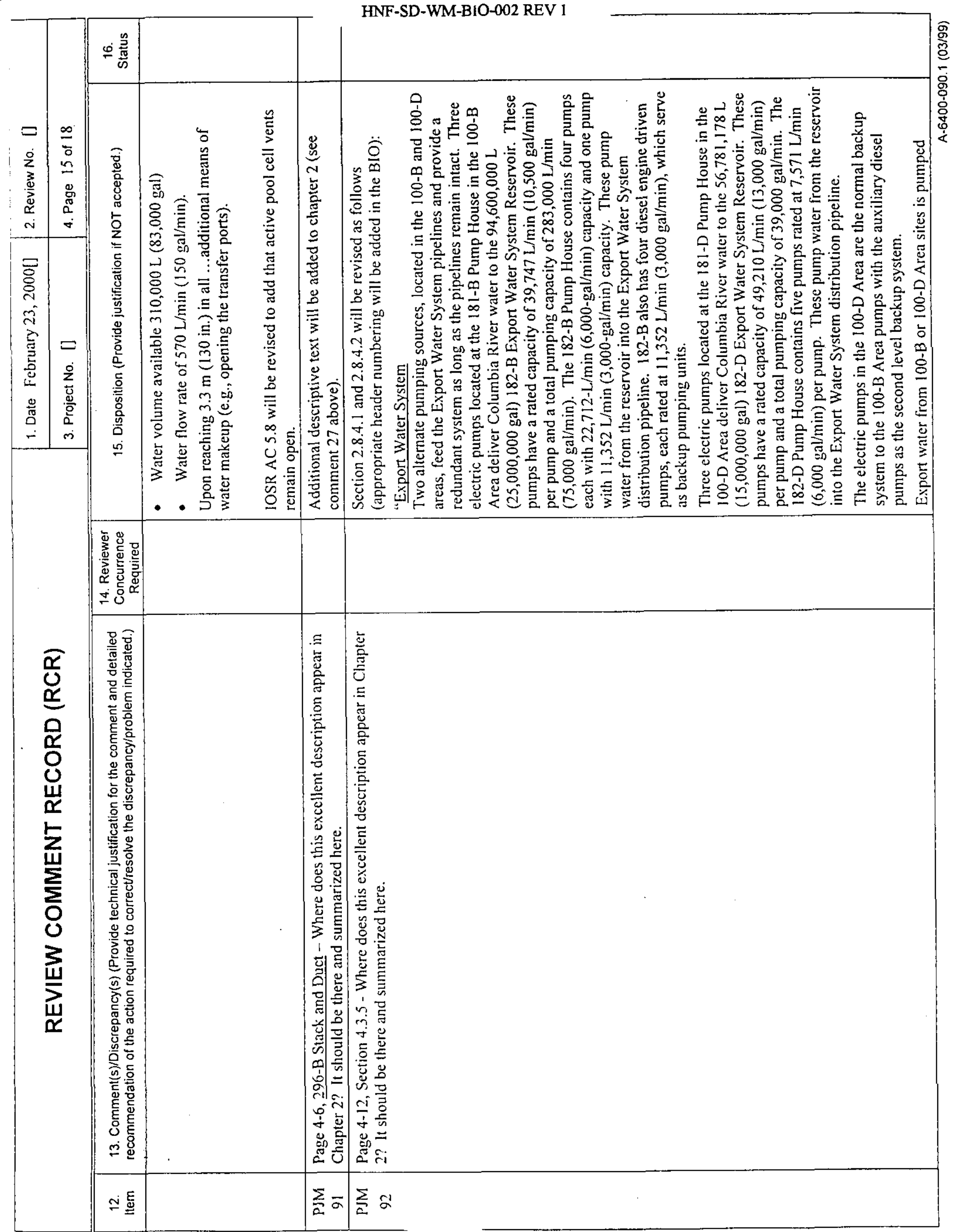




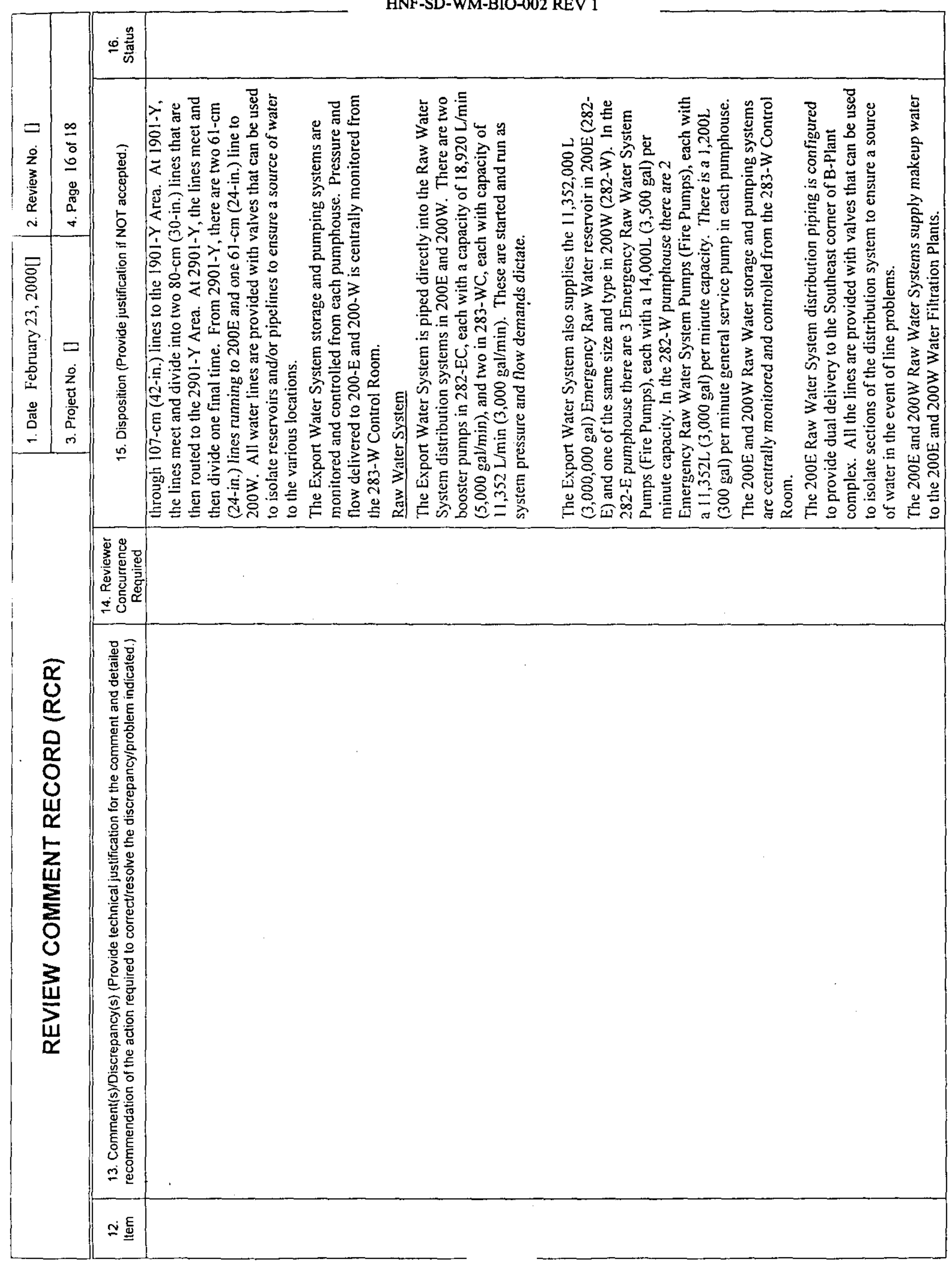




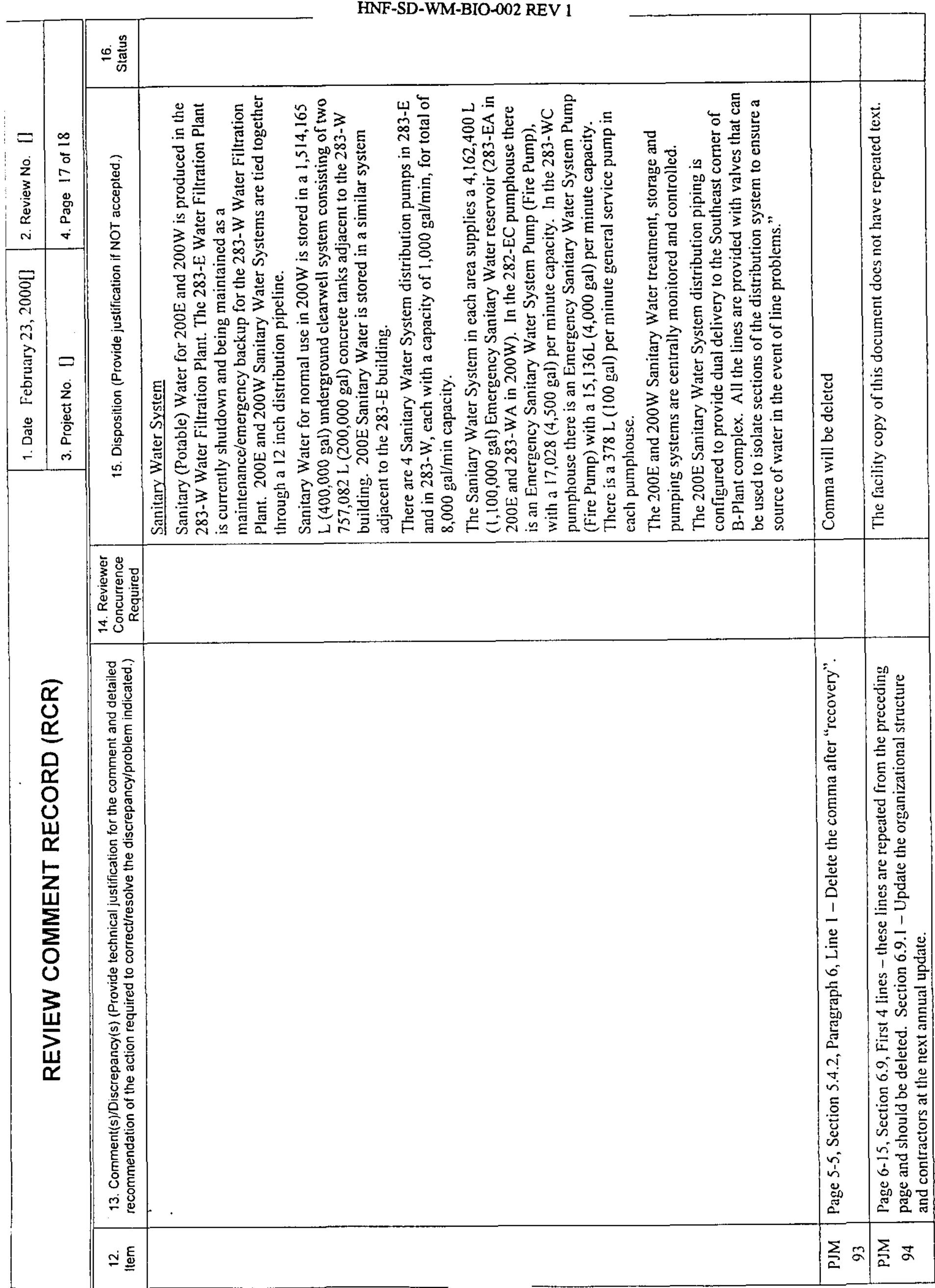




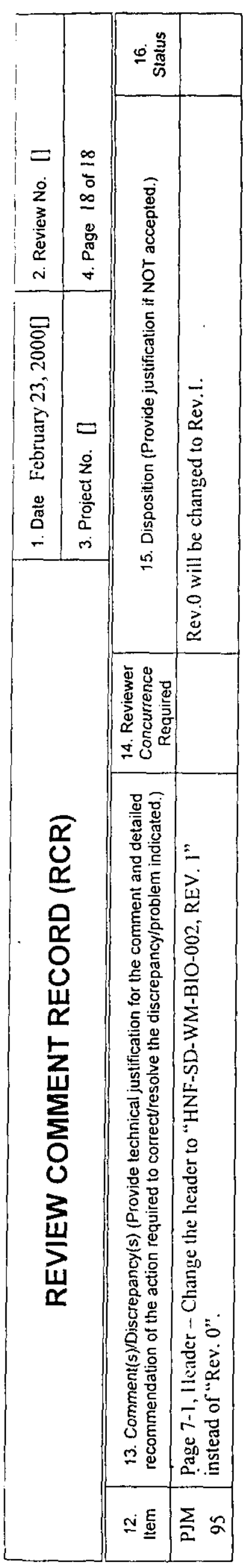




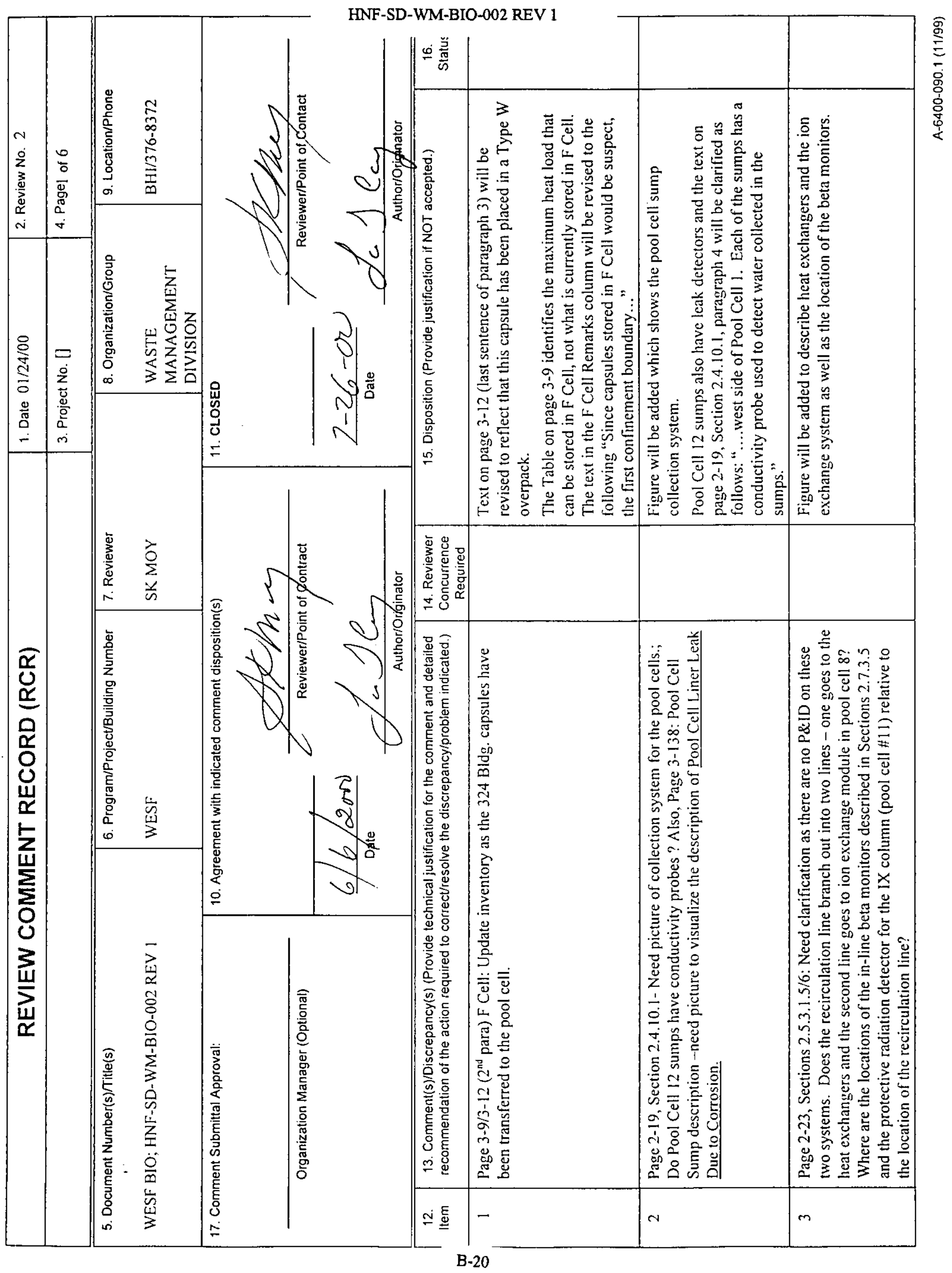




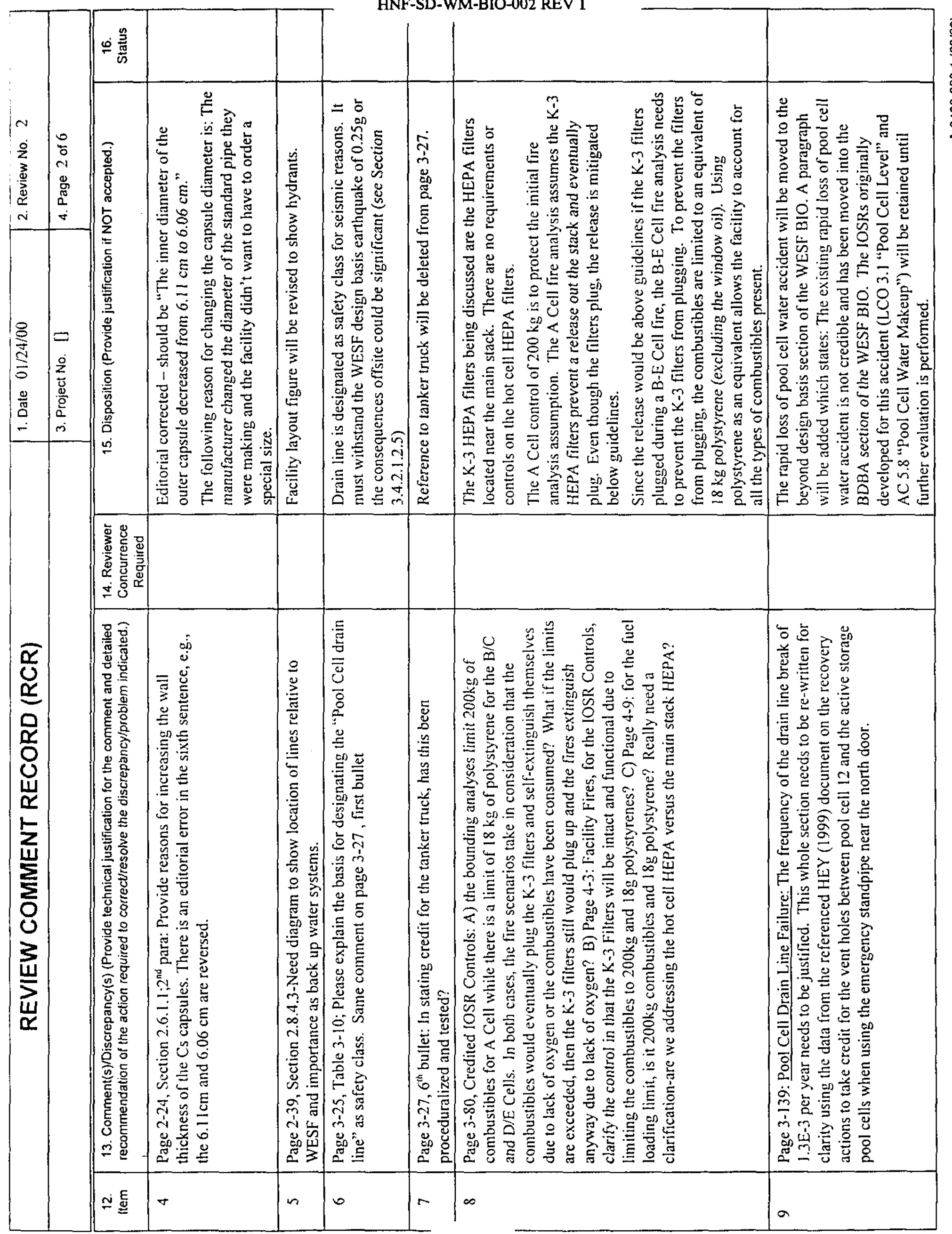




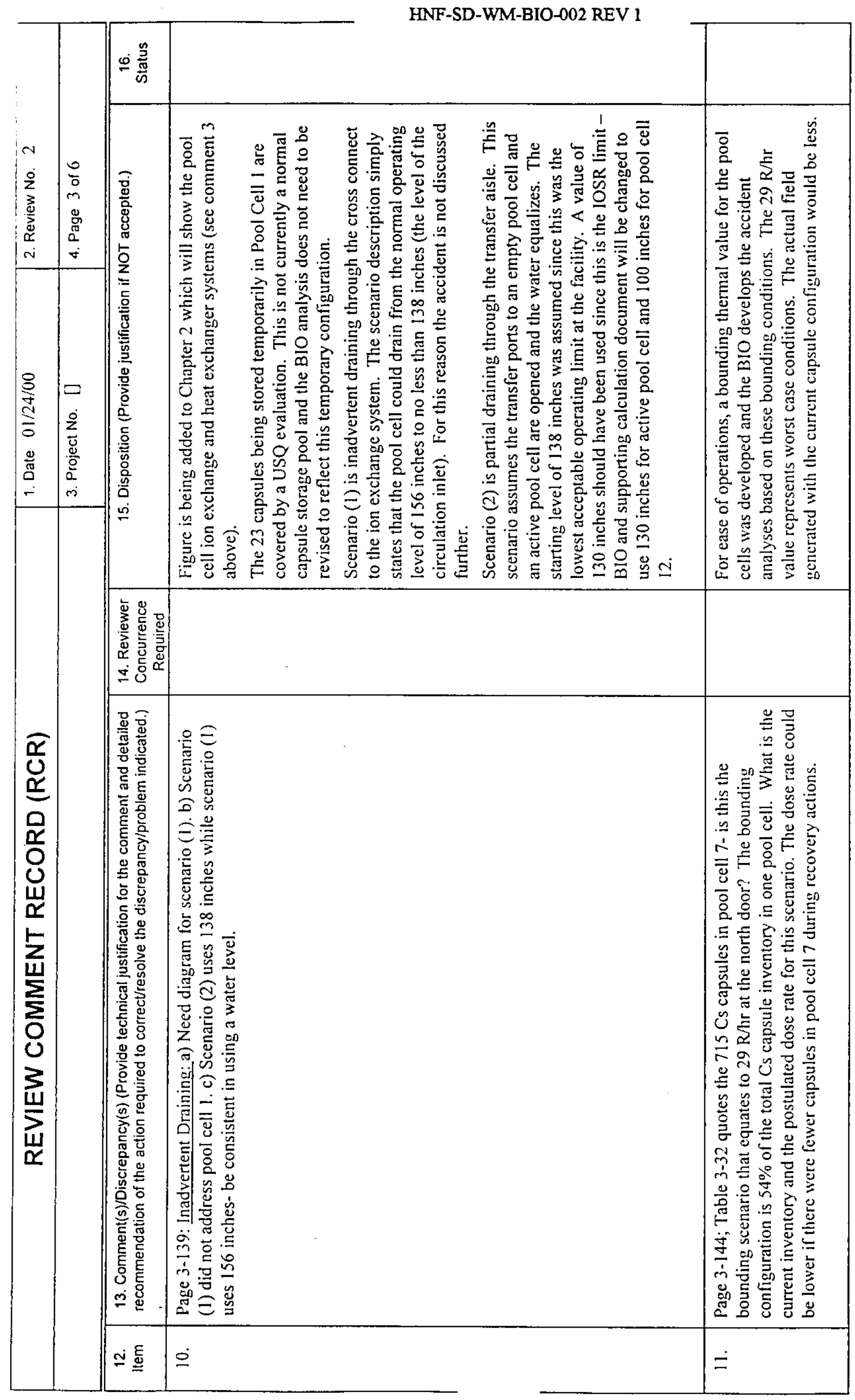


HNF-SD-WM-BIO-002 REV 1

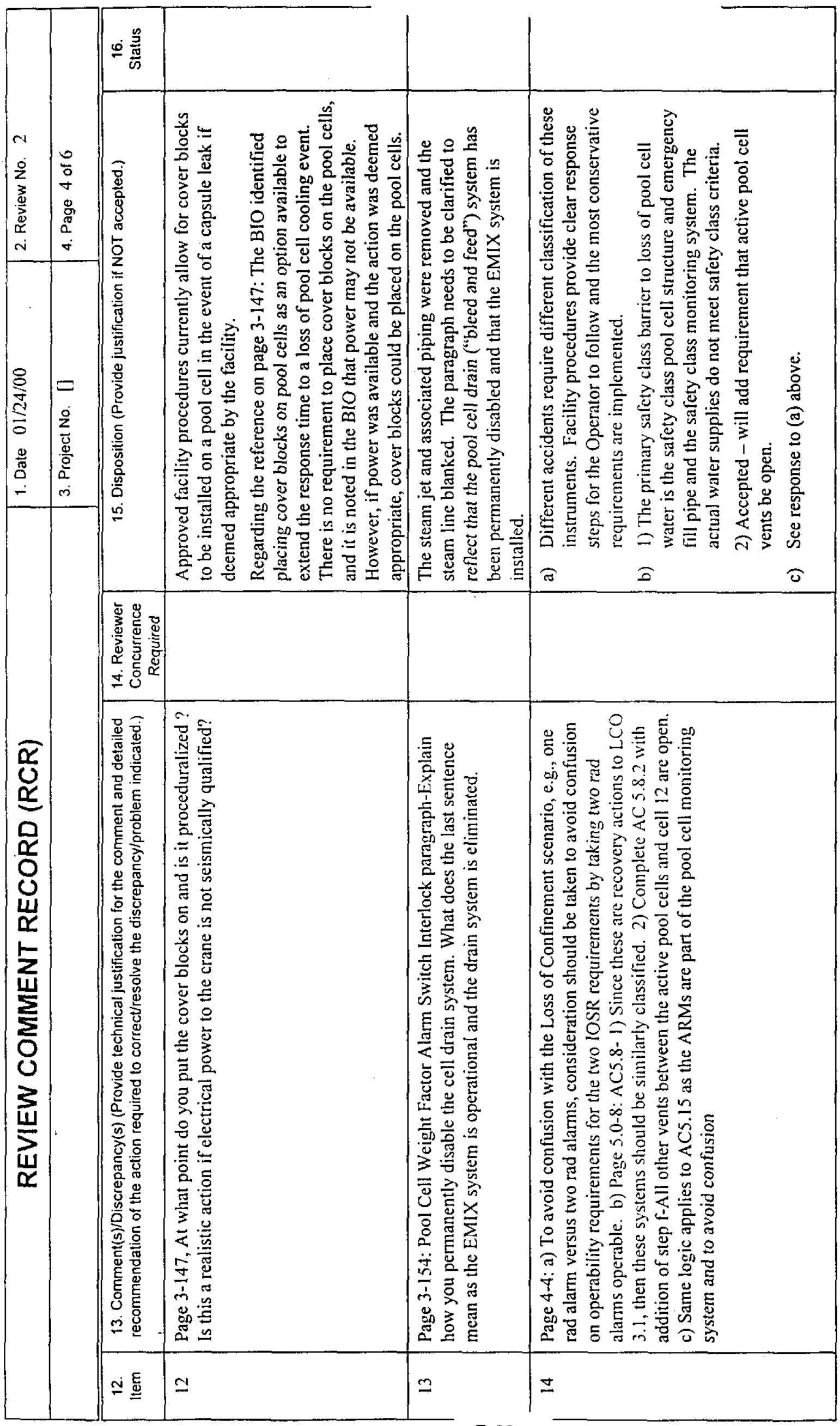




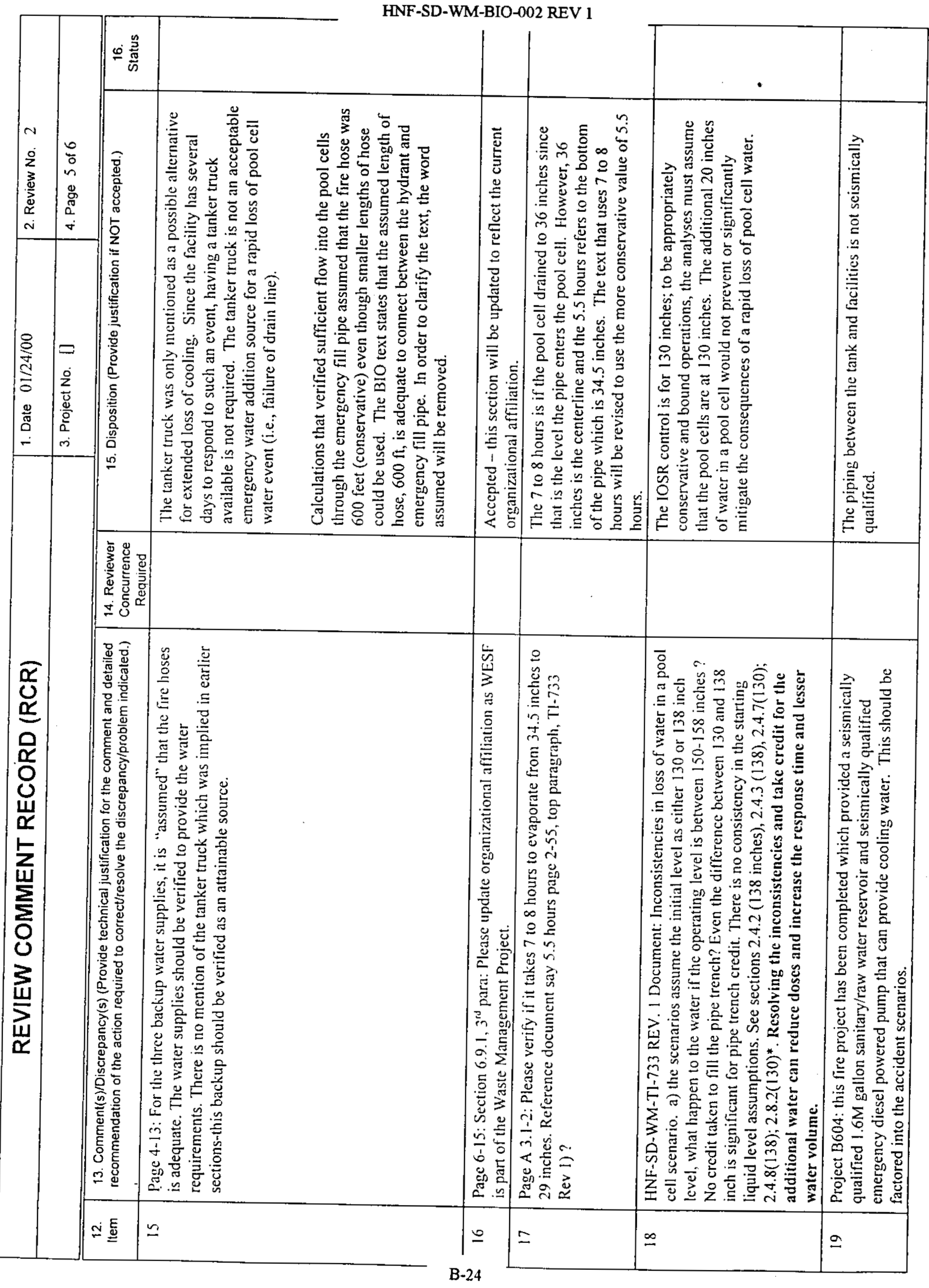




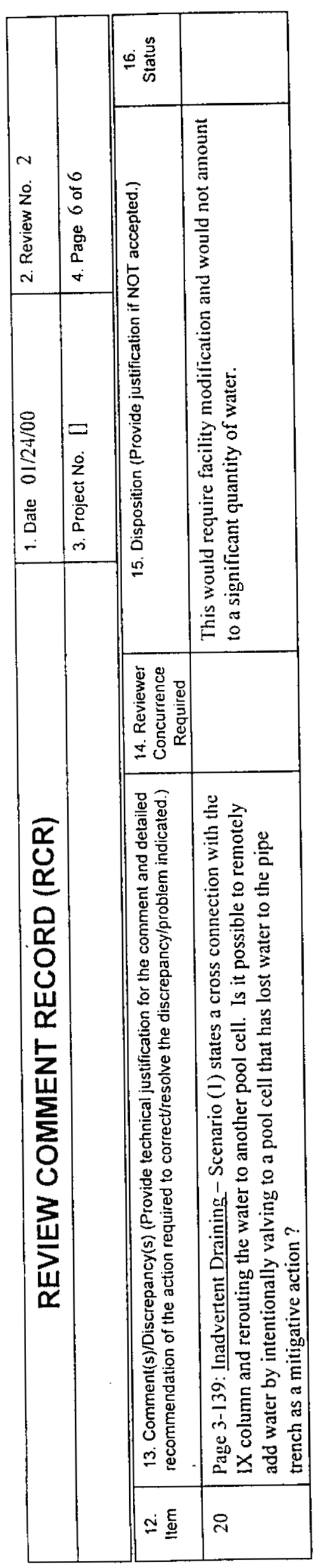


HNF-SD-WM-BIO-002 REV 1

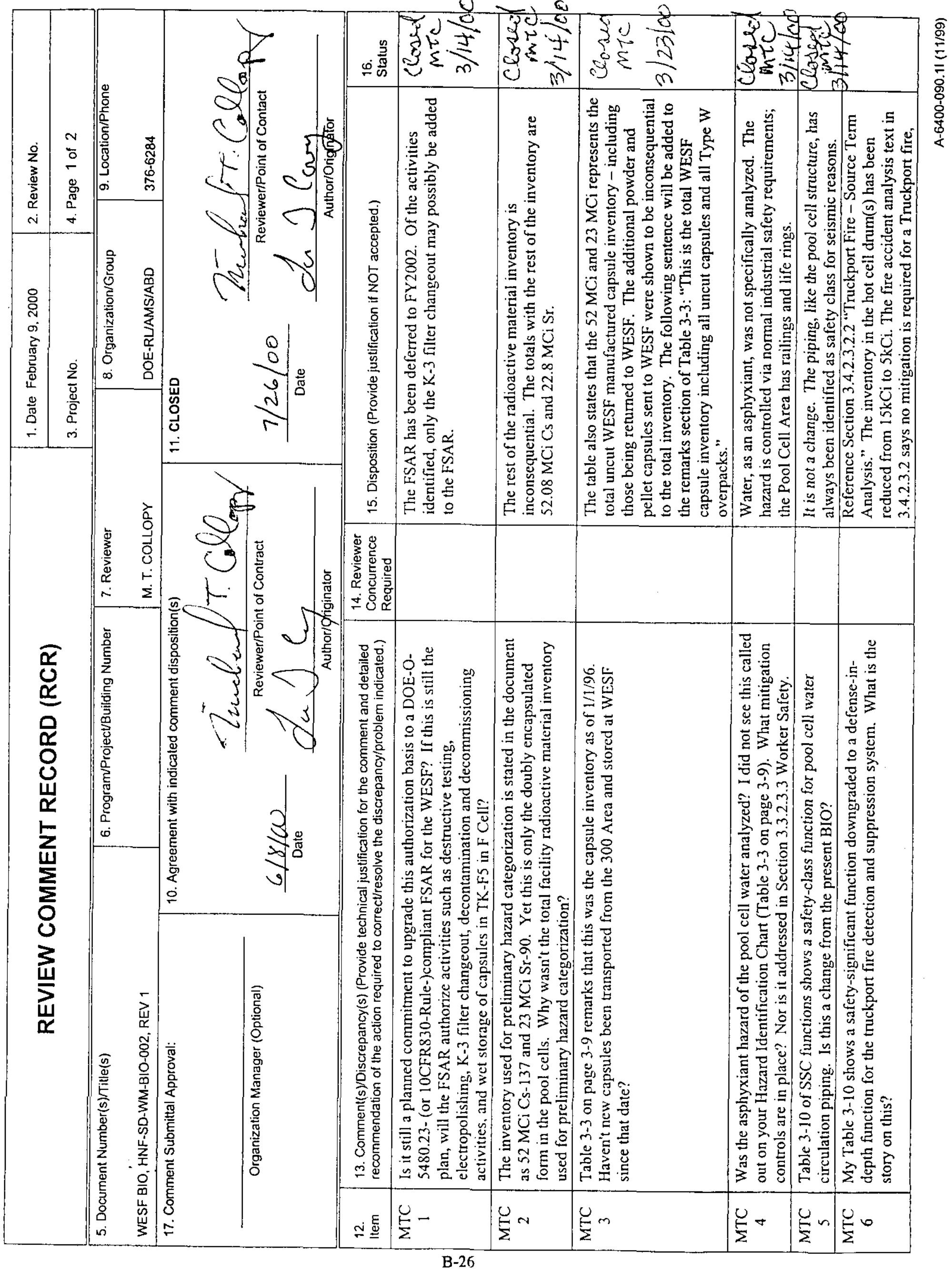




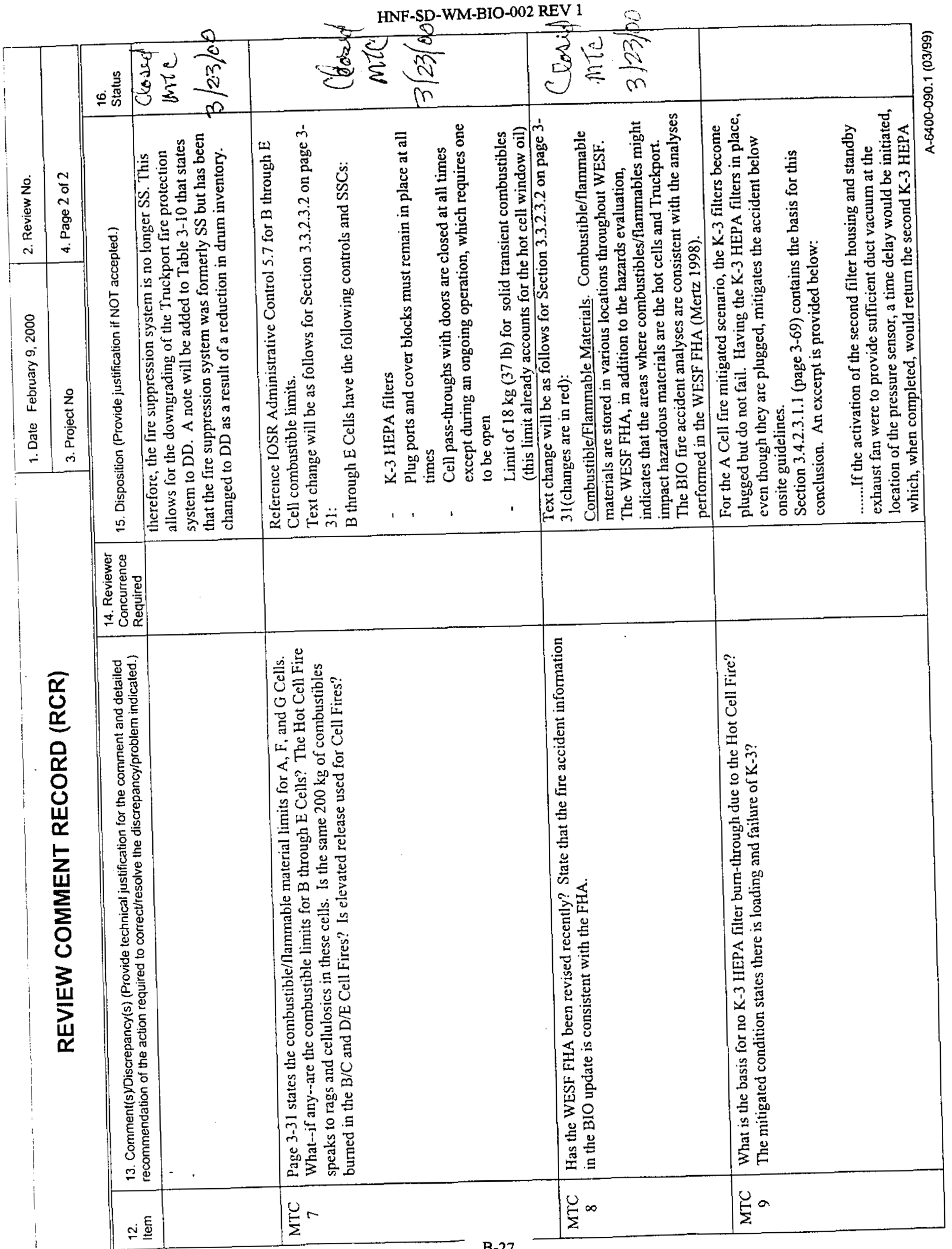




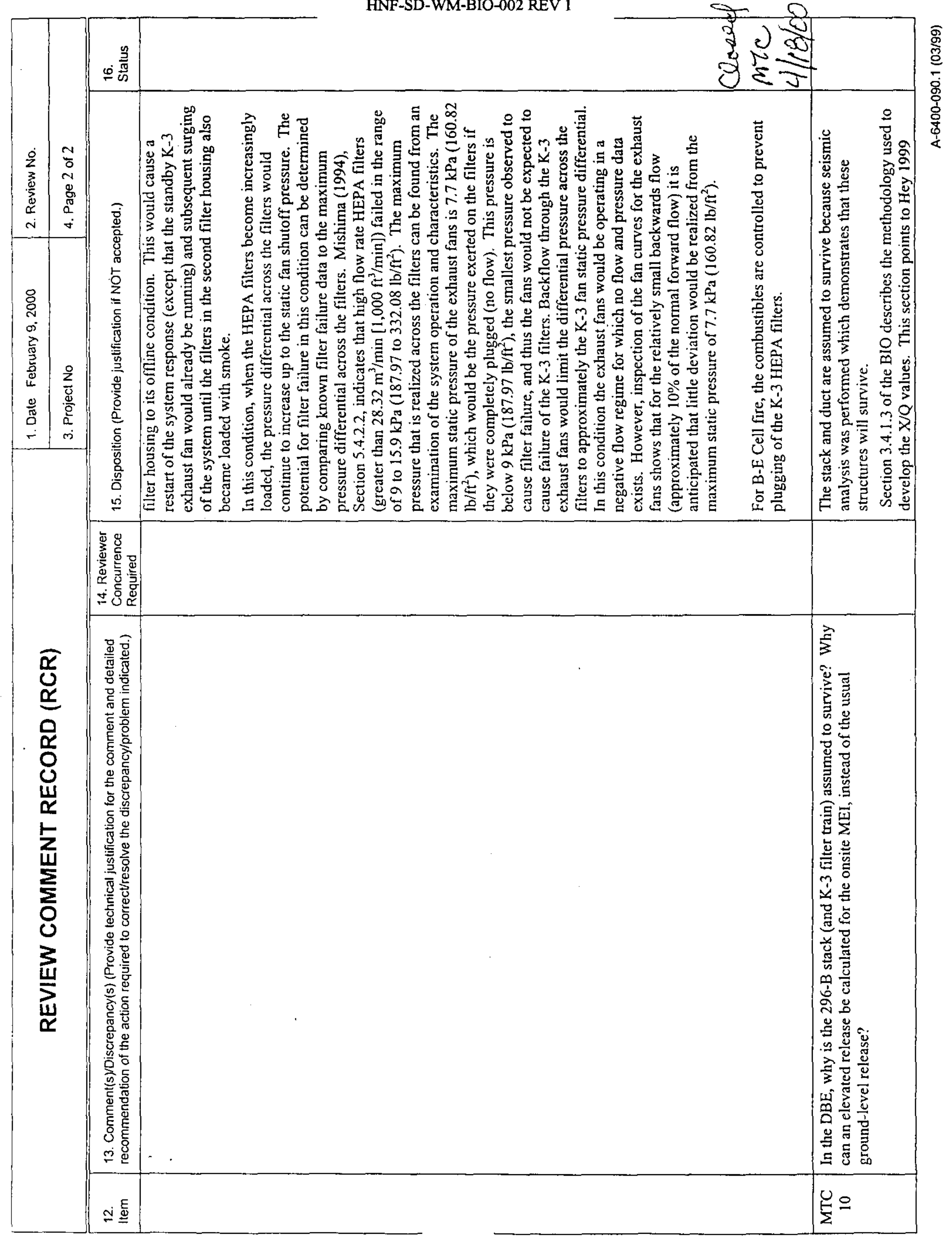


HNF-SD-WM-BIO-002 REV 1

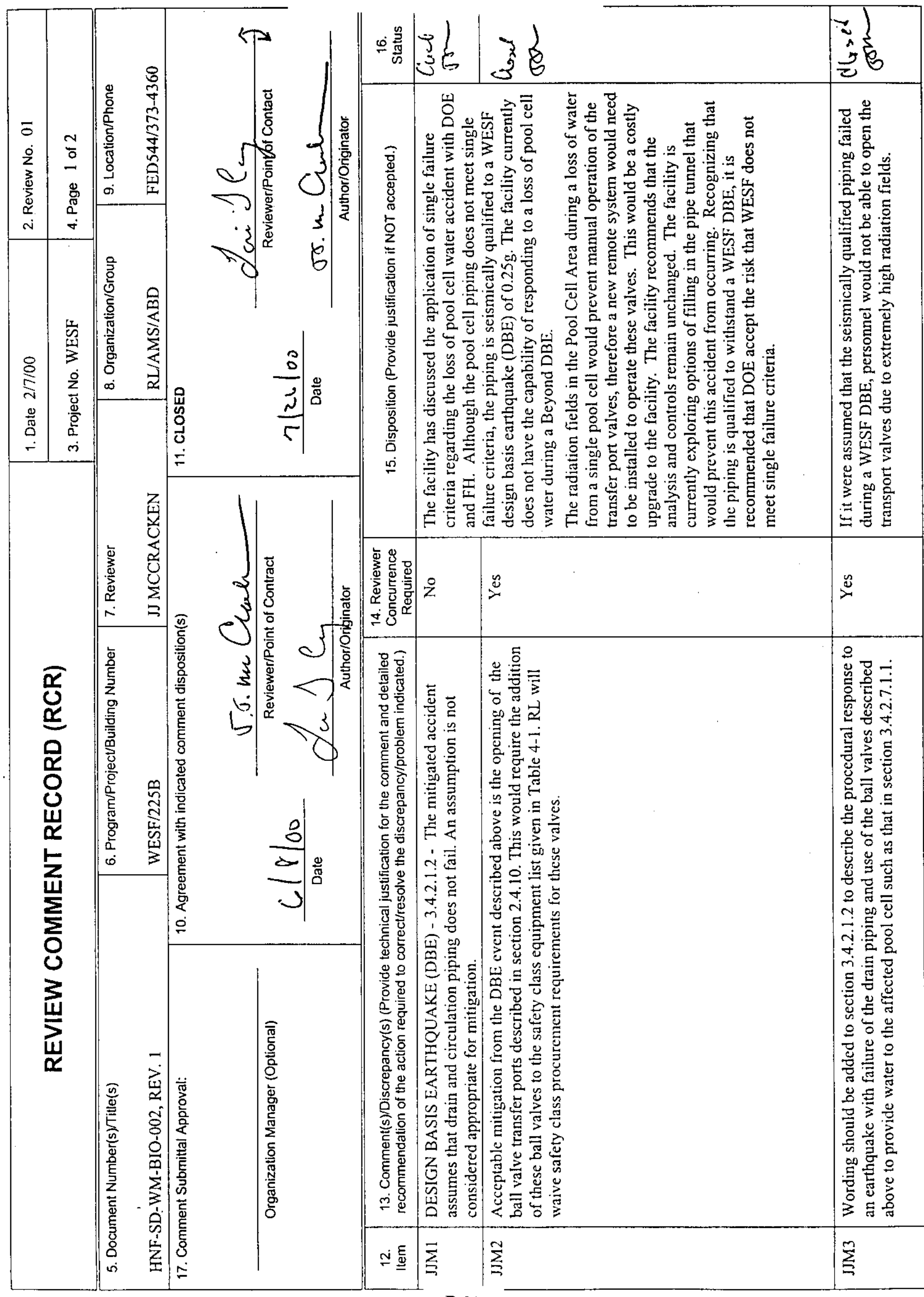




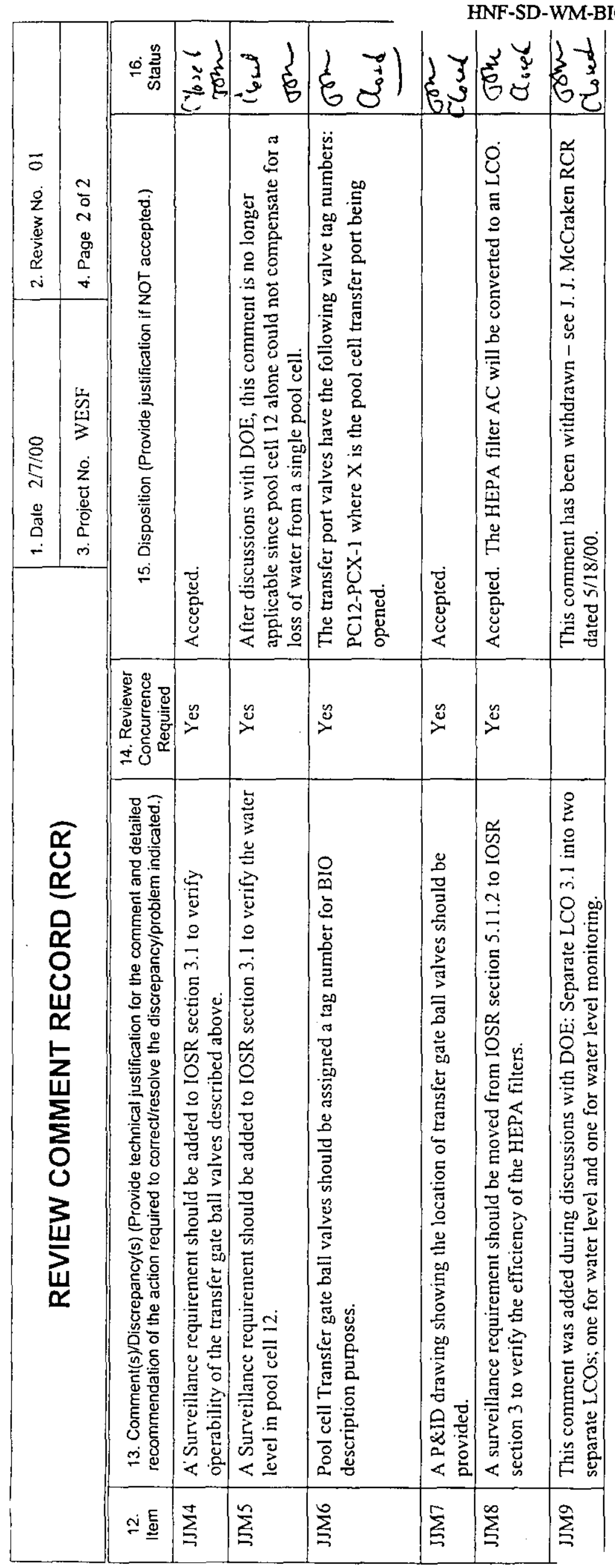

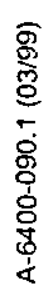


HNF-SD-WM-BIO-002 REV 1

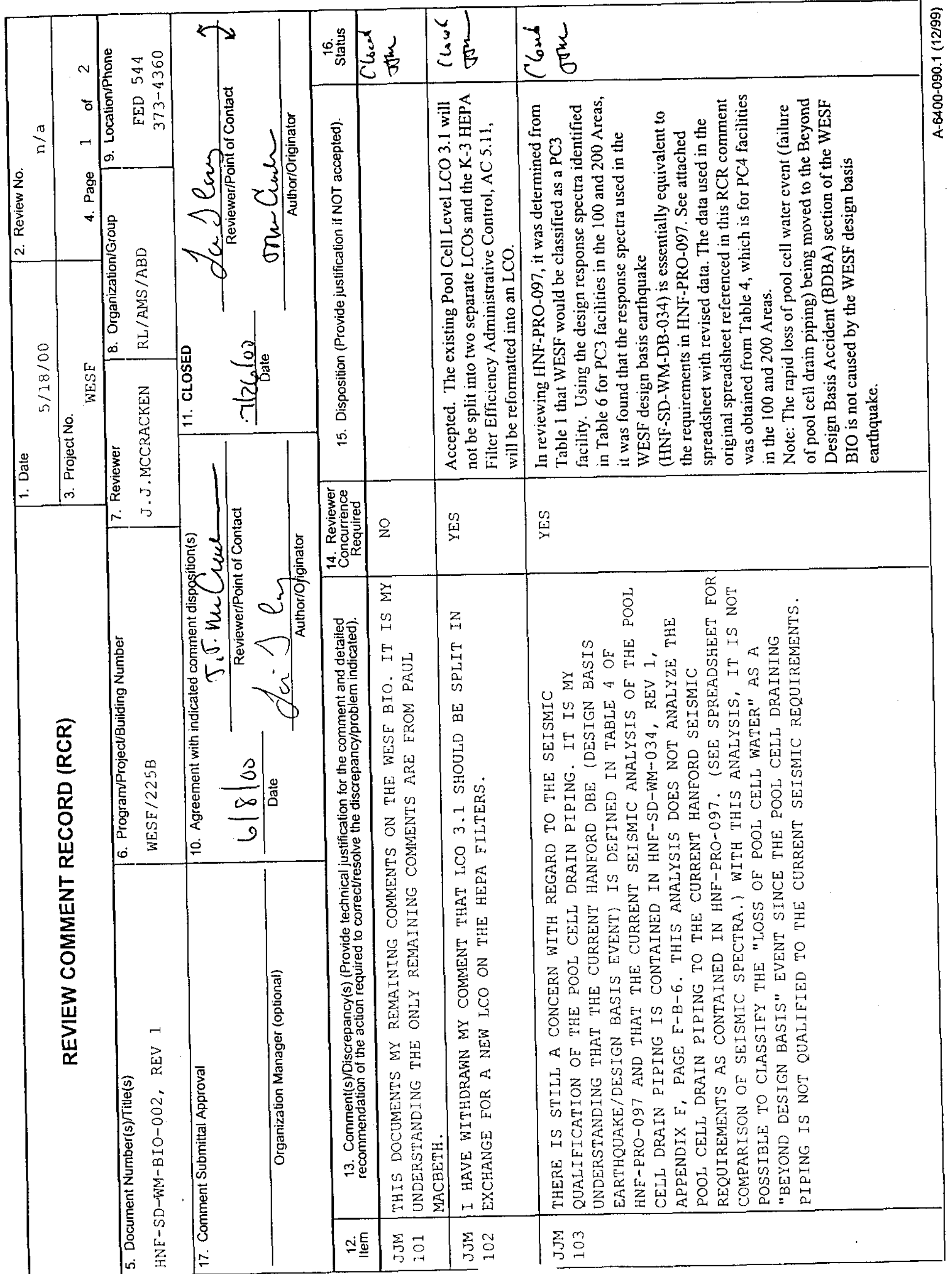




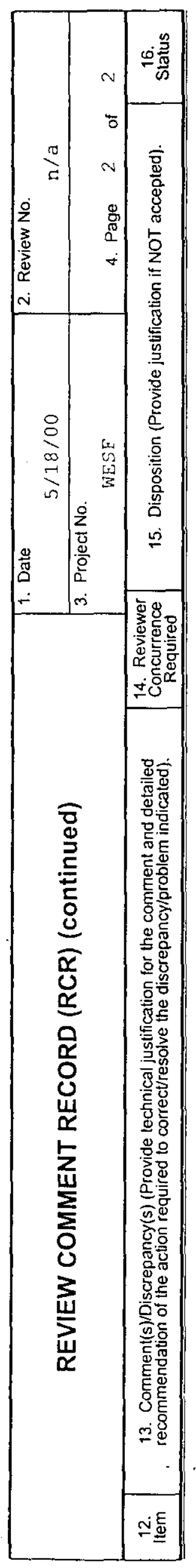



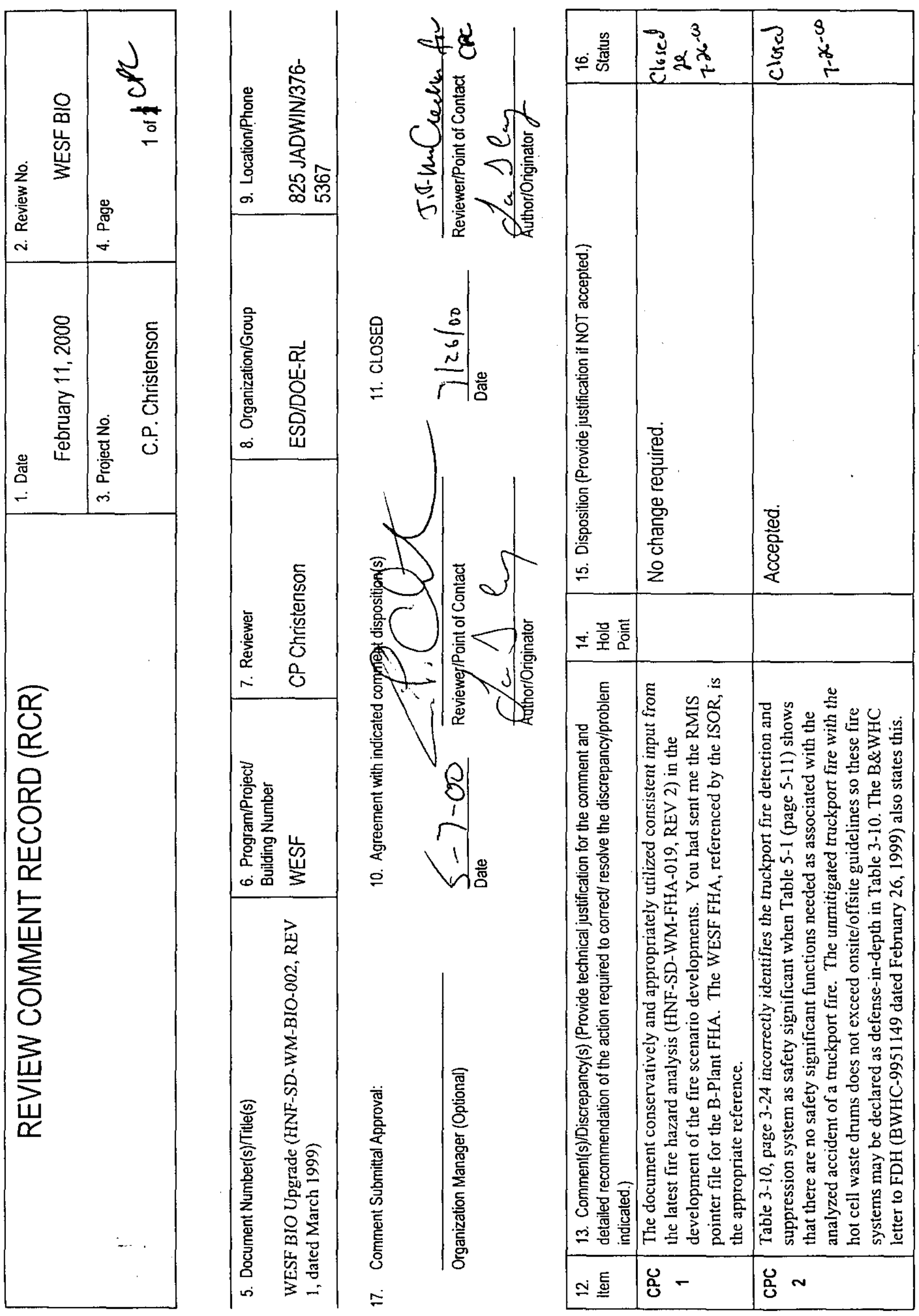
HNF-SD-WM-BIO-OO2 REV 2

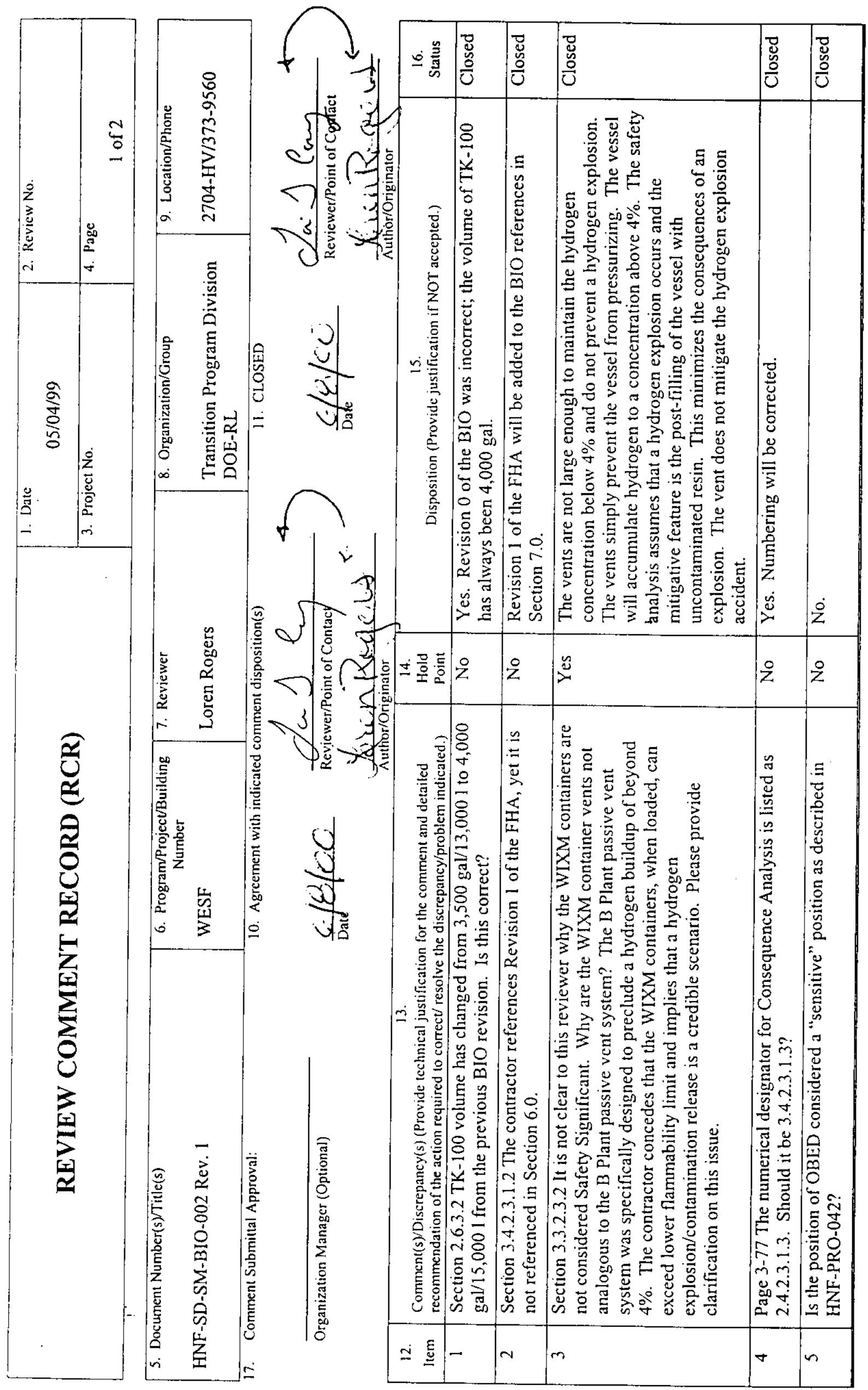


HNF-SD-WM-BIO-OO2 REV 1

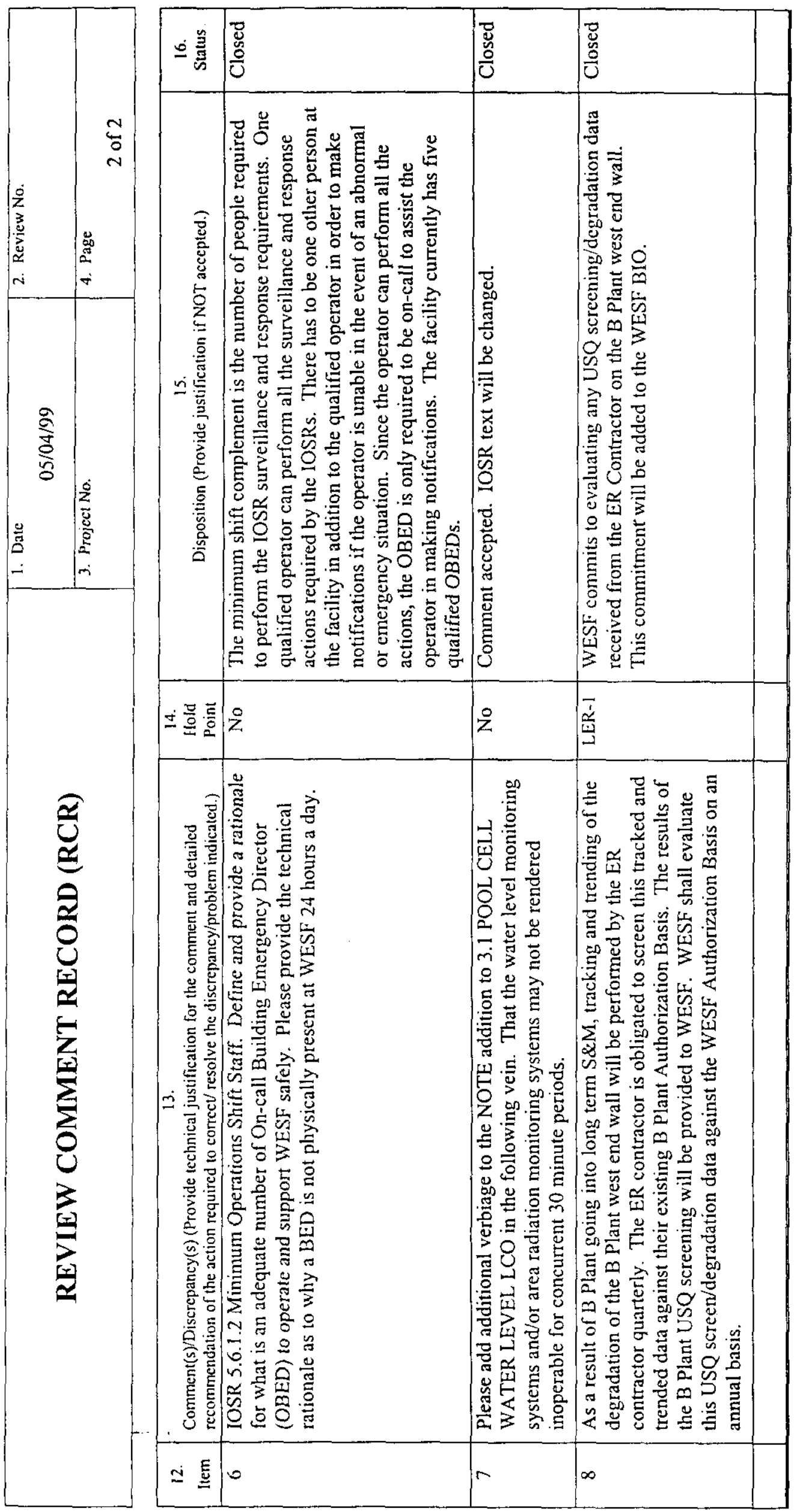


HNF-SD-WM-BIO-002 REV 1

This page intentionally left blank..

B-38 